$$
\text { Dn }-1510
$$

\title{
An Assessment of Industrial Energy Options Based on Coal and Nuclear Systems
}
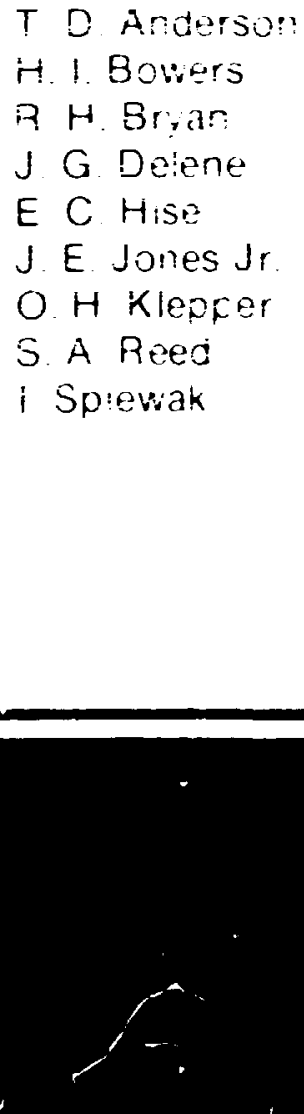
(1)

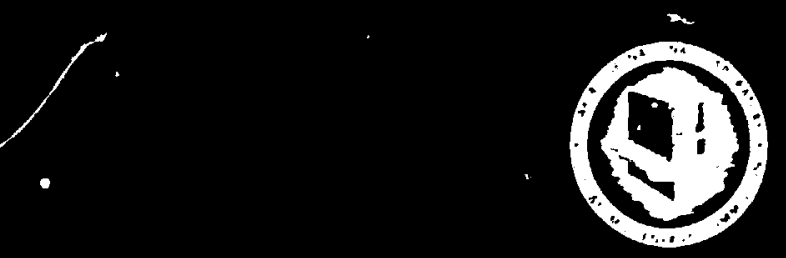

QAK RIDGE NATIONAL LABORATORY

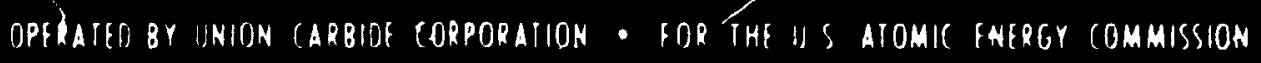
$\mathbf{s}$ 


\begin{tabular}{|} 
Printed in the United States of America. Avaibable from \\
National Technical Information Service \\
U.S. Department of Commerce \\
5285 Port Royal Road. Springt:edd, Virginia $22: 61$ \\
Price: Printed Copy \$10.60; Microfiche $\$ 2.25$
\end{tabular}

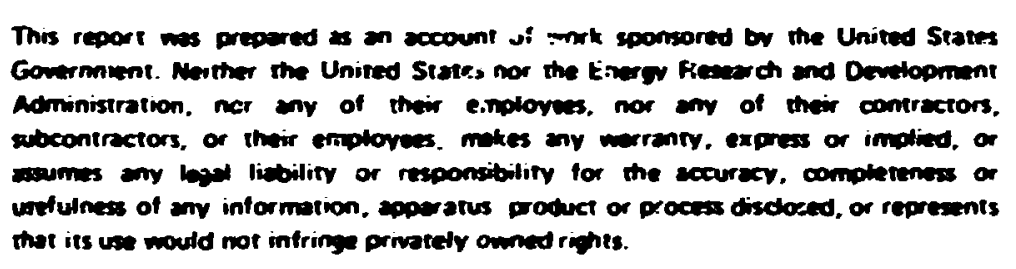




\title{
AN ASSESSMENT OF INDUSTRIAL ENERGY OPTIONS BASED ON COAL AND NUCLEAR SYSTEMS
}

\author{
T. D. Anderson \\ E. C. Hise \\ H. I. Buwers \\ $\therefore$ t. Jones $\mathrm{Jr}$. \\ H. Bryan \\ O. H. Kiepper \\ J. (;. Deiene \\ S. A. Reed \\ I. Spicuaí
}

\section{Industrial Participants}

D. C. Abill. Shell Oil Co.

f. A. Bonham. Jr.. Duw Chemica: Co.

J. T. Cuckbur:. Celanese Ct.cmical Co.

R. P. Cierke. Inion Caibide Corp.

A. r. Payne. Monsa:ilo Co.

I. L. Ragan. Cslane ae Fibers $C u$.
1.. P. Sineu. Intemationa! Paper Co.

H. G. Summars. Crown Zellerbacil Corp.

E. J. Sundstrom. Dow Chemical Co.

R. H. Wendes. Amuio Oil Co.

R. L. Wright. Union Carbide Corp.

JULY 1975

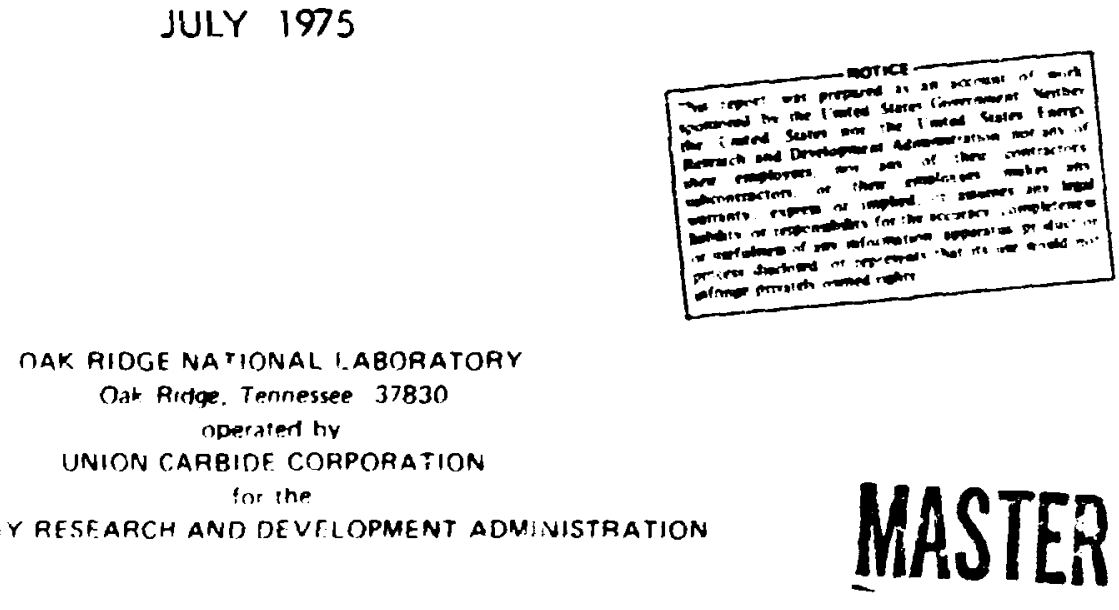

U. 5. ENEFI":Y RESFARCH AND DEVRLOPMENT ADMINISTRATION 


\section{Contents}

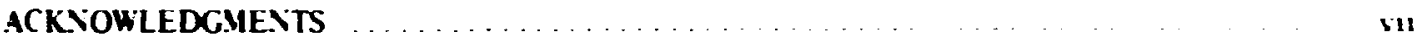

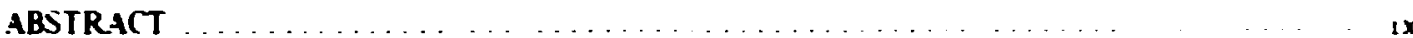

PART i. EXECUTIVE SUMMARY

1. ISTRODLCTION

1.i Purpuse and Siope

1.2 Need for Altematives

1.3 Energy Aiternatives Considered

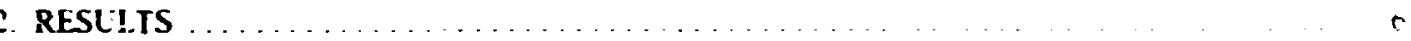

2.1 Desiription and Status of Energy Systems . . .

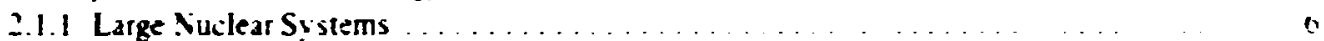

2.12 Small PuR

2.1.3 Direct Cual Firing

2.i. Gas from Coal

2.1 .5 Liquid Fueis from Coal

2.1.6 Solvent-Refined Coal (SRC)

2.2 Assessmient

2.2.1 Kesources

2.2. General Applisbility

: Environmental Considerations

23.1 Suclear

2.3.2 Cual-Bused Systeın?

2 Esoniomis

2.4 I Capital Invesinents

2. 2 Fuei Cusis

24.3 Enarg Pruviuim Cajis

2.4.4 Elfecis of Con: Vamab!s on Fannma Results

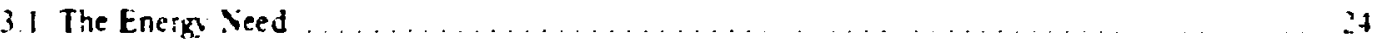

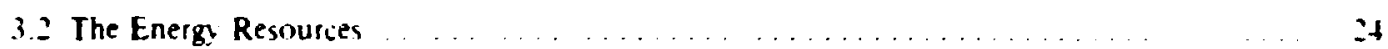

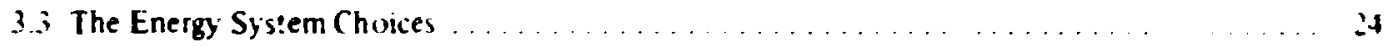

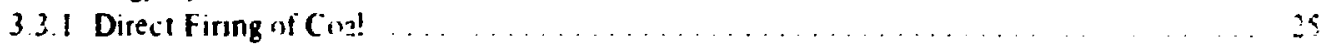

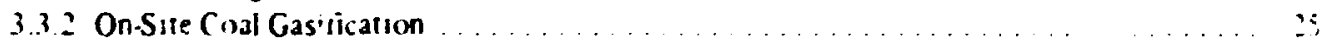

33.3 Mine-Mouth Coal-Conversion Proresses $\ldots \ldots \ldots \ldots \ldots \ldots \ldots \ldots \ldots$

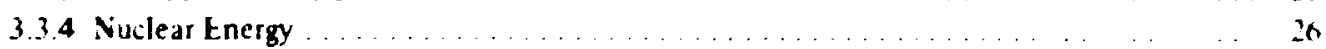

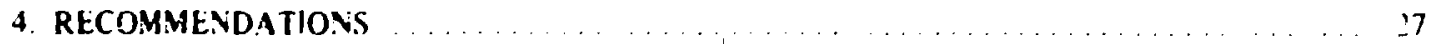

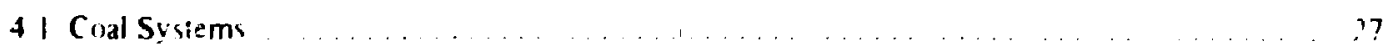

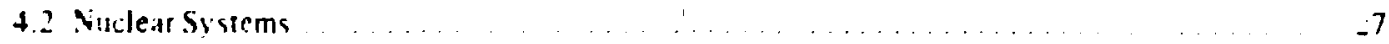


Pat II. ENERGY SYSTENS

\section{NICLEAR ENERG: SISIEYS}

SI Aswevment wi Cranum Resulues

51.1 Cranum As alishili:

$5: 2$ Lranum Demanj

51 : Lranium Price Prulki?

5.1 L Lrunum Enr:chment

5.1 F Fuel Cyde Capital Requirements

: Cimmerisul Suilear Plonis

5.1 Intrinduction

5.2 The BWR Puwer Plant

5 : The PWR Puwer Pint

S.t. The HTCR Piwer Plant

5.25 Environmental Pardmeters

I. o Operating and Mantenance Mannower Neds

5.2.7 Duwntime ior Retuel:ng and Other Mar.ienani:c

(4)

5.20 Eunormi Anuilsis . .... 71

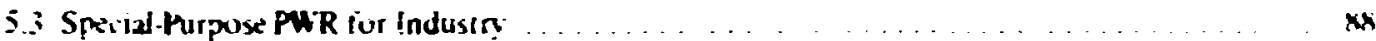

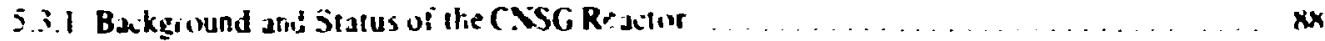

5.: Reditur Plant . . . . . . . . . . . . . . . . . . . . . .

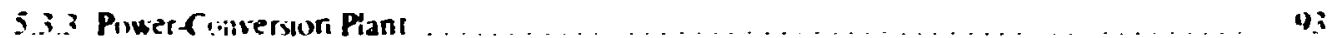

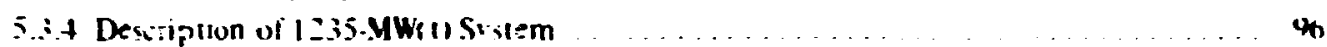

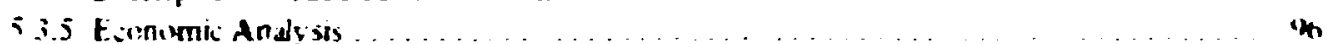

$\therefore$ Mounted CNSG Redi!ur . . . . . . . . . . . . . . . . . 10: 


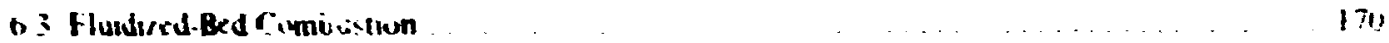

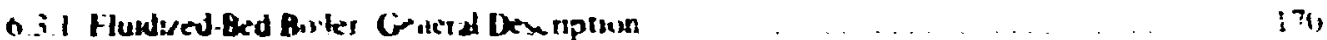

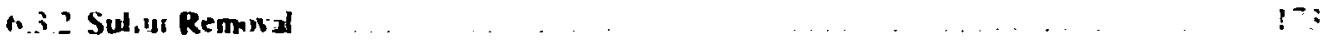

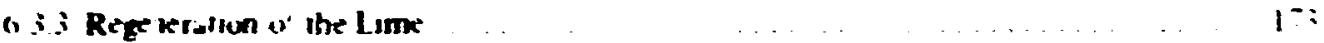

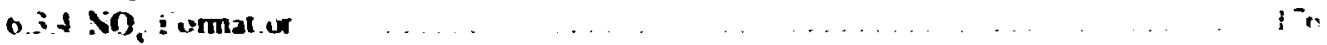

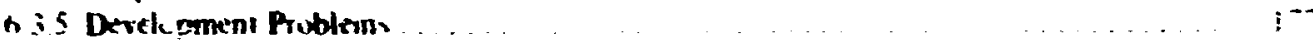

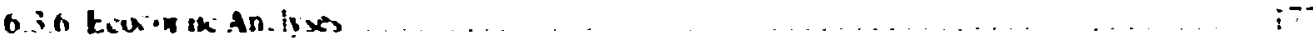

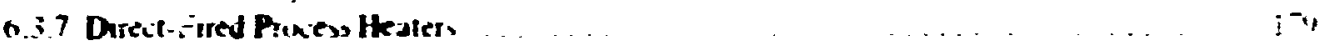

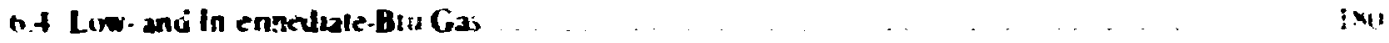

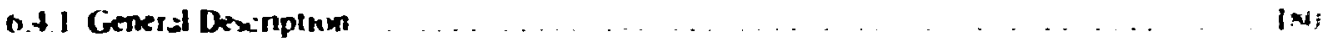

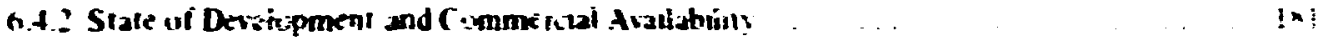

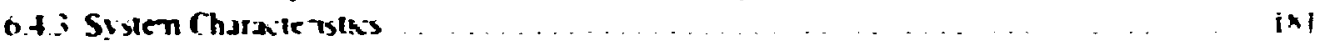

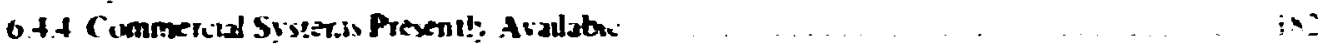

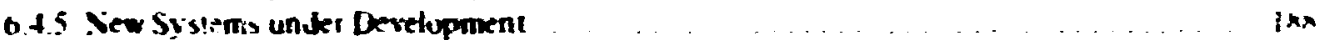

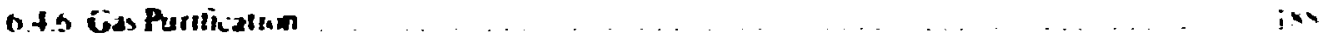

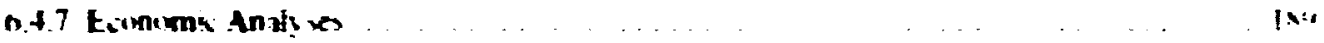

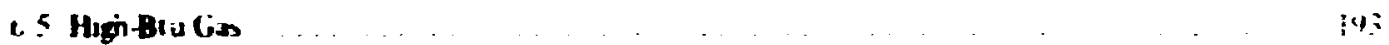

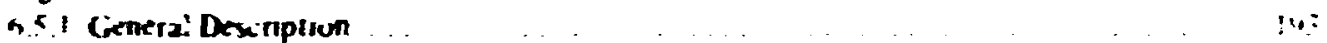

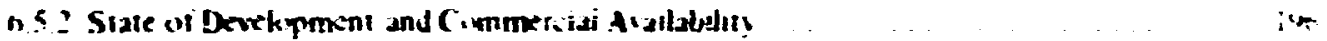

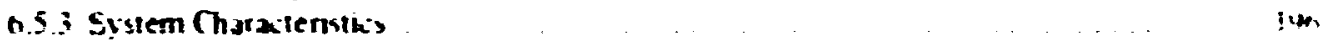

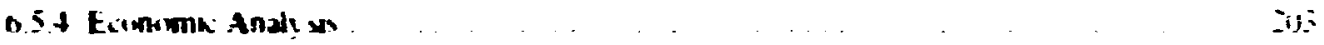

n.5. Avaltubotity . .

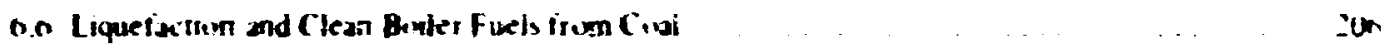

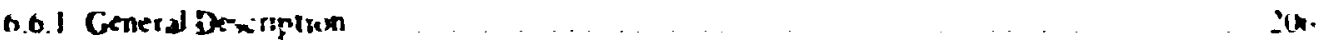

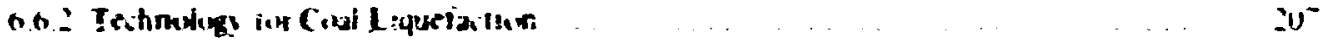

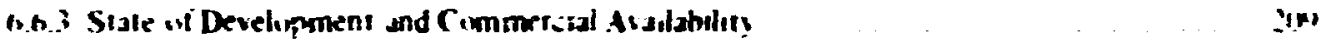

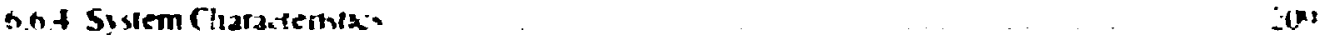

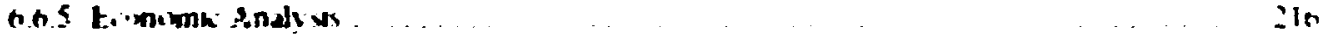

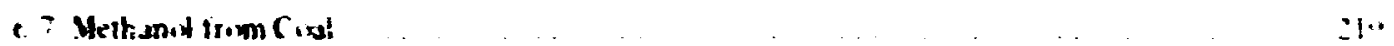

PARt II. ASTESSMENT

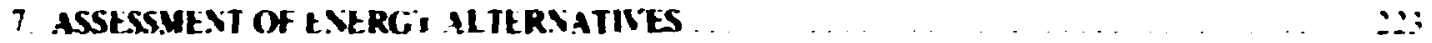

7.1 Nimlesr tnerg! $\ldots \ldots \ldots \ldots \ldots \ldots$

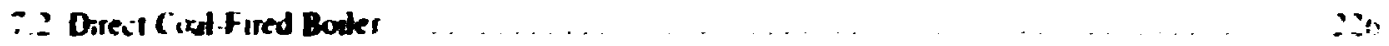

7.3 Lin. Intemediate. and Heh-Btu Cos from Conal . . . . . . . . . . . .:?

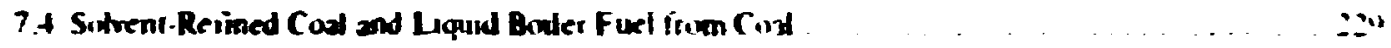

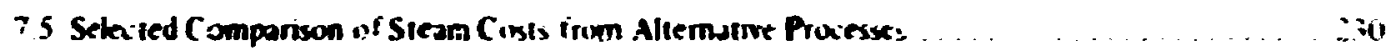

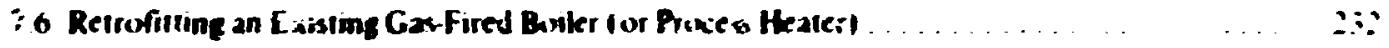

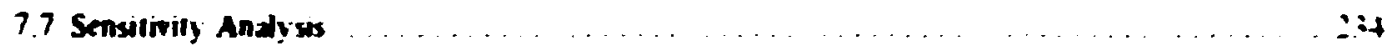

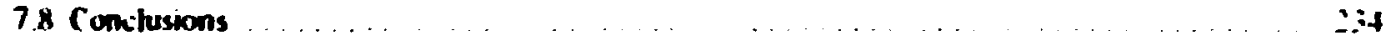

8. INDUSTRIAL VIEW OF ALTEkNATIVES $\ldots \ldots \ldots \ldots \ldots \ldots$

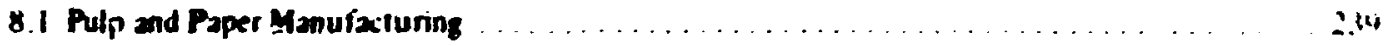

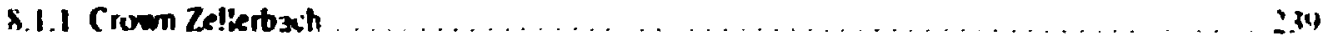

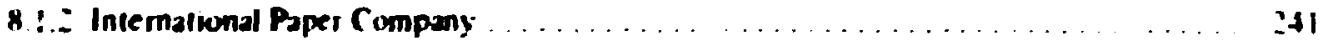




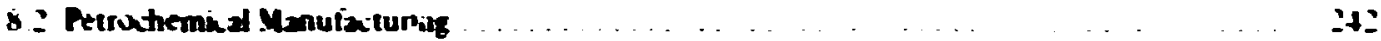

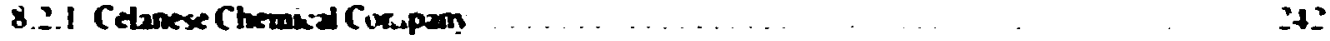

S 2.2 Dow Chemeal USA . . . . . . . . . . . . . . .

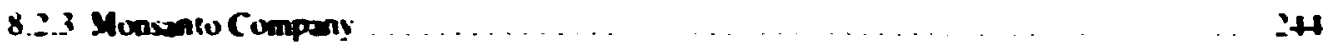

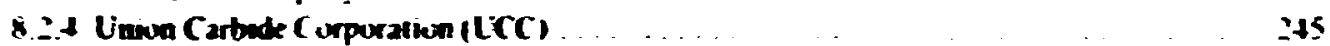

8 i Perrifeum Retiaing . . . . . . . . . . . . . . . . . . . .

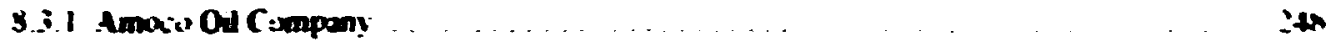

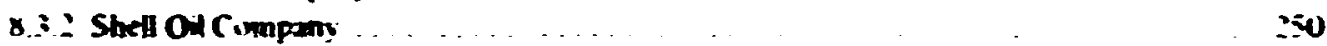

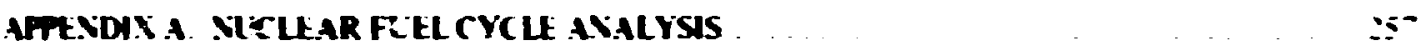

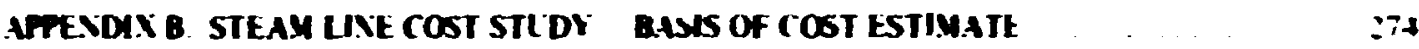

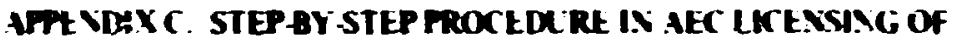

NLCEEAR WOWER REACTORS . . . . . . :

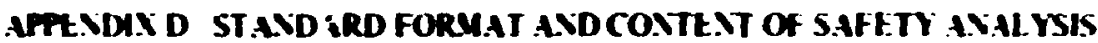

RFPORTS FOR NiCLEAR FOWER FLATS :Wo

AITNUX E ST ADARD FORMAT AND CONTEMT OH ENVIRONMENT AL

REMORIS FOR VCLLAR FONER PLANTS iny

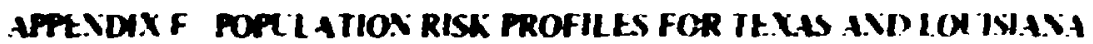

INDESTRILIZED APEA 


\section{Ackinuwledgments}

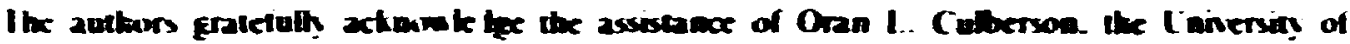

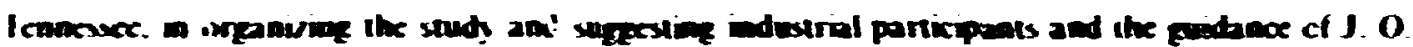
Rekerts and I Bereonsti. ERI)A.

M 1. Mvers. I. I. Indte. and M. : Minton assisted in the preparation of lle nuctear coss

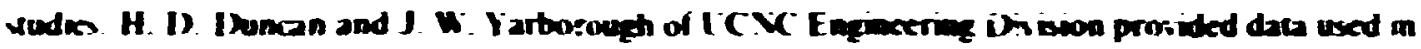
aktublang the cacts: (stedmi transport coses.

specal thanks is in ordet for the many people who were responsible for coordinatine and

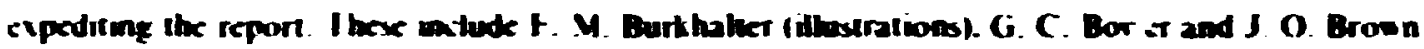

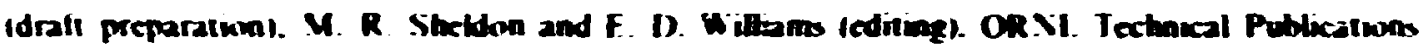
(kepartment ifinal componitum). and B. S. Harmon (reakeup). 


\begin{abstract}

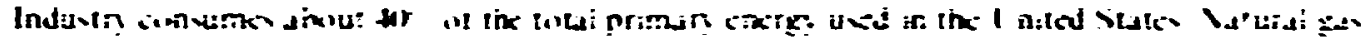

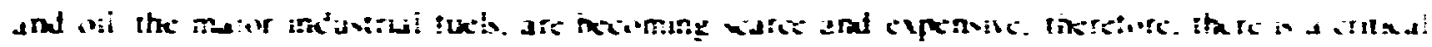

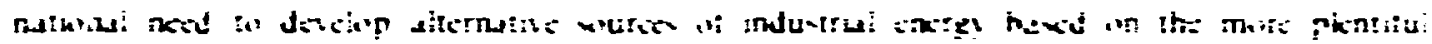

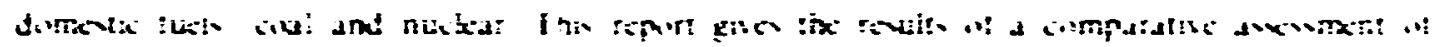

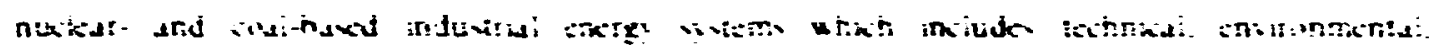

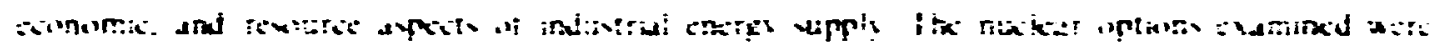

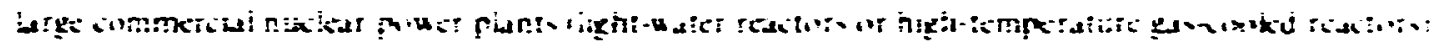

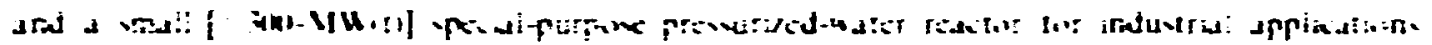

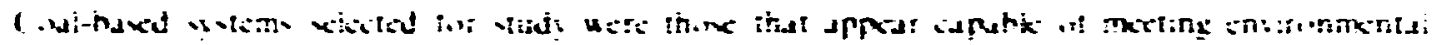

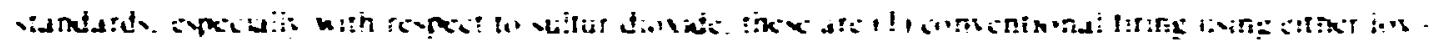

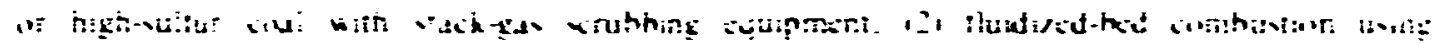

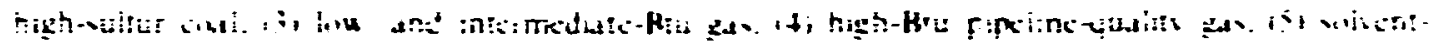

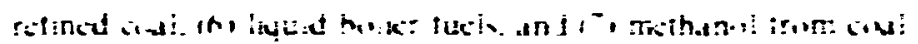

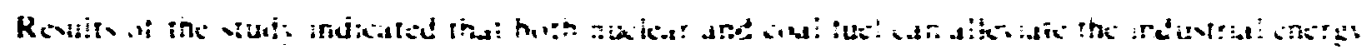

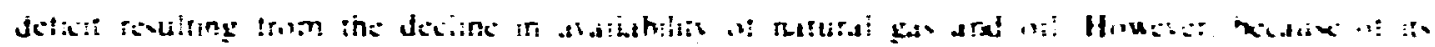

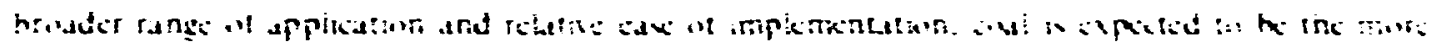

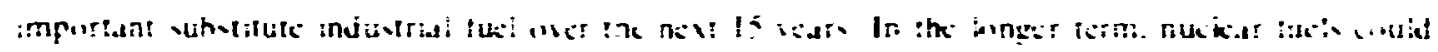

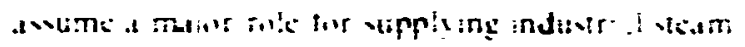




\section{Part I. Executive Summary}

\section{Introduction}

\section{PERPOSE AND SCOPE}

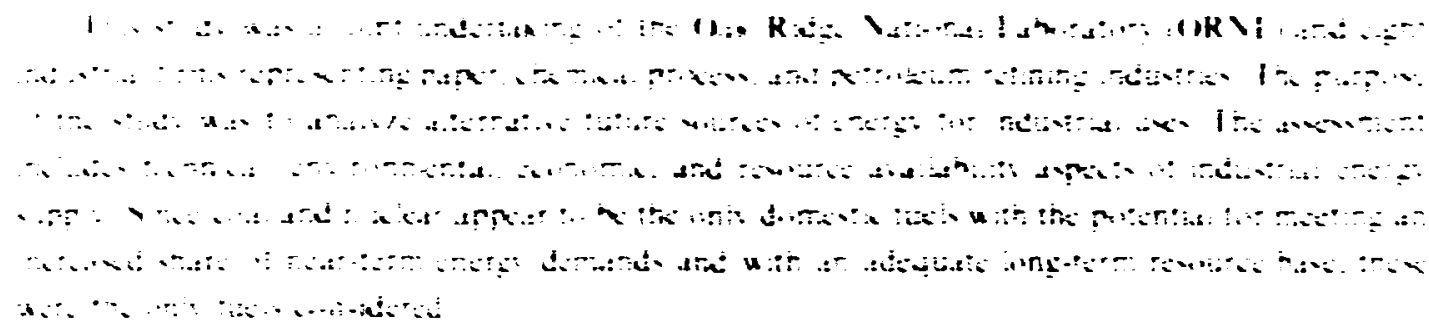

\subsection{NEED FOR ALTERNATIVES}

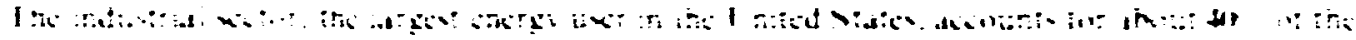

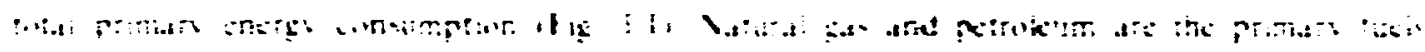

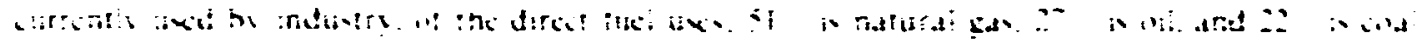

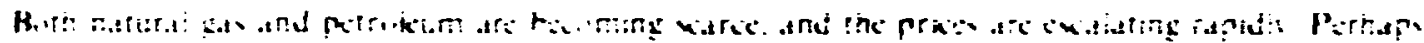

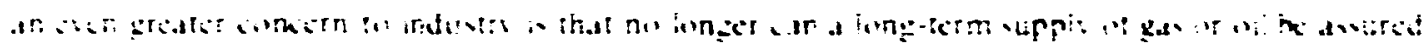

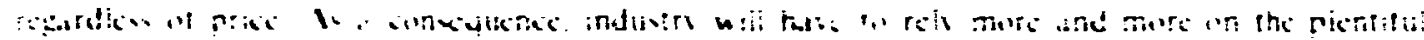
domeln :

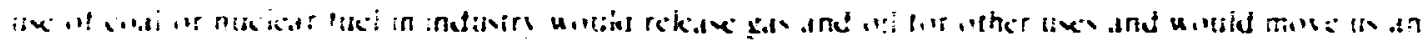

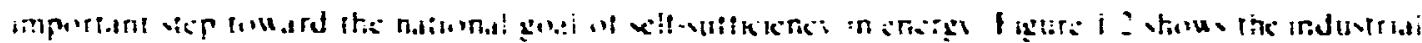

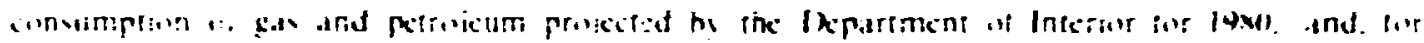

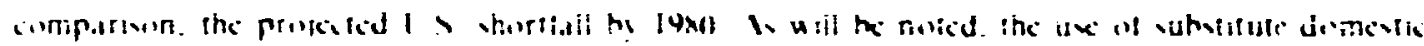

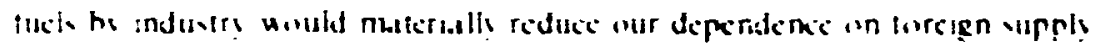

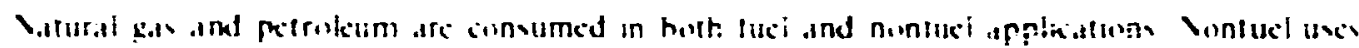

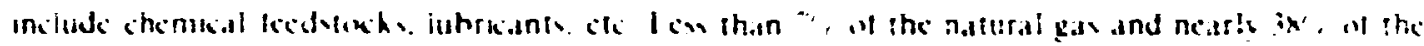

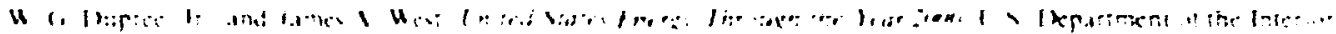

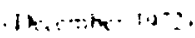




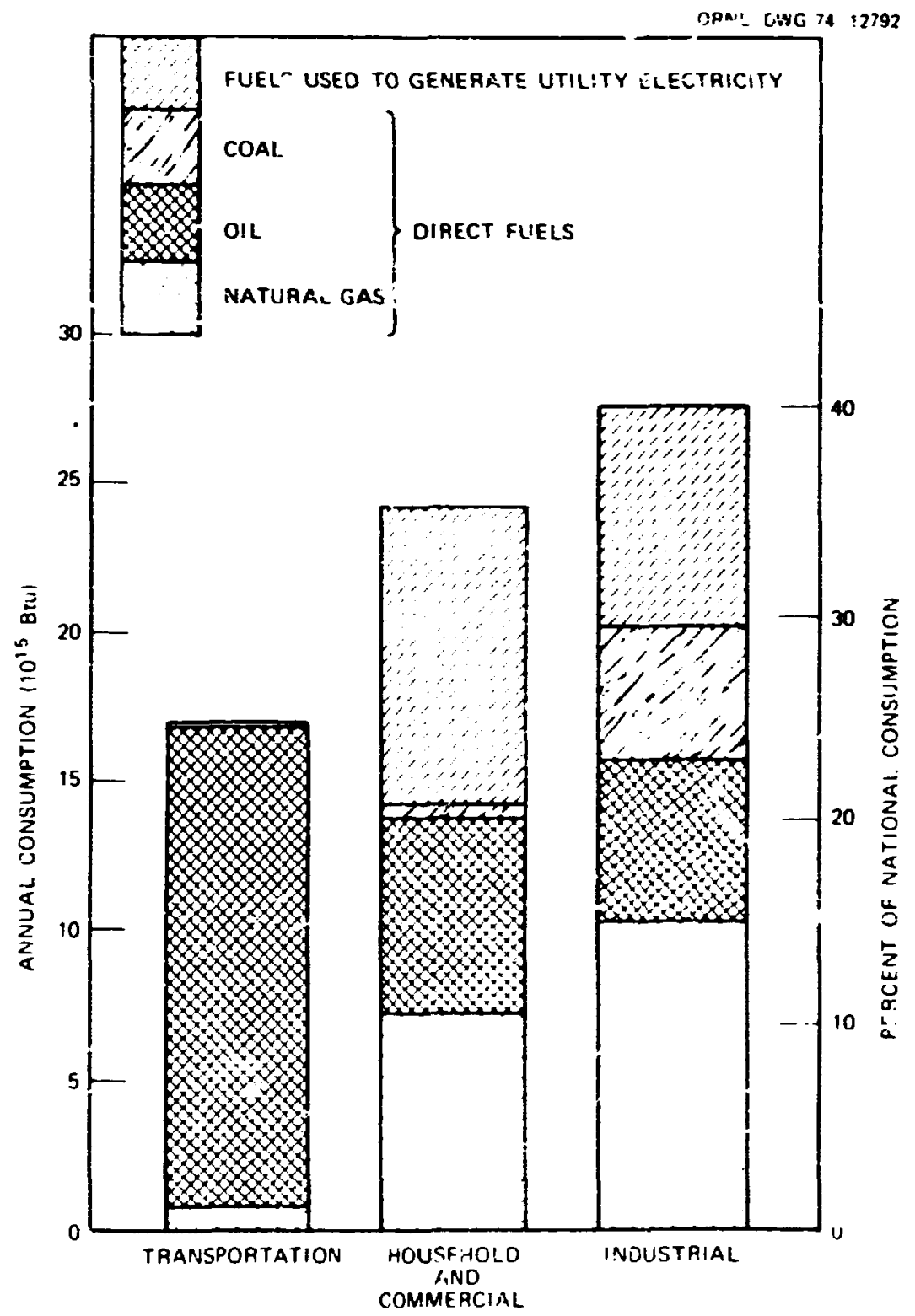

Fig. 1.1. Fnergy corisumption in the linited s.ates, 1971.

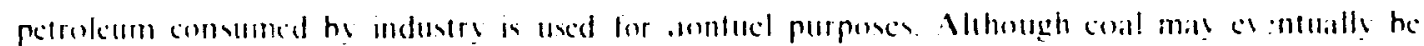

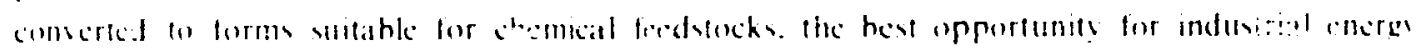
shositulums in tice arca of fects.

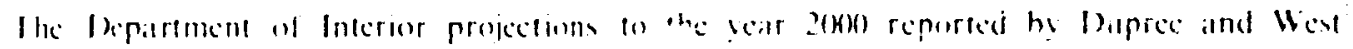

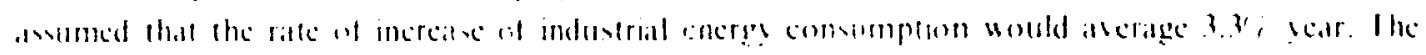

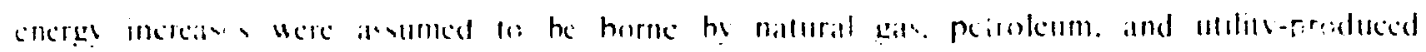

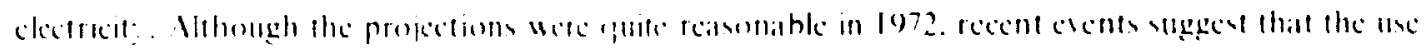




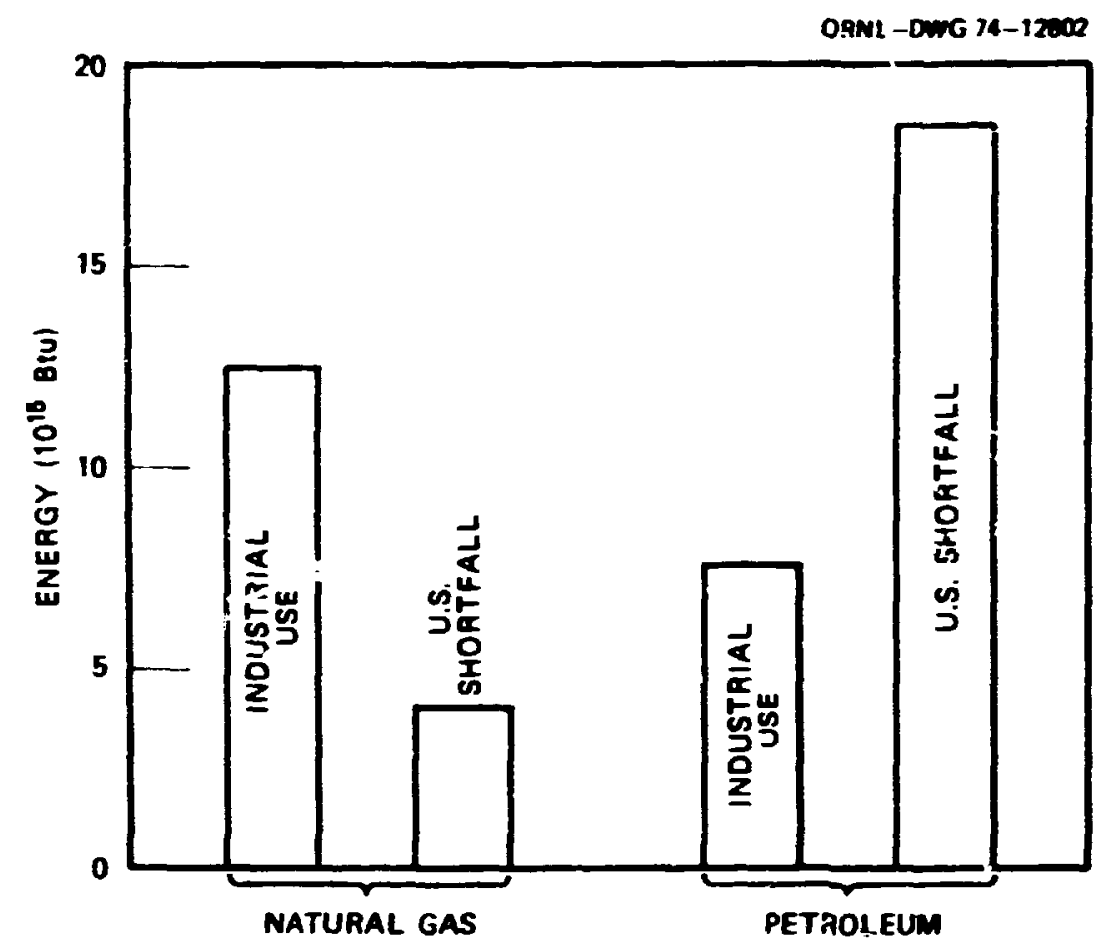

Fig. 1.2. Comparison of industral consumption and V.S. defics: of natural gas and petroleum in 1900 . 15ource. Hevt and Inprese. 1

of gas as an industrial fuel will decline hecause reserves are inadequate to meet demands. Ite increased use of oil for indistrial flicl mas. in lact. come ahout, hut this is contrary to the goal of self-sulticiency in energy.

Another possible senario developed from the Department of Interior projections is shou $n$ in 1ig. 1.3. In developing these data. the following assumptions were made.

I. Jotal industral energy use and the contrihutions of coil and efectricity to the total are the sime as those reported by Duprec and Wiest.

2. The nonfucl energy wurt.s are the same as those reporicd by Itupree and West.

3. Vatural gas for industrial ruel will be phased out linearly starting in 1975 and ending in. 1985.

4. Oil for industrial fuci will be phased out linearly starting in 1980 and ending in 1990.

The deficit in industrial fuels resulting from the assumed phas:out of oil ard gas. illustrated in Fig. I.3. Would have to he made up by coal, nuclear. and other energy sources. According to this scenario. the rate of changeover in the decade 1975 to 198: would need to be very great. For example, the new capacity of indutrial hoilers and process hezters added in that period. as showil in Tat.le I.1. Would he nearly 6); of the thermal energy capacity that will he installed hy the elcetric utilicy industry in the same time perind. It should be rioted that nearly threefourths of the "res. industrial energy capacity for the 1975 to 1985 period will be obtained hy retrofitting existing industrial plants. There is serious dombt as to whether the assi'med rale of phaseout of gas and oil is f(as:ble hecause (I) some promising methods of utilizing colal or nuclear for industrial fucls are not sufficiently developed for commercial application. and (2) cquipment mallufacturers and the fuci resource industries will he hardpressed to meet hoth the industral and clectric utility demands. 


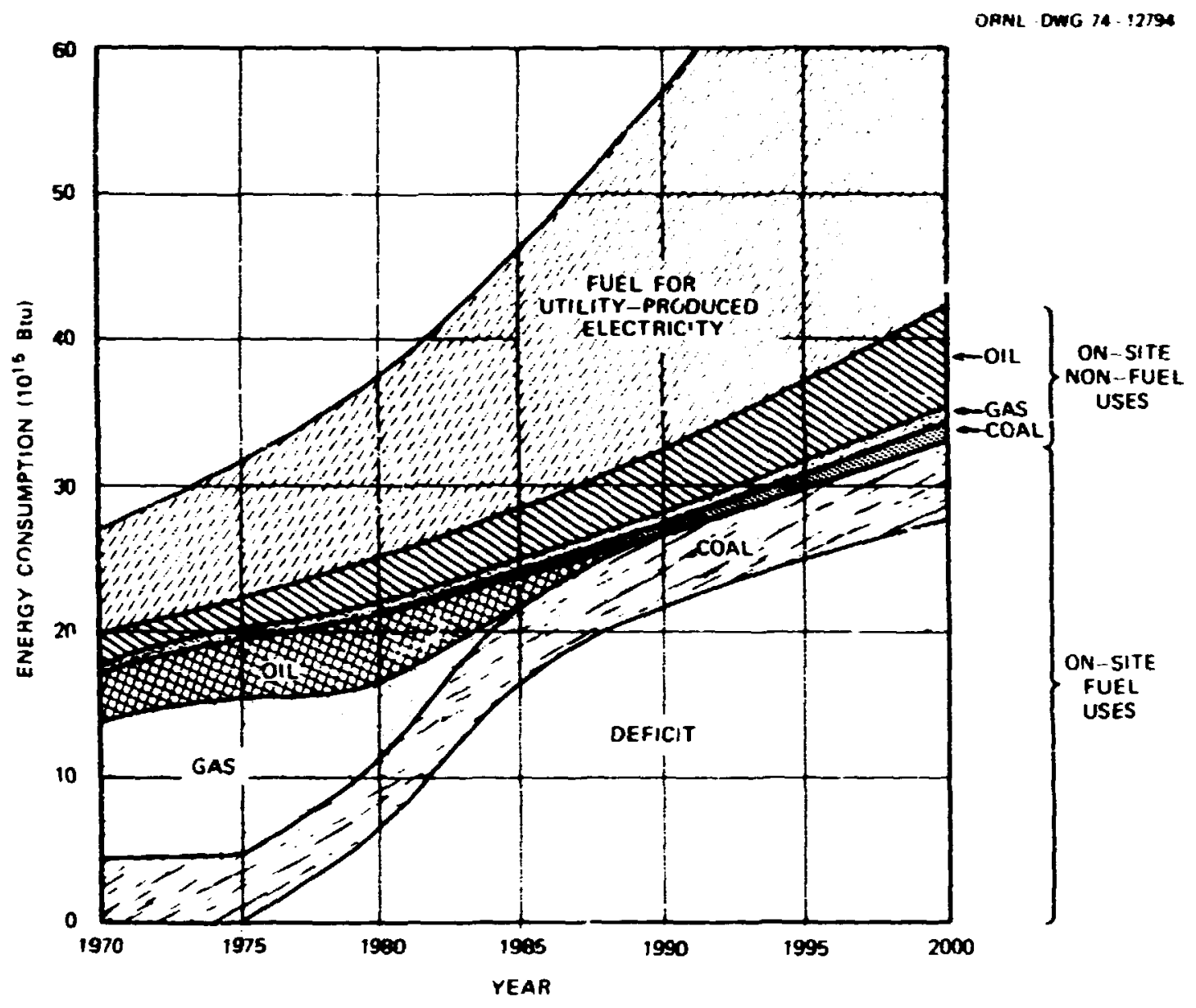

Fig. 1. Industrial energy supply to the year 2000 assuming phaseout of gas and oit.

Table 1.1. New industrial boider and process heacer capacity required in the year 2000

\begin{tabular}{|c|c|c|c|}
\hline & \multirow{2}{*}{ Peikid } & \multicolumn{2}{|c|}{ New capacit, $[M(w i t)\}$} \\
\hline & & For perind & Annual dverage \\
\hline 1975 & 1980 & 289.000 & 57.800 \\
\hline 1980 & 1985 & 449.5110 & 89.900 \\
\hline 1985 & 1990 & 222.000 & $44.4(n)$ \\
\hline 1990 & 1995 & 126.000 & 25.2000 \\
\hline 1995 & $2(x)$ & $125.5(k)$ & $25.191)$ \\
\hline \multicolumn{2}{|c|}{ Sortal 1975 2000} & $1.212 .0 \mathrm{MO}$ & 48.5100 \\
\hline
\end{tabular}

"Phvilers and process heaters assumed in uper ate at 9 r.: plant factur and with a fuet-lo-heat conversion efficiency of $85 \%$. 
I he prexint trend in industrks that bum natural gas is to convert process heaters and boilers w vil. Although most industric's recognize that this colid be a sop-gap measure. there aie essentiall! no: other alternatives at the present time. Thus. there is an urgent need to asvelep energs on sns baxed on domestic fuets for the industrial sector.

\subsection{ENERGY ALTERNATIVES CONSIDERED}

There are a number of energy systems options based on either coal or nuckear fuel. The nuclear options examined were large commercial nuckear power plants [light-uater-cooled reactors (1.WRs) or high-temperature gas-cooled reactors (HTGRs)] and a small [ 300-MW(t)] special-purpoxe pressurized-water reactor (PWR) for industrial applications. Coal-based systems selected for stud! were those tha: appear capable of meeting entironmental standards. especially with respect to sulfur dioxide: these are (1) conventional tuing using either low-sulfur coal or high-sulfur ccal with stack-gas xrubbing. (2) nuidied-bed combustion using high-sulfur coa.. (3) lou- and intirmediatc-Btu gas. (4) high-Btu pipeline-quality gas. (5) solvent-refined coal (SRC). (6) liquid boike fuels and $(7) \mathrm{n}$ ethanol from cal.

Although much of the assessment of energy systems is applicable to all regions of the country. the emphasis of the study was on the Gulf Coast area. since industries in this region are large energy consumers and the primary fuel is natural gas. Since both technical and economic data en encrg! systems are changing rather rapidly. it should be kepl in mind that the assessment given in this study is based on data obtained during the first half of 1974. Furthermore. only those energy systems that have the potential for significant commercial impkementation wit..in the next 15 years were considered. Thus, energy seurces such as breeder reactors. fusion. and solar uere not examined. 


\section{Results}

\subsection{DESCRIPTION AND STATUS OF ENERGY SYSTEMS}

\subsubsection{Large Nuclear Systems}

Large nuckear power plants commercially asaiable are the boiling-uater reater (BWR). the PWR. and the HTGR. Both BWRs and PWRs use slightly enriched uranium diux.'le pelkets as lusel and demineralued water as cextunt and moderator. The fuel of the $H I$ ( $i R$ is a mixture of uranium carbide thighly enriched in " $($ ) and thorium oxide. the moderator and core structure is graphite. and the coulant is helium.

All prexent reacturs were de:eloped to serve the nezd: of the eke:tric utility indastry. and. With one exception. all existing or planned large reactors are singke-purpose electricity-generating plaias. I he Consumers Poucr Midland. Mkhigan. nuckat station. which $\because$ ill commence operation in $19 \times 0$. is designed to produce both eketricity for the grid and process steam for the bou (hemicui Company complex located n:arby

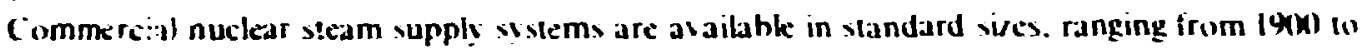

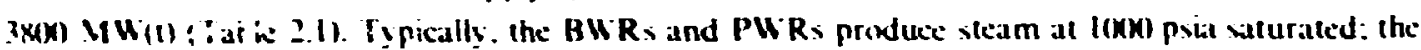
HI (iR steam conditions are 2400 pola and $510(950)$ F).

Tabke 2.1. Commetial nuckear steam supply șistems

\begin{tabular}{|c|c|c|c|}
\hline & & Reatiot type & \\
\hline & BWR & PWR & HTC;R \\
\hline Sumber al L.S manutdeturers & 1 & 3 & 1 \\
\hline Sire range. Yhit! & $1956 \quad 3833$ & 1882 IXI8 & Z(MN) $3(1)$ \\
\hline Steam sinditurns. pris & $\begin{array}{l}\ln +1) \\
(x-1) .\end{array}$ & $\begin{array}{c}9151125 \\
\text { ist. }\end{array}$ & $\begin{array}{c}2410 \\
145011\end{array}$ \\
\hline
\end{tabular}

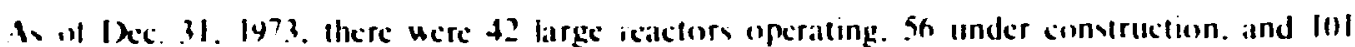
planned or on order. The large sice of the units. coupled with a relaticels comples regulatory proces. results in a long perind of planning ald construction totaling 7 (1) (1) vears. Nlter a

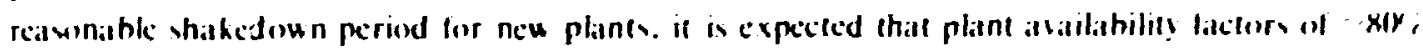
vin he achiesed.

\subsubsection{Srnall PWR}

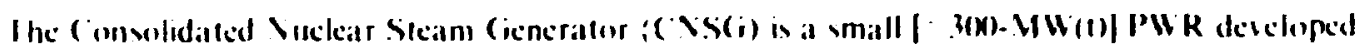

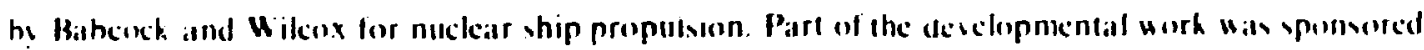

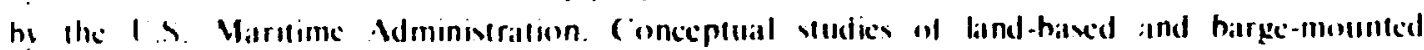

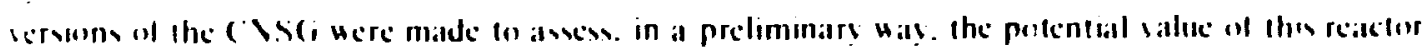
lin molustral applealiom 


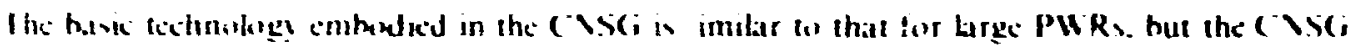

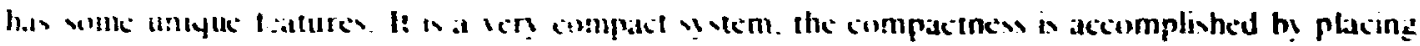

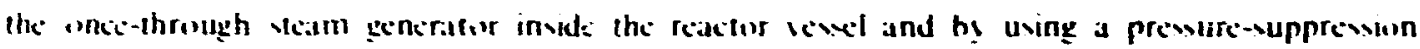

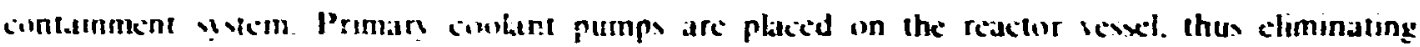

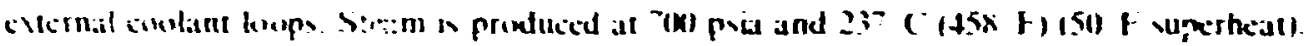

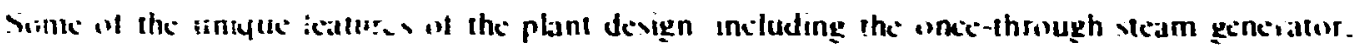

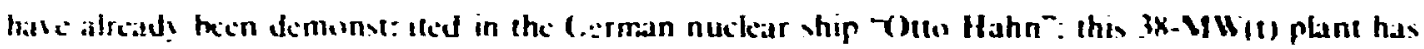

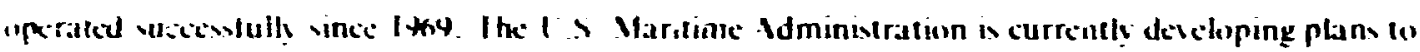

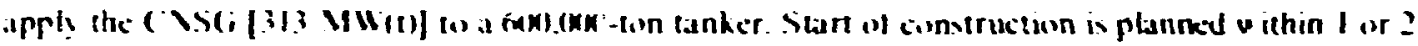
scars. It would appear that onls a smatl imount of decelopment woukd he reyuired to adapt the C.Si lindustral uxe.

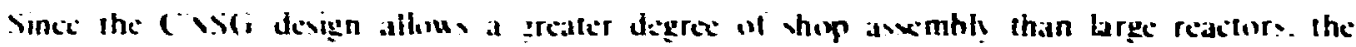

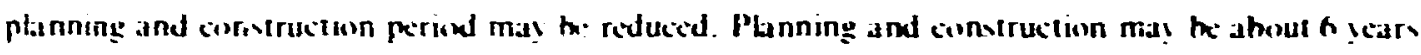

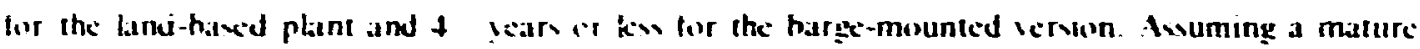

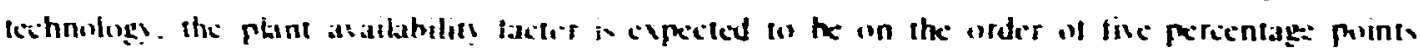

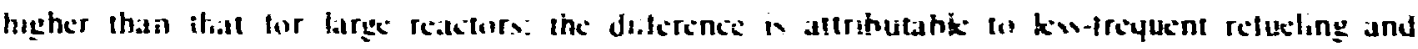
reduced relueing lins.

\subsubsection{Direct Coal Fuing}

Withen environen:ntal constraints. there are threc methods ot directl using coal for buikers 1 ou-sultur coal can $x$ hurned in a concentional boiler will precipitators to teduce particulate enmwon. High-sultur coill can he fired in a ronsentwnal hovike cquipped with stack-gas cerubbers to $1:$ mox $S()$ or in fluidied-bed cisal combustors with limentone injection. All these methods appear

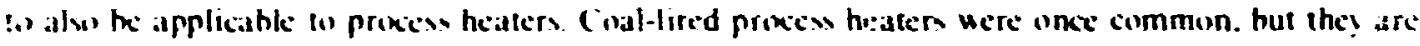
nou prexnty heing manutactured in the I nited states: they uere displaced hy gas- and oil-tired

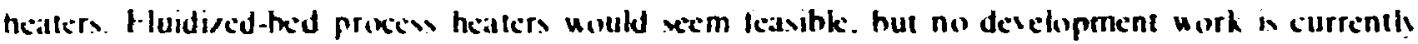
heing̣ donce.

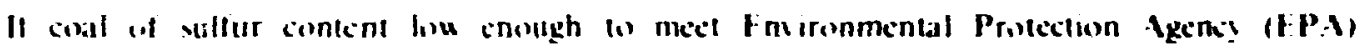

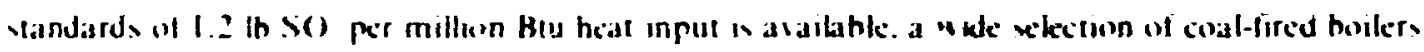

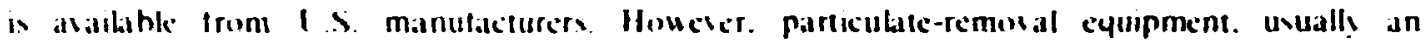

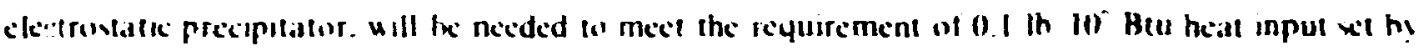
IP. Conicntional cobl-fired hoilers are avalable to produce seam at lemperatures and presures sutahle for all industral appleallons in sies ranging trom a te'u hundred pounds per hour lo everal milluen pounds per helur. Planning and constructuon perkods are on the order al 2 years, and

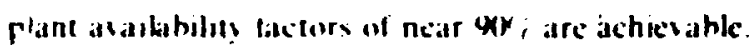

A consentwhal boike or direct coal-firce proces heater hurning high-sulfur coal woukd reyuire

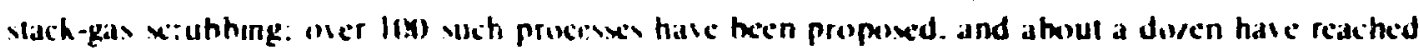

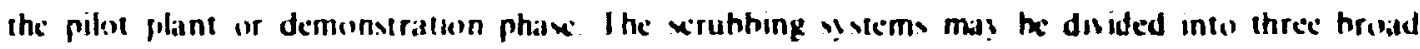

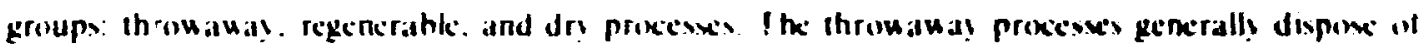

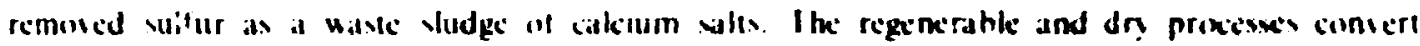

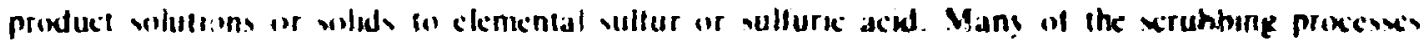

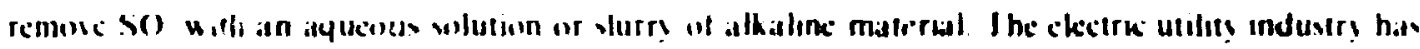
placed gecate-st :mphass an the desclopnent and demonstration of lime and limestome slurrs

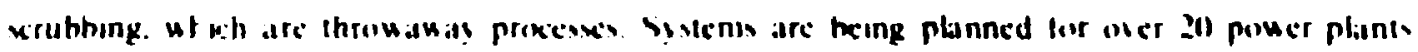


Houceer. operating experience to date has not bea entircly satisfactory hecause of xaling. pluzging. crosion. and currosion.

Fluidied-bed combustion of coal. a rebtively neu technolog! appears to the very promising as an environmentally acceptabk method of burning high-sulfur coal. Combustion is accomplished in an uncrt bed. consisting mainly of ash and limestone. which rests on a plate containing nor/ks. Conbustion air introduced throught the nowles expands the bed to a kel greater than tis static depth. Crushed coxil is injected into the bottom of the bed. Bed turbuknce aids in transferring heat Io the luci and also provides intimate mixing of fuel and air. thus promoting rapid combustion. Bed temperature is contublled at 870 to $982-(1600$ to I800- - h! remosing approximately halt of tia heat through hea: Iransfer surfaces iamersed in the bed. The relatic ely iou combustion temperature sharply raduces the formation of nitrogen oxides. and the conditions of temperature and turbulence in the bed fasor the reaction of sultur oxides and limestone. Thu: the injection of limestone is vers cllectice in reducin: $\$ O$ : emissions. Fluidived-bed hoikers are not aou commercially avalable but are under desekopment. A demonstration boiler that produces $3(x)$ (x)o lb of steam per hour [ - I(x) MU:II] is wheduled for completion in mid-1975.

\subsubsection{Gas from Coal}

There are a number of processes ior producing fuel gas Irom call. whe of which are in the desclopment slage and whers commercially asaiblak. The luel gas:s produced are clawitied acoording to the higher heating value of the gas as follows: 11 lou-Btu gas. 120 (o $2(x)$ Btu $x \cdot 1$. (2)

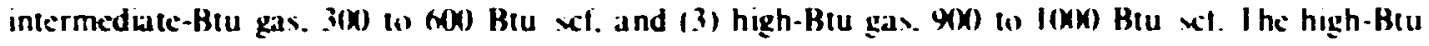
gas is similar w natural gas buth in composition and heating valec. I ahte 2.2 gives a comparison of compesitions and heating values of the coal-deri.ed gaxs.

I ou-Btu gasification is achicsed b! reacting coal with saam and air. Partial combustiun of the coal prosides the heat necessary to caux sleam to react with carhon. producing hudrogen. carhon

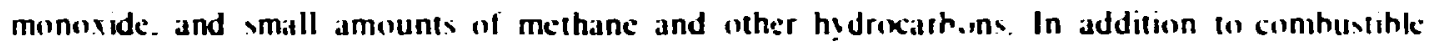
gaxs. the fucl also contains significant yuantities of $(O)$ and nitrogen as shoun in $I$ ahle 2.2. Sulfur contained in the coal appears in the gas principally as hydrogen sultide (ll.S). which can he urubbed from the fuel gas.

Table 2.2. Representative properties of kw-. intermediate. and hiph-Bu gas

\begin{tabular}{|c|c|c|c|}
\hline & \multicolumn{3}{|c|}{ (iascompositun : by vilume) } \\
\hline & I $\because \mathbf{B : U}$ & infermediate Btu & Iligh Btu \\
\hline Carhein dionde & 15 & 46 & 1 \\
\hline Garboin mencivide & 15 & 341 & \\
\hline Hydrugen & 2.1 & 3749 & 5 \\
\hline Methane & 4 & 114 & 92 \\
\hline Nifrigen & 42 & 46 & 2 \\
\hline Other hydreartous & 1 & 07 & \\
\hline $\begin{array}{l}\text { Ipprov. hugher he'atinge } \\
\text { b.slik. Hris net }\end{array}$ & 176 & $x(x) 5(m)$ & l(n)o \\
\hline
\end{tabular}




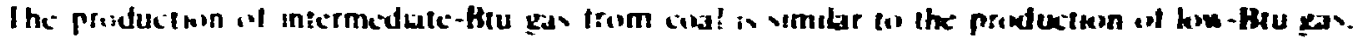

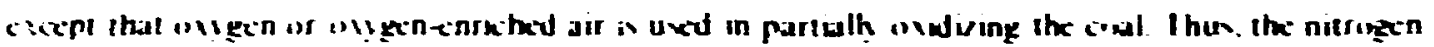
esnecent of the priduct gad N subsantally rcduced.

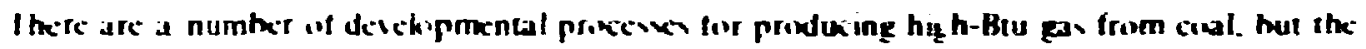

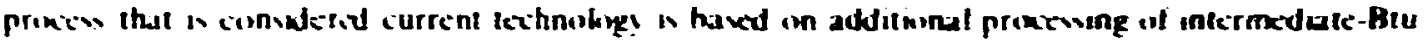

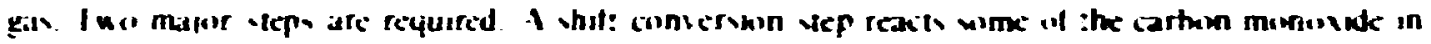

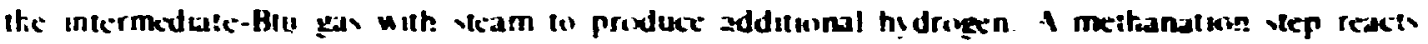

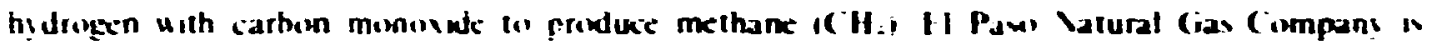

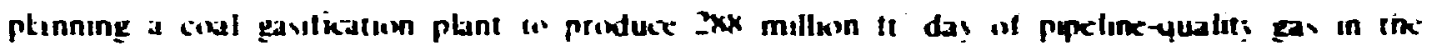

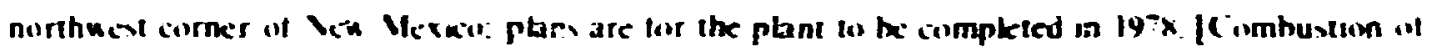

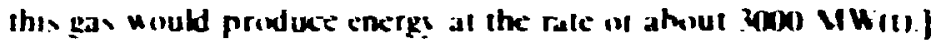

\subsection{Liquid Fuets from Coal}

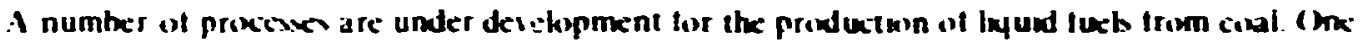

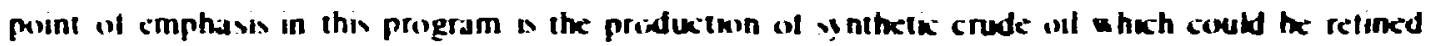

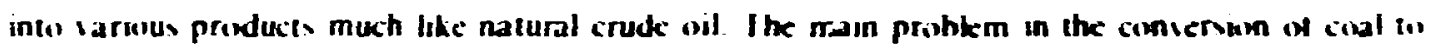

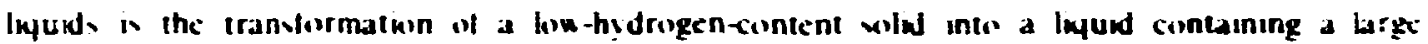

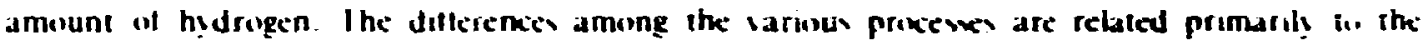
methond of hidrogenation. Siome hydrogen can he added without a cataly. hut a satalys is

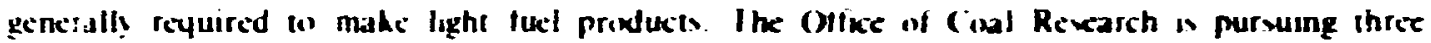
princises lore cobal liyuctaction. and it wexpected that a commercal procen will he delekiped hy the carly IYxik.

\subsubsection{Solvent-Refined Coal (SRC)}

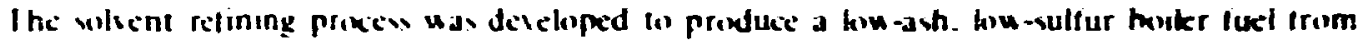
cosil with a minimum of hydrogenalion. I he product $N$ a wild al room temperature. In the SRC prikew. crushed coal 1 slurrked with anthracene-wi wisent and hidrogen. the mixture as heated in

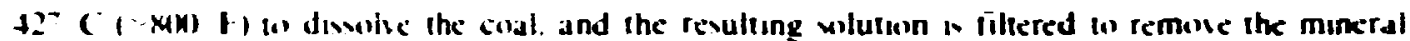

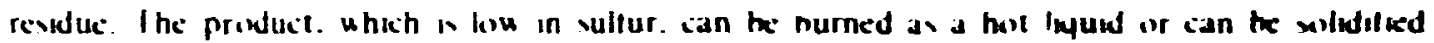

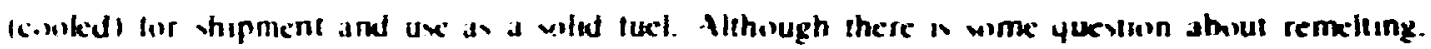

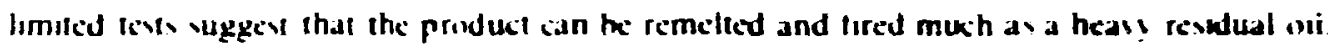

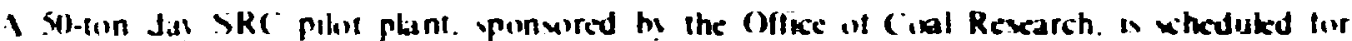

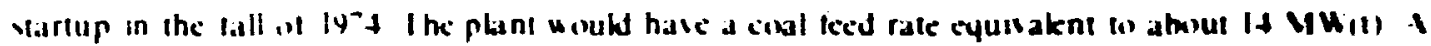

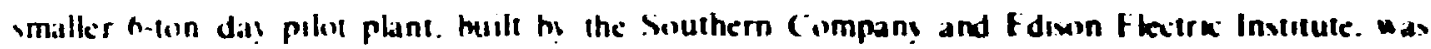

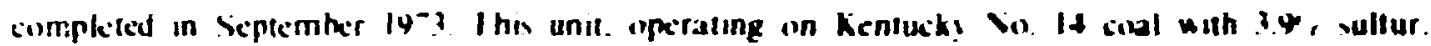

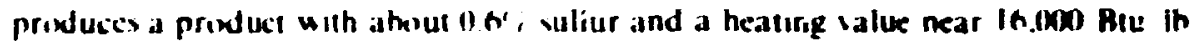

\subsection{ASSESSMENT}

\subsubsection{Rewoures}

Both coal and uranium are relaliseis ahundant. hut there are limitasuons to exphotatun tor cach. I ranium. Which is uidely diseributed in the carthis crust. W more ahundant than gobs or silet 
and about the same as moly benum or tin. Howerer. the acrage concentratun in the carth's cruss $D$

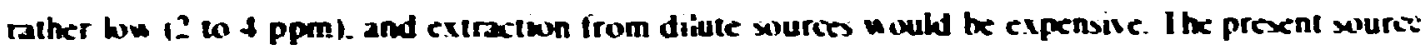
of uranium ore in the I nited Stales is contanned in sedimentan stata. partxubrly thoxe livund in the Cohwrado Ptateau and in the Hyome basin. The averagi concentraimon of uranium in prexntl! mined ore is abuut $2100 \mathrm{ppm}$ and the marlet prixe is 56 w 510 per pound of 1.0 . Knom and odimaied rexerves in conveniwnal uranium ore demosits are expected to be depleted by ihe end ot the centurn. Assumine no new mining regions are discovered. the uranium -aply will then shitt to more dilute sources.

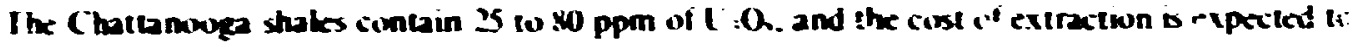
be $\$ 50$ w $\$ 100$ per puend of $t$ : (2. Other seurces of uranium include western lignite depmiss 150 it

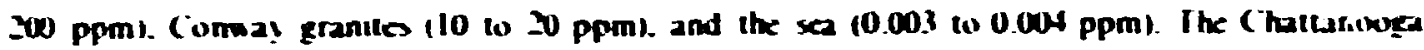

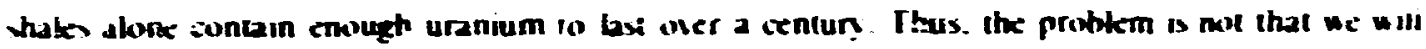
run sut of uranum but that its pros. and the ens ironmental eftects of mining hu-grade ore will

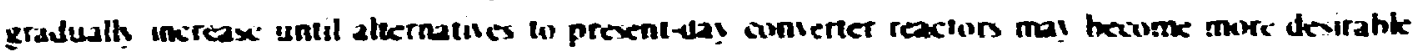

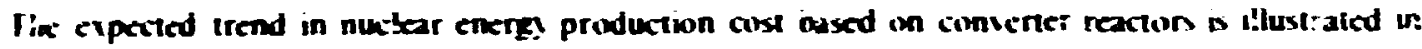

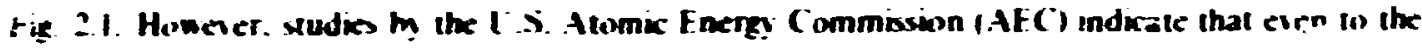
sear 300. comerter reactors will sill be more cconomical than cial for haxe-load central-siatiun

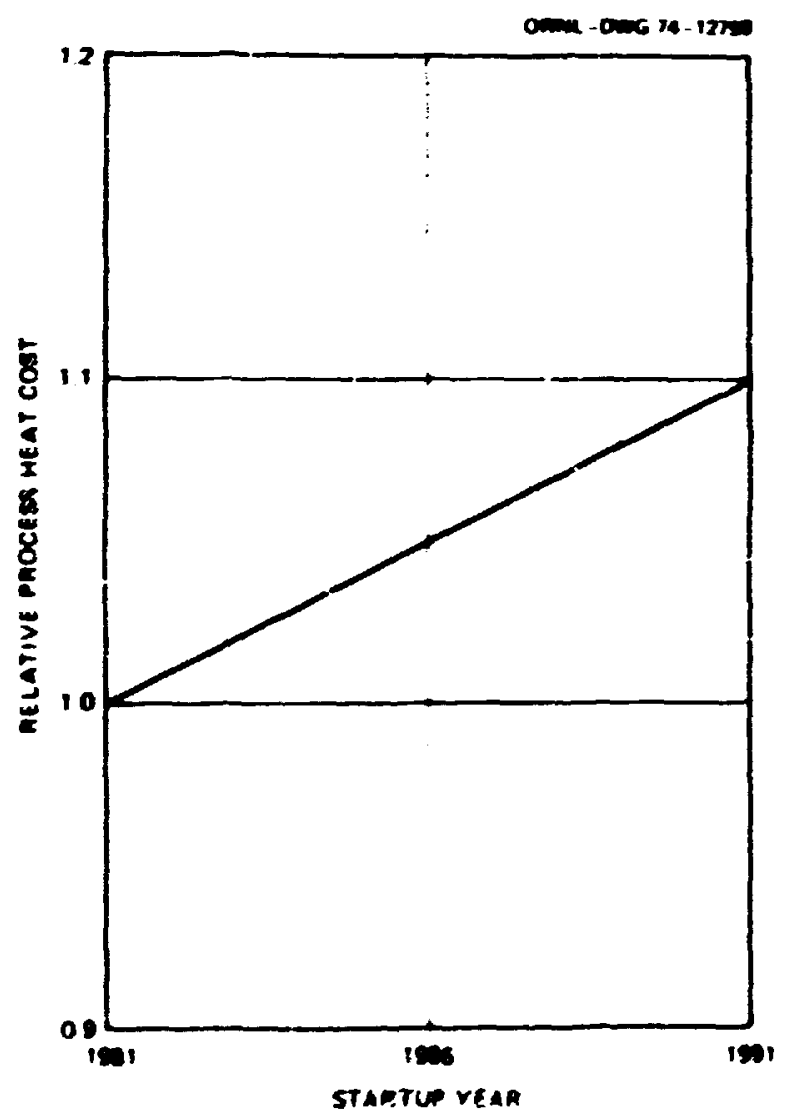

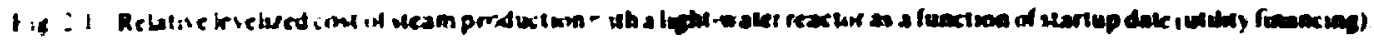




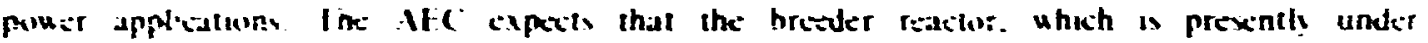

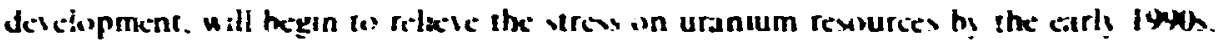

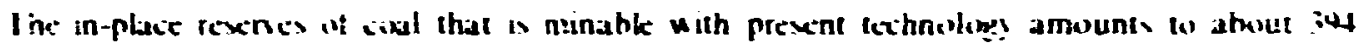

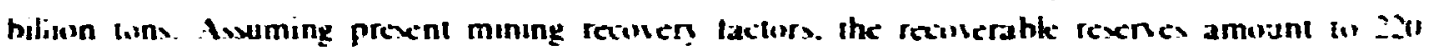

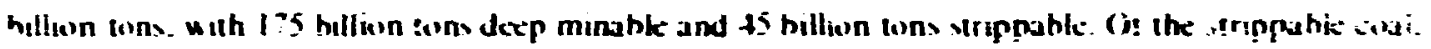

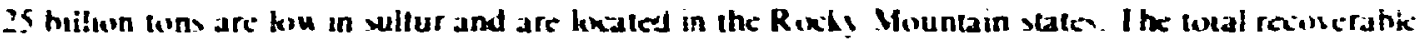

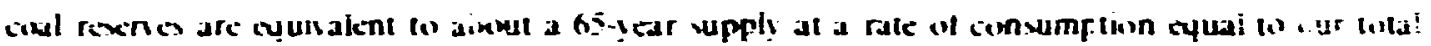

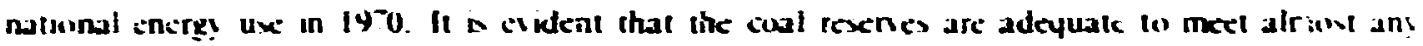

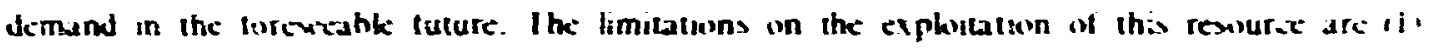
cn ironincntal cunstraints on mining. 12) coal-industn deseksment. and 1,il transportas:on.

Most at the prexnt concern atwout eavironmental etfects is relaied to strip mining. Becilix ai

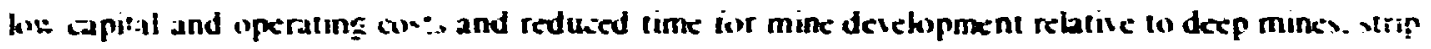

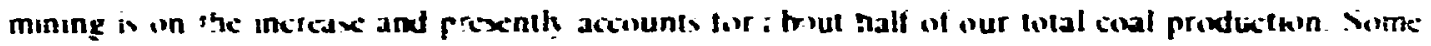

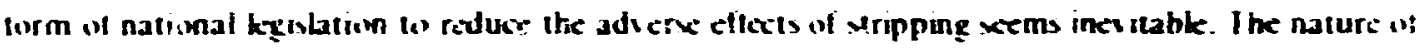

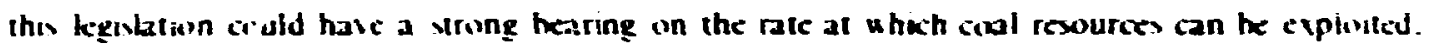
cyecialls ni, sice west. Aside from the environmental censtrants. there are other limitatwns to casi

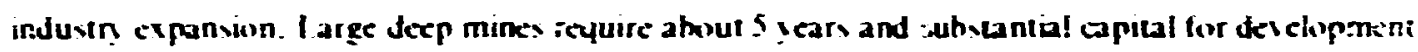
Much of the financing will need to come trom outside the coal indusiry

The transportation industry as alw an important ekment of the caral energy supply sistem. Rait transportatish is partikularị important. and iimilatkons on the rate of modemisation and crpansis'n "f this industry uill alfect the rate of coal resuurce detekpment. When all iactiors are tatien inu' ionsideration. the Vatronal Petroleum cinuncil helietes tha: coal productun idn

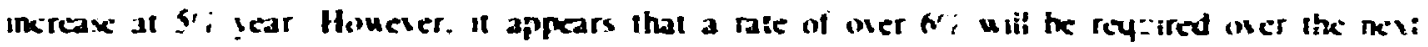
sacade w simply hold the rates of wil and gas consumption in the utility and industral wit.r. at

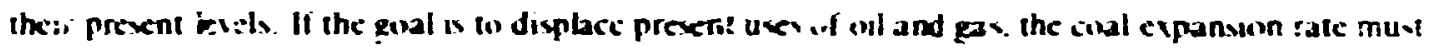
be even aigher. It appears that cial supply will be hard preved in meet demand. at kast "let !ns next dexade.

\subsubsection{General Applicability}

Industrial needs for akerg! include seam process ineat. ckectricity. and chemsal teedvikh. Blochs of energy san in we from a few to veveral hundred thermal mega watts. Much of the cursent reed for new cnergy ssstems is for retrofiting evisting industral plants inai are prexntly hurning gas or oil. hut there as abo a need for energ! systems ur expanswn of present plants and fur ncu "grass roots" industrial plants. Ihe energ: altematives consideted in this study crhibit difictent degrees of Rexibiinty rebline to meeting the various reyuiremenis for undustria' energ? syscms

\section{Sine}

The question of how well the output of indinidual supply systems math the consumptrin il energy is of significance onh for the nuclear systems. (ienerally. the commercial nuckar powci plants produce more energy than undividual industrial plants can use. Even for barge petrot:um refineries. which are among the most energy-intensive industrial operations. there is a mismalih between the output of commetcial reactors and refiniry energy needs. For exampk. it

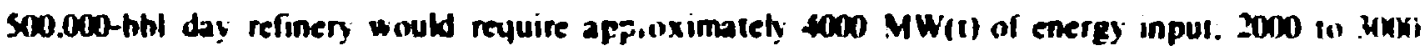
MW!t) of this would the hased on purchased fuels. and tixe remainder would be supplied hy 


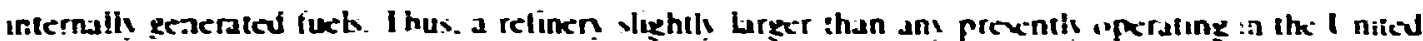

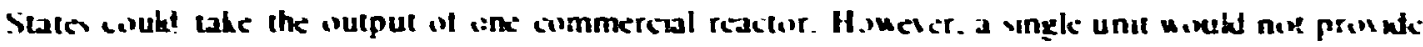

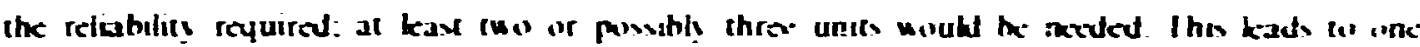

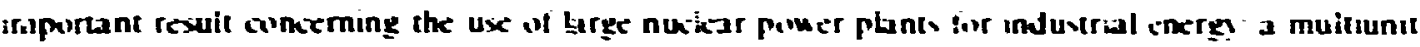
stathen will be needed. and the output will he hared by a provep it indusriai plants or by wik of

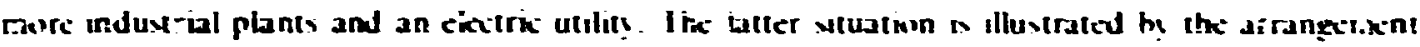

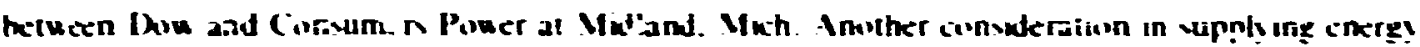
trom a nukkar power satmon to wutị ing indewrxs s that thermal energ. whether it the team or prinens heat. mes need to be transported wer a cennatershte distame

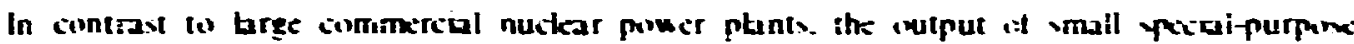

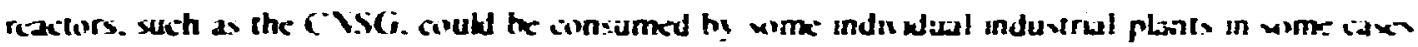

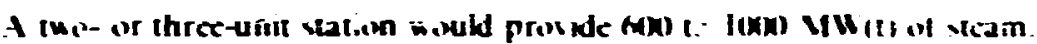

\section{Application by energy form}

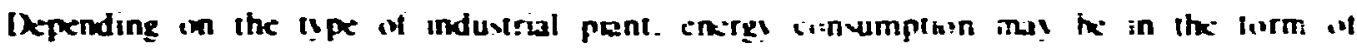

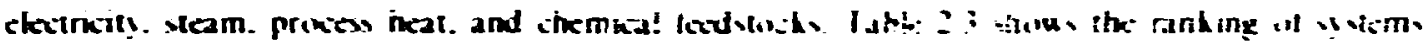

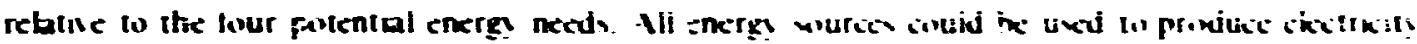

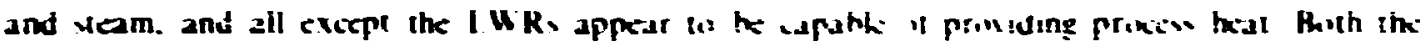

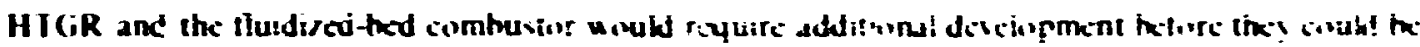

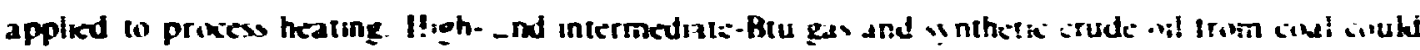
be used as wurces of cher inal feeds'inch.

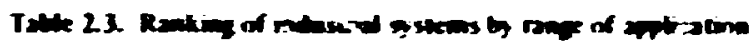

\begin{tabular}{|c|c|c|c|c|}
\hline surem & I ketrats & Sicem & $\begin{array}{l}\text { Mriness } \\
\text { bes: }\end{array}$ & $\begin{array}{l}\text { (thempind } \\
\text { iesturith }\end{array}$ \\
\hline 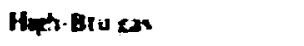 & - & - & - & $=$ \\
\hline Irotermabie biu on & - & . & & • \\
\hline lefind I axts & ' & - & . & 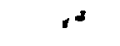 \\
\hline Low-mugr & ' & $\cdot$ & r & \\
\hline Sitrent-refined sast & - & - & - & \\
\hline F hudared bed corminusts & , & , & .0 & \\
\hline Coventinual forms & · & $\cdot$ & $\therefore$ & \\
\hline HTr;R & . & . &,$A$ & \\
\hline Small IMR & $r$ & s & & \\
\hline Lage LWR & . & $r$ & & \\
\hline
\end{tabular}

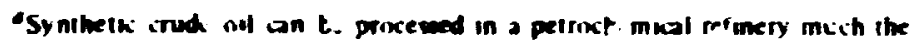
cane as matural. Heary bosker fuets from cisal would nitt be a surce of themkal feedseniks.

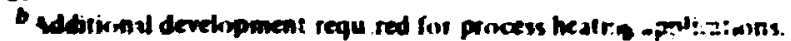

'Direcl ioatired proces healers have been used bul ate mil precently manulacti:ed in ilue L.S. 


\section{Eaxe of retrofining}

Existing industrial plants. expecally those that presenth use natural gas. may need io be sw itched to ancuther fuel in the tuture. The anking of the enere! sources by the caxe of retrotitting cristing gas-lired unstallations is as folkms:

1. high-Bru gas.

2 intermedute-Biu gas.

3. Iyund turels.

4. whent-retuned coval.

5. low -Bry gas.

6. Hindied thed comineusor.

- consentunal firing with kow-sulfur coal.

x. consenturral firing with wach eas ckanup.

Y. HICR.

I0 smal! I UR.

11. brge I UR.

Hegh- and intermedate-Btu gav Irom ival wiruld require the kasl change in existing hotien and

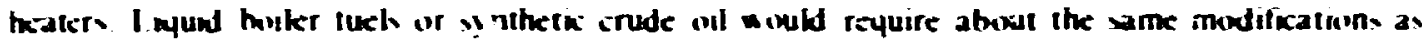

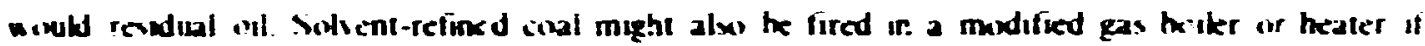

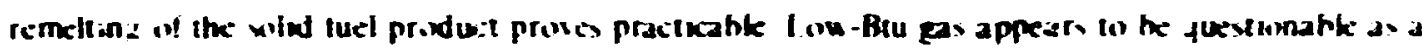

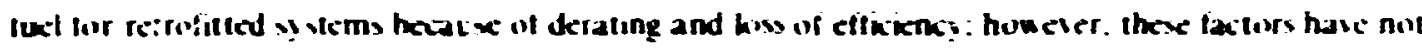

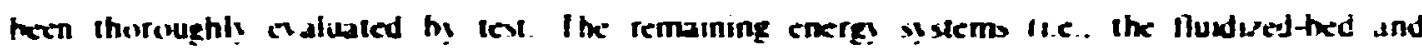

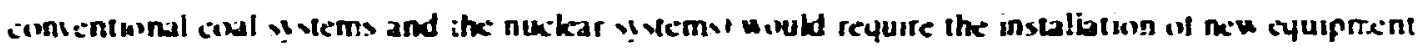

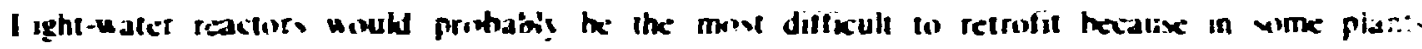

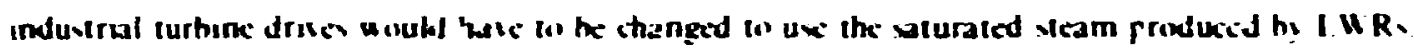

\section{Enersy acquisinion}

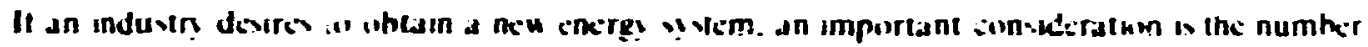

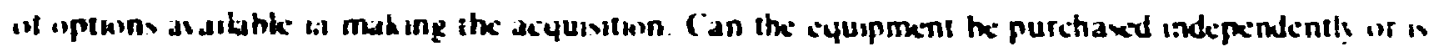

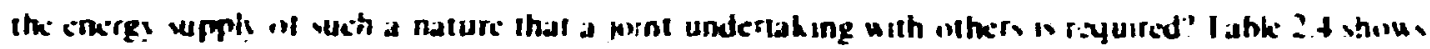

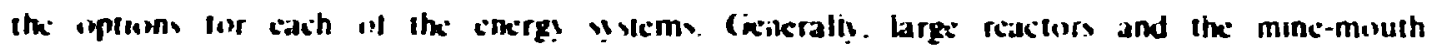

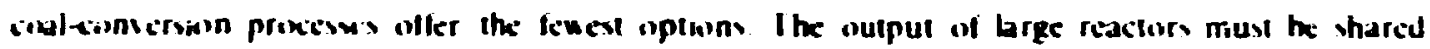

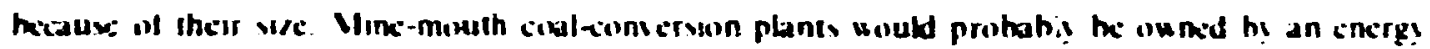
compans villing tuchs

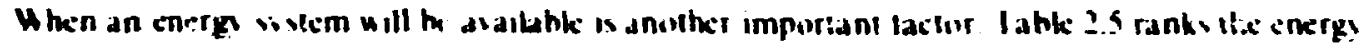

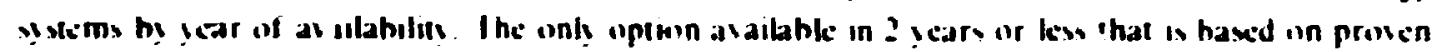

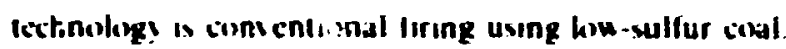




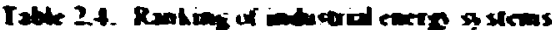
in exer's uptiunes fue zione

\begin{tabular}{|c|c|c|c|}
\hline Sistem & $\begin{array}{l}\text { Mrrithix } \\
\text { opupresa: }\end{array}$ & 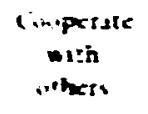 & $\begin{array}{l}\text { Puthex } \\
\text { ised .t } \\
\text { ensty }\end{array}$ \\
\hline Low- and in!r mardate-Bis ged & $\cdot$ & $\cdot$ & - \\
\hline Smalt cestans & • & - & $\cdot$ \\
\hline 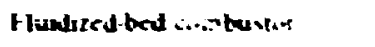 & * & $\cdot$ & . \\
\hline Cimtentanul :urnạ & · & , & - \\
\hline Lere exters & & · & • \\
\hline Iropud iueds & & $\cdot$ & $\cdot$ \\
\hline Siviventertixed ines & & $\cdot$ & . \\
\hline Hugh-Btu xss & & & $\cdot$ \\
\hline
\end{tabular}

Tatte 25. Raekmo of indestrial cacro sy stems on date of eartest conmmacidiration if application

\begin{tabular}{|c|c|}
\hline Sysiem & bu:c \\
\hline 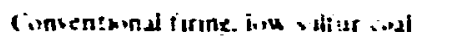 & 14in \\
\hline Conventernal tume-stsk & $107 \mathrm{n}$ \\
\hline Lum-Biugesis & Iwin :s \\
\hline Intermeduta hlu gas & llith $7 x$ \\
\hline Fludized-bed inmbuss, rs & $1977-9$ \\
\hline Swtvent-resined ins $\mathrm{F}^{\mathrm{s}}$ & $1474 \times 1$ \\
\hline Lquad tuels" & I JNI X: \\
\hline Lorre nucless puswet plonis & $\mid 4 \times 1 \times 4$ \\
\hline Small nudeat puwer phonts & $198 \mathrm{i} \quad \mathrm{N4}$ \\
\hline Heb-Blu goss & $197 x^{\circ}$ \\
\hline
\end{tabular}

IDif commeriully dermonstrated.

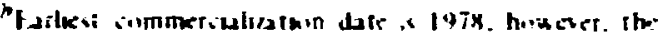

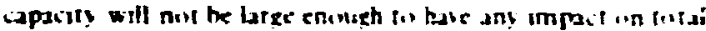
as rupoty.

\subsection{ENVIRONMENTAL CONSIDERATIONS}

\subsubsection{Nuclear}

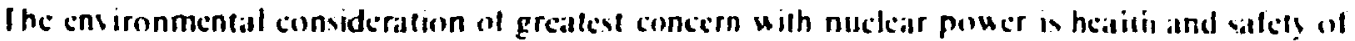
the puhlic. I his wue is complex. hut it hasicalts insolses profection of people againd any harmfui

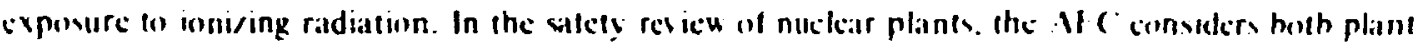
devign fealures and environmental eharacleristics that combl aderacly alfect fhe plants silets

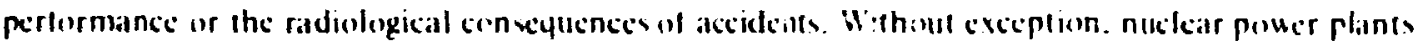




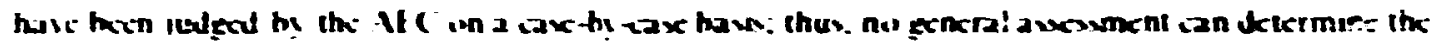

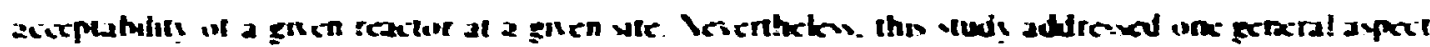

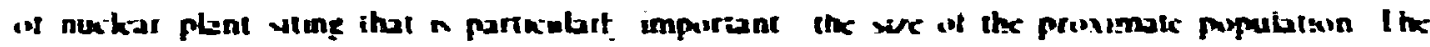

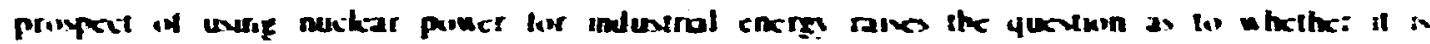

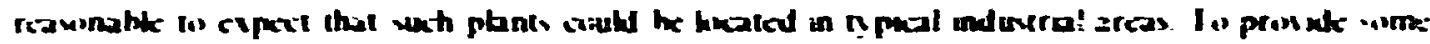

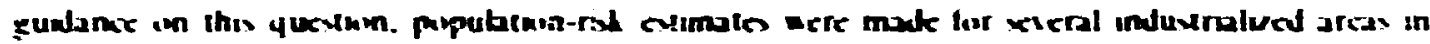

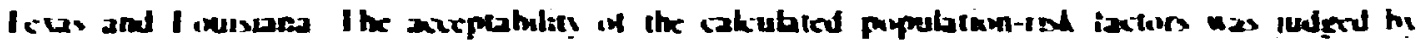

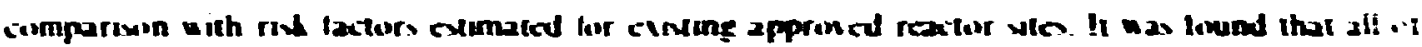

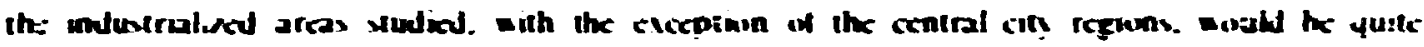

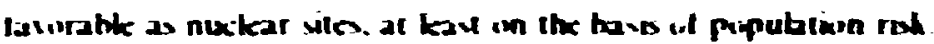

\subsection{Couthased Sysars}

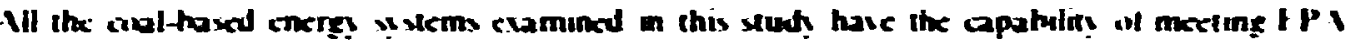

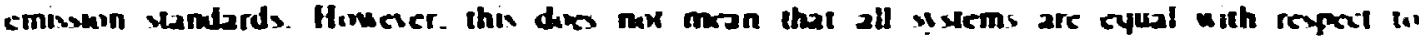

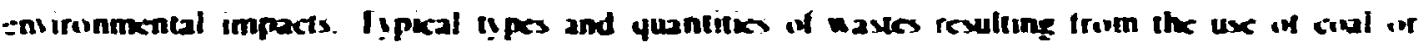

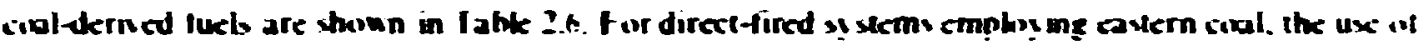

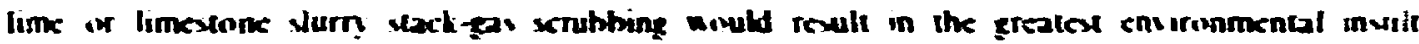
herause ite shudec produced is nox elen suitable as bnd fill unkes it o whected bo further treatencent

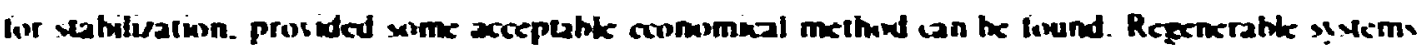

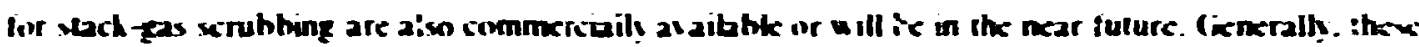
sysems recoser ulfur in the form of welfurk aed or ekmental sulfur. the batter heing more

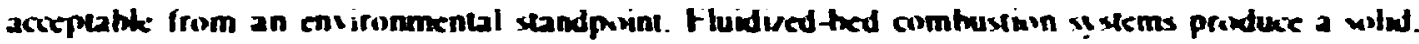
readily handled residue which would he suilahte as bind fill ar possibly for road or mawnr construction. The processes for coalderin ed fucls produce wume sald wasic in the form of ash. char.

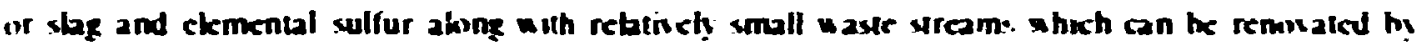

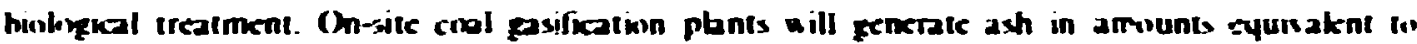
direcr-fired ssstems. and the ash can he handied in a conceniunal manner. I or mine-musuth plants the wid wastes. including the incrt elemental sulfur if it camnox be marketed. will be returned to the mine for fill.

The coal-enniersion princesses elamined in this sud! require vaning amivunts of water as shoun in Jable 2.7. which also lists water consumplion rates for nuckar fucl processng and anl refining for comparison. Ite higher values of water consumption shom include that reyured for process or utility conding. most of which is unce-through. Whik the general irend is tou ard clowed cuaporation systems to reduce thermal pollution. Ihexe systems have a greater ev aporation hoss than one-through systems. and. conseyuently. conling water uill continue in 1 : the largesi increment of water usage. Fxeluding conling requirements. The water comsumption for the comal-conicrsonn ststems is modest. Typically in a liquefaction plant for producing fuel oil from coval, ahout $\$$; of the Intal water reyuirement is ennsumed in hydrngen production. Ahout 25; is used for scruhhing or washing the pascous and liquid product sineam. All hut a small fraction of this can he subjected in hiological treatment and recovered for reuse. By comparison. the wolvent-refincd coval process reyluites only ahout one-fifth of the water needed for conal lixucfaction processes.

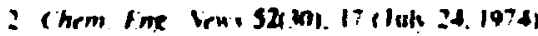


Table 2.6. Typical wastes generated when using coul or conlderi od fuels fns boilor or protesu heat fuel

\begin{tabular}{|c|c|c|}
\hline Methud of cabal urilization & Characteristicer of waste product & $\begin{array}{l}\text { Approximale quantity of wasle } \\
\text { available in fiutl }\left(1 \mathrm{~b} / 10^{6} \mathrm{~b}(\mathrm{u})\right.\end{array}$ \\
\hline \multicolumn{3}{|c|}{ On-sile utilization } \\
\hline \multicolumn{3}{|l|}{ Cunventiunal fin... } \\
\hline $\begin{array}{l}\text { Low-sulfur (western) coul } \\
\left(<0.5 \% \text { S, } 4-8 x_{i} \text { ash) }\right.\end{array}$ & Dey ash, yasuous $\mathrm{SC}_{2}$ & S II) Ib d ah: $r 1 \mathrm{lb} \mathrm{sO}$ \\
\hline \multicolumn{3}{|l|}{$\begin{array}{l}\text { High-vulfur (easter:, cual } \\
(312 \% \text { S. \& 20: ash) }\end{array}$} \\
\hline $\begin{array}{l}\text { Lime or limestune siurry } \\
\mathrm{SO}_{2} \text { removil for stack teas }\end{array}$ & $\begin{array}{l}\text { Thixutrupic sludye } 130 \cdot 60 \% \text { water mixture } \\
\text { of lime ZaSO, and axh }\end{array}$ & 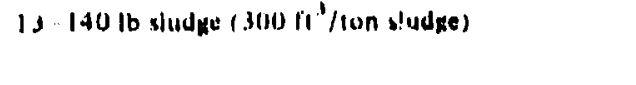 \\
\hline $\begin{array}{l}\text { Rezuse yable scrubbing to } \\
\text { remove } \mathrm{SO}_{2} \text { from stick gas }\end{array}$ & 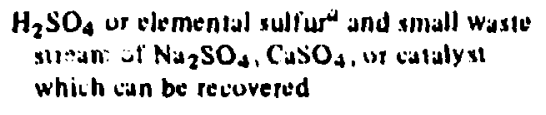 & 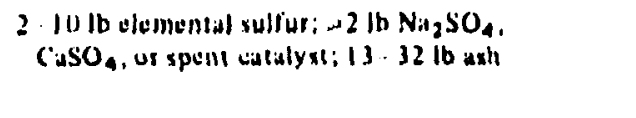 \\
\hline $\begin{array}{l}\text { Flujdiced bed conibustion usink } \\
\text { limestun: injection for } \mathrm{SO}_{2} \\
\text { abateinent }\end{array}$ & Diy residiae sumpoxed of ash and $\mathrm{CaSC}_{4}$ & y 30 lb of dry solids. \\
\hline \multicolumn{3}{|l|}{ Coalderiver luuls } \\
\hline $\begin{array}{l}\text { Low-and intermediale-Biu gas lirum } \\
\text { castern coal }\end{array}$ & $\begin{array}{l}\text { Dry ash. elemental sulfur, acid wash waler } \\
\text { (which must be truated before disposa!) }\end{array}$ & $13=2$ lb ash, 2 l'l lb sulfur, I lb wash water \\
\hline \multicolumn{3}{|c|}{ Mine.unouth production (castorn coal) } \\
\hline No. 4 and No. 6 ty pe luel oils & $\begin{array}{l}\text { Eilemental sulfur, wasle yas }\left(\mathrm{CO}_{2}\right) \text {, char, } \\
\text { waste water }\end{array}$ & $210 \mathrm{lb}$ sultiur, $\sim 107 \mathrm{lt}$ waste kus, $\sim 7 \mathrm{lb}$ chur \\
\hline Sulvent-lelined coal & $\begin{array}{l}\text { Ash, waste water (ttealed), clemental } \\
\text { sulfur }\end{array}$ & I S lb sulfur, $13190 \mathrm{lb}$ axh, $60 \mathrm{lb}$ waste water \\
\hline Hikh-Biu kass & Elamental sulfur, wasle yas a.ad water, slay & 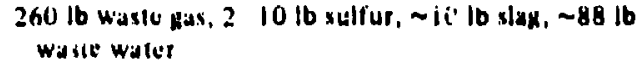 \\
\hline
\end{tabular}

aSulfuric acid is lexs desirable, since it has limiled commercial value and cannot be transported ecunumically except fur short distances. liemental sulfur has commercial value and will therefore not neciessarily be disciarded as other wasce products. 
Tabte 2.7. Wiater usage tor

enerp tourarsion provestes

\begin{tabular}{|c|c|}
\hline Process & Love (gal; $10^{\circ}$ Btu) \\
\hline 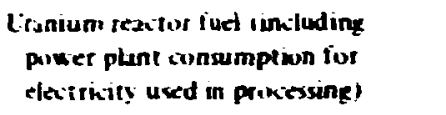 & 14 \\
\hline Ohi rt:ining & 7 \\
\hline \multicolumn{2}{|l|}{$\begin{array}{l}\text { Pipet. ne gas from anal ilurgi } \\
\text { prov =3s) }\end{array}$} \\
\hline Water cinoling & $72 \cdot 158$ \\
\hline Partal its of demand) air coving & $37-79$ \\
\hline OH front cioal & 31200 \\
\hline Sitvent-retuned cisal & $6+10$ \\
\hline
\end{tabular}

\section{ECGNOMICS}

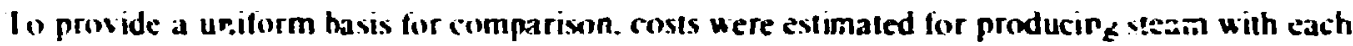
of the eneigy systems considered.

\subsubsection{Capital Investments}

The capital insestments that must he made at the industrial site. shown in Table 2.8. range from

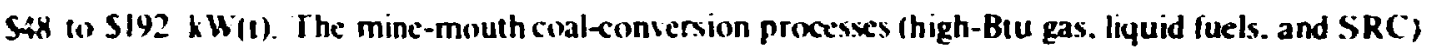
reyuire the least investment at the industrial plant. but. as will be discussed later. fuel costs are relatively high. Of the coal-haseu systems. low- and intermediate-Btu gas processes requir: the

Table 2.8. On-site capita investments required per anil of steam production (early 1974 dollers)

\begin{tabular}{|c|c|}
\hline System & $\begin{array}{l}\text { Unit investment } \\
{[S / \mathbf{k} W(t)]}\end{array}$ \\
\hline Iligh-Btu gas & $48^{\alpha}$ \\
\hline B.ivent-sefined cual or liquid fuels & $48^{\circ}$ \\
\hline Convintinnal firing with low-sulfur coal & 58 \\
\hline$\therefore$ luidized-becí Iniler & 6) \\
\hline $\begin{array}{l}\text { Conventionai furing with highsi fur coal } \\
\text { and start-ps scrubbing }\end{array}$ & 73 \\
\hline $\begin{array}{l}\text { Commercil LWR, 2-unit st (ion. } \\
\text { I875 MW(1) each }\end{array}$ & 93 \\
\hline $\begin{array}{l}\text { Commercial IITC;R, 2-unit sfution. } \\
2000 \mathrm{MW}(1) \text { each }\end{array}$ & 105 \\
\hline Intermedia,c-Btu gas & 129 \\
\hline Low-Btu gas & 141 \\
\hline Bargemounted CNSG;. 2-unit station, 314 MW (t) each & 154 \\
\hline Lind-tased CNSG, 2-unil station. $314 \mathrm{MW}(1)$ each & 192 \\
\hline
\end{tabular}

a fes not include off-site investments required for mine-mouth coatecrv::sius, procesues. 
largest on-site inve:-ment because the costs of the gasification equipment and boikers are buth included. The nuclear plant investments do not include reboikers: these may be reyuired to 'solate the nuc'ear ster.m jupply system from the industrial steam system. As will be noted. the CXSGi reyuires the largist investment per unit of output. The barge-mounted version of the C.Sici is expecied to cost about 20\% less than the land-based system because it is assumed that barge-mounted units would be factory conseructed.

\subsubsection{Fuel Costs}

The prediction of future prices of energy resources is diffeult because or the current state of uncertainty concerning fossi! fucls. In this study, kevelized nuckear fuel cycle costs were estimated for reactor startup dates :9 1991 for both utility and industrial financing condilions. The estimates : 1 nuckear fuel costs were based on what seem to be reasonable projections of uraniurr: ore resurces and uses and expected trends in the cost of " $I$ separation (separative work). fukl fabrication, and luel reprocessing. Since the electric utility industry is a major consumer of both coal and nuckear fuel. it was assumed that the ka:a-ferm price of coal will stabilise at a kevel that will make it competitive with nuckear fuel for som: types of electricity generation.

I he estimated nuclear fuel-cyck costs are summarived in Tabk 2.9. Iepending on the type of

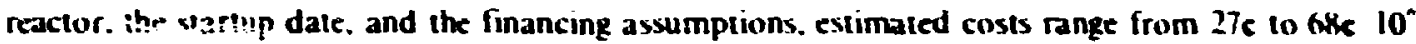
Btu.

I wo sources of coa! uere considered in this study: castem bituminerrs coal of high-sulfur content from southern Illinois or western Kentucky and wejlern subhituminous coal of hu-sulfur cuntent trom Wyoming. Estimates were made for the ensts of coal at the mine and deivered to the Ciull Coast area (specifically to Houston and lieu Orleans). The estimates are summarized in Iable 2.10. Mine-muuth values of conal $u$ ere selected so that coal would he competitive with nuclear energy lor producing non-base-load electricity. The reference coa! values are 50e $10^{\circ}$ Biu for eastern high-sulfur bituminous coal and $30 \mathrm{c} 10^{\wedge}$ Btu for western low-sulfur subbituminous coal. These alues are womewhat lower than present market prices. especially for eastern coal, hut if $u$ as assumed that prexent prices represent a esponse to a relatively short-term supply and demard situation.

Table 2.9. Reference fuet-cycte costs (evly 1974 dollars)

\begin{tabular}{|c|c|c|c|c|c|c|}
\hline \multirow{3}{*}{ System } & \multicolumn{6}{|c|}{ Start up dat: } \\
\hline & \multicolumn{2}{|c|}{1981} & \multicolumn{2}{|c|}{1986} & \multicolumn{2}{|c|}{1991} \\
\hline & Utility & Indusfrial & Etivity & Industria! & Utility & Industrial \\
\hline $\mathbf{L} \mathbf{R}$ & & & & & & \\
\hline $\begin{array}{l}d^{\prime} 10^{6} \text { B(u } \\
\text { millsikWhr(e) }\end{array}$ & $\begin{array}{l}27.3 \\
2.91\end{array}$ & $\begin{array}{l}32.7 \\
3.49\end{array}$ & $\begin{array}{c}31.0 \\
3.31\end{array}$ & $\begin{array}{l}38.0 \\
4.05\end{array}$ & $\begin{array}{r}34.6 \\
3.69\end{array}$ & $\begin{array}{c}43.4 \\
4.63\end{array}$ \\
\hline $\begin{array}{l}\text { UTriR } \\
\text { /lin" Biu } \\
\text { mills/k Whr(e) }\end{array}$ & $\begin{array}{c}30.2 \\
2.67\end{array}$ & $\begin{array}{l}38.7 \\
3.42\end{array}$ & $\begin{array}{c}33.0 \\
2.91\end{array}$ & $\begin{array}{r}43.0 \\
3.80\end{array}$ & $\begin{array}{r}35.9 \\
3.17\end{array}$ & $\begin{array}{l}47.3 \\
4.17\end{array}$ \\
\hline $\begin{array}{l}\text { (NSG; } \\
\text { d/In Btu } \\
\text { milis/k'Whe(t:) }\end{array}$ & $\begin{array}{l}41.4 \\
4.86\end{array}$ & $\begin{array}{l}52.4 \\
6.15\end{array}$ & $\begin{array}{l}46.7 \\
5.48\end{array}$ & $\begin{array}{c}60.3 \\
7.07\end{array}$ & $\begin{array}{l}51.8 \\
6.08\end{array}$ & $\begin{array}{c}68.1 \\
7.99\end{array}$ \\
\hline
\end{tabular}




\begin{tabular}{|c|c|c|c|c|}
\hline & \multicolumn{4}{|c|}{$\left.\operatorname{Cost}(t) 10^{\circ} \mathrm{Btu}\right)$} \\
\hline & \multirow{2}{*}{ Transpurtation } & \multirow{2}{*}{$\begin{array}{c}\text { Coai } \\
\text { (f.o.b. mine) }\end{array}$} & \multicolumn{2}{|c|}{ Total delinerue cost } \\
\hline & & & Base & Range \\
\hline \multicolumn{5}{|c|}{ Eastern hich-sulfur coul } \\
\hline $\begin{array}{l}\text { To New Orekans } \\
\text { ares }\end{array}$ & 18 & 50 & 68 & $55-81$ \\
\hline To Housson area & 24 & so & 74 & 6088 \\
\hline \multicolumn{5}{|l|}{ Eastern ber-sulfur coal } \\
\hline $\begin{array}{l}\text { To New Orieans } \\
\text { area }\end{array}$ & 18 & 80 & 98 & $25-110$ \\
\hline To thouston area & 24 & 80 & 104 & $90-118$ \\
\hline \multicolumn{5}{|c|}{ Western xubituminuess coal } \\
\hline $\begin{array}{l}\text { To New Oricans } \\
\text { area }\end{array}$ & 57 & 30 & 87 & $71-103$ \\
\hline \multicolumn{5}{|l|}{ To Houston ares } \\
\hline $\begin{array}{l}\text { Va New Orleans } \\
\text { Direct urit trin }\end{array}$ & $\begin{array}{l}66 \\
45\end{array}$ & $\begin{array}{l}30 \\
30\end{array}$ & $\begin{array}{l}96 \\
75\end{array}$ & $\begin{array}{l}78-114 \\
60-89\end{array}$ \\
\hline
\end{tabular}

\subsubsection{Energy Production Coss}

The extimated costs of producing steam with new installations in the Houston. Tex.. area are shown in Fig. 2.2. The steam production costs include capital charges. operation and maintenance. and fuel costs. I he capital charges depend on the financing assumptions. The assumptions made in this study, shown in Table 2.11. are intended to be a representative set of conditions but not necessarily applicable to any particular industry.

The results given in Fig. 2.2 show that large nuclear plants offer steam at the lowest cost of any energy system investigated: steam costs from large nuclear plants range from 7 ke to $144 \mathrm{e} 10^{\circ}$ Btu. deperding on reactor type, size. and method of financing. The nuclear plants are followed by the direct coal-fired systems. conventional firing and fuidized-bed combustion: steam costs range from I54e to I84c 10^ Btu. Solvent-refined coal is the most economical of the fuels derived from roal. with an estimatiod steam production cost of $215 \mathrm{c} 10^{\wedge}$ Btu. The land-based version of the C.:SC; would produce steam for about $242 \mathrm{e} 10^{\circ}$ Btu. A factory-built, barge-mounted CXsG wnuld be somewhat less expensive. but no ovarall energy cost estimates were made for this concept. The most expensive energy systems are those based on liquid and gaseous fuels derived from coal: steam production costs range from 266 to $345 \mathrm{e} 10^{\wedge}$ Btu for liquid fuels and pipeline-quality gas respectively. Methanol derived from coal (not shown in Fig. 2.2), the most expensive of all boiler fucls. would result in a steam production cost of about $400 \mathrm{e} 10^{\wedge} \mathrm{L}(\mathrm{u}$.

The results discussed above are for new installations. hut the largest near-term market for alternative energy sources is for etrofitring existing plants. Intuitively, it would seem that the coal-derived fuels. especially low- or intermediate-Btu gas. would make a better showing for the 


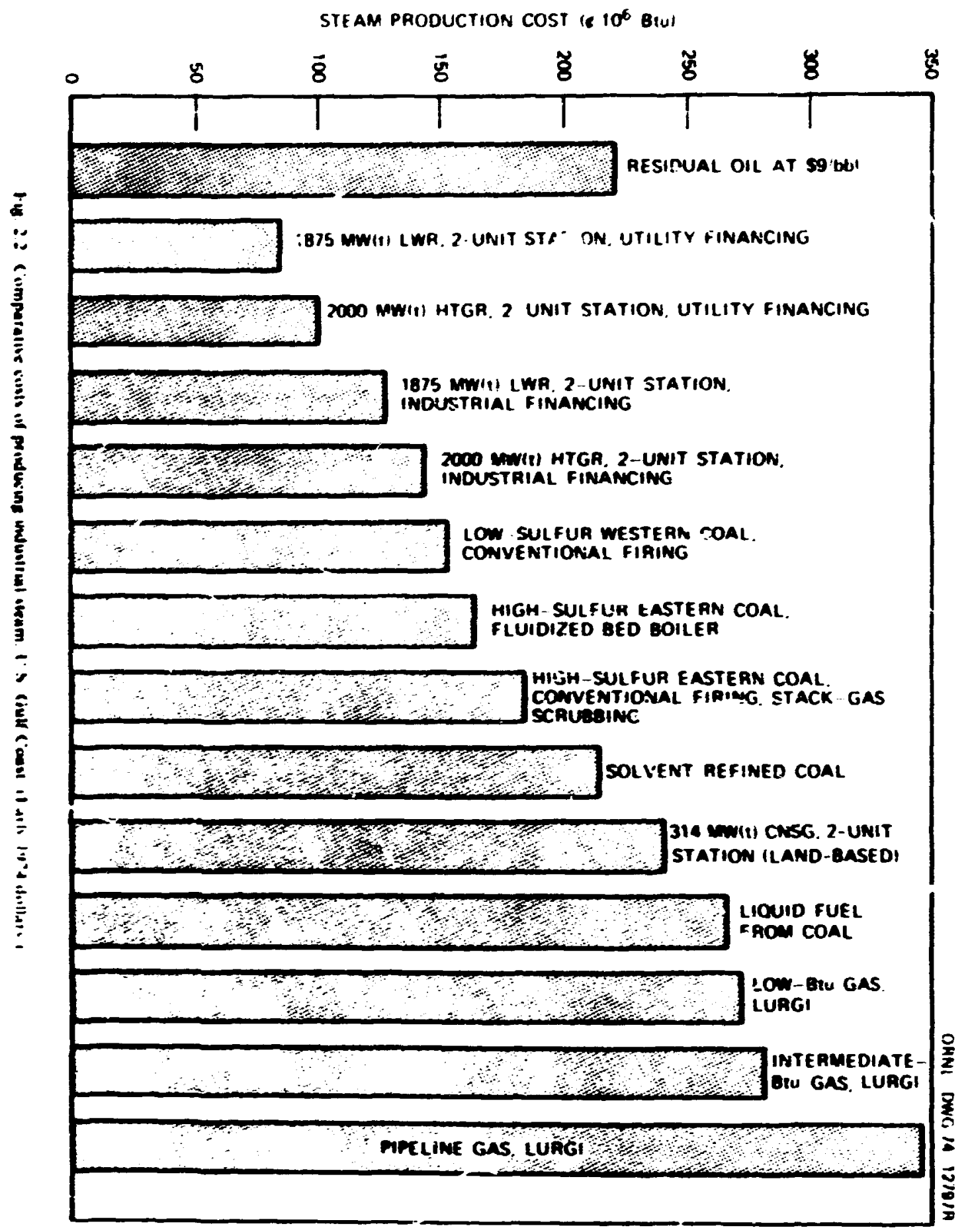




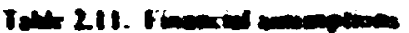

\begin{tabular}{|c|c|c|}
\hline & \multicolumn{2}{|c|}{ 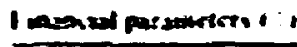 } \\
\hline & ( tabt) & Inderitel \\
\hline 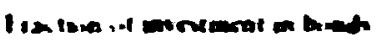 & is & 3 \\
\hline 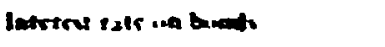 & $\mathbf{a}$ & $\mathbf{a}$ \\
\hline Mrtatis +on apuan & $1 \%$ & is \\
\hline 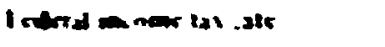 & stit & 4 \\
\hline 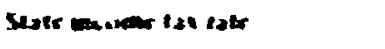 & $\mathbf{I}$ & 3 \\
\hline 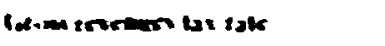 & 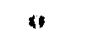 & $\omega$ \\
\hline lind proputh al este & 3 & 3 \\
\hline 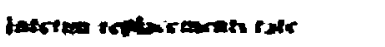 & e.15 & 0.5 \\
\hline Propres ander on & a.:e & $\mathbf{a} \div$ \\
\hline Ahat werter. iret & 30 & 90 \\
\hline
\end{tabular}

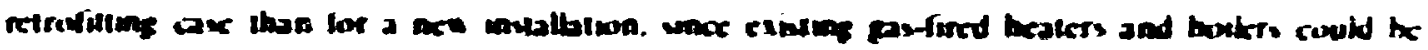

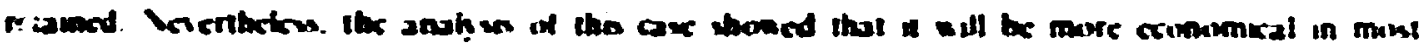

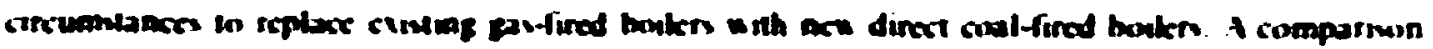

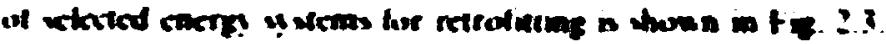

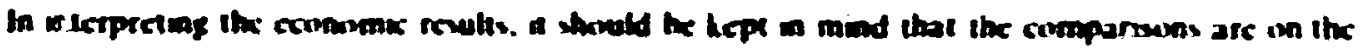

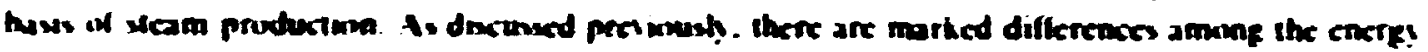

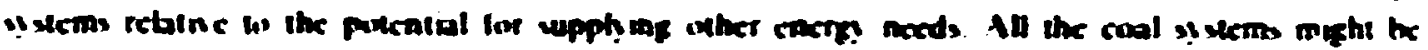

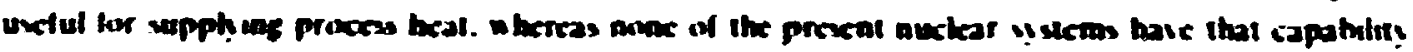

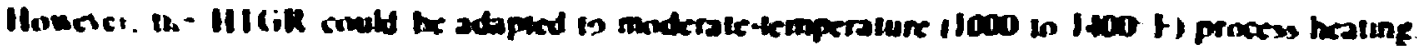

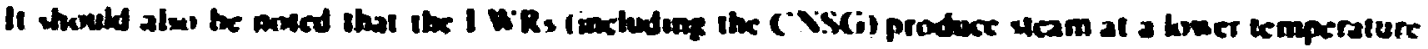

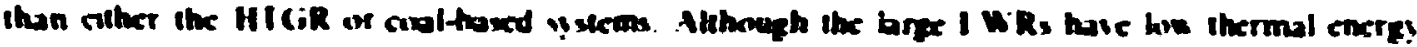

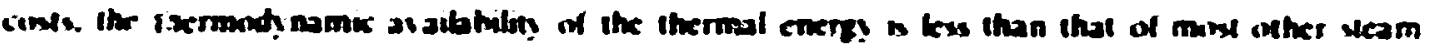

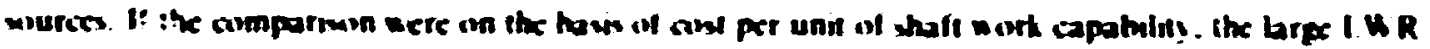

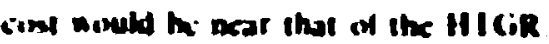

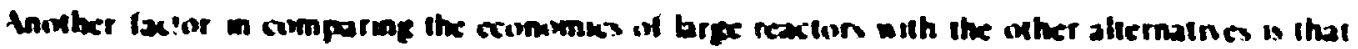

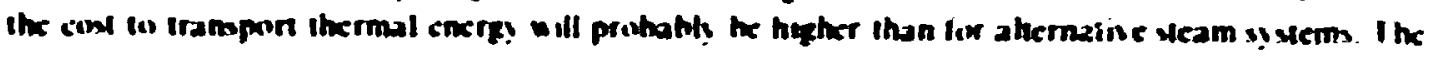

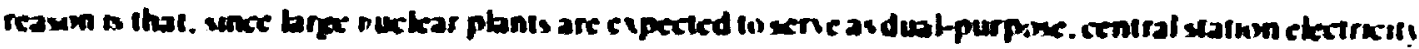

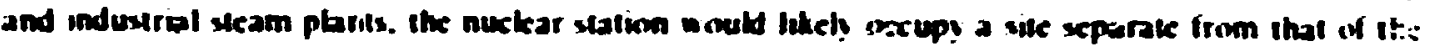

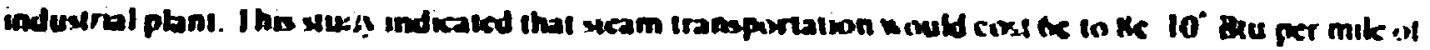
eransporn.

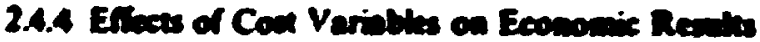

Ihere are a number of cout uncertaintives that could affect the absolute values of estimated eners cosus as well as the rebine ranking of the varwous enerny systems insestigaiced.

Estimated opital investments are mose certain for bre nuclear stations and conventurnal cual-fired hoikers and keast certain for develupmental systems wuch as nu dived thed hoikrs, small 


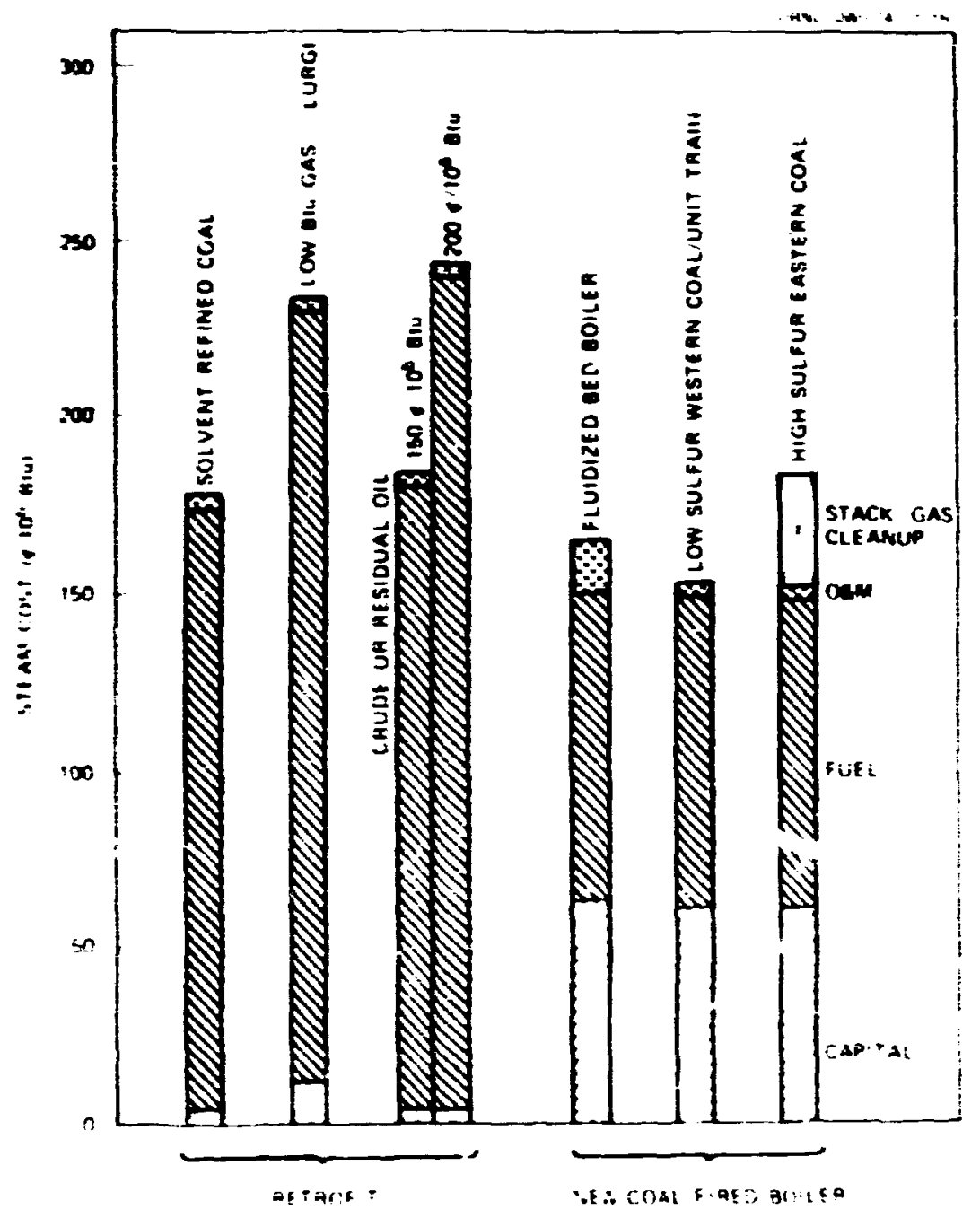

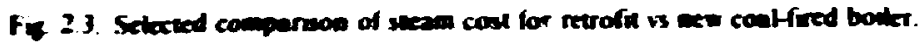

reatsors. and cralderised tuek. Whether the actual costs ol these "ystems will be more or kis ihan the colimules given in this...d! cannot be determincd at the prexent time.

The cost of mones is another important ccomomic sarbahk. and the effects of changes in the cllectic cont of mone! on veam production costs were investigaled. I he higher the cost of mones.

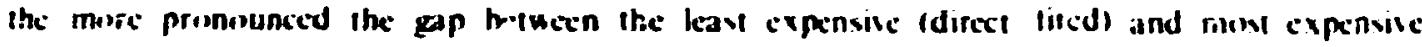

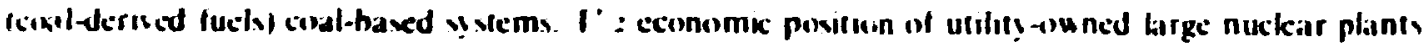

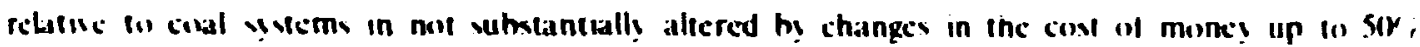
greatci than the relerence values given in Iahle 2.11. I he cont of energs production tor the small

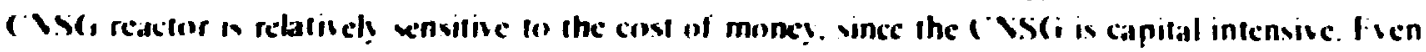
$w$ the ranking of all energs sslems hy cost is unchanged from that shou $n$ in lig. 2.2 for changes in the cout of mone! up to sur, greater than the reference values. 
Current cisi procs arc sumbentialty higher than the hise balues uxed in the present sudy. As

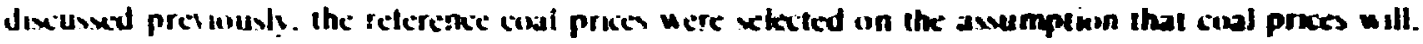
in the long tun. readjust is a competitic pusition with nucbar for uime central satum power applkatiuns. If cial prext do not declinx. 1 l) the cant ditferential hetween the direct-lired sy stems ard the cialderived tuels will hecume sen brger. hecause the direct-fired sysems are muse

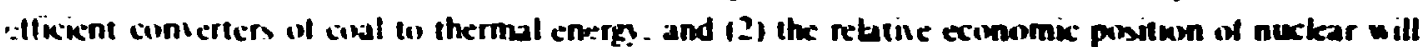
the substantiall improici 


\section{Conclusions}

\subsection{THE ENERGY NEED}

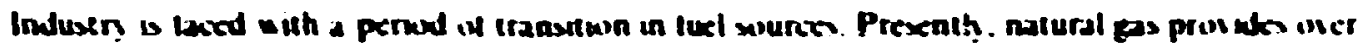

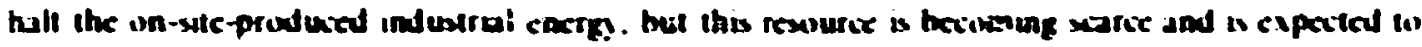

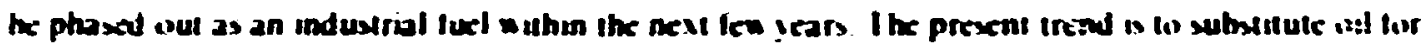

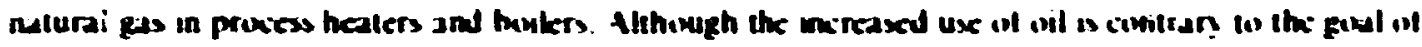

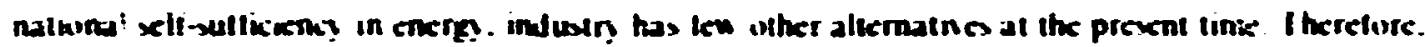

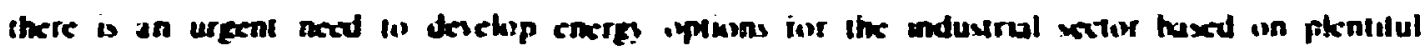
domosik inels. I hus is epeculh umpertant when it is consuleted that indus:n - insumes muse encigy than any other cimemu vatis

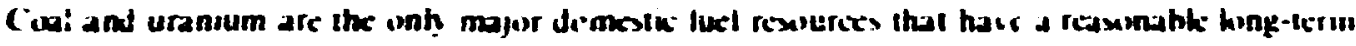

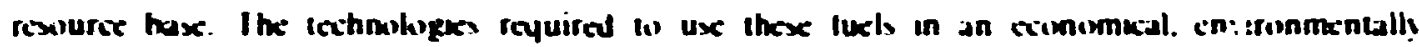

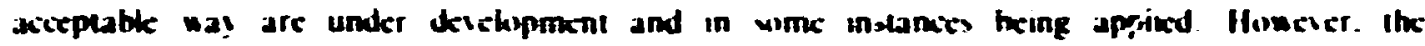

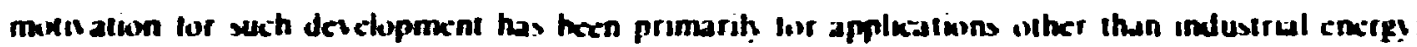

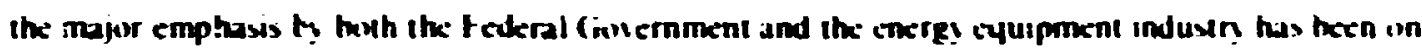

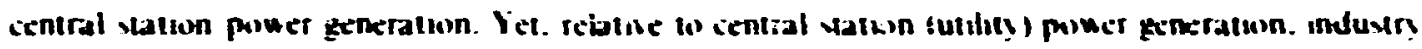
consumes nearly thice the petrektem and abuut thres tumes the natural gess. Ihus. a stringer nathonal emphasis in the industrial lukel need is justilicet.

\subsection{THE ENERGY RESOURCES}

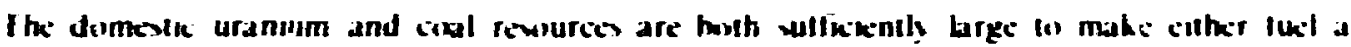

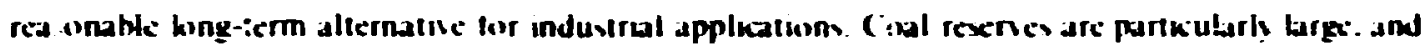

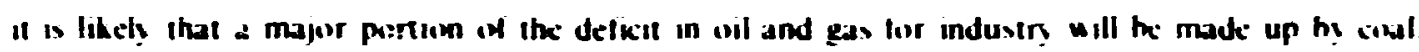

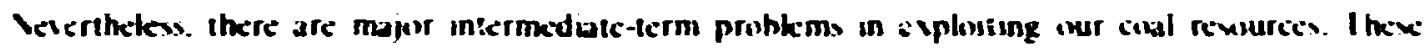

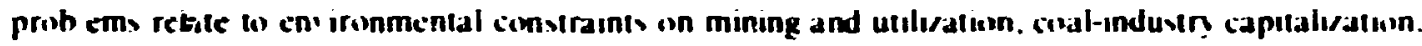
and ranoportation. When all faclors are consdercd. It appears that the woply wi cowl will he hard proved to met demand. at keast iner the nevt decade. I he current influted prke structure appears

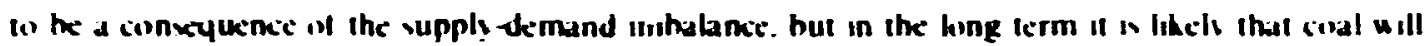

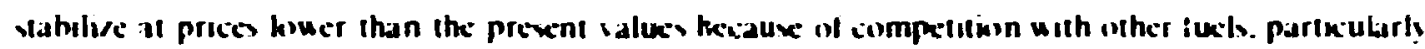
nuckar

I he high-grade I: exe:- of uranium may he deplefed hy the end of the centar!. Inuming nis

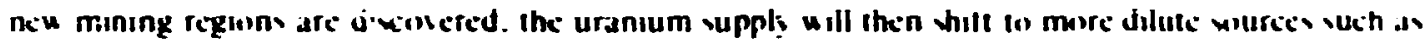

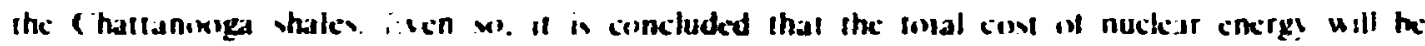

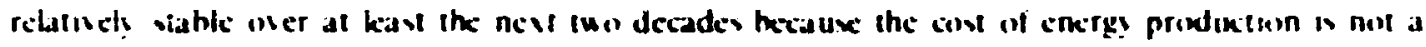
irong lunclion ol uranium a.re cont

\section{3) THE ENERGY SYSTEM CHOICES}

Cial and nucleat luel an cach erte as a has: for a number ol mientully altractusc industrul energ! yslem chokes. Hoth luek can and prohably will help allet ale the energe deficil resulting trum the decline in avaliability of nalural gav and ml. Hecauce of its brodeder range of application

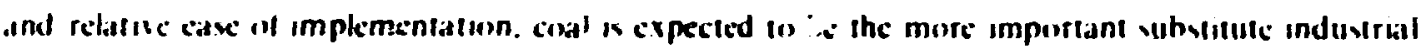

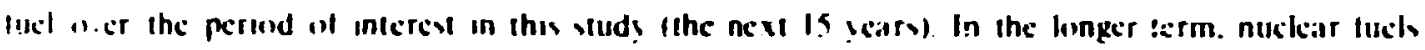




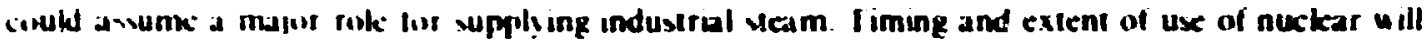
depend. in part. in ellurts espended to resolse institutional problems. Conclusions about sperisk

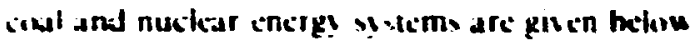

\subsection{Direct Firias of Coal}

(inencrall!. the dircet tiring ill coal in industral moikers and process heaters will he more

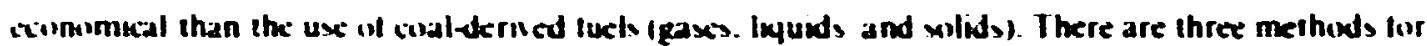

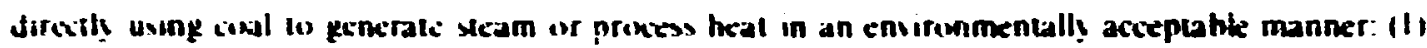
lin -sulfur civil. 12: lludiscd-bed combusinon. and 13) high-sulfur coal with stack-gas xcrubbing.

I he mont realisic coal-haxed altemative at the present time is low-sulfur coal tired in a cintentional muler. If lew-sullur coul hecomes alatable in sufficient quantities. this is the hucest-iont cial allernative in the Ciult Cinat area.

I he mont promising methind of using high-sultur coal is the fluidired-hed hoiker. If deselopment gavals are achicued. the process ofters ikexibility in fuel supply as well as low cost. Fluidired-hed combustun may also hold promix tur process heating. hut no devetopment work is heing done on lluidicathed prixiss healtrs.

Wet limestone xeruhting appears til he the kast expensive and hest developed ai the stack-gas ike,anup st st:ms With sdditiumal detelopment. thexe systems will. no doubt. become workabk. hut werall uperating experience has heen purr. Wet limestone scrubhing and other throwaway processes hase one divinet disudsantage lor industrial applkations: the large wlume of waste sludge will be Jillicult ti dispox of in many industrial areas. For this reason. it appears that urdespread industrial ux il sta:k-eils xrubhing must a watt the development of economical regenerable systems.

\subsubsection{On-Site Coal Gasifiantion}

lur-blown gasificis provducing lou-Btu gas $1 \sim 150$ Btu sct) and oxygen-blown gasitiers priducing incermediate-Hes sus : -30n Btu xefl are commercially available. Ion-Btu gas is marginalls lou er in somt. hut interm date-Rtu gas is a hetter choice for industry because $(1)$ it can he uxed as a retrotit luei lor existing gas-fired twilers and process heaters and (2) it is more readily itwhle as a chemical tecdslinh. As fucls. however. Ion-and intermediate-Btu gases are more - vpensise than dircit-fired coal. Fxlensice indusirial applications of on-site coal gasifiers will require the development ot a lou-covi intermedate-Btu gas process.

\subsubsection{Mine-Mouth Coal-Conversion Processes}

Methods are under deselopment for conserting coal to high-yuality fuels at the mine mouth: the luels to be produced include $(1)$ whlent-refined coal: $(2)$ lixuid fuels, including sy nthetic crude, hoiler luels. and methanol: and (3) pipeline-quality (high-Btu) gas.

Solvent-refined coal is potentually the least expensive of the coal-derived iuels and looins especially promising if it can he remelted and used in the same manner as residual oil.

I.iquid boiler fuets may have promise for the future. hut the cost is likely to exceed that of SRC.

The technology for nroducing methanol from coal is well developed. but the cost is too high for its use as an industrial fuel. Methanol is presently an important chemical feedstock. and this is the most likely use for coal-derived methanol. 


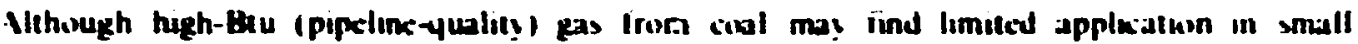

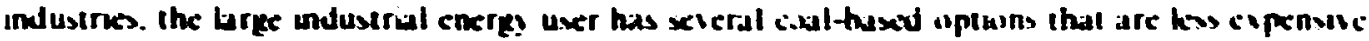

\subsubsection{Nuctear Enero}

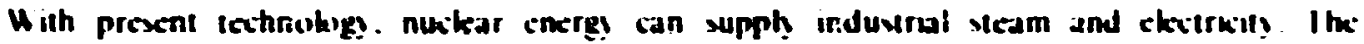

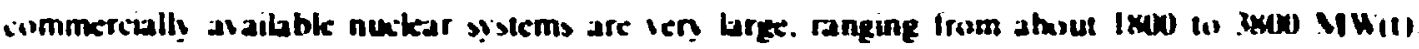

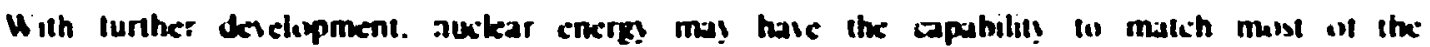

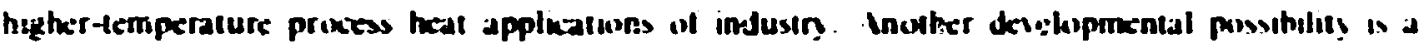
smalter reactor that mure nearh matches the energe demand of industrial planis. (me impurtant

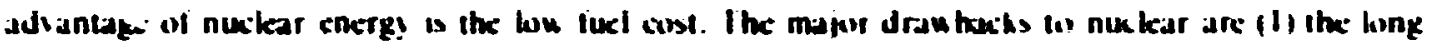
kedd tumes reyuired ur the planning and censtructurn of pouer plants and 121 the dilluculties in

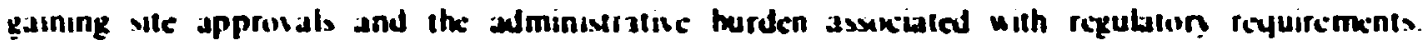
Comiusiuns comerning specitic nuckear alternatives are given beliu.

I arge commercial nuktear power plants ofiter industrial steam and electricit! at the iuncest cisst

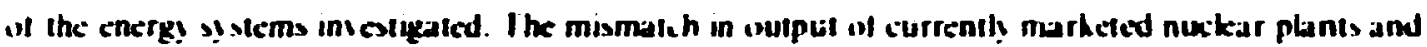
the consumptem rate of indiv ulual industrial plan:s. coupted with the need for multipk units (1)

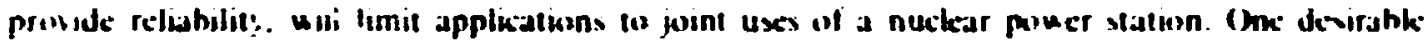

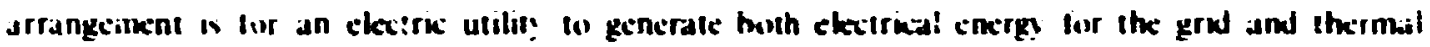

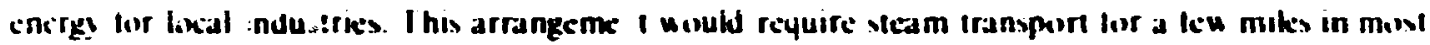
areas.

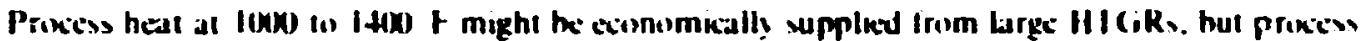
hedt HIC IR, are not commercially abailable. Such units coubl be developed. if uarranted hy mathel

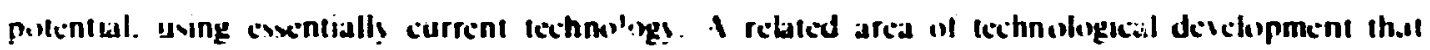

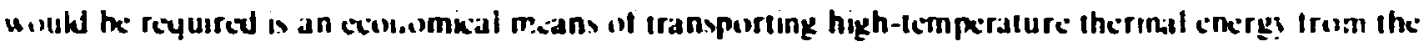
nusledr piant w the prescesces.

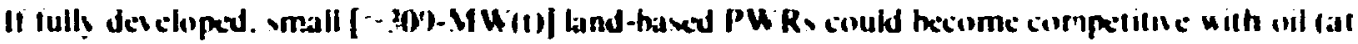

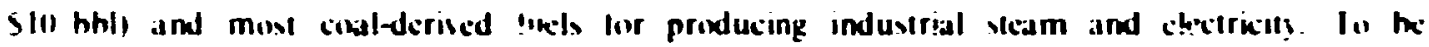

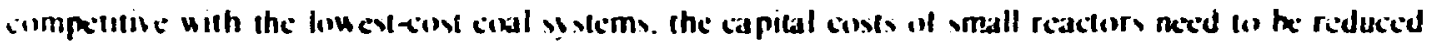
helou prexent istimates. I he deschopment of lactorn-asembled harge-mosunted units has the

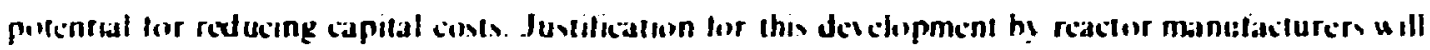
degend on their perception of market potential. Inother yuestk'n that r-quires xertilus consideration W whether a barge number of small reaclers would he more dillicult to regulate to awure the ame high level in witcts expected with current reactors. 


\section{Recommendations}

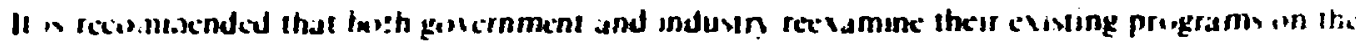

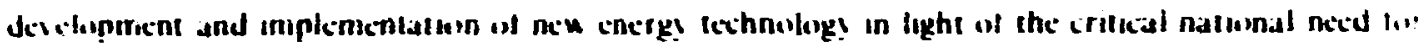

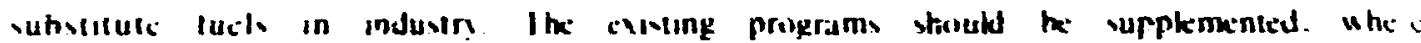

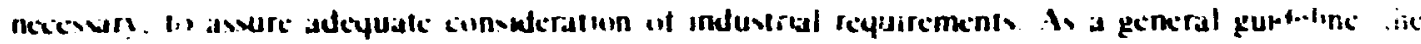

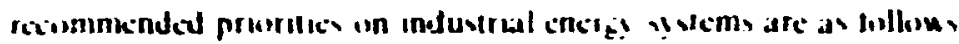

Cind islems

1. Fust prorts

Flindired thed cinmbistinnt

Silkent refined $\cdots a$,

2. Sei ind pritris

Regenerable stach-gas sirubhing

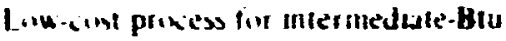
Ras trith alid
Venclear ș sicins

1. Irse p?wili!

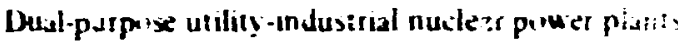

2. Secind prourily

Small reators fin industrial uses

Pincess heal HTCR.

Sime specilic recomendalouns are gaben bolou

\section{I COAL SYSTEMS}

- Impientent a program to demonstrate mudieathed hoskers for industral uses. Ihis demonstration program theuld be a joint eflort between the govemment and industre arid should ink-lude tho or merc projects with unit outputs in the range of $50.0 \times 0$ to $5100.0 \times 0$ th $\mathrm{hr}$ of seam

- Perlorm de ign and cous studkes lo determine the leasibility and henclits of descloping tludized-bed proxess heaters.

- Conduct analyxs and tosts on Ispkal industrial hoikers and prexess heaters to determine the teashilits of retrolitting these des kes to hum solvent-tefined coal.

\subsection{NUCLEAS SYSTEMS}

I Indertake a sicty (o examine one or more realisic applications of commerial nuckar plant, for the supply of indusirial steam in the Ciuli Cinst area. The purpose of the in:estigation uould the to determine the desitability of undertaking ictual projects at specific siles. I he applicattun envisioned would he similar to the Itiu-fonsumers Power arrangement at Midlind. Mich iho sudy should te a cooperative undertaking invoising the govemment, a pouer compans. and unc or more industrial geoups.

- Indertake a narhet stricy of the geographical distribution of the industrial steam demand in the 1 .S. Fstimate what fraction of the demand could he supplied in 1975 hy himithelical steam

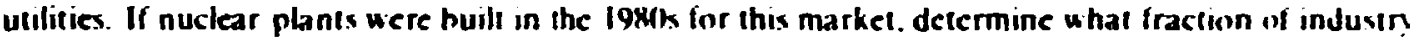
might be served by 1990 and hy 2000 .

- Make a more detailed design and cost stt.ḍ of a factorn-aswembled. harge-moun:zu s.sall I Wk for industrial applications. This work should be orenied toward resolsing the ụurstion of whether expected henefits justify a development program. A similar study should he made for a small HIGR. 
- Indertake a broad assessment of the custs. benefits. and marhet potential of adiancec gass-ooled reactors lor producing high-lemperature process heat.

- Make a study to determine ine feasibility and extent of potential application of central statiun senerated electricity for process heating. Although this altematic was not examined in the present study, it is another means by which both coal and nuckear cnerge could be applicd in industry. 


\section{Part II. Energy Systems}

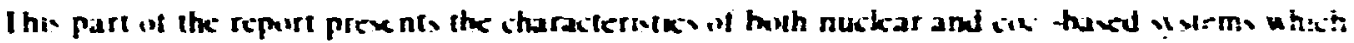

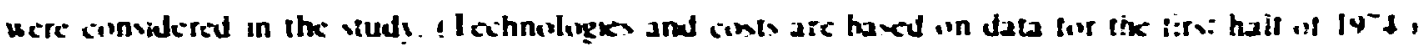

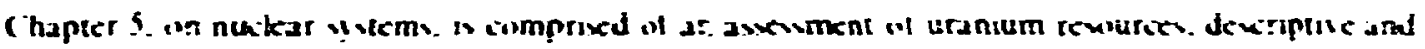

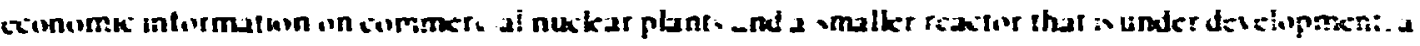

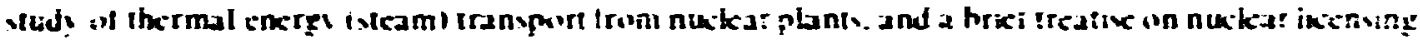

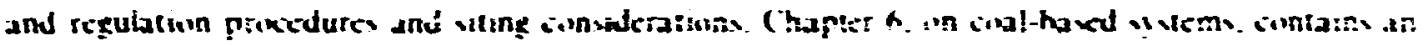

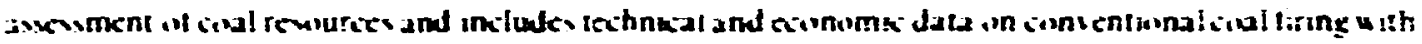

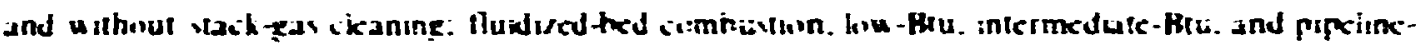

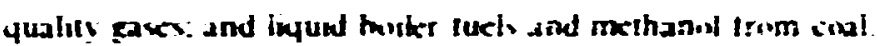

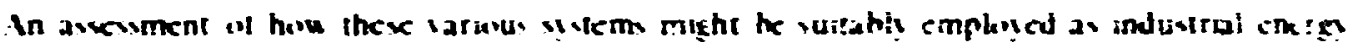
wurces is prescnied in Pait !ll.

\section{Nuclear Energy Sistems}

\section{S.I ASSESSMENT OF LRANILM RESG. RCES}

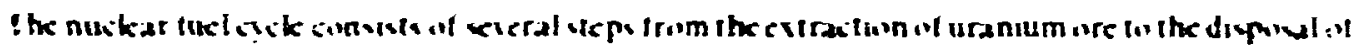

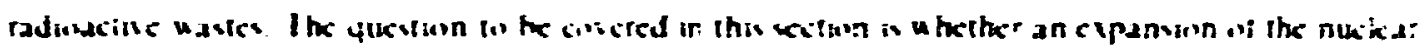

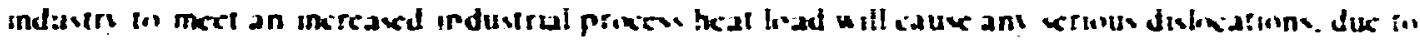

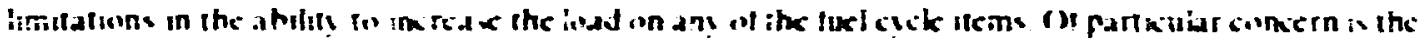

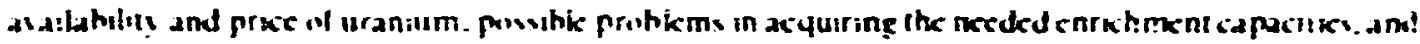

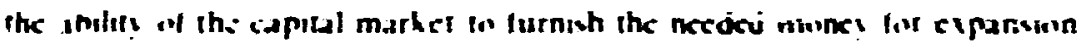

\section{S.1.1 Iranium Araibbility}

I ranium is w rely distribuled. with an aserape concentratun of 2 w ipsm in the continentalcrusls

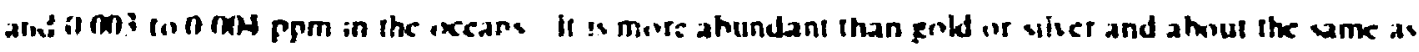

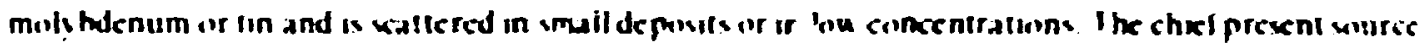

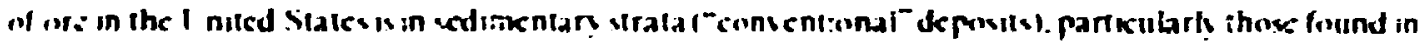
-

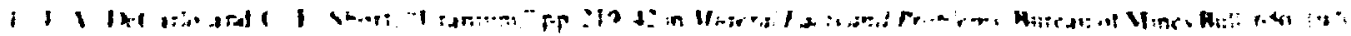


the Civorado Plateau araj in the Wyoming basin geologic regions. Mlost of our h now n low -eost rexerses are located in these areas.

Iable 5.1 is an estimate of the cumulative : anium. esource up to sarious cost-cutoff kesels. Irformation is prow ided as to the reasonably assured rescres and ion the estimaled additional or potential resencs. This latter eategong refers to additiontl uranium which is believed to exist it: taw orable geologic regions primarily adjacen: to steas at hnoun reserves. It dices not account for possible discoseries of ne-u mining areas or districts.

\begin{tabular}{|c|c|c|c|}
\hline $\begin{array}{l}\text { Cons cutoff } \\
\text { is ib } \mathrm{C}_{3} \mathrm{O}_{3} \text { ) }\end{array}$ & Reserves & $\begin{array}{c}\text { Extimaied } \\
\text { sdditinul revires }\end{array}$ & $\begin{array}{l}\text { Fotal } \\
\text { sculutie }\end{array}$ \\
\hline$\cdots$ & & $\ldots \ldots$ & - \\
\hline 8 & 273 & 451 & $72:$ \\
\hline 10 & $3+0$ & 770 & 1.1111 \\
\hline 15 & $=30$ & 101011 & 1.010 \\
\hline 30 & 7811 & 10511 & 2.4301 \\
\hline 50 & & & $7.4(k)$ \\
\hline IMI & & & $15 .+(x)$ \\
\hline
\end{tabular}

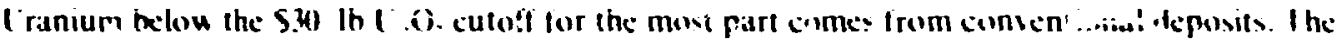

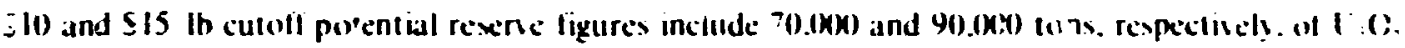

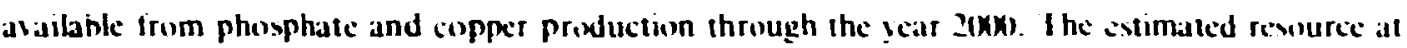

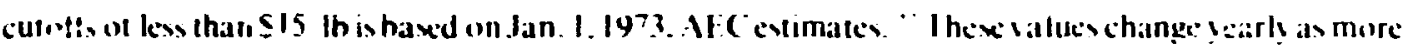
cxploration is dione.

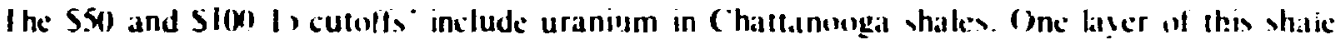

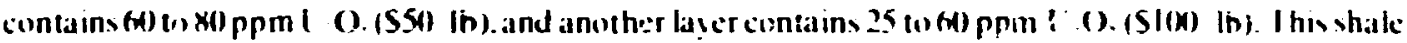

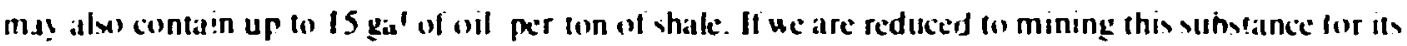
uranium apon exhaustion of in: louer-cost resulures. the powihility of an interesting by-product

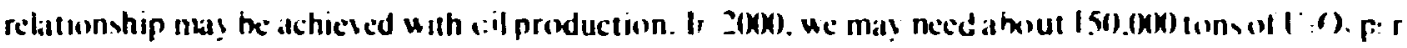

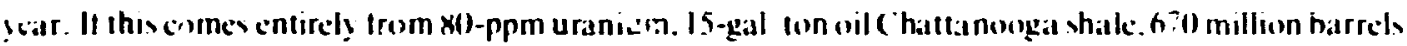
"i wil per year a 8 million harrels per dayl could ine p............!

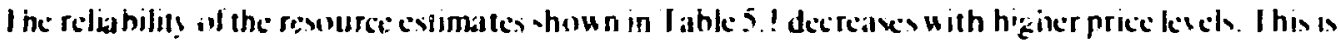

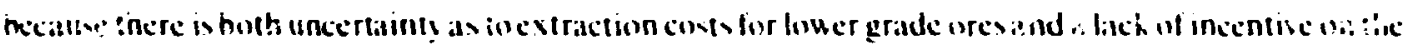

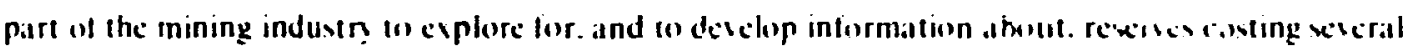
times the current uranium market balue.

Other polential wources include uranium in the lignite deposils $n$ the western I Haholas and eastern

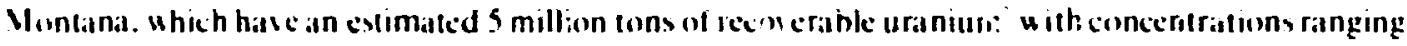

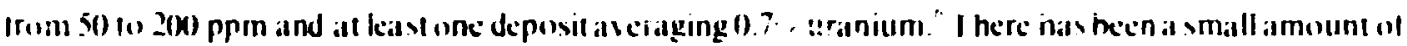
commictia! delelopment of high-grade uranium deposit. hut no rexine cost eslimates halse heon

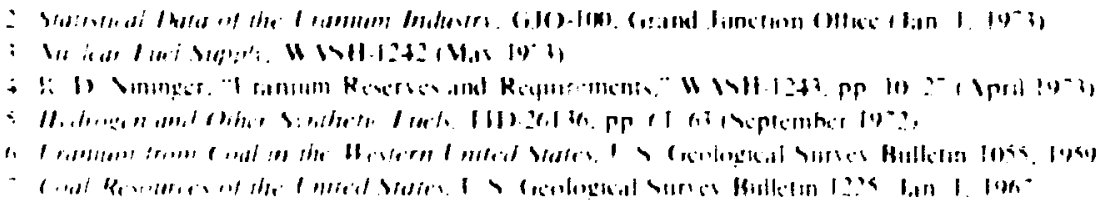


lound Hercalws. some cor-product ceonomics might be beneficial. I he possibility of using the lignite in a givilication. liyselaction, or hydrogen production process and extracting ulanium from the residuc mat he cconsomically feashle at some puint.

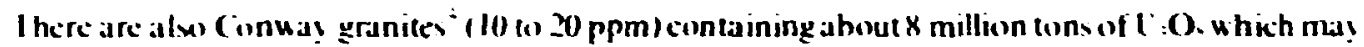
he evtracted at about $\$ 2(x)$ lh. I he ultimate surce of uranium is, howeser. the exean. which contains at

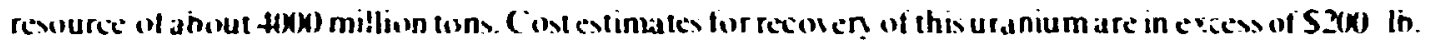

\subsubsection{Uranium Demand}

I he mow detailed information on the grou th of nuckear pouer generalion and its ceftect on uranium

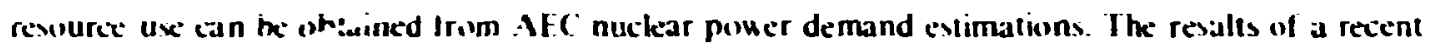

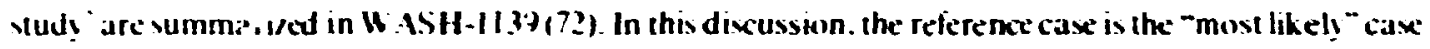
projection axed in that study. Ihis case propects an instalked nuckat-electric capacits of 1200 million

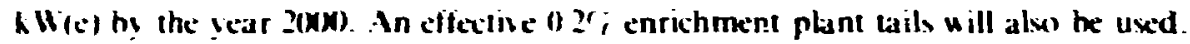

The uxe of 0.24 ; tails instead of the prexent 0.31 ; will reduce ore reyuirements hut. at the same time. raix the xparaive work reyuireriknts. There are werd reawns, for making this choice. Becaux of the prexent split tails policy. the 0.2'; figure is the effective tails currently sen by the enerichment customer. the difterence in ore reyuirements being made up from government surplus. Also. if the consen ative

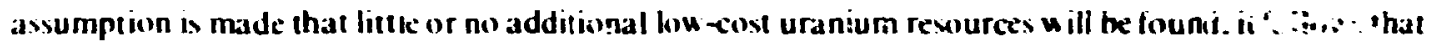
the price of uranium ore must rix. This in turn will kad to a kwer tails enrichmeri. both from an cconomic and a rewurce conxervation standpoint. Any assumption of a continued 0.3 , tails uxuld include $u$ ith it an expanding rewrie picture.

The cumulatice $1:$ () requirenients for the reference case are shown in $1 \mathrm{ig}$. 5.1 . Along with the cumulative $1: 0$. reyuirement for an assumptior. if enhanced industry grow th. This enhanced grouth was assumed to be caused by the impact of industria' process heat. Startinz in $19 x 1$. uranium requirements are assumed 6 increax cumulatively by $1 \%$; year over the reference case uranium requirements. I his means that b! $20 \mathrm{~K})$. the yearly ore requirements will he $20 \%$; hik... - than the reference ralc.

\section{S.1.3 Uranjum Price Projections}

The yuestion now is what effect the enhanced uranium demand will have on the market price of uranium and on the fuel cyck costs of reactors. In making any projections as to future price of a commodity materia!. one is necessarily on shaky ground. W' hen the recent price changes in other energ! rewurces (coal. (bil, and gas) are factored in. the uncertaintics increase.

In making these estimations, several assumptions were made regarding resource avaibibility and price response as the rewurce is depleted. An attempt was made to be conservative in the assumptions. resulting in prices which should he considered on the high side. It was assumed that the ult imate resource availability is as given in Table 5.1. which means that the discoveng rate is only sufficient in halance mining losse: such as would be encountered by ieaving low-grade ores tehind because they are not economic."

An orderly conversion of potential in assured reserves was also postulated. This conversion rate was assumed to be price sensiti:e. since as prices rise the incentives to explore also rise. At 510 Ib $1: 0$. $5 \% ;$ of the potential reserves was assumed converted to assured reserves: at $\$ 15$ th. $25 \%$ at 520 ib. $50 \%$ :

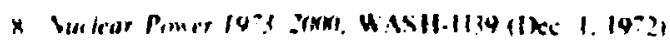


OAIL-DWG 24-6163

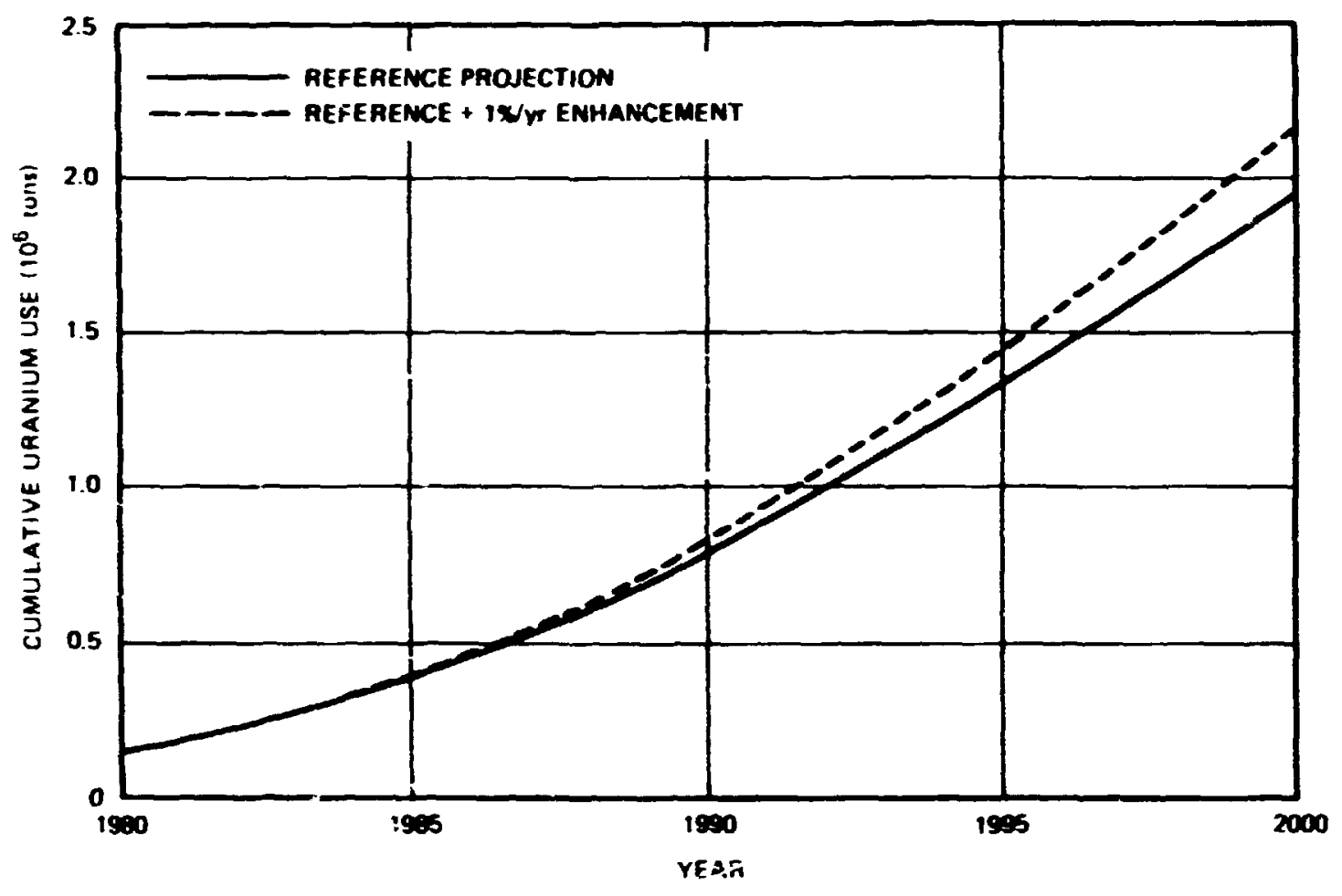

Fy. 5 1. Cumulative urannm requirements.

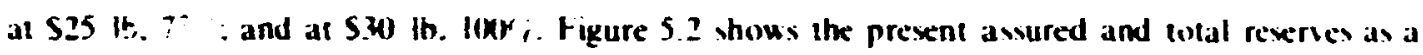

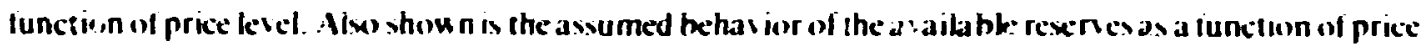
kelel. For example. ihe latter cunce shous that when the price off uraniun, reaches S21) Ih (1 (). ). there will be an accumb'ative abailability of about $1.25 \times 10^{\prime}$ th extraclable at this price or kes.

The alailable resene is price cunc. howeser. does not determine what the market price uill be. First. this curve is for cost of extraction and does not include ans profits. Second. since it takcs a linite time to deplete a given mining operation. not all of the louer cost rexerses will be uxed up belore mining ol the higher-cost rexerves is hegun. Nwo it takesabout 8 yearsirom the start of exploratory drilling until production of the uraniem concentrate begins." Hefore a mining company will undertake the delelopmen! oi a high-cost rexerse, il must have reawnahk awurance that the sentuti will be cconomic. which usually means competilise at current prices. It is pestulated that an $x$-jear lorkard rexerve ot uranum at current prices is needed to assure adeyilate production.

In this analy s. an 8 -sear foruard rexerce was assumed to cxist. Ihe ore price al a gisen time was

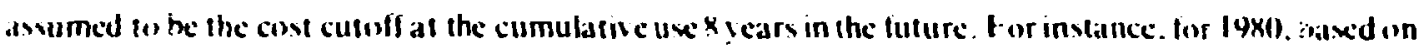

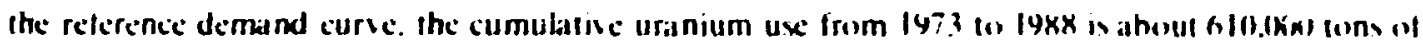

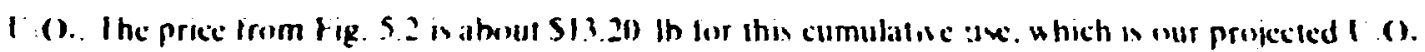
price at ithe end of 1980.

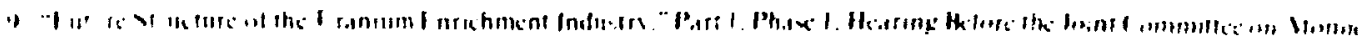

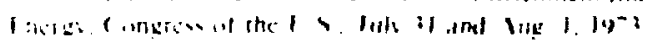




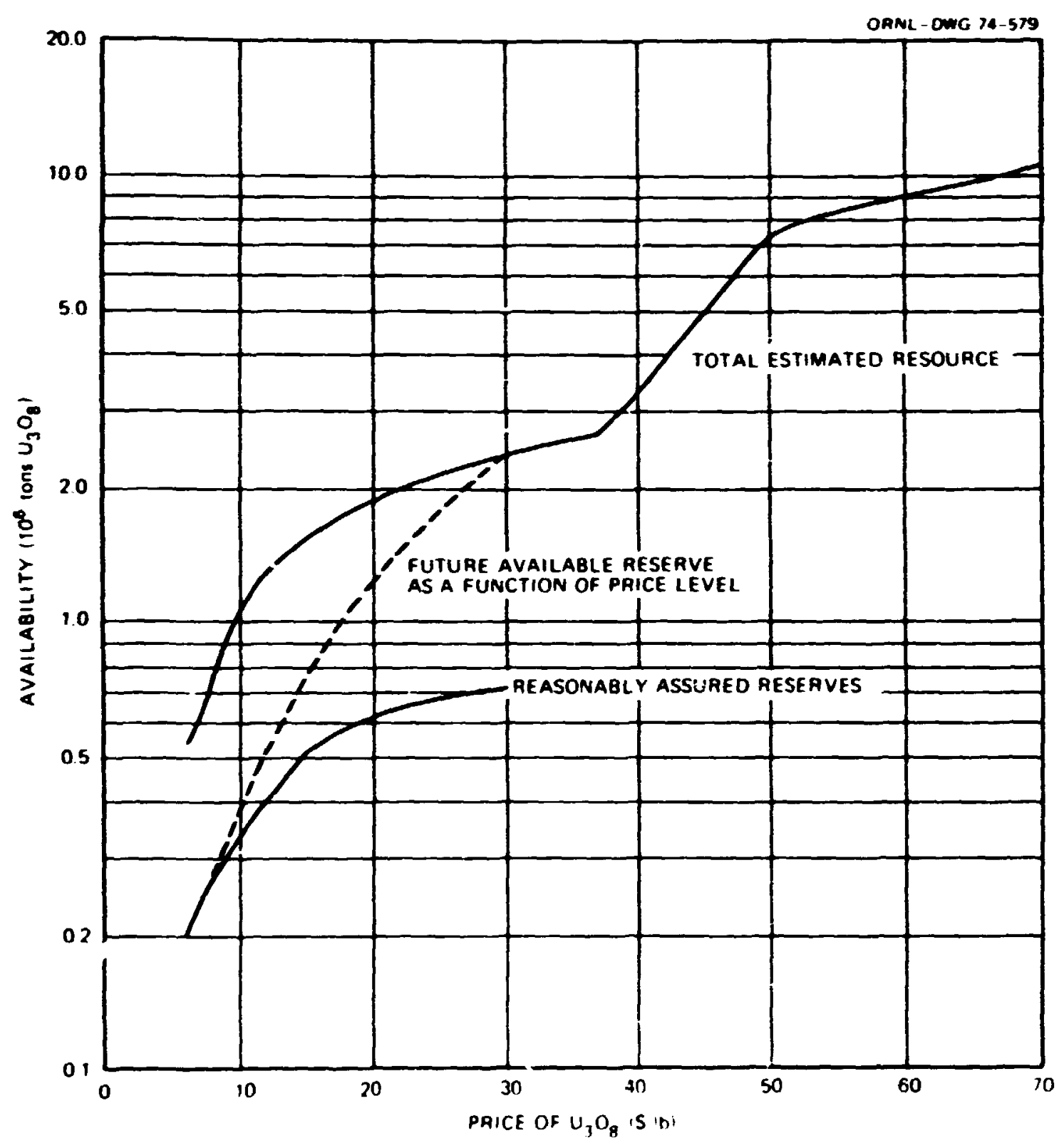

Fis. 5.2. U.S. uranium resource. 
Figure 5.3 shows projected I (if prices through the year 2000 . Iratuded are our estimates lor the reterence case. AEC baxe and high projections for our reference ore tixe." a projecthen mive tor Vorthease l tilitics, and wome recenth repurted sake and asked prices. " All figures excep thox for the Vortheast lilitives are in 1973 dollars.

Figure S.4 shous our projected ore costs as a functeon of tince for the reference tase along w ith the

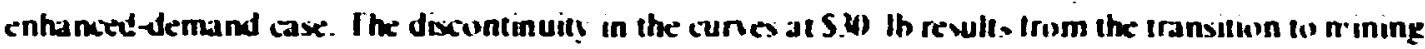

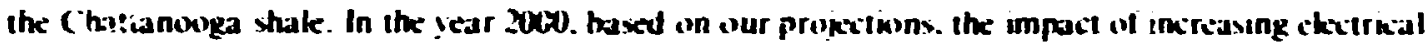

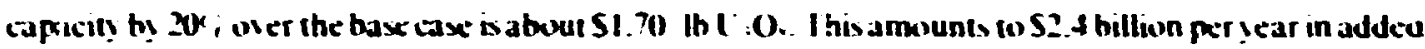
ore conts when the incteased sakes at the higher price are lactured in. The relative eftect of uranium prive "n the fuel eycle crosts for PWR. H JGR. and C.SG sistems is shoun in fig. 5.5 . I thexe costs are haxed on a constant uranium price wer the reactor lifetime. a 0.24 ; tails enrichment. and the utility cionsmx

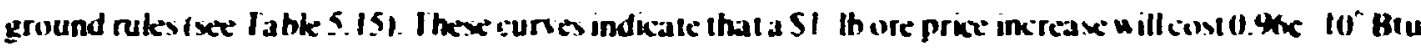

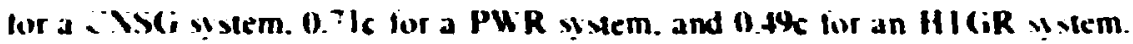

\subsubsection{Uranium Enrichment}

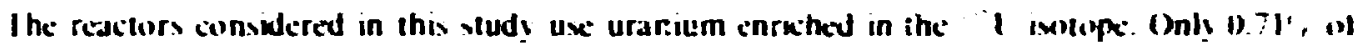

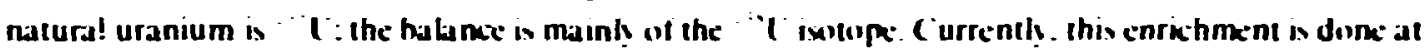

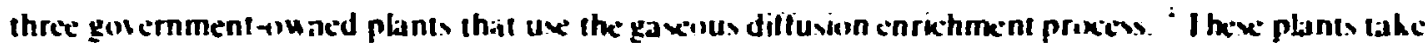
uranium in the form of $(\mathrm{F}$. and return urantum at the devired enrihment in the ame lorm.

I he enrichment capacity of the prevent plants is 17.2 millun xeparatioc worh units 1 SW I I per sear. I hexe plants are expected fo he updated to a capacit: of 27 .? million SWI :

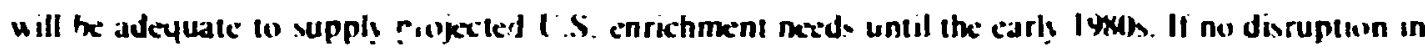

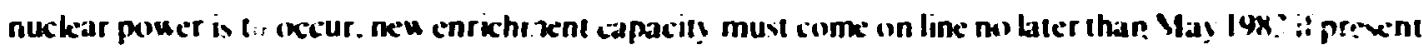
-mos: likels- projections hold. (urrelt plans are to add enrichment capacily in units if $\times .75$ milliun SWI sear. It May 198, is the stanup date of a ne'u enrichment plant. a exiond plant will he nevded about 5 month, biter. ino plants w) close toge:her could calase prowirement problems due to the industrial impact of ino nearly simeitancous large orders. Io as.ure an orderly development of enrichment capacit!. If is estimated that approximutely 18 months spacing is necded hetucen plitnis Iherefore. the first earichment plant should come on line by mid-19x2.

It will take irom o to 8 :ears frim the time a neu enrichment plant is approved until startup. A decisisn is therefore needed wemetime in 1974. It a prexent diffusion plant site is lo be used. the decision could be delayed lor abuut a sear. Iny reduction in the nuckear plant kad times or increases in orders abose projections would hasten the lime at which new enrichment capacity w ill be reeded. Ans increales in lead time or drop in orders belou projections weuld delay this rime. I herefore. the re is still adeyuate time. hut decisions will have Io be made in the near future if no discuption is to ixceur in the nuclear husiness.

I uo majur decision, (one technological and one political) will hate lo he made hefore the next enrichment plant is authorized. I he technologial decision is the type of enrichment proxess fo use. and the pollical question is whether this plant will be publicly or prisatels ou ned

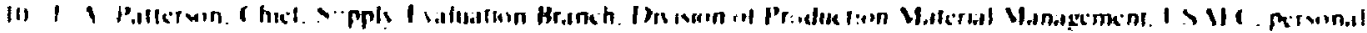

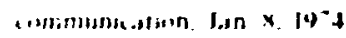

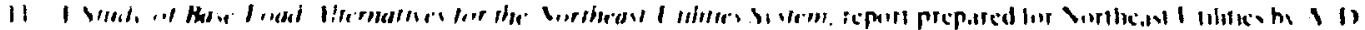

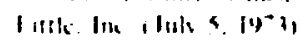

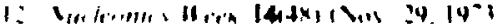

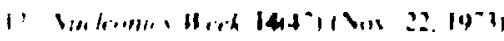

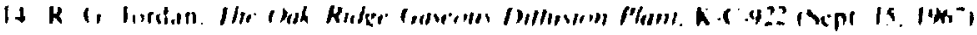




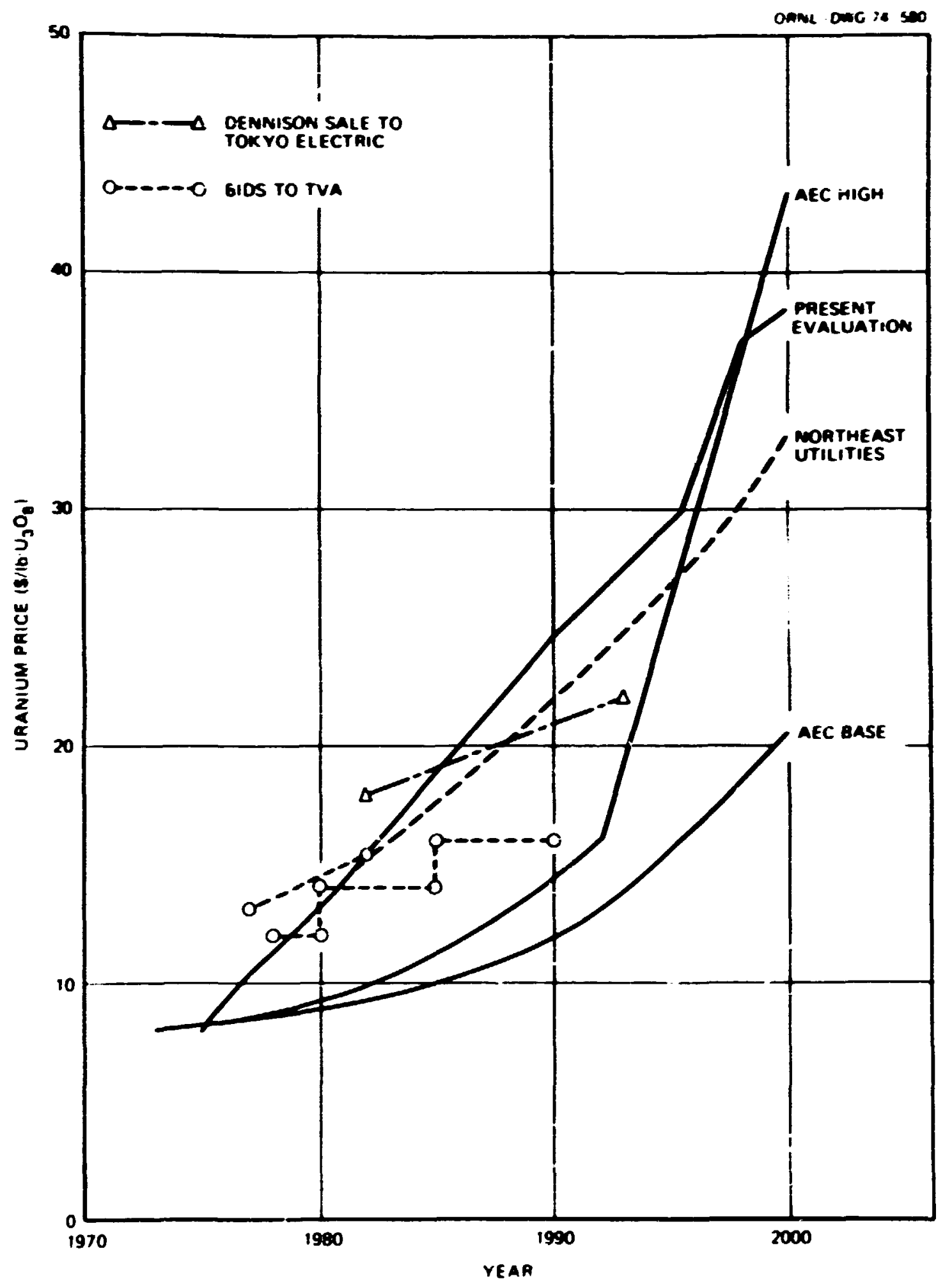

Fis. 53 Comparafive uranium price projections. 
36

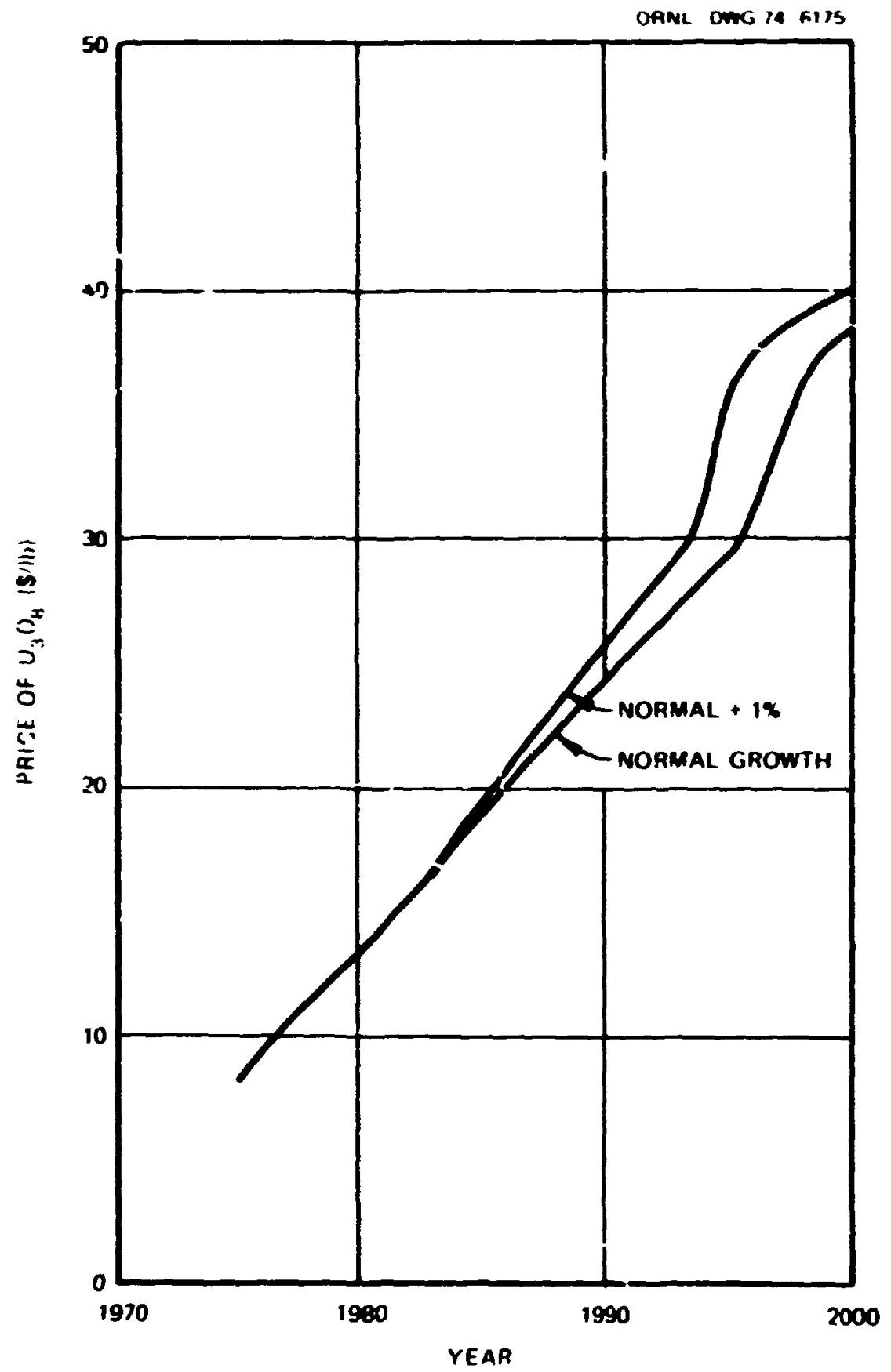

Fo 54 . Cranum ponce piofectons for larkus industry growt i rates 


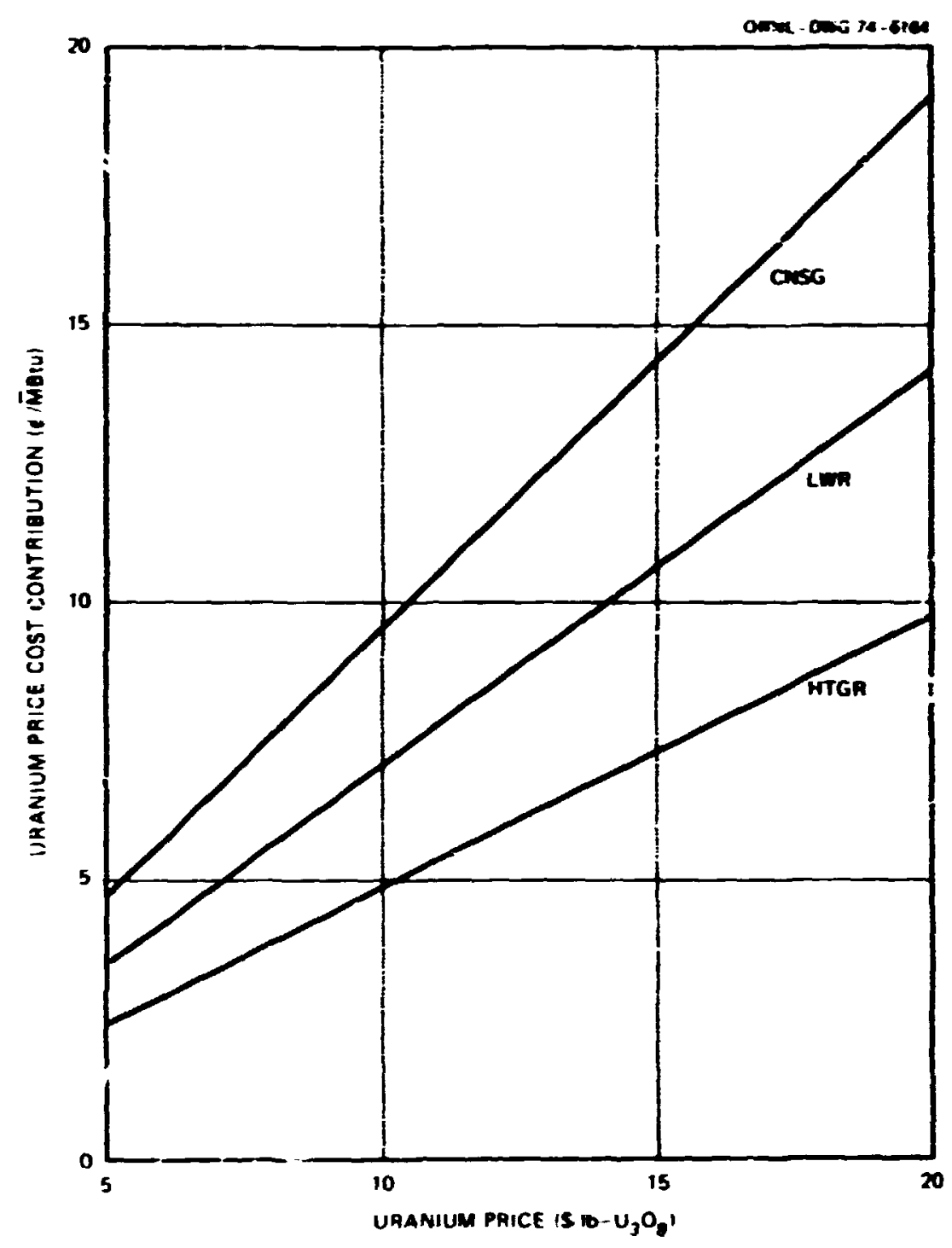

F4. 5.5. Effeel of uranum price on fuel cycle cose

There are tho types of enrichment proceses unde: actise consideration: the gaseous diffustun process and the gas centrifuge pricess. A third prixess. laser separation. has recently heen suggested: houever. many technological obstacks will have to he overcome hefore it can to used to obtain targe commercial quantities of enriched uranium. Its major adiantage, besides yel undefined costs. is the pessibility of ertending uranium reseres by reducing the tails enrichment.

The major advantage of the gascous diffusion process is that the technology is already we!l developed. I he chicf disduantage is that it uses a great deal of electric pouer. An 8.75 mullon SWI year plant neads $2 \$ 1 M$ MW of electricity-generating capacit! to satisfy its needs.

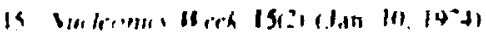




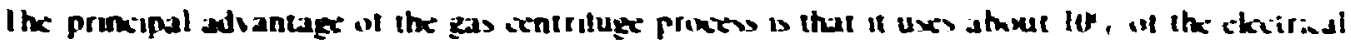

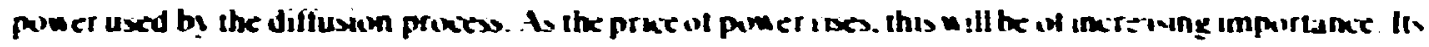

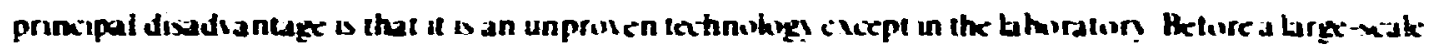

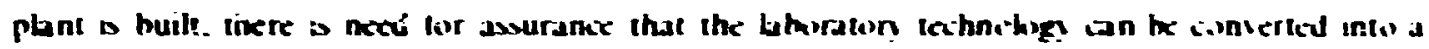
comrrxical manufacturing tciknathes

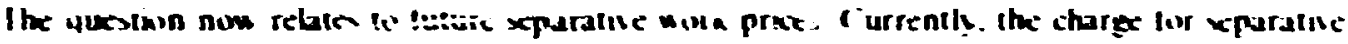

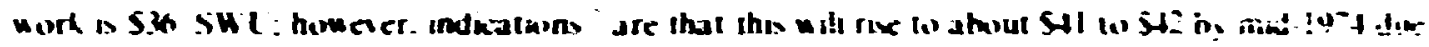
inainh to the recent unceax un I I pumer casts

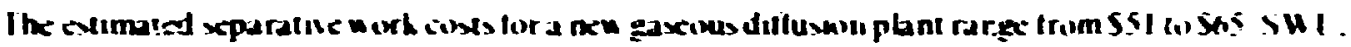

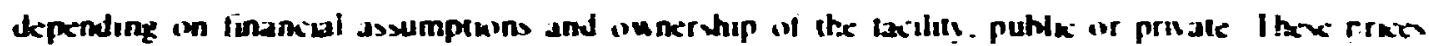

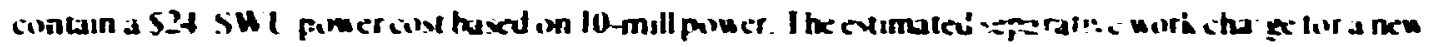

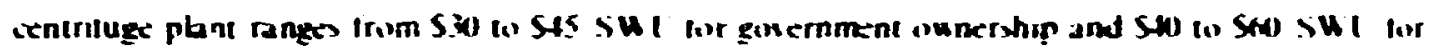
prisili ownership.

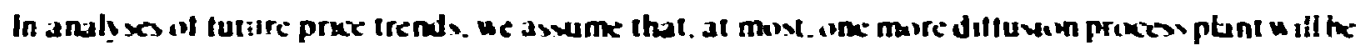

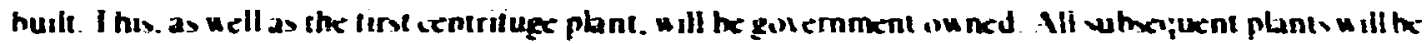

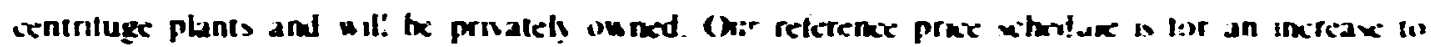

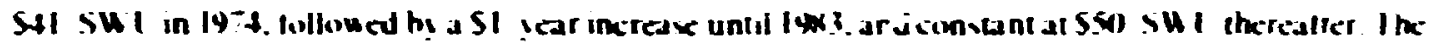

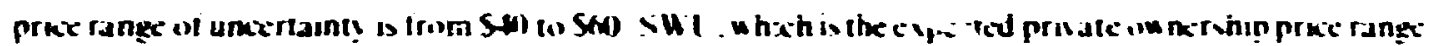

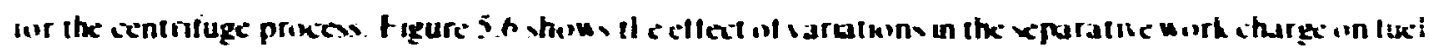

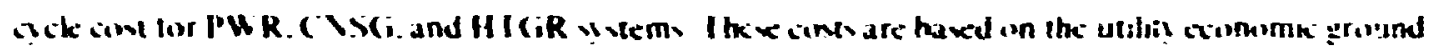
rukind a 0.2 . tailv enrkhment

\subsubsection{Fuei Cyck Capieal Requirements}

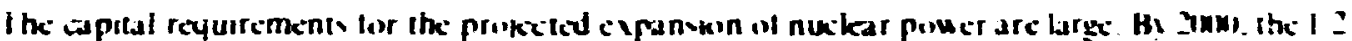

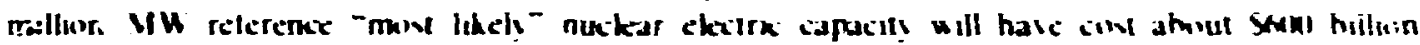

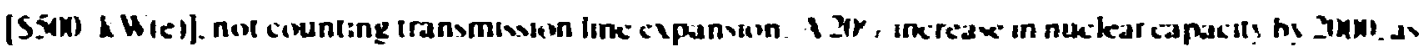

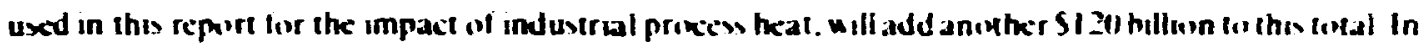
addition to this. capital must be expended to cxpand mining. miling. and enrkhment capieits and !.,

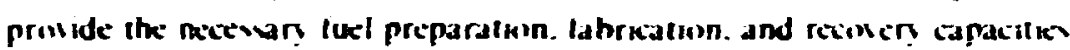

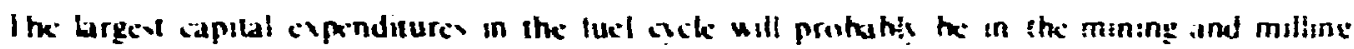

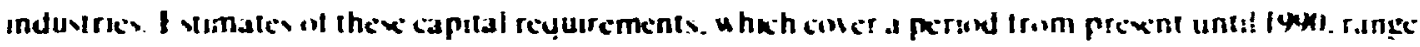

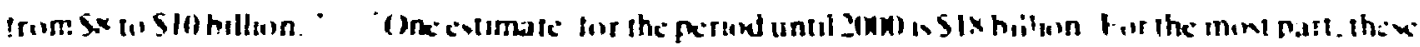

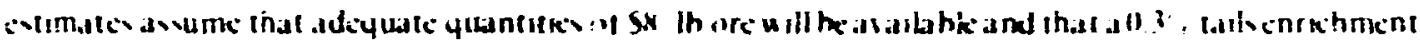
will he und at the enrlechment plants.

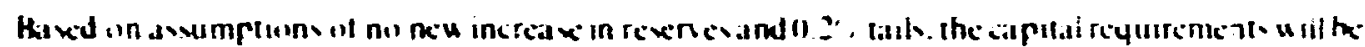

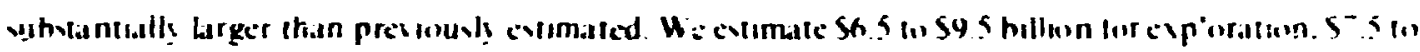

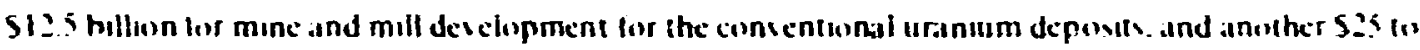
5.5 hillow lor the decelupment of the Chattanowga shales. The total mining and miling caprisl

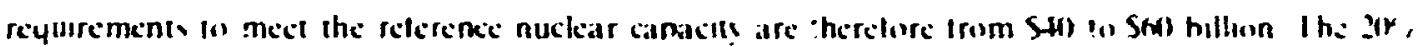

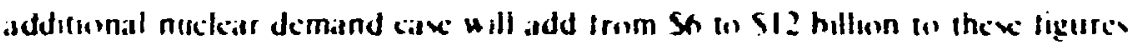

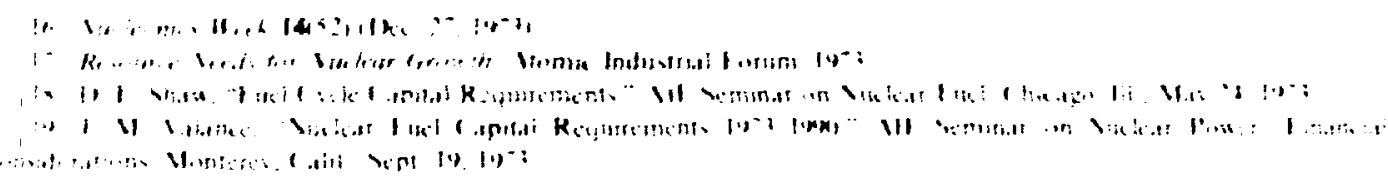




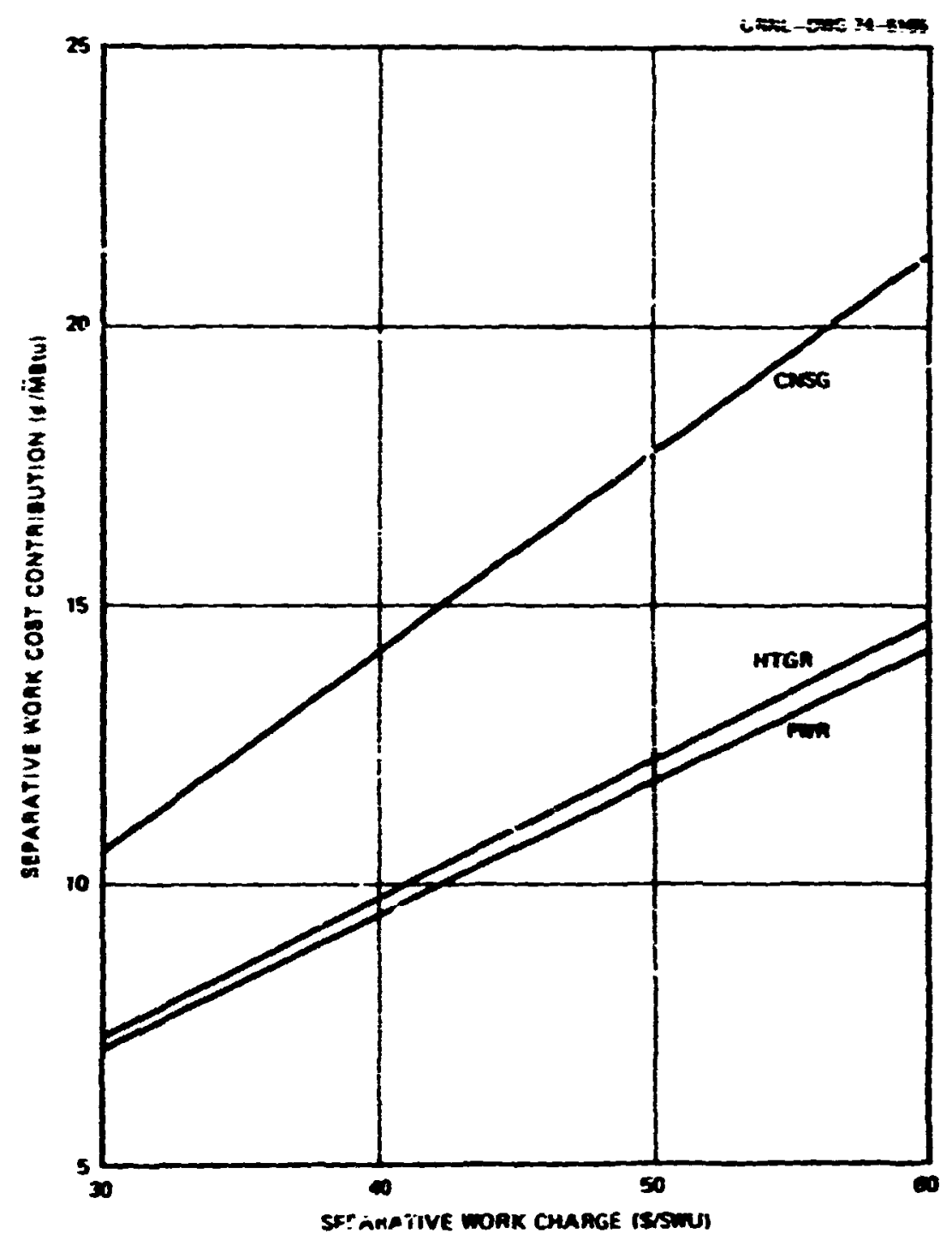

Fie 5.6. Effect of sparative wort chare on fuel cycke cos.

The second largest !uel ayck capilai cost component is new enrichment plants. By the year 2000. eight additional 8.25 million $\$ W$ !- year plants will be needed to st isfy the $U . S$. reference projection demands at 0.2 ; tails. The cast of a new 8.75 million SWL year diffusion plant will be 51.2 to 51.4 billion." In addition. 2400 MH(e) of generating capacity will be needed for this process. Th: capital cost estimates for the centrifuge process range from $\$ 1 . i$ to $\$ 1.7$ billion for an 8.75 million SWL year plant. In addition. the capital cost of the necessars electric capacity is about $\$ 0.1$ bilion.

The total enrichment prant capiilat cost for the reference nuclear demand is from $\$ 10$ in $\$ 20$ billion. depending on the process used An additiunal $\$ 2$ to $\$ 3.3$ billion will be needed for the 20 ; additional nuclear capacity by the yeal :000.

The other fuel cycle items include the conversion. fabrication. reprocessing. shipping. and waste disposal steps. Captal costs per unit of throughput and scale factors may be extracted from several 
reterences. "I he apizal rsyuirements through the vear 2000 lor thuse items are ciumated as Sa billwn tor the reference demand ase and another 515 billion for the 39 ; dedithmal demand axe. Ithe olimaled apital reyuirements are summaried in I abk 5.2. Ihe additonal capital reyuired lor the 20 :

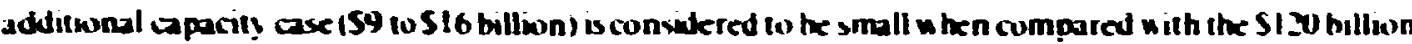
which mal be needed to huild the nuctear systems.

\begin{tabular}{|c|c|c|}
\hline Item & Base :-ase & $\begin{array}{l}\text { whltevn fur } \\
\text { zor: expanswn }\end{array}$ \\
\hline $\begin{array}{l}\text { Fiphratun, muatuge milling } \\
\text { finrichment } \\
\text { Oxhers }\end{array}$ & $\begin{array}{r}100 \\
1020 \\
8 \\
\end{array}$ & $\begin{array}{ll}6 & 12 \\
2 & 3 \\
1 & 1.5 \\
\end{array}$ \\
\hline Tolal & $58 \cdot 88$ & 916 \\
\hline
\end{tabular}

\section{S.2 COMMERCIAL NUCLEAR PLANTS}

\subsubsection{Introtuction}

Commercial vuclear plants presently available are BWRs. PWRs. and HICRs. Both BWR. and PWRs use slight! enriched uranium dioxide peltets as fuel and Jemineralized water as coolant and moderator. The H! $; R$ fuel is a mixture of uranium carbide highly enriched in "I and thorium oxide. Ire modera!or and core structural material is graphite. and the corlant is helium

With one exception. ai! large nuclear plants in the Inited States are singke-purpowe electricity-generating plants. Irin I of the Consumers Power Midland Plant is designed hoth to zenerate ekctricity and to produce process steam for the Inow ( rimical Compien! at Midland. Wichigan. I he reactor plant for unit 1 will generate 10.200 .000 th hr of prime steam. (Of this

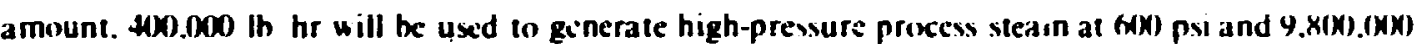
Ih hr will be delivered to the turbine throttle. Turbine extraction steam will be uxed to generate 3.650.000) ih $\mathrm{hr}$ of low-pressure extractios? sleam at 125 pi. Init 2 will be a singk-purpox electricity-generating plant.

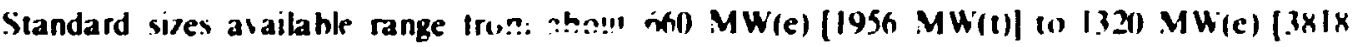
MW(t)]. Overall plant efficiencies are about $33 \%$ for the PWR and th: BWR and about 38 ; for the HTGP.

The commercial BWR was developed and is marketed by the Cieneral Flectric (ompany Drexden 1. the forerunner of the large BWR. is owned and operated hy Conmonuealth Idison Company. Commercial service began in August 1960 and the rated capability of 200 VW(c) was reached in 1962

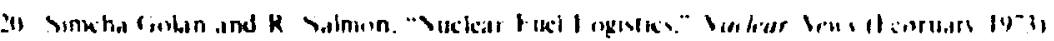




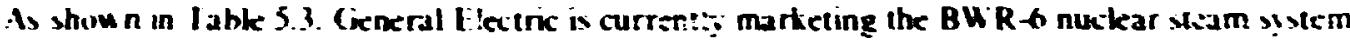
in live sandard sires.

I he first cummercial PWR nuckear steam system was developed and marketed by Westinghoux Electric Corpuraion. Westinghesuse and Duyuesne Lyht Company started constriction of the Jemunstration PUR power plant (Shippingwort) in March 1955. This plant reached its full rated

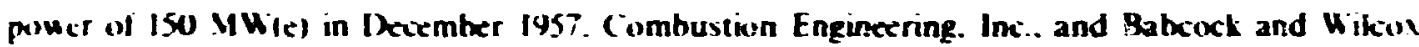
Company are nou also marketing comnercial PVR nuckear steam systerms. Both the Wies aginoux ani Coubusion Enyinceruz systems peduce saturated steam using $l$-iube steam generators, whik: Babsoch and Wikox systems produce slightly superheatef stam asing a once-through steam eenerator

The Babcuck and wikox nuckar stcam system utilives two coutant bops. each of which contuins a steam generalor and tw o primary coolant pumps. Table 5.4 lists the three sues of thexe anit. prexently beirg marketed.

Combustion Enginetring manufactures the rivckar stean system witt. the coolan! hups. Each with 3 steam generator and tho rejetor coolant pumps. Four sives are given in Tabke 5.5 .

Westinghouse offers : andard nuckat steam system designs with two. three. and focir ceviant lexps. Current ratings are given in Tahte 5.6. The tuo-loop system is not avaibble in the I nited stalcs hut is marketed ahroad.

Table 5.3. Teneri textrx nomial phat raturs

\begin{tabular}{|c|c|c|c|c|c|}
\hline fuel assemblies & 581 & SoO & 592 & 73 & 784 \\
\hline Tiermal power. MWin & 1956 & 2444 & 2894 & 3579 & $383:$ \\
\hline Electrical poust. MW(e) & 300 & 850 & 985 & 1220 & 1270 \\
\hline Steam prescure. pra & 1140 & 1140 & 1940 & 1140 & 1040 \\
\hline
\end{tabular}

Table 5.4. Babeock and wikox nominal plant rating

\begin{tabular}{llll}
\hline Fuel ascemblies & 145 & 205 & 241 \\
Thermal power, UWit) & 2443 & 3621 & 3818 \\
Fiectrical power. VWie) & 880 & 1244 & 1320 \\
Sieam pressure. pria & 925 & 1060 & 1125 \\
\hline
\end{tabular}

Table 5.5. Combustion Enpineering nominal plant rating

\begin{tabular}{lllll}
\hline Fuel ascemblies & 177 & 217 & 217 & 241 \\
Thermal power. MW(1) & 2825 & 3410 & 973 & 3817 \\
Electrical power, MWie) & 980 & 1160 & 1197 & 1303 \\
Steam pressure. psig & 900 & 900 & 1000 & 1100
\end{tabular}


The HTGR plant is relatively new $w$ the etectric utility indusiry in this country. Ithe tirst

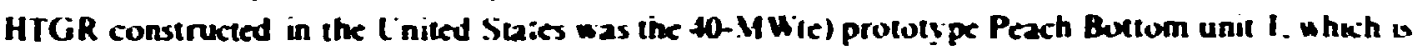
iwned and operated by the Phibadelphia Eketric Iompany. Cicneral Atomx (ompari ass respunsible for the design of the nuckear steam s: stem associated with this plant and ivt the research and development on both the plant and the nurbar fuel: thet also supplicd the mupr cumponents of the nuckar steam system.

Cieneral Atomic Company is abo serving ts prime contractor to Publk Sern ke Compan! "I Colorado to construct the 330-MU(e) HTGR fon St. Vrain Nuckear Generating Sitation. Ithe the Peach Bottom reactor, it was built under the I SAEC Power Reactor Itemonstration Program. Fort St. Irain is the first plant in this country to use a prestressed conciete reator sosel (PCRI).

The HTGR nuclear steam system built is Cieneral Atomic Compant is araibate in tud, standard sives. as shown in Table 5.?

\begin{tabular}{|c|c|c|c|c|}
\hline Nunbes of hoops & 2 & 3 & + & 4 \\
\hline Fuel dsce:nbives & $1=1$ & $15:$ & $19:$ & {$[+]$} \\
\hline Ithermal puswer. SWirt & 8x: & 2785 & .425 & 391 \\
\hline Ekitricsl puter. $\mathbf{M u _ { i e l }}$ & sinj & $9(0)$ & $5: 50$ & Inw) \\
\hline Steam pressure. pry & 920 & 9.4 & $I(x)=1$ & $110 \times$ \\
\hline
\end{tabular}

\begin{tabular}{|c|c|c|}
\hline Number of luxpox & 4 & $n$ \\
\hline Thetral power. MWi, & $2(m) \times 1$ & (40)11 \\
\hline Fketrical power. YVice & -70 & $1(n)$ \\
\hline Siesm pressure. pias & $2+15$ & 2515 \\
\hline
\end{tabular}

\subsubsection{The BWR Power Plant}

The nuclear steam system

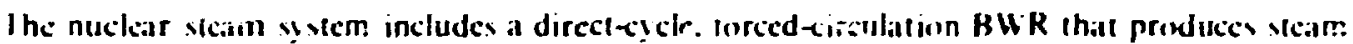
in the corc lor direct ux in the steam turhine. A diagram shouing the major parameters of the

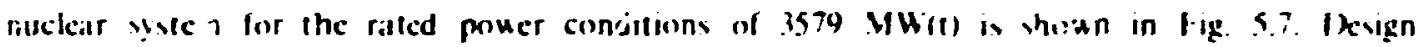
characteristics of the ystem are shoun in Jable S.X.

Fuel for the reactor core consists a'. slightly enriched uranium dioxide pellets xaled in /ircilloy futhes. I hexe luhes for fuel rods) are atsemhled into individual fuel assemblies. (iross control of the core is achicied hy movahle botlom-entry controi rods which alo cruciturn in shape and are disperued throughurut the ballice of fuel asemblies the control rods are positioned by individual contribl rad drises. 


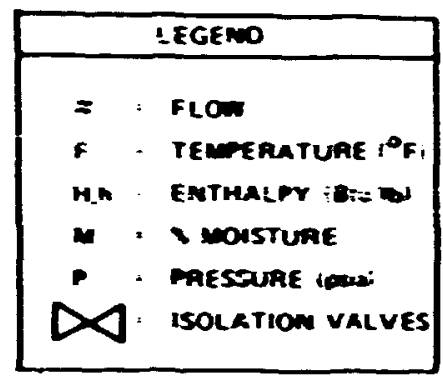

\begin{tabular}{|c|c|}
\hline assuncting 5 & \\
\hline THERUR II & $\pi$ \\
\hline
\end{tabular}

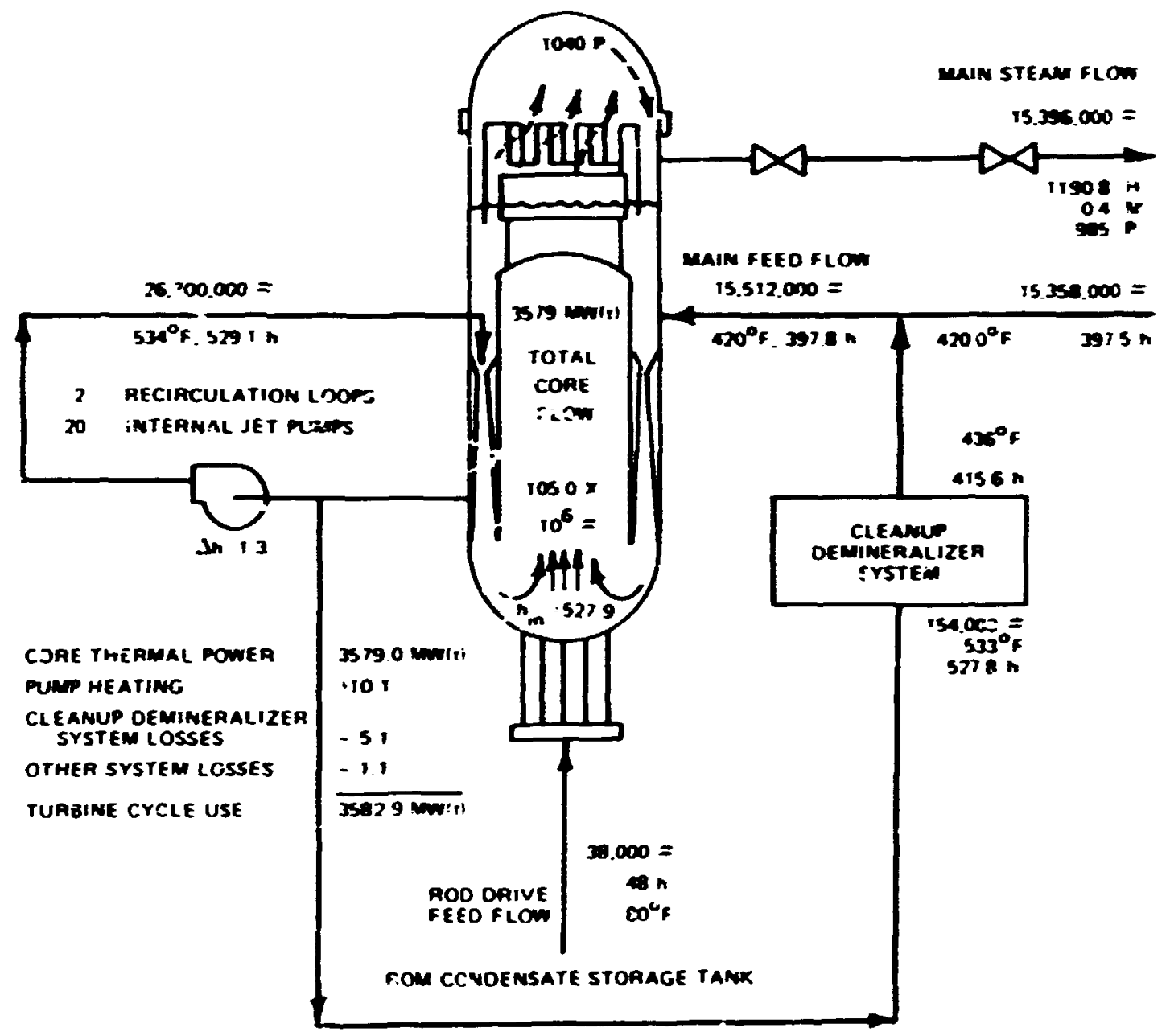

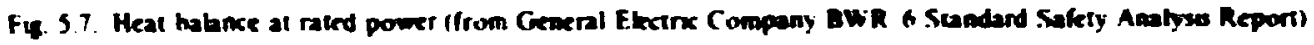


Table 5.8. Dexign characteristio [3579-MW(1) BWR]

\begin{tabular}{|c|c|}
\hline \multicolumn{2}{|l|}{ Thermal and hydraulic design } \\
\hline Rated power, MWitt & 3579 \\
\hline Steam flow rate. $10^{\circ} \mathrm{lb} / \mathrm{h}$ & 15 \\
\hline Cor: cur!ant flow rale. $10^{\circ} \mathrm{lb} / \mathrm{hr}$ & 105 \\
\hline Feedwizter now rate, 1$)^{\circ}$ lb/hr & 15 \\
\hline System pressure. numinal in steam dome. pia & 1040 \\
\hline Feedwater temperature. ${ }^{\circ} \mathrm{C}^{\circ} \mathrm{F}$ ! & $2101+26 !$ \\
\hline \multicolumn{2}{|l|}{ Reactor bessel desizen } \\
\hline Haterial & Low-illuy steel partiall! tad \\
\hline D.iz 7 pressure. psuz & 1250 \\
\hline Desik: temperature. $\left.{ }^{3} \mathrm{C}^{2} \mathrm{~F}\right)$ & $302(575)$ \\
\hline Inside vi:s, zeler. tit-in. & 1910 \\
\hline In side heipht. It in. & 7010 \\
\hline
\end{tabular}

Each fuel assembly has severas lel rods with gadolinia $($ (id :O) $)$ mixed in solid $\mathbf{s}^{\circ}$....ion wi:h the LO: The Gd: $O$ : is a burnable poison whish di:ninishes the reactisity of the fresh fuel. It is depleted as the fuel reaches the end of its first cycle.

The reactor ve: ex contains the core and supporting structures: the steam separators and dryers: the jet pumps: the control rod guide tubes: the distribution liues for the teeduater. core >prays. and liquid control: the in-core instrumentation; and other components. The main corriections to the vessel inctude stean: lines. coolant recirculation litic : feeduater lines, control rod drive and in-core nuclear instrument housings. high- anc low-pressure core spray lines. residual heat remosal lines. standby liuuid control line. core cifferential pressure line. jet pump pressure sensing lin:es, water level instrunentation, ard centrol rox drive sysiom return lines.

The reactor sesset i.; design:d a!! i tabricati:d ia accordance with applicable codes for a pressure of 1230 psig. The nominal operating pressur: in the steam space atwose the separators is lot) psia. The vessel is fabricated of low-alloy stect and is clad internally with stainless stecl fexcept for the top head. nozsles, and norsti we'? sones. which are unclad)

The reactor core is cooled by demineralized water ihat enters the lower portion of the coes an 1 boils as it nows upward around the fuel rods. The steam leasing the core is dried by steam separators and dryers located in the upper portion of the reactor sessel. I he sleam is then directed fo the turbine through the main steam lines. Fach steam line is prosided with two isolation sa'ses in series, one on sach side: of the contairment harricr.

The reactur recirculation system pumps reactor coolant through the core. Ihis is accomplished by tho recirculation loops external to the reactor vesw! hit inside the confatinment. Fach exi-rnat: loop contatis four motor-operated balses and wic hydraulials operated valve. I wo of the motor-operated valves are used as pump surtion and pun." discharge shutolf valves. The third motor-operated valve is a small shutoff walve used to bypass ihe large discharge valse to ustrm the pipeline during hot standby. I he fourth molor-operaled valve is in a by pass line that by passes both the flow control valse and the discharge shutoff valve; this valte is manually wet in :' fired posicion to adjest the bypass flow. The varable-position flou control value in the main recircuialio.s pipe allows control of reactor pous lesel through the eflects of coolant flow rate on moderator void confene.

The internal portion of the loop consists of jet pumps which contain no moving parts. These purrps provide a contiruous ir . wal sirculation path for ibe major portion of the core coulars thos 
and are lowated in the annular region beturen the core shroud and the seswel inner uall. A resirculation line break will stull allow coie flooding to approximately two-thirds of the core height the level if the inlet of the jet purrps.

l.oad followile is normally accomplished b; sarying the recirculation fow to the reactor. This method of pouer level control takes advantage of the reactor negative void coefficient. To increase reaciur power, it is necessary only to increase the recirculation flow rate. which sweeps some of the roids from the moderator and causes an increas in core reactivity. As the reactor power increases. more steam is formed. and the reactor stabilizes at a new power level with the transient excess reactivity balanced by the neu void iormation. No control rods are moved to accomplish this power level change. Conversely. When a power reduction is reyuired, it is necessary to reduce the recirculation fow rate. When this is done. more voids are formed in the moderator. and the reactor power ievel stabilizes commensurate with the new recirculation flow rate. So costivl rods are moved to accomplish the power reduction.

A power range of control of approximately 35\%; cin be achieved through the recirculation flow control system. For power ranges beyond this level of control, the control rods are moved. Ramp load changes up tc $30 \%$ min are asailable through use of the recirculation flow control.

Correct distribution of core coolant now among the fuel assemblies is accomplished by the use of an accurate!y calibrated fixed orifice at the inlet of each fuel assembly. Each orifice is located in the fu:I support piece. They serve to control the flow distribution and hence the coolant conditions within prescribed bounds throughout the design range of core operation.

The core is divided into two orificed fow zones. The outer zone is a narrow, reduced power region around the periphery of the core. and the inner rone consists of the core center region.

Refueling is accomplished by removing the pressurc vessel head and flooding the voluine above the pressure vessel. thus providing for underwater handling of fuel and other reactor internals. Inderwater storage of the irradiated fuel and reactor internal parts is accommodated by special pool st:orage facilities.

The fuel loading is base. on a 4-year cycle. Approximately one-fourth of the core is replaced each year. The minimun downtime reyuired for depressurization, cooldown, refucling. repressurization. and reactor startup is estimated to be 8 to 10 days.

Auxiliary systems are provided to perform the following functions:

1. purify reactor coolant water:

2. cool system components:

3. remove residual heat when the reactor is shut down;

4. cool the spent-fuel storage pool;

5. ample reactor conlant water:

6. provide for emergency core cooling:

7. collect reactor costainment o-ains:

8. provide containment spray:

9. provide containment ventilation and cooling:

10. process liquid, gaseous, and solid wastes: 
11. provide seal water for pipes penetrating containment following a loss-of-ccolant accident (LOCA):

12. provide redindant means of removing hydrogen from the containment following an LOCA:

13. provite primary coolant kak-detection system:

14. inject borcied water by a stansby emergency linuid control syst=m.

\section{Balance of plant}

The turbine-generator system design is subject to sorre variation. A typical 10(0-MW(e) plant would have a tandem-compound 1800-rpm turbine with one high-pressure and thre: low-pressure sections. Six combination moisture separator-reheater units are used to dry and supeineat the steam between the high-and low-pressure sections. A typical heat balance diagram for a $1000-M W(e)$ plant is shown in Fig. 5.8 .

The containmest structure completely encloses the entire reactor and rearior coolant system and ensures that essentially no uncontrolled leakage of radioactive materiais to the environs would result even on gross failure of the reactor coolant system. The structure provides biological shielding for normal and accident situations and is designed to maintain its integrity under tornado wind loading. impact from tomado-generated missiles. storm uinds. floods. earthquakes. tsunamis. and other natural forces at their worst foreseeable intensity within conservatively established recurrence intervals.

General Electric Company is currently marketing a containment and nuclear design designated the Mark III. which is a complex of three buildings the reactot building. the auxiliary building. and the refueling building. The Mark III containment. shown in Fig. 5.9. uses pressure suppression with the dry containment layout. The dry well. which surrounds the reactor and prir iry conlant system, is a pressure boundary that channels s.eam from the blowdown followir; a postulated LOCA through the :uppression pool. This porl is located in the bottom of a dry containment. A weir wall and three rows of horizonta! vents are used to distribute steam flowing into the suppression pool. The entire volume of the containment is open to the suppression pool. The Mark III concept features an upper pool which provides shielding during normal operation and refueling and is used with the suppression pool for dry-well fooding following an I.OCA.

The containment siructure is similar to that of a stiv dard dry containment and can be designed either as a free-standing steel containment surrounded by a concrete shield building or as a concrete pressure ressel with a liner. The dry well is not linec. since it is a pressure barrier used to channel steam from an 1.OKA through the suppression pool and is not a primary leakage harrier. Auxiliary buildings are provided to house the spent-fuel storage and handling facility, the core standhy cooling system. and other re'sctor auxiliary equipment.

The turbine-generator building requires radiation shielding berause of the direc: cycle of the BWR. Stcam generated in the reactor ; , se conveys some fission priducts to the turbine. Fission product gases. " $\mathrm{Y}$. and some radioisotopes enter the turbine and turbine condenser. Approximately xo'; of the activity is discharged via the ait ejector on the main condenser to a system utilizing catalytic recombination and low-temperature charcoal adsomtiois. The catalytic recombiner recombines radiolytically dissociated hydrogen and oxyzen. and charcoal adsorption beds selectively adsorb and delay xenon and krypton from the bulk of the carrier gas. which is principally air After 


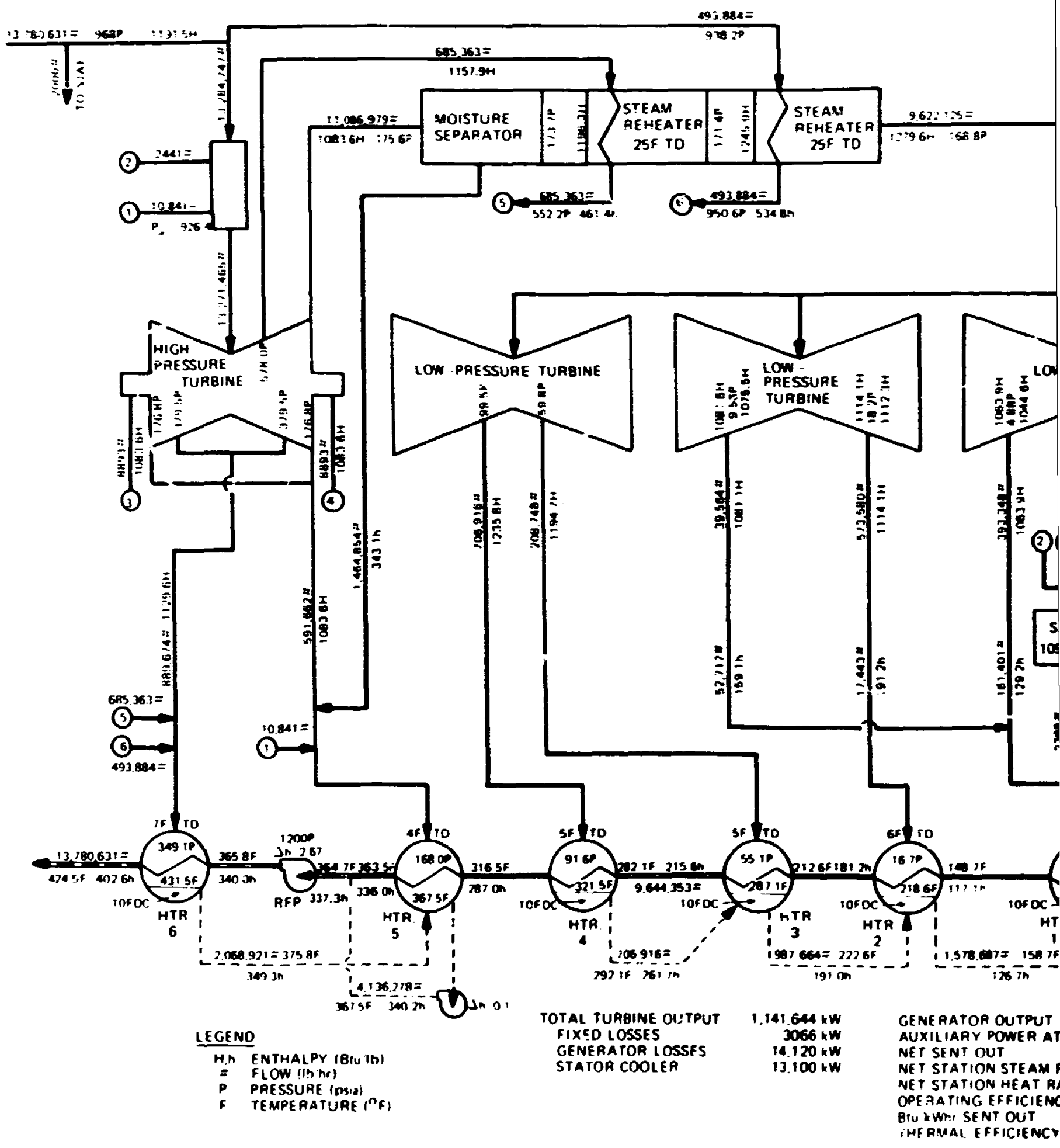

Fig. 5.8. Typical IONO-MW(e) BWR turbine cycle heat belance diagram (from WASH-1230. Vol. II). 


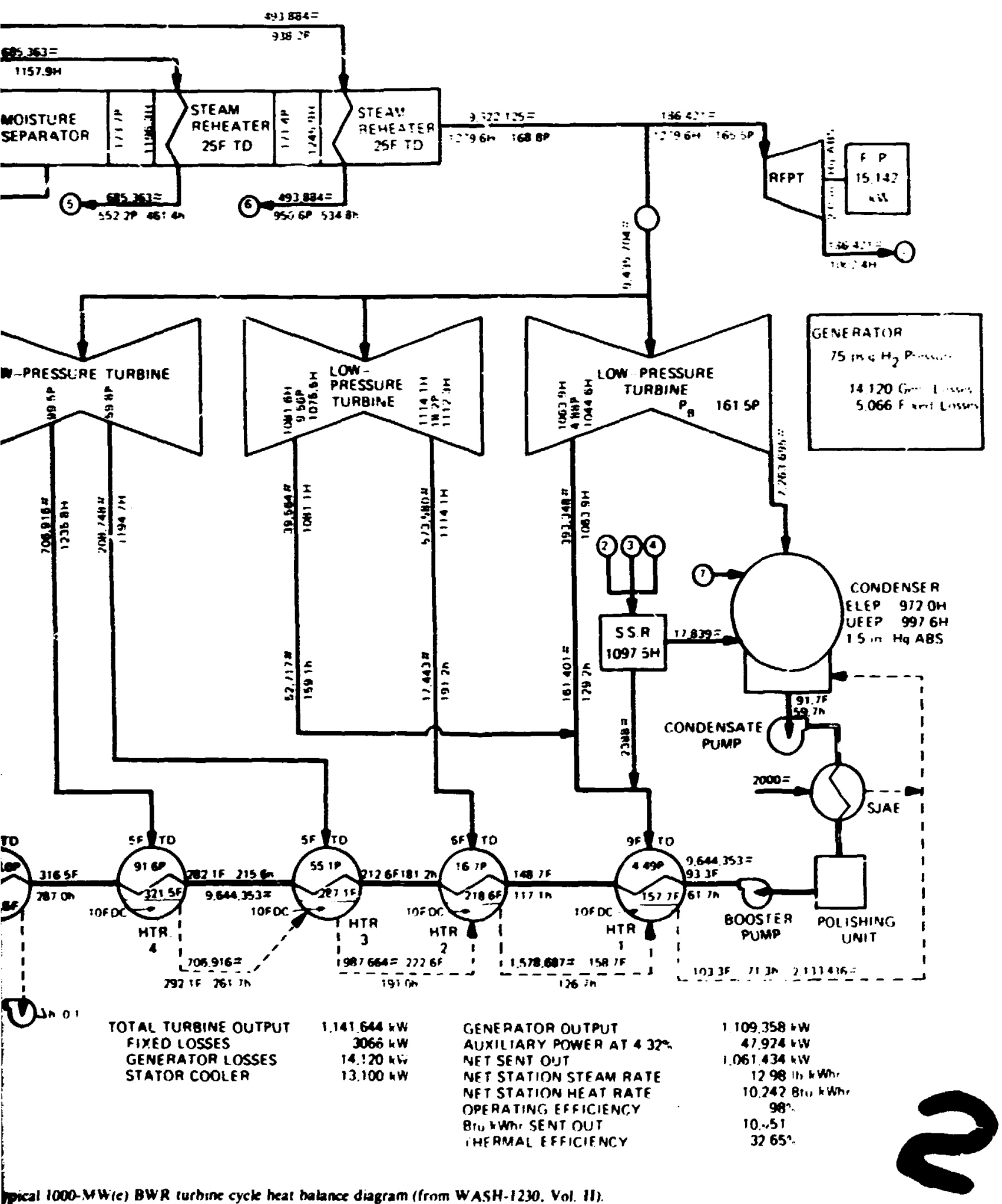


OANL DNG 745671

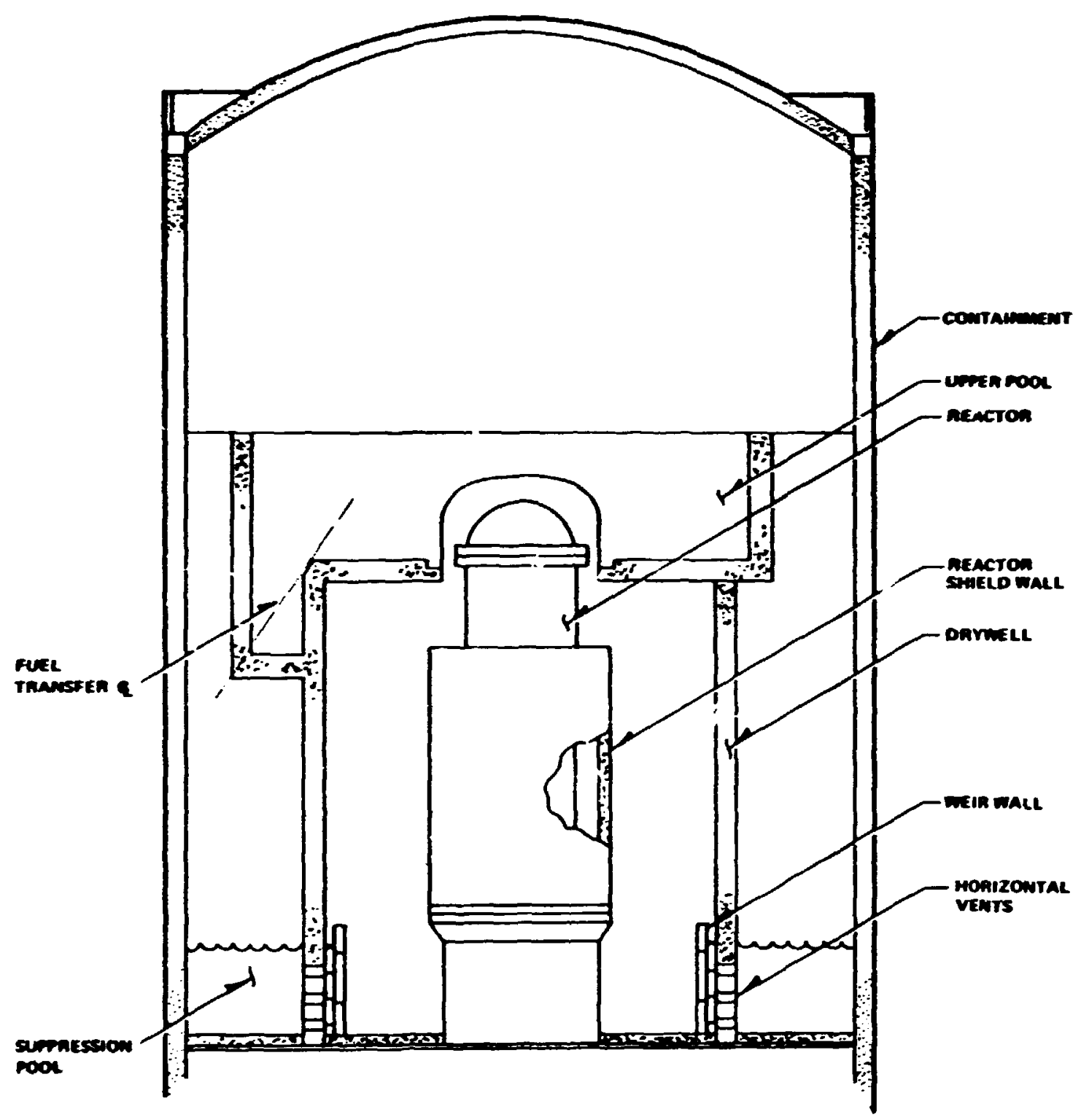

Fis. 5.9. Typical Mark III BWR containment (from General Electric Company Report NEDO-10571).

the delay, the gas is passed through a filter and discharged to the atmosphere. The other $20 \%$ of the activity follows the condersate and is treated by the condensate filterdemineralizers.

Radiation shielding is provided around the following areas:

1. mair steant lines.

2. primary and extraction steam piping.

3. high- and low-pressure curbines. 
4. tecrlsater pumps and turbines.

5 movisture separators.

6. realetur tevduater sistem heaters.

- main cendenxer ard hot uell.

X. air cjectors and steam paching exhauster.

$\because$ condensite demineralizer.

10. vit-gas lines.

Some of the eyuipment. such as the air ejectors. feedwater pumps, and heaters. arr in indis idual room. thus allowing part of the sistem to be shut dow $n$ without interrupting plant operation.

Iac control room huilding houses the instrumentation and controls for reactor and turbine-generator controls. It is designed according to seismic. tomado. and flooding criteria and contains all the necesary instrumentation and control for plant uperation under normal and accident condii.uns.

The diesel-generator huilding is designed to withstand short-term tomado loading. including tornado-generated missiles. This building houses the diesel generators that provide standty pouer.

Miscellanerus structures are required for maintenance shops. chemicals storage. Water-intake eyuipment housing. etc. Other halance-of-plant cyuipment and șstems are similar to those required for a consentional fossil-fired plant. Included are condensers, feeduater pumps. nakeup wat:r treatment systems, circulating water systems. electric plant equipment. etc.

\subsubsection{The PWR Power Plant}

\section{The nuclear steam system}

A PWR nuclear steam system is made up of closed loops in which heat is transported from the reactor core to the steam generators by circulating pressurized water. The sy:tem consists of a reactor pressure veswel containing the reactor core. the steam generator. pump. for circulating the pressurized water, and a pressurier that maintains and controls system pressure. A typical PWR coolant system schematic flow diagram is shown in Fig. 5.J0. Characteristics Iyrisal of a PWR nuclea. sleem system (Babcock and Wilcox plant) are given in Table 5.9.

Fuel for the PWR core is contained in sealed tuhes (fuel rods) which are mianted serrically. The iuel is cylindrical pellets of sintered. loweniched uranium dioxide. The pelkets are clad in Zircalny tubing and sealed by welded Zircaloy end caps. The basic fucl assembly .. composed of fucl rnds. control rod guide tubes, one instrumentation pate assembly, segmented spacer sleeses. spacer grids, and end fittings. The guide tubes spacer grids. and end fittings form a structural cage fo arrange the rods and tubes in an array

Core reactivity is controlled by control rod assemblies and soluble horon dissolved in the primary reactor conolant. The control rids. which move vertically, are actuated by clectricalị drisen control rod drive mechanisms mount:d on top of the reactor pressure sessel.

The reactor bessel contains the core and supporting structures. thermal shicld. in-iore instrumentation. and other components. The main connections to the reactor vesse, are the main 


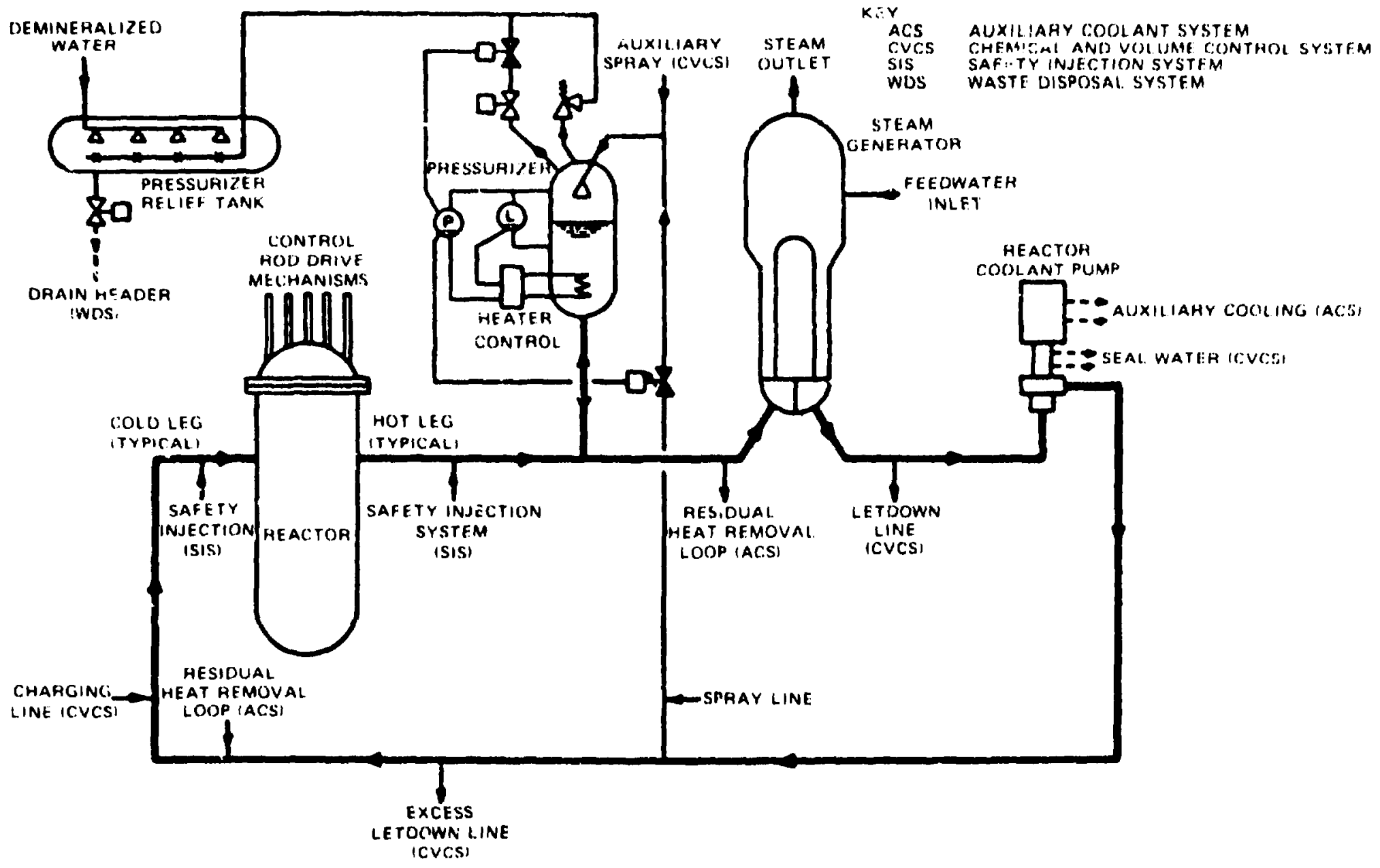

Fig. S 10. Typicul PWH. reactor cow!ent system (from Westinghouse Ekectric Corporation). 
Table 5.9. Design characteristios [ 341 3-MW(8) PMR]

\begin{tabular}{|c|c|}
\hline \multicolumn{2}{|l|}{ Thermal ind hidraulk: desugn } \\
\hline (Desyn cure heat output. NWitt) & 3413 \\
\hline Ximmal system pressire. $:$ in & 2250 \\
\hline Tutal rejitot cowlan: flow. $10^{6} \mathrm{lb} \mathrm{hr}$ & 139 \\
\hline 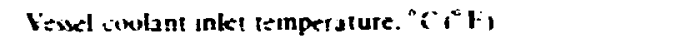 & $311,573)$ \\
\hline 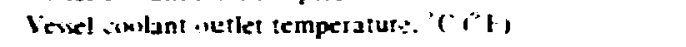 & $332(630)$ \\
\hline \multicolumn{2}{|l|}{ Resifur seswe! dewenn } \\
\hline Material & $\begin{array}{l}\text { SA-56A. Lass } 2 \text { forging. } \\
\text { sA-533. xide B. class I pute }\end{array}$ \\
\hline Deswẹn pressute. psig & $25(x)$ \\
\hline Lexien temperaturc. $(\mathrm{pl})$ & $6 ? 0$ \\
\hline Inside diameter. it in & $15-2$ \\
\hline $\begin{array}{l}\text { Okerall height of vessel and chosure head } \\
\text { cover. cuntrol rod drives. and instrument nuzzles. ft in. }\end{array}$ & $23-378$ \\
\hline \multicolumn{2}{|l|}{ Sieam seneratur design } \\
\hline \multicolumn{2}{|l|}{ Steam conditions al full load } \\
\hline How. $10^{6} \mathrm{lb} \mathrm{hr}$ & 14.86 \\
\hline Temperature. " $\mathrm{Cl} / \mathrm{Fl}$ & $318(603)$ \\
\hline Pressure, psu & 1075 \\
\hline Feedwater iemperaturc. ${ }^{\prime} \mathrm{CH}$ & $245(473)$ \\
\hline \multicolumn{2}{|l|}{ Reactor coulant side } \\
\hline How. $10^{6} \mathrm{lb} / \mathrm{hr}$ & 139 \\
\hline Inket temperature. ${ }^{\prime}(P$ ) & $332(630)$ \\
\hline Outket temperzlure. ${ }^{2} \mathrm{C} P$ ) & $301(573)$ \\
\hline
\end{tabular}

coolunt lines on the side. control rod drise mechanisms on the top. and instrument lines on the boitom. I he vessel is fabricated of lou-alloy steel and is clad intemally with stainless steel.

Ihe reactor core i* cooled by demineralized water that enters the side of the vessel. flous downuard to the lower end of the veswel. upuard through the core. around the fuel rods. and out the pipe connections on the side of the veswe. The coolant is piped to the steam generator. to the main circulating pumps, and hact to the reactor tessel in a cloxed loop. It is necessan to maintain the primary coolant system pressure high enough to pretent boiling. This is done by an elecirkally. inealed pressurizer tied into the sistem that serves to control the coolani pressure and absorb some solume variations of the primary conlant. Steam gexerated in the steam generators is piped to the stcam turli....e. passed through the turbine. cendensed. and returned by a boiler feeduater system in the same manner as in a conventwonal fossil-fired plant.

I he reactor sessel. main coolaut piping. steam generators, pressurizer, and coolant circulating numps are all low Jied inside the containment structure. Stean lines penetrate the containment and consey the steam t.. the turbine building. whi.h is not d containment structure.

Refueling of the reactor is accomplished by remor ing the pressure vessel head and flunding the volume above the vessel. Inderwater handing of fuel and other reactor components is then possible. Inderwater storage of the irradiated fuel and reactor internals is accommodated by pool storage facilities.

The fuet loading of the large PWR core is genera'ly hased on a 3-year cycle. Approximatel onc-third of the core is replaced annually. The minimum dountime required for depressurization. cooldown. reiucling. repressurization and startup is about 10 days. 
Auxiliary systems are providrd to perform the following ilunctions:

1. charge the reactor coolant system:

2. add makeup water:

3. purity reactor coolant water:

- provide ch:-micals tor corrosion inhibition and reactor contro:

5. cool system components:

6. remove residual heat when the reactor is shut ooun:

7. cool the spent fuel storage:

X. sample resctor coolant water:

9. provide for emergency core cooling:

10. collect reactor coolant diai is:

I1. provide containment spres:

12. provide contairsicent isentilation and coxling:

13. dispose of liyad. gaxeous. and solid uastes:

14. proside weal water for pipes penetrating containment follow ing an I.OX:

15. provide cooling for containment penetrations with hot pipes:

16. proside redundant means of removing hydrogen from containment following in I.(X)

17. proside main comlant leah-detection istem.

\section{Balance of plart}

Ihe turbine-generator ystem design is subject to some variolion. A Ispicai (WXX)-MW:el plant would hate a tandem-compound $18(x)$-rpm rurbine with one high-pressure and threc lou-pressure xections. Six combination moisture separator-rehcater units are emplosed to dry and superheat

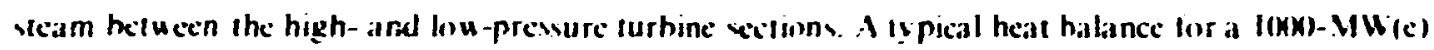
plant is shoun in rig. S.il.

The containment stucture completely encloses the entire reactor and reactor conlant wstem to ensure that eskentially no lakage of radioactise materials to the ent ironment would result clen on grows lavilure of the reactor coolant ststem. I he struction prosides biological shiciding for normal accident cond:terns and is designed lo maintain its integrity under lornator wind loascing. impact trom lornado-generated missiles. storm winds. floxds. earthquakes. sunamis. and other natural forces at their worst forexe thle intensily within consersalisciy establisted recurrence intersals. Ihe containment huilding is a concrete structure with a steel hner to etsure kalk tighiness. A lypicil I(XX)-WW(e) plant has a concrete contasnnent structure with an inside diameter al approsimatels

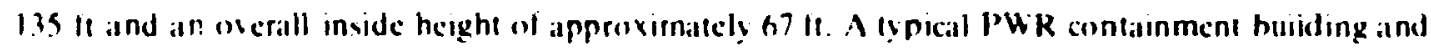
nuclear vam ? ulcm are vhrun in lig. 5.12. 


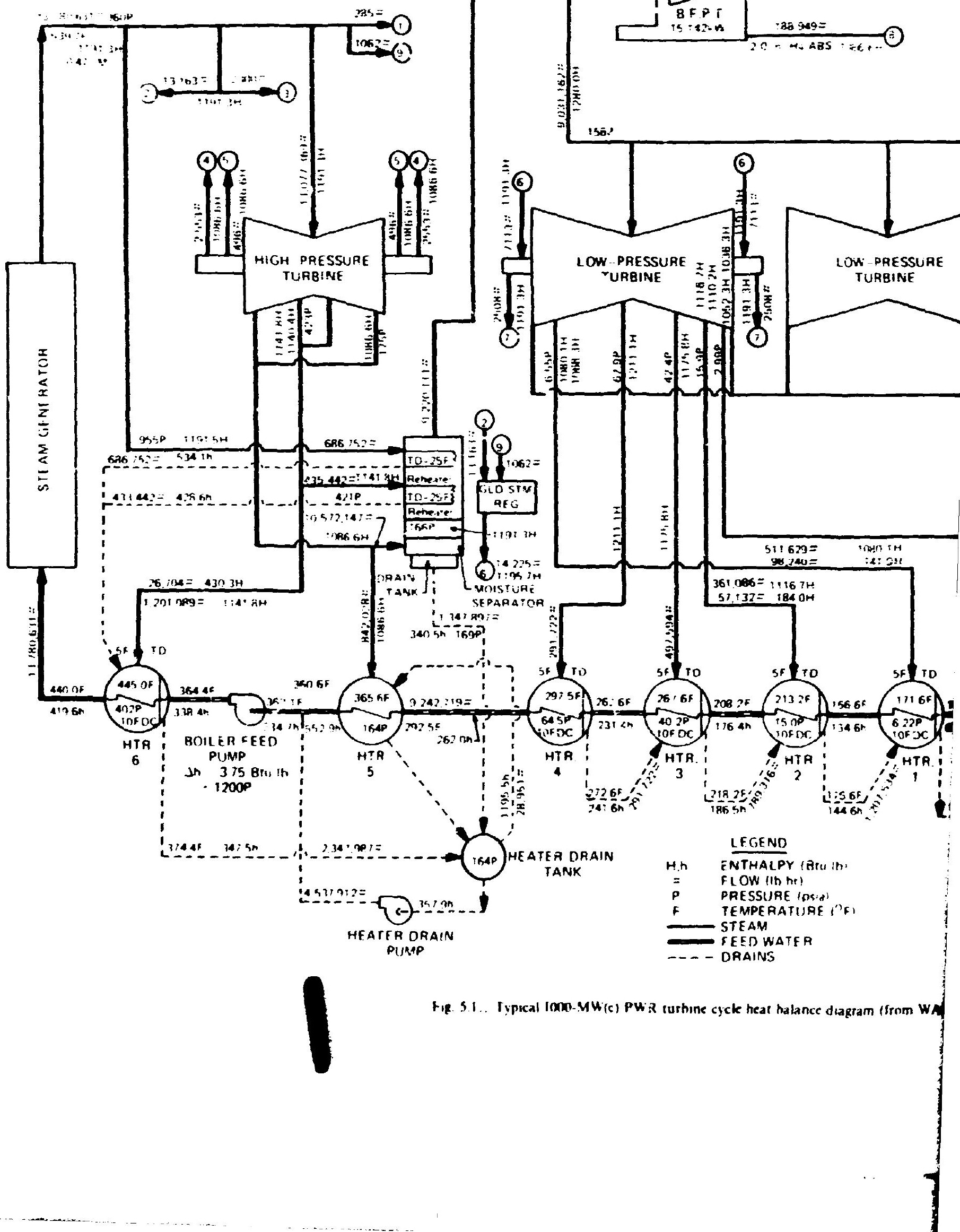


1 ลิ่ $\div \times 9=$

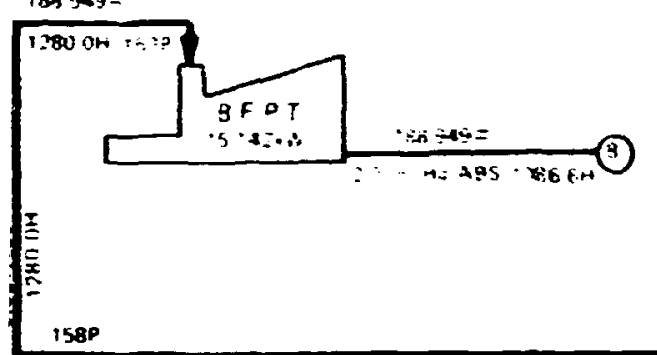

TCIAL TUMANE JUTPU: FixeO LOSSES

CENERATOR LOSSES

ST 2 TCR COOLER

GENERATOR OUTPUT

Ai) XICIARY POEYER AT 600

MET SENT OUT

ver STAYION STEAM RATE

NET STATION HEAT BATE

OPF QATING: EFFICIENCY

BTU KITH: SENT OUT

THERI'AL EFF:CIENCY

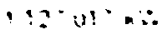

jeriza

$\therefore$. $90: \therefore$

$3: 00-\therefore$

$\because \div+8+34+\therefore$

c= $-96-\therefore$

- 030 6 548 a

$1334: 12: 2 \ldots$

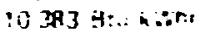

98

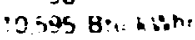

I.

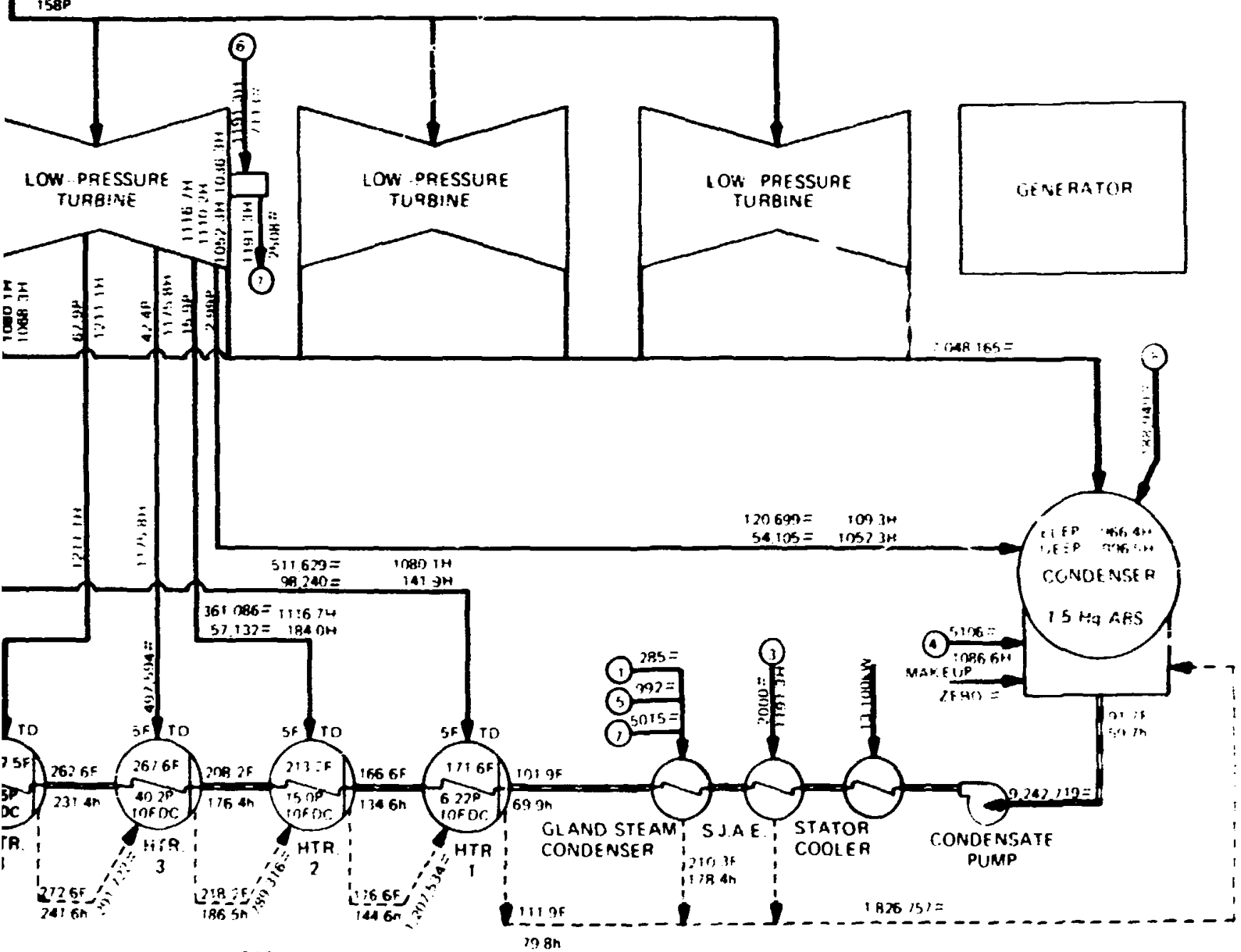

DRRIN INK

EGEND

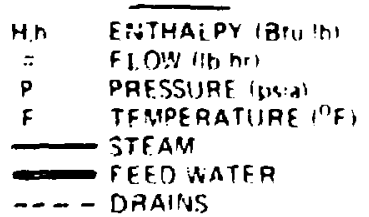

DO-MW(e) PWR turhine cycle heat halance diagram (from WASH-1230. Vol. I)

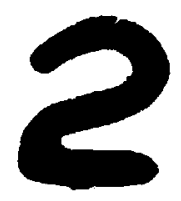




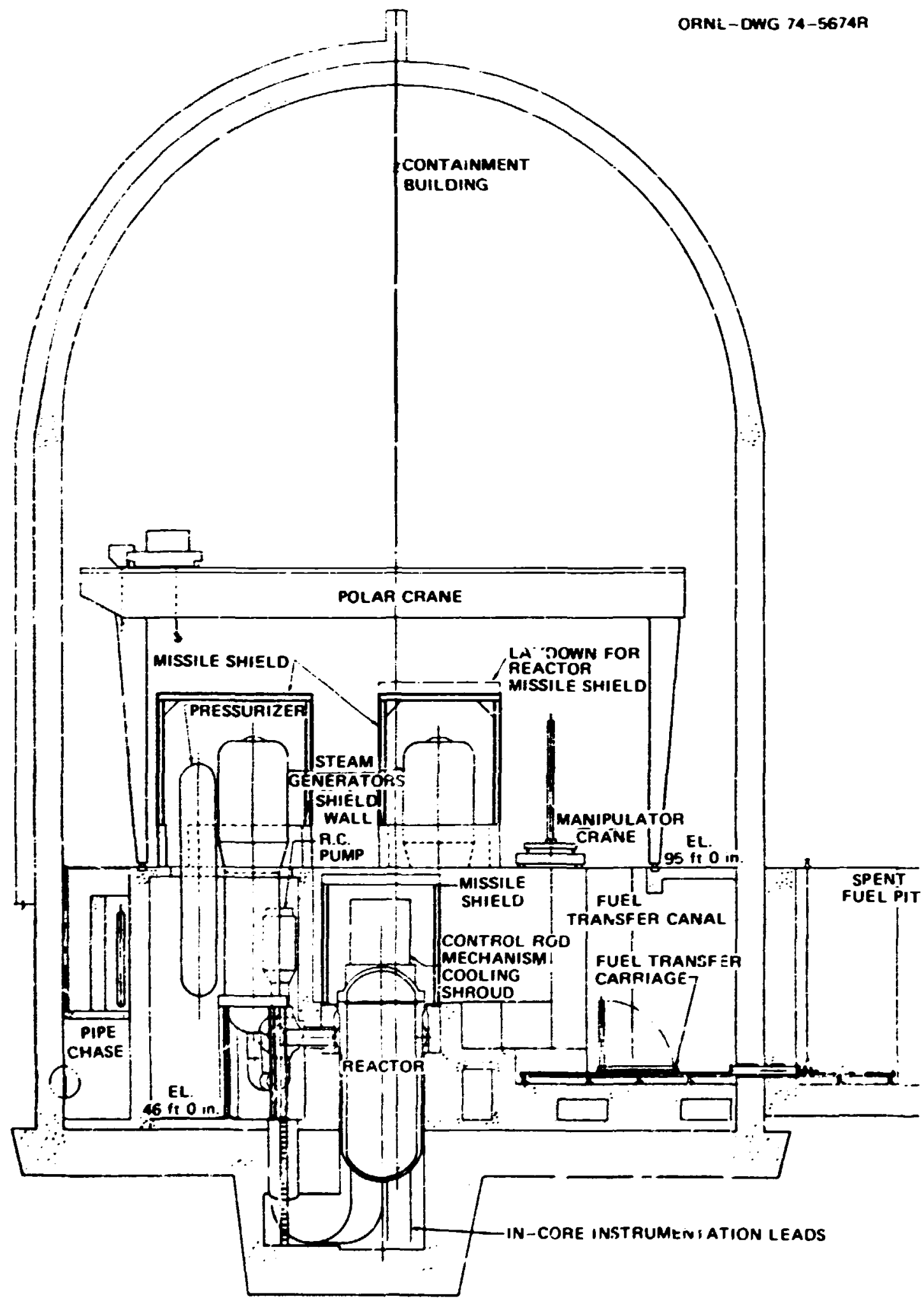

Fig. S.12. Typical PWR containment (from WASH-1082) 
I he controi huilding houx the controf roum, auvilien eyuipment, seatilation syuipmen', and the reacior plan. cusving water ssistem. It is a missile-protected huilding. since it houses silets-related eyuipnent. I he diexel-generater huikding in designed to withstans short-term tornado loiding. including lornado-generated missiles. It houxes the diewel generators that prowide standb! powet. I he turbine-generatur building contains the turbine generator anc other equipment reisted to the concentional portion of the piant. Buikfing design is hased on the arme criteris that are uxed :or a tomil-lired plant turhine-generator huilding

Miverllan:ous stretures are reyuired for fuel siorage. chemicals storage. maintenance shops. uater-intake equipment housing. etc. (jtiker balance-s)-plant equipment and systerns are similar to those required tor a onventional lomsil-fired plant. Includec are item: such as the condensers. tecduater pumps. makicup uater treatment swsem. circulating uater swstems. and electric plant cyuipnent.

\subsubsection{The HTGK Power Plant}

\section{The nuclear steam system}

I he HIC R plants Lxe helium gas as the reactor soolarte and graphite as the moderaior and core structural mate-ial. I he fuel is a mixture of enriched uranium carhise asd thorium oxide used to the form ol parricles indis idually clad with cirami coatings

All malor nuclear steam s!stem romporxnts, including the steam generators. are houxd in a stect-linici. prestresued concrete reactor :essel (PCRV) which also prosides the necessary biological shiciding. The P'CRV. in furn. is houxed in a consentional reinforced concrete secondary containment huilding. The design of the large HIGK $u$ ats haced on information developed in the course of designing and convtructing the Peach Bullom and the Fort St. Vrain plants.

I he nuclear steam sylem of the $1 \mid(x)-M W(c)$ plant produces main superheated steam at 515 (

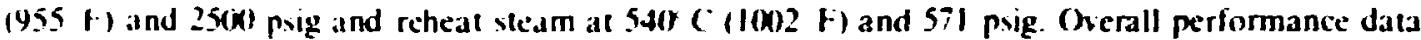
for ar HJ(jR plant are shoun in rahie 5.10. The nuclear slearii system contains six independent primary cololant loups. each uith a helium circulator and steam generator. Helium. at a pressure of abrut ?II polg. is circulated hy means of steam-turhinedriven axial-tlow heliem circulators. The heliun tlows dounuard through the reactur cure and through the single-pass steam generators. localce in the PCRT in separate ewities around the main core casity. belore returning to the helium circulators. The main superheated weam produced in the steam generators at 515 ( 1955 H) and 25(x) psig paves to the high-pressiare element of the steam turhille. I he steam from the high-pressure turbine exhaust in used (1) drive the helum circulators hefore passing to the reheat ection of the scam generatur and on 4 the intermediate- and wo-pressure exctions of the seam turbine

I he reactor cure is made up of hexayunalis shaped graphife fitel clements approximately it in. across the tlats and 31 in. high. Fach graphite block has a central pickup hole for handling purposes. coolant channels. and holes to accommodate fucl rods. Douel pins in each block maintain alignment. I he luel. in thr: form of coated particles of highly enriched uranium carbide as the fissike malerial and thorium oxide as the fertile material. is contained in honded graphite rods. The fuel elements are stacked in collumns cight hlochs high to form the core. This assembly is surrounded hy replaceable and permanent gataphite reflector blocks

Reactor control in hy control sods ste? ended from cahles drisen by electrically anerated drise mechanisms. Ihe control rods mose en vertical pasages in the central colimn of clemsits in each refucling region. fmerecency shutdoun is accomplished by injectme .leutren absorbing balls inio the core cavities. 
Tolte 5.10. Overall performance data for an HTGR phat

\begin{tabular}{|c|c|c|}
\hline & $3000 \mathrm{Mh}(\mathrm{t})$ & $2000 \mu N(t)$ \\
\hline \multicolumn{3}{|l|}{ General } \\
\hline Net plant output, WWi(e) & 1160 & 770 \\
\hline Nei nustear steam system output, MWit) & 2979 & 1982 \\
\hline Vet plant efficiency. " & 39 & 39 \\
\hline Net plant aeat rate. Biu'kWhr & 8843 & 8900 \\
\hline Turbine back pressure. in. Mr (abs) & 2.25 & 2.25 \\
\hline Main steam flow, $10^{\circ} \mathrm{tb} / \mathrm{hr}$ & 8.1 & 5.4 \\
\hline Reheat steam flow. $10^{6} \mathrm{lb} / \mathrm{hr}$ & 8.0 & 5.3 \\
\hline \multicolumn{3}{|l|}{ Primary coolant system } \\
\hline Primary coolant & Helium & Helium \\
\hline $\begin{array}{l}\text { Helium pressure at circulator } \\
\text { discharte. prig }\end{array}$ & 710 & 710 \\
\hline Core irk: temperat ure. ${ }^{\circ} \mathrm{C},{ }^{\circ} \mathrm{F}$ ) & $320(607)$ & $320160 ?:$ \\
\hline $\begin{array}{l}\text { Steam Eeneralor inket duct } \\
\text { temperature. }\left(1^{\circ} \mathrm{C}\right)\end{array}$ & $741(1366)$ & $741(1366)$ \\
\hline $\begin{array}{l}\text { Total heliur. flow ratc to steam } \\
\text { genera ors. } 10^{6} \mathrm{lb} \text {, he }\end{array}$ & 11.2 & 7.5 \\
\hline Numbir of steam generators & 6 & 4 \\
\hline Nur.sber of circulators & 6 & 4 \\
\hline system helium pressure drop, psiz & 20.7 & 20.7 \\
\hline \multicolumn{3}{|l|}{ Reactor core } \\
\hline Number of fuel elements & 3944 & 2744 \\
\hline Fuel residence time. yeats & 4 & 4 \\
\hline Average burnup. Mwd'metric ton & 98.100 & 98,000 \\
\hline
\end{tabular}

Core fuel elements and reflector blocks are removed a:d replaced through access holes in the top of the PCRV. The fuel loading is based on a 4-year cycle. Approximately one-fourth of the core is replaced each year. I he minimum downtime required for depressurization. cooldown, refucling. repressurization. a ad reactor startup is estimated to he 14 days. Figure 5.13 illustrates the arrangement of the core and other parts of the nuclear steam system within the PCRV. Dimensions of the PCRV are shown in Table S.II.

Table 5.II. PCRV dimensions

\begin{tabular}{|c|c|c|}
\hline$\quad-\cdots \cdots$ & 3000 MWi(t) & 2(K) MUirt) \\
\hline Overall height & $91 \mathrm{ft} 6$ in. & 91 ft 6 in. \\
\hline Outside diameter & IfM) ft & $94 \mathrm{ft}$ \\
\hline Central cavity diameter & $37: t$ & $32 \mathrm{ft} 8 \mathrm{in}$. \\
\hline Central esity height & 47114 in. & $47 \mathrm{ft} 4 \mathrm{in}$. \\
\hline Number of steam gencralof citculatst uavities & $\mathbf{6}$ & 4 \\
\hline Dismeter of steam generator/circulator cavities & $14 \mathrm{ft} 2 \mathrm{in}$. & $14 \mathrm{ft} 2 \mathrm{in}$. \\
\hline Number of auxilialy comfing cavities & 3 & 2 \\
\hline Diameter of auxiliary con'ing c.vitipes & $7 \mathrm{fl}$ & $8 \mathrm{ft} 2 \mathrm{in}$. \\
\hline
\end{tabular}




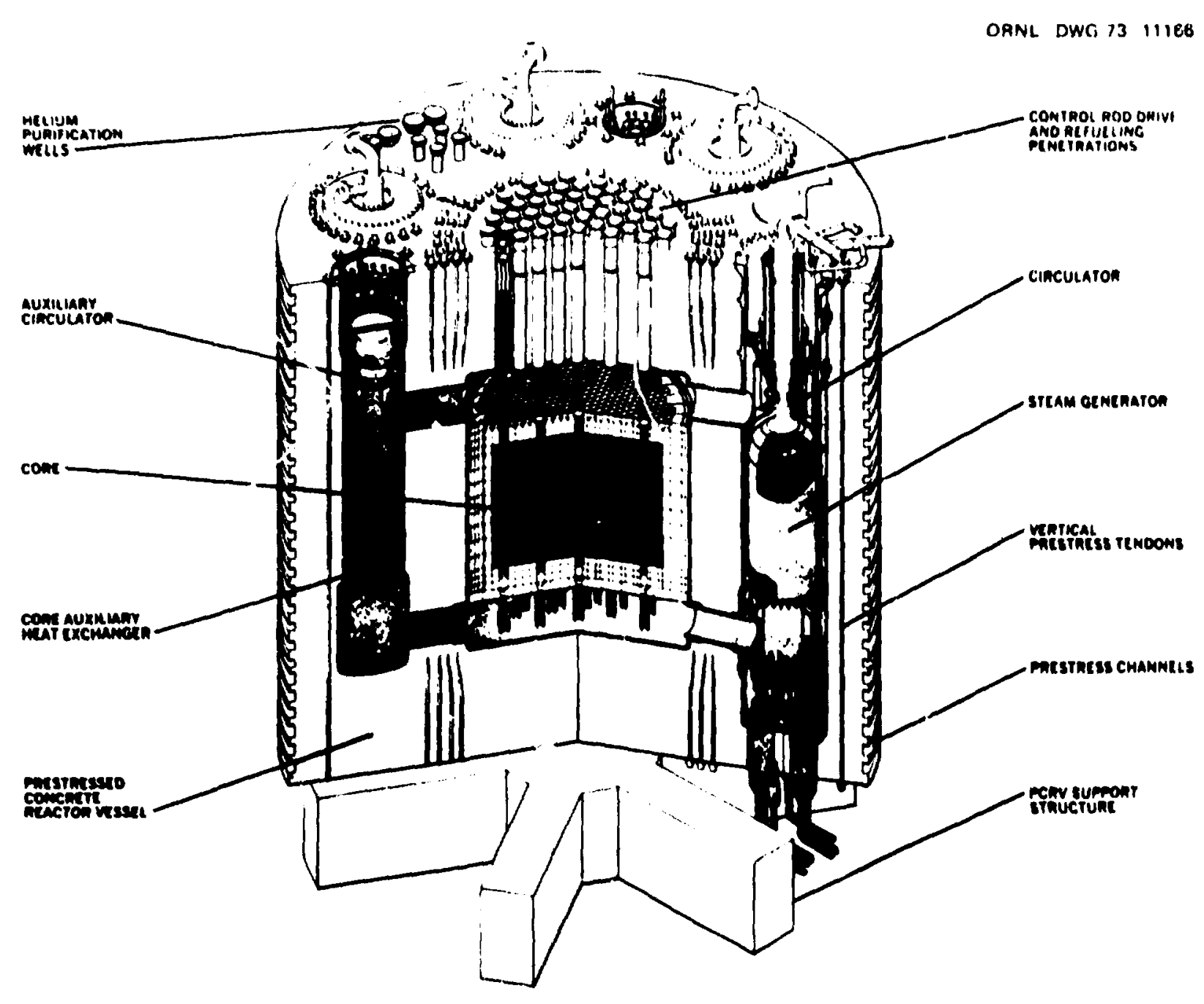

Fig. 5.13. I160-MW(e) HTCiR nuclear system. 
The intermsdiate cooling water system supplies the reactor systems with cooling nater. which. for satety reasons, is in turn cowled in a cloxed circuit bop. I his system sernes to cool the PCKV lino. main and al:aiiary helium circulators. fuel element storage systems. and helium treatment siste.ns.

The helium treatment system is provided for the removal of esntaminants from the thelium coolant. The purification process takes place in a se-ies atrangemi-rit of a high-temperature absorber. Jnger. lou-temperature absorber. and hỵdrogen absorter.

\section{Balunce of plant}

The reactor containment building provides a barrier against fission product release to the atmosphere in case of an accident. It is a concrete colindrical structure $u$ ith a total height of $125 \mathrm{ft}$ and an inside diameter of 126 fi for the $1360-M$ Hife; suc.ear steam system. The inner surface is lined with rabon steel to ensure keak lighıness.

The reactor service building houses new and used fuel storage wells and reactor auxiliary systems thi: are not located inside the containment building. Provisions are also made for storage of reactor moderator parts in this building. which is a multiston structure adjacent to the containment building.

The control huilding houses the controi room. auxi'.ar equipment. ventilathon equipment. and reactor plant cooling uater ststem. It is a missike-prote ed huilding since it hot.xes safety-related cyuipment.

The diesel-generator building is designed to witistand short-term tornado loading. including tornado-gencrated missiles. Ihis huilding houses the diesel generators that provide standby pouer.

The turbine-generator huilding contains the turbine generator and other equipment rebated to the consentional portion of the plant. Building design is hased on the criteria used for a fossil-fired plant turbine-generato: huilding.

Miscellaneous tructures are required for storage of helium bottles. chemicals storige. uater-intake eytip rient housing. etc.

The turbine generator and its controls act integrally with the nuclear steam system for turbine' load control we type of turbine selected is subject to variations: however. a typical heat halance diagram for a $3(x)(x)$-rpn tandem-compound lurbine using four feedwatci heaters is shoun in tig. 5.14. I he circulating uater system provides the major mear. ; of plant heat rejection.

Other halance-of-plant eyuipment and systems are similar to thoxe rey ired for a consentional limil-lired plant. Included are items such as the condensers, fecduater pumps. makeup ualer treatment swstem. circuating uater șsteons. and electric plant equipment.

\subsubsection{Environmental Parameters}

The conseruction of a poues plant. nucleas or fossil fucled. Woll inculably affect the environment. and wome of the effects will he aderese. Fffects a considered adserse if environmental change causes some bistic population or noniable resource to be less sife. less ahundant. or less

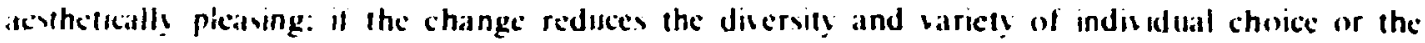

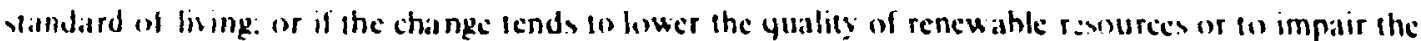
rescling of depletahle rewures. I he sererity of adverse effects should be reduced on minimum practleable kerels 


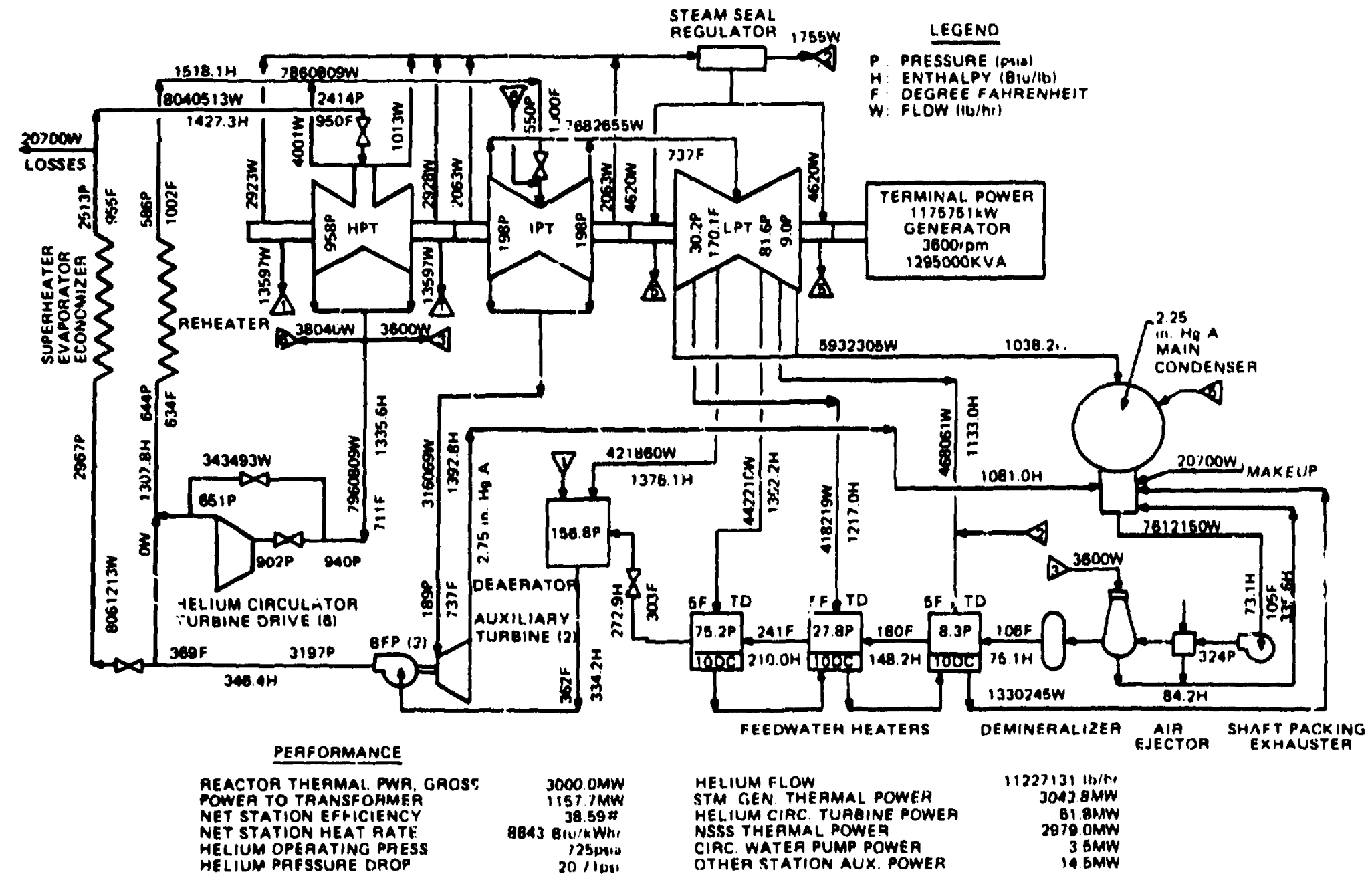

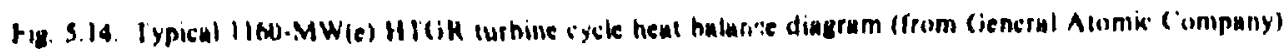


Prior to the issdance of a const ruction permit or operating license ior a nuclear pousr plant. the utility must submit a report on the potential ensironmental impacts of the proposed plant and asseciated facilities. Some of the ensironmental parameters considered in an ens ironmental report are as follows:

1. the site.

2. the plant.

3. effects of site preparation and plant and transmission facilitics construction.

4. elfects of plant operation.

5. effluent measurement and monitoring.

6. elfects of accidents.

7. coonomic and weial effects of plant construction and operation

x. altematisc energy xurces and sites.

In this study. attention is confined to the ensironmental effects af plant operation. I he two principal impacts are due to maste heat and radioactivity. although cheriual eltluents and others are important.

\section{Waste heat}

Regardkss of the thermal source in a poucr plant. about $(x)$ (o 70 ; of the heat producced is rejected to the environment. Figure 5.15 shous leat balanees for threc 1 pe:s of plants. each producing $I(x)$ MW(e). I he I.WR plant is assumed whase an efficienes of 3y $i$, whle the HI GR

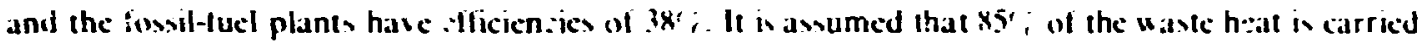
wt hy the condencer cooling water for the fowsi-fuel plant and 95'; for the nuciear-fucl plant. I he I. WR plant deposits about Sar; more waste heat in the condeneer water than the fonsil-fuct platil and about 35', more than the H I $; R$ plant. H G $; R$ plants have about the ame steam conditiors as

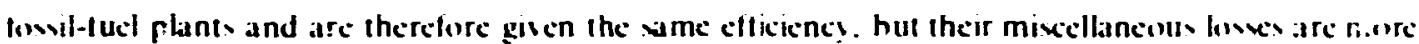
like there ot the I WR plants.

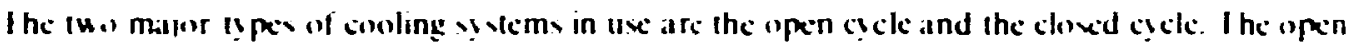

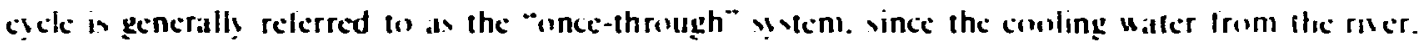
lak:. wean. "r wher wurce is pumped through the condenci and th:n returned fo the wurce. In

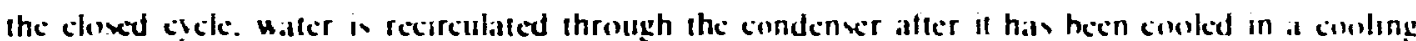
lawer or pond. Cowling touers mas be either wet or dry. natural drall or mechanical dralt. Coulong

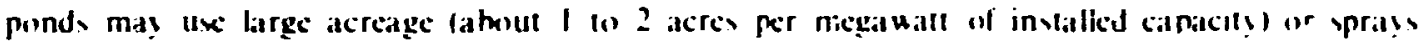
to ensure the desired degree of cooling.

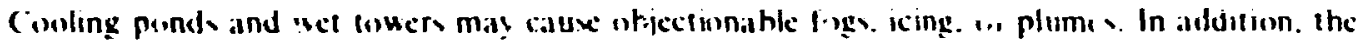
sice of the pond or touer ma! be whicetionable.

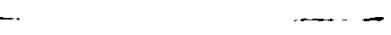

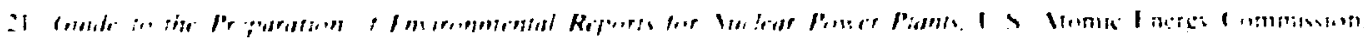

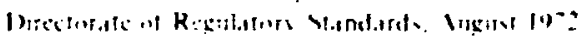



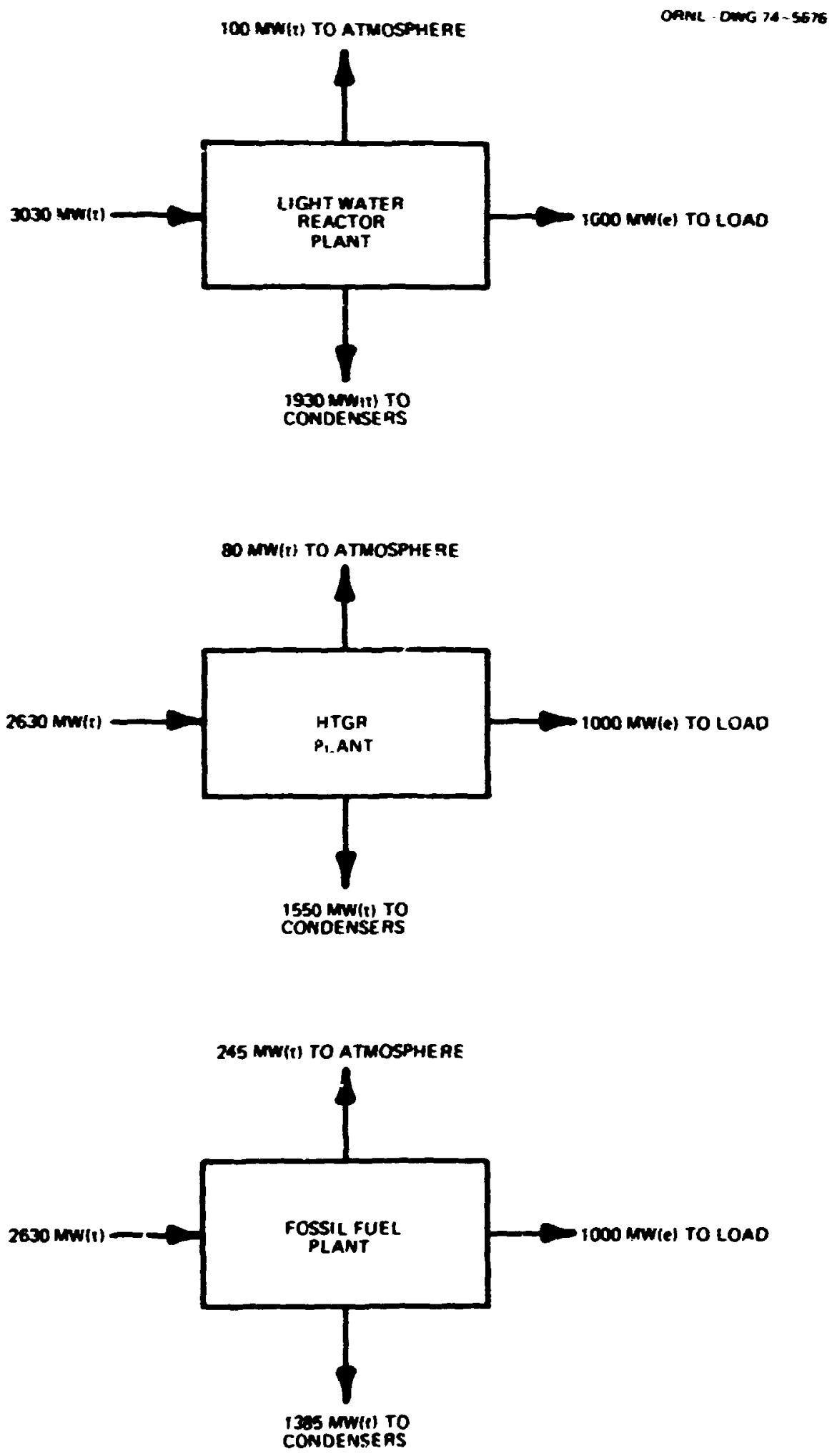

Fig. 5.13. Heat balances !nt LWR. HTGR, and fossil-fuel power plants. 


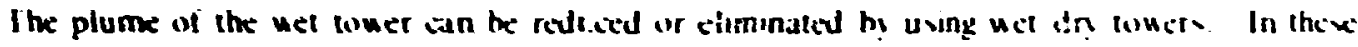

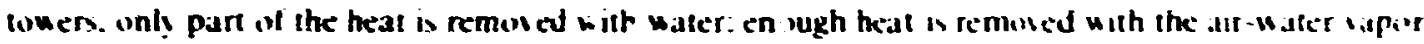

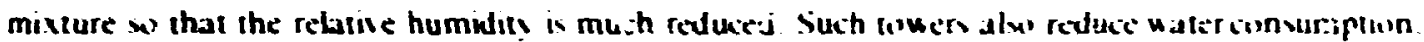

\section{Radiological}

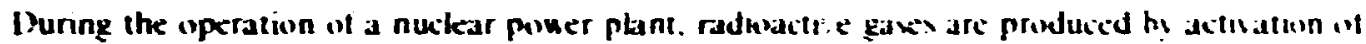

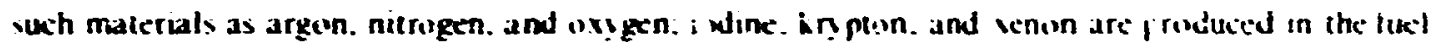

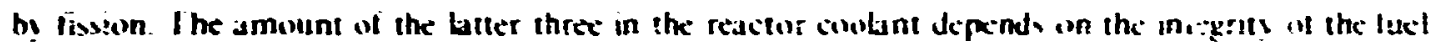

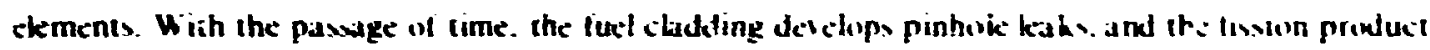
gals cxapes into the coxliant

The plasiv are doggned to operate with tuel element kahage up wh abut I! . In the BWR. the gaxes reteaxed wo the primary cooliant are carted to the turbine and to the condenxt along with the

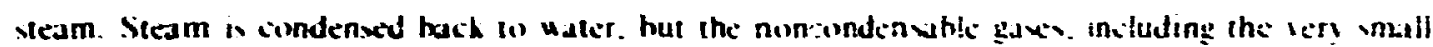

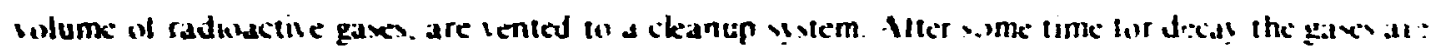
liltered and rekeased to the environment through the tach. In the PW R. movt of the raviudetise

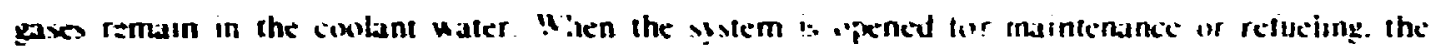
gaxes are sented to a cleanup system from which thes mal be rekased to the atmosphere.

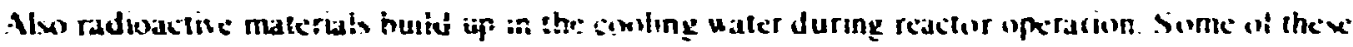

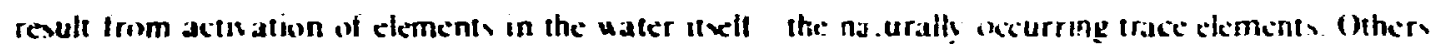

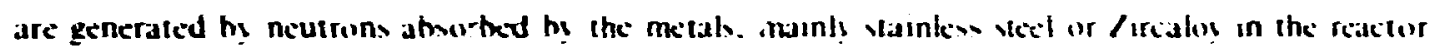
wisem. Other radikactice products leah out of the tuel clements In additun. tritium iv produced in the conlant and fuct elements.

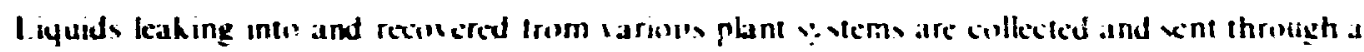

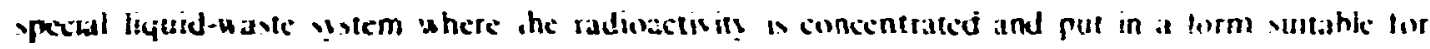

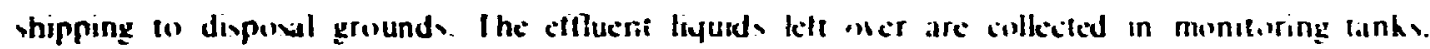
cheched for radioaterot!. and rekand al a controlled rate in the plant condencer corofing waller.

Solid uasics arce generally dispoued if off site

For an HIGR." the wurees of radivactic gaseous Haste that result in releate lo the

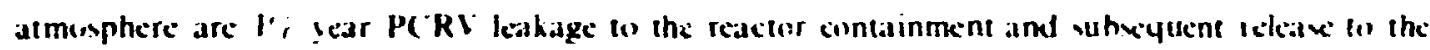

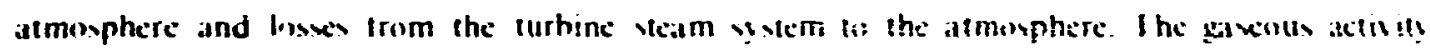
dicharged to the atmosphere iren the vation during normal operation iv lexcluding tritilim) ahout

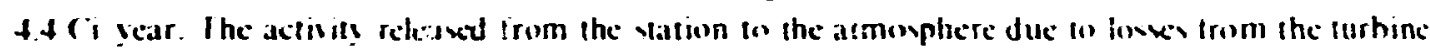
steam wstem during normal operation 1,1 w) (i ist trtium per scar.

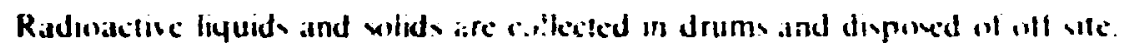

\subsubsection{Operating ard Mainte.ance Manpower Needs}

Ithe stalfing of a commescial nucleas power plant with operating and mainlenance personnel reyures carcful xelection and taining of personnel as ucll a careful liming in the hiring of the vall.

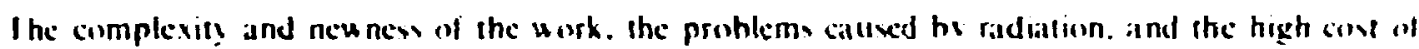
oufage !dvetif more than ordinary planning in the hiring and training of a valf.

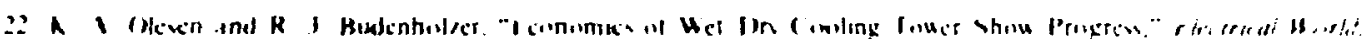
Ihe is $14=$

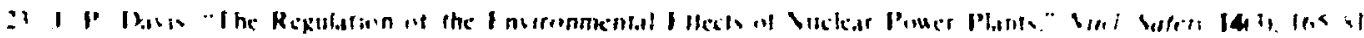
(1), Ine $14+1$,

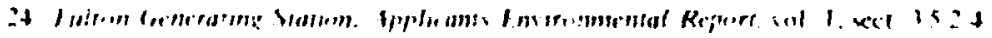


Ihe vall at a large utilit! mal be dis ded into thu large groups: the home otfice for headyturters sall, and the operaling stall. It is assumed that the theadquarters statt is alreads lumetuning. and the emphass w on the operateng and maintenance stall. I he iollowing ge'meral discussion an be applied to all types ot reactors.

\section{Operations and maintenance staff}

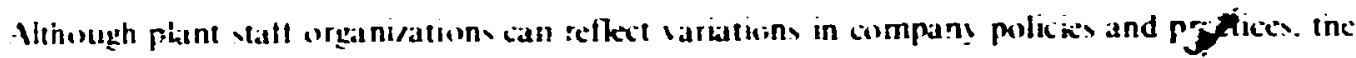

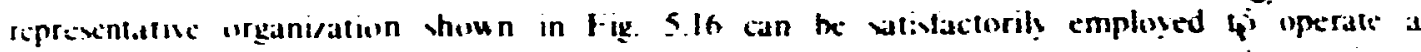
current-genciaturn vingle-unit sation.

Iach sperating hift creu consists of a xenior licensed shift supen isor. tho licented cont ol

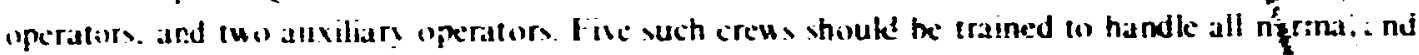
ahnormal uperating procedures. It least one replacement for each ot the three eategories foulu be tained and atailable lo maintain creu strength when joh shifts, resignations. or retirenteras ocess and to accommendate on-sitc lucl handling proxedures.

birect das-to-das technical support for plant operations is a necessity. The vital tech fical aréas

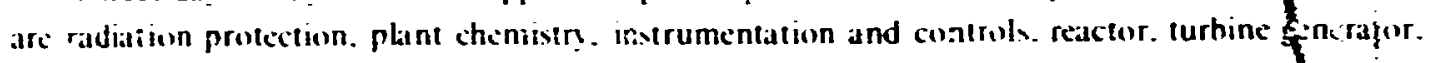

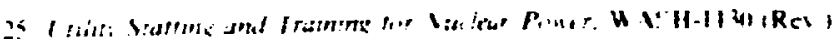

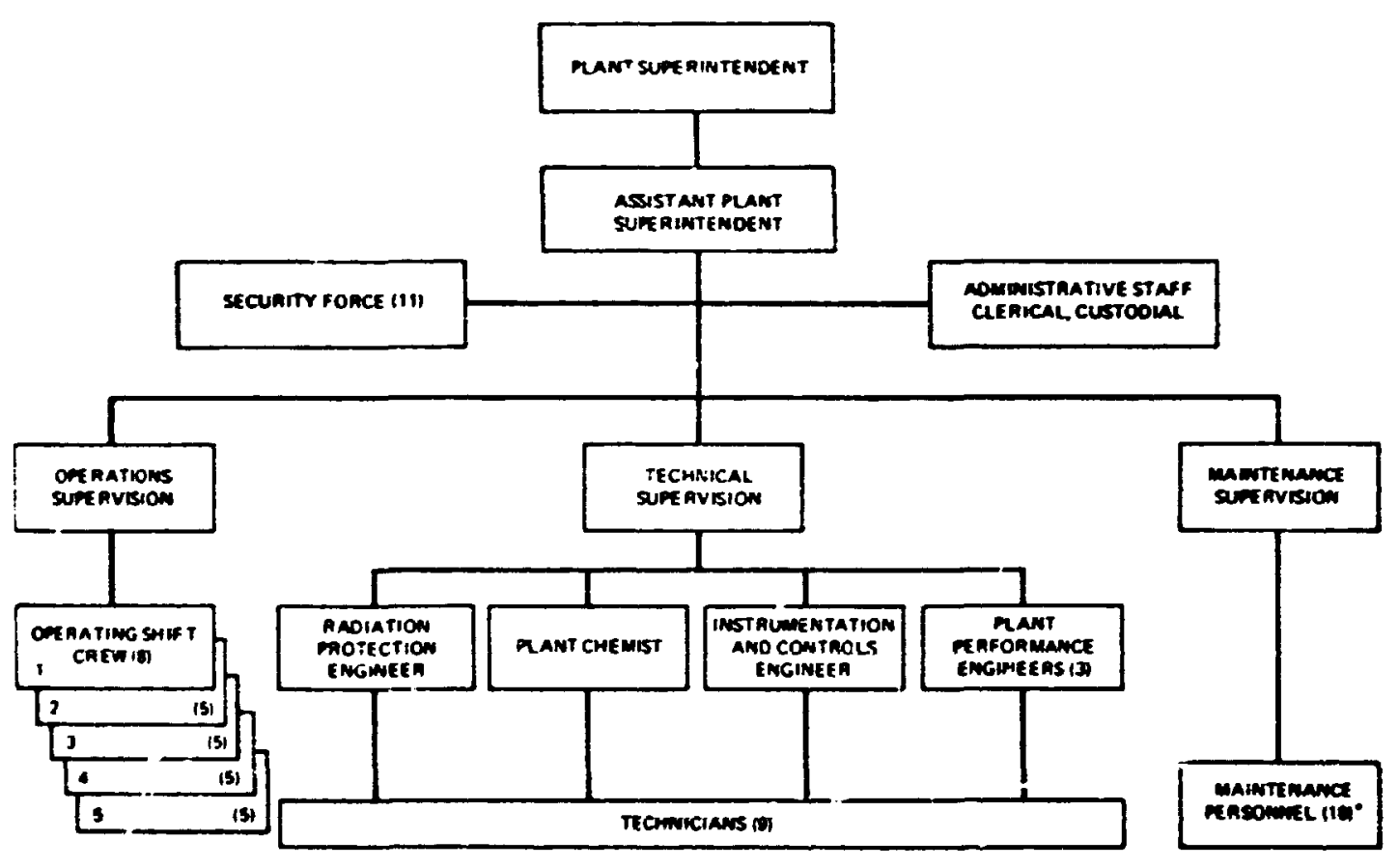

Fig. 5.16. Representative nrganuation for a single-unit central station auclear power plant (from WASH-1130 Revised). 
and balance-of-plant eyupment. Functions include routine musitoring. sur eys, sampling. anolyser. instrument checking and maintenance. performance analysis, $k \dot{s t}$ preparations. and evaluation of results.

Flectrical and mechanical maintenance reyuirements moted are largety aimed toward the presentive maintenance program but will allow for some repair and corrective maintenante. Certain - - - inited craft shills not reutinely needed at the plant site may come from a more centralized șsiemu ide maintenance staff or from outsule organizalions.

A plant security forte of 11 provides for a superisor and 5 shift crews of 2 men eacit for round-1!: :-ock coverage. Due to the specialized training reyuired far security force personnel. they may be adminis!ratively attached to - separate organization reporting to freadyuarters.

The timing of the selection and appointment of personn:l to a plant staff is an important consideration to assure that full yualifications requiremenis are met by the statf when the plant is read. Management and key supervisory personnel should be on board not bater than 4 years before initial fuel loading. Operating crew personnel should be selecied at kast 3 years in advance of fucl loading so that thes will have completed virtually all formal and experience training reyuirements by the time the preoperational test program begins. Technical support personnel should be selected and assigned within the 2- or 3-year period ahead of fuel loading for training and familiariation assignments. Security personnel may he required to protect property early in the construciion pe:iod but should be fully trained atud on the job during preoperational testing.

The safiting of multiple-unit stations must provide for the performance of esientially the same funztions as are required for single units. There are considerations, houever. which may make it unnecessary to duplicate single-unit staff entirels. Some of these are (1) the degrex of simitirity in design features and operating characteristics and the reflection of these in uperability and maintainahitity. (2) the extent to which some ș stems (e.g.. waste managernent) are common. and (3) the ihsence of overlapping stanup and break-in periods for successive units during which manpouct demands may be heavier.

Tables 5.12 and 5.13 display the organizational breakdown for representative multiple-unit ste:ions. Study of the comparison shown with a single-unit station staff structure demonstrates the potintial applicaibility of the above factors. vit.. identical units with a common control room and some shared systems.

Ir will be noted that it also reflects an opportunity for more effective use of manpouct through specialisation of the operational fuel management function on site. A fucl handling team shomld be consiftered in lieu of additional "regular" operating personnel for multiple-unit stations. The team": responsibilities unuld cover all phases of fuel handling on site. from receipt, inspection, storage. inventory control. refueling and unloading the core. spent fuel handling. cask loading, and shipment of spent fuel. The lead fuel handlers (or foremen! of this team would be expected in yuatily for senior operator licenses which can be restricted to cover the senpe of their activities.

\section{Staff training}

Concurrenty with the obuaining of a staff so that the plant may he put in operation upon completion, a training program must be in opcration. Various standards have hecn prepared Uescribing the qualification requirements for . variety of posit, s. The A.SSI N18.1-1971 standard. Selection and Training of Vuclear Power Plant Personmel. specifies minimum general qualifications and specific education. training. and experiencs for all functional levels within an operating 


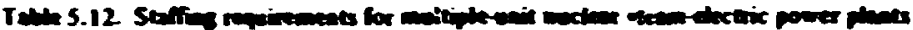

\begin{tabular}{|c|c|c|c|c|}
\hline & \multicolumn{4}{|c|}{ Nant ex } \\
\hline & 1 wait & 2 mits & 3 mants & + mants \\
\hline \multicolumn{5}{|l|}{ Pant mangerment } \\
\hline Superimietatent" & $\mathbf{I}$ & 1 & 1 & 1 \\
\hline Axestimat & 1 & 1 & $:$ & 1 \\
\hline Chets & 5 & 5 & 5 & $\checkmark$ \\
\hline \multicolumn{5}{|l|}{ Operalive } \\
\hline Operat ors supermsocs" & $\mathbf{I}$ & 2 & 3 & 4 \\
\hline Shift s 4Finmors= & 5 & 6 & 12 & 12 \\
\hline Legl inetatorsi fore men" & & s & $s$ & 5 \\
\hline Control operaiors & 11 & 16 & 26 & 31 \\
\hline Auxitc:s operstons & il & 16 & 26 & 31 \\
\hline Leat foel handiers/foremen" & & 3 & ; & 3 \\
\hline F uet handers & & 6 & 9 & 9 \\
\hline \multicolumn{5}{|l|}{ Technol } \\
\hline Tochrical supervisor & $\mathbf{I}$ & 1 & I & 1 \\
\hline Profesponsis & - & 9 & 12 & 11 \\
\hline Tecthnuctians & 9 & 16 & 25 & 3: \\
\hline \multicolumn{5}{|l|}{ Miantemance } \\
\hline Maidemance supetrivors & 1 & 2 & 3 & 3 \\
\hline Crafis and repirmen & 18 & 28 & 4 & ss \\
\hline Secunty & 11 & 16 & 16 & 16 \\
\hline Total & 82 & 133 & 192 & 221 \\
\hline
\end{tabular}

Senior licernsed operator qualifications.

- Licensed operator qualifications.

Tpecial enior iscensed opetator quatifizations.

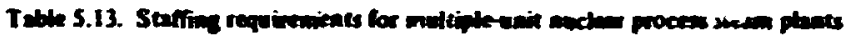

\begin{tabular}{|c|c|c|c|c|}
\hline & \multicolumn{4}{|c|}{ Mant six } \\
\hline & I unit & 2 units & 3 units & 4 units \\
\hline \multicolumn{5}{|l|}{ Phant manxement } \\
\hline $\begin{array}{l}\text { Superintenoent' } \\
\text { Assis:ant }\end{array}$ & 1 & 1 & 1 & 1 \\
\hline Clerks & s & s & 5 & 5 \\
\hline \multicolumn{5}{|l|}{ Ope:1tions } \\
\hline Operations supe msors" & 1 & 2 & 3 & 4 \\
\hline Shift superviors" & 6 & 6 & 32 & 12 \\
\hline Lead operator/foremen & & 5 & 5 & 5 \\
\hline Control operztors ${ }^{b}$ & 11 & 16 & 25 & 31 \\
\hline Auxiluary nperators & 8 & 13 & 18 & 23 \\
\hline Lead fuel handkers/loreanenc & & 3 & 3 & 3 \\
\hline Fuel handkers & & 6 & y & 9 \\
\hline \multicolumn{5}{|l|}{ Technical } \\
\hline Techniral supervivor & 1 & : & 1 & 1 \\
\hline Profescionals & 6 & 9 & 12 & 12 \\
\hline Tectunicians & 1 & 11 & 15 & 19 \\
\hline \multicolumn{5}{|l|}{ Maintenance } \\
\hline Maintenend supervisors & $t$ & 2 & 3 & 3 \\
\hline Crafls and repairmen & 12 & 18 & 24 & 30 \\
\hline Security & 11 & 16 & 16 & 16 \\
\hline Totd & 71 & $\overline{115}$ & 154 & $\overline{175}$ \\
\hline
\end{tabular}

- Senior licensed aperalor qualifictions.

- Licensed operitor quelifications.

especial enior licensed operator qualifications. 
organiratior. that have a direct relationship to technical operational and maintenance aspects of a nuckeas plant

Figure $\$ .17$ is a schedule for training senior operators and operiats at the appropriate time." Other piant saft members new to the nuclear ind:tstry can benefit by participatic $n$ in these programs even thougt they will not need licenses.

Part of tixe training may be provided by reactor manufacturers, governnent agancies. uni.ersities. or consultants In general. most utiities provide their own design familiarioalion and :n-th:-job training just prior to the initial fuel loading and power scalation progi $: \mathbf{m}$.

The typical sched ule given in Fig. 5.17 assumes the indiv idual has no prior know kedge of reactor operations but has pertinent experience in steam plant operations. Trainces who aicady hate or are acyuiring enough nuc!ear experience to yualify for the AtC iiceuse examinations prior to initial

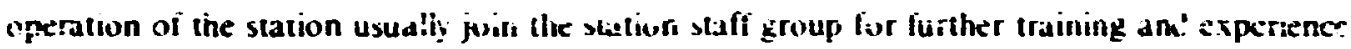

The training (for operators and staif) indicated in Fig. 5.17 is keyed to several different phases considered standard.

Phase I- Introduction to Nuclear Power. Participants receite instruction in basic nuclear physics and mathematics reíresiner, reactor physics concepts (flux, reactivity. cross section). and characteristics and operating behwior of power reactors.

Phasc la Demonstrations of Reactor Properties. A low-power rexearch reactor is ixed in conjunction with or immediately following phase $I$.

Phase 2 On-Shitt Participation. Extensive operative experience at a sinilar power reactor or a combination of experience at a power reactor and a power reactor simulator serves both to gise experience and show the practical applications of theor kearned.

Phase 3 Design Familiarization. Iectures. together with study of plant systems and discussion with various design groups at the nuckear steam supply system designer's location. prosioce familiarity with systems purpose and function.

Phase 4 On-the-Job Training. Details of the indisidual plant operation are learned by assisting in the initial check-nut, writing procedures, and operating the various plant systems. In adition. regularly scher!uled training xessions should be directed toward design. nuclear characteristics. operating procedures. and administrative controls.

Phase 5 Specialty Iraining. Specific job functions (c.k.. radiation monituring or instrument maintenance) are generally taught at the appropriate ime.

\subsubsection{Downtime for Refueling and Uther Maintenance}

Most operating power reactors are refueled approximately once every gear. with the first refueing within 1 or 2 years after the start of commercal operation. Refueling is not necessaily, hut is invariahly. accompanied by major maintenance outage.

A survey of the operating experience of ten reactors for the first half of 1973 shows that the arerage downtime during refueling was about 62 days. The actual refueling time was approximately 31 days.

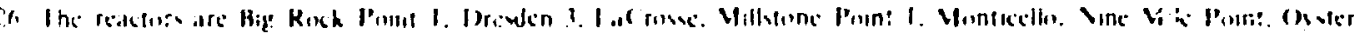

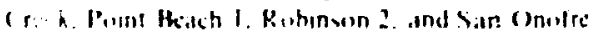

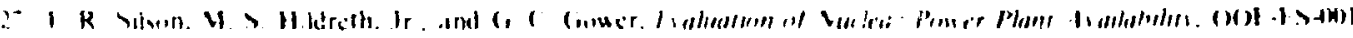
1: $11,1,1,+1$ 


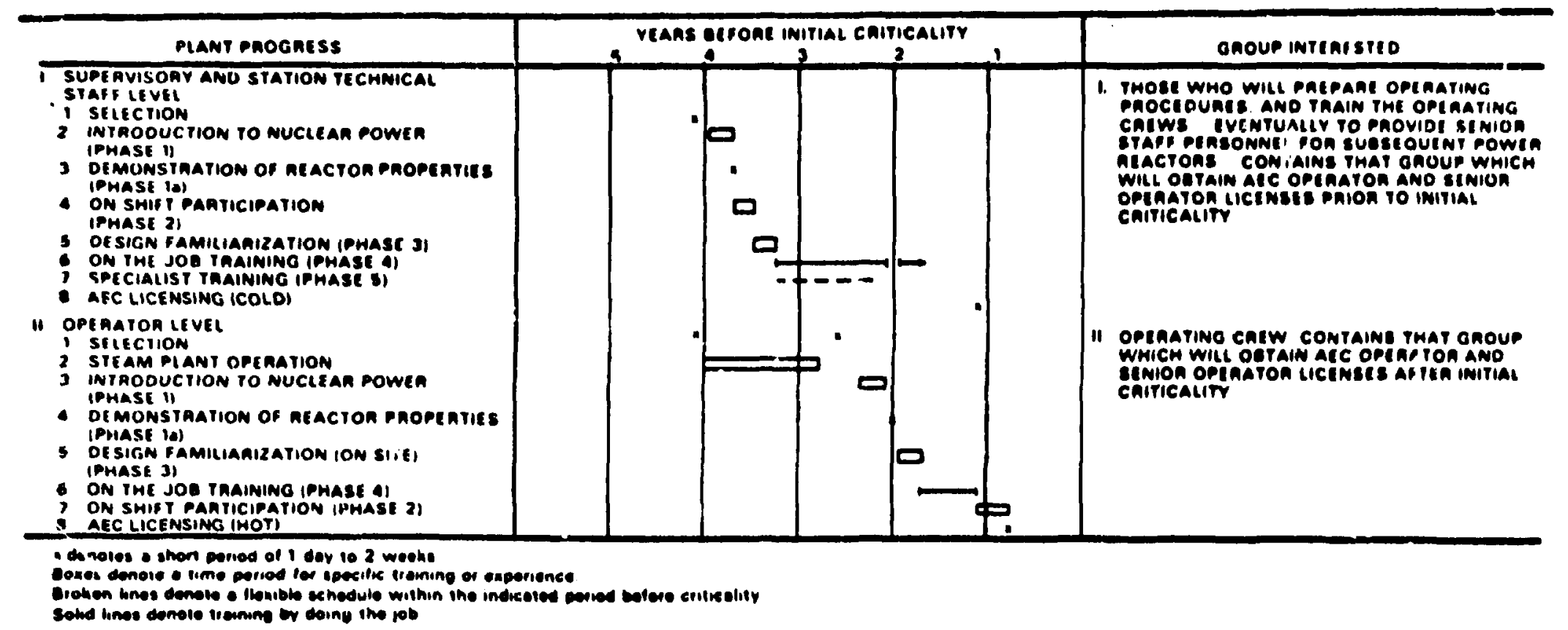

FW. 3.17. Schedule for iraining and experience (from WASH.11,30 Revisell). 
Durng refueling. there is generally a radial reshumine of the old fure!. and aho'll one-third of the fuel is replaced. Sometimes the utility does the refueling. and other times a vindor refueling irew under contract to the utility performs the service.

The a:nuunt of operating experience data for $L$ WR plants that is representative of current ptant designs and power kiots is still somevibat limited. Although 27 nuclear plants were licensed to uperstc by the end of 1972. ont 8 of these plants had operated 4 years or longer. Fin: of these cight had a design power rating of $200 \mathrm{MW}(\mathrm{C})$ or kess. and they vere in effect une-of-a-kind plants.

A study of the 19:2 operating records of 19 licensed nuclear power plan:s was conducted io examine filant availability and to assess the nature. ca"se. and significance of plant shutdowns." Ir: addition. the operating records for 4 of these plants were studied for the total pericd of commercial operation to provide a broader time base for comparison

The average nuclear plant avalability during 1972 was $73 \mathrm{C}^{\circ}$. where plant availability is delined as the time the generator was in operation divided by the total time during the period. Of the IS plants studied. 7 achieved availabilities of $80{ }^{\circ}$ or above.

The 1 plants for which operating records were analyzed over the total period of commercia, operation lad an average plant avilability of $72 \%$. Thes plents had heen in operation from 2 to 3 yours. Analysis indicates that, on the average. a break-in period of from 3 to 4 years is required for a nut rea plant to achieve an avaibability factor "if 80 ; or above.

The average percent of forced and scheduled outas: for the 14 plants during 1972 was 11 and 16\% respec vel;. For the 4 plants with longer service time. forced outages accos:ated fior $12 \%$ of the time and scheduled outages for $16{ }^{\prime \prime}$, of the time since they began operaion.

Five of ihe 19 nuclear plants had forced outage factors exceeding isc; in 1972. Fyuipment malfinction: and tailices were the case of $96 \%$ of the forced outages. while operator errors werc responsible for $4 \%$.

Identification of the nortions of the plant causing forced outages revealed that 43\%, of the total uas attributahli in nuclear-related systems ard components. Hossever. the nuckear-related eyuipment accounted for about $56 \%$ of the downtime. indicating that the time recjuired to repair nuciear cyuipme,it was sumewhat greater than the time reyuired to repair conven: ional eyuipment.

The maior estuipment itcms contihuting to forced outages were valses. pump sals. turhines and their associated auviliaries control rod drives and associated controls. main electrical gen:rators. slcam generators. conder. $x$. and feedwater ststem puillp: a:ıd controls.

Each of the forced witages was elassificed with respect lo its actual or potential wifty significance. Sutales resultirg in the releas: of radioactive effluents from the primary cerslant pressure houndar: an! thow re.viting in the ac:ual or potential biolation of the fechnical specificallo. ns sere consitered to be of potential significance to public nealth and safely. Fialuation of the fore od nutages in th , basis indicated that abnut $4 h^{\prime}$; might be constriked in he related in safety. H..uever. none of :he sorced outages resulted in any injury (1) a mentere of the public ar a release of radoacti: : matet a $s$ in excess of permissible levels.

Scheduled outages f., the 19 plants uere rs nonsible for the plants betng shut onu a an alerage of 16, of the tims. In 6 of the 19 plants. the operating lime lost hecause of wiveduled outages was sell in excess of this average value. Operating repots indicate that a significant amount ot time was

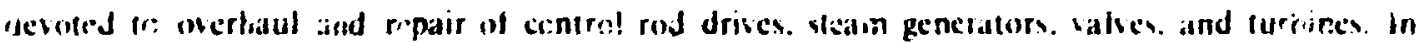

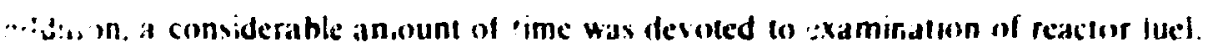




\subsection{Coestruction Schedule}

Figure 5.18 shows in schematic form the major elements of lead time for a $n$ itiple-unit nuckear power plant project from -commitmen' to commercial operation. This schedule is modeled after single-unit plant schedeles developed th the Atomic Industrial forum." The time allowances are typical of the present exeration of custom-designed plants hut include no provision for major celays caused by strikes. contested hearings. or design revisions.

line 1 shows a $4^{i}$ : year on-site construction period for the first unit. followed by a 6-month period of test operation before commercial operacion. Tomalhy. on-site construction cannot commence tiitii issuance of an AEC constnection pernit. The second. third. and fourth units are placed in operation at 1 -year intenals.

line 2 shows the related time scak for fabrication and deivery of long leadtime items of eyuipment. senh as the pressure vessels. steam Eenerators. main coo'ant pumps. and the turbine generaturs. Shop spece mist be resened a! last 6 months in advance of fabrication. which in turn is estimo ed tc require 3 years for she first unit. These major ate.ns of eyuipment are usually scheduled for on-site delivery about ? year before completion of consinuction. To ineet this scheduk. major financial coinmitments must be ixcurred about a year before the completion oi administrative reviews and th: issuanre of an AEC construction permit.

I.inc 3 shows the two pha:s of tix AEC safety review kading to the issuance of a consuruction permit and an operating license respectivek. The preliminary safety analysis report s' culd be filed 2 years prine to the i nce of a constrution permit. allowing ! year for internal Af: staff revien.

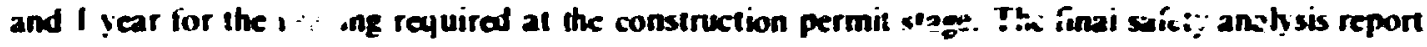
should be filed $I^{i}$, years prior to the estimated tate for completion of construction. when an operating license will be required to perait core loading and initial operation. This tilows I year for the internat AEC staff revicu and 6 munths fis a supplementaiv hearing.

line 4 shows $x$ antitrust revien procesding in paralkl with the hEC sofety review at the coresinuction permit stage.

Iine 5 shows that all necessis: cnvironmental approvals, state and federal. must be coudined through concurrent procedings betiste all interested agencies. and that this process will proced in paralle' with the AEC saie's review over a 2-year period. Allowance is made for an addi:onal 2 years of intensive effort prior to the filine of formal applications. It is assumed that the first year wilt he devoted to obtaining and evalusting preliminany environmental data on several candidate sites and the second will be devirted to an in-depth study concentrated on the principal site selected.

I.ine i show's the coriractilal arrangements necessary to support this schedu': It is assumed that an architect-engineer will be selected at the outset to assist in the preparation of invitations fir hids and in the prelim nary evaluation of potential sites. This permits selection of a manufacturer and identification of the size and chamcteristics of the plant during the vear whike atternative sites are being evaluated and alinws an additional year for detailed engiseering and preparation of the PSAR and other permit applicinions.

The total lead tim: lor the sehxtion-licensing-construction process, as shown in Figs. S. Is and 5.19 for a single-unit custora-desigt ied plant, requires ahout 9 years. divivied roughly as follows: 2 years for site and plant cesign selection. preapplication site revivws, and preparation of the

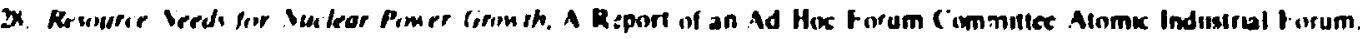
Inx.. 1973 


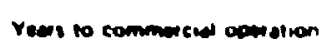
Fine unit Sincond unt Thurd unit

Fowith unit

I On-wie comituction

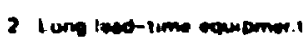

3 AEC whity corven

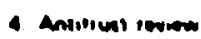

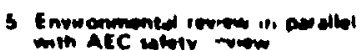

conlisciues arimenomis

ind

1 On inie comeliustion

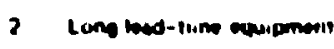

3 AEC wieny iovion

4 Antillull inem

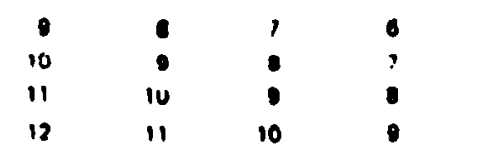

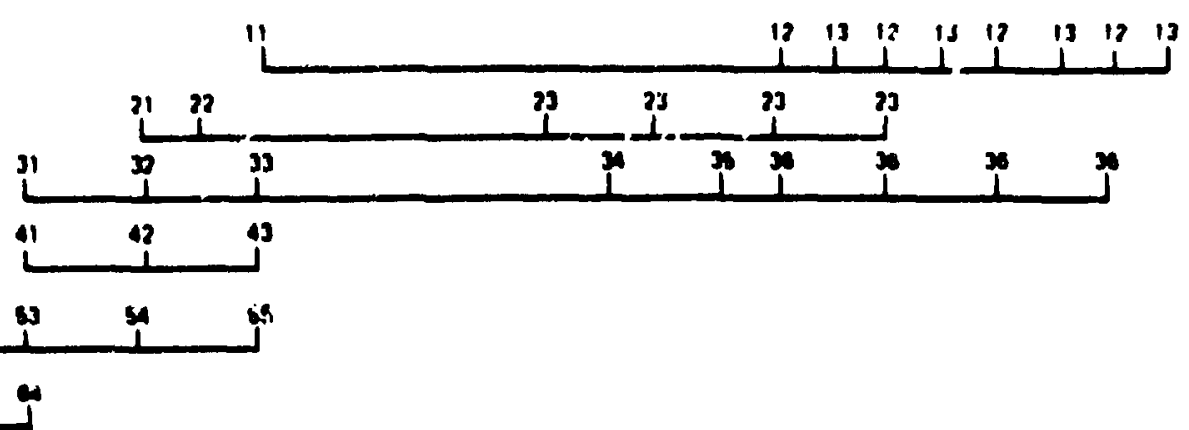

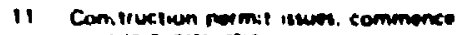
Con-wil romilluetion comolian

13 Commercisl operation

21 Rowerve Wrop wase

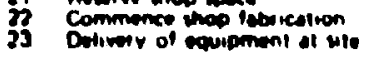

j: Cin MSAh. cummence ACC stell ienow

32 co meving

3月 Comeruction AETme isum.

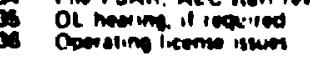

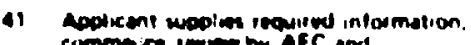

commentico infer by AEC and

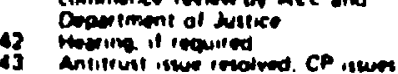

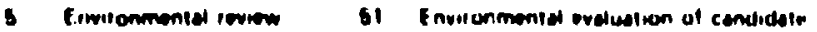

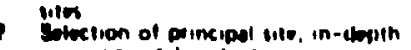

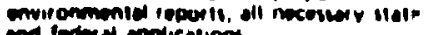

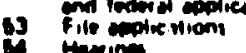

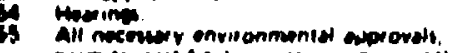

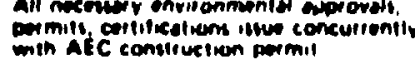

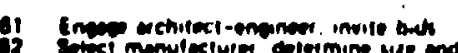

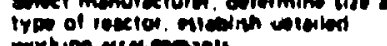

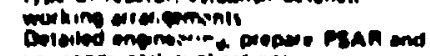

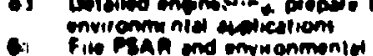

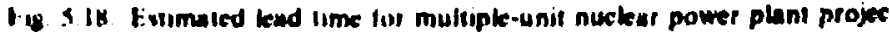


applestion: I years for r.onstruction permit resieus and hearings: and 5 years for construction. uprating likenxe revk'w. and operational testing.

Av alx) shown in fig. 5.19. scandardiation of plant designs in the next 3 to 4 years might make powible a reduction of about 2 sears in the total lad time." It is anticipated that about a vear can be sived fiom the time reyuired for AFC retien of the conseruction permit application. and. as experkence is gained in duplicating major portions of plants. it shoukd be rossible to reduce the reyuired construction time hy a scar.

OANe - Ong 745000

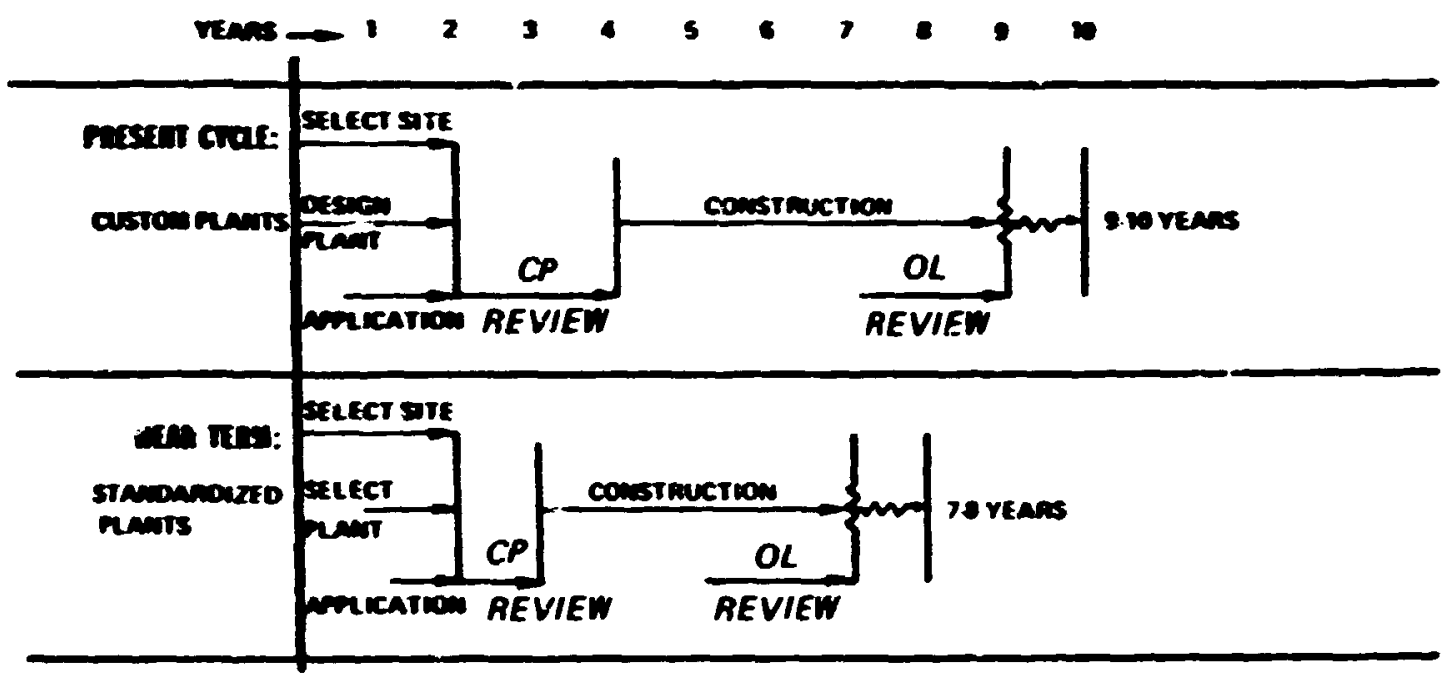

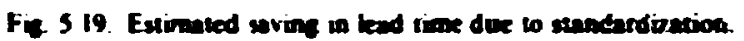

\subsubsection{Economic Analysis}

Production conts werc estimalod for large- and in:ermediate-size commerciai nuctear electric plant: and prexess sleam planis in accordance w sth the economic ground ruks show $n$ in Tablex 5.14 and 5.15. The estirtalcs for large plants aic for single units only. Whik the estimates for the intermediate-sice plants are for one-. tuo-, threc-. and four-unit plants. In all cases the kngth of the design and construction perind was held cunstant. although it could be argued that the construction period for the smailer piants might be womewhat slorter. The iuel cycle costs for the intermediate-sise plants nere assumed io be about le to $2 \mathrm{c} 10^{\circ}$ Beu higher than thuse for the large plants.

lable 5.16 shows a breakdown of the kelired fixed charge ates used in estimating the annual fixed charges un capital investment. Thr poWfRCO cade" was used to perform the discounted

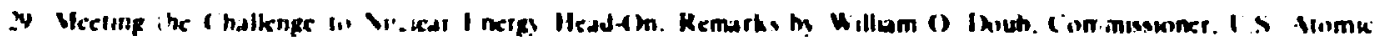

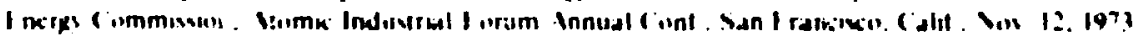

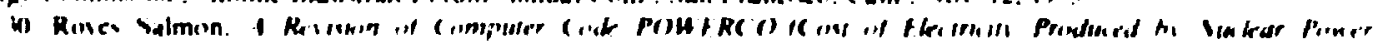

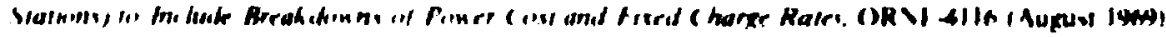




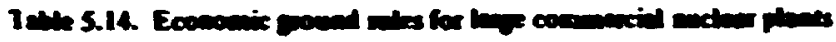

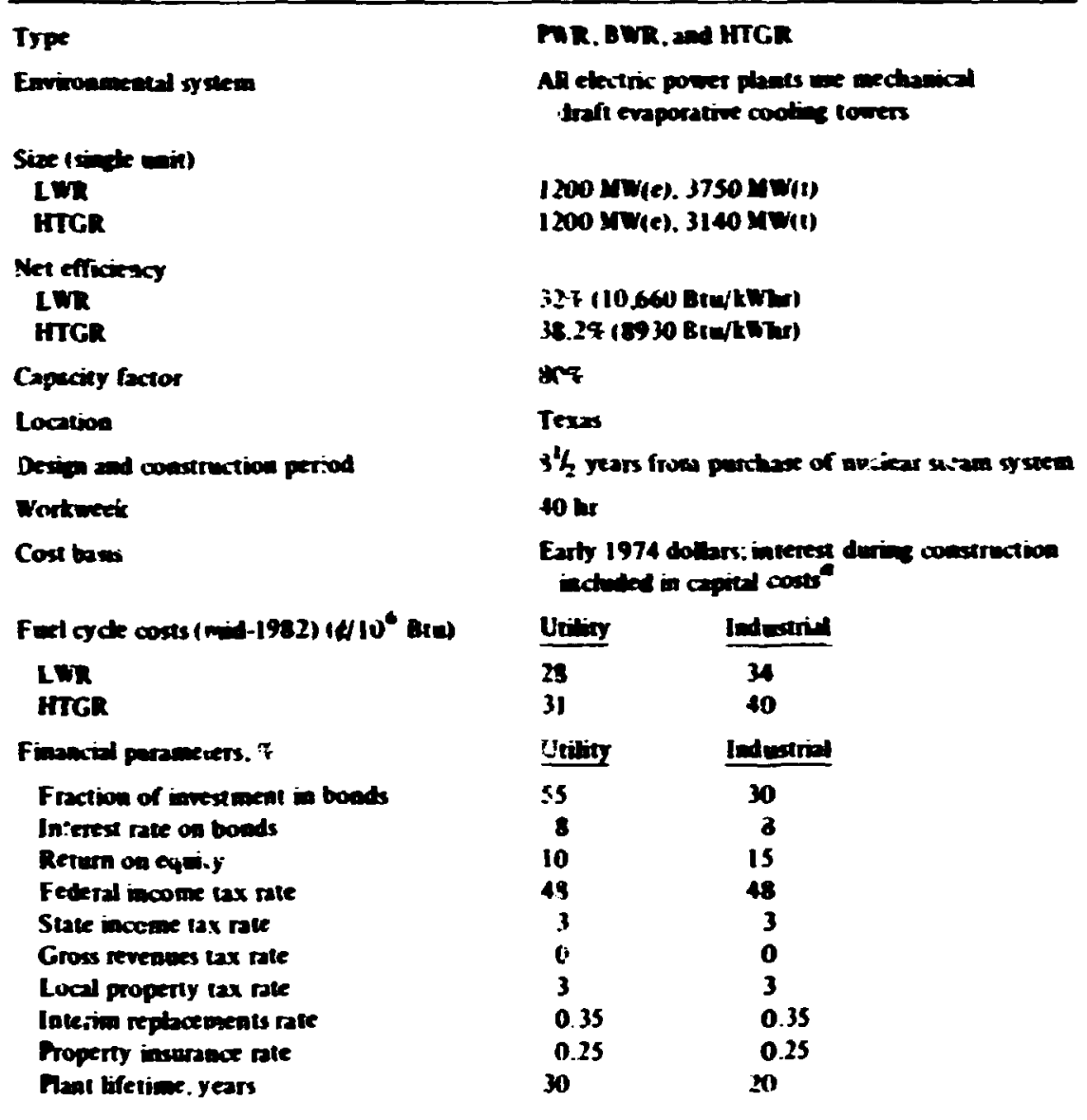

Mb allowanc for excabtion dering cousurection.

cash flow and ketelizing calculations for the fixed charge rates. The higher fixed charge rate for industrial ownership results from (1) the shorer lifetime. 20 years compared with 30 years for utility ownership: (2) the lower bond fraction. 30; compared with $55 \%$ : and (3) the higher return on equity. 15'; compared with 10; ; For propent tax purf:ses the investment is depreciated uniformly and fo: income lax purposes by the sum-rifyears digits method.

A differert set of economic grouno rules. especialty the financial parameters, would result it, a different set of prodection costs and a different set of rebitive costs.

\section{Lane nuclear plants}

Production costs for targe commercial nuckear electic pla ints are summarived in Iabk 5.17 for typical utility and industrial financing assumptions. For the three types of reactors (PWR. BUR. and HICR). Iotal production costs are about equal slighily over 11 mills $k$ Whr for utilit! ownership and just under 17 mills $\mathbf{k}$ Whr for industrial ownership.

Production costs Ior lurge comimarcia! nuckar plants producing only process stcam arc summarioed in Table 5.14 for tygrical utility and industrial finaricing. Solal prime steam prondection 


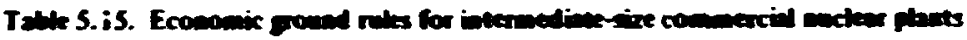

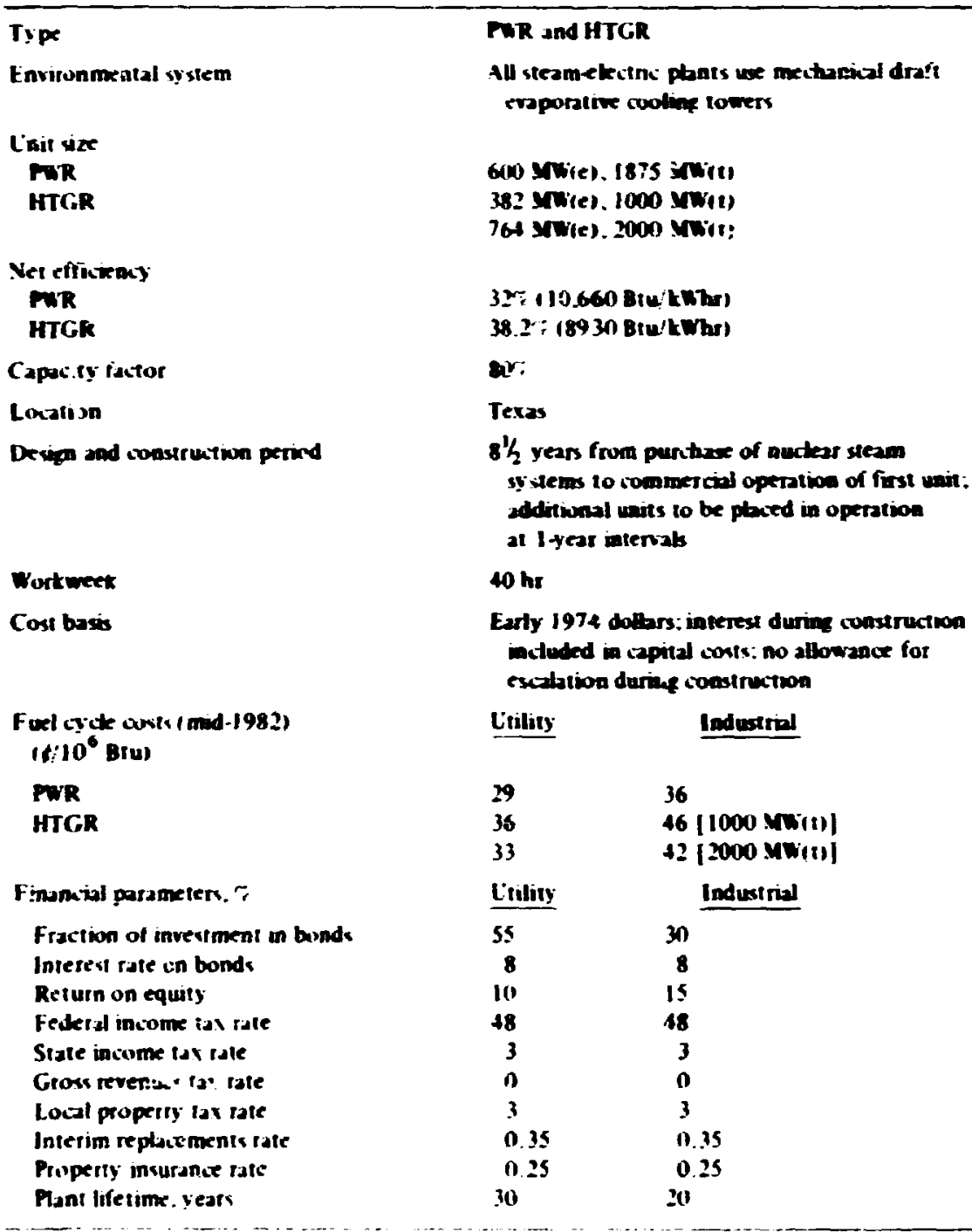

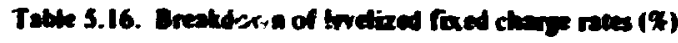

\begin{tabular}{|c|c|c|}
\hline & Utility & Industrial \\
\hline \multicolumn{3}{|l|}{ Recuvery of capital } \\
\hline Averase interest rate & 8.90 & 12.90 \\
\hline Finding fund depreciotion & 0.75 & 1.25 \\
\hline Federal income lax & 1.42 & 5.04 \\
\hline Siste iniome tox & $n .09$ & 0.32 \\
\hline Local propetry tax & 2.13 & 2.13 \\
\hline Inte:im replacements & 0.35 & 0.35 \\
\hline Property insurance & 0.25 & 0.25 \\
\hline Total foxed churge rate & 13.9 & $2 \sqrt{2}$ \\
\hline
\end{tabular}




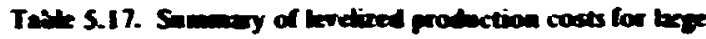
commacied mactere dectic power phess

\begin{tabular}{|c|c|c|c|c|c|c|}
\hline & \multicolumn{2}{|c|}{ PWR } & \multicolumn{2}{|c|}{ BWP. } & \multicolumn{2}{|c|}{ HTGR } \\
\hline & $10^{\circ}$ s year & mills;kBur & $10^{\circ}$ s yeat & milks tente & $10^{\circ} \mathrm{s}$ yat & milk k tist \\
\hline \multicolumn{7}{|l|}{ Itidity owmership } \\
\hline Fived starges & 65.9 & 7.84 & 65.9 & 7.84 & 60.6 & 7.92 \\
\hline OeM coses & 5.2 & 0.62 & 5.2 & 0.62 & 5.4 & 0.64 \\
\hline Fued costs & 25.1 & 2.99 & 25.1 & 2.49 & 23.2 & 2.76 \\
\hline Total & $\overline{9.2}$ & 11.4 & 46.1 & 11.4 & 95.2 & 11.3 \\
\hline \multicolumn{7}{|c|}{ Industrial ownet shep } \\
\hline Fined tharees & 105.2 & 12.51 & los.2 & 12.51 & 106.3 & 12.64 \\
\hline Oen costs & 5.2 & 0.62 & 5.2 & 0.62 & 5.4 & 0.64 \\
\hline Fued cosses & 30.5 & 3.63 & 30.5 & 3.63 & 30.0 & 357 \\
\hline Total & $\overline{140.9}$ & $\overline{16.8}$ & $\overline{140.9}$ & $\overline{16.8}$ & $\overline{141.7}$ & 16.8 \\
\hline
\end{tabular}

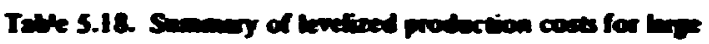

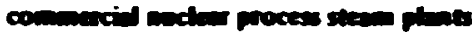

\begin{tabular}{|c|c|c|c|c|c|c|}
\hline & \multicolumn{2}{|c|}{3750 XW(I) FWR } & \multicolumn{2}{|c|}{3750 YNW(t) BWR } & \multicolumn{2}{|c|}{$314^{\prime}$ MT(t) HTR:R } \\
\hline & $10^{6}$ st;ear & $2: 10^{6}$ Bru & $10^{6}$ s/year & $8110^{6} \mathrm{Bu}$ & $10^{6}$ siycin & $8110^{6} \mathrm{Buc}$ \\
\hline \multicolumn{7}{|l|}{ Crility ownetship } \\
\hline Fived charges & $3 \cdot .2$ & 42 & 35.9 & 40 & 39.9 & 53 \\
\hline OeM costs & 3.7 & 4 & 3.7 & 4 & 3.8 & 5 \\
\hline Fuel costs & 25.1 & 28 & 25.1 & 28 & 23.2 & 31 \\
\hline Total & $\overline{66.0}$ & 74 & $\overline{66.0}$ & 72 & $\overline{66.9}$ & 89 \\
\hline \multicolumn{7}{|c|}{ Indus : owner chip } \\
\hline lixed charges & 59.5 & 66 & 57.3 & 64 & 63.7 & 85 \\
\hline oest cissts & 3.7 & 4 & 3.7 & 4 & 3.8 & $s$ \\
\hline Fuel cosis & 30.5 & 34 & 30.5 & 34 & 30.10 & $\$ 0$ \\
\hline Total & $\overline{93.7}$ & 104 & 91.5 & $\ln 2$ & 97.5 & 130 \\
\hline
\end{tabular}

costs arc ahout equal fo; PWR and BWR plants. just over 70e $10^{\wedge}$ Btu fo: utility ow nership ald just wer SI.00 10' Btu for industrial ownership. Total prime steam production costs are about 25';

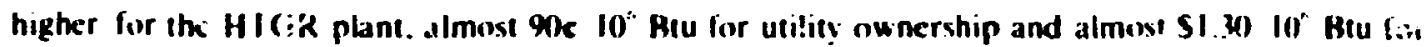
imoustrial ownership. I hese higher costs for the HIC $i R$ reflect the higher capital cost of the HIC;R nuclear stean system. However. it should be kept in mind that the steam is of higher quality. 2500 psi and 515 ( $(955$ F). when compared with $\sim 1000$ psi saturated steam for I. W Rs.

I he capital cost breakdouns are summaried in Iables 5.19 through 5.21 . I otal capital ciosts for the three electric plants are essentiall! eyual. about S400 $\mathrm{kW(s)}$. As shown in I ahle 5.21 , the higher cosl of the HIC steam plant costs do not include costs for rebouless anc otter equipment required for stcam distribution. Rehoilers would most likely be required for all types of reactor plants. especially for the BWR plant. In protect the steam distribution system from possible radioactive contamination and 


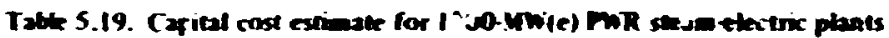

\begin{tabular}{|c|c|c|c|}
\hline & Stam plant & Turbine plant & Jolal \\
\hline \multicolumn{4}{|c|}{ Tivert costs $\left(10^{\circ} \mathrm{s}\right)$} \\
\hline Ea-d and band rughe & $\mathbf{1}$ & n) & 1 \\
\hline \multicolumn{4}{|l|}{ Imy siz' plant } \\
\hline Sinuture and ale facilatixs & 39 & 8 & 47 \\
\hline Reator pbat cyuipment & 8? & (1) & 87 \\
\hline Turbirs plan! cquipment & ) & 88 & 88 \\
\hline Flectric phant equipment & 15 & 14 & 29 \\
\hline Misetlanceres plant equipment & 3 & $\underline{2}$ & $\underline{s}$ \\
\hline Suhtutal (piny wal plant) & 144 & 112 & 256 \\
\hline Spare parts alline ance & 1 & 1 & 1 \\
\hline Continatery allowame & 10 & $?$ & 17 \\
\hline Subrotal tetul physasl pant ) & $\overline{155}$ & 120 & $\overline{2 ? 5}$ \\
\hline \multicolumn{4}{|c|}{ 1. } \\
\hline Congaructinn facilities. cqupment. and cervies & 10 & 8 & 18 \\
\hline Fnaneering and construition manapement servikes & 25 & 19 & 4 \\
\hline Orher cons:s & 8 & 6 & 14 \\
\hline Interest during comstructuon & 69 & 53 & 122 \\
\hline Sublutal indureet costs) & $\overline{112}$ & 96 & 198 \\
\hline \multicolumn{4}{|c|}{ Tolal cons } \\
\hline \multicolumn{4}{|l|}{ T. ial plant sapital cisst st wart of propect } \\
\hline Mille ins of dullars & 268 & 206 & 474 \\
\hline Daphars k Wie; & & & 395 \\
\hline Dollars. $10^{3}$ Biu:hr & 21 & & \\
\hline
\end{tabular}

alwo to protect the nuclear sistem from industrial contamination. Capital costs for I.WR steam-electric plants were estimated with an updated version of the CONCEPT code." This updated sersion includes cossts of all environmental and safety-related equipment and systems required as of early 1973. Capital conts for HTCR steamelectric plants were extrapolated from those reported in WASH-1230 for a 7\%0-MW(e) plant." Capital costs for the nuclear process sleam plants were developed by appropriate modification of the clectric plan: estimates.

Tahles 5.22 and 5.23 stiou estimated annual operation and maintenance expenses. not including fuel. for nuclear electric plants and process steam plarits respectively. The costs for electric plants were estumated using the methods outlined by Myers.": and the process steam plant costs were estimated by appropriate modification of the electric plant estimates.

\section{Intermediate-size nuclear plants}

Production costs for intermediate-size commercial nuclear electric plants are summarized in Tables 5.24 through 5.26 for single- and multiple-unit stations operating at Ror; plant capacils

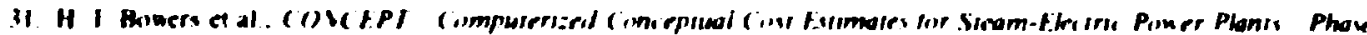

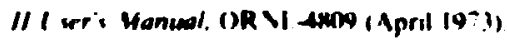

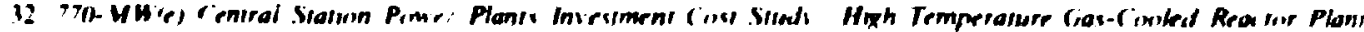
WASH-1230. B(1) V1974)

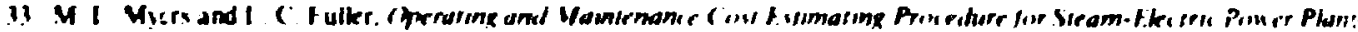
(10 the published). 
Table 5.20. ispitul cost estimate for 1200-MW(e) BWR steanetectix phats

\begin{tabular}{|c|c|c|c|}
\hline & Siram phnt & Turbane plant & Fotal \\
\hline \multicolumn{4}{|c|}{ Diwert $\cos \left(10^{\circ} \mathrm{s}\right)$} \\
\hline Land and bnd rọtis & 1 & " & i \\
\hline \multicolumn{4}{|l|}{ Physial plan: } \\
\hline Strutures and sie fixilities & 35 & 12 & 47 \\
\hline Resitur pbat equipment & 36 & 0 & 86 \\
\hline Turbixe pbnt cquipment & 0 & 88 & $\mathbf{8 8}$ \\
\hline Electri- phant equipment & 15 & 15 & 3) \\
\hline Miscelbneous phat equipment & $-\underline{3}$ & 2 & 5 \\
\hline Subtotal iphysical plani) & $\overline{139}$ & $\overline{1: 7}$ & 256 \\
\hline Spare parts alhowance & 1 & 1 & 2 \\
\hline Contingemy allowanxe & $y$ & 8 & 17 \\
\hline Subtutal (total physical plant) & $\overline{149}$ & $\overline{126}$ & $\overline{2 ? 4}$ \\
\hline \multicolumn{4}{|c|}{ Indirect costs $\left(10^{\circ}\right.$ s) } \\
\hline Construn:ion faridities, equip.nent. and setvines & 10 & $\mathbf{8}$ & 18 \\
\hline Enginceriag and construction management etvices & 24 & 20 & $\$ 4$ \\
\hline Othet costs & 8 & 6 & 14 \\
\hline Interest dunng consiruction & 66 & 56 & 12 \\
\hline Subtotal i.ndirect (osts) & ing & $4 i$ & $\overline{19 x}$ \\
\hline \multicolumn{4}{|c|}{ Tocal costs } \\
\hline Total ptant capital iost $n$ start of prenect & & & \\
\hline Millions of dotlars & $25 \mathrm{k}$ & 216 & $\$ 74$ \\
\hline Dollars kW(e) & & & 395 \\
\hline Enthers fin ${ }^{3}$ Hit hr & 2n & & \\
\hline
\end{tabular}

factor. Single-unit plants show a cost of about I mill whe higher than multiple-unit plants for the same type of reactor. Iotal unit eosts for the 7t4-MW(e) HI(iR, are eslimated to be abxut I mill kWhr louer than those for comparable 600-MW(e) PWRs. and the 382-MW(e) HI(iRs have tota! production costs about 3 mills $k$ Whr higher than comparabk 7h5-WW(c) HICRs.

Production costs for intermediate-sice nuclear plants producing only process stcam are summaried in lables 5.27 through 5.29. Total prime steam production costs for PWR, are estimated to range from $\times 2 c$ lo $89 \mathrm{c} 10^{\circ}$ Btu for utility ounership and 51.19 (10 51 . 2X I0) Btu for

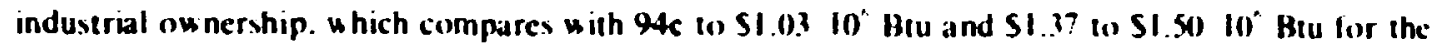

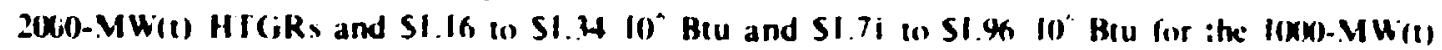
HI iRs. Again the higher costs of process stem from the HI iR rellect the higher ciapital covt of the HIGR nuclear steam sstem. I he ur it costs for the intermedute-sile wlems are 20 I0 30), higher than those for the large nuclear systems. mainly because ot the unfawrable waling elfects in capilal ossts and operation and maintenance costs for the smalker reaclors.

I he estimateJ capilal cost breakdou ns are summariced in lables 5.3 ) (o 5.32 for nuckar electric plants aid in I ables 5.13 to 5.35 for nuclear process steam plants. It is estimated that a four-unit clectric plant would cost in the neighbortood of $\$ 1$ billion not including cocalation during. construction. which at present rates would add another .30; to the plant capital cost. Fitimatcd capital costs for the frour-unil process steam plants range from $\mathbf{S O X}$ ) millown to almost SX(1) million. 
Table 5.21. Capiol cost estiante for $1200-M W(e)$ HTGR sean-electric plants

\begin{tabular}{|c|c|c|c|}
\hline & Steam plant & Turbine plant & Total \\
\hline \multicolumn{4}{|c|}{ Divect cooses $\left(10^{6} \mathrm{~s}\right)$} \\
\hline Land and and raphis & 1 & 0 & 1 \\
\hline \multicolumn{4}{|l|}{ Physical plant } \\
\hline Structures and site factitities & 49 & 6 & 55 \\
\hline Rezitor phant equipment & 91 & 0 & 91 \\
\hline Turtaice plant equipment & $\mathbf{0}$ & $\mathbf{8 1}$ & 81 \\
\hline Flectric plant equipment & 13 & 13 & 26 \\
\hline Miscelbnerous plant equipment & 3 & 3 & 6 \\
\hline Selvial (physial plant) & $\overline{156}$ & 103 & $\overline{259}$ \\
\hline Spare parts allowance & $\mathbf{1}$ & 1 & 2 \\
\hline Contineemiy alkwance & 10 & 7 & 17 \\
\hline Sublotal I tolal physial pleni; & $\overline{167}$ & $\overline{111}$ & $\overline{278}$ \\
\hline \multicolumn{4}{|c|}{ Indinect costs $\left(10^{6} 5\right)$} \\
\hline Conciruction tacilitixs. equipment. and servikes & 11 & 7 & 18 \\
\hline Fngincering and crmslnution manapement services & 26 & 18 & 4 \\
\hline Ohet costs & 8 & 6 & 14 \\
\hline Interest durise construction & 74 & sn & 124 \\
\hline Subtotal (indirect costs) & 119 & 81 & $\overline{200}$ \\
\hline \multicolumn{4}{|c|}{ Total coosts } \\
\hline \multicolumn{4}{|l|}{ Total plant apital exst af start of project } \\
\hline Nitions of doltars & 287 & 192 & 479 \\
\hline Dolbarsikwi(e) & & & 399 \\
\hline Dollars $/ 10^{3}$ Btu $/ \mathrm{hr}$ & 27 & & \\
\hline
\end{tabular}

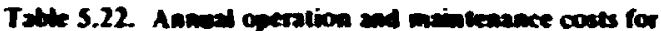

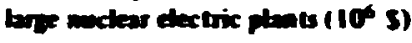

\begin{tabular}{|c|c|c|}
\hline & LWR & HTSP \\
\hline \multicolumn{3}{|l|}{ Fixed costs } \\
\hline Staff & 1.66 & 1.66 \\
\hline Maintenance & 1.32 & 1.34 \\
\hline Supplies and expenses & 0.26 & 0.35 \\
\hline Insurance and tees & 0.59 & 0.55 \\
\hline Administrative and general & 0.42 & 0.44 \\
\hline Fotal fixed costs & 4.25 & 4.34 \\
\hline \multicolumn{3}{|l|}{ Variable costs } \\
\hline Maiptemance & 0.53 & 0.51 \\
\hline Supplies and expexases & 0.45 & 0.50 \\
\hline Toial prible ants & 0.98 & 1.01 \\
\hline Total anowal ory cnats & 5.2 & 5.4 \\
\hline
\end{tabular}

mor plant cepecity izctor. 
Table 5.23. Anmel operation and maintenance ic uts for bre ancteas process stean plats $\left(10^{\circ} \mathrm{s}\right)$

\begin{tabular}{|c|c|c|}
\hline & LKR & IITCiR \\
\hline \multicolumn{3}{|l|}{ Fired costs } \\
\hline Staff & 1.50 & 1.511 \\
\hline Mairtename & 0.75 & 0.77 \\
\hline Supplies and expenses & (1.16 & 0.21 \\
\hline Insurance and fees & 0.59 & 0.55 \\
\hline Administrative and scencral & 0.28 & 1 in \\
\hline Total fixed corsts & 3.28 & 3.33 \\
\hline \multicolumn{3}{|l|}{ Variable custs } \\
\hline Maintemane & 0.25 & 0.26 \\
\hline Suppties and expenses & $\underline{0.16}$ & 11.21 \\
\hline Total rariable costs & 3.41 & 0.47 \\
\hline Tolal annual OeM costs & 3.7 & 3.8 \\
\hline
\end{tabular}

usor phnt apacily tiditor.

Table 5.24. Summary of kelized production costs for multipli-unil [600-4Wie)] PhR steamelectric planis

\begin{tabular}{|c|c|c|c|c|c|c|c|c|}
\hline & \multicolumn{2}{|c|}{$1-1$ it statiun } & \multicolumn{2}{|c|}{ 2. Lnit siation } & \multicolumn{2}{|c|}{ i-l nil station } & \multicolumn{2}{|c|}{ H.Init sution } \\
\hline & $10^{\circ}$ s:yar & midls:kHhr & $10^{6} \leq$ yesr & roills'kHht & in sisear & mills: $: H h r$ & $11^{n}$ S your & molls $k$ hint \\
\hline \multicolumn{9}{|l|}{ Cidity ownership } \\
\hline Fixed tharges & 42.1 & 101 & 79.1 & 9.4 & 117.5 & 9.3 & 157.3 & 93 \\
\hline OAM curts & 4.1 & 1.0 & 6.5 & 0.8 & 8.9 & 0.7 & 11.2 & $n .7$ \\
\hline Fuet cussis & 13.2 & $3 !$ & 26.4 & 3.1 & 39.5 & 31 & $\$ 2 . x$ & 3.1 \\
\hline Total & 59.4 & 14.1 & 112.0 & 133 & $166 . .7$ & 13.1 & 221.3 & 13.1 \\
\hline \multicolumn{9}{|c|}{ Industrial ownershir } \\
\hline Fixed chatges & $6 ? .3$ & 16.0 & 126.3 & 15.1 & 187.6 & 14.9 & 251.3 & 14.9 \\
\hline OeM costs & 4.1 & 1.0 & 6.5 & 11.8 & $\$ .9$ & 0.7 & 11.2 & $0 . \bar{i}$ \\
\hline Fuet cosis & 15.9 & 3.8 & 31.8 & 3.8 & +7.7 & 3.8 & 63.6 & 3.8 \\
\hline Total & $\overline{87.3}$ & $\overline{20.8}$ & $\overline{164.6}$ & $\overline{19.6}$ & $\overline{24.2}$ & $\overline{19.4}$ & $i \overline{26.1}$ & 19.4 \\
\hline
\end{tabular}

Tabte 5.25. Summary of kelized production conts for multiple unil [7ht-WWi(e)] HT(;R sleam electric planis

\begin{tabular}{|c|c|c|c|c|c|c|c|c|}
\hline & \multicolumn{2}{|c|}{ ! I nit station } & \multicolumn{2}{|c|}{$2-1$ nit statmin } & \multicolumn{2}{|c|}{ H' Init station } & \multicolumn{2}{|c|}{ H.Init station } \\
\hline & $10^{4}$ S year & millsikWhr & $1 n^{\wedge}$ sisear & millsik Wh: & in s'year & millskWh: & $10^{n}$ S'year & milkiknhr \\
\hline \multicolumn{9}{|c|}{ i : iutly awnership } \\
\hline Fixed charges & 49.5 & 9.2 & 91.9 & 8.5 & 136.1 & 8.5 & 182.1 & 9.5 \\
\hline OSU conts & 4.9 & 0.9 & 7.5 & 0.7 & 10.2 & 0.6 & $12 x$ & 0.6 \\
\hline Fuel consts & 15.6 & 2.9 & 31.2 & 2.9 & 46.8 & 2.9 & $62 \pm$ & $\because 9$ \\
\hline Total & $\overline{710 . n}$ & $\overrightarrow{13 n}$ & $\overline{130.6}$ & $\overline{12.1}$ & $\overline{19 ! 1}$ & $\overline{12 n}$ & 2.7 .3 & 121 \\
\hline \multicolumn{9}{|c|}{ Indesitial wwrership } \\
\hline Fixe! :-turges & $79 . n$ & 14.8 & i46.7 & 13.7 & 2173 & i3.s & $2 \cdot m x$ & .38 \\
\hline DeM consts & 4.9 & 0.9 & $? . .5$ & 0.7 & 10.2 & 16 & 12.8 & 11.5 \\
\hline Tuet cosps & 20.1 & 3.8 & \$n.? & 3.8 & $6+1,3$ & $1, x$ & 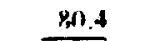 & 3.8 \\
\hline Tinfal & $\overline{104.11}$ & $\overline{19.5}$ & $\overline{194.4}$ & $\overline{18.2}$ & $\overline{287.8}$ & $1 \overline{17.9}$ & $\overline{364.11}$ & $\overline{14.2}$ \\
\hline
\end{tabular}


T ble 5.26. Summary of ketized proxluction costs for multiple-unit [382-VWi(e)] HTGR steam etectric plantsa

\begin{tabular}{|c|c|c|c|c|c|c|c|c|}
\hline & \multicolumn{2}{|c|}{ 1- 1 ni. stutikn } & \multicolumn{2}{|c|}{$2-Y$ nir stutken } & \multicolumn{2}{|c|}{3 - Unit siation } & \multicolumn{2}{|c|}{ 4tinit statun } \\
\hline & :10 5 year & mells & $10^{\text {h }}$ S year & mills:khhr & $111^{\circ}$ siyear & millsikwhr & $11^{n}$ S Syear & mills:kWhr \\
\hline \multicolumn{9}{|l|}{ Vulty :wnership } \\
\hline Fined charzes & $\because 4$ & 121 & $5 \times .7$ & 11.11 & 95.8 & 10.7 & 112.9 & 10.5 \\
\hline OEM ciosts & 3.6 & 1.3 & 5.3 & 1.0 & 7.1 & 0.9 & 8.9 & 0.8 \\
\hline fuel costs & 8.6 & 3.2 & 17.2 & 3.2 & 25.8 & 3.2 & 34.4 & 3.2 \\
\hline Totsl & 44.6 & 16.0 & $\overline{81.2}$ & 15.2 & $\overline{11 \times .3}$ & $\overline{14.8}$ & $\overline{156.2}$ & $\overline{14.5}$ \\
\hline \multicolumn{9}{|c|}{ Industrial ownership } \\
\hline Fived charker & 51.7 & 19.3 & 93.7 & 17.5 & $137,0)$ & 17.1 & 180.3 & $16 . \AA$ \\
\hline OEY conss & 3.6 & 1.3 & 5.3 & 1.0 & 7.1 & 0.9 & 3.9 & 0.8 \\
\hline t uel coosts & 11.11 & 4.1 & 23.0 & $4 . !$ & 330 & 4.1 & 44.0 & 4.1 \\
\hline Trusal & $\overline{66.3}$ & 24.7 & 1210 & 22.6 & $\overline{177.1}$ & 22.1 & 266.2 & 21.7 \\
\hline
\end{tabular}

A Pirsplated from $770-\mathrm{MW}$ (e) commerciai plants.

Tabk 5.27. Summary of kvelized production costs for multiple-unit [1875-Mwie)] Purg piscess plants

\begin{tabular}{|c|c|c|c|c|c|c|c|c|}
\hline & \multicolumn{2}{|c|}{ :-Unit station } & \multicolumn{2}{|c|}{ 2-Linit station } & \multicolumn{2}{|c|}{ 3-Lnit station } & \multicolumn{2}{|c|}{ 4-1init station } \\
\hline & $10^{6}$ siyear & dilo Btu & $10^{6}$ s/year & $810^{\circ}$ Btu & $10^{6}$ s/year & $2110^{6}$ Btu & $10^{t}$ S/year & $\mathrm{A} / 1 \mathrm{C}^{5} \mathrm{Btu}$ \\
\hline \multicolumn{9}{|l|}{ Ctility wunership } \\
\hline I ived charges & 24.2 & 54 & 45.3 & 51 & 67.3 & sn & $8 \varsigma .9$ & 50 \\
\hline O\& $Y$ conts & 2.8 & 6 & 4.2 & 5 & 5.0 & 4 & 6.1 & 3 \\
\hline Iuel costs & 13.2 & $\underline{29}$ & $\underline{26.4}$ & 29 & 39.6 & 29 & 52.9 & 29 \\
\hline Total & $\overline{\text { tn.2 }}$ & $\overline{89}$ & $\overline{75.9}$ & $\overline{85}$ & $\overline{111.9}$ & $\overline{83}$ & $\overline{148.7}$ & $\overline{82}$ \\
\hline \multicolumn{9}{|c|}{ Industrial "swnership } \\
\hline Fixed charges & 38.6 & 86 & 72.4 & 31 & 107.4 & 80 & 143.4 & 80 \\
\hline De.y costs & 2.8 & 6 & 4.2 & 5 & $5 ! !)$ & 4 & 6.1 & 3 \\
\hline Fuet costs & 15.9 & 35 & 31.8 & 36 & 47.7 & 36 & 63.6 & 36 \\
\hline Total & $\overline{57.3}$ & $\overline{128}$ & $\overline{108.4}$ & $\overline{122}$ & $\overline{16 ! .1}$ & $\overline{120}$ & $\overline{213.1}$ & $\overline{119}$ \\
\hline
\end{tabular}

Table 5.28. Summary of levetized prodortion costs for multiple-unit (2000-MW(I)] HTGR proces steam plants

\begin{tabular}{|c|c|c|c|c|c|c|c|c|}
\hline & \multicolumn{2}{|c|}{ I-I'nit station } & \multicolumn{2}{|c|}{ 2-1inil station } & \multicolumn{2}{|c|}{ 3-linit station } & \multicolumn{2}{|c|}{ 4-Uni: station } \\
\hline & $10^{x}$ s/year & $d / 10^{x}$ Bru & $10^{6}$ s/year & $2 ! 10^{6}$ Bru & $10^{x}$ S/year & $2 / 10^{6} \mathrm{Btu}$ & $10^{6}$ s'year & $2 / 10^{6} 310$ \\
\hline \multicolumn{9}{|l|}{ Vitdity ownership } \\
\hline Fixed chatges & 3. 2 & 63 & 55.3 & 58 & 81.6 & 57 & 1091 & 57 \\
\hline OeM cosis & 3.3 & 7 & 4.8 & 5 & 6.4 & 4 & 7.9 & 4 \\
\hline Fuel costs & 15.6 & 33 & 31.2 & 33 & 46.8 & 33 & 62.4 & 33 \\
\hline Tolal & $\overrightarrow{49.1}$ & $\overline{103}$ & $\overline{91.3}$ & $\overline{96}$ & $\overline{134.8}$ & 94 & $\overline{179.4}$ & $\overline{94}$ \\
\hline \multicolumn{9}{|c|}{ Industrial ownership } \\
\hline Fixed charges & 48.2 & 101 & 88.4 & 92 & 1 30.3 & 91 & 174.3 & 91 \\
\hline OEM costs & 3.3 & 7 & 4.8 & 5 & 6.4 & 4 & 7.9 & 4 \\
\hline Fuet cossts & 20.1 & 42 & 4n.: & 42 & 60.: & 42 & 80.4 & 42 \\
\hline Tolal & 71.6 & 1 in & 133.4 & 139 & $\overline{197.0}$ & $\overrightarrow{1.37}$ & $\overline{262.6}$ & $\overrightarrow{137}$ \\
\hline
\end{tabular}


Table 5.24. Sum arary of levelized production costs for muleiple-anit [ 1000MW(t)] HTCR process steam phants

\begin{tabular}{|c|c|c|c|c|c|c|c|c|}
\hline & \multicolumn{2}{|c|}{ 1-Uril station } & \multicolumn{2}{|c|}{ 2-linit station } & \multicolumn{2}{|c|}{ 3tinit statinn } & \multicolumn{2}{|c|}{ 4-linil siation } \\
\hline & $10^{\circ}$ s/yeas & $t ! 10^{6} \mathrm{Btu}$ & $10^{6}$ Siyear & $1 / 10^{6} \mathrm{Blu}$ & $10^{\circ}$ s/year & $4 ! 10^{5}$ Blu & $10^{\circ} \mathrm{S} /$ year & $\$ 110^{6}$ Blu \\
\hline \multicolumn{9}{|l|}{ Utility ownership } \\
\hline Fixed charges & 20.6 & 86 & 36.2 & 76 & 53.2 & 74 & 71.2 & 74 \\
\hline Oen $M$ costs & 2.8 & 12 & 3.7 & 8 & 4.8 & 7 & 6.1 & 6 \\
\hline Fuet costs & 8.6 & 36 & 17.2 & 36 & 25.8 & 36 & 34.4 & 36 \\
\hline Total & $\overline{32.0}$ & $\overline{134}$ & $\overline{57.1}$ & $\overline{120}$ & $\overline{83.8}$ & $\overline{117}$ & $\overline{111.7}$ & $\overline{116}$ \\
\hline \multicolumn{9}{|c|}{ Industrial ownership } \\
\hline Fixed charges & 32.9 & $! 38$ & 57.9 & 121 & 85.0 & 119 & 113.7 & $: 19$ \\
\hline OAM costs & 2.8 & 12 & 3.7 & 8 & 4.8 & 7 & 6.1 & $\Leftrightarrow$ \\
\hline Fivel costs & 11.0 & 46 & 22.0 & 46 & 33.0 & 46 & 44.0 & 46 \\
\hline Total & $\overline{46.7}$ & $\overrightarrow{196}$ & $\overline{83.6}$ & $\overline{175}$ & $1 \longdiv { 1 2 . 8 }$ & $\overline{? 72}$ & $\overline{163.8}$ & $\overline{171}$ \\
\hline
\end{tabular}

Table 5.30. Capital cost estimates for 600-MWi(e) PHR steam electric plants

\begin{tabular}{|c|c|c|c|c|}
\hline & $\begin{array}{l}\text { I-linir } \\
\text { statson }\end{array}$ & $\begin{array}{l}\text { 2-tinit } \\
\text { station }\end{array}$ & $\begin{array}{l}\text { 3-t nit } \\
\text { statio, }\end{array}$ & $\begin{array}{l}\text { +-linin } \\
\text { s'at:on }\end{array}$ \\
\hline \multicolumn{5}{|c|}{ Direct rosts $\left(10^{6} \$\right)$} \\
\hline Land and land tightx & $\mathbf{I}$ & $\mathbf{I}$ & 1 & $\mathbf{1}$ \\
\hline \multicolumn{5}{|l|}{ Physica! plani } \\
\hline Siructares and site faciiities & 27 & 5i) & 72 & 94 \\
\hline Reactor plant equipment & 57 & 113 & 170 & 226 \\
\hline Turbine plant equipment & 51 & 100 & 150 & 200 \\
\hline Fiectric plant equipment & 19 & 36 & 52 & 68 \\
\hline Miscellaneous plant equipment & 8 & 1 & 10 & 12 \\
\hline Subtotal (physial plant) & 158 & 306 & 454 & 600 \\
\hline Spare parts allowance & 1 & 2 & 3 & 4 \\
\hline Contingency allowame & in & 20 & 29 & 39 \\
\hline Sublistal irotal physical plant) & 169 & 328 & 486 & $6+3$ \\
\hline \multicolumn{5}{|c|}{ Indisect $\cos 1 s\left(10^{x} s\right)$} \\
\hline Construction facilities. 'quipment. and services & 13 & 20 & 27 & 35 \\
\hline Fagilzering and construction mariagement services & 31 & 50 & 70 & 90 \\
\hline Other costs & $! 0$ & 16 & 22 & 28 \\
\hline Interest duing construction & 79 & 154 & 239 & 335 \\
\hline Subrotal (indirect ensts) & 133 & 240 & 364 & 488 \\
\hline \multicolumn{5}{|c|}{ Total costs } \\
\hline \multicolumn{5}{|l|}{ Tolal plant capial cost at start of project } \\
\hline Millions of dellars & 303 & 569 & 8.45 & 1132 \\
\hline Dollars/k W & 505 & $4 i 4$ & 469 & 472 \\
\hline
\end{tabular}




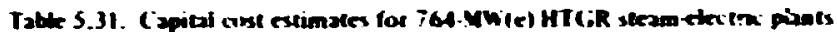

\begin{tabular}{|c|c|c|c|c|}
\hline & $\begin{array}{l}\text { I lins! } \\
\text { satera }\end{array}$ & $\begin{array}{l}21 \mathrm{mal} \\
2 \mathrm{cth}\end{array}$ & 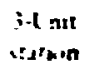 & 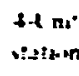 \\
\hline \multicolumn{5}{|c|}{ Dinet costs $\left(10^{\circ}\right.$ s) } \\
\hline I and and land rixches & $\mathbf{l}$ & 1 & $\mathbf{I}$ & I \\
\hline \multicolumn{5}{|l|}{ Favousl plant } \\
\hline Structures and site factlaks & is & $A^{-}$ & कs & $12 n$ \\
\hline Reactuse plant squipmen: & 69 & 13 & $1+7$ & $\mathbf{2 6 1}$ \\
\hline Turbine plant equiqment & 56 & 111 & 166 & 2011 \\
\hline Fleitric plan: squipment & $2 n$ & $3 \pi$ & $\$ 4$ & 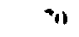 \\
\hline Misuellanerus plant equipaneni & b & $n$ & 14 & IX \\
\hline Subterfal iphysizal plane) & $i n 9$ & $35:$ & 527 & 695 \\
\hline Spare parts alkixunce & 1 & 2 & 4 & $\leq$ \\
\hline Contingenty illowance & 13 & 28 & is & 45 \\
\hline Subtovial Itotal phycisi p'ant) & $\overline{2035}$ & $\overline{383}$ & $\overline{565}$ & 74 \\
\hline \multicolumn{5}{|c|}{ Indinect conse $\left(10^{n}\right.$ s) } \\
\hline 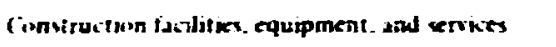 & 14 & 23 & 31 & $\sin$ \\
\hline 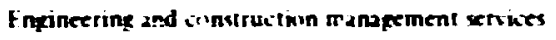 & 34 & \$I & an & I'4 \\
\hline Other cousis & 11 & is & 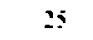 & 32 \\
\hline Interest durnæ consiruitivis: & $9:$ & 179 & $27 ?$ & jax \\
\hline Subintal indite: conits & $\overline{152}$ & $\overline{27 \%}$ & $\overline{413}$ & $\overline{5 n t}$ \\
\hline \multicolumn{5}{|c|}{ Total ensis } \\
\hline \multicolumn{5}{|l|}{ Tutal plant apital wist at statt of provect: } \\
\hline Millinens is dollars & 356 & 661 & $9: 9$ & 1310 \\
\hline inllars kW & 465 & 232 & +27 & 420 \\
\hline
\end{tabular}

Tabk 5.32. Capiral cost estimates for 382-MW(e) HT(iR steanetentric phats

\begin{tabular}{|c|c|c|c|c|}
\hline & $\begin{array}{l}\text { ! l lnit } \\
\text { suthon }\end{array}$ & $\begin{array}{l}\text { :-i nit } \\
\text { statwon }\end{array}$ & $\begin{array}{l}3 . \operatorname{linul} \\
\text { station }\end{array}$ & $\begin{array}{l}\text { folinit } \\
\text { sarwon }\end{array}$ \\
\hline \multicolumn{5}{|c|}{ Direci costs $\left(10^{n}\right.$ s) } \\
\hline Land and land nehis & 1 & 1 & $\mathbf{I}$ & $!$ \\
\hline \multicolumn{5}{|l|}{ Phy sical plant } \\
\hline Struitures and site facilities & 22 & 38 & 5. & 71 \\
\hline Reactor plant equipment & 46 & 89 & $|3|$ & 172 \\
\hline Tw:ine plant equipment & 32 & 64 & 95 & 116 \\
\hline Fectric plar equipment & i3 & 24 & 16 & 47 \\
\hline Miscellanenus pla::? equipment & 4 & 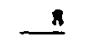 & in & 14 \\
\hline Subtotal tphyskal piznt) & 117 & 222 & 326 & 422 \\
\hline Spare parts allowance & 1 & 2 & 2 & 3 \\
\hline Continkency allr,wance & $\underline{8}$ & 15 & $\geq 1$ & 28 \\
\hline Subtotal (tolal physical plant) & $! 26$ & 239 & 349 & 453 \\
\hline \multicolumn{5}{|c|}{ Indiver couss $\left(10^{\circ}\right.$ s) } \\
\hline Construction facilities, equipmen!, and services & 11 & 16 & 21 & 26 \\
\hline Fngineering and construction manakement sevices & 25 & 39 & 53 & 67 \\
\hline Other consts & 8 & 12 & $1 ?$ & $2 \mathbf{i}$ \\
\hline Interest during constructinn & 62 & 115 & 176 & 244 \\
\hline Suhfortal rindirect cossis) & ins & 18: & 267 & 358 \\
\hline \multicolumn{5}{|c|}{ Tolsi couts } \\
\hline \multicolumn{5}{|l|}{ Total nI: ' capital conl at staft of project } \\
\hline Millurons of dollars & 233 & 422 & al: & 812 \\
\hline Imilars'kn & bII & 552 & 53 & $\$$ \\
\hline
\end{tabular}




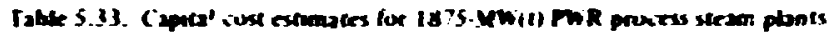

\begin{tabular}{|c|c|c|c|c|}
\hline & $\begin{array}{l}\text { I. I ni: } \\
\text { tidin-n }\end{array}$ & 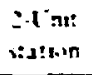 & $\begin{array}{l}\text { idrut } \\
\text { ritemen }\end{array}$ & $\begin{array}{l}\text { Al } \mathrm{nt}: \\
\therefore \operatorname{tin} n\end{array}$ \\
\hline \multicolumn{5}{|c|}{ Derec (anses $\left(10^{\circ} \mathrm{s}\right)$} \\
\hline t and ind Lint rechis & $\mathbf{I}$ & $!$ & 1 & I \\
\hline \multicolumn{5}{|l|}{ Phiskil ptant } \\
\hline Strui-tures and wite faibles & $\because$ & $\$ 1$ & s4 & $\because$ \\
\hline Resitur plant equipmen! & 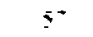 & $11:$ & 17 & 20 \\
\hline Iuthne plast equipmen! & $\therefore$ & $\|$ & i) & ") \\
\hline I tectric plant cquipment & 4 & IN & 20 & if \\
\hline Uisclloneus plint cquipment & $z$ & \pm & 5 & 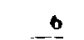 \\
\hline Subior al 'phy sal plont ! & $\overline{\$ 1}$ & $\overline{17}$ & $\overline{2 n+1}$ & is: \\
\hline Sr ue poris dlkiesnat & 1 & i & $=$ & $:$ \\
\hline Cint:nectiy allowounce & 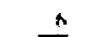 & : 1 & $1:$ & $\because$ \\
\hline Subrovts intal phyocal pun:l & $\overline{9}$ & $\overline{i .48}$ & $9-4$ & $\overline{3+}$ \\
\hline \multicolumn{5}{|c|}{ Indered costs $\left(10^{n}\right.$ s) } \\
\hline 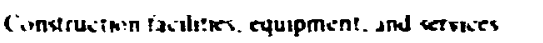 & $\because$ & !! & 15 & II \\
\hline 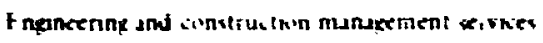 & 14 & $\therefore 9$ & $\$ 1$ & 51 \\
\hline Orhet cousts & 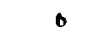 & 4 &.$;$ & 16 \\
\hline 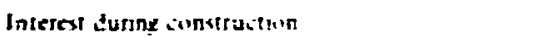 & \pm & sis & 136 & $\mid+1$ \\
\hline Subt.ntal inderest ...sts) & -6 & $\overline{15}$ & $2 ! n$ & $\overline{278}$ \\
\hline \multicolumn{5}{|c|}{ Total costs } \\
\hline \multicolumn{5}{|l|}{ 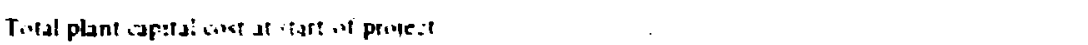 } \\
\hline Molliwns if dollai: & $1-1$ & $\therefore 26$ & +84 & $6+8$ \\
\hline Doliers [10 Htu he & $\because ?$ & $\therefore$ & 25 & 25 \\
\hline
\end{tabular}

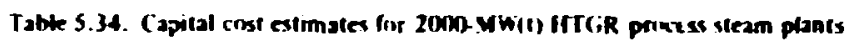

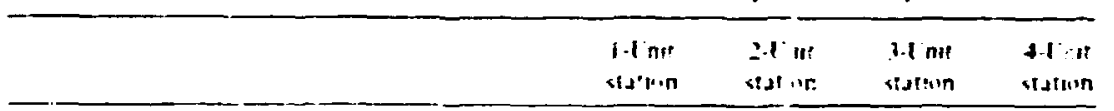

Dinect $\cos \left(s+10^{n}\right.$ s)

I and and land rights

\begin{tabular}{|c|c|c|c|}
\hline 1 & & 1 & 1 \\
\hline 34 & AN & 45 & 111 \\
\hline (1) & 13 & 107 & $2 \times 1$ \\
\hline 1) & 11 & ! & 1) \\
\hline III & 19 & $\geq 7$ & 15 \\
\hline 1 & $t$ & 7 & $q$ \\
\hline IIA & 216 & ila & 418 \\
\hline 1 & I & 2 & 3 \\
\hline$y$ & 14 & $3 n$ & $\geq$ \\
\hline 125 & 211 & 3.44 & tth \\
\hline
\end{tabular}

Physul plant

Sirustures anal sitr tiatifines

Reab"e! pliat equipment

Turhine pi int equipment

Flectric plani equipment

Visellaneivis plati equipment

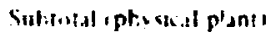

Spase parti alluturince

tinn:Ineens allew ince

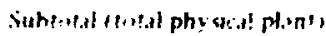

\section{$0^{*}$ s)}

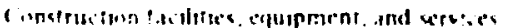

t nancering ind construction manasement cerver

ither itests

Interesf Juring ioneiruition

Suhteril infireri corsts

9

$\begin{array}{cc}10 & 24 \\ 4 x & 62 \\ 15 & 19 \\ 166 & 215 \\ 248 & 118\end{array}$

Total conts

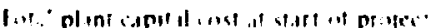

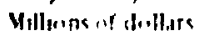

inillers lil' Bla he

\begin{tabular}{|c|c|c|}
\hline ו ו": & IN4 & $\{8\}$ \\
\hline$\because$ & (") & $21)$ \\
\hline
\end{tabular}




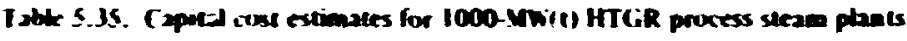

\begin{tabular}{|c|c|c|c|c|}
\hline & $\begin{array}{l}1.1 \mathrm{mit} \\
\text { Wutsin }\end{array}$ & $\begin{array}{l}2-8 \mathrm{~ns} \\
\text { Wa(k)n }\end{array}$ & $\begin{array}{l}3+f \text { nut } \\
\text { sathen }\end{array}$ & $\begin{array}{l}\text { timt } \\
\text { statmen }\end{array}$ \\
\hline \multicolumn{5}{|c|}{ Derel costs $110^{\circ}$ si } \\
\hline I Ind ind Lind rethis & 1 & $\mathbf{1}$ & $!$ & 1 \\
\hline \multicolumn{5}{|l|}{ Mumal plent } \\
\hline Structures snd ute : scitiver & 34 & 34 & 59 & 64 \\
\hline Resiforr plant equenornt & 46 & \$x & $13 n$ & $1: 2$ \\
\hline I urhine plan' cquipment & " & $" 1$ & a & 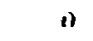 \\
\hline flattri phos cquppment & 6 & 12 & in & 23 \\
\hline Mexellumerus plont equipment & 2 & \pm & 5 & $=$ \\
\hline Suhtolal iphysuad punt: & -4 & $\overline{138}$ & 292 & $\overline{206}$ \\
\hline Spare parts alhin ane & 1 & 1 & I & $\geq$ \\
\hline foritiremis albuari:e & 5 & 9 & 13 & 18 \\
\hline 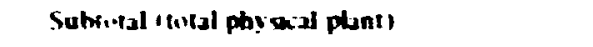 & (M) & {$[48$} & 216 & 286 \\
\hline \multicolumn{5}{|c|}{ Indivect costs $110^{\circ}$ si } \\
\hline Construith n iscyltiker. equipmetit. and erion & $;$ & ln & 13 & 16 \\
\hline 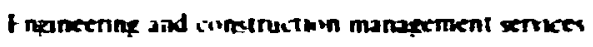 & 16 & 24 & 33 & 42 \\
\hline Other cinsts & $s$ & $?$ & 11 & 13 \\
\hline Inteicst Junna :orgstrustron & 39 & 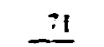 & $\underline{\operatorname{lng}}$ & 154 \\
\hline Suhtortal (indirect (1)sts) & 67 & 112 & 166 & 295 \\
\hline \multicolumn{5}{|c|}{ rotol comes } \\
\hline \multicolumn{5}{|l|}{ Totel plant aptal cose at start of prokest } \\
\hline Millnipe of wollars & $1+8$ & 261 & 383 & 512 \\
\hline Ixillars I $^{3}$ hiuhr & $\div 3$ & 38 & 37 & 38 \\
\hline
\end{tabular}

The process sleam plant costs do not include costs for reboiiers and other equipment re fuired for steam distribution. Capital costs for PHR steamelectric plants were estimated with the updated version of the CONCFPT code." Capitai costs for IITCR stramelectric plants are hased on thove reported in WASH-1230 for a 770-MUie) plant." (apizal sosts for the nuclear process steam plants were developed hy appropriatc mosification of the electric plant estimates. Since a IOMO-MW(t) HT(iR is not conmercially abalable. costs were extropolated from the 2000-MWit) Hi(iR estimates

Tables 5.36 to 5.41 show the estirtated annual operation and maintenance expenses. nut including fucl. for both nuclear electric plants and process steam plants. The costs for electric plants were es'imated using the methoxs outlined hy Myers,: and the process steam plant costs were estimated hy modif:cation of the electric plant estimates.

\section{Prime steam for process applications from LWRs and HTGRs}

Producing prime steam for process applications or extracting steam for process applications from an I.WR is a matter of providing a reboiler and adjusting the turbine-generator size for eliminating it for total steam to proces: heat). Frime steal, is approximately IOMO (1) IOS0 psi and

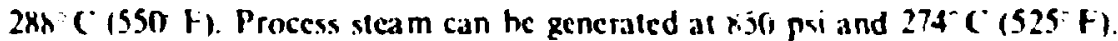

I he $\mathbf{A l}$ (iR is a more complex system. Figure 5.20 illustrates the current H I (iR concept and the limits of steam exeractoon conditions which can be achieved [approximately 500 psi and 399 ( 


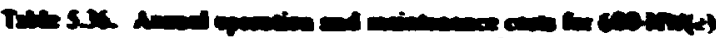
Prem (n)

\begin{tabular}{|c|c|c|c|c|}
\hline & ה-1H & 24 mas & HUin & 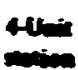 \\
\hline \multicolumn{5}{|l|}{ Fenes } \\
\hline & $\begin{array}{l}13 \\
\text { ass } \\
\text { a17 } \\
\text { ans } \\
\text { a2s }\end{array}$ & $\begin{array}{l}105 \\
: 45 \\
077 \\
073 \\
07\end{array}$ & $\begin{array}{l}2.31 \\
230 \\
035 \\
1.2 \\
0151\end{array}$ & $\begin{array}{l}277 . \\
315 \\
\text { ins } \\
131 \\
\text { is }\end{array}$ \\
\hline Tond tis lens & $\overline{25}$ & $\overline{4.52}$ & $\overline{c s}$ & $\overline{921}$ \\
\hline as & $\begin{array}{l}0.7 \\
0.41\end{array}$ & $\begin{array}{l}0.3 \\
0.74\end{array}$ & $\begin{array}{l}127 \\
110\end{array}$ & $\begin{array}{l}1.55 \\
1.37\end{array}$ \\
\hline 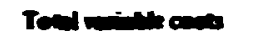 & & 119 & 2.33 & $3 \Omega$ \\
\hline 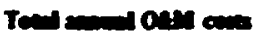 & 4.1 & as & 29 & 112 \\
\hline
\end{tabular}

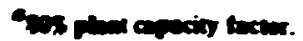

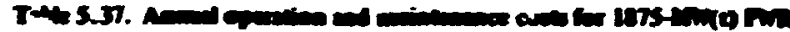
10.0 (10)

\begin{tabular}{|c|c|c|c|c|}
\hline & 1-Uin & 24luis & 3end & Hinia \\
\hline \multicolumn{5}{|l|}{ Fan } \\
\hline 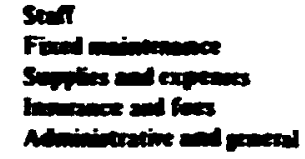 & $\begin{array}{l}1.25 \\
\operatorname{a.p} \\
0.11 \\
0.44 \\
0.18\end{array}$ & $\begin{array}{l}1.65 \\
0.15 \\
0.16 \\
0.73 \\
0.27\end{array}$ & $\begin{array}{l}2.25 \\
1.20 \\
0.21 \\
0.96 \\
0.35\end{array}$ & $\begin{array}{l}2.49 \\
1.11 \\
0.26 \\
0.61 \\
0.43\end{array}$ \\
\hline Toen fored cossos & $\overline{247}$ & $\overline{\mathbf{3 . 6 7}}$ & $\overline{4.33}$ & 5,30 \\
\hline \multicolumn{5}{|l|}{ 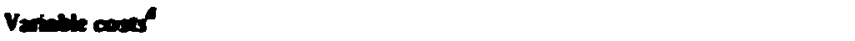 } \\
\hline 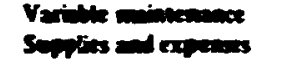 & $\begin{array}{l}0.16 \\
0.13 \\
\end{array}$ & $\begin{array}{l}0.28 \\
0.20 \\
\end{array}$ & $\begin{array}{l}0.40 \\
0.27 \\
\end{array}$ & $\begin{array}{l}0.51 \\
0.31 \\
\end{array}$ \\
\hline 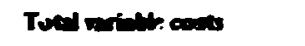 & $\overline{0.29}$ & $\overline{0.48}$ & $\overline{0.67}$ & $\overline{0.55}$ \\
\hline 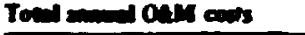 & 28 & 4.2 & 5.0 & 6.2 \\
\hline
\end{tabular}

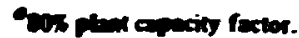

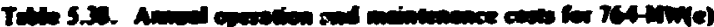

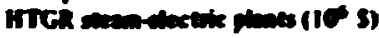

\begin{tabular}{|c|c|c|c|c|}
\hline & IfUnit & 2-Unis & Hoin & HIInim \\
\hline \multicolumn{5}{|l|}{ Fined cons } \\
\hline $\operatorname{sen} \pi$ & 1.66 & 2.22 & 2.77 & 3.32 \\
\hline Fibed mantenesore & 1.10 & 1.96 & 2.76 & 3.53 \\
\hline dies end expenses & 0.20 & 0.31 & 0.42 & 0.51 \\
\hline ance ent ans & 0.45 & 0.76 & 1.06 & 1.37 \\
\hline 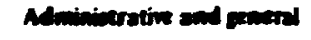 & n.30 & 0.45 & 0.60 & 0.74 \\
\hline Toed fisued costs & $\overline{3.79}$ & $\overline{5.70}$ & $\overline{7.61}$ & $\overline{9.47}$ \\
\hline \multicolumn{5}{|l|}{ Vartale costest } \\
\hline 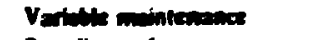 & 0.53 & 0.97 & 1.40 & 1.82 \\
\hline 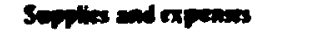 & n.5s & 0.00 & 1.14 & 1.47 \\
\hline Tnet rutulk ensts & $\sqrt{1.06}$ & 1.77 & $\overline{2.54}$ & $\overline{3.29}$ \\
\hline Totel ammol OsM cons & 4.8 & 7.5 & $\ln .2$ & 12.8 \\
\hline
\end{tabular}

Con phem copaciny focion. 


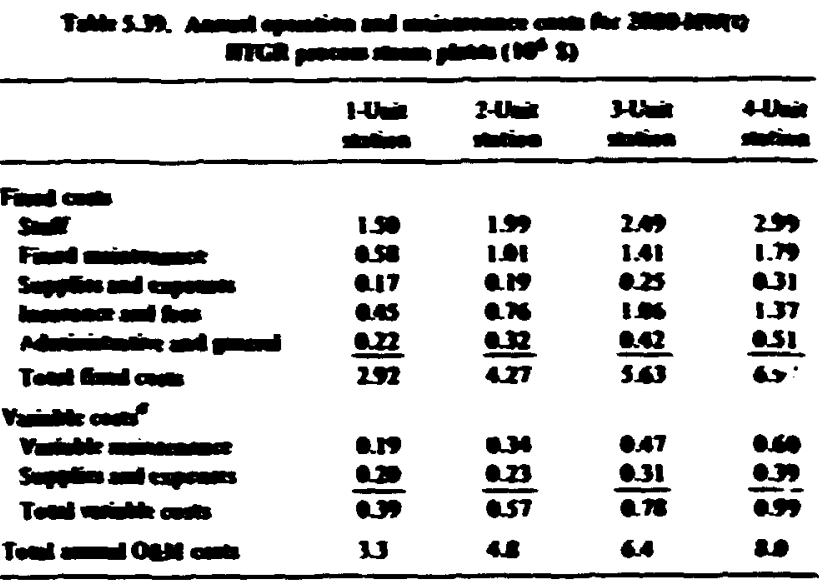

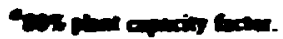

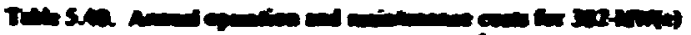
DUER Dom of

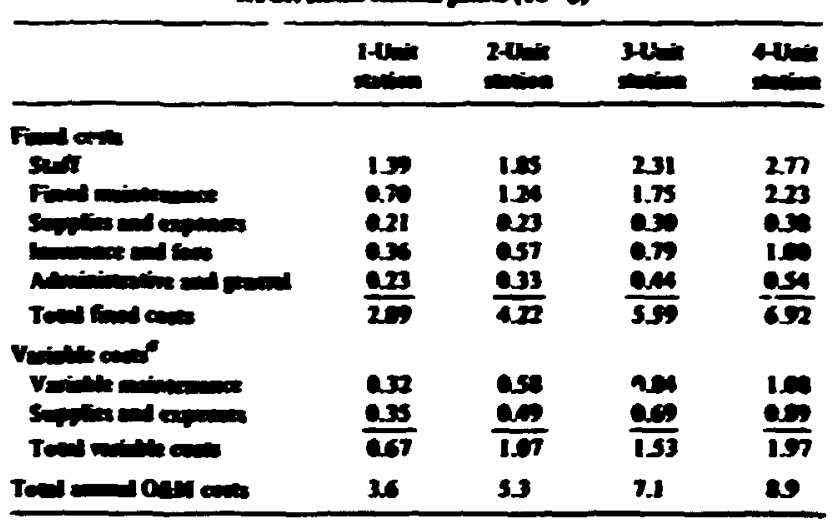

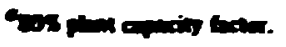

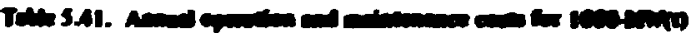

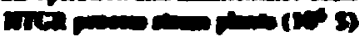

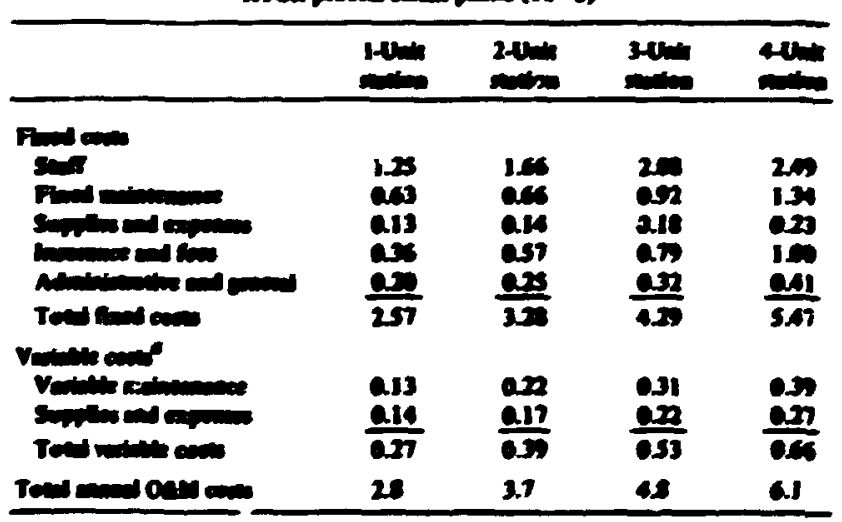

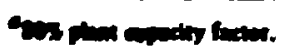


5
1
8
8
8
1
$\frac{8}{8}$
8

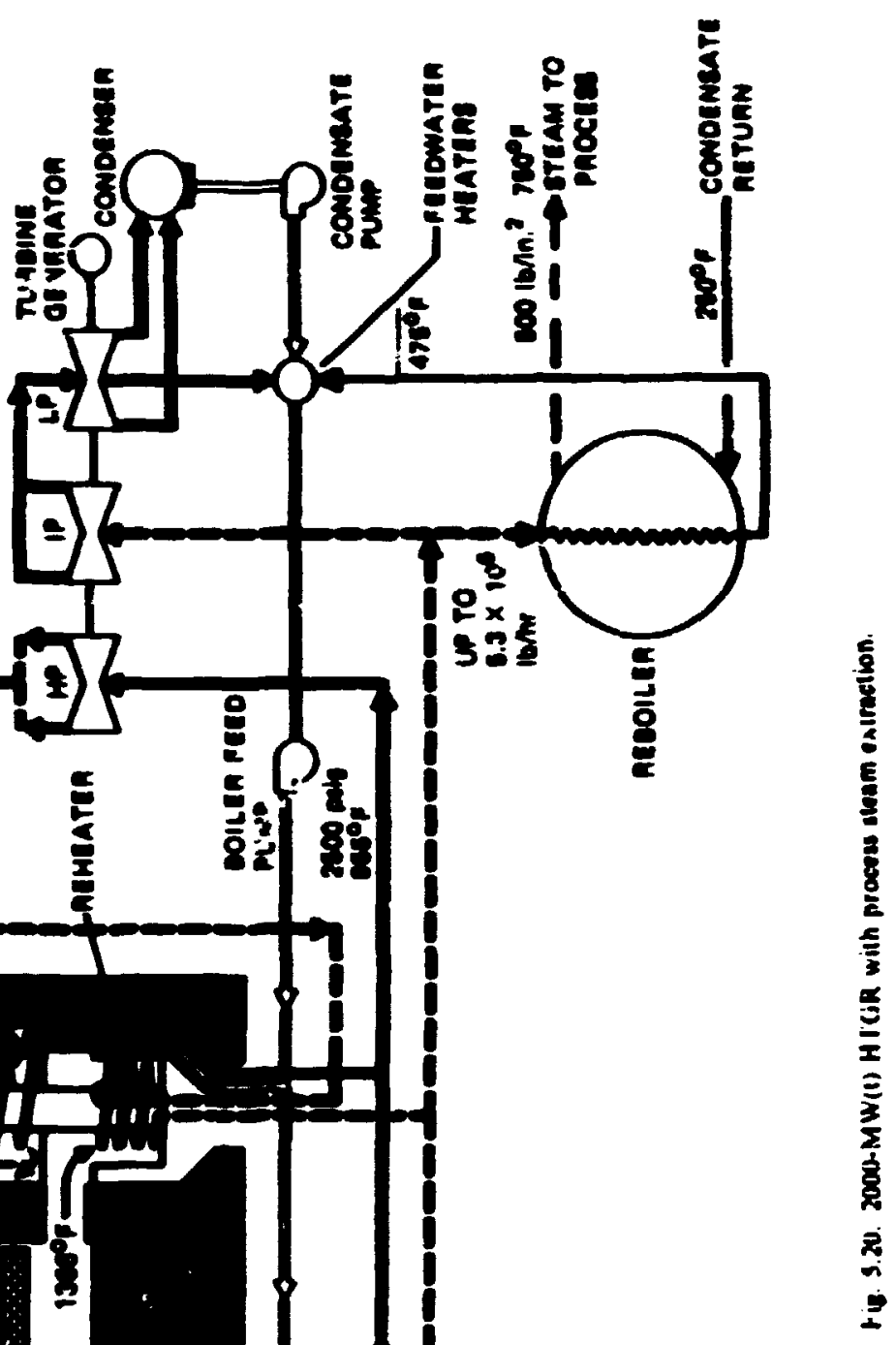




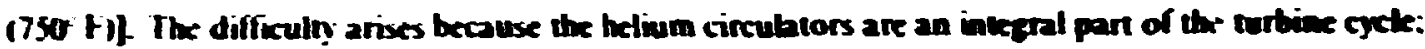
that is the tool prime stean for passes from the high-pressure turbine throng the cincublot drives to the intermal rehealet. No extrection can be caken prior so the outet of the rebeater withom ralesign of the auclear steam system.

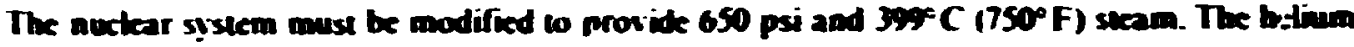
circubtor turbine would be rodesigned to utiline prime steam directly, and a resuperbeater might be incleded in the cycte followiag the helium cieculator. High-pressure. bigh-lemperature stean ( 2000

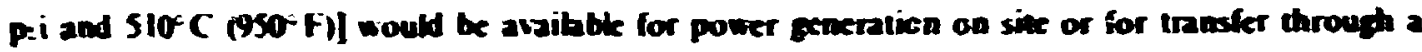
rebciler to a secuadary system for trampont off siec."

A pretiminary evalustion has been made for the reboilet for isobtion of the ouclear steam. For the I.WR. heat is transferred from saturated steam at 1050 psi and 286C (5SOF F) to saturaled steam at 850 psi and $274^{\circ} \mathrm{C}\left(525^{\circ} \mathrm{F}\right)$. The be mean temperature diffenence is approximatety $14^{\circ} \mathrm{C}$

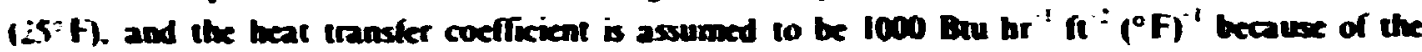
Ev wable conditions of trassferting heat at saturnted stean conditions on both sides of the tubes. For 10 lb hr seam.

$$
\begin{aligned}
A \text { (surface area required) } & =\frac{\text { Quantity of heat }}{U \Delta t} \\
& =\frac{980 \times 10^{\circ} \mathrm{Btu} / \mathrm{ht}}{1000(25)} \\
& =39.200 \mathrm{st}^{2} / 10^{\circ} \mathrm{b} / \mathrm{hr} .
\end{aligned}
$$

The direct cost of high-pressure fead water heaters is typically $\$ 15$ to $\$ 20 \cdot \mathrm{ft}^{\circ}$ of surface. It is assumed the retoiler would be of similar design. Assuming a $\operatorname{cotal} \cos$ of 50 fi for the reboikt yields approximately 51.600000 total cost for the reboikt or $\$ 1.60$ pet pound per hour of steam. The approximate unit cost for the reboiler, assuming industrial financing. would be

$$
\text { Unit cost }=\frac{51.600 .000(0.222 / \text { year })}{1.000 .000 \mathrm{lb} / \mathrm{hr}(8760 \mathrm{hr} / \mathrm{yent})(980 \mathrm{Brw} / \mathrm{bb})} \times 10^{\circ}=4 / 10^{6} \mathrm{Btw} .
$$

The HTGR reboiks would have a much higher temperature driving force but lower heat Iransfer performance in the supertieat regions. It is esimated 10 cost somewhat less than the LWR reboiker. The cost would depend on 1 detailed anabysis of the specific prime steam conditions achieved with the modified system.

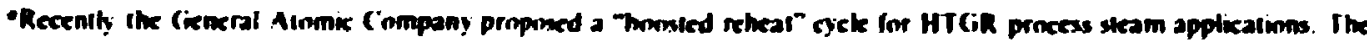

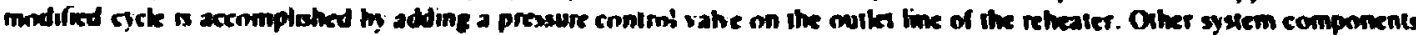

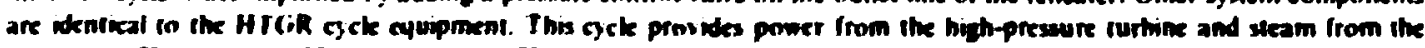

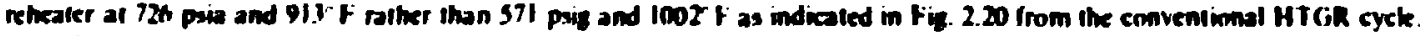

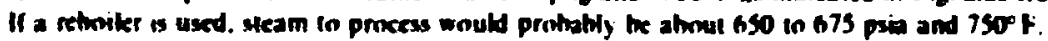




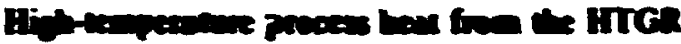

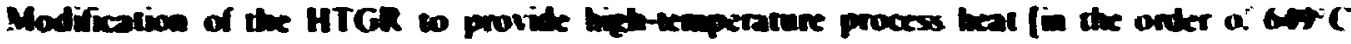

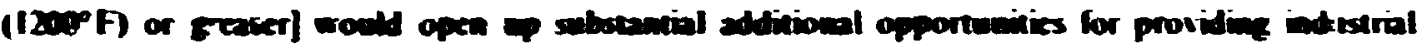

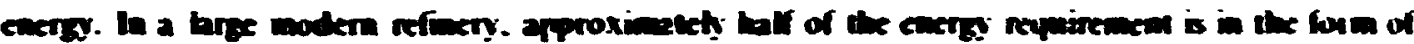

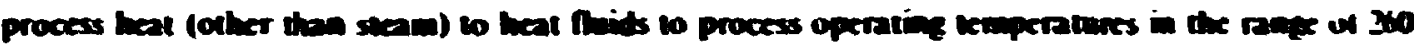
to $330 \mathrm{C}(500$ io $1000 \mathrm{p})$.

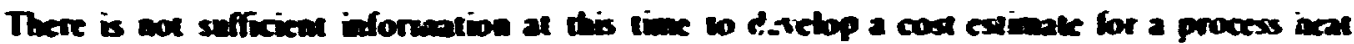

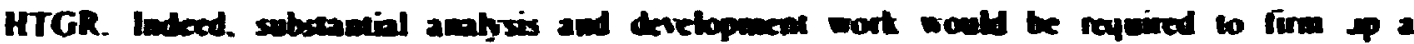
concepteal design for a process bea iTTGR.

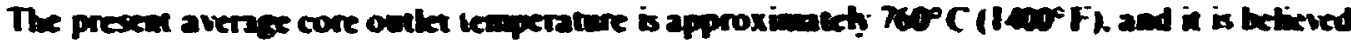

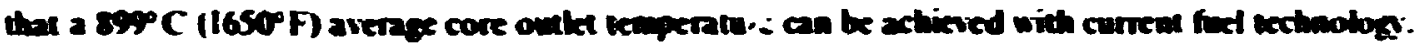

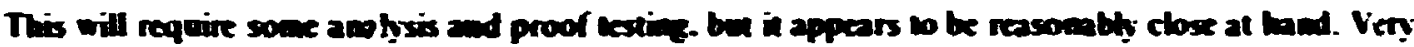

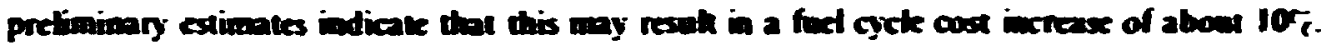

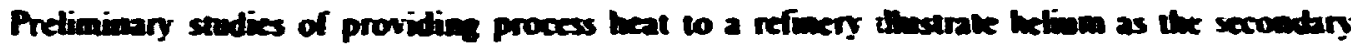
heat transfer luid pessing directly from the best exchanger wilhis the prestressed concrete reactor

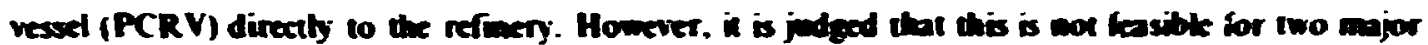
reasons: (I) isolation from possible radionetive or industivi conenmination will ven liteh be

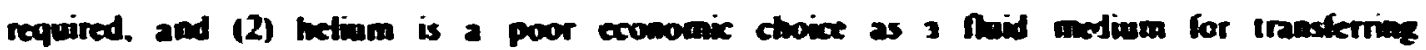
hiph-temperisture hat over lons distances.

In the range of $87 \%$ C (I600 F). radionetive iritium can puss through the wall of the heat exchanger tubes and in:o the secoatary faid. The level of tritium concestration in the primary

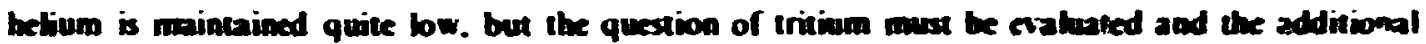
attenuation of a scoudary heat exchanger outside the PCRV mast be cosuifered. Conversety. be possibility of introducing industrial conaminants (petroleum. etc) into the reactor vesed most also be considered and my in itself require a secondary heat exchanger.

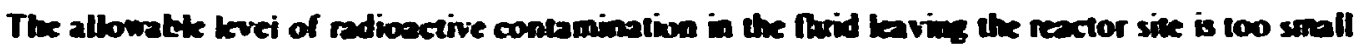
to be mesured by on-line instrumentatioa or monitors. A secondary hat exctanget allons sanples to be manitored from the iatermediate hetiom bop at frequent intervis with the added salety of an additional physial batries.

\section{S.3 SFECIALFURPOSE PWR FOR INDUSTRY}

\subsubsection{Dackpound and Sartes of the CNSG Reactor}

The development of the Consolidated Nuclear Steam Generator (CNSG) for muclear ship proputsion has been under way" at the Babeoct and Wibox Conpany since 1959. Scone of the unique features of the plant desion. includins the once-throrefh steam generator housed within the reactor vessul. have already been demonstrated" in the Federol Cenman Repobtic nuclear ship "Orio Hahn." which has opereted succesufully since I969. The U.S. Maritime Adminisamion has contianed to sponsor work in the areas of design, testing, and evaluation of the CNSG conceph, and curreat

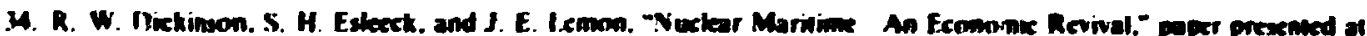

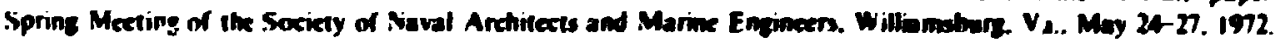

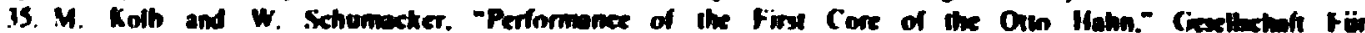
Kemenergiev":rwertung. Ciermany. presented at the Symposium on Sicclear Ships. Rin de Jeweiro. Mrevil. Mav M. 1972. 


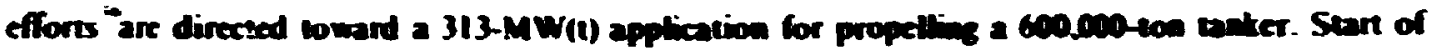
construction is hoped for widhin 1 or 2 years.

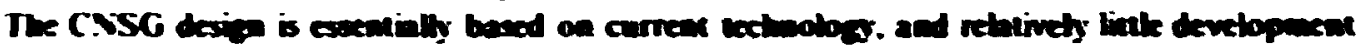

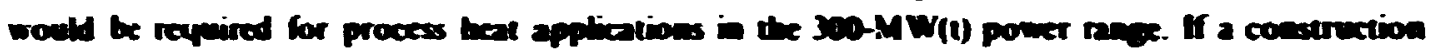

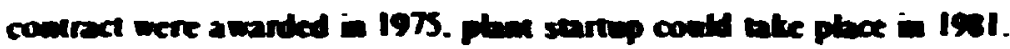

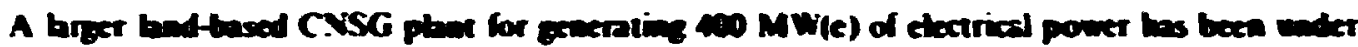

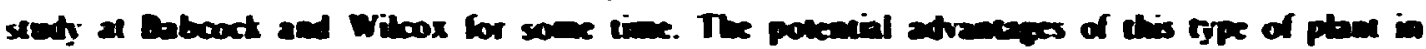

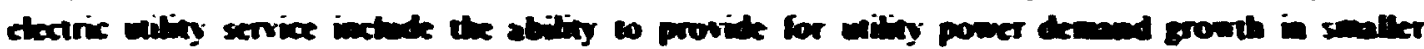

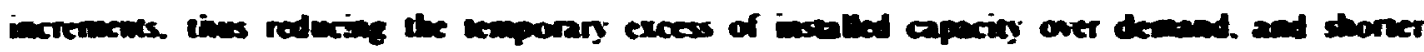

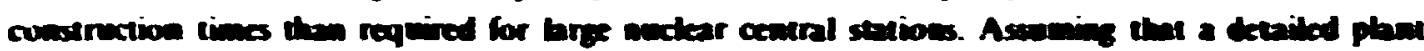
desien coudd be deveboped in aboun 2 years and allowing aboen 8 years between project stan and

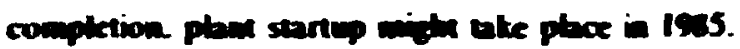

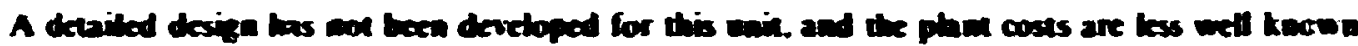

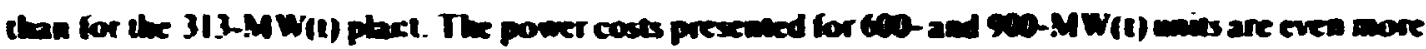
kenteine. since they sice besol on inerpolations of the major cose componemens of the 313- and the 1235-MW(1) planes.

\subsection{Reacour frod}

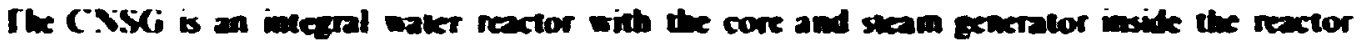

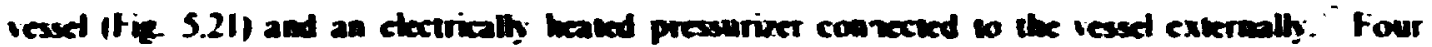

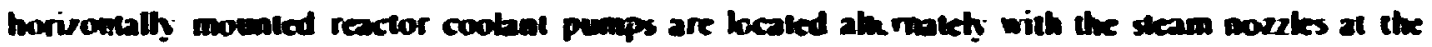

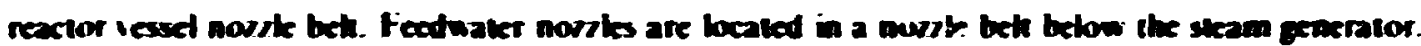
ithe resctor core consists of Zirealoy tebes contaiaing shighth earitued uraviuan dioxide pellets

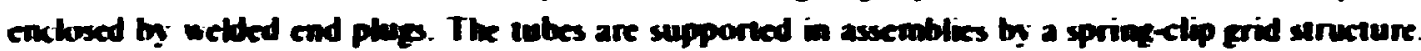
The onectanial conarol rods are chusters of absorbet mods that mose in guide tebes within the fuel assembly.

Ithe steam gercerator is a telically coiled. once-through unit bocked in the anmulus abone the top ket of the core. The operation of ithe steam generator otilives four sets of kedwater inlet and seam

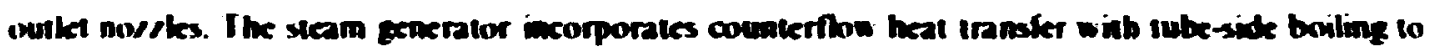
produce steam at a constamt pressure. The reactor coobnt system operates at a constant alerage iemperature ower the nowmal boed range. Major reactor parameters are shown in Tabte S.4Z.

Ihe reactor contairmem shell (Fie 5.22) as a free-slanding steel cylinder with elliptical neads.

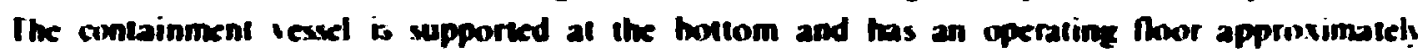
hallwas up the containment. The center section of the upper head is remnable for servicing and instaltation of major components and for refucling: it is fited with a double seal. Ithe peromnel hatch. which is abso a doubletharrier design. is localed near ithe operating Roor. prosiding access for routine maimenance and inspection. The rapor-supprassion pool is formed by a second cyliodrical shell below the operating Moor: the annublar wet well is divided into eight separate compartments with one vent discharging into exh compartment.

A reactor building (Fig. 5.23 ) completety enchoses the reactor and its presuure-suppression priman containuent. This seructure provides secondany containment when the primary containmeut

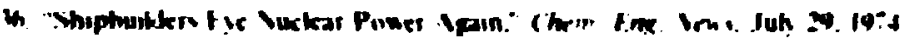

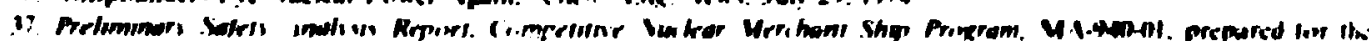

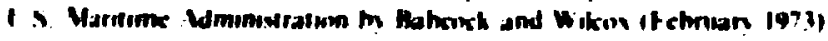




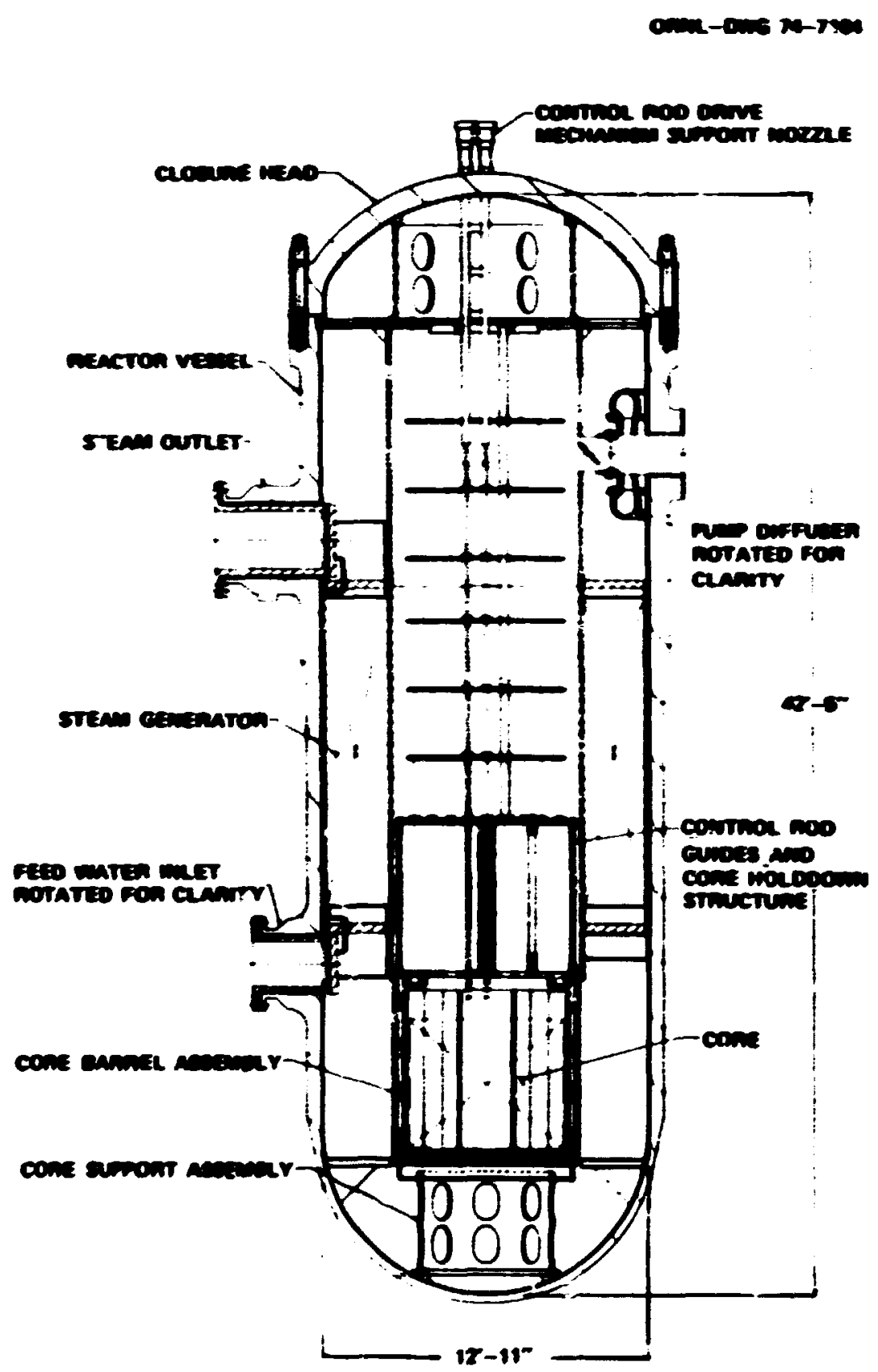

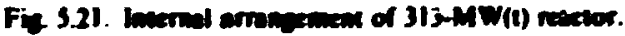




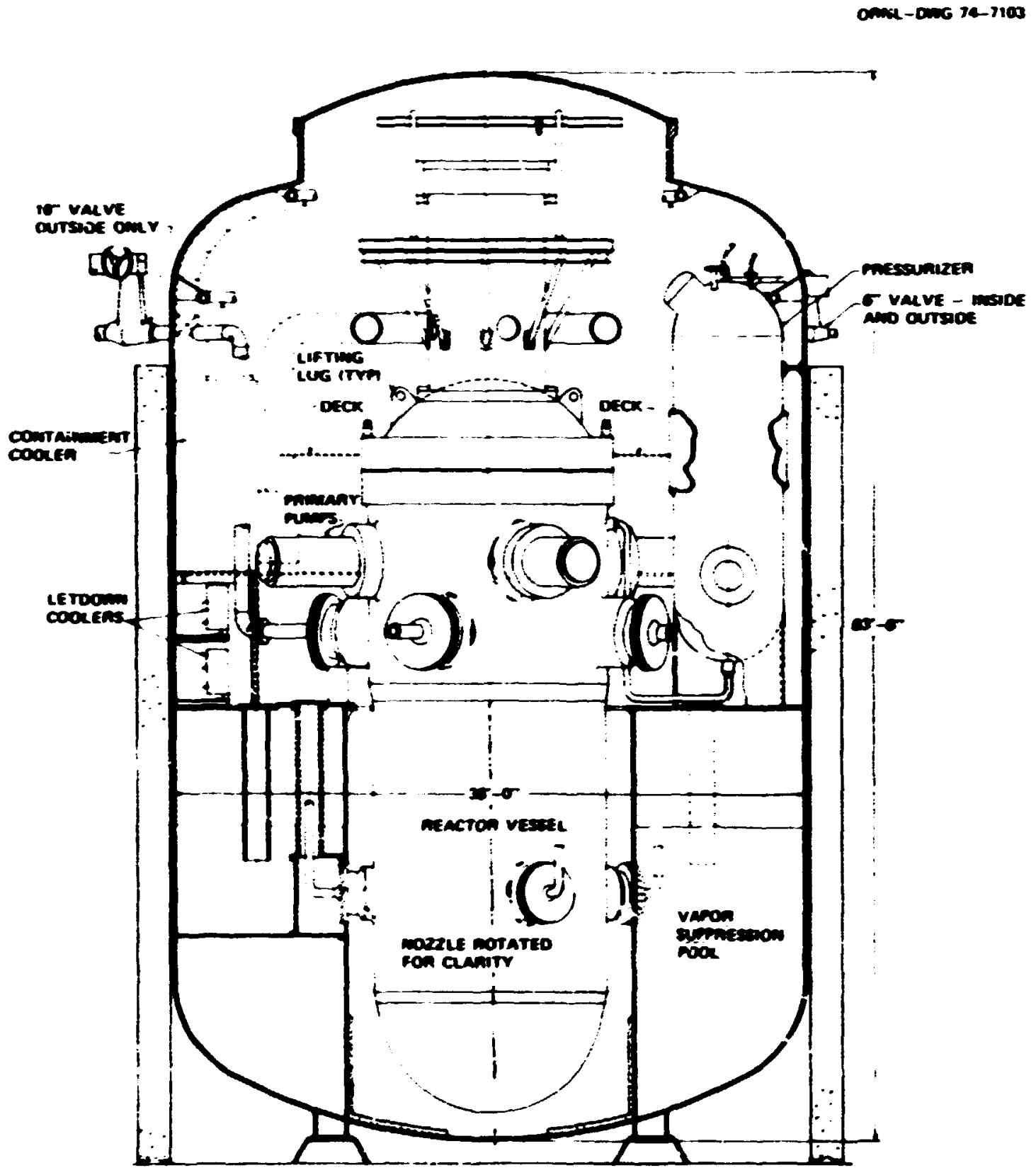

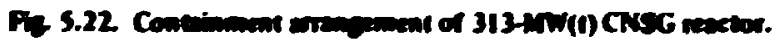


CIACULATING SYSTEM INTAKE AND OISCHARG

2 75-ton CRANE

3 VESSEL HEAD STORAGE

4 FUEL mandLING HCOL ANO IN'ERNL'S STORAGE

5 125-ton CRANE

6 SHENT FUEL. STORAGE

7 SPENT FUEL SMIPPING PIT

B NEW FJEL STORAGE

9 REA TOR BUILOING

10 AIR I.OCK

II DEMINERALIZER

12 PAESSURE SUPPRESSION POO
13 91-MW(O) TURBINE-GENEAATOR

14 REACTOA

15 PAIMARY CONTAINMENT

16 CONTRO ROOM

17 SERVICE QUILOING

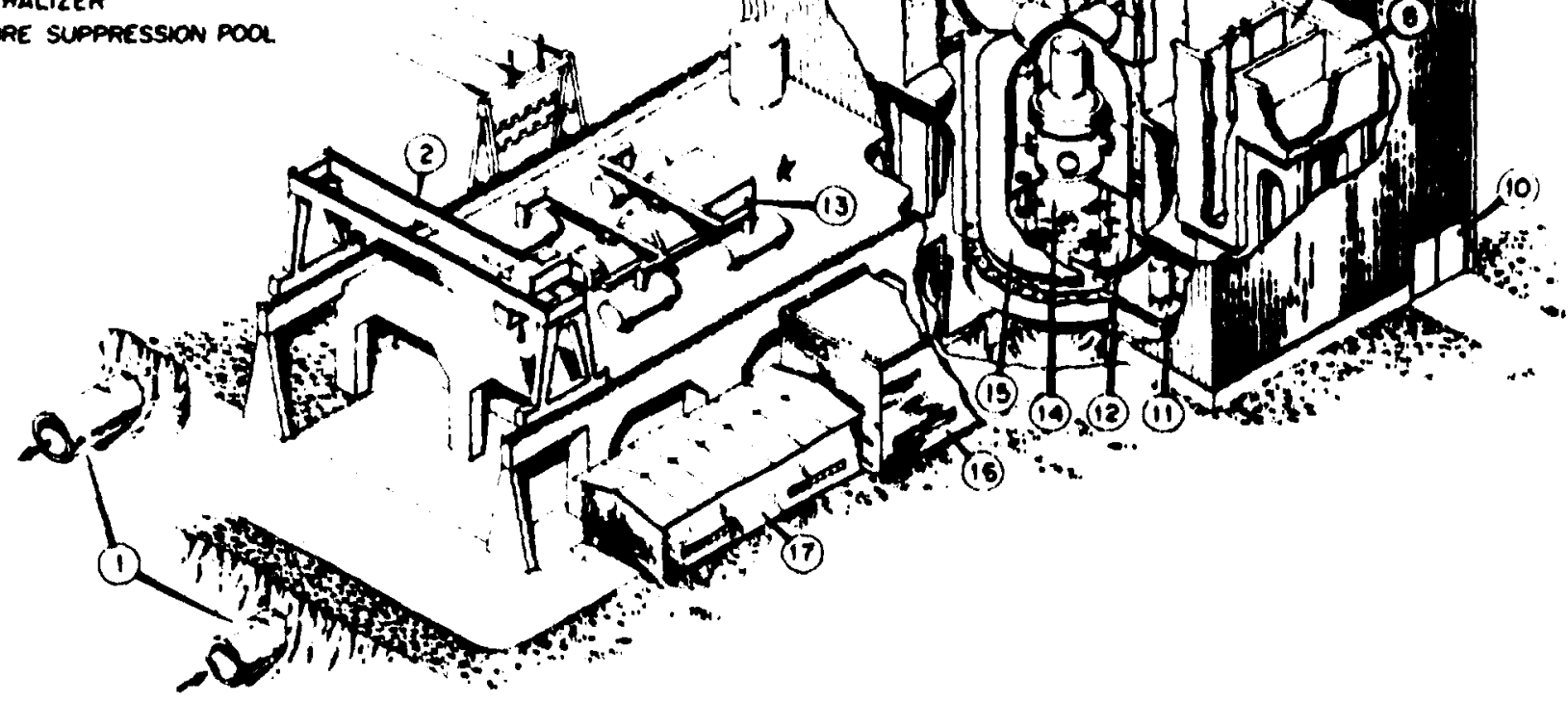

Fic. 5.23. Vucleas steam supply for $313-M W(1)$ reactor with $90-M W(0)$ turbine ennerator. 


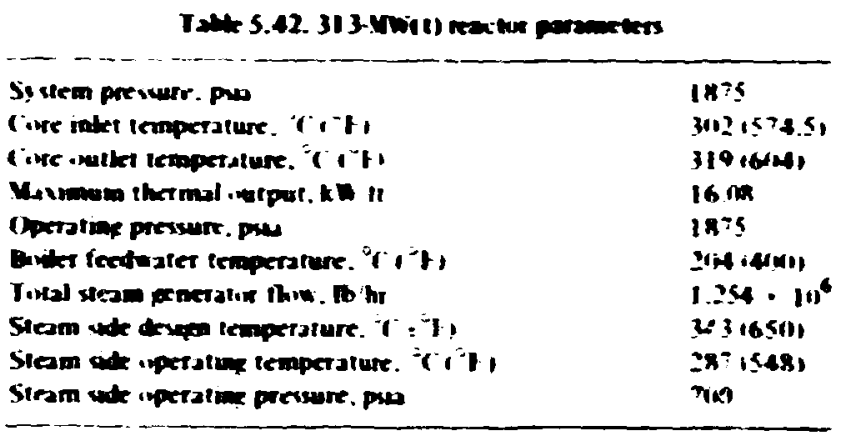

is in sinice and torms the priman containment during fueling or repais of the reastor sysem. I the reactur huibling houws the relucling and reactor en wing cyuipment. new and spent-luxl storage tacilites. and athet ristor auxilan of en.ce cyuipment (demineraluen, sandby lixuid control sytem. control rou judraulic sysem. and eketrikal eyuipment). From a saleguards consideratkon.

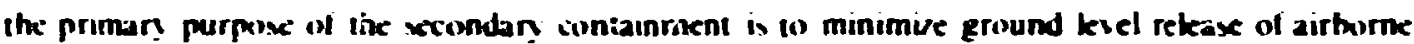
radiosactise materials and is priside lor corifolled and filtered rekasc of the buibding atmurphere under accutent conditiens.

\subsubsection{Power-Comverion Phat}

Ihree approaches for providing process energy from the reacior plant were esaluated: (I)

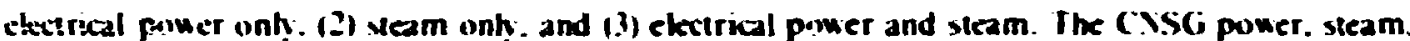
and fizd uater conditions remained unchanged throughout. ( nder condition 1 . steam at 700 psis and

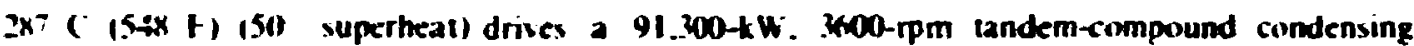
turbine that exhausts steam at 2 in. He to a once-through water-conkd condenser. For conditions ? and 3. it was assumed that the process steam would be generated in a reboikt in order in prevent the transter of comtaminants hetween the nuclear steam supply and the industrial processes. The process veam was assumed to exil from the rehoike ar saturated conditions: the process steam flow rate is shoun in fig. 5.24 as a function of process steam temperature. The temperature of the refuming process water was gencrally taken as 2 F below that of the retoikr. However. for process steam above 205 ( $102 \mathrm{~F})$. the retuming water temperature was held constant at $100 \mathrm{~F}$. Corresponding to the (MSC dexign feed water temperature of $204^{\circ}$ ( $(400 \mathrm{CF})$. No makeup losses were assumed for the process steam system. The process heat delivered hy the retoike is show $n$ in Fig. 5.25 as a function of process steam temperature.

Inder condition 2. CXSG steam at 700 psia and $287^{\circ} \mathrm{C}$ (54k= fil fows shrough the rube side of the reboiler to generate $1.24 \times 10^{\mathrm{N}}$ it he of 566 psia saturated steam on the shell side. To meet condition 3. electrical power is generated in a back-pressure turbine exhausting to a rehoike. whikh in turn generates process steam. Turhine back pressures ranged from 67 10 515 psia. corresponding to saturated process steam flows ranging from $934.000 \mathrm{lb}$ hr at 49 psia to $1.218 .000 \mathrm{lb}$ hr al 423 psia respectively. Output from the turbine generator of course diminished with increasing back pressure. ranging from $5500 \mathrm{~kW}$ at 515 psia iurbine exhoust pressure to $51.300 \mathrm{~kW}$ at $67 \mathrm{psia}$. The net generator output is shown in Fig. 5.26 as a function of process temperature. 


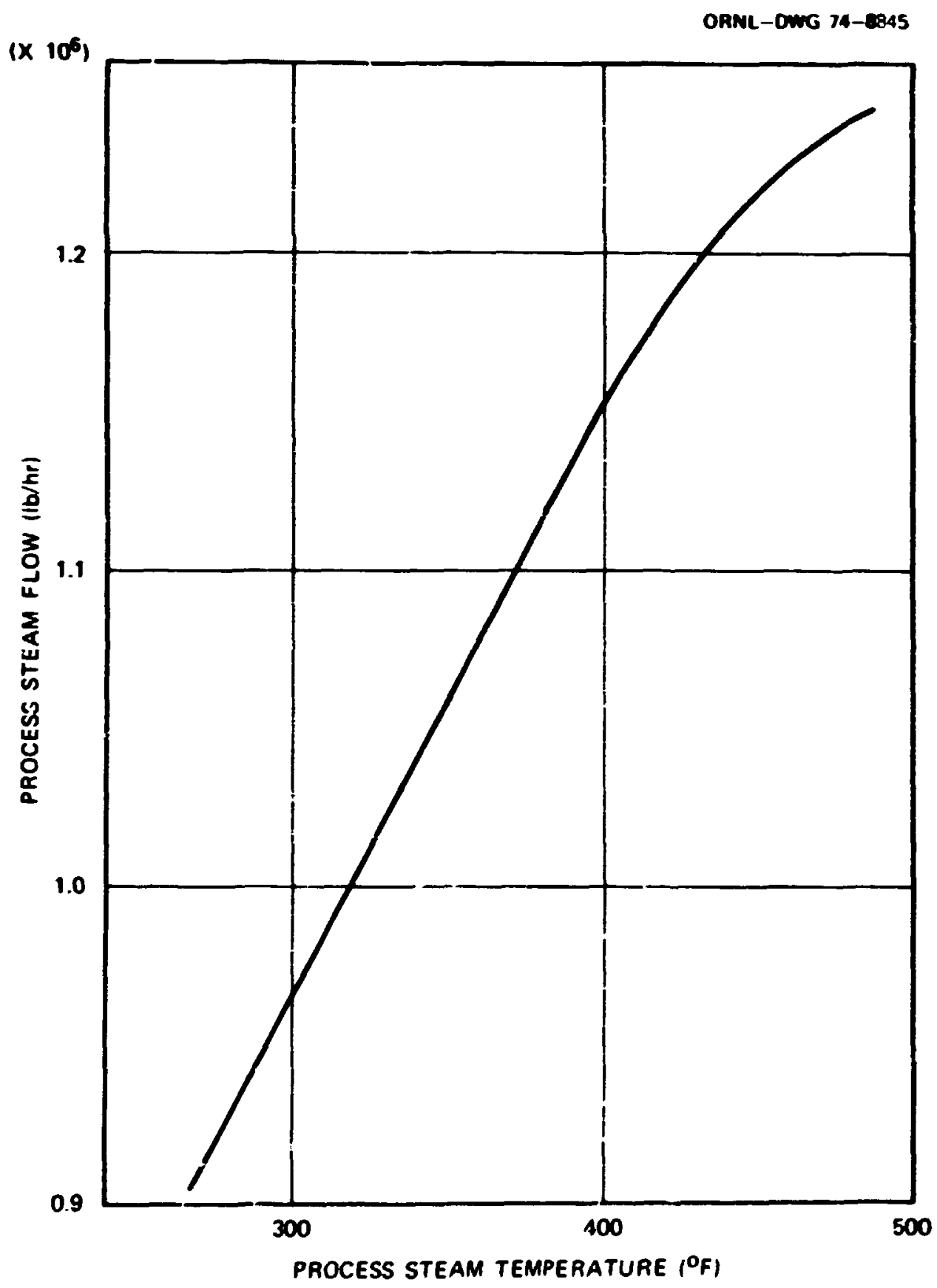

Fig. 5.24. Prucr:ss steam now for 313-MW(1) CNSG as a func:i-n of steam temperature. 


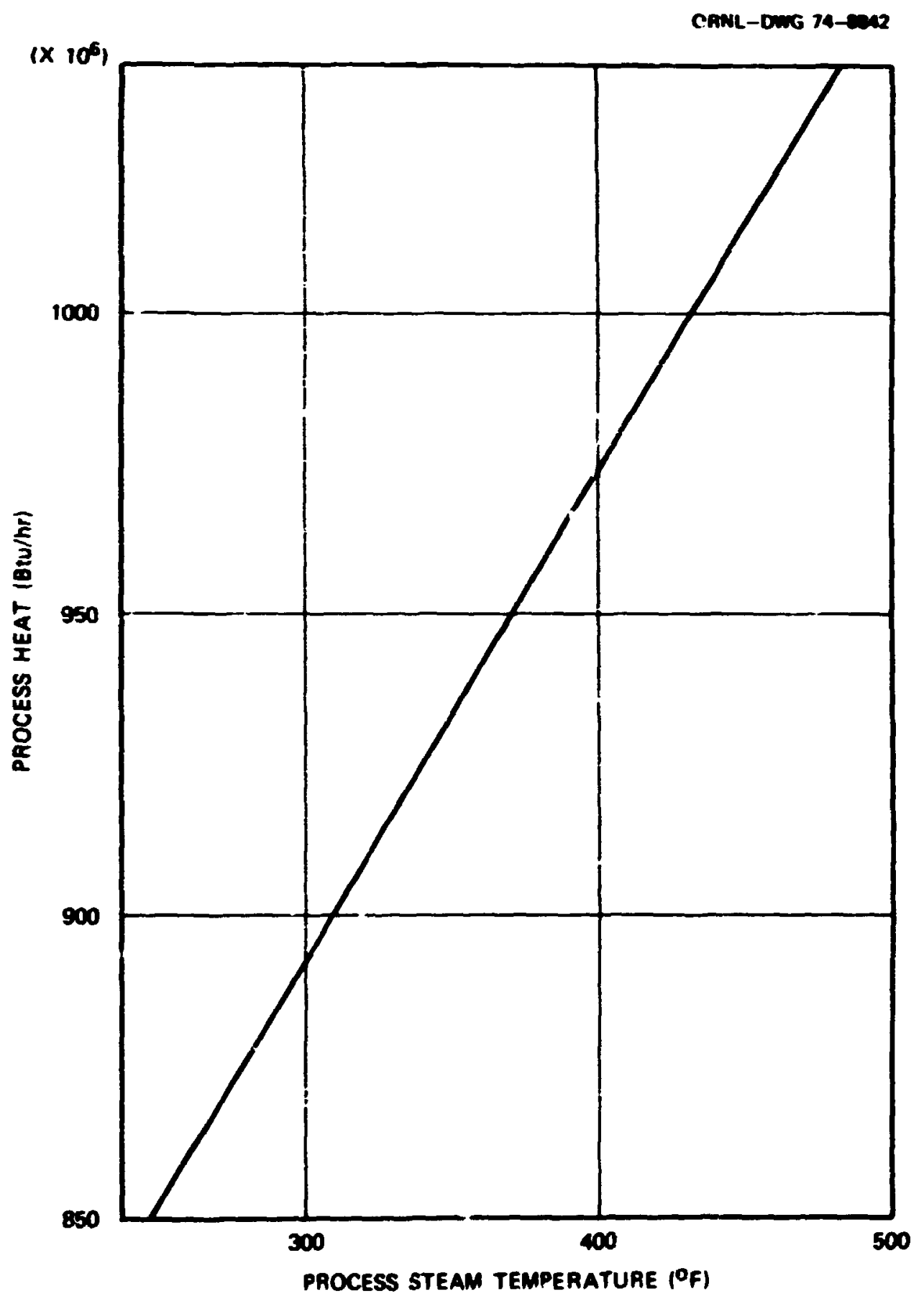

Fie. 5.25 Process heal for 3! 1-MW(E) CNSG as a function of steam temperanure. 


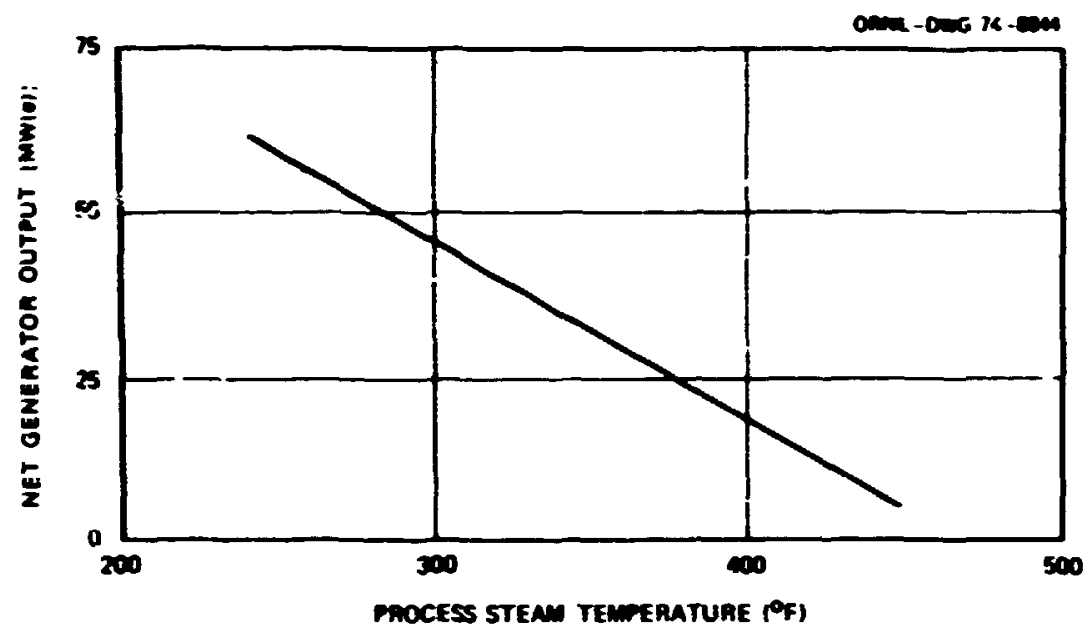

Fin 5.26. Net generator output for 313-MW(t) CNSG as a function of process stean tempenture.

\subsubsection{Description of 1235-MW(t) Syrtem}

Detailed plant designs for larger land-based CNSG stations have not been developed at this tirre. Studies by Babcock and Wikox st:zgest that C.NSG technology is directly applicable to power lesels up to $5100 \mathrm{MW}(\mathrm{e})$. with power output limited by the size of the reactor vessel that can be fabricated in current manufacturing !arilitiex. Plant operating conditions were assumed to approximate those of the 313-MW(t) C.NSG described in a previous section. The reactor vessel diameter is about 17 it 8 in., and vessel height is increased to about 38 ft: thermal output totals $1235 \mathrm{MW}$. The functional arrangement of the reactor containment, fuel-handling system. and reactor building remains as describe? for the 313-MWi:! plant.

Two altemative power-conversion systems were evaluated. The first. intended for the generation of electrical power only. consists of a 400-MW(e). 3600-rpm tandem-compound steam turbine-generatol unit. supplied with steam at 700 psia and $287^{\circ} \mathrm{C}\left(548^{\circ} \mathrm{F}\right)$. exhausting at $2 \mathrm{in}$. $\mathrm{Hg}$ to a once-through water-cooled condenser. For the alternative system. intended for the production of process steam only. CNSG steam at 700 psia and $287^{\circ} \mathrm{C}\left(548^{\circ} \mathrm{F}\right)$ nows through the cube sid: of a reboiler to generate about 5 million ib hr of 56 psia saturated sidatu on the shell side.

\subsubsection{Economic Analysis}

Capital and operating costs have been estimated for CXSGi-type stations of 313 and $1235 \mathrm{MW}$ of thermal capacity. The larger reactor has not heen developed in as much detail as the 313-MW(t) shiphoard-hased design. and the cost estimates for the 12.35-MW(1) station are therefore morc tentative. However. the values derived are believed adeyuate for the purpose of evaluating the economic potential of the concept for industrial process energy applications.

\section{Plant capital costs}

Costs for the major components of the two (XSG; nuclear steam supply systems summarized in Table 5.4.3 are approximately $\$ 6.3$ million for the $313-\mathrm{MW}(1)$ unit and $\$ 117$ million for the 


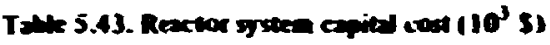

\begin{tabular}{|c|c|c|}
\hline & 313 anw(t) & $1235 \mathrm{M}$ (wit) \\
\hline \multicolumn{3}{|l|}{ Structures and inpenveduculs } \\
\hline Yard work & 800 & $\infty$ \\
\hline Reactor buiditip & 22000 & 5.130 \\
\hline Dieset temerator baiding & 150 & 300 \\
\hline Adroinistration beiching & 200 & 200 \\
\hline Control room & 500 & 500 \\
\hline Service builting & 200 & 200 \\
\hline \multirow[t]{2}{*}{ Rexctor containment } & 2,340 & 3.070 \\
\hline & $\overline{6,990}$ & $\overline{10.200}$ \\
\hline \multicolumn{3}{|l|}{ Reactor phat equiponent } \\
\hline \multirow{4}{*}{$\begin{array}{l}\text { Nuctea stam supply, incluaing atiotion } \\
\text { Fucthandlias system } \\
\text { Radiation monituries system }\end{array}$} & 33.900 & $\$ 9,000$ \\
\hline & 800 & 2,250 \\
\hline & 250 & 250 \\
\hline & 34.950 & 51500 \\
\hline Electrical plont equipment & 1.300 & 4000 \\
\hline \multirow{3}{*}{$\begin{array}{l}\text { Total reactor direct cost } \\
\text { Continatroy }\end{array}$} & 43,240 & 65,700 \\
\hline & 500 & 6.000 \\
\hline & 43.740 & $71, \overline{700}$ \\
\hline \multirow{4}{*}{$\begin{array}{l}\text { Constnuction facilities, equipment, services (6x) } \\
\text { Enginecrife and construction manapement services } \\
\text { Other costs (5\%) }\end{array}$} & 2,624 & 4.302 \\
\hline & 4,374 & 10.755 \\
\hline & 2,187 & 3.585 \\
\hline & $\overline{52,925}$ & $\overline{90,342}$ \\
\hline Interesx during construction (4 years at 10x) & 9.791 & \\
\hline \multicolumn{2}{|l|}{ Interest during construction (6 years at $10 x$ ) } & 26,470 \\
\hline Tolal con in 1974 & 62,716 & 116,812 \\
\hline
\end{tabular}

1235-MW(t) system. These costs. which are given in 1974 dollars. include the interest during construction but exclucie cost escalation for startup heyond 1974. The costs for the nuckear steam supply systems remained fixed in the economic evaluation of the two altermative power-conversion uptions examired. The capital costs given in iable 5.44 are for powe:-conversion systems intended for the production oi electrical power only.

The cost of a reboike and other components that might be required to utilize the process steam and to return the process water to the nuckar steam supply system depends on live particular reyuirements of the energy iser and is not included in the cost tabulations. The reboiler costs might incrase the price of process steam from the $313-\mathrm{MW}(\mathrm{t})$ unit by about $4010^{n}$ Btu at an annus! fixed charge rate of $13.9 \%$ and by $7 c^{\prime} 10^{\prime}$ Btu for a $22.2 \%$ charge rate. The corresponding values for the $1235-\mathrm{MW}(\mathrm{t}) \mathrm{CNSG}$ are $4 \mathrm{e}$ and $6 \mathrm{c} \cdot 10^{\mathrm{h}}$ Btu respecively.

\section{Openting and maince rance costs}

The annul operating and mainienance costs shown for the nuckar steam suppiy system in Tables 5.45 and 5.46 apply to both of the operating modes examined. The powerinnversion system costs apply to the case of electrical power generation only. Operating and maintenance costs were not charged to the power-conversion system for the process-steam-only option. 


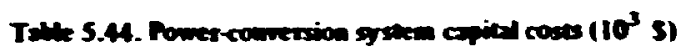

\begin{tabular}{|c|c|c|}
\hline & $313 \mathrm{MNi}(\mathrm{t})$ & $123534 W(1)$ \\
\hline 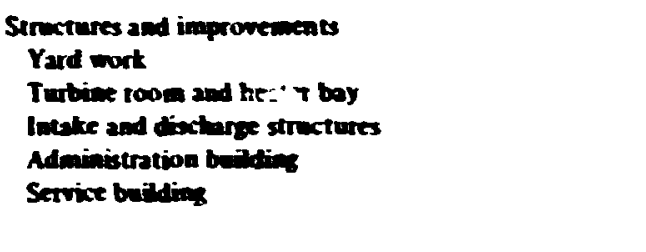 & $\begin{array}{l}400 \\
450 \\
360 \\
100 \\
100 \\
1.410\end{array}$ & $\begin{array}{r}400 \\
1.700 \\
160 \\
100 \\
100 \\
2.660\end{array}$ \\
\hline 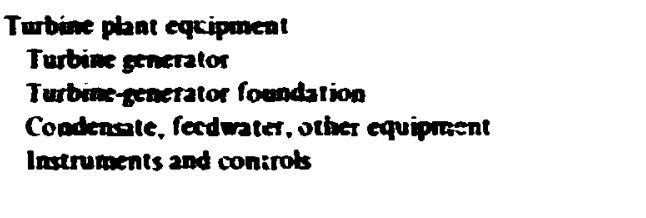 & $\begin{array}{r}6.600 \\
150 \\
+500 \\
1.100 \\
12.350\end{array}$ & $\begin{array}{r}18.000 \\
400 \\
15.000 \\
1.100 \\
34500\end{array}$ \\
\hline Electrical plant equipment & 2000 & 6.000 \\
\hline Misceflaneous power-conversion equipment & 900 & 3000 \\
\hline $\begin{array}{l}\text { Total powet conversion system direct cost } \\
\text { Contingency }(6 \%)\end{array}$ & $\begin{array}{r}16.060 \\
\frac{1.000}{17.660}\end{array}$ & $\begin{array}{r}46,160 \\
2,770 \\
48,930\end{array}$ \\
\hline $\begin{array}{l}\text { Construction facilities. equipment. services (6\%) } \\
\text { Enqineering, construction. management services (1SF) } \\
\text { Orher costs (SF) }\end{array}$ & $\begin{array}{r}1.060 \\
2.649 \\
\quad 883 \\
22.252\end{array}$ & $\begin{array}{r}2,936 \\
2,339 \\
2,446 \\
61,65 !\end{array}$ \\
\hline Interest during construction (4 years at 107 ) & 4,117 & \\
\hline Interest during construction (6 years at 1074 ) & $\overline{26,369}$ & $\frac{18.064}{79,715}$ \\
\hline
\end{tabular}

Table 5.45. Amaral operating and maincenance cnsts $\left(10^{3}\right.$ s) tor 31 3-Mw(t) plant

\begin{tabular}{|c|c|c|c|}
\hline & $\begin{array}{l}\text { Turbine- } \\
\text { generator } \\
\text { plant }\end{array}$ & $\begin{array}{l}\text { Nuclear steam } \\
\text { supply plant }\end{array}$ & Total \\
\hline Operating staff & 150 & 665 & 815 \\
\hline Fixed and variable maintenance & 132 & 437 & 569 \\
\hline Supplies and expenses & 30 & 74 & 104 \\
\hline Nuclear insurance & & 284 & 284 \\
\hline Operating fees & & 25 & 25 \\
\hline $\begin{array}{l}\text { Administration and general } \\
\text { In-service inspection }\end{array}$ & 50 & $\begin{array}{r}200 \\
36\end{array}$ & $\begin{array}{r}250 \\
36\end{array}$ \\
\hline Total & 362 & 1721 & $\overline{2083}$ \\
\hline
\end{tabular}




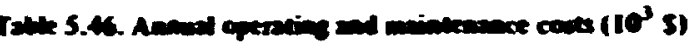

Cor $1235-\mathrm{Am}(1)$ inem

\begin{tabular}{|c|c|c|c|}
\hline & $\begin{array}{l}\text { Terbior- } \\
\text { penerator } \\
\text { phat }\end{array}$ & $\begin{array}{l}\text { Nodear stous } \\
\text { sepits phas }\end{array}$ & Total \\
\hline nexeating seaff & 160 & ess & 1035 \\
\hline Fined and :aribble mintemance & 367 & 717 & 1004 \\
\hline Suppies and expenoss & 83 & 122 & 205 \\
\hline Naxtear insurance & & 350 & 350 \\
\hline Operation faes & & $\infty$ & 8 \\
\hline Administration and grweral & 6 & 240 & 300 \\
\hline Inservice inapection & & 36 & 36 \\
\hline Total & 690 & 2900 & 3090 \\
\hline
\end{tabular}

\section{Process beat and power costs}

Encrgy cosis (in 1974 dollars) for 1981 startep of the process-steam-onty plants are summarized in Tables 5.47 and 5.41. These costs are bused on two altermative lixed charge rates. 13.9 and $22.2 r_{i}$ year, which are representative of utility and private industry financing respectively. Cosis were le elized over a 30-and 20-year plant life respectively. A plant factor of 0.8 . commonly assumed for hirge nuckear central stations. was aced for the 1235-MW(t) CNSG plant. A

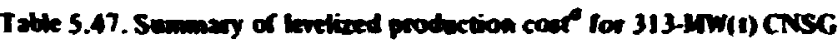

ineleor prodes stem thent

\begin{tabular}{|c|c|c|c|c|}
\hline & \multicolumn{2}{|c|}{ 13.9* Fixed chare mie } & \multicolumn{2}{|c|}{ 22.2\% Fixed charge rate } \\
\hline & $10^{6}$ s/year & $1 / 10^{\circ} \mathrm{Bru}$ & $10^{6} 5 /$ yar & $1 / 10^{6} \mathrm{Blo}$ \\
\hline Fixed charges & 8.9 & 111 & 14.1 & 178 \\
\hline Operating and maintenance costs & 1.7 & 22 & 1.7 & 22 \\
\hline Fuet costs & 3.2 & 40 & 4.0 & $\underline{50}$ \\
\hline Tolal & 13.8 & 173 & 19.8 & 250 \\
\hline
\end{tabular}

Coss in 1974 dollars: startup in 1981: 85\% ptant fas $10 x$.

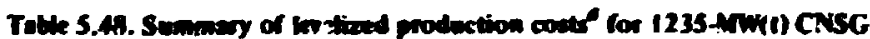

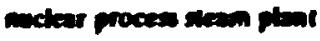

\begin{tabular}{|c|c|c|c|c|}
\hline & \multicolumn{2}{|c|}{ 13.9\% Fixed charge rate } & \multicolumn{2}{|c|}{ 22.2\% Fixed charpe rete } \\
\hline & $10^{6} \mathrm{~s} / \mathrm{rear}$ & $d / 10^{6}$ Btu & $10^{6}$ s/year & $1110^{6} \mathrm{Bru}$ \\
\hline $\begin{array}{l}\text { Fined charges } \\
\text { Operating and maintenance costs } \\
\text { Fuet costs }\end{array}$ & $\begin{array}{r}16.8 \\
2.4 \\
8.7 \\
\end{array}$ & $\begin{array}{r}57 \\
8 \\
30 \\
\end{array}$ & $\begin{array}{r}26.8 \\
2.4 \\
10.7 \\
\end{array}$ & $\begin{array}{r}91 \\
8 \\
35 \\
\end{array}$ \\
\hline Total & $\overline{27.9}$ & $\overline{95}$ & $\overline{39.9}$ & 134 \\
\hline
\end{tabular}

"Costs in 1974 allars; startup in 1981 ; 807 phas factor. 
plant factor of 0.85 was employed for the 313-MW(t) C.SSG. since the smalke plant can be refueked more quickh. The basis for the fuel cyck costs is given in Appendix A. Process heat costs ranged from $\$ 1.73$ to $52.5010^{\circ}$ Btu for the 313-MW(t) station and from 95e to $51.3410^{\circ}$ Btu for the 1235-MW(t) plant.

Tables 5.49 and 5.50 summarize the exergy costs in 1974 dolbrs for the case of electrical power generation onb. again considering fixed charge rates of 13.9 and 22.2\% from 26.0 to 38.0 mills $\mathrm{kWhr}$ for the smalker station and from 13.9 to 20.5 mills $\mathrm{kWhr}$ for the brger plant.

Figure 5.27 shows the effect of changes in uranium ore prices on process steam costs for plant startup during the time period from 1981 to 1991 . Over this 10-year span, the process energy costs for the 313-MW(t) unit increased by as much as $6^{\prime} ;$ : the corresponding increase for the $1235-\mathrm{MW}(t)$ plant is up to $9 r_{c}$. Costs are presented in 1974 dollars. and escalation is. of course. sut accounted for in these comparisons.

For the two power kevels investigated. the results show that the CNSG unit energy costs decrease considerably with increasing power kiel. Therefore. it became of interest to predict the power costs at intermediate power outputs in the range from 313 to $1235 \mathrm{MW}(1)$. These resu!ts. shown in Fig. 5.28. were obtained by assumin; that the plant capital costs could be represented by an equation of the form:

$$
\text { Capital cost }=A+(\text { thermal power output })^{n} .
$$

where $\boldsymbol{A}$ and $\boldsymbol{n}$ are constants. Experience has shown that this type of equation can express the effect of unit size on costs reasonably well. Fuel cycle costs were derived from graphical interpolation.

Talle 5.49. Semanary of kretized prodection coses" for 313-MW(t) (NSG unctear etectric ptat

\begin{tabular}{|c|c|c|c|c|}
\hline & \multicolumn{2}{|c|}{ 13.9\% Fixed charge rate } & \multicolumn{2}{|c|}{$22.2 \%$ Fixed charge rate } \\
\hline & $10^{6}$ s/year & $\overline{m i l l s / k v i n s}$ & $10^{6} \mathrm{~S} /$ yeas & $\overline{\text { mills/kWht }}$ \\
\hline Fixed charpes & 12.4 & 18.2 & 19.8 & 29.0 \\
\hline Operating and maintenunce costs & 2.1 & 3.1 & 2.1 & 3.1 \\
\hline Fuet costs & 3.2 & 4.7 & 4.0 & 5.9 \\
\hline Total & $\overline{17.7}$ & $\overline{26.0}$ & $\overline{25.9}$ & $\overline{38.0}$ \\
\hline
\end{tabular}

"Coss in 1974 dallars: startup in 1981: 85\% ptant factor.

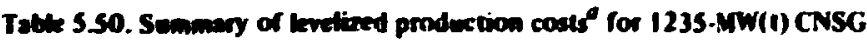
inclear electric plast

\begin{tabular}{|c|c|c|c|c|}
\hline & \multicolumn{2}{|c|}{ 13.9\% Fixed charge rate } & \multicolumn{2}{|c|}{ 22.27 Fixed charge rate } \\
\hline & $10^{6}$ s/year & $\overline{\text { mitlls/kWhr }}$ & $10^{6}$ s/year & mills/kWhr \\
\hline Fixed charges & 27.3 & 9.7 & 43.6 & 15.6 \\
\hline Operatink zat s:aintenance costs & 3.1 & 1.1 & 3.1 & 1.1 \\
\hline fuet conts & R.7 & 3.1 & 10.7 & 3.8 \\
\hline Tolal & 39.1 & $\overline{13.9}$ & 57.4 & $\overline{20.5}$ \\
\hline
\end{tabular}

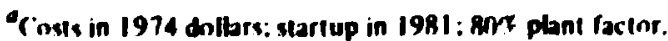




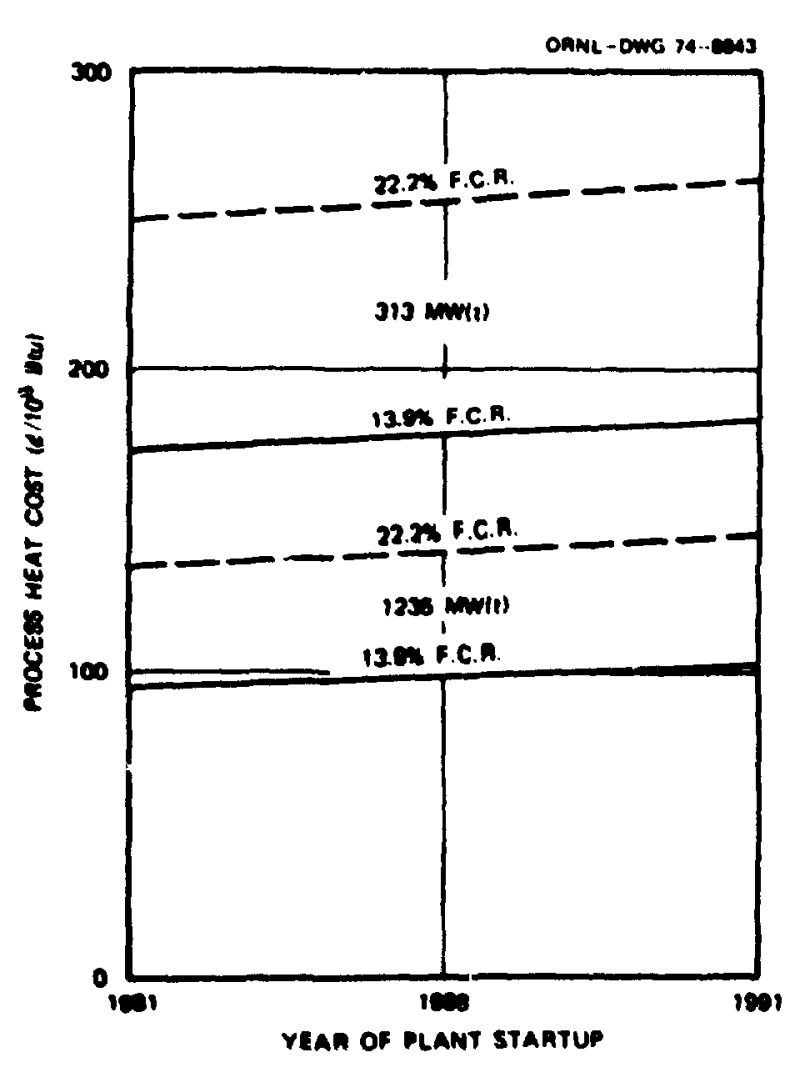

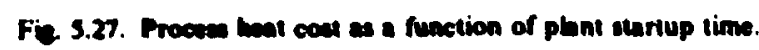

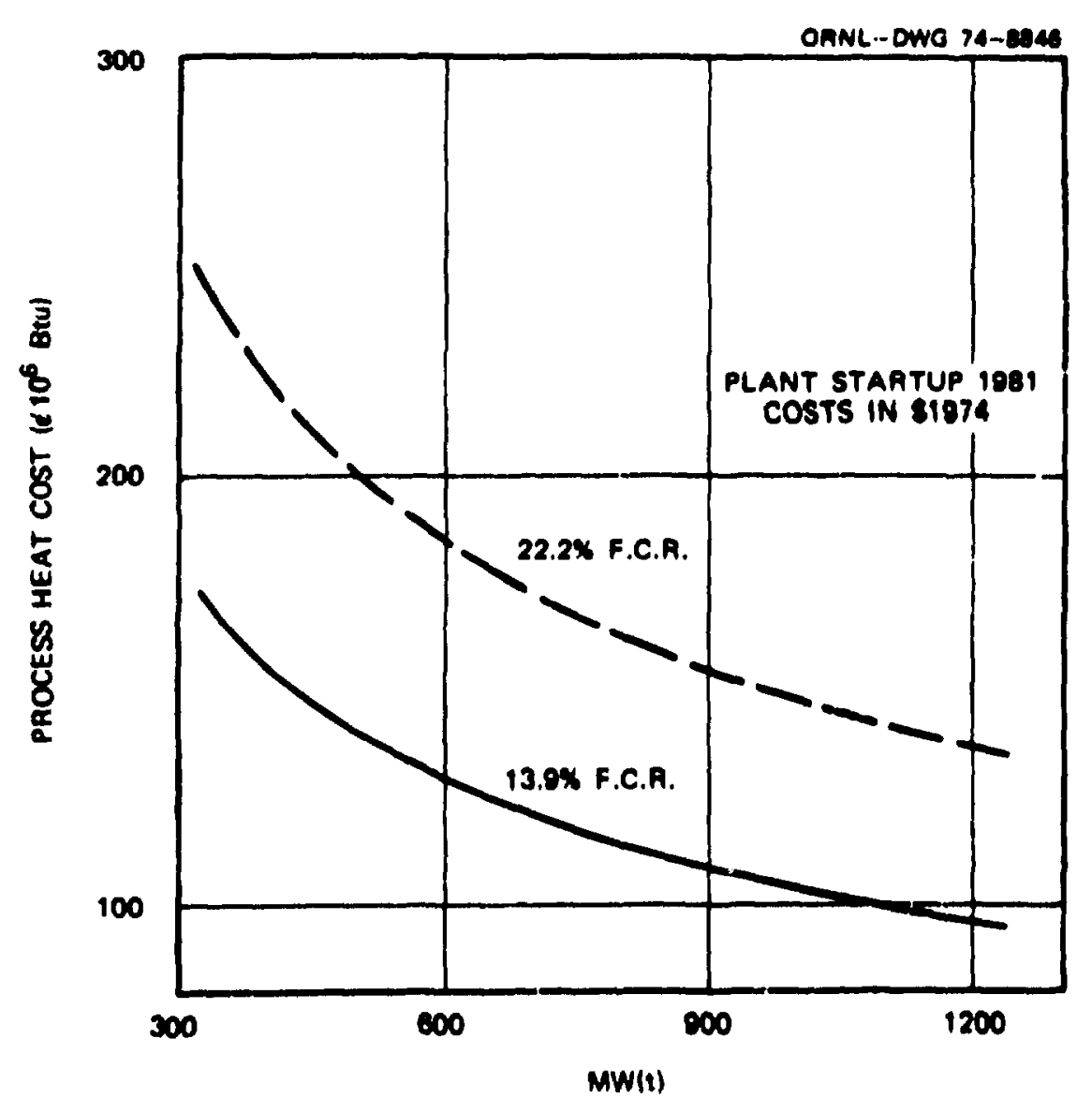

Fin. 5.28. Procesu hat cost as a function of plare capacity. 
Although the costs shown are quite tentative. they are believed to be useful in illustrating the effect of reactor size on process encry costs for small- and intermediale-size special-purpose re actors.

\section{S.3.6 Phuform-Momed CNSG Reactor}

The possibility of mounting brge power reactors on flating platforms has been siudied " " for some time, and the commercial introduction of barge-mounted oentral-station ispe PWRs has been scheduled for 1985 by Offshore Power Systems of Jacksonvilk. Fb. One of the major incentives for the development of floating nuclear power stations has been the sean:ty of suitable reactor sites near the areas of brge electrical power demand. Siting advantages probably wiil not the a major consideration in the development of phatform-mounted nuckear energy sources for industrial use: however, the advantages resulting from shipyard construction. including a short-ned construction period. accelerated licensing procedures. and more economical construction. may be inportant.

The lower plant costs projected for shipyard construction are predicated or a inarket demand sufficient 10 resule in the fabrication of a sizable number of Juplicale units at one building yard. For example. a construction rate of four 3400-MW(t) PWRs per year is anticipated on a so called "mass production" basis at the Offshore Power Systems facility being readied at Jacksonvilk. Fla. A lower production rate of perhaps one or two units per year may be economical for small industrial energy reactors because they can be constructed in existing shipyards.

The potential impact of small noating industrial energy reactors on meeting the nation's energ! requirements is limited by the extent of the geographical region accessible to that type of plant. Thus, a brief survey was made to identify some of the waterways that might allow passage to a bal ge-mounted C.NSG-type reactor plant. Figure 5.29 depicts the major inland waterways" of the central and astern linited States: this extensive network of navigable channels includes nearly 7600 miles of waterways either completed or under construction with a minimum water depth of $9 \mathrm{ff}$. During part of each year. many of these waterways are maintained at a minimu:u depth of $12 \mathrm{ft}$. allowing passage of craft with as much as II ft of draft whik allowing a I-ft ckearance beneath the hull." " Thus. a draft of up $i .1$ about 1 I ft appears acceptable for a harge-mounted industrial energy source. The beam and k'ngth oi the unit arz limited by the sire of locks that must be passed through. These dimensions are 110 by 100 fi for the locks of the more extensively used waterways. "lats. limiting the harge beam to abrut 105 ft: the hull kngth permitted by the locks is considerably in excess of the kngth .squired for a small platform-mounted reactor plant. The vertical ckarance under bridges p!eces a further restriction on the dimensions of a floating power plant. A minimum

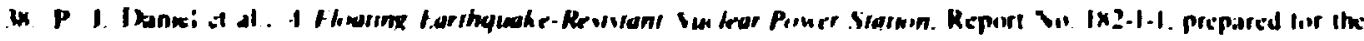

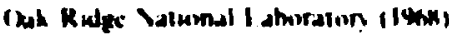

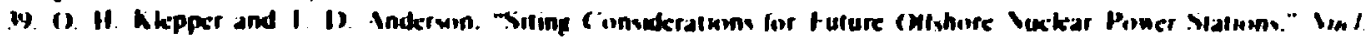

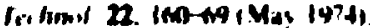

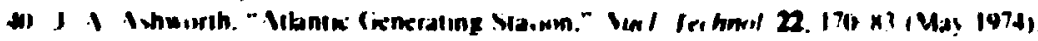

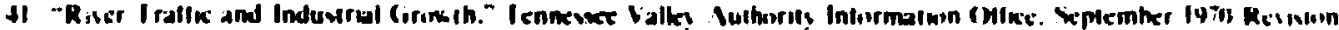

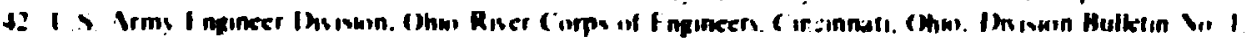

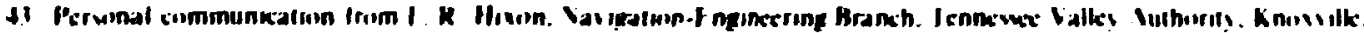
I:nn. In $\$ 4.1974$

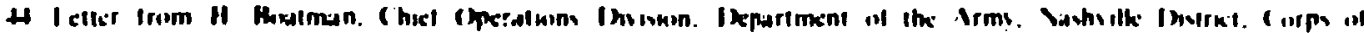
I nyinets. II (I) II Kkepper. (OR VI. Ith. 5. 1474

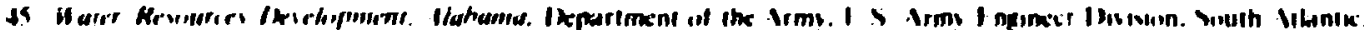
I.In I. $\left|\mathbf{Q}^{+}\right|$ 
OPNL-OWG 74-8040

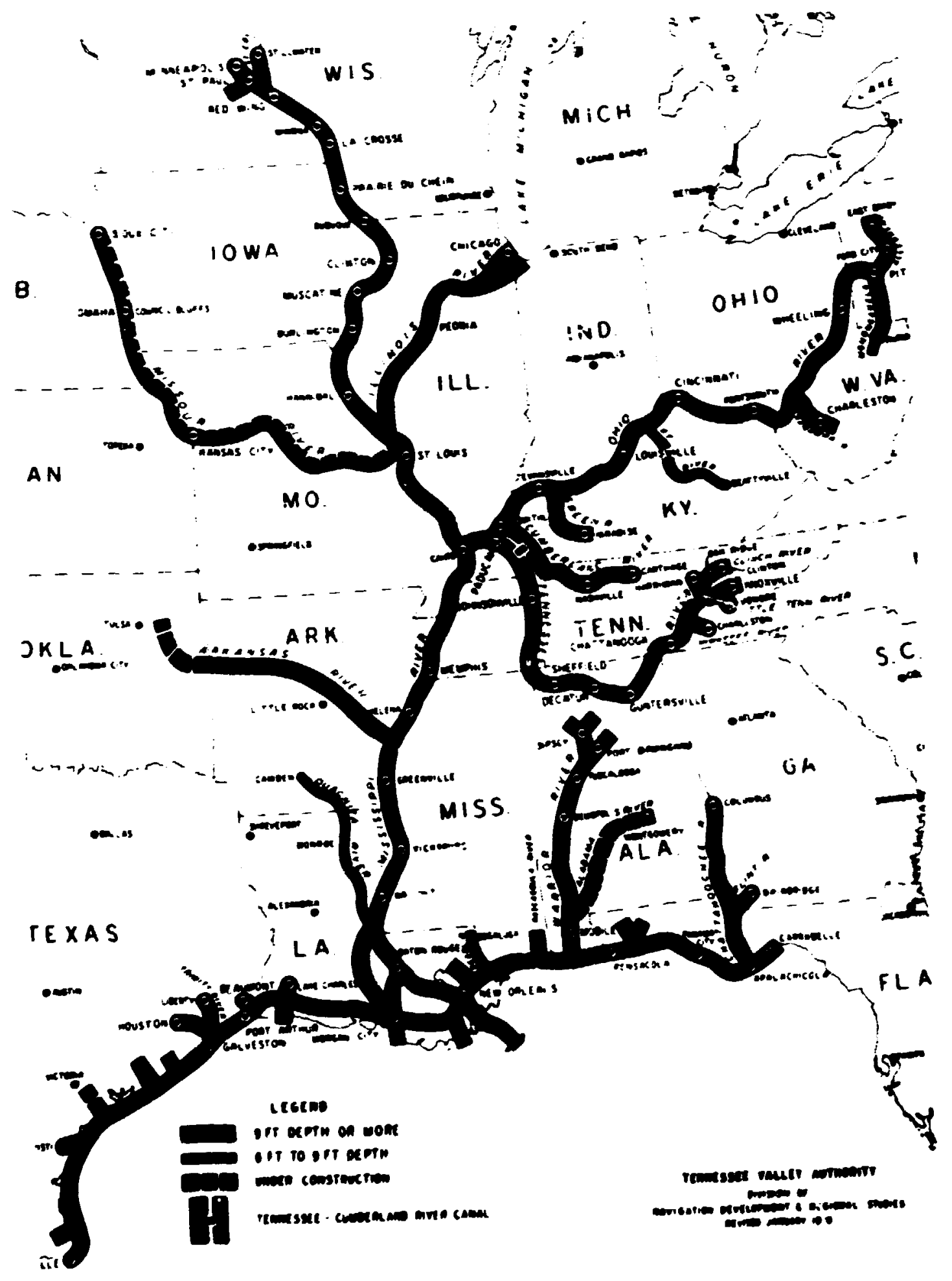

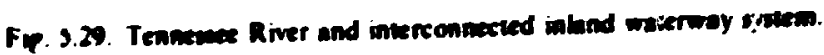


bridge height of about 57 ft is maintained over extensive regions of the waterways. "sins "allowing a tolal height of about 68 it from the underside of the barge to the top of the supersinuctures. These dimensional restrictions an be met by the phtforn-mousted CNSG reactor concept developed b: G. G. Sharp. Inc.. under contract to the Oak Ridge National Laboratory." and th: this basis it appears that miny of the waterways shown in Fig. 5.29 weuld be accessible. For example. on the Mississipoi River. passage is feasible as far north as mile $84 \%$. within 10 miles of Minneafalis. Minn. The Illinois River woald be accessible to mike $\mathbf{2 3 1}$. hithin about 70 miles of Chicago. III. The Ohio River would be passobte as far as Pittsburgh. Pa. The Cumberbnd Ris ir coubl alford passagi to the lloating urit as iar as Charkstille. Tenn.. and on the Tennessec River the barge could reaih Chatcanouga Extensive regions of the Inited Statex East and Gulf Coasis would be accessible via the Intracoastal Wateruay ${ }^{\text {th" }}$ and by soaitwise voyage. Coastal hays. canals. and estuaries accessible to oceangoing ships provide furthei access routes to the sites of possible energy-zonsuming industries.

No deviled assessment has been made of the number of poten!ial industries located near waterways or of the associated power requirements. It is helieted that a more detailed analysis would show a potential market sufficient to aborb the output of several facilities set up specifically for the series production of small platform-mounted reactors.

The appliesbility of floating nuckear industrial energy wurces will also be circumxibed by the population distribution near potential operating sites It is expected that the population separation distance requirements for a barge-mounted unit would be about the same as those for a land-baxed plant: thus the discussion ef nucker siting in bater sections alw applies to the Nloating reactur concept.

\section{Platform description}

The general arrangement of a platform-mounted 313-MWit) [91-MV(c)] C NS(i reactor plant is depicted in Fig. 5.30. This configuration. designed for plant operation in a lloating condition. fornis the base case for the plant arrangement and cost studies. However. design modifications lor placing the platform on a permanent dny foundation. as well as plants designed for the proviction of process steam oniy. were also studied."

Ihe major components of the nuckear steam supply system are identikal to those of the land-hased concept described previously. The turbogenerator was also assumed to be the wime as for the land-based plant: however, the secondary plant auxiliaries (such as the condenser. circulating pumps. diexel generaiors. electrical gear, and fluid-handling systems) satisfy shiphoard reyuirements.

The heavy reactor installation is located near the center of the barge. with the spent-luel pit and the lurbogenerator at opposite ends. thus tending to balance out the individual cffect on hull irin, tsec Fig. 5.31). Similar to the arrangement of the land-based concept. a reactor building provides

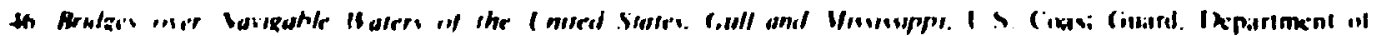

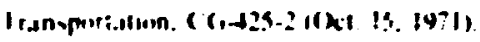

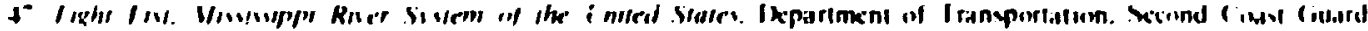

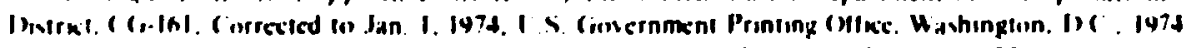

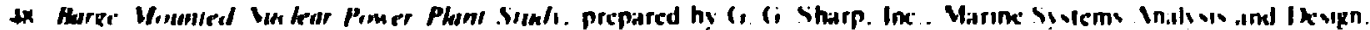

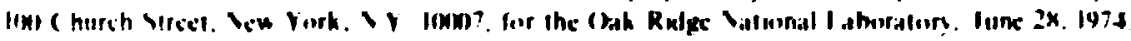

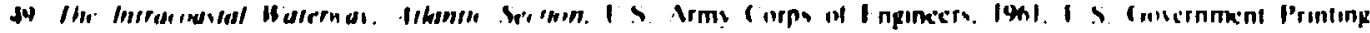
(Mike. K.othington. Is

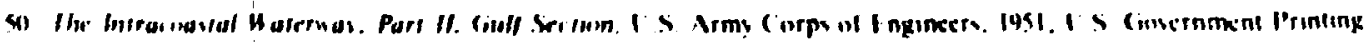
(MIkc. Henhinglin. I) 


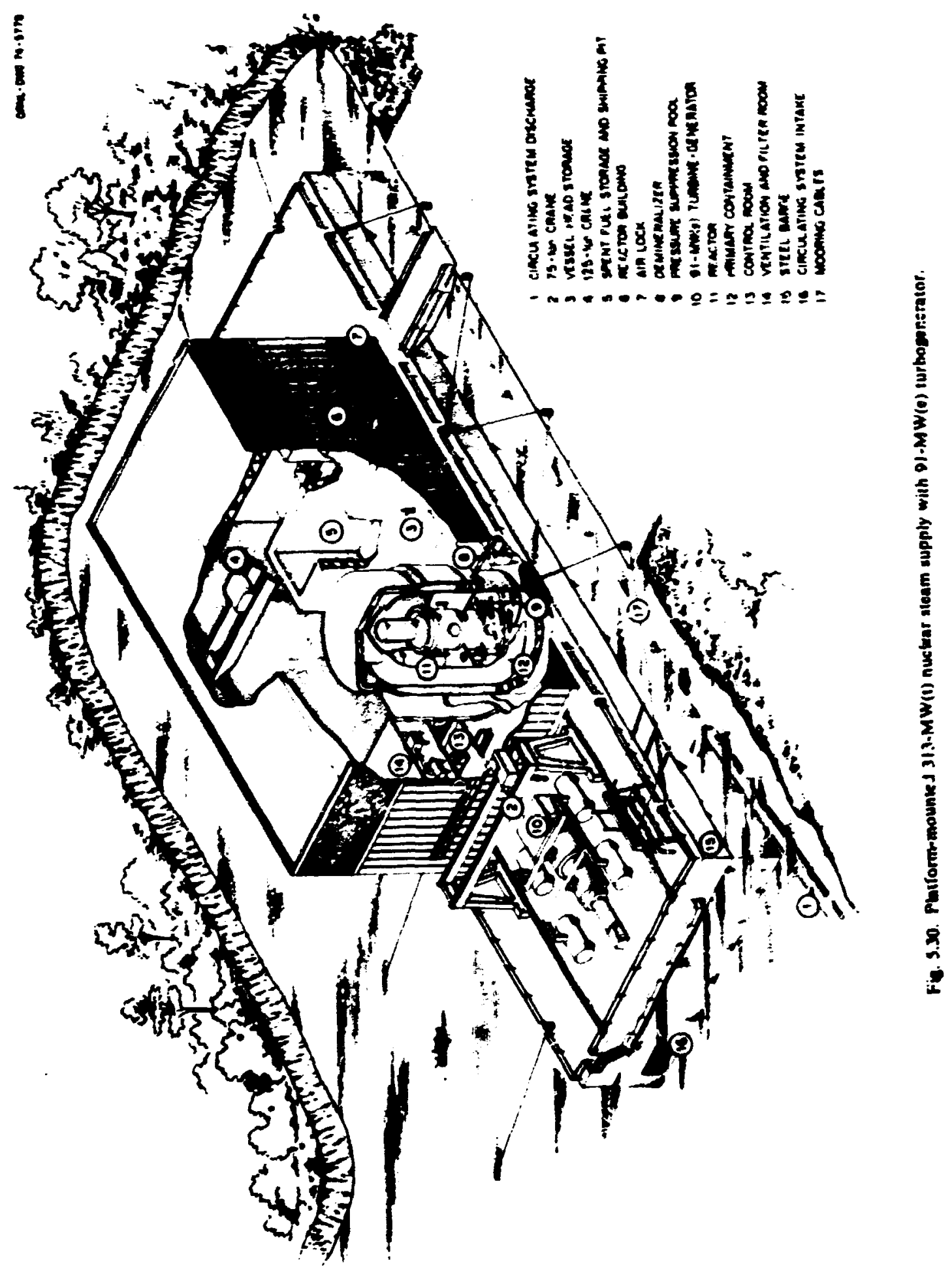




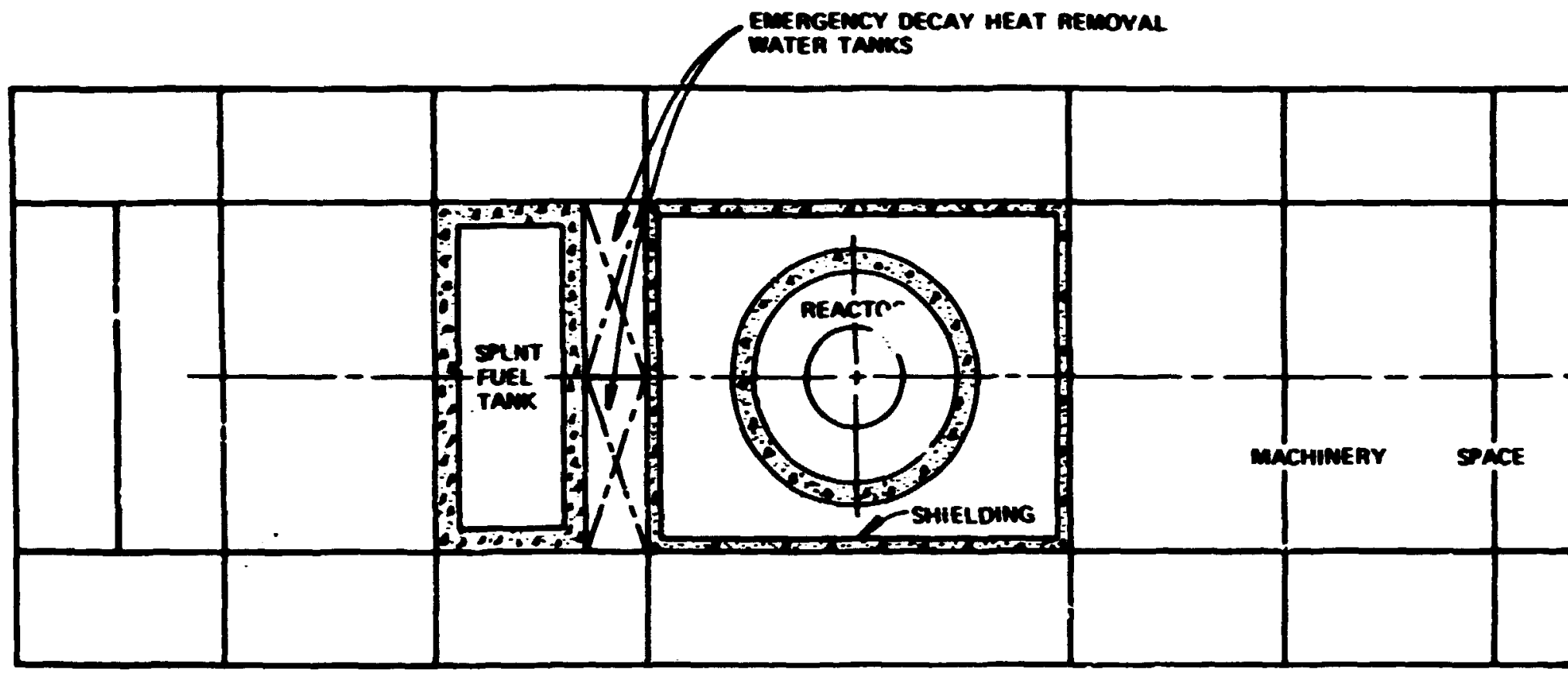

PLAN AT $7 n-6$ m. LEVEL

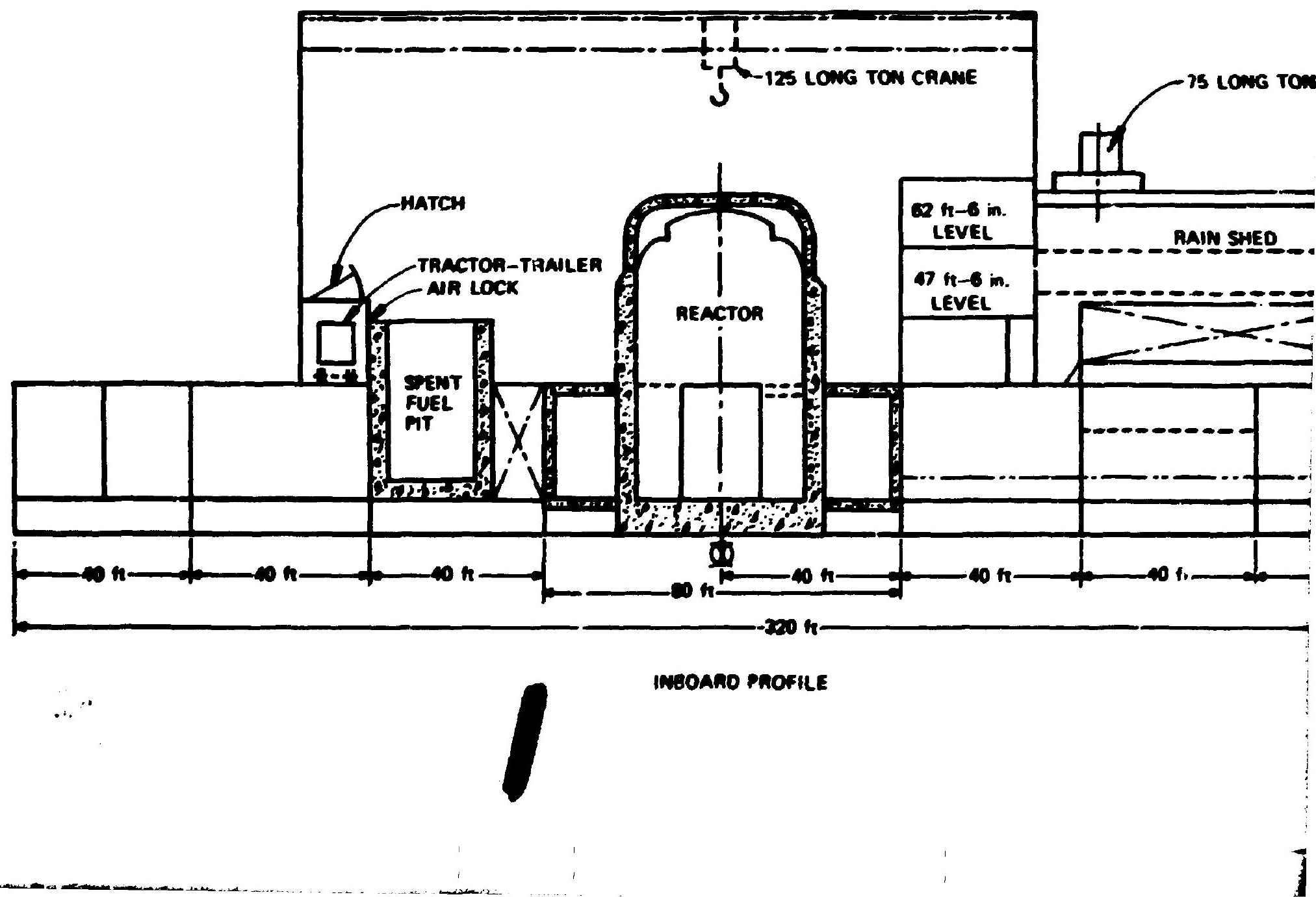


secondary containment around the CNSG pressure-suppression primary containment. The building also houses the reactor auxiliary systems. bborator: spaces. the reactor control room. the radioactive waste systems. and the spent-fuel handline systen.

The turbogenerator is mounted outdoms on: ite main deck, an arrangement suitable for a warm climate. The exnerator is protected by electrical swikchgear mounted on the berge: however. the switchyard was assumed to be located on shore. The main condenser is arranged in the hull immediately below the turbine. Circulating water enters the hull through a submerged sea chest in the barge end: the circulating system discharge pipe passes through the barge side to remove the condenser waste heat. The bulk of the power-conversion system auxiliaries are beated in the hull compartments under the turbogenerator. A bilze-and-balbst system is required for maintaining hull trien.

Hull beam was limited to 105 it in order to allow passage tinrough the 110-fi-wide hocks commonly used on inland waterways. A, bage length of 320 ft was required in order to minimize fore and aft trim under operating constations.

The draft during the tow to the operating site can b- limited to kss than $\mathrm{Il}$ ft by deferring the installation of the concrete for the reactor shield and sperat-fuel pit until after the barge is emplaced. The total weight of the complete unit is about 20.03.$)$ tons. corresponding to a draft of $20 \mathrm{ft}$. Preliminar; stability calculations showed that winc hids produce quite moderate angles of hull indication: the angle of heel for a 180 -mph wind would be about $4^{\circ}$. The corresponding value for a 300-r.ph wind is $11^{\circ}$.

For operation afloat the barge may have to meet the U.S. Coast Guard requirements" for nuckear ships. Thus the hull is designed to withstand the flooding of any two compartments without sinking. Experience with the U.S. Maritime Administration byup flet in fresh and brackish water has shown that hull corrosion can be controlled with cathodic protection systems, and the use of such a system will obviate the need for periodic drydocking to carry out hull maintenance. A hull constructed of consrete would have superior corrosion resistance; however. the hull weight could increase by as much as 3000 to $\mathbf{4 0 0 0}$ tons. Because of the limitations on draft and beam. the heavier concrete harge would have to be considerably longer than a steel hull, resulting in higher capital costs.

A platform-mounted unit for the production of prosess tieat unly could be shortened to $260 \mathrm{ft}$. a reduction of $\mathbf{6 0} \mathrm{ft}$. because of the absence of the turbogenerator and its auxiliaries.

A barge hull dexigned for emplacement on a dry for ndation will be less costly than one to be sited afloat. In the former instance. the unit will not be required to meet Coast Guard requirements for nuclear vessels. and therefore the double bottom and some of the water-tight bulkheads will not be neecied. The overall length of a platform unit for the production of $91 \mathrm{MW}$ of electrical power can ine reduced to about $260 \mathrm{ft}$. since there will be no rey'lirement for minimizing hull trim during plant operation. A hull length of about $230 \mathrm{ft}$ will sutixce for a dry emplaced unit designed for the production of process stcam only.

\section{Platorm-mounted reactor plant capital costs}

The capital costs for the various platform configurations are hased on data developed in Ref. 48. moditied to place them on a consistent hasis with the costs of land-bosed CNSG plants given in a

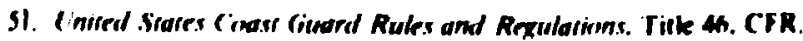


previous section. The expenditures for the support bacilities needed at the sile of the industrial energy wer were not estimated at this time, since detaiked site requirements have of been determined. The extent of facilities already existing at the industrial site (such as elect: . steam. and process fluid distritution systems) will inflience the cost of siting a platform-mounted reactor ptant. The local terrain. soil conditions. the type of barge empbeement (afloat or dry). and the number of reactor units will also affect the site capital expenditures by several millions of dolbars. Because of these uncerainties. the present eximales are limited to predicting the capital cost for only the items that comprise a phatfonu usia.

A representative platform building schedule was developed (assuming shipyard construction under a manufacturing license) in order to estimale the incerest chargeabte during the construction of a 313-MW(t) phatform-mounted plant (Fi. 5.32). For comparison purposes. a project schedule for a 313-MW(t) bnd-based CNSG phant is abo shown in the figure. indicating that actual phant construction spans a period of 43 months compared with only 19 months for the barge-mounted plant. The procurement of lony-kad-rime components consumes nearly two-thirds of the 55 months

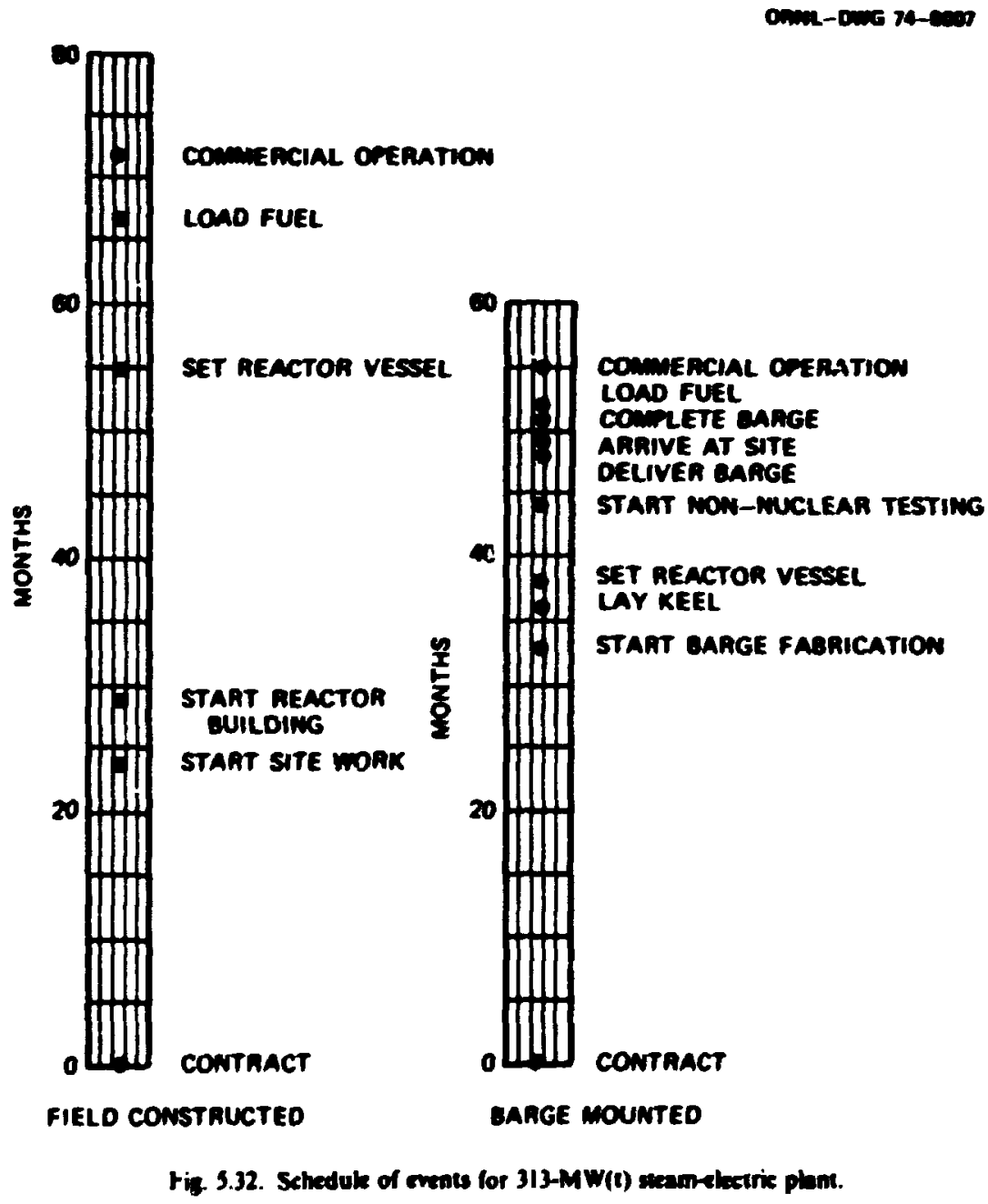


required to bring the barge unit on-line. Shortened procurement periods ear!ld reduce the overall plant construction schedule by a signitiont fraction.

Iabte 5.51 summarizes the capital costs for a 313-MW(t) phiform-mounted reactor ptant designed to furnish $91 \mathrm{MW}(\mathrm{c})$. Costs are given in 1974 dolbrs without escalation for stantup beyond 1974. A shipyard profit rate of $S_{i}$. believed to be representative of averzge economic conditions. was assumed. In estimating the bbor costs. credit was zken for the economies resulting from ite repetitive production of a standard design. Towing charges are for a distance of 1400 miles at a speed of 6 knots. The cost catgory "secondary plant" also includes the cost of sysuems not directly assaxiated with the turbogenerator: thus this cost ategory annot be directly compared with the power-conversion system costs given in Tabte 5.44 . The total cost of 568 million for a floeting ptant represents the base case for the configuntion shown in Fig. 5.30. Capital costs for a phatform de: igned for operation on a dry foundation will be about 51 million less.

The capital costs for a $313-\mathrm{MW}(t)$ barge-mounted reactor for the production of process heat only (1.24 million b hr of 566 psia saturated steam generated in a seboiler) are listed in Table 5.52

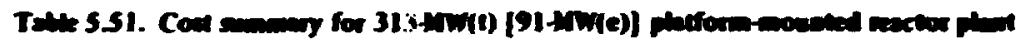

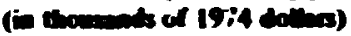

\begin{tabular}{|c|c|c|}
\hline & Floeting phat & 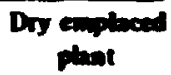 \\
\hline 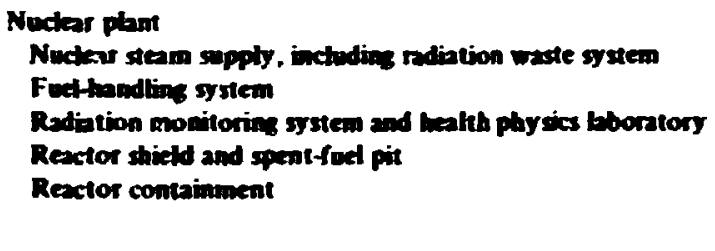 & $\begin{array}{r}30,267 \\
650 \\
274 \\
1,189 \\
881 \\
33,761\end{array}$ & $\begin{array}{r}30.76 ? \\
630 \\
274 \\
1,169 \\
891 \\
33,761\end{array}$ \\
\hline $\begin{array}{l}\text { Secondary plapt } \\
\text { Turbogyenerator } \\
\text { Auriliny systems }\end{array}$ & $\begin{array}{r}6,018 \\
5,997 \\
12,015\end{array}$ & $\begin{array}{r}6,018 \\
5,991 \\
12,015\end{array}$ \\
\hline Electrical phant & 2,168 & 2,168 \\
\hline $\begin{array}{l}\text { Baje and equipmeut } \\
\text { Hull and structures } \\
\text { Ovifit. inalation, and joiner wort } \\
\text { Coasings and cathodic protection } \\
\text { Cranc for turbogenerator }\end{array}$ & $\begin{array}{r}2.474 \\
520 \\
157 \\
350 \\
3,501\end{array}$ & $\begin{array}{r}2606 \\
\frac{350}{2}\end{array}$ \\
\hline Total direct cost & 51.445 & so,900 \\
\hline $\begin{array}{l}\text { Shipyand overtead (115\% of direct bbot) } \\
\text { Shipyand profit (5\%) } \\
\text { Engineering and drafting (distributed ovet five units) } \\
\text { Ingurance }\end{array}$ & $\begin{array}{r}4.049 \\
2,775 \\
337 \\
350 \\
58.956\end{array}$ & $\begin{array}{r}3,756 \\
2,545 \\
337 \\
350 \\
57,808\end{array}$ \\
\hline Interest durine conssruction (J0\%/yeu) & $\frac{9.138}{68.094}$ & $\frac{8,973}{66.861}$ \\
\hline $\begin{array}{l}\text { Towins } \\
\text { Tow insurence }\end{array}$ & $\begin{array}{r}60 \\
200\end{array}$ & $\begin{array}{r}60 \\
200\end{array}$ \\
\hline Total cose exclusive of sile improvements & 68,354 & 67.121 \\
\hline
\end{tabular}




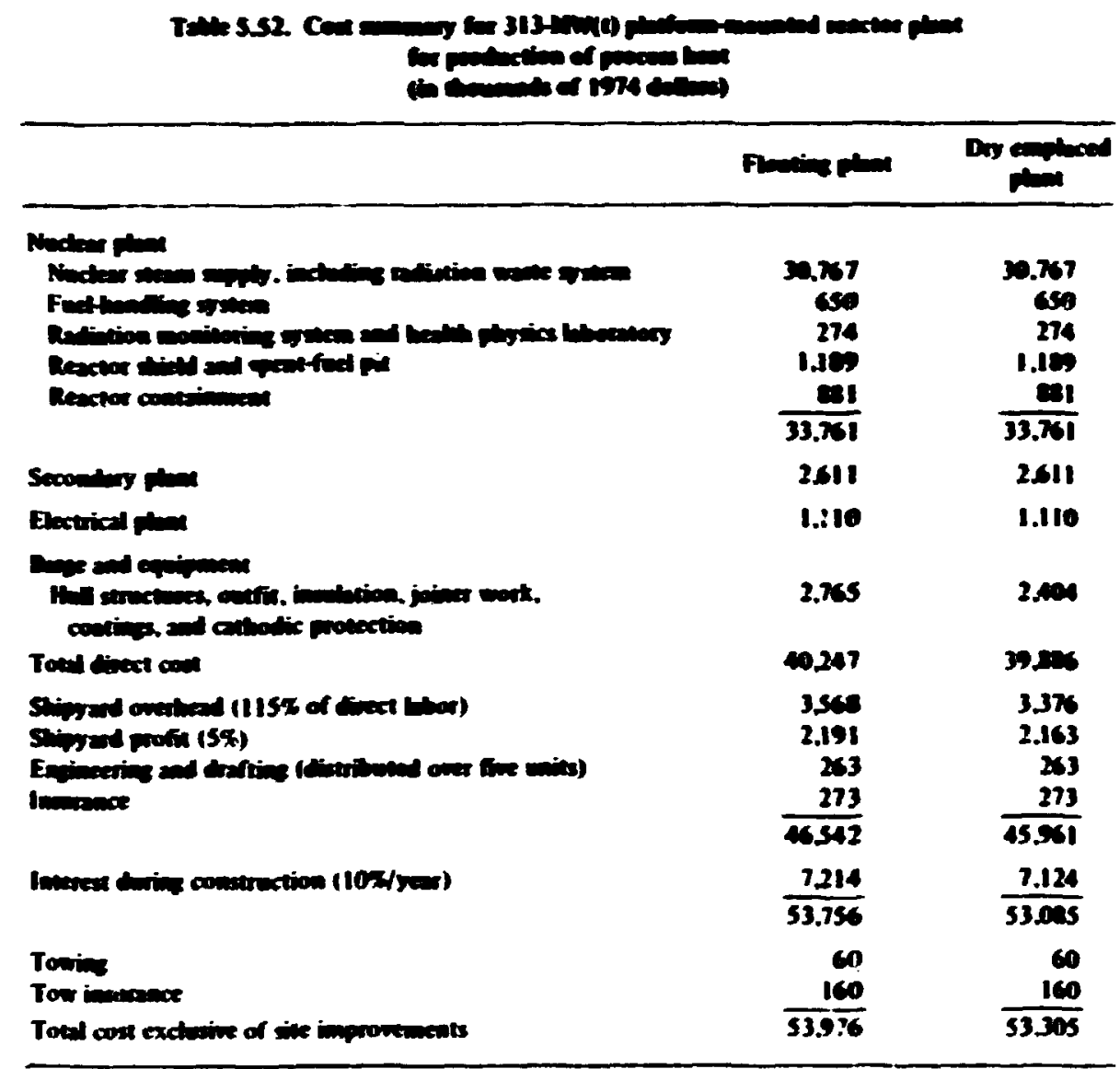

for \& floating and for a dry emplax t unin Deketion of the turbogenerator allows shortening the hull In. about 60 ft: the resulting cost reduction is about $\$ 400.000$. The cost of a reboike and other components that might be required to utilize the process steam and to retum the process water to the nuclear steam supply system have not been included in the total cost. The total amount for a plant operating alloat is ahout SS4 million: dry emplacement reduces the platform cost by about $\$ 700.000$.

The capital costs for the varioss phatform configurations are given in Tabk 5.53 along with cost: for the correspondine land-based rXSC reactor concepts. A fair comparison between land-based and pbatform-mounted concepts requires that site improvement costs be added to the costs tabulated for the biter concepts. Therefore the intal capital cost for the bnd-based platform units may increase hy up to several million dolbrs: however. it appears that substantial savings (on the o-der of 20 ii) will still be achievable rebtive to field-constructed ptants. An overall comparison het veen tikese two approaches must await a more detaled definition of the site facilities reyuired for platform-mounted reactor plants. so that the capital costs as well as station maintenance and operating costs can be assessed. 


\begin{tabular}{|c|c|c|c|}
\hline & \multicolumn{2}{|c|}{ 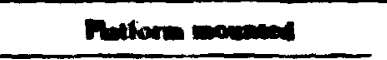 } & \multirow[b]{2}{*}{ Lat } \\
\hline & Plowings & Din & \\
\hline 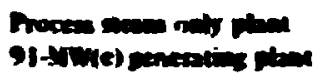 & sa & $\begin{array}{l}53 \\
67\end{array}$ & $\rightarrow$ \\
\hline
\end{tabular}

Sim tration

The support facilities needed tor operating a phtform-nowaned reactor phant will depend on the characteristics of the sive and of the indusung that uses the eneres produced by the reactor plant. A detailed determination of ithexe requirements for representative applizativas is beyond the scope of the present study. and this is merely a broad ountine of the major requiremeats that must be wet by the site facilities.

Basic to the phant concept is the idea that the reactor will be starned up and operated at one sile only and that no provision be mate for moving the uait subsequeath for operation etsenthere. This approach simplifies the plant design and avoids the difficuhies associnted with the movernent of a radicactive thor" reactor plant. A case by case determination probably is required to determine if towing the ptant away for decommission will be advantageows. A cemal tacility for decommissioniag Roating offshore nuclear power plants has been sugessted previously:" ithat facility: might also be suitable for final disposal of platform-mounted reactor plants of the type studied here.

For sites accesuble onh by fairty shall is mavigation channels. construction equipenem must be avaibate to complete the installation of the concrete for the reactor shield and the spent-fuel pir. The top of the reactor building will have to be erected at the site if bridges or power lines encuuntered enroute to the site do not allow passape of the complete structure. Other site construction work will include emplecement of the barge (either afloat or on a foundition) and the installation of electrical. process. and other systems needed to connect the energy source is the industrial phant anc to the local electrical grid.

The facilities for mooring a foating power phat must be capabie of withstanding wind and wave forces imposed on the barge: changes in water elevation must abo be accommodated. The plant must also be protected against ship collision and consequent fire or explosion if the sive is exposed to these hazards. Plant sinkine in shallow water can be accommodated by enclosing equipment escential to reactor safety in water-tight compartments."

Emplacing the platform on a dry foundation is one alkernative to mooring the barze. This could be accomplished by dredging out a basin alongaide a waterway with water admitted after a concrete foundation has been constructed below the waterway level. The barge could then be foated over the foundation and the water pumped out from the basin after the latter has been sealed off. The advantages of dry emplacement inchude absence of hull motion, avoidance of ship collision possibility. and hull accessibility for inspection and repairs. An effective connection is escential

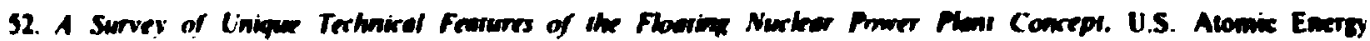
(ommisaion, Directorate of I.icensine (Mareh 19/4). 
between the bull and the foundation to resise seismic forces and wo prevent bull movement should the

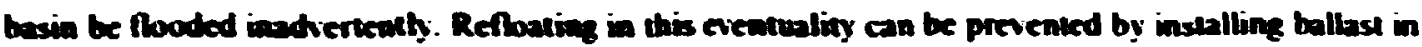
the barge and th providing toodiag openings in some bull compartments.

\section{S.4 THERMAL ENERGY TRANSTORT FROM NUCLEAR PLANTS}

The transmission of energe in the form of high-ymality steam was evaluated in conjunction with the nuctear comocpls, since nuxtear reactors appear to be the most hitely source of energy for tarex blocks of thermal emengy tramsmission. It is assumed that process steam is avaibble at 850 psia and S3: $F$ from an LWR and at 650 psin and 750 F from an HTGR. Producing process stean reyuires the use of a retoiler for the I.WR and more imajor system modifications for the HTGR. These factors are discussed in Section S.2.

The HIUn priase stem was originally considered for Iranspon. but the extremsty high pressure-temperature comdition appears to be imaprectical for long-distance transportation.

Transportation coses. summarinad in Tabte 5.54. are craholed on a per mike basis and should be valid over the ":- to lo-mik range of incerest.

Loss of heat is estimated to be 0.3 to 0.4r; mik. Pressure drop is treated parametricalty. with 12 pai pressure drop per mike being selected for an economic evaluation. Figure 5.33 shows pressure drop as a function of steam rate.

The steam line cost estimale includes a condensate return line. The estimate is beliked to the consernative. It is substantialty higher (by about a factor of 2) than other recent exsimates of similar steam lines: howerer. sufficient information for a detaikd comparison is non avaibble.

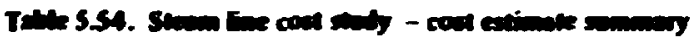

\begin{tabular}{|c|c|c|c|c|}
\hline & Materiel & Labor & $\begin{array}{l}\text { Indiect rows } \\
25 \%\end{array}$ & Total \\
\hline 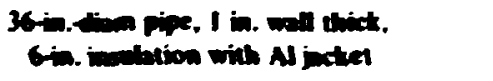 & 31.760 .000 & $\$ 1.190 .000$ & $5738 \Omega 10$ & $\$ 3.900 .000$ \\
\hline \multirow{2}{*}{ 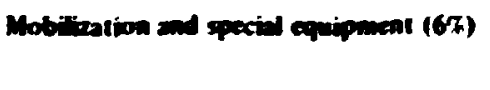 } & & & & 212.000 \\
\hline & & & & $\$ 3,900.000$ \\
\hline Condensole return bine ( - 1S\%) & & & & 600.000 \\
\hline Comingerwey $(\sim 10 x)$ & & & & 400.000 \\
\hline Total cost per mile & & & & $\overline{34,900.0000}$ \\
\hline 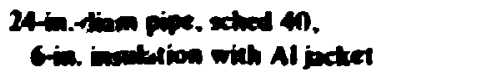 & $\operatorname{se3} 3.000$ & s5960ro & 5357.000 & 51.716 .000 \\
\hline \multirow[t]{2}{*}{ Mobilization and speciel eqpipment (67) } & & & & 114,000 \\
\hline & & & & $\$ 1.900 .930$ \\
\hline Conadewore retern biace $(\sim 15 x)$ & & & & 300.000 \\
\hline Contingency $(\sim 1 . x)$ & & & & 200000 \\
\hline Totel cose per mile & & & & $32,400,0 \mathrm{Mn}$ \\
\hline 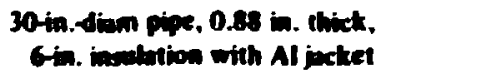 & \multirow{2}{*}{\multicolumn{3}{|c|}{ (Fxtrapolation of 24 and 36-in- pipe extimates) }} & \\
\hline Totel cost per mile & & & & $\$ 3,600.0 \mathrm{mo}$ \\
\hline
\end{tabular}




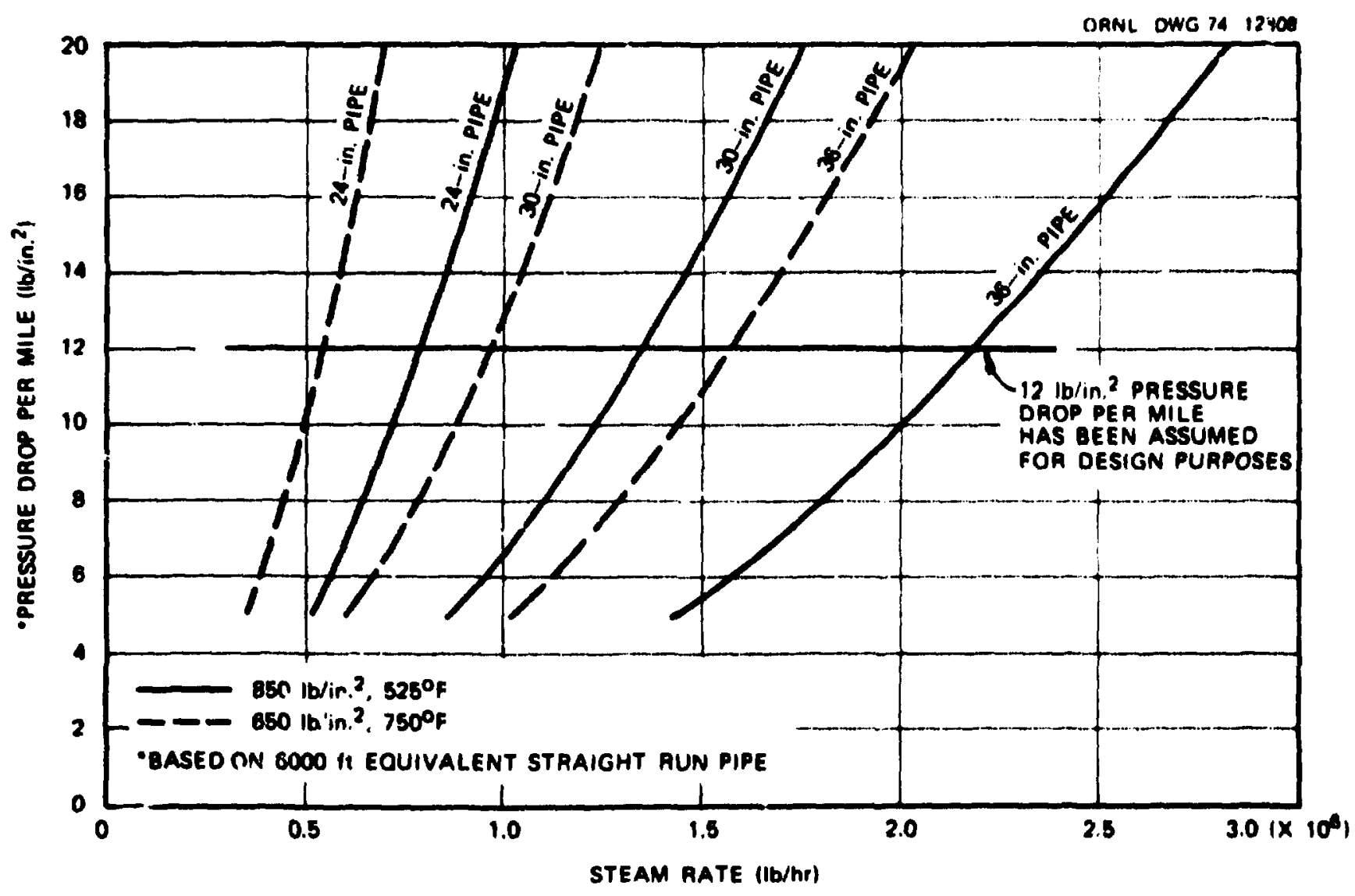

Fic. 9.33. Preceure drop as a fusction of evam ma. 
The estianales are based on steam trasportation viz a singte pipeline oner the sire range shom n.

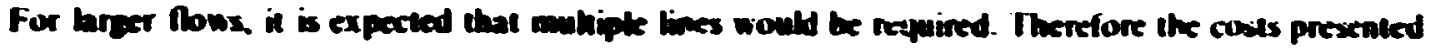
- Fiz. 5.34 camol be directh extrapolated wo breer flows.

Ensed on the estimale. the unin tramportation cosd per mik saries liren the $10^{\circ}$ the at $2 \times 10^{\circ}$

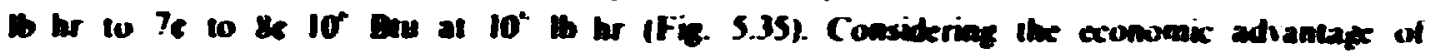

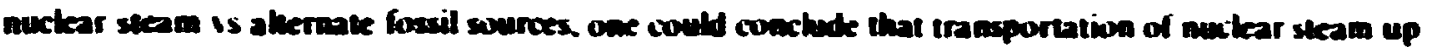
to about 10 miks is pro tical and ecomomically attrective in comnarison to alternake fossil wources that were considered. (Details of the stean bie cosi estimate are einen in Appendix B.)

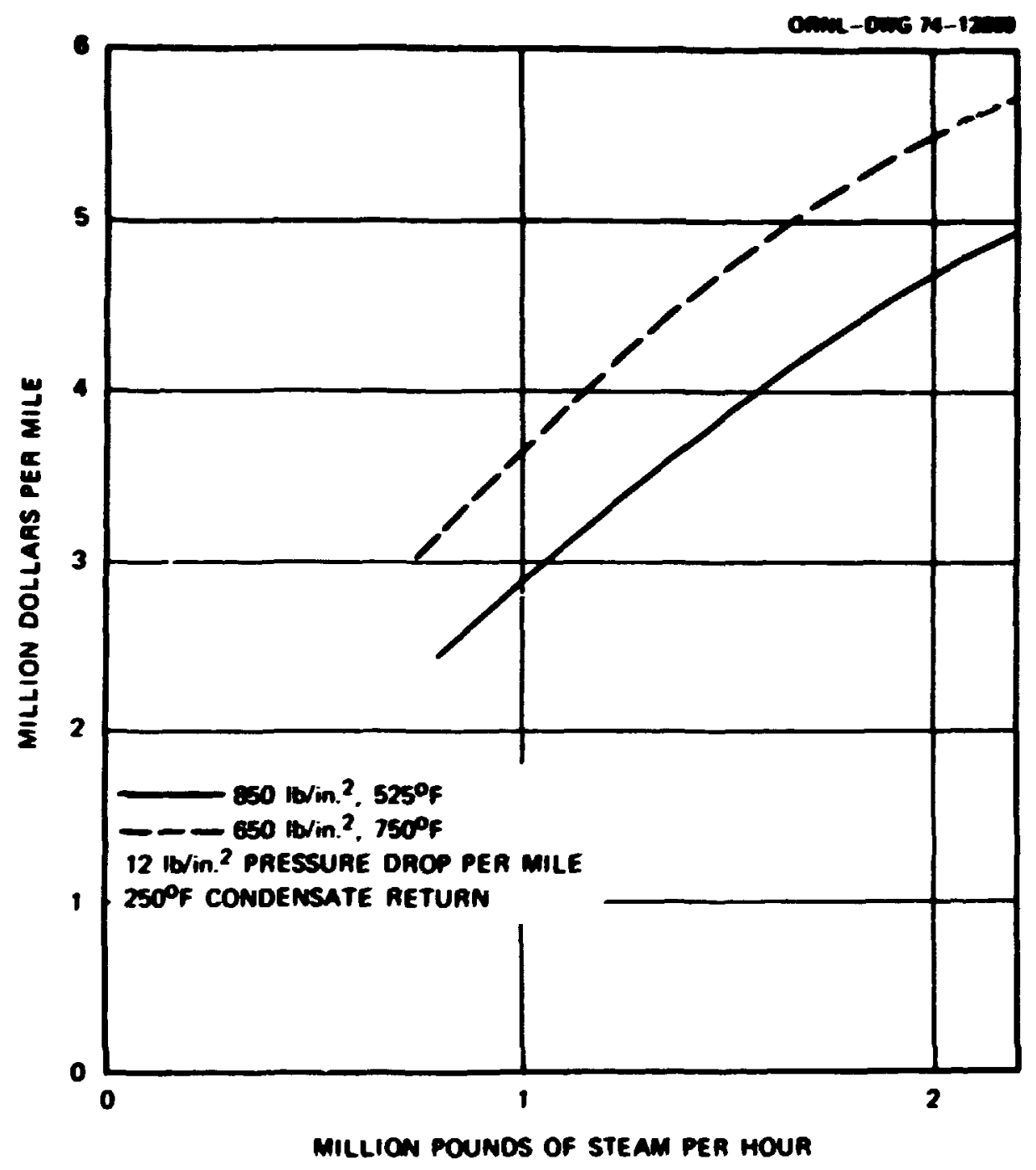

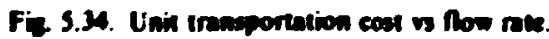




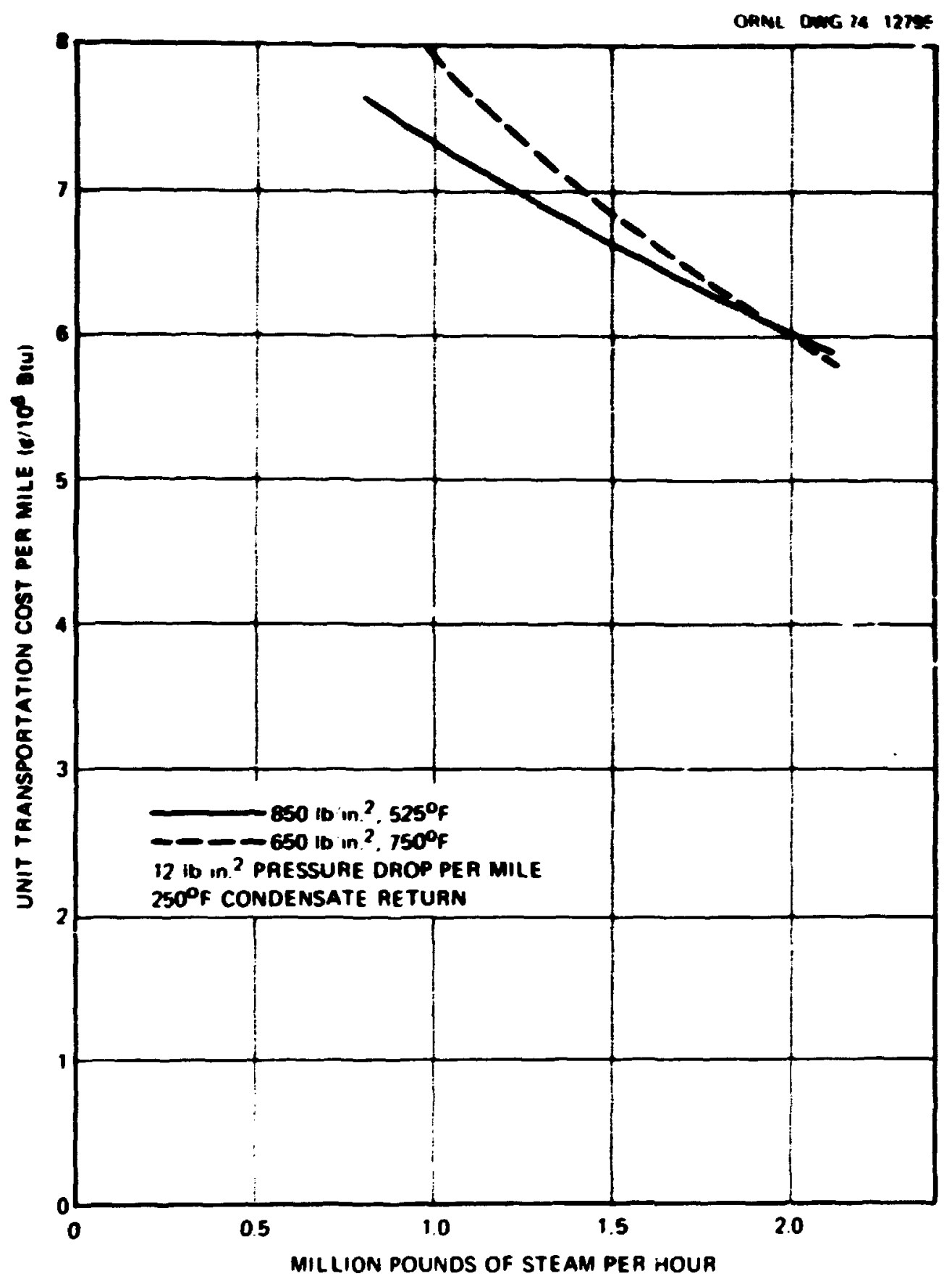

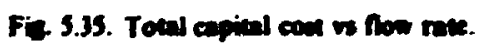




\section{S.S NUCLEAR FLANT STIMG, LCENSING, AND REGULATION}

\section{SS.1 Livening and Reguntion}

Inavedmetion

The acyuisition and use of a nuctear power phat are subject to the restrictions of the Alomic Energy Act of 1954 (AE.A), as amended. Cenerally. the AEA prohibits, except under AfC license. the transfer or receipt in intersate commerce. manufacture. production. Iransfer. acyuisition. poscession. use. import. or export of nuckear reactors and the materiats used in or produced in nuctear reactors." The AEA authorives the AEC to formubte rules and regutations and to issue zeneral and specific licenses for these activities. The AEA prescribes conditions for various types of licenses and sets out the judicial reniev and administratix n procedures to be applied to regubtory actions of the AEC. Cenerally. the provisions of the Administratlie Procedure Act" are involed. AEC regulaton actions are also subject to the requirements of the National Environmental Policy Act (.NEPA) of 1969."

A firm intending to use a nuclear power plant may the reyuired by law to obtain one or more of the following types of licenses. depending upon the rebtionship of the form to the necessary facilitics and activities: special nuckear material. source material. byproduct material. utilivation facility. Injividuals operating a nuckear reactor are licensed by the AEC also.

\section{Specinlized terms uned in AEC licencing}

Byproduct material. The term "byproduct material" means any radioactive materiai (except special nuckear material) yielded in or made radioactive by exposure to the radiation incident to the process of producing or utiliving special nuckear material."

Financial protection. The term -financial protection" means the ability to respond in damages for public liability and to meet the costs of investigating and defending chaims and settling suits for such damages."

Nuclear reactor. "Nuckear reactor" means an apparatus. other than an atomic weapon. designed or used to sustain nuckear fission in a self-supporting chain reaction."

Operator. The term "operator" means any individual who manipulates the controks of a utilization or production facility."

Person. The term "person" means (I) any individual. corporation, partnership. firm. association. trust. estage. public or private institution. group. Government agency other than the Commission. any State or any political subdivision of, or any political entity within a State, any forcign government or nation or any politicil suhdivision of any such government or nation. or other entity: and (?) any kgal successor. repreventative. agent. of agency of the foregoing."

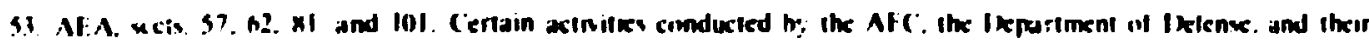
cuniraclours are cepected.

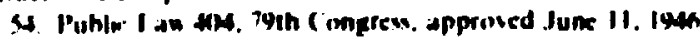

5. Pr:inik I an $91-190$

4. IkIminum quasied from Af:A

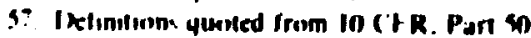


Production facity. -Production facility" means: (1) Any nuckear reactor designed or used primiarily tor the formituon of phutontium of uranium 213; or (2) Any facility desiened or used for the exparstion of the imstopes of uranium of the isotopes of plutonium. except bboratory scak lecilities desened or used for experimental or anabitical purposes only: or (3) Any tacility designed or used low the processing of irradiated makeriats containing special nuctear makerials. excepe (i) tuburatury sake becilitive dexigned or used for experimental or amabical purposes. (ii) facilities in which the onh pecial nuctear materials contained in the irradiated material to be processed are uranium enricted in the isotope 1-235 and plutonius produced by the irradiation. if the mulerial procesived contains not more than $10^{\circ}$ grams of plutonium per gram of $1-235$ and has lission product activity $\mathrm{me}$ in excess of 0.25 millicuris of fission products per gram of U-235. and (iii) lacilitics in which processing is conducted pursuant to a license issued under Parts $\mathbf{3 0}$ and 70 of this chapter. or cyuivaknt regubtivas of an Agneement Siate. for the receipr. possession. use. and transter of irradiated special nuckear maternal. which authorises the processing of the irradiated material on a batch basis for the separation of selected fission products and limits the process batch to mot more than 15 grams of special nuckar material."

Source maberial. The kerm "source material" means (l) uranium. therium. or any ot:er material which is determined the Commission pursuant to the provisions of section 61 to be source material: or (2) ores containing one or more of the foregoing materials, in such cancentration as the Commission may by regulation determine from time to time.

Special muclear anterial. The term "special nuclear material" means (1) plutonium. uranium enriched in the isctope 233 or in the isolope 235. and any other material which the Commission. pursuant to the provisions of section 51. determines to be special nuckear material. but does not include source material: or (2) any material artificially enriched by any of the foregoing. but does nut include source material."

Utiliation facility. -Utilization facility" means any nuckear reactor other than one designed or used primarily for the formation of plutonium or U-233."

\section{AEC rules and requlations}

The AEC rules and regulations are modified in Titk 10. Cock of Feckeral Regularions. Chapter I. The parts of this chapter of interest to prospective nuckar reactor licensees are as follows:

1. statement of organization and general information:

2. ruks of practice:

8. interpretations:

9. public records:

20. standards for protection against radiation:

30. rules of general appliability to licensing of byproduct material:

31. general licenses for byproduct material:

32. specific licenses to manufacture. distribute. or import exempted and generally licensed items containing byproduct material:

33. specific licenses of broad scope for byproduct material: 
34. licenses for radiography and rediation safety reyuirements for radiugraphic operations:

35. human uses of byproduct material:

4. lioensing of source moterial:

50. Ticensing of production and utilization facilitic:

55. operators licensex:

70. special auctear material:

71. pactaging of radio-active material for transport and iransportation of radio-2stive material under cerrain conditions:

73. physical protection of special nuclear material:

100. reactor site criteria:

140. Financial protection requirements and indemnity dgreements:

170. fees for facilities and materials licenses under the Atomic Energy Ac: of 1954. as amended

Nuclear power plant licensing is dominated by the processes of AEC safety and environmental evaluation of the nuckear reactor (the "utilization facility-) itself. The necessany materials licenses. subject to the appropriate parts of the regutations. are considered by the AEC as pan of the utilization facility licensing process.

The ruks and regulations. which are issued under statutory authority, are enforcibte thy the AEC through administrative action of the Commission itself and through judicial axtion in appropriate federal courts.

Other official requbtory guides.

The AEC has published aumerous guides of interest to prospective reactor licensees. A consolidated series of Regulalory Guides was instituted in 1972. The distinction of guides from regulations is stated by the AEC as follows:"

"The primary purposes of Reg(itatory Guides are (I) to describe and make available to the public methods acceptable to the AEC Regulatory staff of the umplementing specific parts of the Commission's regulations and in some cases to delineate techniques used by the staff in evaluating specific problems or postulated accidents and (2) to provide guidance to applicants concerning certain of the information reeded by the Regulatory staff in its review of applications for permits and licenses. Regulatory Guides are not intended as substitutex for regulations. and therefore compliance with these guides is not reyuired."

The mijor divisions of the Regulatory Guides are as follows:

I. power reactor guides.

2. research and test reactor guides. 1972

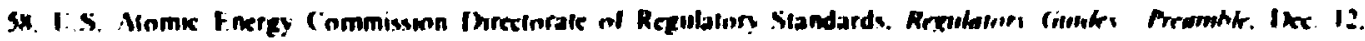


3. fucls and malerials facilities guides.

4. ens ironmental and situng guides.

5. materials and ptam protection guides.

6. product guides.

7. Iransportation guidex.

x. occupational health guides.

9. antitrust resiew guides.

10. exicral guides.

The guides are predominanth tecthnical in conkent, and those dealing wich sabety of power reactors (division I) would uswall be of preater iaterest to the designer than to tixe person onining and

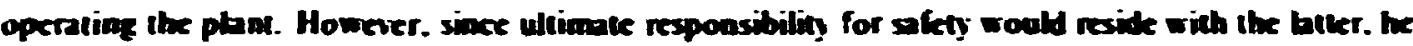
should be familiar with the guides.

\section{The licencien process}

The formal licensing process" starts with the filing of an application for licewse for construction permit) with the AEC and eads (if the license is issund with the uermination of the license through AEC-approved transter of dismanaling of the faxility. The description of the process is presented in en rally nontechnical terms to introduce the subject to persons not familar with AEC lieenring. Many detaits will he passed over casually: nothing more nor kess that the AEC rules and requations inemselves would describe the licensing process proxisety.

Several formalty distinct groups of people set for the AEC in licensing actions. These groups are identified in fig. 5.36 and described helow.

Comavision. Ithe fre-member Commission exercises the fral authority with the apency with respect to determination of major or novel questions of policy. bw. or procedure." licensinge decisions or actions of an Alomic Salety and Lieensing Appal Board (ASL.AB) may be reviewed by the Commission on its own motion in some circumstances.

Acomic Safety and Licending Apped Boad. A three-member tribumal reviews initial decisions arising from public harings of an Alomic Salety and I.ecensing Brand (ASL.B) and consulers any exceptions in such decisions as may be fined thy a party to the proceeding. The Commission has authorized the ASI.AB to exercive the authority of the Commission with expect to such appeals and will not entertain a request for review of an ASI.AB decision or action.

Alowie Salety and livencing Doand. This boand conducts hearings and iscues decisions in proceedings in grant, suspend. revoke. or amend licenses.

Requbeory sanf. The Direetor of Regubtion of the AEC and the offrcints under his authority perform the adminisirative review of an application for a license. They dischange other licensing func::uols, except where a final decision resus with an Asl.B. The regubtony stafl reters applications for power reactor licensex to the Advisony Commintee on Reactor Sarieguands (ACRS) and to the

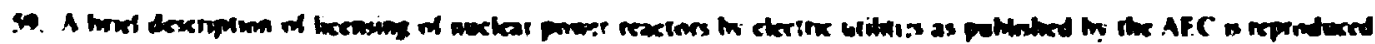
as Aprendix C.

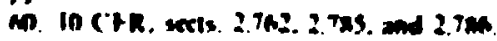




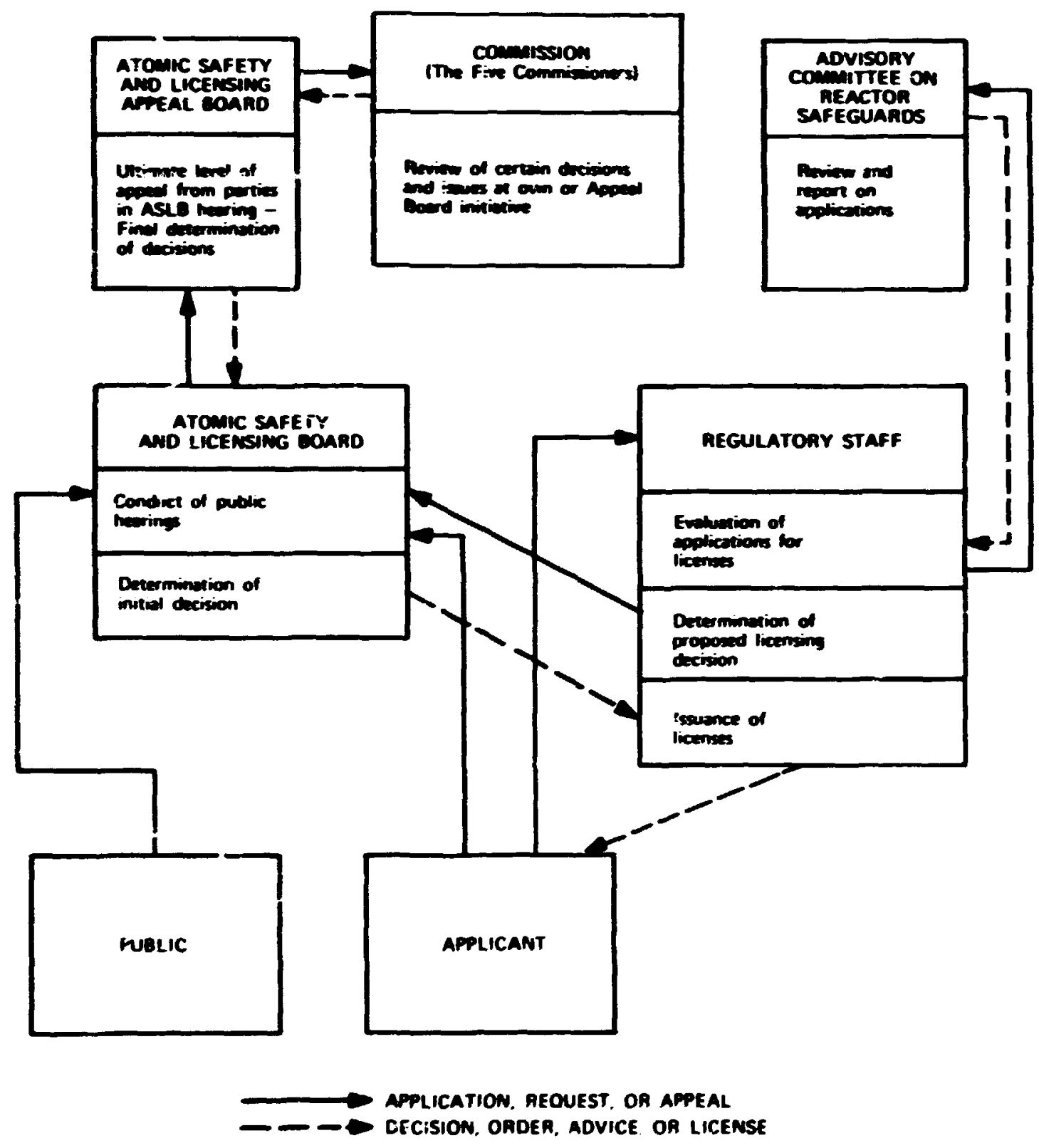

Fic 5.36. AEC beencine functions and retationdips. 
Attorney (iencral (for review of antitust matters). The regubtory saff is a perty to the pubtic hearing before an ASI.B. The regubtory staff issues liuenses and amendments to licenses. including those ordered by a board or the Commission.

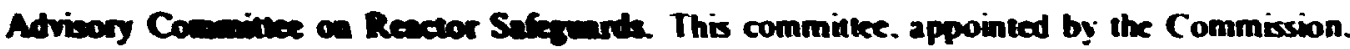
is reuvined by bav to review and repont to the AEC on each application for a power reactor license.

The phases of the licensine process are listed in Tabk 5.55 . licensing may proceed with great variation in detail: thenefore. only the general features of the process are described. The times indicated are also nomianal representative values.

Before AEC licenses are applied for, tixe anticipated construction and operation would be phaned and defuned in sufficient detail to comply with the AEC guides for preparation of Environmental Reports (ERs; and Sakty Analysis Reports (SARs). Durine the first step. the supplier of the nostear steam supph system and the arehitect-engineer would be selected. Usually these furms prepare the purtions of the SARs pertaining to their respective parts of the job. The SAR is the besis for the AECs safety decision. Information needed for the AEC's consideration of environmental yuality would ato be developed for the ER. usualty with the assistance of consultants in specialized fields. like aquatic ecolosy. if the applican belks experise.

The scope and depth of these requisite documents are indicaled by the tables of contents of the AFC guides shown in Appeadices $D$ and $E$.

The AEA requires a two-step licensing process: a consanction permit and an operating license. This statutory constraint plus practiol licensing problems have led to two-siep appliations. The

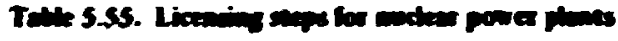

\begin{tabular}{|c|c|c|}
\hline Siep & $\begin{array}{l}\text { In in irom stan } \\
\text { of construction } \\
\text { (years) }\end{array}$ & Description \\
\hline $\mathbf{I}$ & $-310-11 / 2$ & Preparation of applicatura for bicrase finctading a consaruction permill \\
\hline 2 & $-1 \%$ & Appliation for tixense \\
\hline 3 & $-1 / 210-1 / 2$ & Repatatory stafl seview, inctaling review by the ACRS and the Atworacy General \\
\hline 4 & $-1 / 3+1 \%$ & ASLB public hearias (monde isty) \\
\hline $\mathbf{s}$ & $\begin{array}{l}\mathbf{0} \\
\mathbf{0}\end{array}$ & 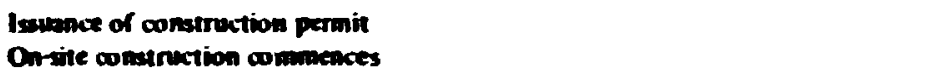 \\
\hline 6 & 0 to 5 & Regulatory staff inspection of conar."ition \\
\hline 7 & 3h in $4 \%$ & 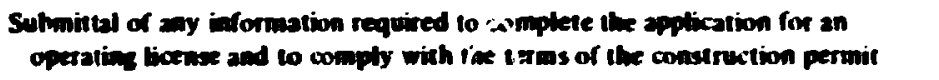 \\
\hline 8 & $34104 \%$ & Requbtory staff review of the amended application for license \\
\hline 9 & & ASLB poblic bearing (if required by circumataces) \\
\hline 10 & $\mathbf{s}$ & 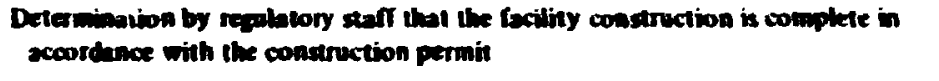 \\
\hline 11 & s & 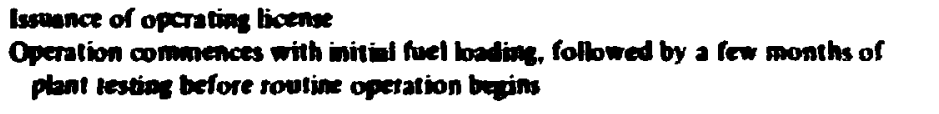 \\
\hline 12 & 51045 & $\begin{array}{l}\text { Operation: repelotory actions include inspection, operating report evpluation. } \\
\text { and authoriation of chanows in ticense conditions }\end{array}$ \\
\hline 13 & 40 & Tesmination of license \\
\hline
\end{tabular}


application for a construction permit includes a pretiminary SAR (PSAR). an ER. and other information concerning matiers of fmancial qualifications. anterust. and national security. It is abo permissible to present at this time all the technical information requisite for an operatine license. Whik this has not been a useful option to dale for applicants proposing 'o construct poner reactors. the development of highty sandardized designs could change this sievarum.

In step 2 the application is submined to the Director of Rezubtion, who heads the AEC's regubtory staff. After a quict pretiminang review (about 30 days), the regubtory senff determines whether the application is reasonably complete. If so. the staff review and other formal licensing processes commence. An application fee. prescribed by 10 CFR. Pan 170, is required. as stown in Tabk 5.56. Applications for multiple-reactor instalbtious may be combined. but separale licenses will be issued.

Tane sist solvente of foes

\begin{tabular}{|c|c|c|c|c|}
\hline Facitisy & $\begin{array}{l}\text { Antication foe } \\
\text { for construction } \\
\text { nituin }\end{array}$ & Consunction & Omaring & 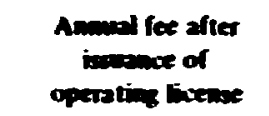 \\
\hline Power reactore & 570.000 & $560,000+550 / 4 w(1)$ & $5125.000+555 / 2 W(t)$ & 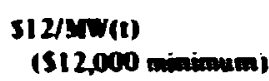 \\
\hline
\end{tabular}

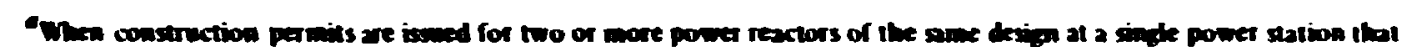

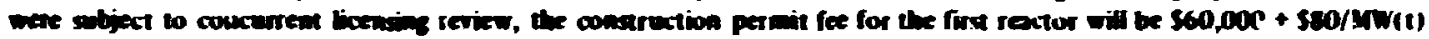

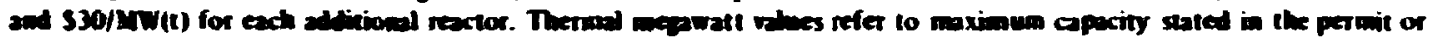
beres.

When operation betwes are isoned for two or more power reactors of the same dexiga at a sinde power station that

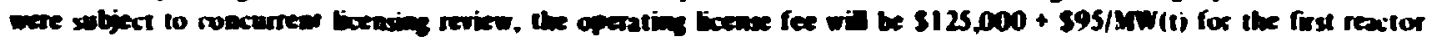
and $595,000+560 y 3 W(t)$ for each allitional reactor.

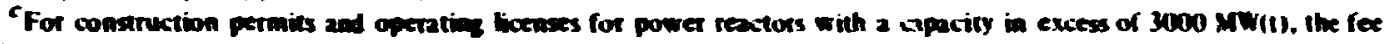
will be compoted on a maximum power level of $3000 \mathrm{MWW}(\mathrm{ll}$.

The regubtory staff review, step 3. is the fundamental process in which all of the requirements of bw and policy are a pplied to the case. The more visible parts of the staff evaluation deal with technical safety and environmental issues. but the stoff also determines if the questions of financial qualification. mational security. and antitrust are properly settled. Ancillary licenses for licensabke materials are considered in due course to permit the receipt, inspection. and storage of fuel materiais on site at the proper time.

Without exception. the safety and environmental issues require preparation of supplementary information by the applicant. During the period of staff evaluation, the ACRS also considers the case. Numerous meetings of applicant. staff. and ACRS are usually held to exchange iechnical information. but the formal evaluation must rest upon the data formally submitted to the AfC.

In step 4. the formal issues defined by bw and regulation are considered in a puhlic hearing conducted by an A.SI.B. Thr applicant and the regulatory staff are always parties in this hearing. and other interested persons may intervene either pro or con. 1 he formal issues are summarived below:

1. healih and safety of the public.

2. technical and financial qualifications. 
3. cronmon ciefense and security.

4. mational ens irunmental poliey.

5. consistency with antitust bus (gencralty considered in a separate puitlic hearing).

6. conflicting applications for limited opportunity.

7. consistency with the AEA.

8. compliance with AEC regubtions.

9. useful purpose.

The applicant bears the burden of proof in Gior of issuing a consinuction permit. The regulatory staff may favor or oppose this proposal. but as a practical matter, it is unlitely that an applicant would pursuc his case to this point in the face of staff opposition. The ASLB issues an initial decision hased upon the evidence presented. The decision may be appealed to the ASLAB by any part to the proceeding. The ASLAB may refer the case to the Commission for certain determinations or the Commission itself may initiate a review in certain instances. A decision to issue a construction permit is made by the Director of Regulation.

The construction phase. st:p 6. must be conducted in conformance with the terms of the permit. Rezulatory staff inspectors check on-site and shop activities during this time.

This phase is also exerally the time when final designs and final safety evaluations are developed by the applicant and his contractors. In the course of their construction permit review. the regulatory staff identifies subject areas in which additional or more definite information must be presented in the FSAR. The SAR guide also indicates areas. such as plant staffing. in which litte specific information is needed until operation is imminent. The time for presenting this information to the regulatory staff. in step 7. can be chosen by the applicant: in any case. it should precede the expected date for loading nuckear fuel by at least 12 months.

The operating license consideration by the regulatory staff. step 8 , is similar to their earlier review in that the basic issues are the same and the ACRS is consulted. The construction permit is not a guarantec that an operating license will be issued. and new safety issues may be raised. However. the normal continual contact between applicant and regulatcry staff during construction has always provided adeyuate notification of any likely complication or modification of safety standards. Therefore. this step is generally concemed with resolving particular questions that may have been raised in the construction permit review and other issues which were deferred by the applicant.

A second public hearing. step 9. is not mandatory and generally would be held only if the applicant or an intervenor requested it. If the second meeting were held. the formal issues would be limited to contested questions appropriate to the operating license stage. The Director of Regubtion publishes a formal notive of intent to issue an operating license. which he would proceed to do unless a hearing is requested. The license can be issued. unless the hearing decision should be adverse. as soon as the regulatory staff determines by inspection that the facility has bex s completed in accordance with the construction permit and the reactor is ready to be loaded with nuclear fuel (steps 10 and 11 ).

The operating license consists of the license to operate a "utilizatiun facility" under 10 CFR. Pan SO. and all the ancillary AEC materials licenses needed. The licensex must, pr or to licensing. 
provide the fimancial protection and execuke the indemainy agreenents reyuired by 10 CFR. Pan 140. to ensure that the boensece will have the ability to respond in damages for public liability.

The period of licensed operation. step 12. involves adverence to specific operating conditions. mainkenance and surveithnoce requirensents, and staffing requirements set oul in Technical specifications" incorporaked in the license. These are concerned with maintaining the validity of the safety and eavircanental evaluations upon which the license was premised.

The licensee mass have a competeme nuclear plant staff. inchudiag operators and supervisors licensed as individuals nader 10 CFR. Pant 55. Operating lisenses require the submission of reports to the regulatory staff periodically and on the occasion of probtems arising which may have safety implications. Inspections of licensed fecilities are made rezuarty. Modifications in the facility desizn and operating program are restricted by the lechnical specifications with the intent that the licenser can generally make aherations without prior approval of the AEC if they would not involve unreviewed alety questions. Ohter modifications are generally considered on a case-by-case basis by the regulatory staff. and approprinte approvals are granted. frequently in the form of changes to the technialal specifications.

Termination of an operating license. step 13. can take many forms. Generally. the AEC regulations anticipate that a licensee would have proved his qualifications to maintain his status as a licensce in good order until the licensed facility and nuckear makerials are disposed of so as to terminate his responsibility. A license for a utilization facility may be issued for a term not exceeding 40 years. but the AEC is authorized to extend a license at any time to that limit. A licensec must obrain the consent of the AEC in order to transfer. assign. or in any marner dispose of a license or any right thereundet.

\section{5 .2 Siting}

\section{General comaideretions}

Nuclear power ptant licensing is contingent upon sat sfying the AEC with respect to the issues listed in the previous section. the most difficult of which is the question of health and safety of the public. This issue is a complex one in itself but basicalty involves protection of people against any harmful exposure to ionizing radiation. The necessities of nuclear safety have heen the object of extensive research for more than 30 years. and experience with evaluation of the safety of individual nuclear power plants covers the hast 20 years.

Without exception. nuclear power plants have beet judged by the AEC on a case-by-case basis: no two plants are exactly alike. To the extent shat ptants are alike. the AEC takes into account the way common safety probtems have been resolved in the past. Thus water-conled reactors of the BWR and PWR types and gas-cooled reactors of the HTGR type used for generating electricity are well developed in terms of safety and licensability. The use of PWRs commercialty for production of processs steam has precedence in the Midland. Michigan. case. in which a power plant operated by the Consumers Power Company will supply process steam to a Dow Chemical Company plant.

The case-by-case evaluation of nuclear power plant safety is prompted by several factors that distinguish one phont from another. (1) changing technokgy. including differences in design detaiks: (2) safety perspectives that change with time: (3) different operating organizations: and (4) different plant sites. Tone of these factors will be :-elected in an AEC licensing review of new applicalions for nuckear process heat plants. but site acceptability is a qualification of special importance.

I here are two kinds of safety questions concerning siting of nuclear power plants. Firs. what are the se: ionnmental characteristics that could adversely affect the plant's salety performance? 
Second. how do envirunmental charecteristics affect the potential rediological consequences of axcidents:

The plant environment provides the commonly accepted elements required by an industrial facility. including adeyute structural foundation. operating space. and adequate water for cootant makeup and heat rejection. Although these ekments are so well recogaized as to make it untikeh that they woild be aeglected in phaning a nuclear facility. their importance to safety requires that uncommon care be exercised in providing the desired suppon for auctear power reactors. This special concem for safety. on the other hand. has had litule inflenence on site selection. Sites oherwise accepuble for heavy industrial facilities have, with only on exception beca adequate ia this respect. The onfy natural feature that has ever completely disqualifed a site is tectonically active faults. The AEC nejected a Californin site. after several nillion dolbrs were spept in sine development. because of geologic evidence of active fauting. The AEC did not at that time. and probably would not in the near future. accept an engineered arcommodation of ative fauline. The detailed criteria for ecologic evaluation of sites is a pan of the AEC regulation. Title 10. Code of Feckel Rexulations. Part 100. "Reactor Site Criteria." Texas and Levisiana have several proposed nuclear power phants under active revies at this tine, and there in no indiation of any unusanl concern with faulting in this region.

The second basic site-related question-emironmental characteristics affecting radiological consequences of accidents--is also a subject of the AEC's -Reactor Site Criterin-" As with active fauting. the size of the proximate popubtion is the only impedianent of this second category of site problems that has not been and cannot be resolved by engineering alone. A few formally proposed sites have been reiected by the AEC.

Popolation rist-fector eximates

The prospect of using nuclear power reactors for process heat raises the general juestion as to whether it is reasonable to expect that such plants could be beated safely in industrial areas. for the purpose of providing practical guidance on siting. we have evaluated the Houston Ship Channel-Catveston Bay area in Texas and areas along the bover Mississippi River in Louisiam. This study consisted of a survey of popubtion distributions and densities throughout these two areas. The paricular method utilized should yield a good indieation of whether. from the standpoint of population risk. large nuclear power reactors would be licensable in axch areas, inasmuch as hypothetical sites in the areas are compared with real reactor sites already evaluated and acceped by the AEC.

The areas of interest in Louisiana and Texas have been evaluated by calcubting a popubtion risk factor for a set of points within ach region. The particular points for which the calculations were made are hypothetical sites on's in tinc broadest sense. Hundreds of such points have been evaluated by this process in order to can the regions with sufficient density to perswin some conclusive characterimtions to be made.

The areas evalualed in Texas and Louisiana are shown in Figs. 5.37 and 5.38 respectivety. Risk sans were made along stright-line traverses within each of the 11 quadrangular anos in Texas and Lowisiana. The precise locations of the traverses are dexcribed in Table 5.57. Generally the scans covered the areas with a spacing of 1 to $3 \mathrm{~km}$. although some scans were made at about 0.5 -km intervals.

The population risk profik of each traverse is displayed gmphically in Figs. 5.39 through 5.49. A complete set of profiles is given in Appendix $F$. 


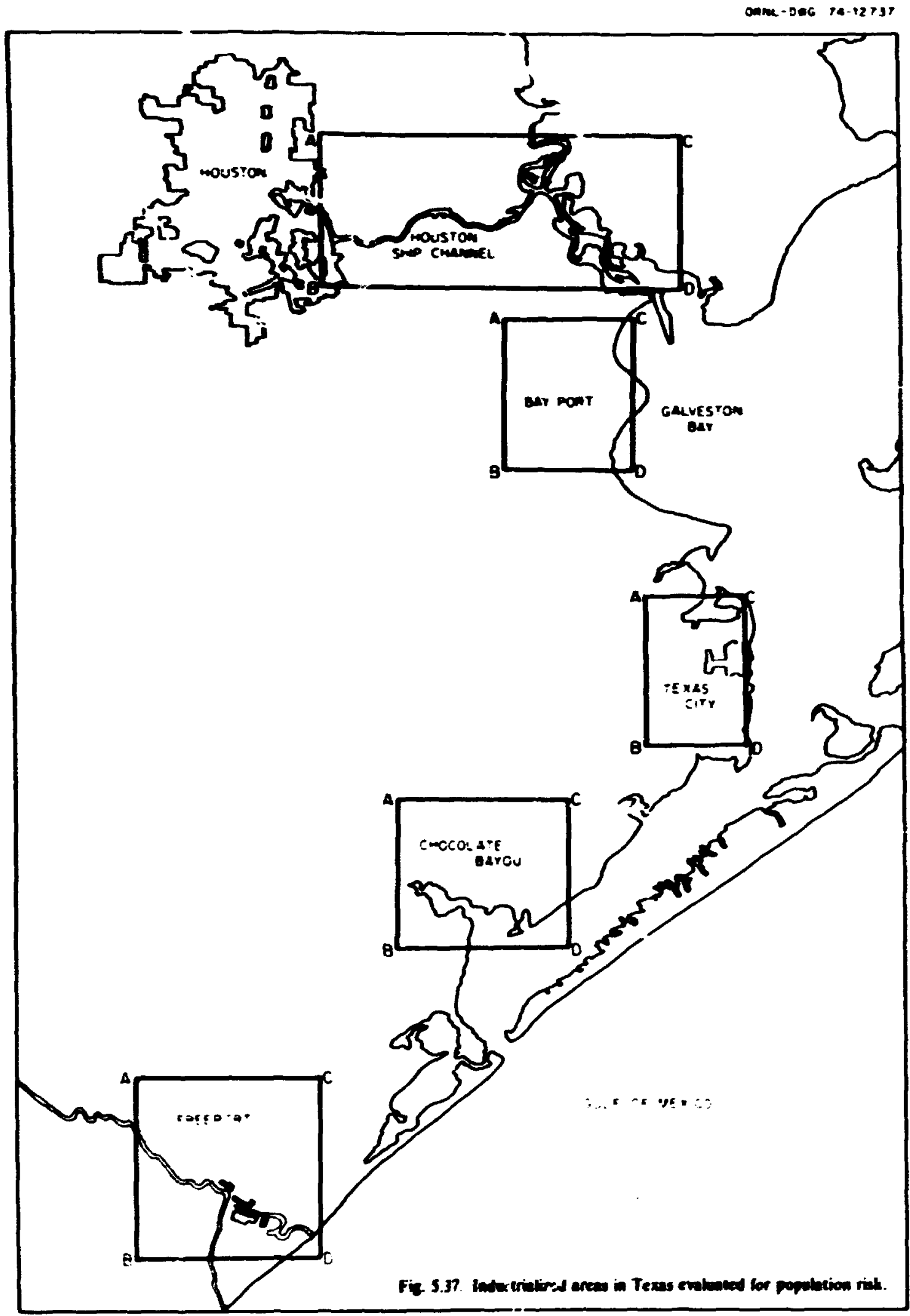




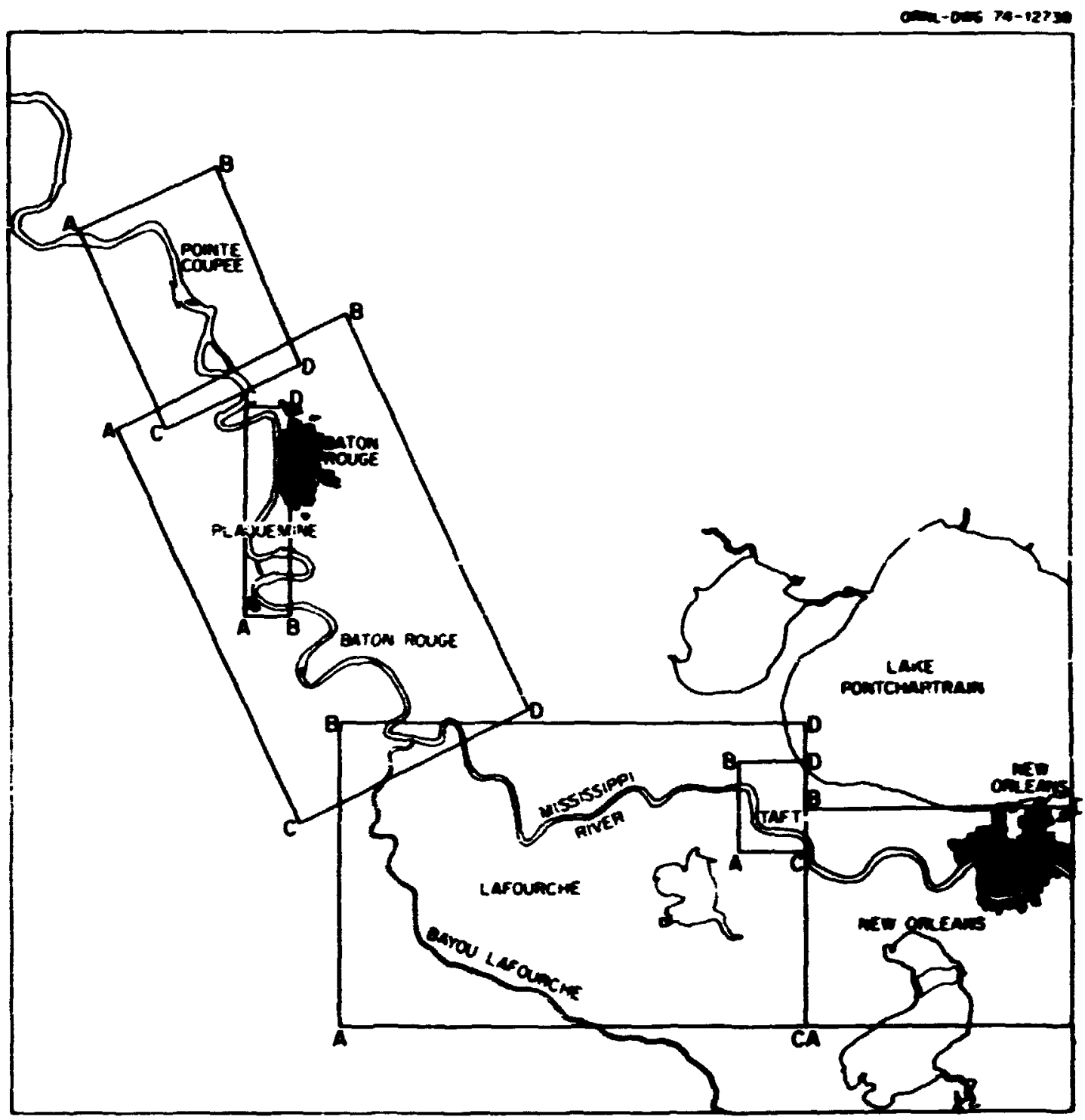

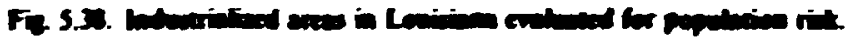




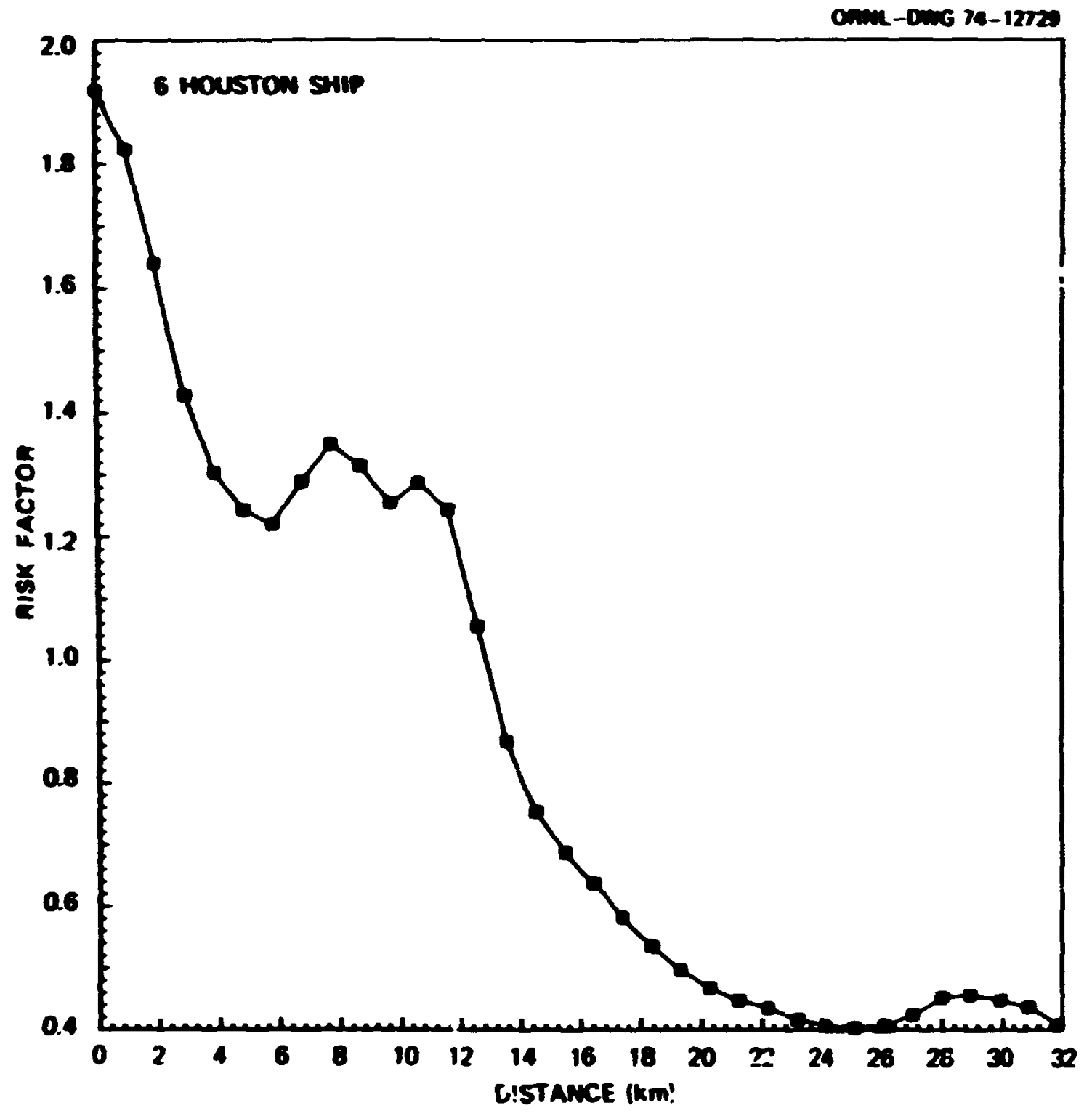

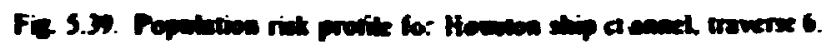




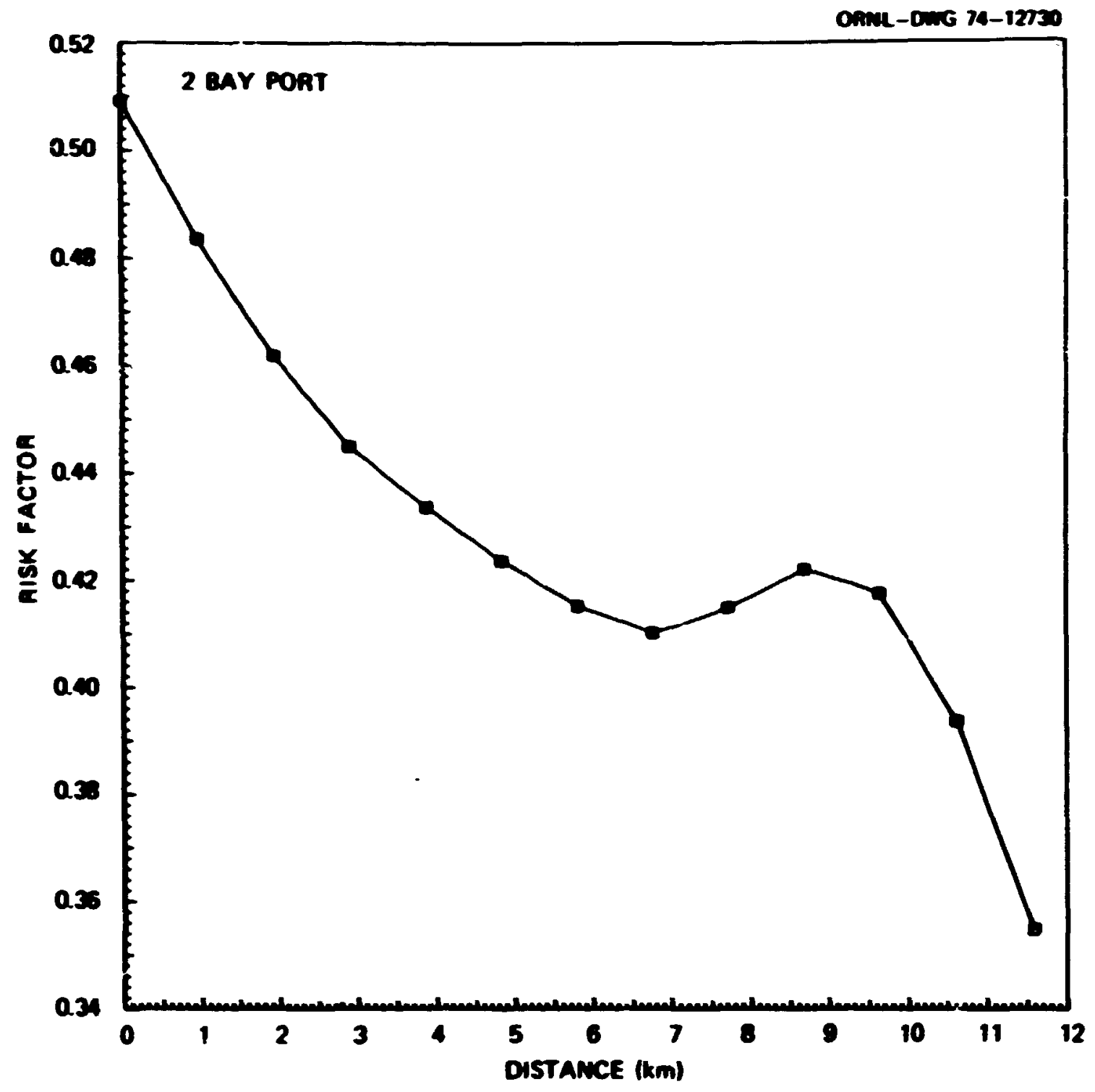

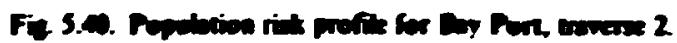




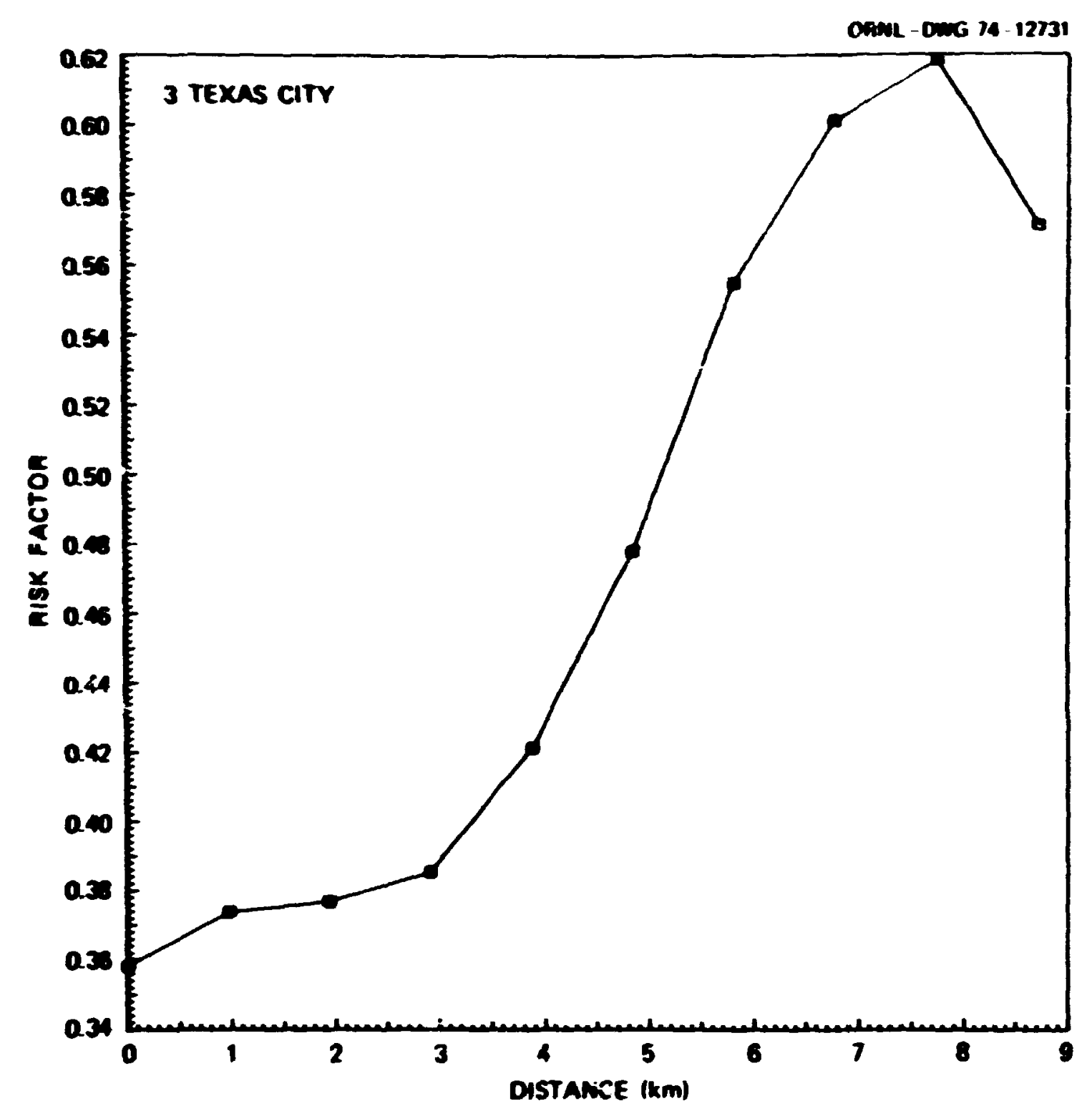

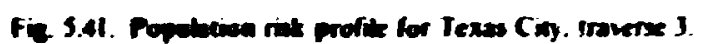




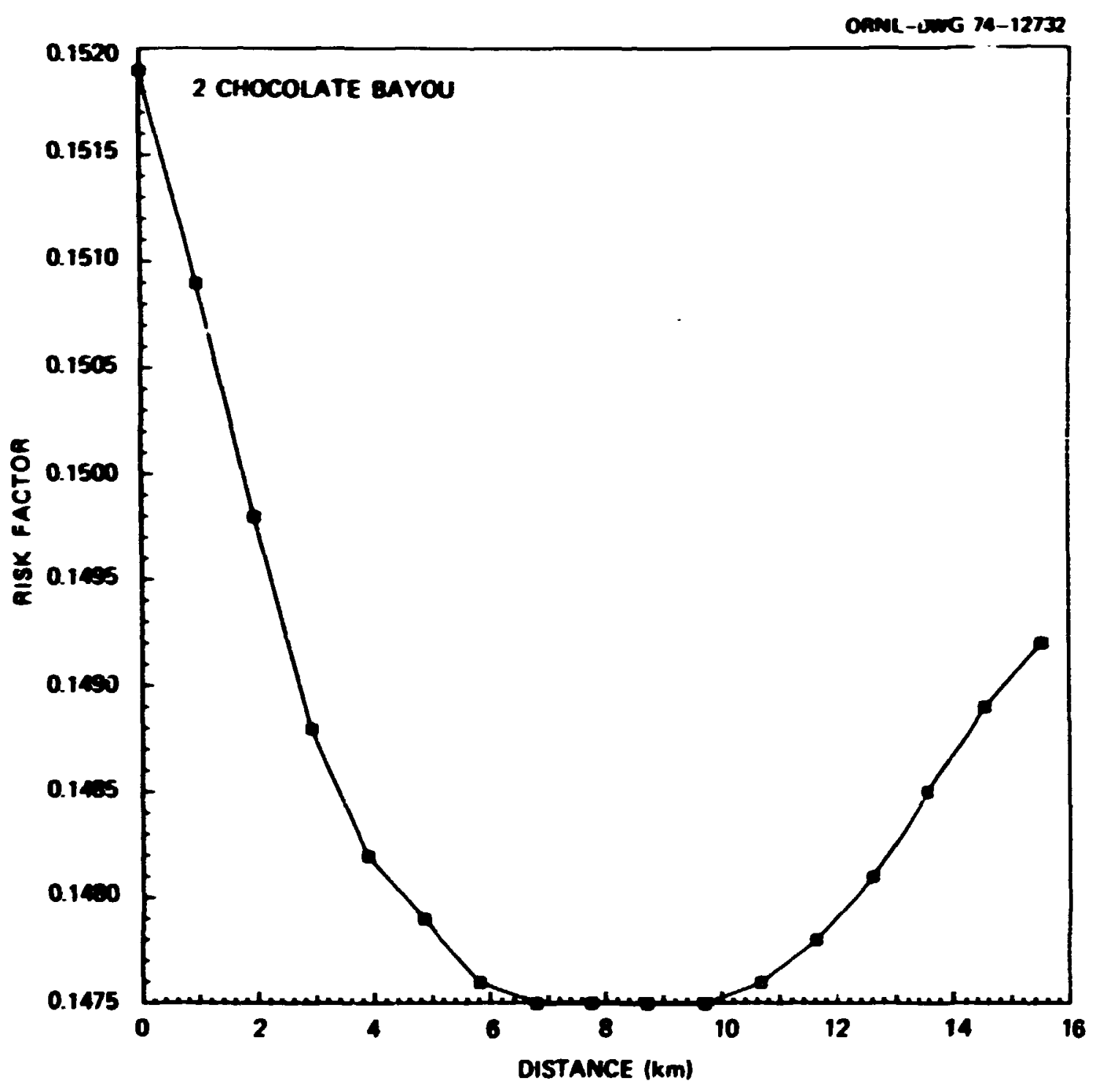

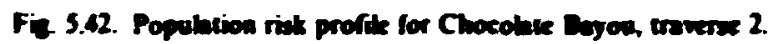




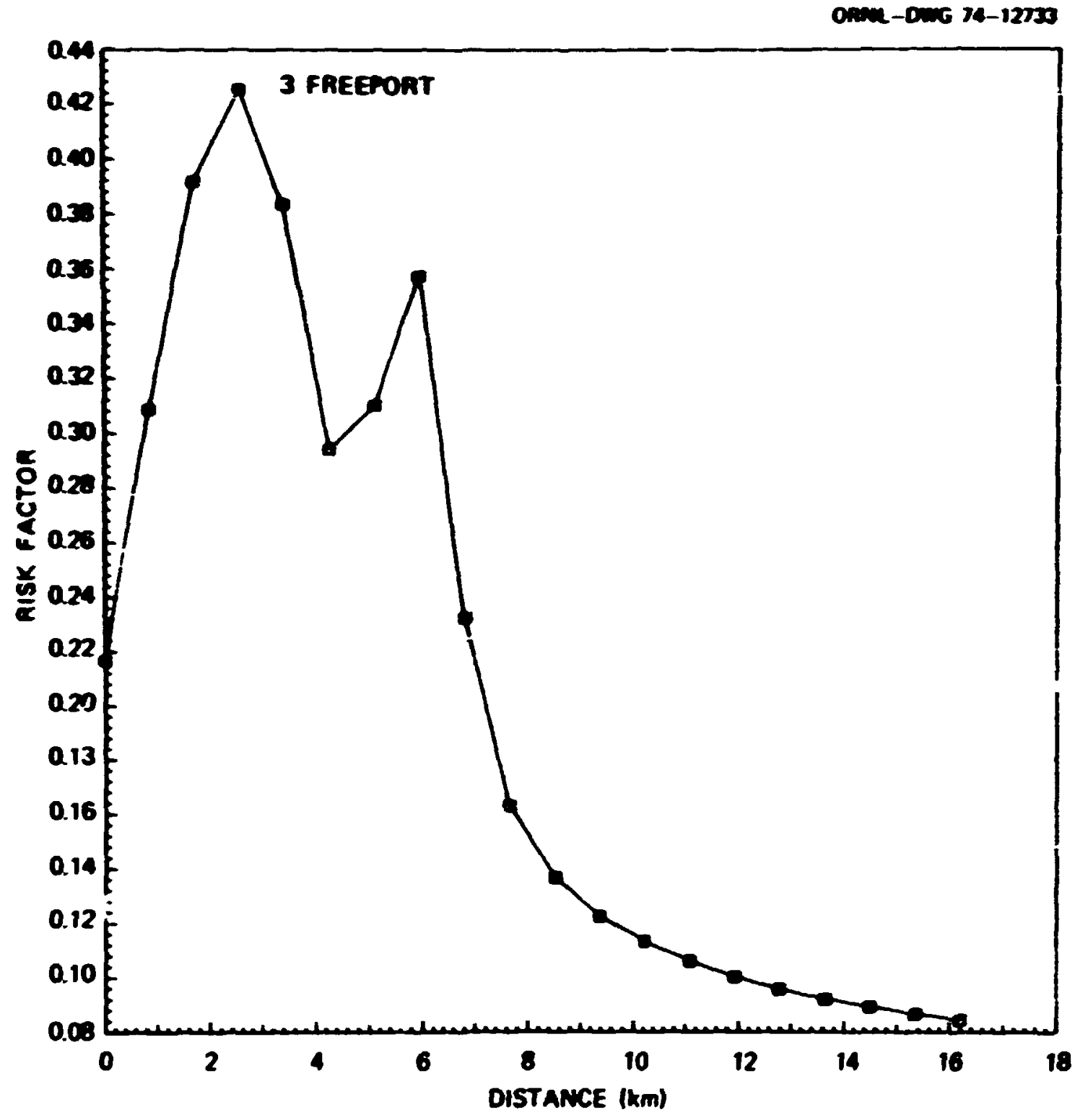

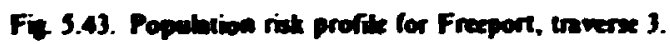




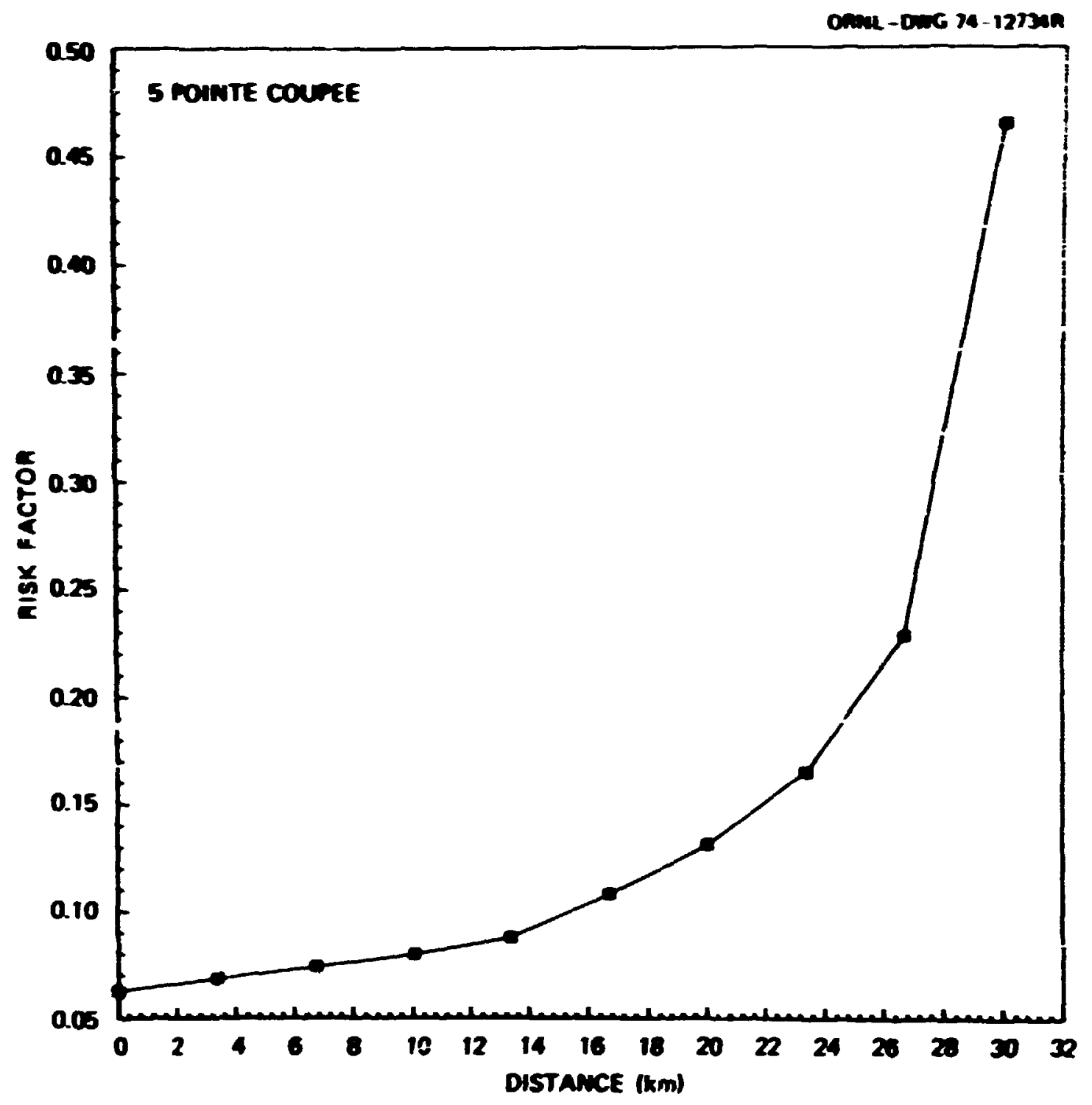

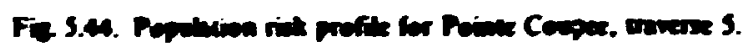




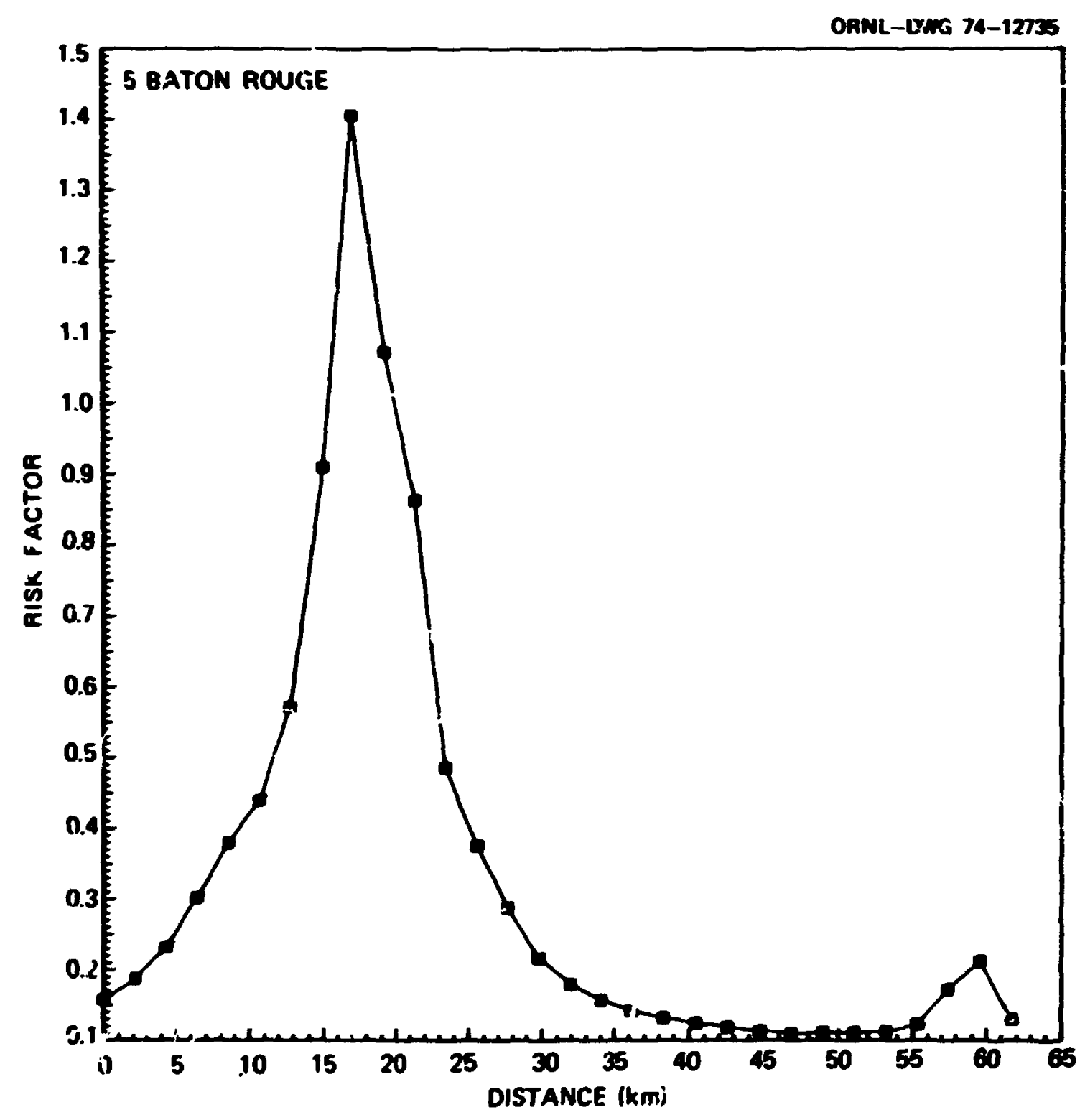

Fick 5.45. Popolntion risk profile for Bulon Roune, traverse S. 
OANL-DWG 74-12730

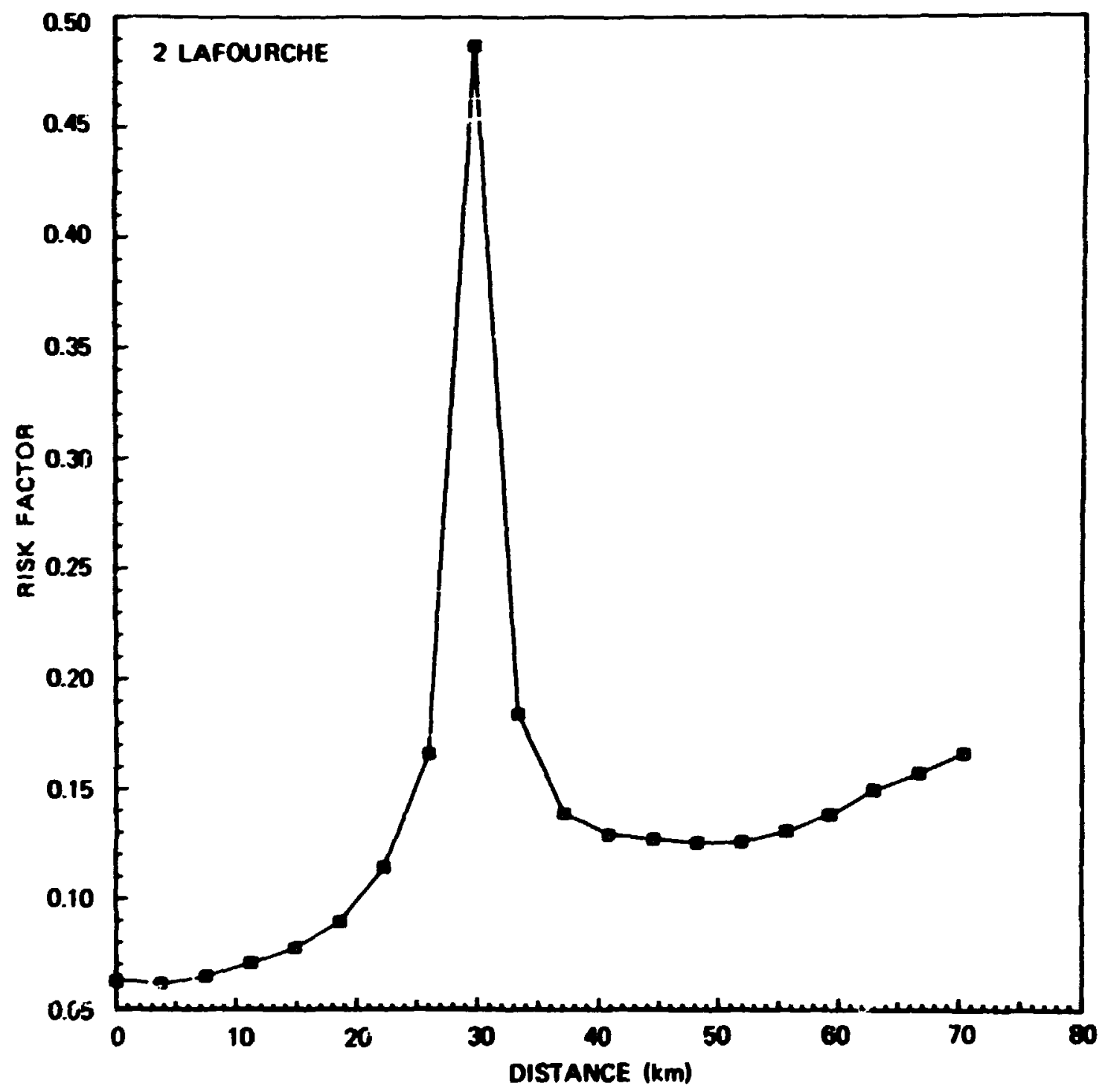

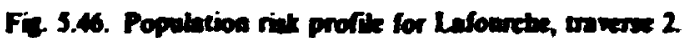




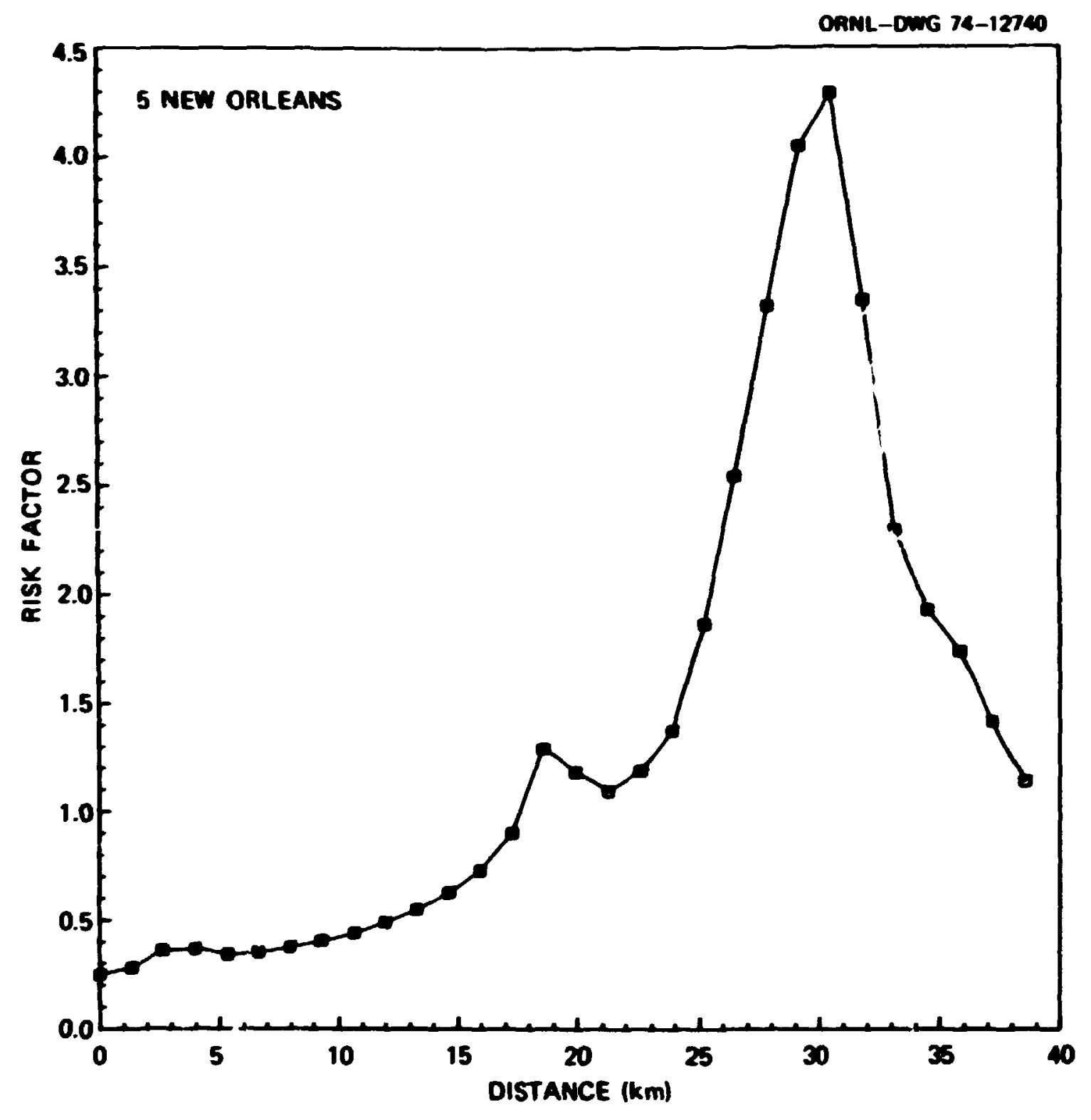

iit 5.47. Popalation riat profite for New Orienss. traverse S. 


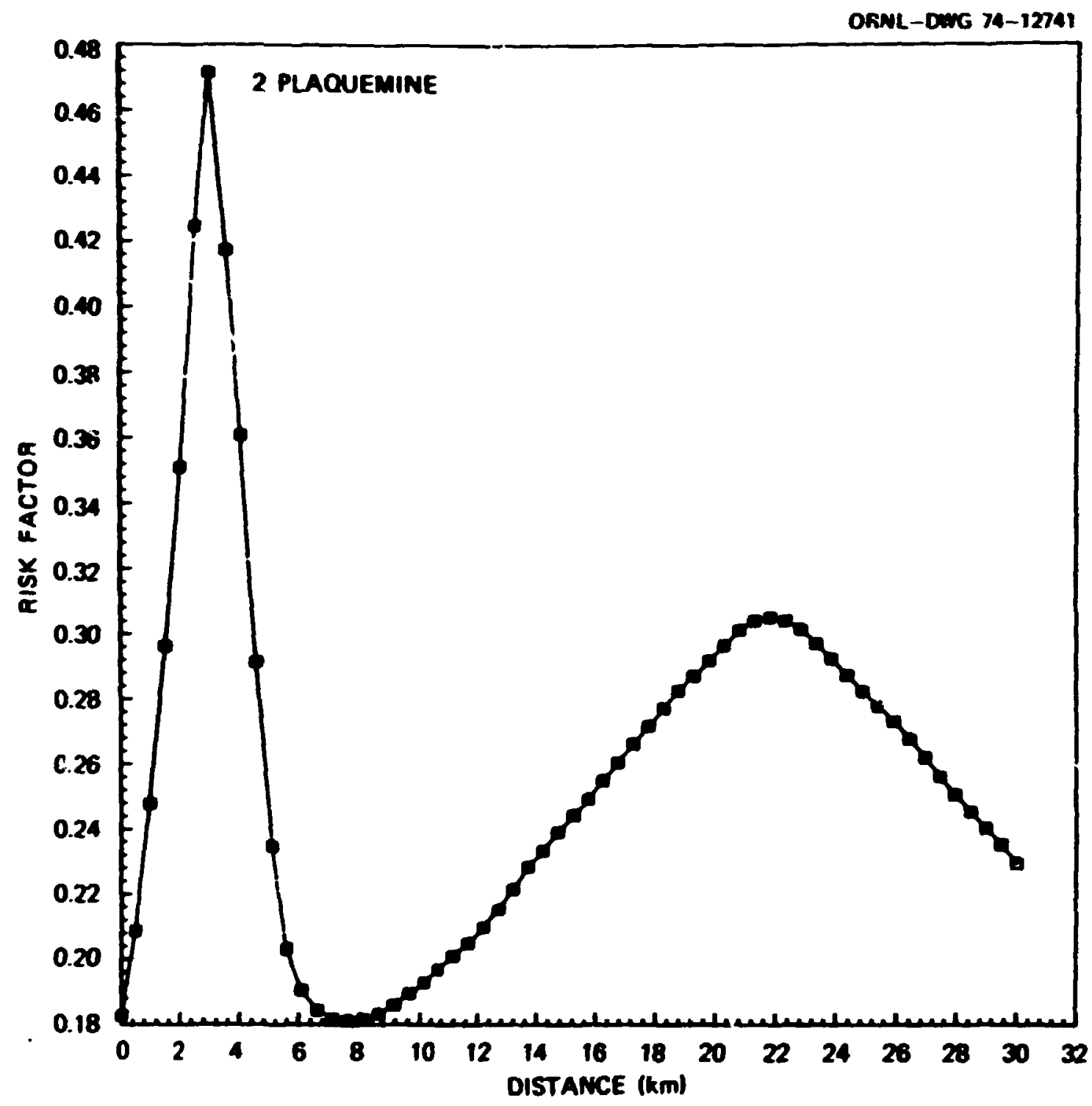

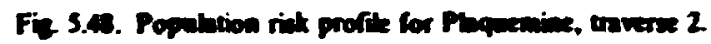




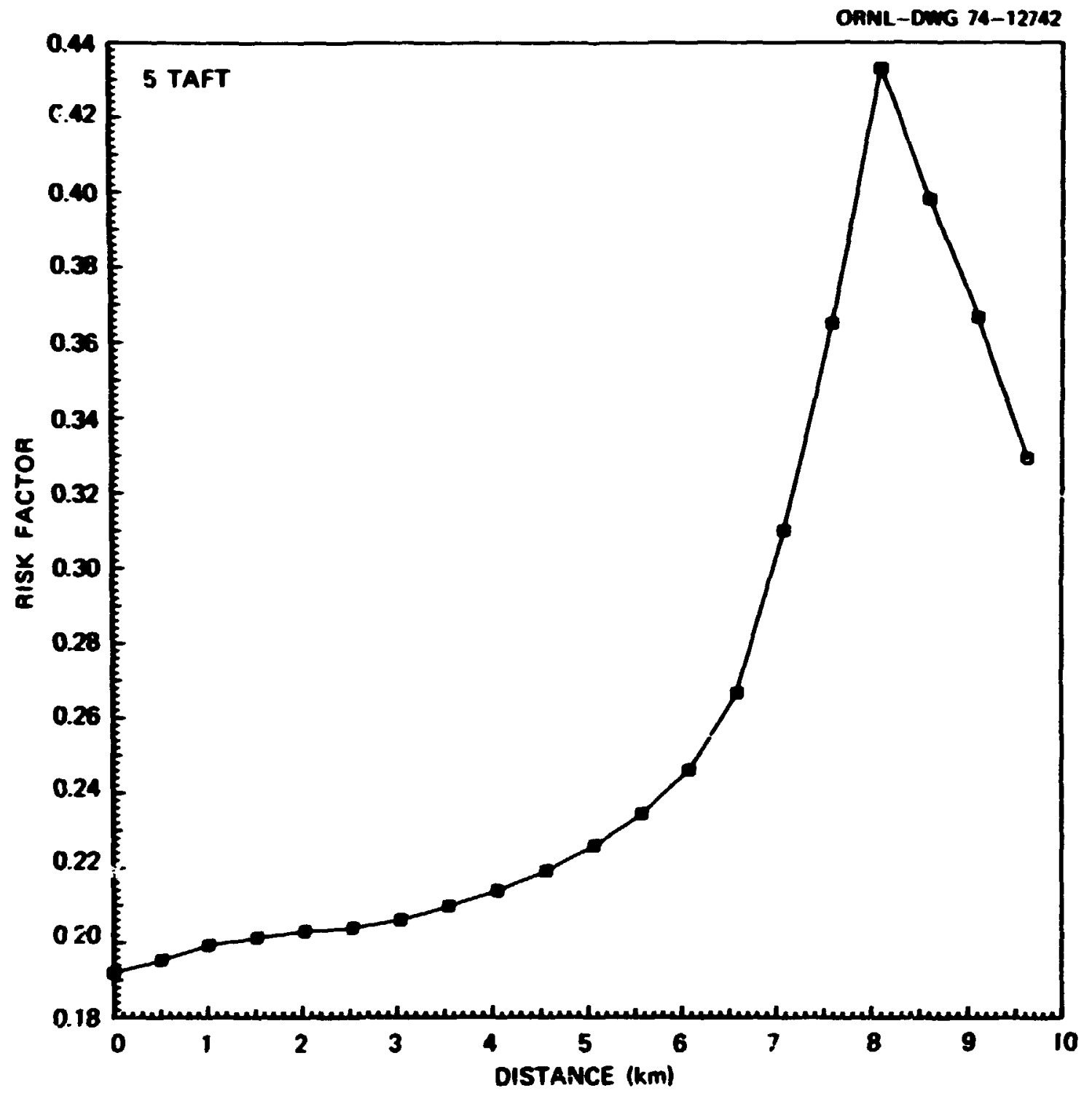

Fie 5.4. Popalaion rial profile for Taft, traverses.

i 


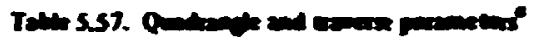

\begin{tabular}{|c|c|c|c|c|c|c|c|c|c|}
\hline \multirow{3}{*}{ Autrenge } & \multirow{3}{*}{$\begin{array}{c}\text { Nomber } \\
\text { of } \\
\text { towaress }\end{array}$} & \multicolumn{8}{|c|}{ 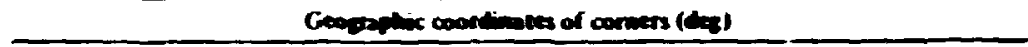 } \\
\hline & & \multicolumn{2}{|c|}{$\mathbf{A}$} & \multicolumn{2}{|r|}{$\mathbf{D}$} & \multicolumn{2}{|c|}{$\mathbf{C}$} & \multicolumn{2}{|c|}{$\mathbf{D}$} \\
\hline & & Latien & Lompune & Latiture & Longiture & Lativente & Longituse & Latianse & Lengivens \\
\hline \multicolumn{10}{|l|}{ Teras } \\
\hline 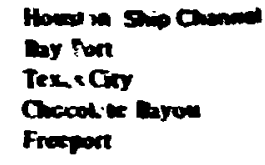 & $\begin{array}{r}7 \\
7 \\
7 \\
1 \\
11\end{array}$ & $\begin{array}{l}29.8100 \\
29.6000 \\
29.4000 \\
2920100 \\
29.0 \times 10\end{array}$ & $\begin{array}{l}\$ 5.2 \% 00 \\
\$ 5.1200 \\
\$ 4.5 \times 10 \\
\$ 5.2200 \\
\$ 5.4583\end{array}$ & $\begin{array}{l}23.6500 \\
295010 \\
24.3200 \\
29.16010 \\
24.9167\end{array}$ & $\begin{array}{l}\$ 5.2400 \\
\$ 5.1300 \\
54.5100 \\
\$ 5.2210 \\
\$ 5.4593\end{array}$ & $\begin{array}{l}2.8100 \\
2.0100 \\
2.4000 \\
29.2100 \\
29.0500\end{array}$ & 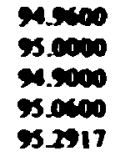 & $\begin{array}{l}20.500 \\
295400 \\
20.3210 \\
29.1601 \\
2.9167\end{array}$ & $\begin{array}{l}94.5 \times 40 \\
\$ 5.0400 \\
\$ 4.5000 \\
\$ 5.0600 \\
\$ 5.2417\end{array}$ \\
\hline \multicolumn{10}{|l|}{ Lomising } \\
\hline 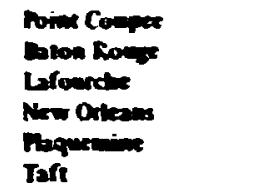 & $\begin{array}{r}5 \\
8 \\
9 \\
7 \\
7 \\
13\end{array}$ & $\begin{array}{l}30.7500 \\
305000 \\
29.7500 \\
29.7500 \\
30.2000 \\
79.5000\end{array}$ & $\begin{array}{l}91.5010 \\
91.4433 \\
91.1300 \\
90.4100 \\
91.2500 \\
515900\end{array}$ & $\begin{array}{l}30285 \\
30.447 \\
30.1340 \\
300238 \\
3,2 \times 10 \\
300104\end{array}$ & $\begin{array}{l}91.215 \\
91.9 \times 12 \\
91.1300 \\
50.4010 \\
91.1200 \\
505000\end{array}$ & $\begin{array}{l}305020 \\
300100 \\
20.7500 \\
20.7500 \\
305300 \\
2.5090\end{array}$ & $\begin{array}{l}91.3002 \\
91.1637 \\
50.410 \\
901010 \\
91.2500 \\
50.400\end{array}$ & $\begin{array}{l}305785 \\
30.1447 \\
30.1300 \\
300730 \\
305300 \\
30510\end{array}$ & 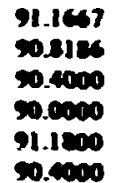 \\
\hline
\end{tabular}

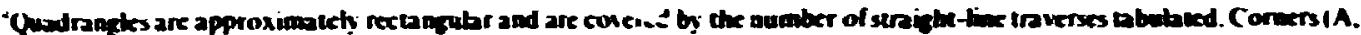

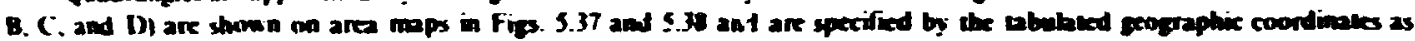

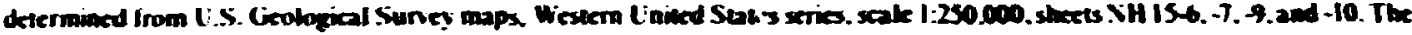

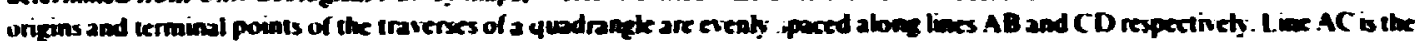
first taverse of a yeadrangle. and line BD is the bas.

The significance of the poperlation risk factor is in its representation of the cumulative rist to the entire poputation from potential exposure to the radioactive materials released by accident fror. a particular hypothetical site. It is obtained by computing a weighted average of the surrounding population. The weighting function approximates the retative radiation exposure of a single individual: this relative exposure is a function of distance and was chosen for this study to vary with distance $(r)$ as $r^{-3.4}$. This particular exponent was used in order to simplify the comparison of this study : vith information contained in an internal AEC regubtory staff working paper." The population risk factor used for this study has also been normaliad in the same way as the AEC 3. namely. by requiring the risk factor to have a value of 1.0 for a site having a uniform popubtion density of 1000 individuals per square mile within 50 miles of the hypothetical site and a densily of zero beyond. A zero density. for normalization. within $0.3 \mathrm{~km}$. of the site, to account fot a nominal plant exclusion distaice. was also assumed in the present study.

The site evaluation utilized data from the official 1970 census of the United States in the form that gives the greatest detail available in the actual geographical beation of each popubtion segment. These data are the populations and geographical coordinates of each official "enumeration district. - it An enumeration district is a geographically contiguess area having nominally 1000 or less resident persons.

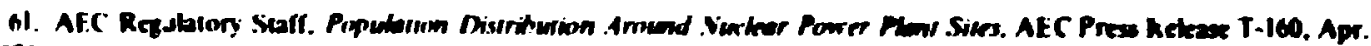
9. 1974.

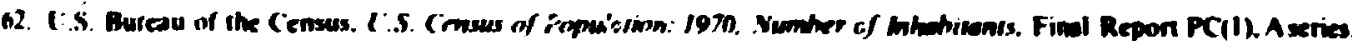

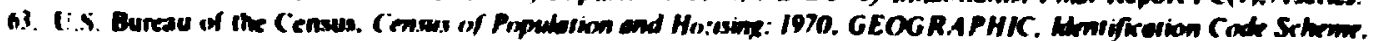
tinal Repon PHCIRr-3.

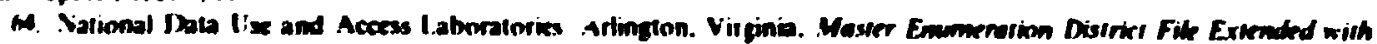
Cinminoues. MFI)-X Census thata Tapes. 
The calcubtions of this study differ from those described in the referenced AEC docunient in two respects: (1) the AEC bumped the entire popubtion around a site (within SO miles) into ten annular areas of asumed uniform density. whereas this evahuation considered each enumeration district separately; and (2) the AEC used population dat evidently extracted from various licensine documeats, while the besis in this study was the 1970 census.

The influence of these differences in procedure have been andyzed in detail for the lodian Point site. This is the site o' a three-unit nuctear power phant owned by Consolidated Edison Company of tiew York, Inc., and is one of the few power reactor sites in the United States near a metropolitan are. A comparison of hypothetiol sites with this important site. already evaluated and accepted by the AEC, is a significan test of the acceptability of the former.

The AEC procedure of muping the popubtion into brge seganents gives a "site popubtion factor" for this site about $0.5 \%$ bss than the population risk factor. provided the 1970 census besis of this seudy is used for both calculations. It was alrady known that the effert of bumping should be small in any ase except with respect to that part of the popubtion close $u$ a site. Therefore. it is resconable that the two procedures should give similar results for the Indian Point site. since the popubtion distribution is dominated by the brge numbet of people living bejond five miles, as shown in Table 5.5. This more distant popubtion contributes about $80 \%$ to the total value of the Indian Point site popubtion factor. In an area where the popubtion density is more nearty uniform or is more concentraled near the site. the lumping of thi popubtion would not be as good an approximation of the ideal population risk factor.

Lumping the popubtion near the Indian Point site leads to an underestimate of the population risk of about 13\% . if only the population within $S$ miles is considered. This is unimportant in the Indian Point ase, as explained above. when the entire population is considered. In a test case in the Houston area. the effect of lumping is more pronounced and, as with Indinn Point. is an underestimate of the population risk. Therefore. :he more precise procedure developed for this study has been used for the evaluation of all hypothetical sites.

In order to evaluate the effect of using population data different from that of the AEC. the two population dit tributions shown in Table 5.58 were used for computing the site population factor in

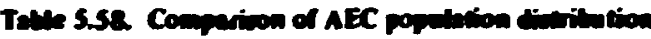

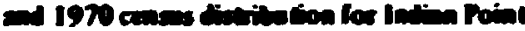

\begin{tabular}{|c|c|c|c|}
\hline \multirow{2}{*}{ 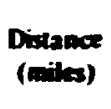 } & \multicolumn{2}{|c|}{ Cunnlative popalation } & \multirow{2}{*}{$\begin{array}{l}\text { Ratio of AEC to } \\
1970 \text { consis } \\
\text { popubtion data }\end{array}$} \\
\hline & $A E C^{C}$ & 1570 censos & \\
\hline 1 & 3,300 & 1,300 & 254 \\
\hline 2 & 18,000 & 10,700 & 1.68 \\
\hline 3 & 30,000 & 27,500 & 109 \\
\hline 4 & 40,030 & 41,500 & $0 . \%$ \\
\hline $\mathbf{s}$ & 65,000 & 65,600 & 1.07 \\
\hline 10 & 263.000 & 201,900 & 1.30 \\
\hline 20 & $1,694,060$ & 896,240 & 1.32 \\
\hline 30 & $4,410,000$ & $4,002,400$ & 1.10 \\
\hline 40 & $10,630,000$ & $10,177,300$ & 1.27 \\
\hline SO & $16,500,000$ & 16.007 .000 & 1.03 \\
\hline
\end{tabular}

Estimated from crude graph. 
accurdance with the AfC procedure. The values si this factor, as a function of distance, are shown in Table 5.59. This tabulation demonstrates the significant effect of using imprecise population data close to the site. Although the total popubtions differ by onty $3 x_{i}$, the site popubtion factors differ by 17\%. This disproportionality of the site popubtion factor with respect to toeal popubtion is evident in Tables 5.58 and 5.59 at all distanues.

In order to be consistent in the cualuation of all sites. the value of the population risk betor computed from the 1970 census data for Indian Point was considered to be the relevant value for that site.

A site is generally at least as good as the Indian Point site if the popubtion risk factor is no greater than 1.29. The prufiles of Fib. 5.39 through 5.49 (and Appendix F) show that almost all the areas scanned are much betier than Indian Poine. Or all the Texas ereas, only small areas along the wesi and south edges of the quadrangle covering st.e Howston Ship Chamel would be of questionable acceptability. In Louisiana, a small central ara in Baton Rouge and the central city of Niew Orkans are unfavorable.

As can be observed from the population risk profiles. there is a wide variation in the merits of a site with respect to this one factor. If all other qualities of alternative sites were equal, one would want to choose the size having the lowest popubtion rat. The AEC would give some consideration to this possibility. Conversely, it is important to recognize that the AEC acceptance of existing nuctear power plant sites has taken such alternatives into account and would, indeed, in the future make allowance for the fact that a plan: may uned to be in a particular bocation in order to be useful. Tixe Midland ruclear plant. which will supply process stem to an industrial facility, would probably have been located larther from the city of Midhand had there not been a special need in that ease. Other factors. such as size of plant, also favor the industrial process heat case in comparison with the real power reactor sites. These factors make the conciusion all the more reasomble that all the industrialized areas studied, except for the central city regions included in the survey, would be quite Gvorable as nuclear process heat plant sites, at least on the basis of popubtion risk.

\begin{tabular}{|c|c|c|}
\hline \multirow{2}{*}{$\begin{array}{l}\text { Distance } \\
\text { (miles) }\end{array}$} & \multicolumn{2}{|c|}{ Site popplation factor } \\
\hline & $\begin{array}{l}\text { AEC } \\
\text { dat }\end{array}$ & 1970 censess \\
\hline 1 & 1.05 & 0.41 \\
\hline 2 & 1.20 & 0.58 \\
\hline 3 & 1.12 & 0.67 \\
\hline 4 & 1.03 & 0.67 \\
\hline 5 & 1.01 & 0.69 \\
\hline 10 & 0.96 & 0.71 \\
\hline 20 & 1.12 & 0.72 \\
\hline 30 & 1.24 & 0.93 \\
\hline 40 & 1.45 & 1.20 \\
\hline so & 1.51 & 1.29 \\
\hline
\end{tabular}




\section{Coal-Based Systems}

\subsection{ASSESSMENT OF COAL RESOURCES, AVAILABILIT, AND COST}

\subsubsection{Resowre Bane}

Coal deposits are widely distributed throughout the United States as shown in Fig. 6.1. The coal resource base is estimated to be $3.21 \times 10^{12}$ tons," equivalent in energy content to over 1000 years at the total energy consumption rate of the U.S. in 1970. Approximately one-half. or $1.56 \times$ $10^{12}$ tons, lies in beds more than 14 in. thick at depths of 3000 fi or less in mapped and explored areas. The distribution of the $1.56 \times 10^{12}$ tons by rank (type of coal) and by stace is shown in Fig6.2. Or the total bituminous resource, two-thirds is located east of the Mississippi, with Illinois containing the brgest quantity of any state. Subbituminous coal is predominantly contained in the Rocky Mountain states of Montana. Wyoming. and Colorado and in Abska. New Mexico abo has substantial reserves. About $98 \%$ of the nation's lignite is located in Nonth Dakota and Montana.

\subsubsection{Recoverable Reserves}

The coal resource base described above does not constitute a usable resource because of both technical and economic constraints. Coak considered to be avaibble at present prices with present technology are the measured and indicated reserves with 1000 ft or less of overburka and in beds of thicknesses 28 in. or more for bituminous and anthracite and 5 ft or more foi subbituminous and lignite. On this basis." avaibble reserves total $394.1 \times 10^{\circ}$ tons (about one-eighth of the tolal resource base) distributed by rank as follows: bituminous. $66 \%$; subbituminous. 18\%; lignite. 13\%; and anthrecite. 3\%. A breakdown of avaibble reserves by rank and state is given in Table 6.1.

Or the $394.1 \times 10^{\circ}$ tons considered to be avaibble. $45 \times 10^{\prime \prime}$ tons are strippable: most of this would be recoverable. since the recovery factor for serip-inined coal exceeds 90\%. For deep-mined coal. however. the recovery factor with present mining practices is about 50r: so that of the $394.1 \times$ $10^{\circ}$ tons of deep-minable reserves. only about $175 \times 10^{\circ}$ tons are recoverable. The recoverable reserves are equivalent to about 65 years at a rate of consumption equivaknt to the total national energy use in 1970.

Most of the low-sulfur coal is located in the western United States in the form of stripnable subbituminous coal and lignite. As shown in Fig. 6.3. of the $45 \times 10^{+}$tons of strippable reserves. about $25 \times 10^{*}$ tons are bow sulfus raal located in the Rocky Mountain states."

\subsubsection{Avainbility}

It is evident that the coal reserves are adequate to meet almost any desoland in the fore:crable future. The limiting factors on the use of coal are (1) environmental constraints on mining and combustion. (2) coal industry development. and (3) transportation.

65. Paul Averitt. (ind Rerenurier af the (nired Siotes. I Stis Bulktin 1275. Ian I. 1957

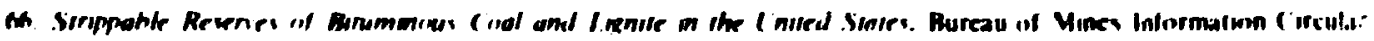
X5.11. 1971 


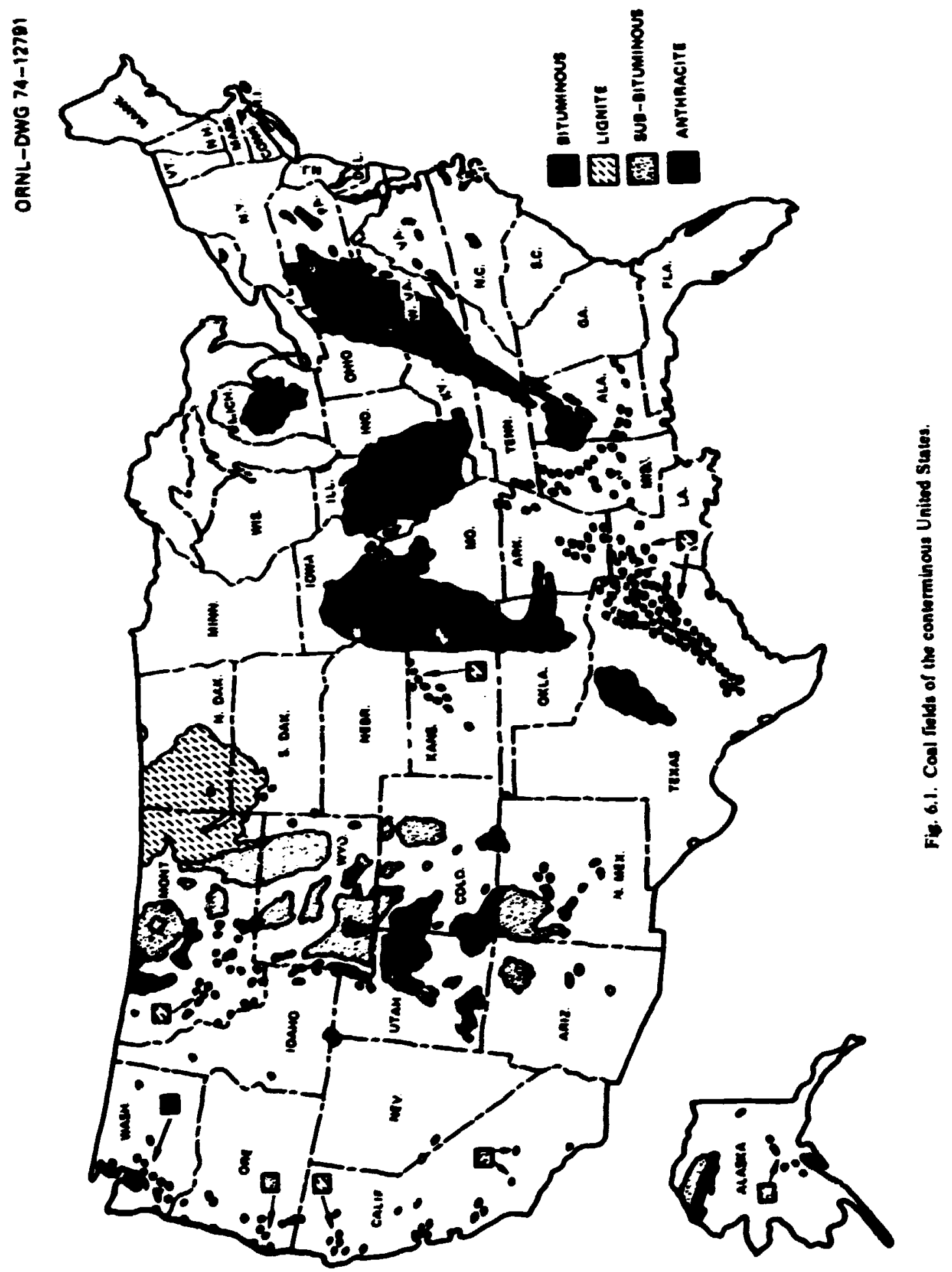


ONA4-ONG 74-12310

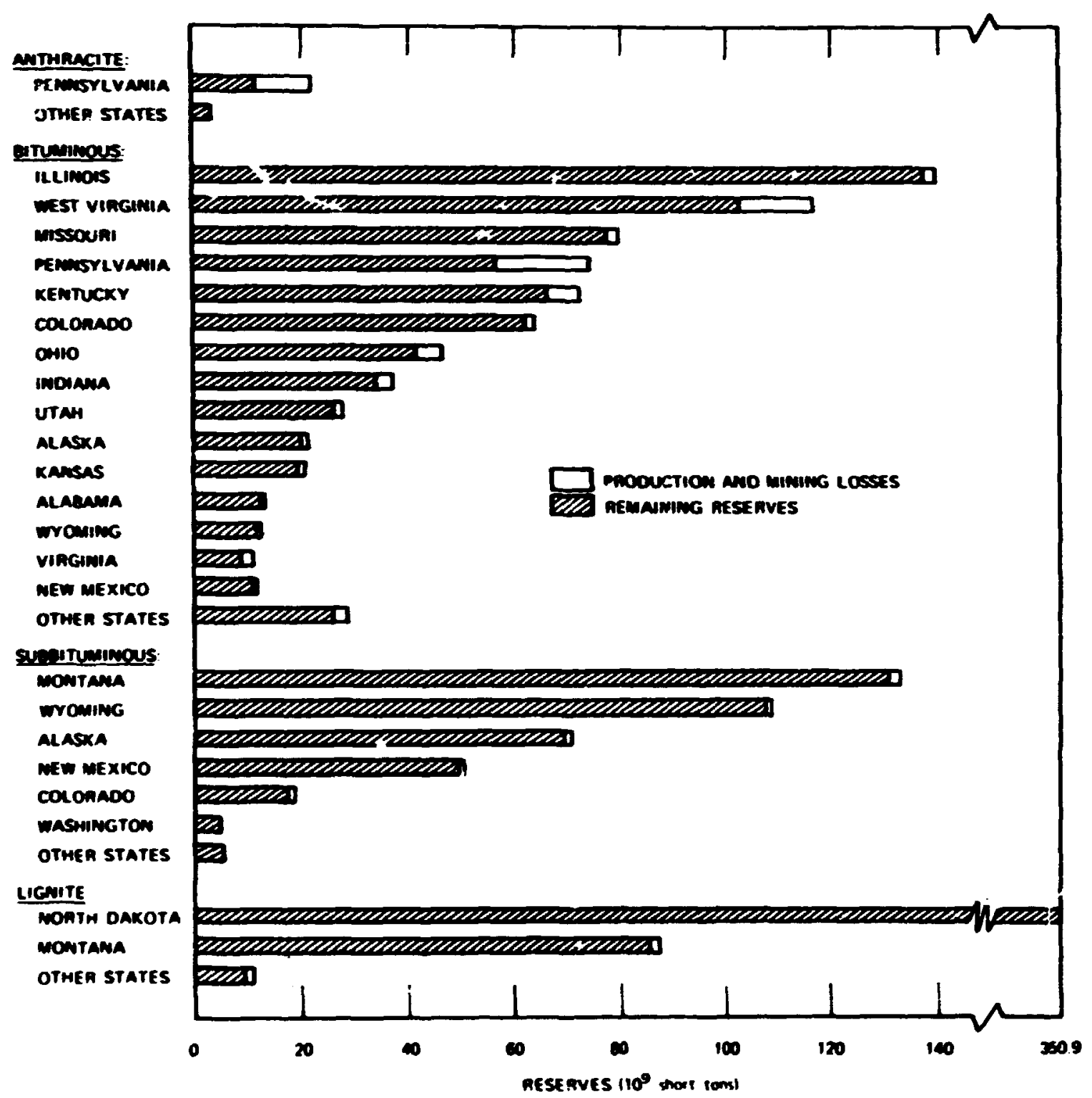

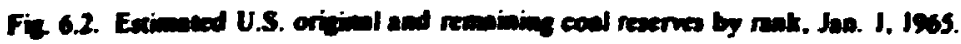




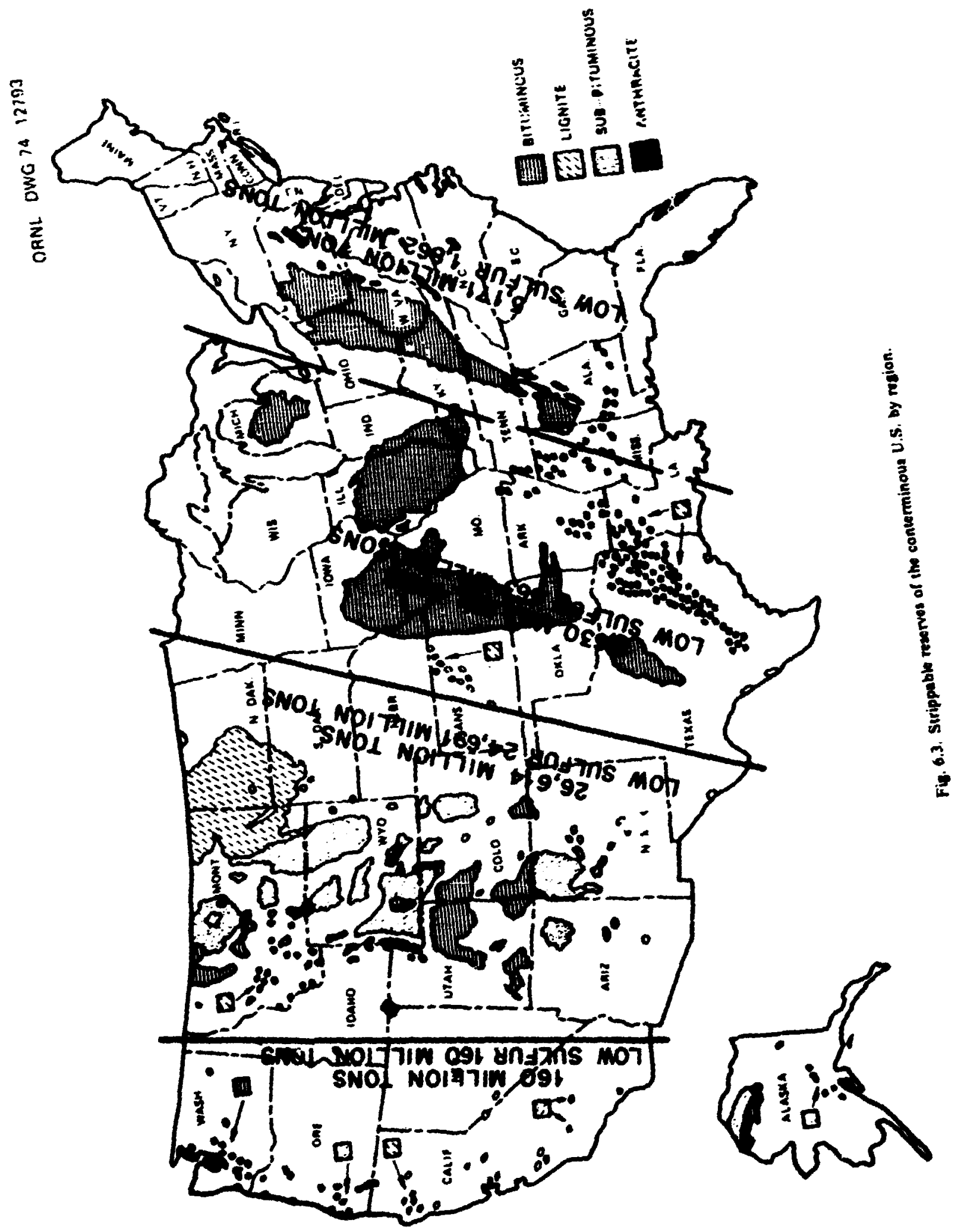




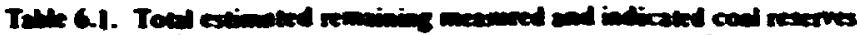

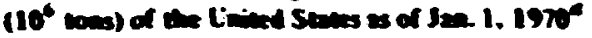

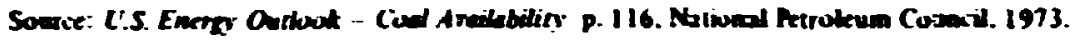

\begin{tabular}{|c|c|c|c|c|c|}
\hline State & Biruminoes & Selbbituminoves & Lispite & $\begin{array}{l}\text { Anthracite and } \\
\text { seminocherise }\end{array}$ & Tocal \\
\hline Abbam & 1.731 & o & $b$ & $\mathbf{0}$ & 1.731 \\
\hline Absta & 667 & 5.345 & $c$ & $d$ & 6.012 \\
\hline Artanases & 313 & o & $b$ & 67 & 300 \\
\hline Colorado & 8.811 & 4.453 & 0 & 16 & 13.200 \\
\hline Caurpia & 18 & $\mathbf{0}$ & $\mathbf{0}$ & 0 & I8 \\
\hline miseois & 60.007 & $\mathbf{0}$ & 0 & o & 60.007 \\
\hline Indian & 11.177 & $\mathbf{0}$ & 0 & $\mathbf{0}$ & 11.177 \\
\hline Lowa & 2,159 & o & $\mathbf{0}$ & o & 2.159 \\
\hline Kanses & 328 & $\mathbf{0}$ & $\mathbf{0}$ & $\mathbf{0}$ & 328 \\
\hline Kentuctsy (wext) & 20.876 & $\mathbf{0}$ & 0 & $\mathbf{0}$ & 20.876 \\
\hline Keatucky (eas) & 11.049 & $\mathbf{0}$ & $\mathbf{0}$ & o & 11.049 \\
\hline Marybad & $\$ 57$ & $\mathbf{0}$ & o & $\mathbf{0}$ & 557 \\
\hline Schiran & 125 & $\mathbf{0}$ & o & 0 & 125 \\
\hline Miscouri & 12.623 & $\mathbf{0}$ & $\mathbf{0}$ & $\mathbf{0}$ & 12.623 \\
\hline Moatana. & 862 & 31.228 & 6.878 & $\mathbf{0}$ & 38.968 \\
\hline$N=$ Mexico & 1.339 & 779 & $\mathbf{0}$ & 2 & 2.120 \\
\hline North Carolina & 5 & 0 & $\mathbf{0}$ & $\mathbf{0}$ & b \\
\hline North Dakota & $\mathbf{0}$ & o & 36.230 & $\mathbf{0}$ & 36.230 \\
\hline Otrio & 17.242 & $\mathbf{0}$ & $\mathbf{0}$ & $\mathbf{0}$ & 17.242 \\
\hline Otclaboma & 1.583 & 0 & 0 & o & 1.583 \\
\hline Oregon & $f$ & $f$ & $\mathbf{0}$ & 0 & $f$ \\
\hline Renmsylozin & 24.078 & $\mathbf{0}$ & 0 & 12.525 & 36.603 \\
\hline South Dakota & 0 & o & 757 & $\mathbf{0}$ & 757 \\
\hline Tennessee & 939 & o & 0 & $\mathbf{0}$ & 939 \\
\hline Texas & $f$ & 0 & 6.870 & 0 & 6.870 \\
\hline Utah & 9.155 & 150 & 0 & o & 9.305 \\
\hline Virginin & 3.561 & 0 & 0 & 125 & 3.686 \\
\hline Washington & $3 ! 2$ & 1.188 & 0 & $\mathbf{0}$ & 1.500 \\
\hline West Virgenis, & 68.023 & 0 & 0 & o & 68.023 \\
\hline Wyoming & 3.975 & 25.937 & c & 0 & 29.912 \\
\hline Oihet stales & I & f & 46 & $\mathbf{c}$ & 46 \\
\hline Total & 261510 & 69.080 & 50.781 & 12.735 & 394.106 \\
\hline
\end{tabular}

Afikures are reserves in gound. about half of which may be considered recoverable. Includes all beds with kess than 1000 if of overburden and over 28 in. in bed thickness for bituminous and anthracite and 5 ft or more for subbit uminous and lignile.

bsmall reserves of lignite in beds less than 5 ft thick.

'Small reserves of bignite included with subbituminous seserved.

dSmall reserves of anthracite in the Bering River field believed to be too badly crushed and folded to be economically recoverable.

eNegligible reserver with overburden less than $1000 \mathrm{ft}$.

Data not available to make estimate.

\section{Environmental constraints}

Most of the present concern is related to the effects of strip mining on tand and water. However, it should be noted that underground mining also has adverse impacts. including dcath and injury rates approximutely live time:; higher than those for strip mining." The Coal Mine Health

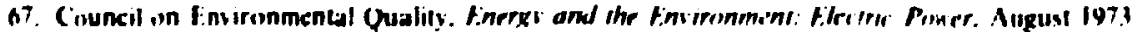




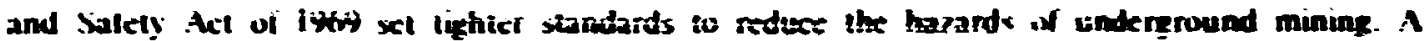
sibe eflect of the Act was a decrease in productivity and an increase in capital investanents required for deep mining. As a conseyvence. strip mining aceelerated because of the improvement in the nelative competitive position of this form of mining. Strip mining now excounts bor approximately enc-half of the total coal production. With the trend to mone stripping and the vast devastation of had and water rescurces that have been experienced in some areas. mam proposals. ranging from improved reclamation practices to outrigh bans. have been made to reduce the adverse effects of strip mining. Reclamation of strip-mined areas involves bectflliag-compecting soil conditioning. regrading. and revegctation to achicve a natural appesance. Current estivates" "* for rectamation range from $\$ 2000$ to 5000 per acre. the biter figure corresponding to $20 \mathrm{c}$ to $30 \mathrm{C}$ per lon of coal (for coal yields of 20.000 to 30.000 lons aere). For western cool from thick beds. the surcharge for reclamation might be onty 36 to 46 ton. It would appeat. if these figures are correct. that the issur in strip miaing is not reclamation costs, since the contribution to the cost of coal would be minor. Rather. the issue scems to concern the question of what consin sies acceplable rectamation. There is no reasomable way to restore stripped band to its original condition-onty to a condition that some would consider acceptable. Litimatety. society must make $t^{\prime}$, judgment concerning benefies and costs of surface mining. If. as some have sugessed. surface i iling were banned. the ability of coal to satisfy a brexer portion of our nation's energy needs wori.6 be seriouxhy impaired. The National Petrokum Council (XPC) ${ }^{\prime \prime}$ estimated that the coal produc: i, n rould decline by over $40 \mathrm{f}_{\mathrm{i}}$, at heast until 1985, if stripping were banned.

Coal pruduction and coal processing in some western sates pose additional emironmental and socictal problems. Water use associated with strip recbivition. slurry pipelines. and. in particubr. coal gasificatinn plants could be significant. Strch use would be in direct competition with established agricultural and industrial activities. The water question will be an important issue in the expansion of the coal industry in the West."

\section{Coal mining expansion}

The XPC" estimated that a maximum growth rate of 5\% year could be sustained by the coal mining industry. This growth rate. and probably a higher figure. would seem to be supported by historical evidence. Fizure 6.4 shows coal production over the period 1935 to 1970 . In the years just prior to and during Work War 11 . underground mining increased at an average rate of $8 r_{r}$ year. Since 1954. strup mining has increased at an average mte of 6.15. year. Potential limitations to expansion include the availability of capital, equipment. and manpower. The NPC estimatrs that up in S15 billion 1970 dollars in capilal will be required over the preriod 1970 to 1985 . Although this is a significant sum. the capital required to mine the coal will be small rebtive to the capilwi needed to use it. Much of the capital required for expansion must coine from outside the industry. and investors generally require long-term contracts for the output of a new mine before offering finanring. Present uncertainties concerning the possibilities of future restrictions on cernain kinds of mining and the environmental acceptability of certain types of coal excourage caution on the part of

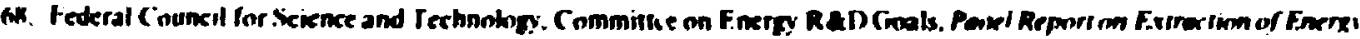
Fivel.s. Junc 1972

49. C. 1. Wilson. "A Plan for Eneres Independence," Forrign A/foirs. pp. 657-75. July 1973

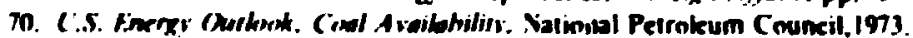

71. Ausiness Hirk. Feh. 9. 1974. p. 140. "l.etler Irnm Powder River." 


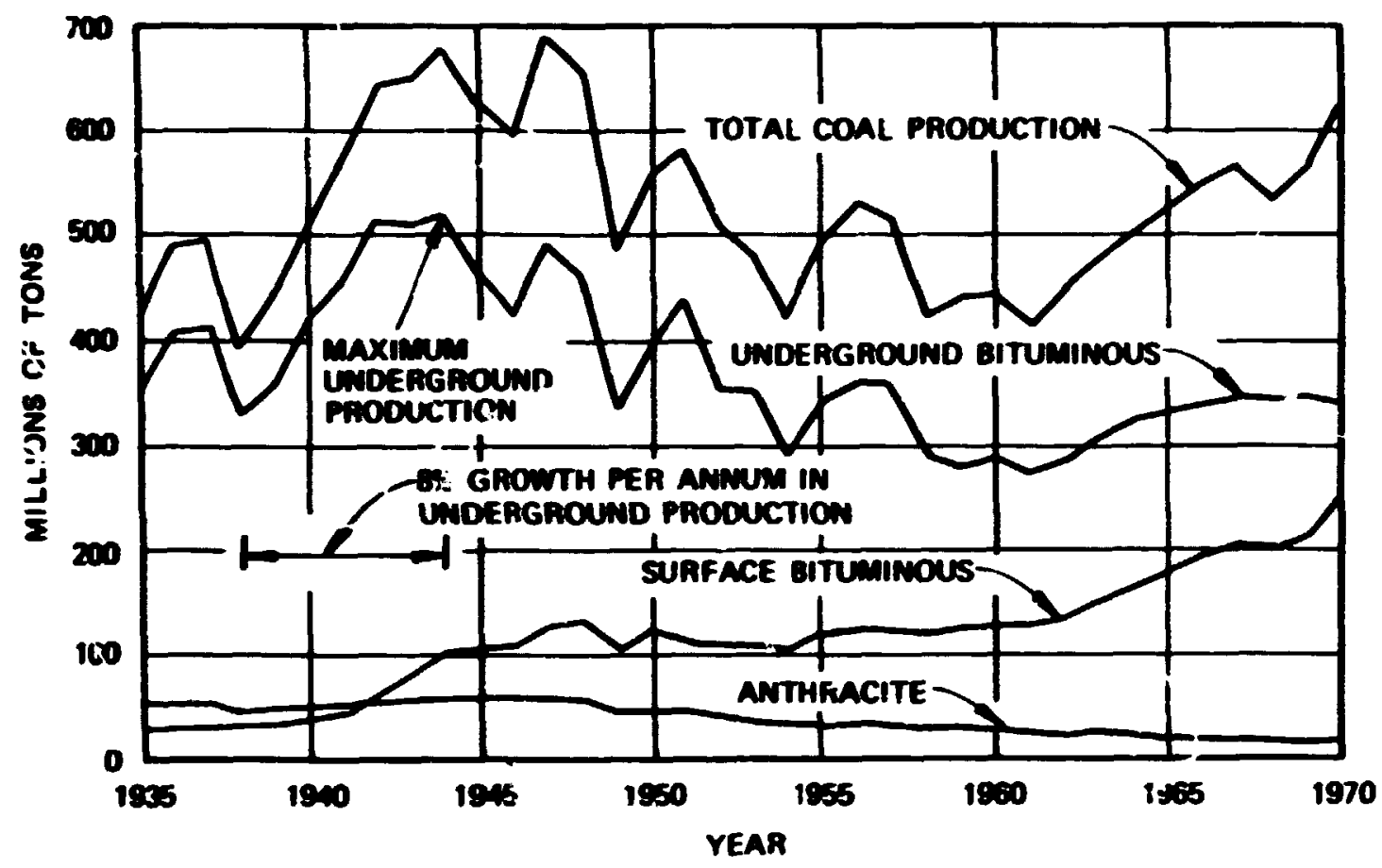

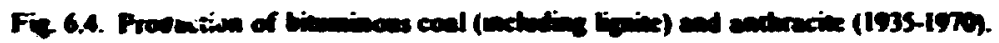

kenders. Neverticless, the avaibbility of capital woild not appeat to be seriously restrictive relative to the growth of the mining industry.

The time required to dzvelop a new mine is a definite limisation on the rate at which the coal indusery can respond to increased demands. It is estimated that the time required to develop a new mine and bring it to full production is 5 years for a deep mine and 3 years fur a surface mine." Debys in equipment procurement could increase these times. Examples of present eyuipment procurement probkems are kew drag lines for stripping (kead times of 4 to 5 years) and coof bolks for underground mines. Some believe that demands for heavy equipment will exceed the supply capabilitics of U.S. manufacturers and that some equipment will need to be imported." Oher studies" concludk that equipment delivery will pose no serious probtem in expanding mining capacity. Although there may be some near-term equipment delivery problems, it seems reasonable that the long-term development of coai mining capacity will not be limited by equipment availability.

Although there are differences in opinion on the question, it would appear that skilled manpower may be one of the more serisus limitations on the rate of mining expansion. The

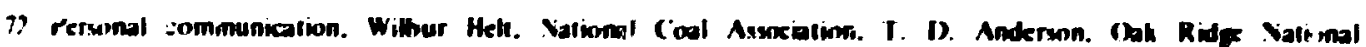
1 ehoratory

73. Prrmonal communication. Zane Murphy. U.S. Bureau of Mines, I. D. Andersm. Oah Ridge Vation. I I ahoralory.

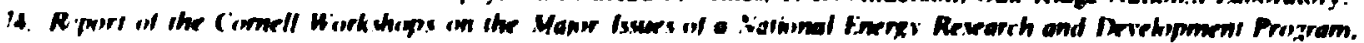

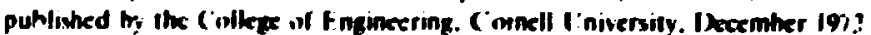


Aational Coal Association (NCA) points out that. be ause of a period of stagmation. in coal mining. the present work force is concentrated in wo age groups: over 45 and under 30 . The 30- to 45-year age group. which would nomally be expected to fill keadership roles in an expanding industry. is essentially missing. One specialty that is especinlly important for underground mining is mining engineering. and miniog engineers are in short supply"

Tranportation

Rail is by far the most impartant mode of transportation for coal, but water shipracnis are signitisani and are increasing raf Aly. Coal slurry (50 wt th water) pipelining ma also becume important in the iuture. especially fer westem coals that uijs be transported long distances to markets."

Duruig the 1960s. rail coal traffic ixxreases averaged 2.4\% year. "A greater rate of expansion in the future would seem to be required if coal is to phy a more significant roke in energy supply. The railroad industry currenity suffers from severe financial problems. and it is generally agreed that the Federal Government will need to underwrite the necessary modernization and expansion of railroads. The genead financial problems of the rail indus:ry have not had a noticeable effect on the invessment required for coal shipment: one reason for this is that sorte of the new investument for coal cars and terminal facilities has come from outside sot rees. priaxipally the electric utilities. Aside from futur: trazacial problems, these is substantial room for ir.provement in existing investment. For example. in 1968. open-top hopper (coal-carnjing) cars spent only 7.70 of the time in lire-hiul service (baded and empty movement in trains). ${ }^{i 0}$ The trend to greater use of unit trains would be expected is improve car utilization in the future.

3arge movement of coal, where applicable. is the most economical mode of transportation. A sifaifkant portion of coal movement is by joint raitwater transportation. Long-haul movements are the most rapidly gruwing portion of internal waterborne coal carringe. One of the more notable bong-haul movements is the carringe of southern llinois and Ohio Basin coal to Gulf Coast destinations such as New Orteans, Gatvestun, and western Fborida. Coel for coastal areas is transported to New Orkans by barge and transshipped by oceangoing vessek. Transshipment "in the New Orleans area increased from 0.6 million tons in 1960 to 3.1 million tons in 1969 . The NPC believes that a serious impediment to bng-haul coal movement is the inadequacies of locks at the central intercharige of sis navizable rivers on the boundary of southem llinois. The economic capacity of thesr locks has already been exceeded. and. although consuruction of new facilities has been initiated. the bottkeneck will not be removed before the bitter 1970s.

Transportation system expansion is particularly crucial if there is to be extensive use of the vast reserves of low-sulfur strippable coal in the west. especially in Wyoming and Montana. Some expanston is in the planning stage. The Burlington Northem Railroad and the American Commercial Barge Line plan to develop a raitto-bare cool terminal on the Missiasippi River in north St. Louis County. "The facility is expected to be completed in 1976 and will handle about 20 million tons of coal per year. Low-sulfur coal will be delivered to the kerminal by unit train from Wyoming and Montam and will be imansferred by barge to users served by the Mississippi River

75. The Poventid of Cod in Mert the Enerer Crisis. National Coal Aseociation. Dax. 20. 1973.

76. E. J. Wasp and T. L. Thompron. Tlumy Pipetines Energy Movers of the Future," Gil Gos J. 7I(52). 45-30 (1)ex, 24. 1973).

77 "Plans ior 2 New "nn facilinies Annownced." St. Lawis Chobe-Demorror. Jan. 30.1974. 
and its tritutaries. Other phas for pipelines into the midsouth and to Texas bave bee $n$ rumored. ben in conirmation is presently avaibuble.

\subsubsection{Denned}

The NPC" estimated that the demand for coal (Tabte 6.2) would grow from 590 miltion toas in 1970 to I billion tons in 1985. As noted eartier. the XPC atso estimaled that the potential productive capacity of the coal industry could increase by SF, year. resuhing in a polential capacity of 1.57 billion tons in 1935. Thus, according to this view. there will be an excess of polential capability over demand.

The XPC analysis was mode before the energy suppth disnuptions of 1973. The general viewpoiat now is that the Linited Stales should strive for energy independence. One inportant etement that will contribute to energy independence is the substitution of coal for oil and gas where it is feasible to do so. The ndustrial and utility sectors are the most adaptable to coal as a subsituce for other fossil ferts. To gain some insight into the effect of this substitution on coal demand. in is assumed that the projected grewth of fossil fuel use in the industrial and utility sectors after 1975 will be based on coal. Table 6.3 shows that this substitution would resul in an increase in demand of 300 miltion cons per year by 1985: adding this increase to NPC's original estimate would indicatie a total demand for coal of 1.3 billion sons in 1935. The NCA believes that the coal output in 1974 will be 640 miltion tons. An increase in annual production from 600 million to 1.3 billion tons in 11 years would imply an average growth mie of 6.4F year. Thus, if the growth of industrial and stectric utility fossil fuel use is to be based on coal. the growth of coal production must exceed the maxin.um rate of SPi year assumed by the NPC.

\begin{tabular}{|c|c|c|c|c|}
\hline & 1970 & 1975 & 1980 & 1985 \\
\hline $\begin{array}{l}\text { Coting conl } \\
\text { Dass furnuces } \\
\text { Fousdries anj mincellaneous }\end{array}$ & $\begin{array}{l}86 \\
10\end{array}$ & $\begin{array}{r}102 \\
10\end{array}$ & $\begin{array}{r}110 \\
10\end{array}$ & $\begin{array}{r}116 \\
10\end{array}$ \\
\hline Total & 96 & 112 & $12 i$ & 126 \\
\hline $\begin{array}{l}\text { Donestic coal (U.S.) } \\
\text { Residential/commercial } \\
\text { Industivl } \\
\text { flectix utilitics }\end{array}$ & $\begin{array}{r}10 \\
91 \\
322\end{array}$ & $\begin{array}{r}7 \\
87 \\
4 ! 3\end{array}$ & $\begin{array}{r}5 \\
525\end{array}$ & $\begin{array}{r}3 \\
650\end{array}$ \\
\hline Total & 519 & 621 & 734 & 863 \\
\hline $\begin{array}{l}\text { Fxport coal } \\
\text { Coking cool } \\
\text { Electric ufidity }\end{array}$ & $\begin{array}{l}56 \\
\text { is }\end{array}$ & $\begin{array}{l}76 \\
16\end{array}$ & $\begin{array}{l}94 \\
17\end{array}$ & $\begin{array}{r}120 \\
18\end{array}$ \\
\hline $\begin{array}{l}\text { Total } \\
\text { Totap }\end{array}$ & $\begin{array}{r}71 \\
590\end{array}$ & $\begin{array}{r}92 \\
713\end{array}$ & $\begin{array}{l}111 \\
845\end{array}$ & $\begin{array}{r}138 \\
1001\end{array}$ \\
\hline
\end{tabular}

OThese quantities are kess than the istal demand figures shown in

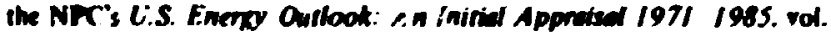
I (Juby 1971). because thoy do nc I include "Asaumed Repbcement for Shortiall in Other fivet Supplies." The added quantities for coal, in rerms of cons of creai, movid be 30 miflion tons in 1975; 65 million tons in 1980: and 70 million tons in 1985. 


\begin{tabular}{|c|c|c|c|c|}
\hline & \multicolumn{3}{|c|}{ 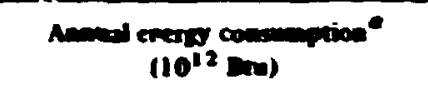 } & \multirow{2}{*}{ 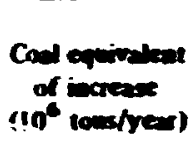 } \\
\hline & 1975 & 19:2s & Ints-ises & \\
\hline Nerrolem & $\begin{array}{l}10.050 \\
15540\end{array}$ & $\begin{array}{l}15.700 \\
16.400\end{array}$ & $\begin{array}{l}5.450 \\
1.150\end{array}$ & $\begin{array}{r}247 \\
50 \\
\end{array}$ \\
\hline Toul & 25,630 & 32.470 & 6210 & 297 \\
\hline
\end{tabular}

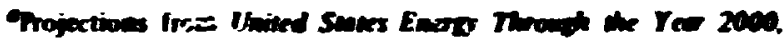

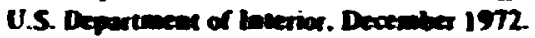

\subsection{Crelcoss}

\section{Coal velues at aine}

Treach, past and presen Aft ir a bage period of stability, the price of coal started rising signiftcantly after 1969. From I965 through 1969, the U.S. avenge price (f.o.b. mine) of conl sold on the open

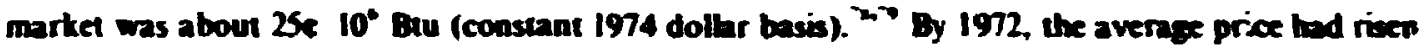
to about 35e $10^{\circ}$ Beu. Figure 6.5 shows the price trends through 1972. the hst year on whic.: complete data are avaibble. The U.S. averaye prices tend to reflect the value of coal mined east of the Mississippi. Abo shown in Fig. 6.5 are prices for subbituminous coal and liznite produced in selerted western states; generally. prices for westem coal have tended to decline with time-at least :hrough 1972.

The data of Fig. 6.5 are bosed on reports by the U.S. Bureau of Mines 2000 and the National Coal Association." Modifications to the original data were made to conven from cust per unit weight to cost per unit energy and to convert to a constant $19^{-} 4$ dolbr basis. Ahhough the heating value of coal varies substantially even within a given rank. the following values. used by the NPC." were adoped for this study:

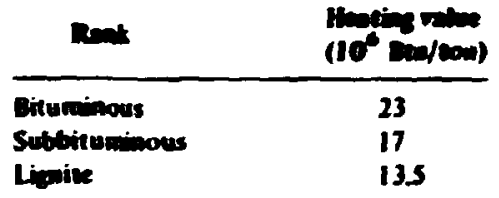

Price adjustments to January 1974 were mode using the wholesele price index for industrial commodities.

Although there are no compilations of current coal prices. it is evident from various reports that coal prices. along with those of other fuels, rose dramatically in ble 1973 and early 1974.

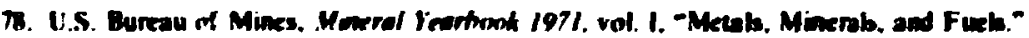

79. National Ccal Aseociotion. Binuminowus Coul Dave 1970 Edition. March ImI.

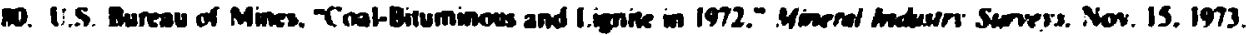

81. National Coal Asanciation. Dinminomes Coul Faris 1972. 


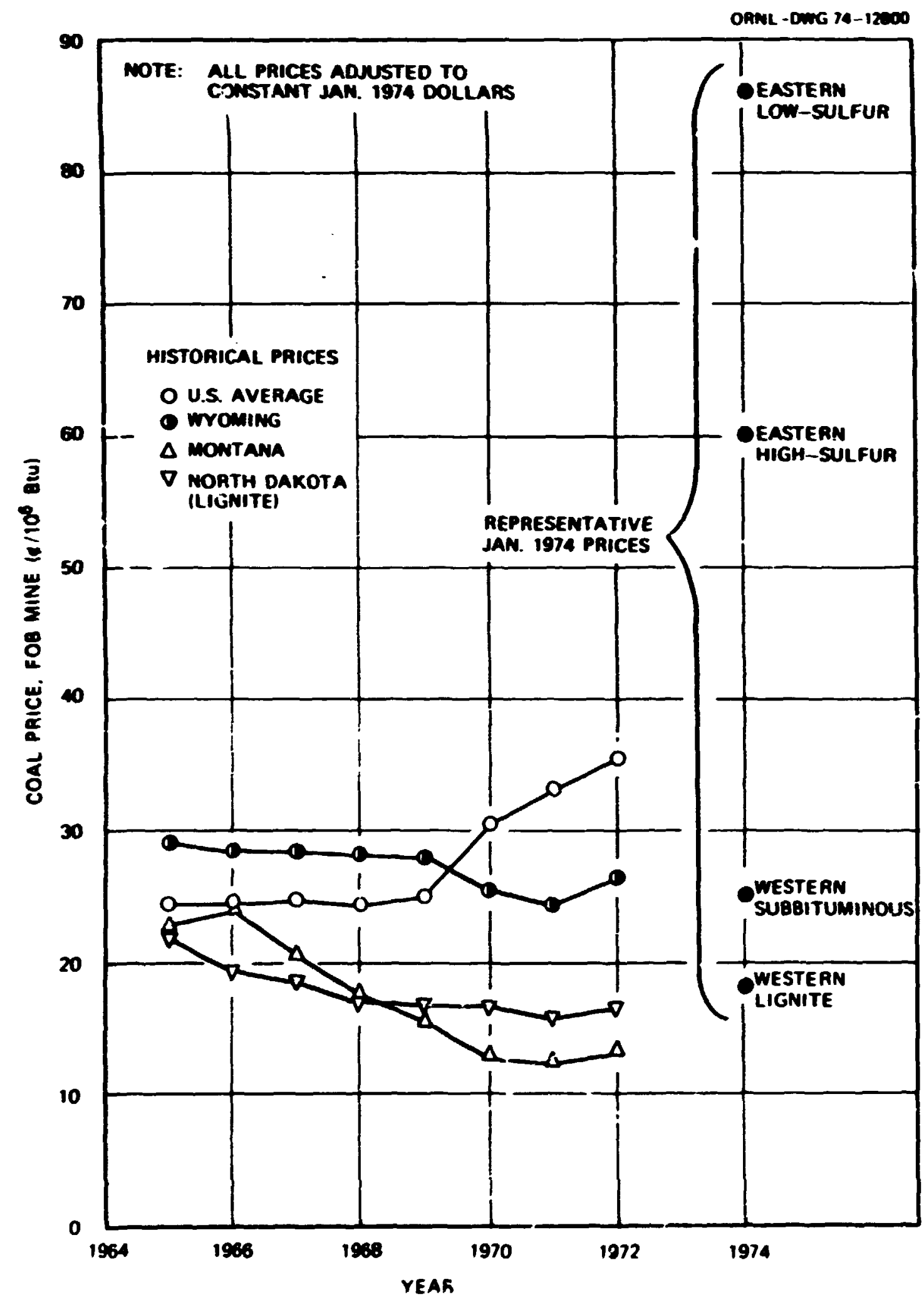

Fie 6.5. Treade in eod priest. 
The Teanessec Valley Authority (1 VA)" reponts that prices mane from 58 to 530 per ton (f.o.b. mine). depending on the type of contract. qualing of coal and location. A reasomable range for high-sulfur (3 10 4\%) strip-mined coal from western Kentucty and sombern Itinois is $\$ 12$ to $\$ 18$ per ton (f.o.b. mine) or SOc to 75x $10^{\circ}$ Bu. Coal purchases" for AIC phats in Kentucty and Tenass $x$ mode in the Gill of 1973 were at a price of 59.75 lon. Recent (Jamary 1974) prives were aboun 515 per ton (3.45 sulfur. 12500 Deu B) or 60e $10^{\circ}$ Bue. De Sounh Carolian Public Servize Authority reperted" a coal price increase of 399, in the bst five mondus of 1973. As of Jan. 1. 1974. the detivered price was $\$ 17.25$ per ton. After allowing for transportation, the mine price is inferred to be $\$ 12$ to 514 per ton. Public Serice Electric \& Gas Company (New Jersy) (PSERG) paid an average of 525.36 per ton fo: "ww-salfur coal delivered duriag Jamang 1974." This represenved a 47, increase from the average price in October 1973. The range on Jamanry 1974 delivered prices paid by PSERG was from 522.90 per ton for coal under coneract to $\$ 2951$ per ton for spot purchases. These figures sugesest a mine price of S18 10 S2S per loa for eastern bow-salfur coal.

Recent data avaibble on westem coal prices are stetchy. Netrasta Public Power District purchased Colorado and Wyoming bow-sulfur coal for 5Sc to $62 \mathrm{c} 10^{\circ}$ Bu (delivered) daring Oetober and November 1973. Allowing 55 per con for delivery to ptants at Lincoln and Beflive. the derived mine coes would be 30e to 43e $10^{\circ}$ ber.

November 1973 purchases by Bbct Hills Power aad Lighine" of subbituminous bow-sulfur coal from Wyoming for phens at Oxage. Wyoming and Led. S.D. ranged in delivered prices from 20.3e to 32.8e: $10^{\circ}$ Btu. Since the power phans are rebtivety near coul fields. the transportation cous would presumably be on thr order of Se $10^{\circ}$ Bet. Receat delivered prixes": of tignite at phats in North Dakota and Momama ranged from II.6c to 28.7c. $10^{\circ}$ Bu. Since these power phuts are wear the lignite deposits, the trassportation component of the delivered price shesuld be small. The general impression is that westert coal prices have not increased as substantiaing as thore for eastern coal.

Representative prices derived from the sources described above. shown in Table 0.4. range from 186. $10^{\circ}$ Btu f,r western lignite to $861^{\circ}$ Btu for castern low-sulfu: bituminous coal. In

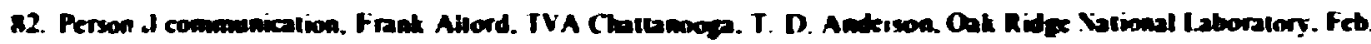
15. 1974.

83. Personal commoniotion. Mariin Schwem. Union Cartide Mucker Divivion. Oak Ridk. Tena.. T. D. Andersea. Oak Ride National Laboratory. Feb. IS. 1974.

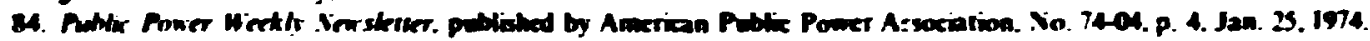

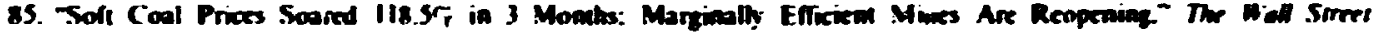
Jinumel. Feb. B. 1974.

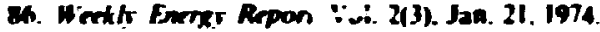

87. Eleririral wient. Feb. II. 1974.

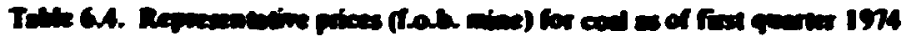

\begin{tabular}{|c|c|c|c|c|c|}
\hline & \multirow{2}{*}{$\begin{array}{l}\text { Hating } \\
\text { Dalece } \\
\text { (Exw/B) }\end{array}$} & \multicolumn{2}{|c|}{$\operatorname{Cos}(s / 100)$} & \multicolumn{2}{|c|}{$\operatorname{Cos}$ pa $10^{\circ}=10$} \\
\hline & & Value & $\operatorname{Ron} 2$ & Valas & 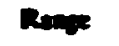 \\
\hline \multicolumn{6}{|l|}{ Nituminoms (exstetn) } \\
\hline $\begin{array}{l}\text { Hiph siffer (>35) } \\
\text { Low solfer }(<13)\end{array}$ & $\begin{array}{l}11500 \\
11500\end{array}$ & $\begin{array}{l}14 \\
20\end{array}$ & $\begin{array}{l}10-18 \\
16-25\end{array}$ & $\begin{array}{l}60 \\
86\end{array}$ & $\begin{array}{l}43-78 \\
69-103\end{array}$ \\
\hline \multicolumn{6}{|c|}{ Sobbituminow (watern) } \\
\hline Low selfer $\quad 0.5 \%$ & 8,500 & 4.25 & $3.40-6.20$ & 25 & 20.40 \\
\hline \multicolumn{6}{|l|}{ Lipine (mestern) } \\
\hline Low sedfor $(-0.5 \%)$ & 6.750 & 2.50 & $1.60-3.25$ & 18 & $12-24$ \\
\hline
\end{tabular}


determiniags the future applicability of coal to industrial and other uses, it is necessang lo judge whelber the recent brge price increases for eastern coal represent a respono to a short-term supply-dewand simation or whether they are permanent. This yoestion is examined in the following section.

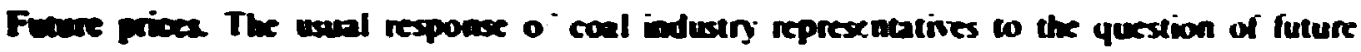

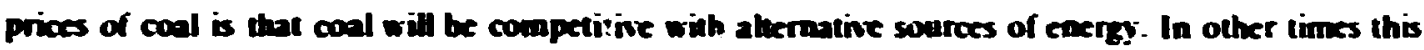
observation might be useful bu with the preseat thad situation on supply and price of other fucts. particularty petroleven. the anabsis of competivine posinions of various fucts is highty speculative. Teverthera: one point of conpetition for energy that is rensonably well defined is the electric poner industry. Moa projections asoune that nuctear and coal will be the basic fuels used in the future expansion of the power indestry. The cost of auchar electric power stould therefore influence the price of coal. A cos study was ande of central station auctear and coal phenes to determine break evea priass for coal (ice. the price of coal that would recult in coalfored central station ptants being competiaive with auctar). The basic cost assumptions used in the anabsis are shown in Table 6.5.

Results for bese-baded (00, phat Ector) phats are given in Table 6.6. For a coal-fired central station phan burning high-sulfur coal with stack-eas sulfur-removal epquipuent, the 1974 break-even value of coal is $24610^{\circ}$ Deu (S5.50 toa) detinered to the power plant. The break-even value would be expected to increase to 50 . 10 b4u(5I I.50 ton) by 1991 . For a ptam using low-sulfur coal and no stactps sulfar-removal equipment. the break-ven values are ene and $75 e$. $10^{\circ}$ Beu for 1974 and 1991 respectiveb. These figures indicate that the delivered value of low-sulfur coal is $25 e$. 10 Btu greater than that of high-sulfur coal.

For power pants constructed to meet intermediate-bad demands (40\% phant betor). the competitive position of coal is considerably improved. as indieated in Tabk 6.7. The delivered brak-even value for high-sulfur coal is $46.10^{\circ}$ Bru in 1974 and increases to $87 \mathrm{e} .10^{\circ}$ Bqu in 1991 .

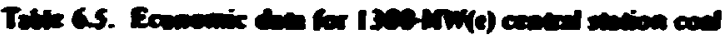

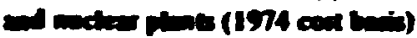

\begin{tabular}{|c|c|c|c|}
\hline \multirow[b]{2}{*}{ Cost item } & \multirow[b]{2}{*}{$\begin{array}{l}\text { Lifhemater } \\
\text { reactor }\end{array}$} & \multicolumn{2}{|c|}{ Cousfived plant } \\
\hline & & $\begin{array}{l}\text { With } \\
\text { sack ofs } \\
\text { clemanp }\end{array}$ & $\begin{array}{l}\text { Widhout } \\
\text { stact th } \\
\text { chenup }\end{array}$ \\
\hline 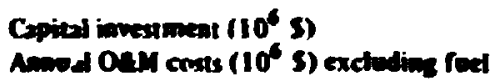 & 546 & 450 & 385 \\
\hline $\begin{array}{l}\text { Fisced } \\
\text { Varivile: }\end{array}$ & $\begin{array}{l}4.48 \\
1.90\end{array}$ & $\begin{array}{c}7.1 \\
12.82\end{array}$ & $\begin{array}{l}3.75 \\
3.36\end{array}$ \\
\hline Total & $\overline{6.38}$ & $\overline{19.92}$ & $\overline{9.11}$ \\
\hline $\begin{array}{l}\text { Fad } \cos { }^{\circ}\left(1 / 10^{6} \mathrm{mo}\right) \\
1974 \text { startip } \\
1901 \text { startiop } \\
1991 \text { sartop }\end{array}$ & $\begin{array}{l}19.0(13)^{\circ} \\
31.0(20)^{\circ} \\
41.0(23)^{\circ}\end{array}$ & & \\
\hline
\end{tabular}

- Eused an ros phant factor.

Cosis rebied to burnop. 


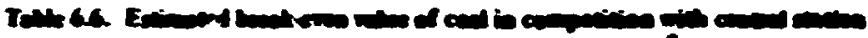

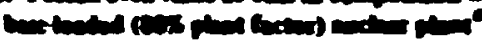

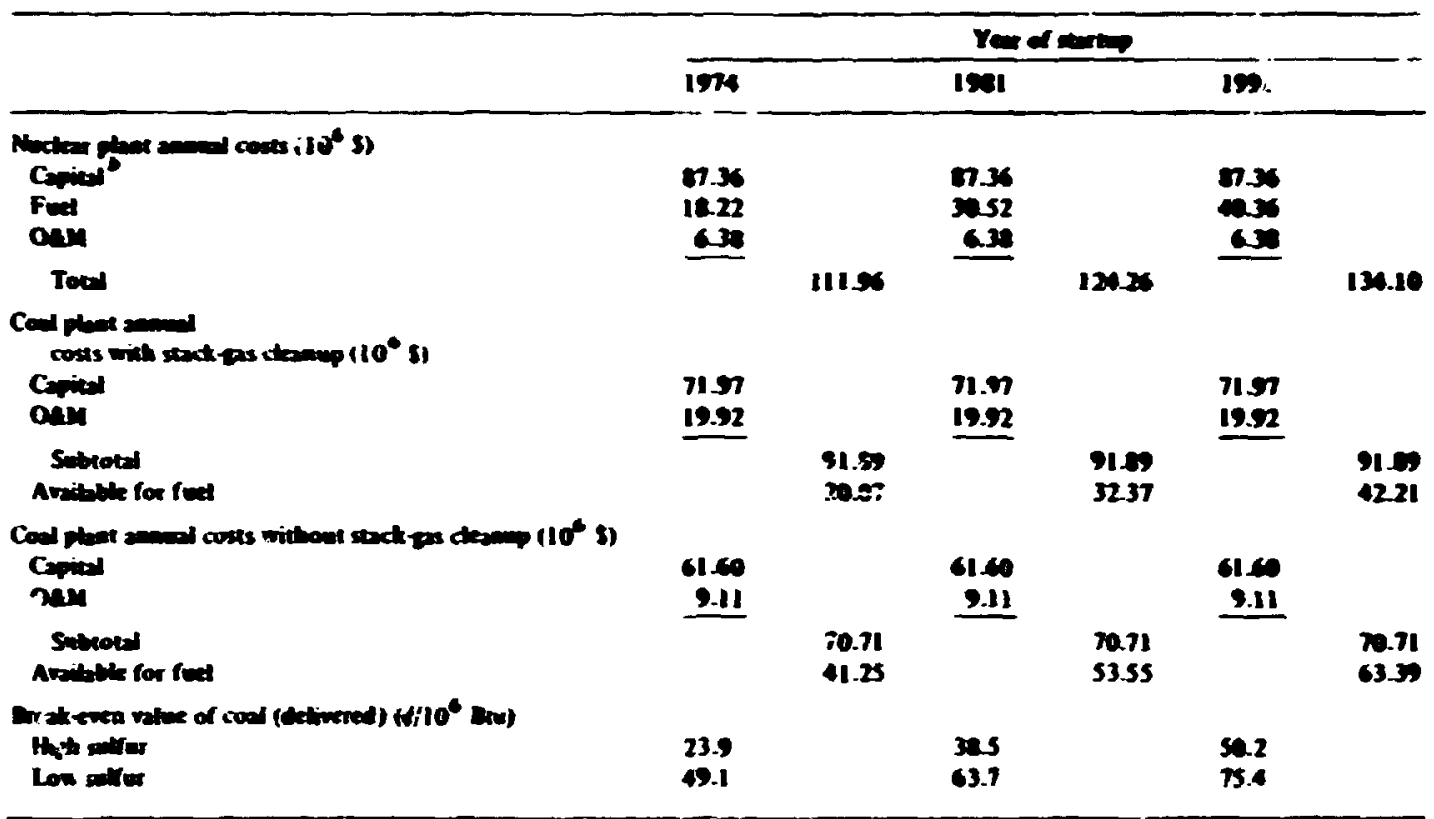

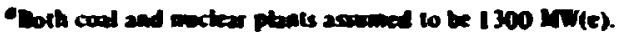

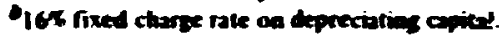

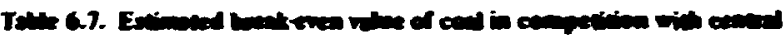

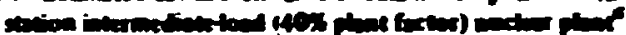

\begin{tabular}{|c|c|c|c|c|c|c|}
\hline & \multicolumn{6}{|c|}{ Yex of startip } \\
\hline & 1974 & & 1981 & & ISs! & \\
\hline \multicolumn{7}{|c|}{ Neclear fbat anaual cosis $\left(10^{\circ} \mathrm{s}\right)$} \\
\hline Caprta' & 97.36 & & 87.36 & & en.36 & \\
\hline Fued & 12.00 & & 20.67 & & 29.04 & \\
\hline orM & 5.43 & & 5.43 & & 5.43 & \\
\hline Solal & & 104.79 & & 113.46 & & 121.83 \\
\hline \multicolumn{7}{|c|}{ (oal plant annual costs with siact tas cleapop $\left(10^{\circ} s\right)$} \\
\hline Capital & $71.9 ?$ & & 71.97 & & $71 . .7$ & \\
\hline osix & 13.51 & & 13.51 & & 13.51 & \\
\hline Subtolal & & $\mathbf{8 5 . 4 8}$ & & 85.48 & & 25.4 \\
\hline Avaibbic for fuet & & I9.3I & & 27.96 & & 3.35 \\
\hline \multicolumn{7}{|c|}{ Coal plant annual costs without slack tes ckanup $\left(10^{*} \mathrm{~s}\right)$} \\
\hline Capilal & 61.60 & & 61.60 & & 61.07 & \\
\hline OMM & 7.43 & & 7.43 & & 7.43 & \\
\hline $\begin{array}{l}\text { Subtotal } \\
\text { Araibble for fuel }\end{array}$ & & $\begin{array}{l}69.03 \\
35.76\end{array}$ & & $\begin{array}{l}69.03 \\
4.43\end{array}$ & & $\begin{array}{l}\mathbf{6 . 0 3} \\
52.00\end{array}$ \\
\hline \multicolumn{7}{|c|}{ Break even value of corl (delivered) $\left(\$ / 10^{\circ}\right.$ Bur) } \\
\hline Iligh sulfur & $\mathbf{4 . 0}$ & & 6.6 & & 06.5 & \\
\hline Low sulfur & 85.1 & & 105.7 & & 125.7 & \\
\hline$\ldots$ & & $\ldots \ldots$ & . & 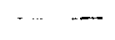 & $\cdots$ & $-\cdots$ \\
\hline
\end{tabular}




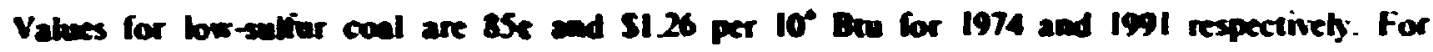

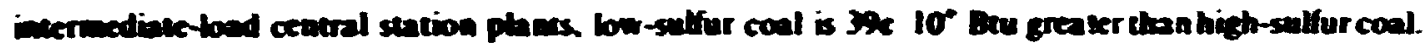

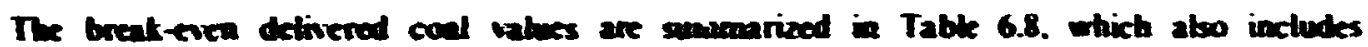
extimated wive values for both asken bituminoms conl detivered to castern power plants and

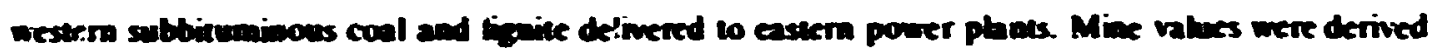
using trasportation costs of $5:$ and 510 per wo for easuern and western conl respectivety. The 1 istern coal mime values are applizaite to poner phens bocated reasomably ctose fon the order of 200

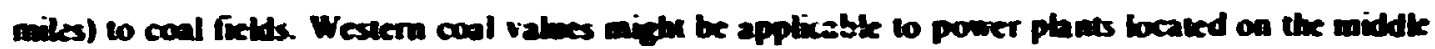
to bower Othio River.

Another sousce of information on possibte future coal prices is the study made by the NPC." They developed ecomomic usidets for surface and deep mining applicabte to coal produced cast of the Misciscippi. For dexp-sined coal. and assumine a ISf discouned cash flow rak of return, the reselts indicated a shap rixe in price to the mid 1970 s. keveling out at about $50 \mathrm{10} 10^{\circ}$ Bin (adjusted to January 1974 dollars). Surthoe-mined coal wnuld rive at a kswet rake bet over a bager period of tive, reacting aboun 36e $10^{\circ}$ beu by Ises.

Figure o.d sumanarizes the projections of the NPC. the breatever values extimated in the present study for bigh-sulfer eastern coal. hislorial inends in average coal pricas. and earb; 1974 representative prices. Figure 6.7 presents simibr data for westem bow-sulfur subbituminous coal. For castern high-sulfur coel. it is conchuded that the curreat price kevels cannot be sustained if coal is to make a significant comribution to new cemal station power generation. On the ofher hand. it is also evident that prices will not fall bos enough. at bast in the foresceable future. so that eastern high-sulfur coal will be competitive with nuckear pbnts for base-bad central station power generation: competitive price ketets of coal for this application woult not ene adequale profitability even for strip-mined coal. For purposes of the present study, a base price (f.o.b. mine) of Sox $10^{\circ}$ Bu. with a range of 406 to $60 \mathrm{Oc} 10^{\circ} \mathrm{Bru}$. was assumed. since this price kvel would appear to give an adequale retum and still allow some degree of competitiveness with nuclear for non-base-tad power exmeration.

\begin{tabular}{|c|c|c|c|c|c|c|}
\hline & \multicolumn{3}{|c|}{ Dan } & \multicolumn{3}{|c|}{ 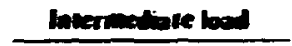 } \\
\hline & 1974 & Isal & 1991 & 1974 & 1981 & 1991 \\
\hline 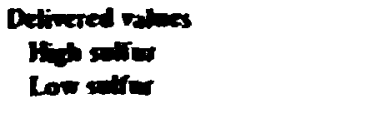 & $\begin{array}{l}24 \\
49\end{array}$ & 3 & $\begin{array}{l}\text { so } \\
75\end{array}$ & $\begin{array}{l}46 \\
85\end{array}$ & $\begin{array}{r}67 \\
106\end{array}$ & $\begin{array}{r}87 \\
126\end{array}$ \\
\hline 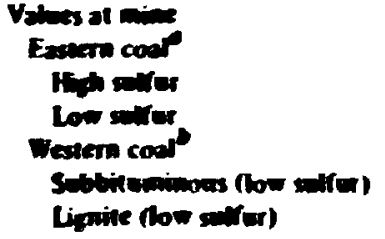 & $\begin{array}{l}15 \\
40 \\
0 \\
0\end{array}$ & $\begin{array}{l}30 \\
55\end{array}$ & $\begin{array}{r}42 \\
67 \\
16 \\
1\end{array}$ & $\begin{array}{l}37 \\
76 \\
26 \\
11\end{array}$ & $\begin{array}{l}52 \\
92 \\
47 \\
? 2\end{array}$ & $\begin{array}{r}78 \\
117 \\
67 \\
52\end{array}$ \\
\hline
\end{tabular}

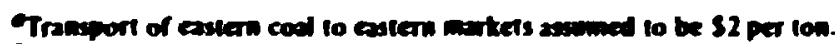

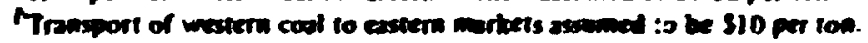




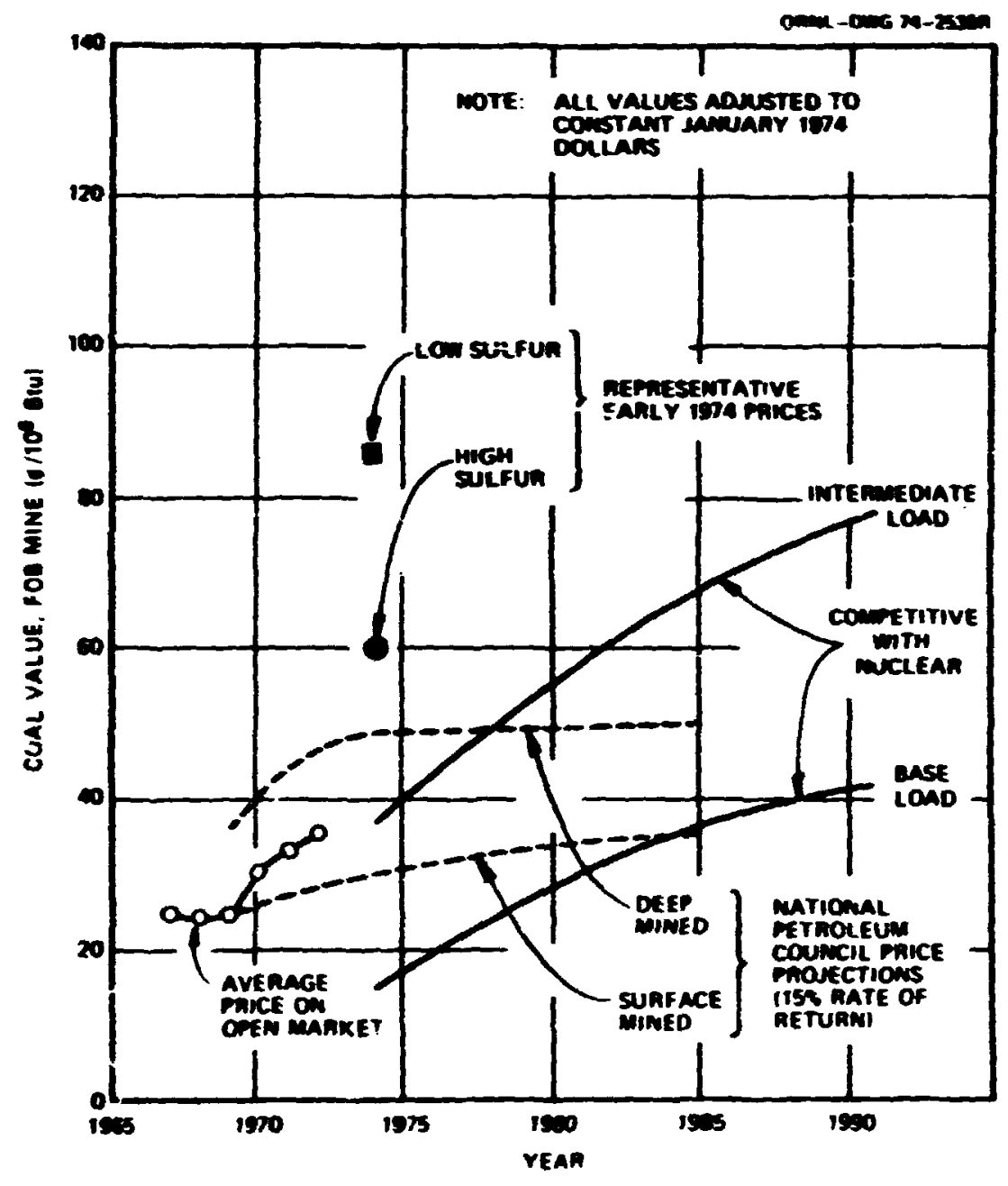

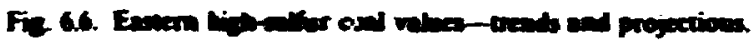

Concerning western low-sulfur coals. it appears that (1) lignite is not of great incerese for distant markets twasuse of high tsasportation costs and (2) subbituminous coal will have a rasonable amount of non-base-tond use at prices near current kvets. For the present study a base price (f.o.b. mine) of $30 \mathrm{C}: 10^{\circ} \mathrm{Btu}$. with a mage of $24 \mathrm{c}$ to $36 \mathrm{e} 10^{\circ} \mathrm{BCu}$, was assumed.

\section{Tramportation con}

Long-distance moversent of coal is by rail. barge, and, in one caxe. pipeline. Rail is by far the most important form of imasportation, but barge muvement on inland waterways is sienificant. Coal slurry pipelines are expected by some to become an imporant made of transportation, especially for moving westem coals to rejions of high energy use.

Rail. The average coss for coal shipment by mil is about $10 \mathrm{milts} /$ ton-mik." Rates are influenced by a number of factors, the most important of which are (1) dianance. (2) volume, and (3) mode of shipment (by individual ar, or by unit tmin). TVA data" for one particulat poser plant. 


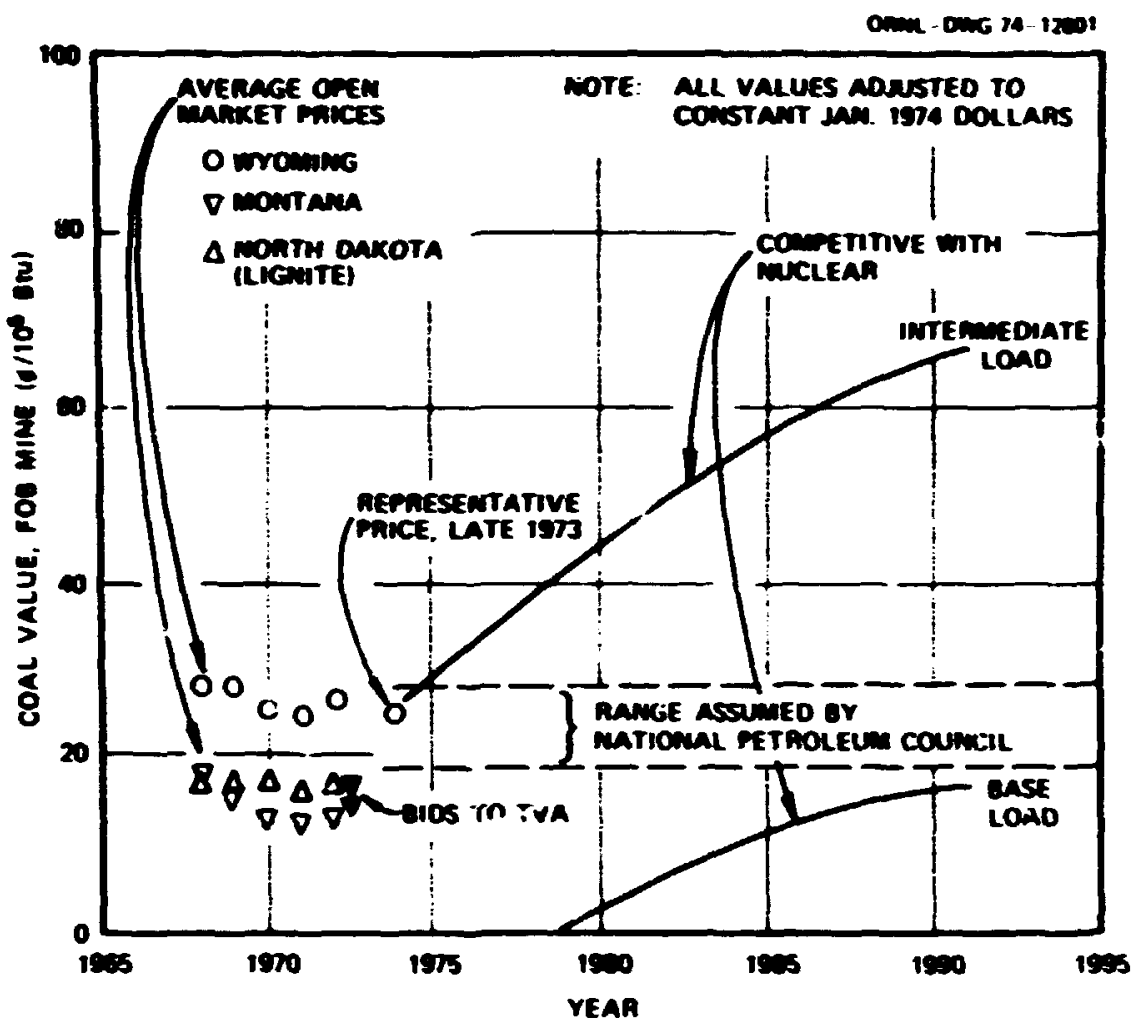

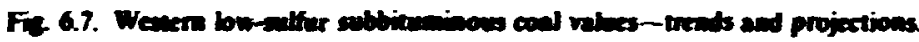

located approximateh 100 miks from the mine. indicate rates of about 14 mills ton-mik for individual cars and 13 mills ton-mik for unit train. In a study of coal pipelines. Wasp and Thompson " suggested 5 to 6 mills ton-mik for kong-haul unit trains. The NPC" indicated a mate of 5 mills for some unit-train hauls. The 1970 Vational Power Survey" presented a range of 3.5 to 8 mills ton-mike for unit train and 1.5 to 4 mills for integral coal trains. Burlington Northern's estimate. as reponed by Oak Ridge National laboratory (ORNL.)." for unit train transport of western coal from Gilktte. Wyo., to St. Lovis, Mo. (1074 miles), is 55.94 per ton or 5.5 mils ton-mik.

For evaluation perposes, it is assumed that short haul $\sim 100$ miles) rail transport would cost 13 mills ton-mile with a range of 10 to 15 mills ton-mik. Long-haul (500 miks) rates were assumed to be 5.5 mils ton-milewith a range of 4.5 to 6.5 mills.

Bare. Unitaf. States average barge mates are reported" to be 3 milis,ton-mile and. with large-volume ghéfiracts. as low as 2.5 mils. $\Lambda$ n ORNL study" indicated a rate of 3.5 mills ton-mile for barge shi, inent of coal from St. Louis, Mo.. to Madison. Ind. In the present study, a base rate of 3 mills ton-mue. with a ravize of 2.5 to 3.5 mills. is assumed.

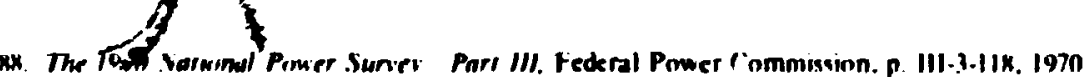

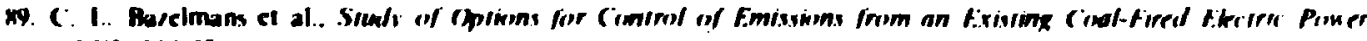
SizIken. ORNI. IM-A9H. 
Pipalie. Wasp and Thompson" derived sherry pipeline costs for various transport distances and capacics. For a 1000 -mik pipeline. estimakd roses ranged from 3 milts of I8 million tons year to 6.5 mills ton-mik for 6 million tons year. A representative value of 4 milb. with a range of 3 to 6.5. was selected for the present study.

Uait cos somary. Basic unit iransponation cost data for bog hauts assunzed for the present study are summarixed in Table 6.9. The costs (c $10^{\circ}$ Stu) for 100 miles of movement for three rakks of coal were derived using assumed heating ialues discussed previously.

\section{Delinered onl cons}

Cost cotimates of various con!s delivered to the Houston. Tex., and New Orleans. La.. areas are shown in Table 6.10. These dala were deived using previously discussed assumptions conceming coal and tronspotation costs. The source of eastem coals was assumed to be either southern Iltinois or western Kentucky. Coal would ice iraniported from the mine by rail ( 50 miles) and transierred to barge for delivery via the Missinsippi River to New Orleans (1000 river miles) or to Houston (IS00 mikes). Western subbituminoess coal was assumed to originate in Wyoning and be shipped to St. Louis by unit train (1100 miles). transfe.red to barge. and shipped to New Orleans (1075 miles) or

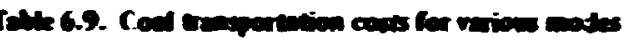

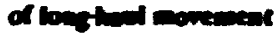

\begin{tabular}{|c|c|c|c|c|c|c|}
\hline \multirow{3}{*}{ rool type } & \multicolumn{6}{|c|}{ Cost per 100 mides $\left(d 10^{6} \mathrm{Dm}\right)$} \\
\hline & \multicolumn{2}{|c|}{ Unit train } & \multicolumn{2}{|c|}{ Dare } & \multicolumn{2}{|c|}{ Fipeline } \\
\hline & Dase & Rone & Dase & Rane & Dase & Range \\
\hline $\begin{array}{l}\text { Siluminous } \\
\text { Sebbiluminoms } \\
\text { lipaite }\end{array}$ & $\begin{array}{l}2.4 \\
3.2 \\
4.1\end{array}$ & $\begin{array}{l}2.0-2.8 \\
2.6-3.8 \\
3.3-4.8\end{array}$ & $\begin{array}{l}1.3 \\
1.8 \\
2.2\end{array}$ & $\begin{array}{l}1.1-1.5 \\
1.5-2.1 \\
1.9-2.6\end{array}$ & $\begin{array}{l}1.7 \\
2.4 \\
3.0\end{array}$ & $\begin{array}{l}1.3-2.8 \\
1.8-3.8 \\
2.2-4.8\end{array}$ \\
\hline
\end{tabular}

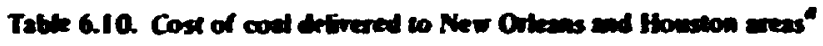

\begin{tabular}{|c|c|c|c|c|}
\hline & \multicolumn{4}{|c|}{$\operatorname{Cost}\left(\alpha / 10^{\circ} B t u\right)$} \\
\hline & \multirow{2}{*}{ Transportation } & \multirow{2}{*}{$\begin{array}{c}\text { Coal } \\
\text { (f,o.b. mine) }\end{array}$} & \multicolumn{2}{|c|}{$\begin{array}{c}\text { Total delivesed } \\
\text { cost }\end{array}$} \\
\hline & & & Bax & Range \\
\hline $\begin{array}{l}\text { Eastem high-sulfur coal } \\
\text { To New Orkans area } \\
\text { To Houston area }\end{array}$ & $\begin{array}{l}18 \\
24\end{array}$ & $\begin{array}{l}\text { so } \\
\text { so }\end{array}$ & $\begin{array}{l}68 \\
74\end{array}$ & $\begin{array}{l}55-81 \\
60-88\end{array}$ \\
\hline $\begin{array}{l}\text { Eastern low-sulfur coal } \\
\text { To New Orlean ; area } \\
\text { To Houston area }\end{array}$ & $\begin{array}{l}18 \\
24\end{array}$ & $\begin{array}{l}80 \\
80\end{array}$ & $\begin{array}{r}98 \\
104\end{array}$ & $\begin{array}{l}85-110 \\
90-118\end{array}$ \\
\hline $\begin{array}{l}\text { Western subbituminous coal } \\
\text { To New Orleans area } \\
\text { To Houston area } \\
\text { Via New Orkans } \\
\text { Direct unil train }\end{array}$ & $\begin{array}{l}57 \\
66 \\
45\end{array}$ & $\begin{array}{l}30 \\
30 \\
30\end{array}$ & $\begin{array}{l}87 \\
96 \\
75\end{array}$ & $\begin{array}{l}71-103 \\
78-114 \\
60-89\end{array}$ \\
\hline
\end{tabular}

-First quarter 1974 prices. 
Houston (1575 miles). An aluernative for the Houston area is stipment by unit train directly trom Wyoming (1400 miles).

\subsection{CONVENTIORIAL FIRING WTHH COAL}

\subsection{Low-Sufur Coal with Comemional Boiners}

Low-sulfur eastern and western coals may be used to fire steam boikers with no special stack-gas eleaning reauired. since sulfur dioxide (SO), emissions generally do not exceed the Environmental Protection Agency (EP.1) standard of 1.2 lb per $10^{\circ}$ Btu heat input. However. particutate-removal equipment. usually an electrostatic precipitator. will be needed to meet the requirement oi 0.1 lb 10 Btu set by EPA.

A wide selection of coal-fired boikers is offered by U.S. manufacturers which will produce steam at various temperature and pressure conditions of interest for noost industrial applications in sizes ranging from a few hundred pounds per hour to several million pounds per hour. Boikers employing either spreader-gtate or putverized-coal firing are offered in sizes up to about $0.5 \times 10^{\circ}$ tb of steam per hour. Larger boikers are conventionally fired with pukerized coal.

Eastern coais generally have a higher ash content (some up to 20 wt $T$ ) than westers caabs (typically 4 to $8 \mathrm{wt}$ ( $)$ : conseyuently, ash-handling and dispeeal costs will be higher for most castern coals. Westem coals generally have a higher moisture content. 12 to 37 wi $\mathrm{F}$ (eastem coals 1 to $6 \mathrm{wt}$ (c). and lower Btu content (8500 Biu lb) than eastern coals (1I.500 to 14.500 Btu lb). Thus the type of coal used will influence th: design and cost of boiker equipment.

Coal sized for spreader-grate firing may not be readily avaibble in some sections of the country. since relatively few mines have appropriate equipment to produce this size coal.

For estimating purposes, a cost of $\$ 20$ to $\$ 25$ per pound of steam generated per hour appears reasonable for the installed capital cost of a complete coal-fired boiker plant in the size range of 1 to $3 \times 10^{\circ} \mathrm{lb}$ hr using pulverized coal. Most steam plants built in temperate climates. such as the southwest and south central states. require only minimum shelter for protection against winter weather. Retrofitting an existing gas- or oil-fired boike to use coal is generally not practical.

\subsubsection{Conventional Boikers with Stack-Ges Treatment}

Fnyironmental Protection Agency standards for new fossil-fuel-fired steam generators require that sulfur dioxide emissions in stack gases not exceed $1.2 \mathrm{lb}$ per $10^{\circ}$ Btu heat input ( $\max 2 \mathrm{hr}$ average) when solid fossil fuel is burned. This is equivatent to $0.7 \%$; sulfur for bituminous coal. Consequenly. any coal containing more than about $0.7 \%$ sulfur which is to be used for firing a steam generator will necessitate some form of sulfur removal, either from the coal before it is burned or from the stack gas.

Over 100 stack-gas scrubbing processes have been proposed: however. only about a dozen have reached the pilot plant or demonstration stage. These pr.cesses may be divided inio three broad groups: throwaway crubbing, regenerable scrubbing. and dry processes.

Almost all the scrubbing processes remove $\mathrm{SO}_{2}$ (an acidic gas) with an aqueous solution or slurry of alkaline material. These processes require a scrubber with liquid recirculation and mist elimination. gas fans, ductwork and dampers. and gas rehrat to restore plume buoyancy. If fly-ash particulates are not removed by an electrostatic precipitator, the scrubher system generally must he 
expanded to alkw for particubte as well as $\mathrm{SO}$ : removal. expecially with regencrable scrubbing. hecause particubtes are usually unacepable in the regeneration system.

The scrubbing processes all require alkali-handling sţstems to provide for alkali makeup and for product recoveny or disposal. The throwaway processes generally dispose of remoted sulfur as a waste sludge of cakium sales and require greater than stoichionetric input of alkali. Since the regenerable processes conven product solutions or solids to sulfur or sulfuric acid and recuele altali. very litik alkali makeup is required.

\subsection{Throwang Serribies}

The lime and limestone shurry scrubbing processes have the greatest commercial appeal to the C.S. utilities. The the gas is scrubbed with a 5 to 1 gri slurry of cleium sulfite sulfate containing small amounts of continuoushy added lime $(\mathrm{CaO})$ or limestone $\left(\mathrm{CaCO}_{3}\right)$. The solids are continuoushy separated from the shurry and uswally disposed of in a settiag pond. The processes are complicaled by simultancous dissolution and crystallioation of the solids in the scrubber. Calcium scaling and pluzging can occur in the scrubber and demister. and sufficient residence time and lingud recircubtion must be provided for reaction of the solids with SO; In addition. the high solids concentration tends to cause eyuipment erosion and corrosion. Not ive least of the problems is disposal of the "solid" waste. usually a sludge "mud" composed of tiny crystals and containing about sor; waier with dissolved cakium and trace metats from the hy ash.

The lime limesuone scrubbing piocesses are being oflered by a number of developers. and systems are being planned and constructed for over 20 ptants.

A number of developers are workirg on double-alkali systems. which regenerate the scrubbing solution by reacting it with lime or lisuestone to form waste cakium sulfite sulfate studgrand recycle alkaline solution. The waste solids should be washed to remove dissolved sodium salts, but otherwise they present the same waste disposal problem as slurry serubbing. The highy efficient sodium alkali solution permits use of very simple scrubbers, such as single-stage venturis, to remove both SO: and particulates. General Motors Corporation and Caterpilbr Tractor Company are designing and constructing industrial boikr applications of double-alkali systems using lime regeneration. Major development of limestone regeneration has been carried on by Showa Denko and Kureha in Japan. A 200-MW Japanese system was scheduled to start up in 1973. EPA is supporting pilot plant work by $A$. D. Little to generate design data on alternate double-alkali processing sebemes.

Chiyoda of Japan has developed a throwaway scrubbing prucess with a different mode of SO: removal. The $\mathrm{SO}_{2}$ is absorbed in dilute sulfuric acid containing ferric ion. which complexes with it. In a separate vessel. the retained $\mathrm{SO}_{2}$ is air-oxidized to sulfuric acid. The product stream of dilute acid is neutralized with lime or limestone to form a high-quality large-crystal-size sypsum product that is easily disposed of and may even be marketable. The system has been tested on an oil-fired boiker and with simulated coal ny-ash impurities. One commercial system is operating in Japan, and several more are under construction.

\subsubsection{Renesernble Serubbias}

The three basic techniques for regeneration of a spent alkali scrubbing solution or slurry are (1) direct thermal treatment to produce SO. (2) acid decomposition of the alkali to SO: and sulfates followed by secondary conversion of the sulfates in acid and alkali, and (3) direct reaction of the scrubbing solution with hydrogen sulfide $(\mathrm{H}: \mathrm{S})$ or $\mathrm{CO}$ to produce sulfur or $\mathrm{H}_{2} \mathrm{~S}$. Thermal treatment 
is the most direct approach and is also better developped. Reaction with H.S or CO will probably be the most costeffecive approach. since it can directly produce sulfur gather than SO:

Many of the regenerable processes produce comienisited gaserids SO: is an intermediate product. Conversion of the SO: to sulfuric acid is straighternard vin reaction with air is a conotinct acid process, but conversion to sulfur is more difficuh. Allied Chemical Comapany has successfiliy operated a very bres phant ( 500 tons. day) that produces sulfur by reaction of methane with a smeker gas containiag $15 \mathrm{C}_{\gamma} \mathrm{SO}$ at temperatures greater than $816^{\circ} \mathrm{C}$ (1S00 F). The primany reactor is followed by a secondary cleanup Chus system reacting residual H:S and SO: to sulfur. The process should work equally well on gases containing 95: $\mathrm{SO}$. Another approach irvolves reacting SO: with $H_{2}$ st $371^{\circ} \mathrm{C}\left(700^{\circ}\right.$ F) to form H.S. followed by reaction of the remaining SO. with H:S in a Chus system. Sulfur can atso be produced by reaction of SO: with $\mathrm{CO}$ at $331^{\circ} \mathrm{C}(700 \mathrm{~F})$. Regenerable processes that produce H.S can use the conventional Chus technshogy ro make sulfur.

The Wellman-Lord process uses direct thermal regeneration of sodium sulfite bisulfite scrubbing solution The solution is completely evaporated to crystallize sodium sulfite for alkali makeup and to generate water vapor containing the removes SO. The SO: is concentrated to 95r; by condensation of the water. Heat at $121^{\circ} \mathrm{C}\left(250^{\circ} \mathrm{F}\right)$ for the evaporator can be supplied by low-pressure turbine steam or a heat pursp. Residusl sulfate formac my SO pickup or oxidation in the scrubber connot be regenerated and is usualh purged as sodium sulfate solids containing 5 to 10\% of the sulfur removed from the stack gas.

Weilman-Lord systems have been treating stach gas from a sulfuric acid plant since i 970 and from a Claus plant (sulfur recurery) and cil-fired boike since 1971 (in Japan). Two nen in, trea:ing sulfuric acid and Chus tail gas are being started up in the U.S. EPA is co-funs :ICO-MW utility demonstration with Nonthem indiama Public Service that is due to start up in liace 1974. The demonstration will incorporate priduction of $\therefore$ - Ifur by the Allied Chemical process.

The magnesium oxide (MgO) scrubbing process. developed in the (i.S. by the (hemico Corporation, differs from the lime scrubbing system in that $\mathrm{MgO}$ sherry is used as the absorbent. The spent sti:-y is treated to recover the $\mathrm{MgO}$ for reuse. and by-product sulfuric acid is produced. As described by Chemico. the spent slurry from a number of plants would be processed at a central location. and the regenerated MgO would he returined to the user. They helieve that the sak of sulfuric acid wnuls pay for the reduction step and still give a satisfactory retum on investment to the user.

With EPA co-funding. (hemicu has constructed a Mg() scrubbing system for a ISO-MW oil-fires poiler at Boston Edison Company. The r.sk:tu't and acid flant are bocated at Rumford, R.I. A similar system has been constructed for Potomac Flectric Company for a coal-fired moiker that will also use the calcining facilities at Rumford. Operation of the system at Roston has demunstrated utilization of the recycied $\mathrm{MgO}$ and better than 90; SO: removal, although numerous minor problems have been enco. ntered with handling of solids.

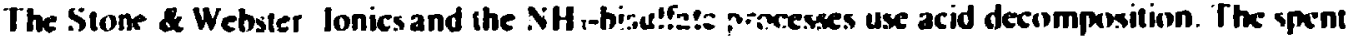
alkaline solution (mostly bisulfitc saits) is reacted with strong hisui'rate acid to produce concentrated SO: gas and sulfate salts. The Stone \& Webster lonics process uses clectrolysis to consert sodium sulfate solution to sodium hydroxide and sulfuric acid (oi sodium hisulfaze). ard the $\mathbf{N H}$-hisulfale process uses thermal decomposition of molten ammonium sultate to ammonium bisulfate and $\mathrm{VH}$. Sulfates produced in the scrubbers cannot be regenerated by acid decomposition. hut they can be removed by neutralizing a portion of the bisulfate acid with limesto,k to produce gypsum waske. If sulfuric acid is produced from the SO:. the Stone Webster lonics prokess can purge sulfates as dilute sulfuric acid for acid plant water makeup. t.PA and Wixconsin Flectric company arc 
currenty co-funding a pibs: pisunt demonsteation of the Stone Webster lonic. process. Tennessec Valley Authority has pibued amanonin scrubbing and seid decomposition. However. NH. scrubbing has a problem with the formation of an amanonium sas perticulate fume that escapes from the scrubber.

\section{$6.25 \mathrm{Dr}$ Procenas}

Iry procesues remone SO: at temperatures in excess of $95^{\circ}$ C (200 F) and leyure wo reheat of treated gases as is reyuired with scrubbing systems. Systems operating above 1496 ( 300 f f) require power ptant madificativas to produce hot gas. Most of the sysletes produce salfer or selfuric aciz.

(atahtic oxidatioin of SO: at 454 to $482 \mathrm{C}$ (85n to $90 \mathrm{CF}$ ) will pertain its removal as 75 to 80 ; sulfuric acid at 149 ( (300 f f). I is Moasanto Company Cat-Ox process effocts this couversion

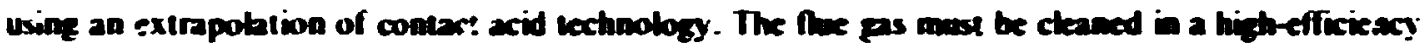
etectiontatic preripitator to preveat phuging of the calahys bed. Hot gas would be baken from the Hotke it $\sim 454$ ( $(850$ F). The powet plant econominer and air heater would be incorporaled in the Cat-Ox procens between the catalyst bed and the acid absorber, and a hiph-kemperature precipitator nould remove particubtes at 454'C (850F). The ineled gas comeaining SO, is scrubbed with recycted acid to produce 80\%; sulfuric acid. it is expected that the system will reyuire 3-day shutdouns crey 3 months to clan the catahst of resdul particuble. Monanto opiated a is-Mw' prototype of the process from 1967 to 1969.

Activaled carbon readih oxidives $\mathrm{SO}$ : and absurbs it as $\mathrm{H}_{2} \mathrm{SO}$ a 93 to $149 \mathrm{C}^{\circ}(200 \mathrm{~s}, 300 \mathrm{~F})$. The three approartes of arbon adsorption procesces differ in theu means of repeneraicen. The procesies developed by Hita'hi and l.urgi wash the loodet carbos with water to produce di!une sulfuric acid that an be neutrained with limestone to give high-qualiny gypum. Systems developers by Reinluft. Sumitomo. and Bergbau-Forschung drise off 10 to 30; SO: by thermal treatmem ai

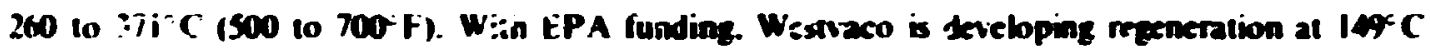
(30Y F) by H:S to produce sulfur on the carbon. The carbon is heated to remove onefournh of the sulfur and trated with hydrogen at $538 . C$ (loweF) to exnerace H:S for recycle to the sulfur exneration.

Hitachi and Sumitomo both have brge prototype instalbtions in Japan. and the Lurgi Sulfacid process is being used on a number of small industrial sources in Cermany. Since none of the processes have been used with cool-fired hue pas. there are uncertainties as to the eflect of fhy ash. All these systems suffer from attrition ol carbon adsorbent. though quatitative requirevents have yet to be eitoblishex:

The Ko,jal Iruich Shell group has developed a process utilizing the oxidation of SO: by copper baded onto alumina to copper sulfate at approximakly $730 \mathrm{~F}$ in reactors desianed expecially to contend with particulates. The process is cyclic: repeneration with hydrosen takes place at the aume remperature to produce a concentrated SO: stream which can be recovered as sux ... oxidized to sulfuric acid. or further hydrocenated in part to $\mathrm{H} . \mathrm{S}$ and fed to a Chus unit. A commercial installation was made on an oittined brike in Japan in 1973. and a demonatation unit is in operation in Tampa. Fla.. using nue gas from a coalfired boiler. The process is offered for licepuse by Shelrs licensing azent. Universal Oil Products Company.

Feoo and Babeock and Wikox (BAW; have developed a simibr process using fired-bed adsorption. No details have been released. but their process is probably similar to the Shell system or the alkalized alumina system worked on by EPA and the Bureau of Mines in the ble sixties. A utility is considering demonatration of the Eseo-BeW system. 
The nolven carbonate process absorts SO, in a molven emectic of lithiam sodium. and

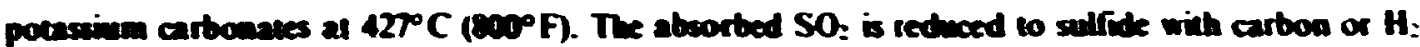

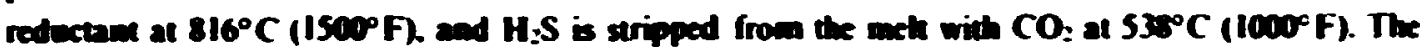
weth is returned to the serbbler. and the H.S is comveried to salfur. Atomies Inernationici developed this process with EPA fonding and is conseructins a 10-MW prototype with the funding of a group of eorthenst milities. None of the commercial appliations are being designed for greater than sor.

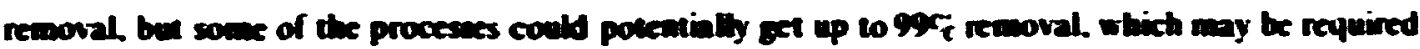
to control andicat salfacte particulates.

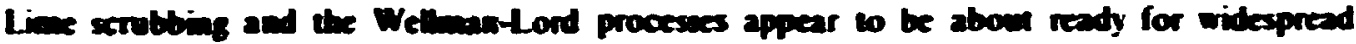
commercial application, with a sumber of procesess with existing or phaned application an far

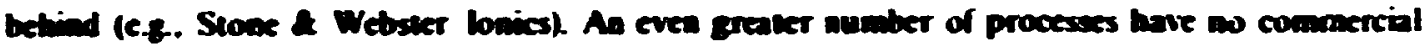

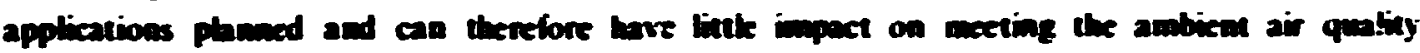

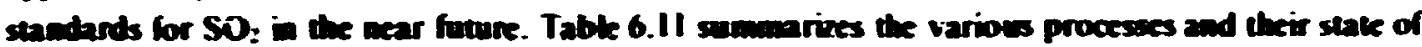
consunercial development.

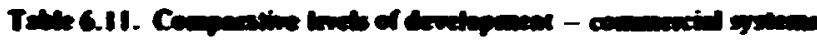

\begin{tabular}{|c|c|c|}
\hline noces & $\begin{array}{l}\text { Deprescatative commerciol } \\
\text { apmotions }\end{array}$ & Teationowos \\
\hline Line exroulms & 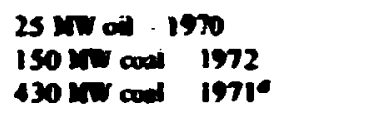 & 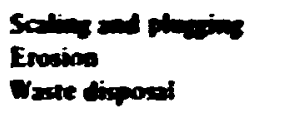 \\
\hline Catentyic oxilation & $100 \mathrm{xw}$ cod 1919 & 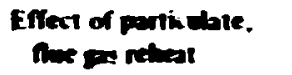 \\
\hline Mo scribing & 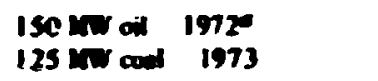 & 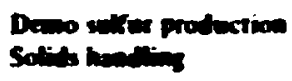 \\
\hline Wenmen-Lors & 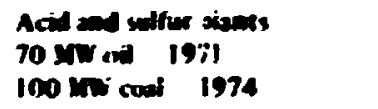 & 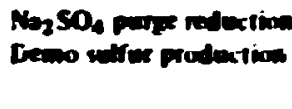 \\
\hline Doulle altati & 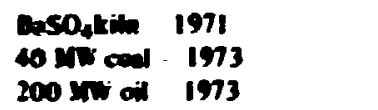 & $\begin{array}{l}\text { Wave dinponal } \\
\text { Solint hemime }\end{array}$ \\
\hline 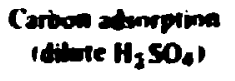 & 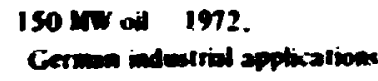 & Prrticuble hanting \\
\hline $\begin{array}{l}\text { Catoon anorption } \\
\left(1 \mathrm{~S}^{\prime} \mathrm{S \textrm {O } _ { 2 } )}\right.\end{array}$ & 60 บ1 ail 1972 & 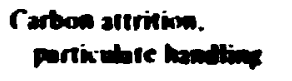 \\
\hline Ces asuorpion & Sn swy od :973 & 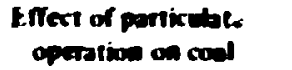 \\
\hline
\end{tabular}

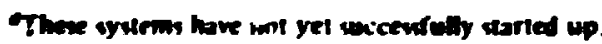

\subsubsection{Enviromanel liment}

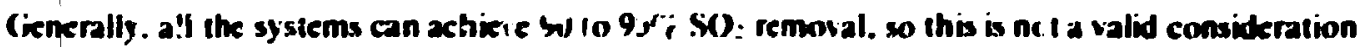

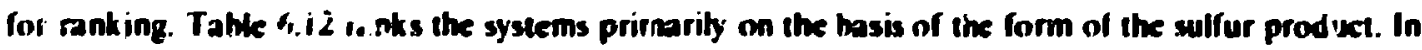
order of incteasing envirinmintal irssult. th: products are elemental sulfur. sulfuric acid. oypsum

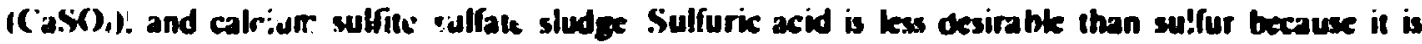




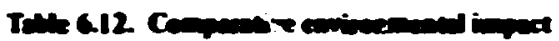

\begin{tabular}{|c|c|}
\hline Mocess & Moducts and maste \\
\hline Mo xintions & 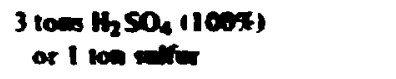 \\
\hline 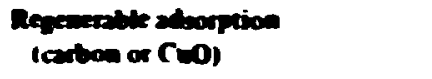 & 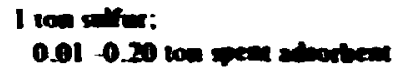 \\
\hline 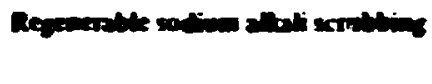 & $0.95 \mathrm{ron}=1 \mathrm{mo}:$ \\
\hline 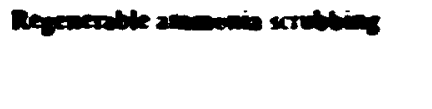 & 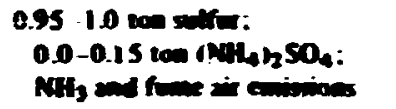 \\
\hline Cantysic oxiladion & $3 \operatorname{tons} \mathrm{H}_{2} \mathrm{SO}_{4}(\cos )_{1}$ \\
\hline Acil nevorritioniven & S.S tons y caso. \\
\hline 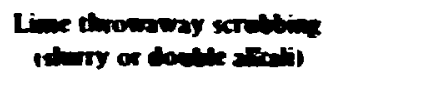 & - $\operatorname{las}_{2} \mathrm{C}_{2} \mathrm{SO}_{3} / \mathrm{SO}_{4}$ \\
\hline 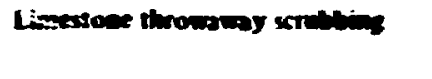 & $\begin{array}{l}8-13 \operatorname{tons} \mathrm{C}_{2} \mathrm{SO}_{3} / \mathrm{SO}_{4} \\
\end{array}$ \\
\hline
\end{tabular}

more Jifficuh to ship and martet and is not a disposable waske. Calcium sultre sulfale stedge is least desirable because of its ctemizal oxs yen demand and brex volume per ton of sulfur. Onter consweeratcons of environdeneal ienpact inctude the quantity and quality of waste maverints from sorbent dzeradation.

The MgO scrubbia system is the cleanest frocess: no waste products are expected from its operation. Limestone scrubbing would hove the brese quantiny of waste makerial. 1013 loms of wet studge per ton of sulfur remoned. There is linte doube that regenerable procesces makiag sulfur are far superior in cavironmemeal iupect to throwaway procesues making cakcium shodse.

The quaciay and quanity of cakivan shode product vany with the type of tho owaway prexess. The Chiyoda and Hitachi procesees divectly produce a high-qualiny martictuble syparm Sy neutralivation of dilute sutfuric acid. Throwaway processes usiag lime produce bess sheder than those

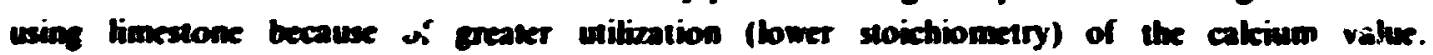
Improvemems are under devehponent in the shode volume and quality from hime limestone scrubbing systems. In dispoen ponds. settlod shedre from limestone scrubbion is 40 to $50 \%$ water and occupies $300 f^{\prime}$ per ton of containest sulfur.

The dry adsorption regenerable procesases are surprisingly clean. Adsorbent aftrition of poisming sexpected to nswh in a limined quantity of waste adsorbem. Carbon adsorbem can be

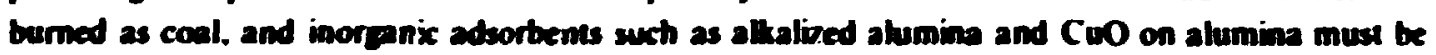
handled as waste solids.

The regenerable scrubbing procesues using sodium or ammonium alkali produce some sulfate that cannot be resenerated. Sodium sulfate con be marketed as such or converted to calcium sulfate for solid waste dieponal. Ammonium sulfate an be marteted or decomposed to $\mathrm{N}_{2}$ and SO.

Ammonia scrubbing processes may suffer from sulfive sulfake fume formation. There appear to be solutions to this problem. but their costs are not inchuded in curnemt cost extimales and their 
feasibility has not been tested. In addition. amanonia serubbing will emin 25 to 100 ppen of gaseows NH.

Almost all the syslems beve pokential for particubte emiasions as entrained solids, sherry. or solution. bu ach entrain nem is easily eliminaled with solution serubbing and on be eliainated for shumy scrubbing and sriids cone tine by property desigaed mist climinators and cyclones. The Cat $0 x$ process ins the environenental advantage (and economic disatrantage) of conplete capture of all rewaining pariculates in the cothys bed.

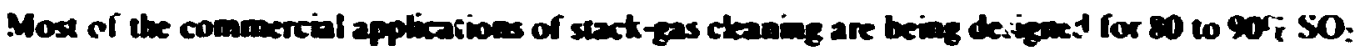

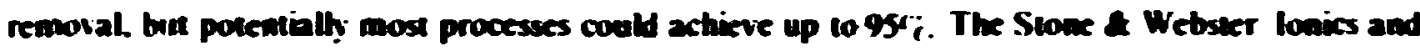

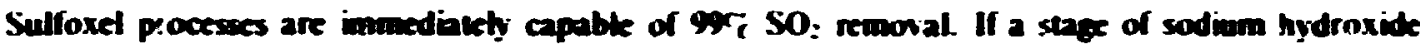
serubbing were added to the Welluan-Lord and double-alkath systems. they could acticie up to sw:

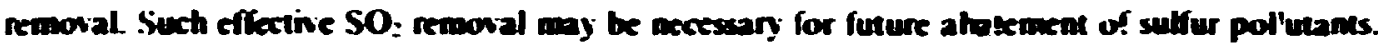

\subsection{Eocosonic Andyis}

The cost of stack-zas cleaning is an inportant criterion in proxess evaluation, becase in will ukimalety deterisine the process to be used if other considerations are eyual. At the same time. process economics is the diost diffeuh cricrion to generalize on a casaparative basis. On the basie of cost inframation from contractors and other sources. the Control Systems Laboratory. EPA. prepared and presented information representine the costs of the major wet scrubbing processes." This information base has been expanded to include the double-alkali. citrate. and Cat-Ox processes."i

Escentialy, all econo nic comparisons published to dace have been aimed at utility systems $h$ ised on 500 MW generating capacity (or Grex). 3.5\%; sulfur coal. a retrofit system, and 60; bad factor. On this basis EPA" estimates installed capital costs of $\$ 24$ to $\$ 36 \mathrm{~kW}$ ior throwaway systems and 539 (cilrak) to 555 (Cat-On) per $\mathrm{kW}$ for recovery systems. These costs inchute pariculats waste removal at SI per ton. no credit for sulfui product. and ro costs for waste disposal facilities. which are usually 55 to $510 \mathrm{~kW}$. These published costs are considerably bower than recent estimi! $x$ prepared by the TVA": for throwaway lime or limescone shum systems (Table 6.13).

The variation of costs with source parameters (sive. sulfur conten:. had factor. etc.) is much greater than the variation of costs betwecu processes. Depending on surce couditions. the

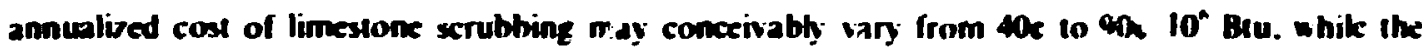
greates varation in process cost is from toxe $10^{\circ}$ But (double alkali) in $51.4510^{\circ}$ Btu (C.at-Ox). The annualized costs include operating costs and 22.2r; capital charges for depreciaticen and return on investrient.

Throwaway processes are favored by simulaneous particulate scrubbing and SO; remaval. kom costs of waste disposal. and bek of a sulfur product market: refenerable proceses are favored by wigh waste disposal costs and gond credits for by-product sulfur. However, sulfur credits dn not have a major impact on costs. The throwaway processes cost about the same as the regenerabte

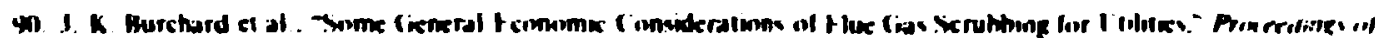

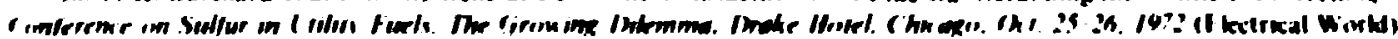

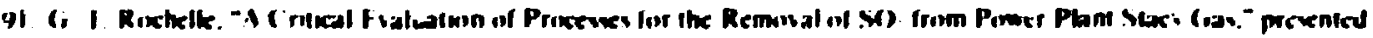

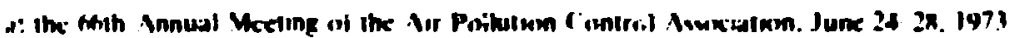

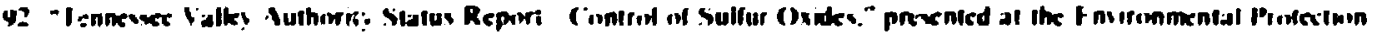

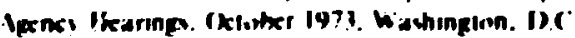




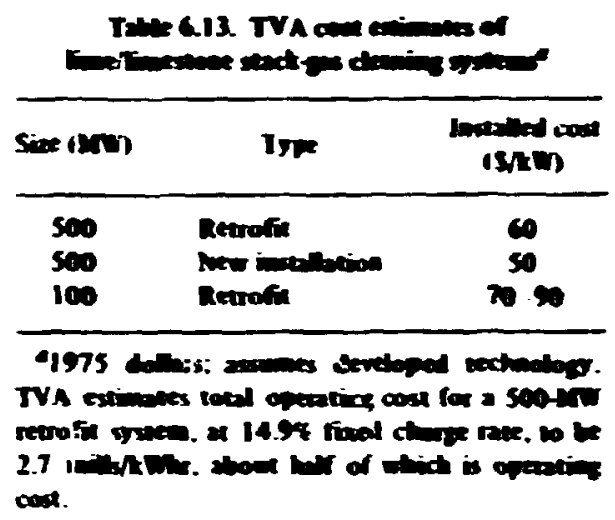

proceses because the adted complexities of aleinm sherry scrubbing babnoce the requirement for sorticat regenctation and prodici, recovery.

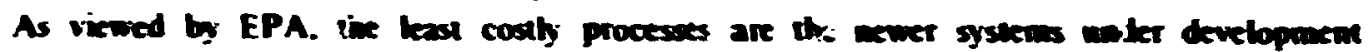
reprosemed by the double-iltali process. However. these new systems are onty expected to reduce abmulined coses 15 to $20 \%$.

The Cat-0x process appears to be the mose expensive systeren and is pertups typical of the dry

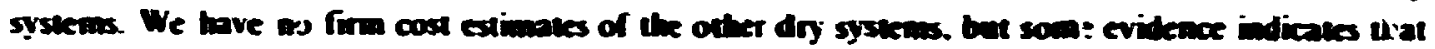
they wiil be more cxocusine than the scrubbing systems. In Ixs. Kellogs evaluened the alkalined abumine process sed abo considered a number of exweraliaed cases spplicabte to moat dry regenerable procewes. In 1971. Kellowe" prepared estivales of several rezenerable scrubbing systems on the same basis. The capital costs of the dry systems were abotil twice as hroe as those of the scrubbing systems. Similarty. capital costs of the Japanese a : ton adsurption syseen appear to be about twice as bre as those of the lapanese scrubbing systems."

The anmualined coses are primarily composed of capizal ctanges for depreciation. return on investment. and maintemance. but utilities and materials costs are siznificamt. The energy reyuirements of the processes are represented in Table 6.14. The throwaway processes tave the lowest energy requirements but the erealest maverial requirements. The lime scrubbing process would require a cotal increase in fuet consumption at the power pham of about 3.5f: Stome a :"ebsuer lonico would require $10.7 r_{\mathrm{r}}$.

The estimaled anmalized costs of removine sulfur dioxide from the seack gaves of a boiler exprating 830.000 ib of steam per hour using bituminous coal containing 3.5f sulfur are semmarived in Tabte 6.15.

Thus. the following conclusions may be drawn for industrial boilers.

I. Reasonably waske-free the gas cleaning procesces are or will soon be avaibble at annualized cons of SSOK $10^{\circ}$ Bru.

2. Lime scrubbing and the Welbman-Lond systems are in commencial prectice; sther procesecs have specific development probtems.

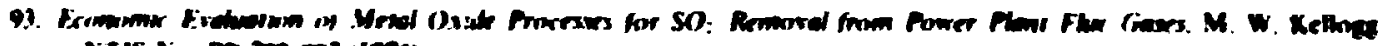

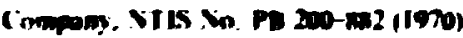

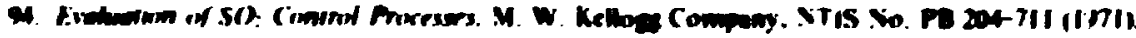

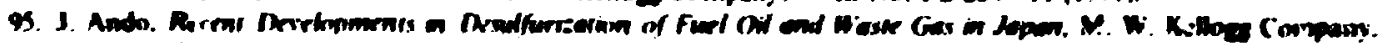
NTIS No. PE 20.230, (1972). 


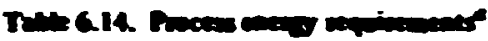

\begin{tabular}{|c|c|c|}
\hline \multirow{2}{*}{$\begin{array}{l}\text { Mequetomative } \\
\text { proves }\end{array}$} & \multicolumn{2}{|c|}{ 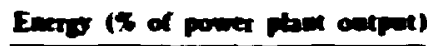 } \\
\hline & nowar & Fed \\
\hline 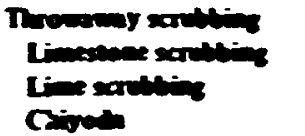 & $\begin{array}{l}2.2 \\
1.9 \\
2.2\end{array}$ & $\begin{array}{l}1.6 \\
16 \\
16\end{array}$ \\
\hline 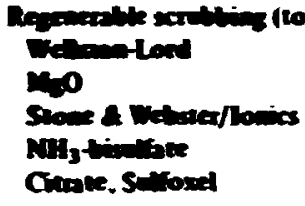 & $\begin{array}{l}45^{\circ} \\
2.3 \\
7.6 \\
1.9 \\
2.0\end{array}$ & $\begin{array}{l}3.1 \\
5.6 \\
3.1 \\
5.1 \\
3.1\end{array}$ \\
\hline 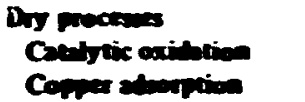 & $\begin{array}{l}20 \\
20\end{array}$ & $\begin{array}{l}3.2 \\
5.5\end{array}$ \\
\hline
\end{tabular}

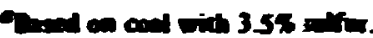

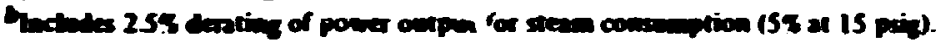

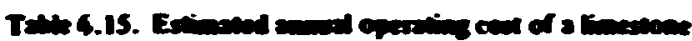

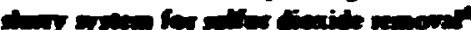

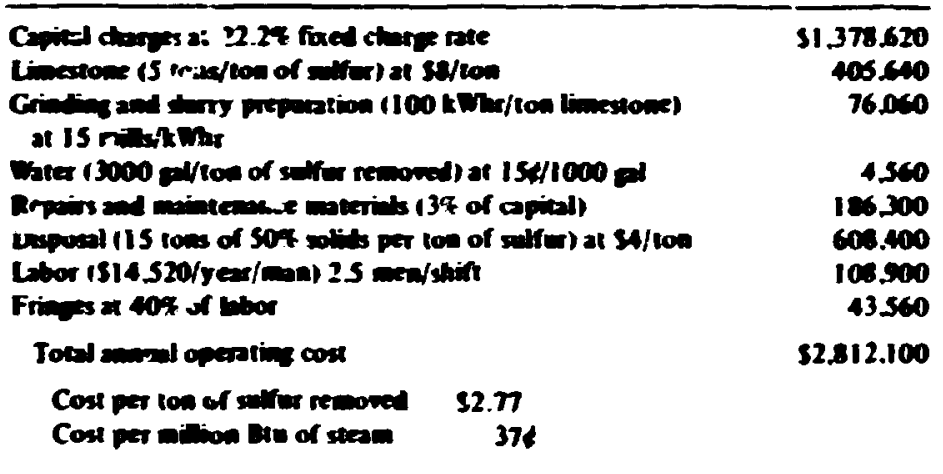

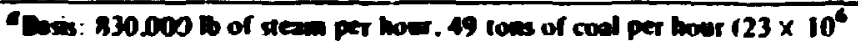

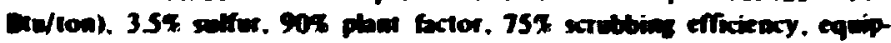
ment capital cost 56.210000 .

3. Cost differences between processes are rerely greater than 15\%. Throwaway processes are signifianth kess costly only where waste disposal is cheap.

4. Regenerable procesces offer kss potential for environmental degradation by waste products. alithough saic of the by-product could be a problem.

\subsection{Con of Steam Usine Coakfired Doilers}

Tat $k$ h.16 compares the cost of steam generation using kow-sulfur eastern and western coals with no siack-gas cleanup and a $3 r$; anliur castern coal with a limestone slurry stack-gas cleaning 


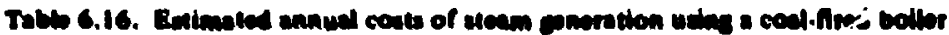

Basia: $10^{\circ}$ 16 uteam/hr, 750 F, 690 palg, condenewlo rolumed is $250^{\circ} \mathrm{F}$

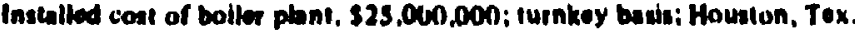

(includes all coul handition cquipmont, slacks, preciptintars, otc.)

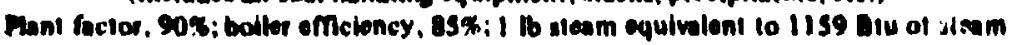

\begin{tabular}{|c|c|c|c|}
\hline & $\begin{array}{l}\text { Satiern call (12\% achl } \\
3,3 \% \mathrm{~s}, 11,300 \mathrm{Bru} / \mathrm{b})\end{array}$ & 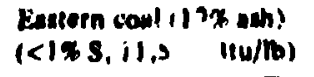 & $\begin{array}{l}\text { Woulern coal (4.37 ahh) } \\
(-0.5 \% \mathrm{~S}, 8,500 \mathrm{Blu} / \mathrm{/b})\end{array}$ \\
\hline Capital charges al 22.24 Axed chares rate & $\$ 3,550,000$ & $\$ 5,550,000$ & \& s,5s1, 000 \\
\hline 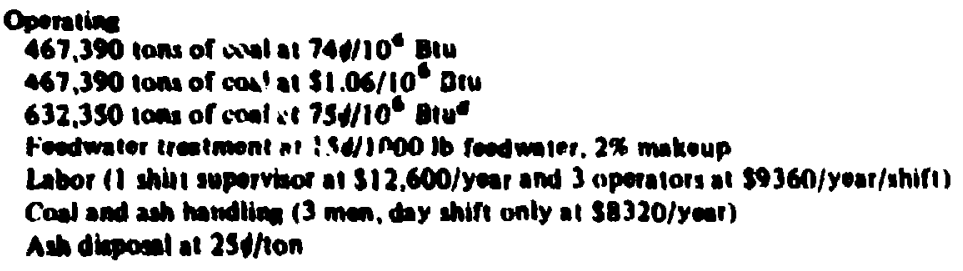 & $\begin{array}{r}26,280 \\
122,040 \\
34,960\end{array}$ & $\begin{array}{r}11,395,000 \\
26,280 \\
122,040 \\
24,960 \\
12,467\end{array}$ & $\begin{array}{r}(8,063,000) \\
26,240 \\
122,040 \\
24,960 \\
6,035\end{array}$ \\
\hline 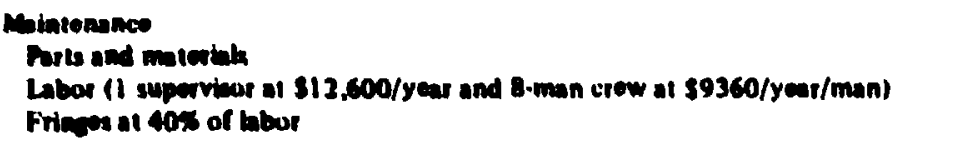 & $\begin{array}{l}30,000 \\
87,410 \\
93,792 \\
\end{array}$ & $\begin{array}{l}30,000 \\
97,460 \\
93,793 \\
\end{array}$ & $\begin{array}{l}30,000 \\
17,480 \\
93,792\end{array}$ \\
\hline 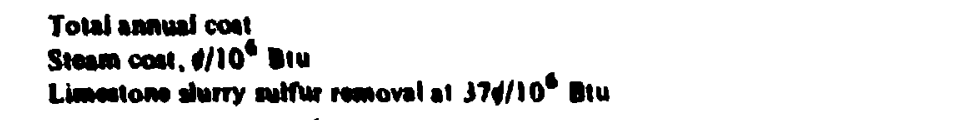 & $\begin{array}{l}\$ 13,890,000 \\
152 \\
37\end{array}$ & $\begin{array}{c}\$ 17,347.000 \\
190\end{array}$ & $\begin{array}{c}\$ 14,004,000 \\
153\end{array}$ \\
\hline Told stens cosl, $1 / 10^{\circ} \mathrm{Bu}$ & $\overline{189}$ & $\overline{190}$ & $\sqrt{53}$ \\
\hline
\end{tabular}

- Coal dattivared by unit irain.

ash removed with sulfur. 
system. Stenm costs are besed on the projected price of cool detivered to the Houstur. Iex.. areas ds discussed in Section 6.1.5.

Based on the assumptions used for these computations, how-sulfur western coal woukd provide the bowest steam cost ( $\$ 1.5310^{\circ}$ Btu), and <IT sulfur eastern coal would be the most expensive ( $\left.151.9010^{\circ} \mathrm{Bro}\right)$.

\section{FLUIDIED-XE COADUSTION}

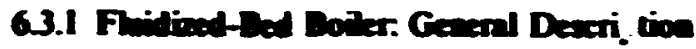

The coatfired Puidized-bed boike is a rebineh new vechwoblogy that at this point secms very promising. Combustion is accomplished in an inen bed. consisting mainhy of coal ash. which rests on a phate full of nozzles. The combustion air is introduced through the nonkes and expands the bed beyond its static depth. The bed moves about and flows much lite a lieyuid: bence the mame thidized bed. If the bed is reised to ignition temperature and crushed coal or any other comb: stible is introduced into the bottom of the bed. it will burn. The bed turbuknce transfers heat into the fuel. promoting rapid ignition: the turbuknce abo provides intimate mixing of fucl and air. promoting combustion with very low excess air. Volumetric heat release rates of the order of ten times those of the powdered-coal suspension-fired fumaces are achieved. The adiabatic combustion temperature of coal-air exceeds $1649^{\circ}$ ( $\left(3000^{\circ} \mathrm{F}\right)$. so heat transfer surface is phaced in the hed to absorb about half the heat released and to control combustion temperature 10871 10 982 C $C$ (1600 16 $1800 \mathrm{~F}$ ). The remainder of the heat is removed in convection surfaces. Again. because of turbuknce in the bed. the heat transfer coefficient of the surface submerged in the hed is three to six times that of convection surfaces. Further. beause the combustion temperature can be controlked :0 871 to 982 ( (1600 to $\left.1800^{\circ} \mathrm{F}\right)$. the superheater surface can be confidently designed for conservative wall temperatures and therefore can be made of rebativety bow-alby material.

A principal reason for the increasing interest in fluidived-hed boikers is that emission control is inherent in the combustion process. The rebatively low combustion temperature sharply reduces the formation of oxides of nitrogen. The conditions of temperalure and turbulence in the hed favor the reaction of sulfur oxides with limestone. so shat the injection of about tu ice stoichiometric limestone into the bed is seny effective in the removal of suifur. Thus the bulk of the waste products are retained in the bed as dry solids. and. since the bed hehaves as a Muid. the wastes can be continuoussly removed through an overflow pipe bocated at the desired maximum height of the expanded bed. Figure 6.\$ presents a schematic view of one concept of an industrial fluidired-hed boiker.

Work on Muidized-bed combustion of coal began in the fiftics. In some instances. the ubjective was to burn fuels such as anthracite fines. lignite. and washen tailings that did not burn well in other types of combustion systems. The bulk of the work was directed touard obto:uing hower cons steam boikrs by taking advantage of the high heat transfer coefficient in a fuidired bed. The most significant effon was started absial 10 years ago in the United $K$ ingdom by the Centrul Flectricity Generating Board" and has been continued at the British Coal Itcilization Research Aswmitation I.aboratory (BCURA)." Most of the work a: BCURA has been with heds ha' ing a cross-sectional

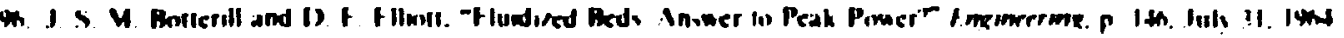

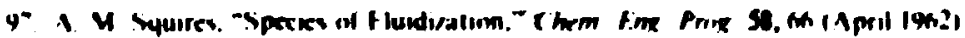

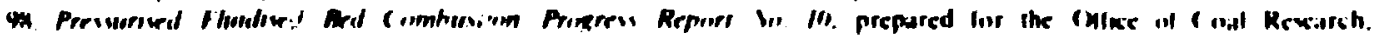

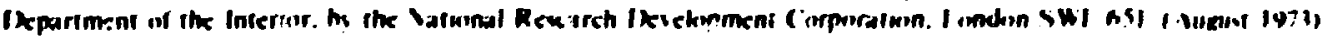




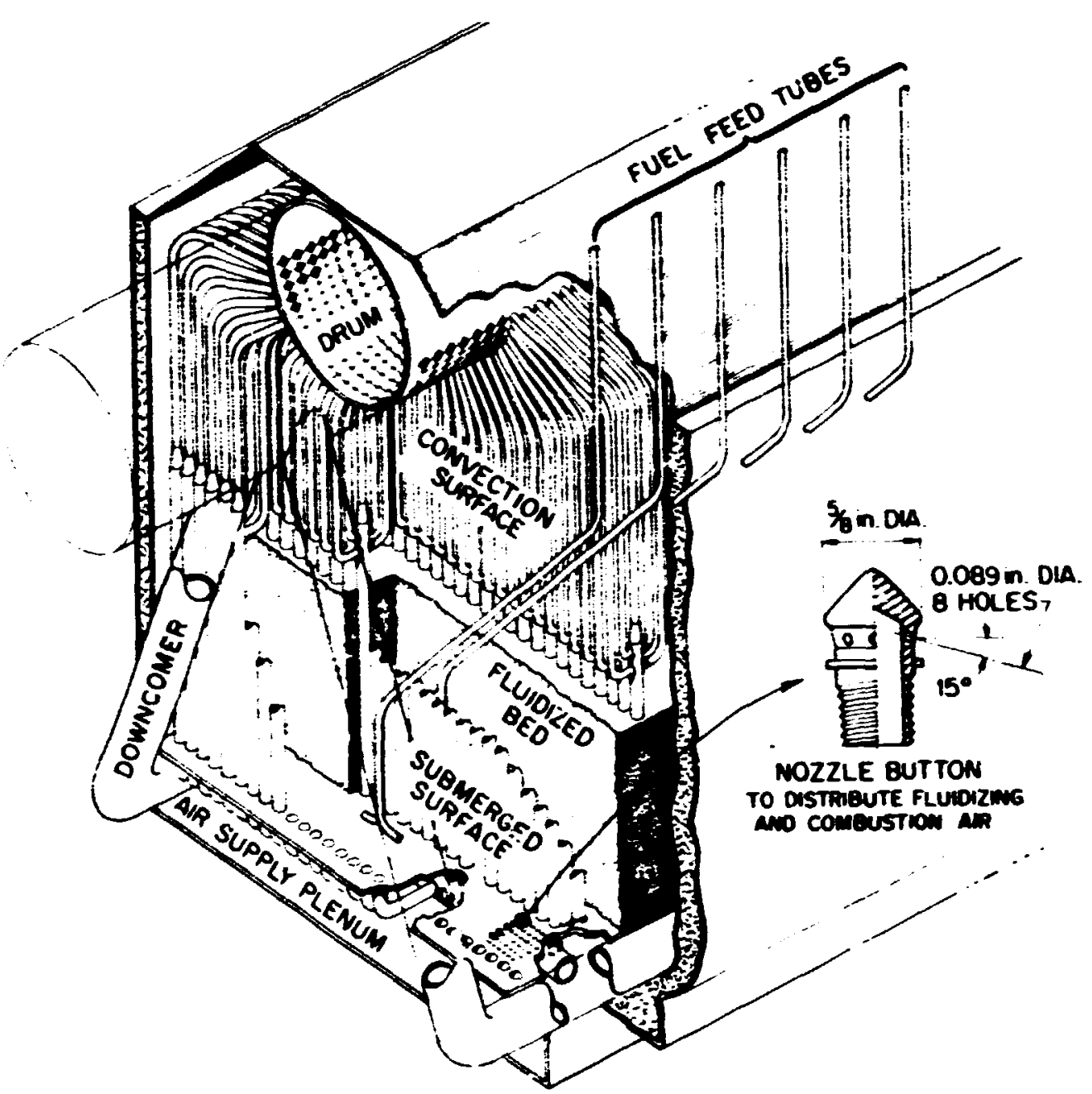

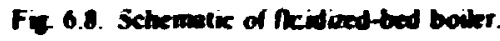

area of about $8 \mathrm{fi}$ : Some of the British effor was supponed by the Environmental Protection Agency (EPA), and BCURA is prograr, is continuing under a recent Office of Coal Reseserch (OCR) contract. In the (I.S.. Pope. Evans. and Kobbins. Inc., in Alexandria. Va.. under both OCR and EPA fundine. has opereted several heds at atmospheric pressure. including a bed having a cross-sectional area of $! 0 \mathrm{ft}^{*}$ and frited with a carbontbirnup cell. "in' The objective in work on the latter has been to deve'op a umall

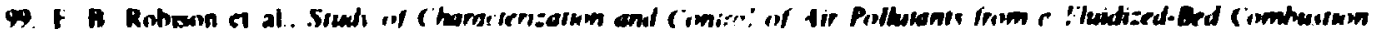

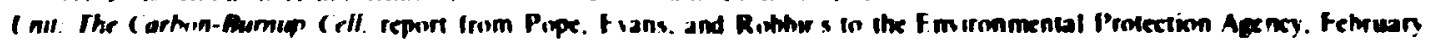
197 .

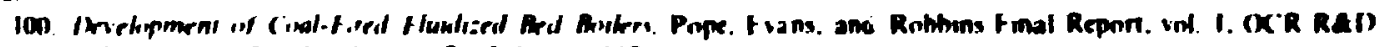

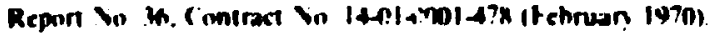


Thiaived-bed combustion chamber and boike cí about 100-MW(t)output that would lend itself to shop fabrication: and shipenem by rail. The woth has emphasized the solution of practical design and operating problems. More rrecnthy. basic heat transfet. flow, and performance data accumulateri hy the British have been supplemented, with EPA funding. by small-scale studies fusing beds 6 to 12 in. in diameter) at the Argonac National Laboratory (ANL) 'ut and Esso Research." Argonne ani Esia explored the basic problems of Muidized beds. with the prime emphasis on optimizing the pollution control capabilities and developing a method for reconstituting the lime to eliminate the waste disposal problem for the targe amounts of cakium sulfate that will be produced. Pope, Evans, and Robbins" also worked on the lime regeneration problem. Both Westinghouse and Foster Whecker have carried out plant design studies, and curreatly Foster Whecker is working with Pope, Evans, and Robbins on the fuidized-bed steam generator mentioned above. ${ }^{10 \text { hion }}$

Fluidized beds have been used extensively for roasting sulfide ores. ${ }^{104}$ Over 200 units are currenty in operation io make sulfuric acid or sodium sulfite (for paper milk) or to obtain metal oxides for reduction to the metal. but usually for both purposes. The heat released in the roasting operation often requires heat removal from the bed; this is accomplished with boiker tubes in the bed.

Wort on Mudized-bed combustion in the U.S. has also included the incineration of solid wastes. both industrial and domestic. Copetand Systems. Inc., has about $\mathbf{3 0}$ units in service for disposal of industrial wastes, including not onfy ubvious fuel materials such as sawdust but also slurries such as paper pulp mili waste liquor with as litite as 35\% solids." The heat of combustion of the solids is sufficient to sustain the reaction. Dor-Oliver ${ }^{\text {ith }}$ has about 80 incinerator units in service that burn mostly industrial and domeatic sewage sludge in aqueous suspension. A fluidized bed for buming municipal solid waste has been under development at Combustion Power. Inc., under EPA contracts for about 8 years." In this system, the compressor of a gas turbine feeds air to a fluidived bed of sand into which suredded solid waste (mostly paper) is injected. The hot gases laving the bed drive the turbine to produce a net electrical power output. The system has also been operated with coal as the fuel under a contract with $\mathbf{O C R}$."

Some insight as to the amount of operating experience that has been gained with fuidized-bed coal combustion systems is given by Table 6.17.

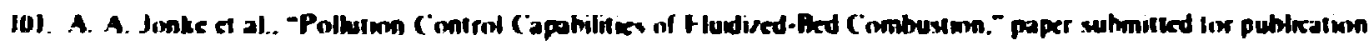
in A.KME Symposium Serixe. Alr 1971. April 1972.

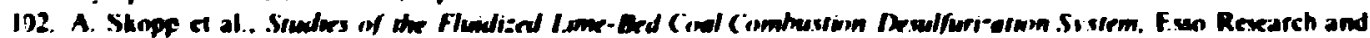
Engin ering Compang. Cenvernment R. warch Imision. I. inden. XJ.. 1971.

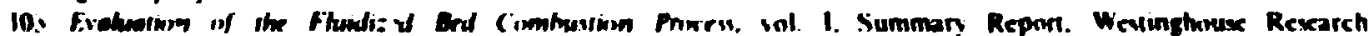
I atmoraliores. Pirtshurgh. Pa. (19?2)

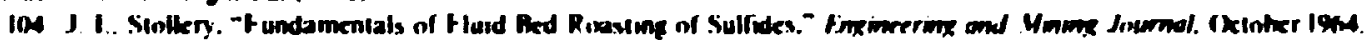

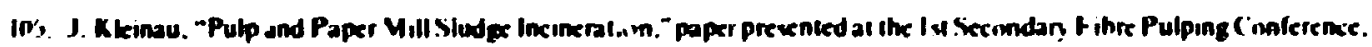
17. 22 25. I94:5.

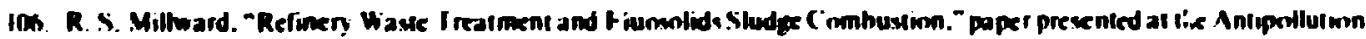
tair. Milan. lably. Vovemher 1972.

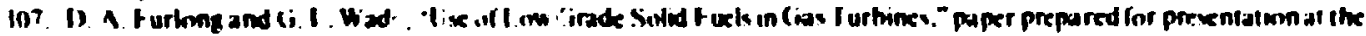
ASWF Winier Annual Meeting. New York. Im. 17 21. 1974. 


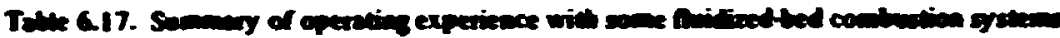

\begin{tabular}{|c|c|c|c|}
\hline $\begin{array}{l}\text { Oraniantion responsible for } \\
\text { dexign and construction }\end{array}$ & Fuet & Objetive & $\begin{array}{l}\text { Som cot: } \\
\text { operation } \\
\text { time (in) }\end{array}$ \\
\hline Copeland Systems, Iac. & $\begin{array}{l}\text { Wood waste, pilp } \\
\text { ail waste, ans: } \\
\text { organic wases }\end{array}$ & Inciarrativa; in soure cans bat recomery & $-10^{6}$ \\
\hline \multirow[t]{2}{*}{ Dorr-Otiver. lac. } & Seware stude & Lecimeration & $\sim 10^{6}$ \\
\hline & Prrites & $\begin{array}{l}\text { Roasting to vieid } \mathrm{SO}_{2} \text { for acid or suifite and/or } \\
\text { metal oxide foe redection }\end{array}$ & $-3 \times 10^{-}$ \\
\hline BCURA & Coal & 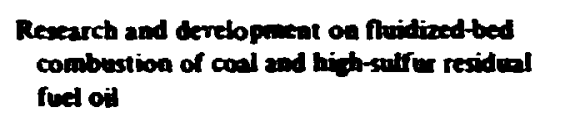 & $-10^{4}$ \\
\hline Pope, Evans, and Robtins & Cool & $\begin{array}{l}\text { Research and developmeat on fluidized bed } \\
\text { combustion of coal }\end{array}$ & -9000 \\
\hline Argonac National Laboratory & Cool & $\begin{array}{l}\text { Research and development on fisitized bed } \\
\text { combestion of coel and linie reveneration }\end{array}$ & 700 \\
\hline Combustion Power. Inc. & $\begin{array}{l}\text { Municipal solid } \\
\text { waste, wood } \\
\text { waste, and coal }\end{array}$ & $\begin{array}{l}\text { Incineration with electrical etery as a } \\
\text { by-product }\end{array}$ & $\begin{array}{l}471^{\circ} \\
271^{\circ}\end{array}$ \\
\hline Esso Research & Coal & $\begin{array}{l}\text { Research and developursat on cool combustion } \\
\text { and lime refenerativa }\end{array}$ & $\sim 100$ \\
\hline
\end{tabular}

Tolal time on bed.

With turbine connected.

\subsubsection{Sulfur Removal}

The effectiveness with which SO: 'missions can be reduced by removing sulfur as $\mathrm{CaSO}_{4}$ in a nuidized-bed combustion system depends on many lactors. The two most importain are the cakcium; sulfur feed ratio and the bed operating temperature. The effects of these two parameters ${ }^{100}$ on SO: roduction are shown in Figs. 6.9 and 6.10. The matter is complicated by the fact inat limestones from different strata vary substan:ially in their characteristics, including their effectiveness in removing sulfur. ${ }^{10 m}$

\subsubsection{Regenerntion of the Lime}

It would be advantageous to regenerate the spent limestone and thus reduce both the consumption of lisestone and the quantity of ash that must be hauked away. Procesces have been investigated inat would yield elemental sulfur, a saleable product. While somewhat different processes have been contemphted in the lime regeneration work carried out by ANL. by Eswo, and by Pope. Evans. and Robbins. they all depend on roasting cakcium sulfate under mildly reducing

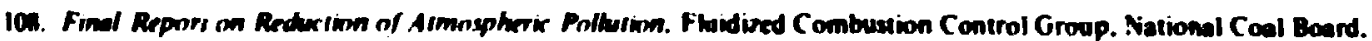
London. prepored for the Emvironmental Procection A ency. Sepuember 1971. 
OAML-DWG 74-12212
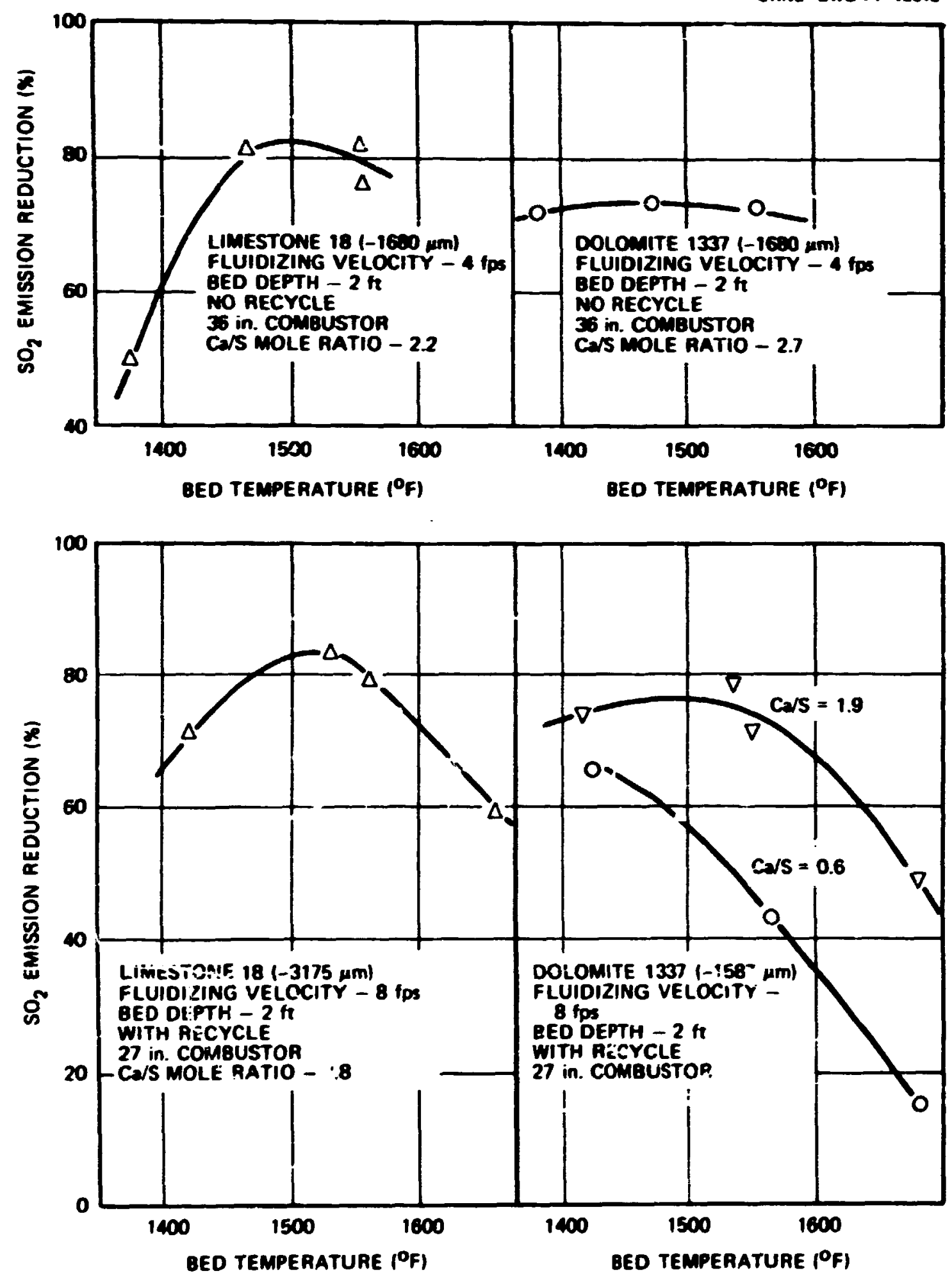

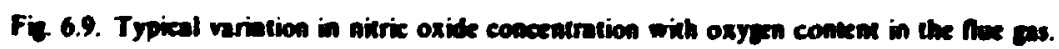




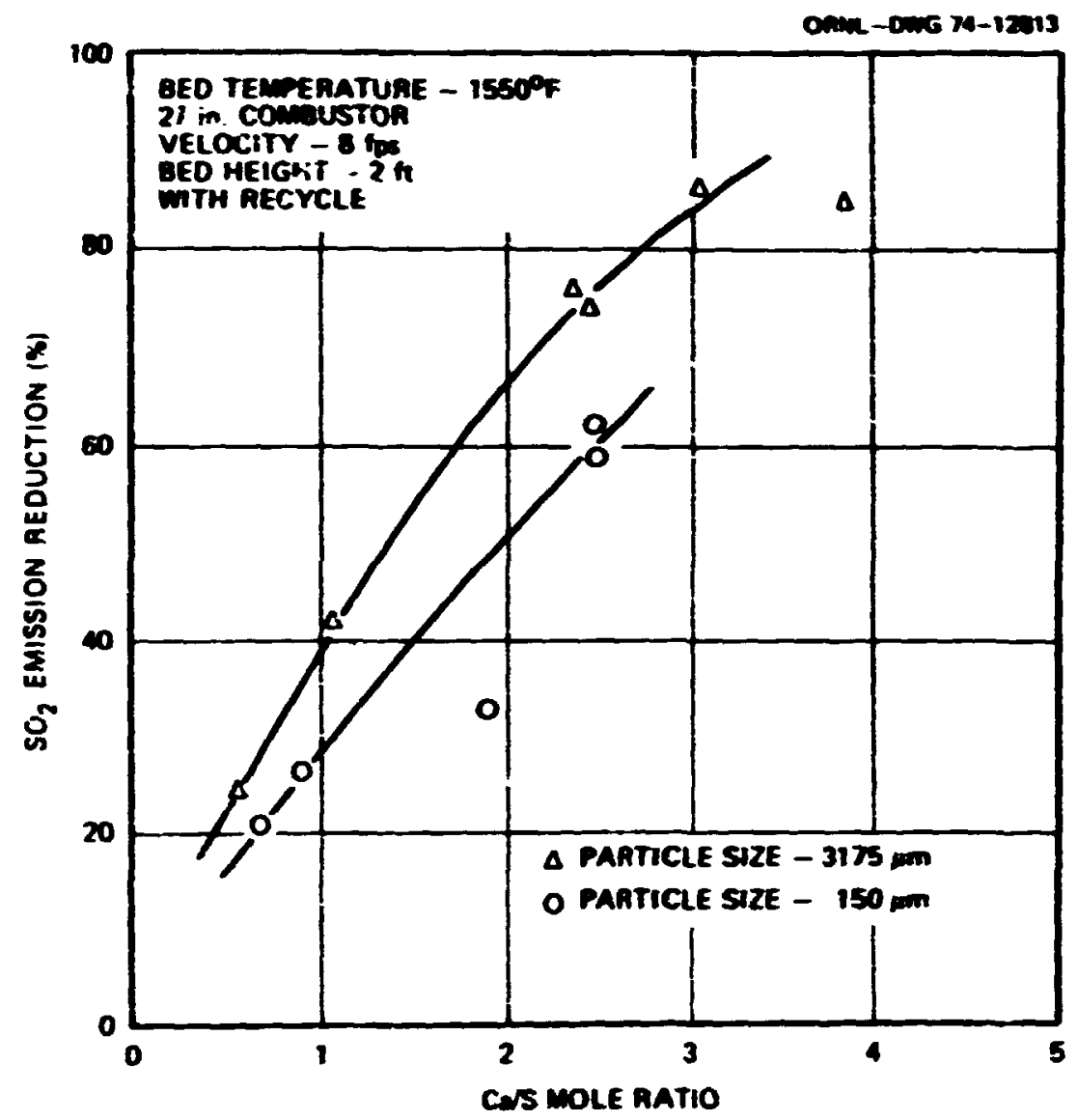

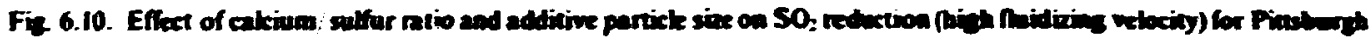
cond and linestone 18.

conditions to evolve a gas that is rich in sulfur dioxide. The regenerated lime has sharply less reactivity than fresh lime due to the high temperature necessany for the roast, about 1950 F. Fresh stone must be supplied at a rate amounting to an appreciable fraction of the sulfur to be captured. on a stoichiometric basis. and a comparable annount of lime must be withdrawn for sake or disposal. To avoid this disadvantage. workers at The City Colkge of New York ${ }^{100}$ have proposed a regeneration scheme which would depend on reduction of the cakium sulfate by a gas containing hydrogen or carbon monoxide to yield cakium sulfide. and on subsequent reaction of the calcium sulfide with steam and $\mathrm{CO}_{2}$ to produce $\mathrm{C}_{2} \mathrm{CO}_{1}$ and $\mathrm{H}_{2} \mathrm{~S}$. from which sulfur may be produced in elemental forn mure readily than from SO. Westinghouse has carried out plant design studies ${ }^{\text {ins }}$ that included a favorable ecnnomic assessment of The City Colkege scheme.

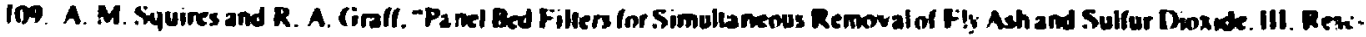

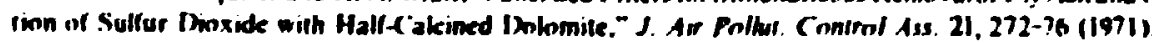




\subsubsection{No. Formtion}

The low combustion temperature characteristic of muidized-bed combustixn tends to keep the formation of NO, to a bow keheh iut the gas trassit time chnsugh the high-temperature region is sufficiently long that the equilibrium concentration of NO, can be reached. As show in in Fie- 6.11. this condition makes the NO, concentration in the stack gas quite sensitive to the amount of excess

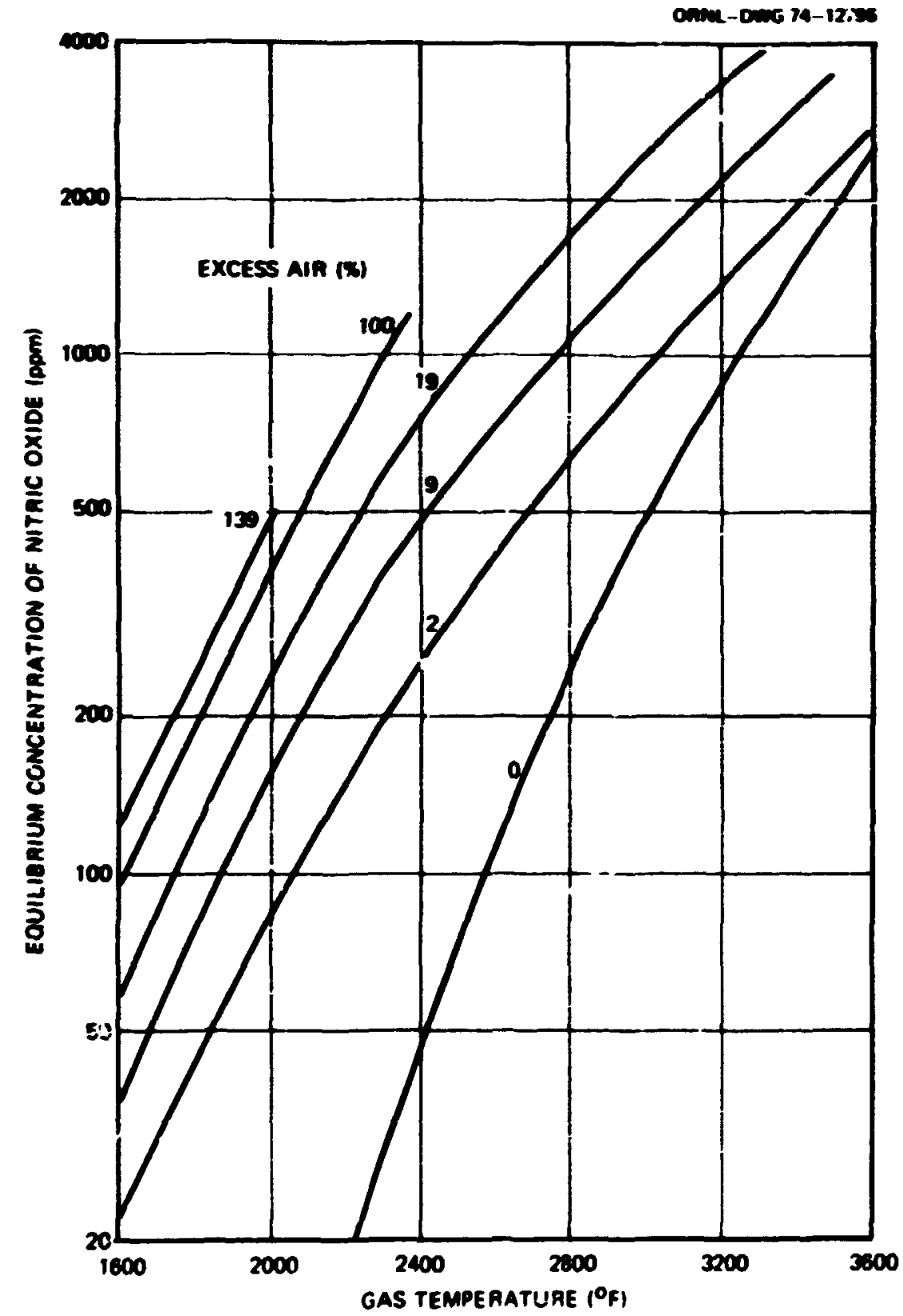

Fiz. 6.11. Effects of gas tempenture and the amoum of excess air on che cakulated iquilibrium nidric oxide concentration ir: combustion products. 
air." a.d this in turn ptaces a premium on the use of a control scheme that will hold the amount of excess air to a bo kvel.

Fludired-bed cumbustion systems can be operated ovitr a wide range of bed temperatures and amounts of excess air. but Fif 6.11 indiates that there is a strong incentive to keep the exwess air to less then 10; and the bed temperatere $1081610871^{\circ}$ C (1500 to 1600 F). These conditions pose certoin constraints on wed operation which may require a soptisticated insarumentation system to control air and fuel durine periods of changing steam demand.

\subsection{Drveteporen Problem}

The major preibleres that have been experienced in the deveiopment wort outlined above bave been with the feed of alve coal and limestone into the bed. Alowthrough of fines and separation of these fines from the gases laving the bed. and either the regeneration of the calcians sulfate to calcium oxide or froding some commerciel uxe for the cakium sulfake ash mixture produced from the proxe is. Retativety linke diffeculty has been experienced in geting good combustion in the bed. the primeifal problex. being the avoitance of excessive barning rates and bot spots at the prints where the coal is introduced into the hed. Nove that the bull of the work carried out to dace has been with beds having areas of 1 to $10 \mathrm{ft}^{\circ}$. where agiontion of the bed is reasombly effective in disuributiof the coal. However. the bivi envisioned in commercial sysaras will Lave areas of 100 ic 200 ft: heace sealeup uncertianies inctude problems associated with de ising provisions for a brge number of coal feed points across the bed. the distribution of coal and linestone across the bed. the upper limits of gas velocity and bed depth. the sive and spacing of heat transfer mbes. and the control of power ketel.

The rate of corrosion erosion allact on the combustion side of the tubes in the coal combustion. chamber has received retatively lituk attention: thus a phase of the future ANL proeram will be directed toward malerials compatibility.

Figure 6.12 presents the projected time scheduk for the current national program to develop nuidized-bed combustion technology." The fluidized bed boiker is not commercially avaibble and cannod be expected to be until the protonge is evaluated. It should atso be noted that most of the effort is directed towand deve'.jpment of systems to be used by electrical utilities. although much of this technology should alss apply to ind ustrial systems.

\subsubsection{Ecomomic Anabres}

Since there are no fuidired-bed boikers comnereially avaibble. there are no commereial prices on which to base an extimate.

Pope. Evans. and Robbins 1000 presented a cost estinate for a complete plant of $500.000 \mathrm{lb}$. hr at 600 psi and $399 \%$ C $(750 \%$ F). They itemized all ripizi i equipment and operating costs for comparable nuidized-bed, spreader-grate. oil-fired, and gas-fired boikers. The owning and operating costs, kess fuel. for the fluidized-bed briker is 1.4 times that of the gas-fired boiker. and that for the spreader grate is $\mathbf{2 . 3 5}$ times that of the gas-fired boiler. The report rationalizes that the fluidized-bed boiket is sigrificantly cheaper than the spreader-zrate boikr because it is more compact. contains less surface. and car' be factory ascembled.

110. Personal communiation from Cienge Weth. Orfice of Cnal Research. to Iruman D. Anderson. ORNI. 
OANL ONC is ins

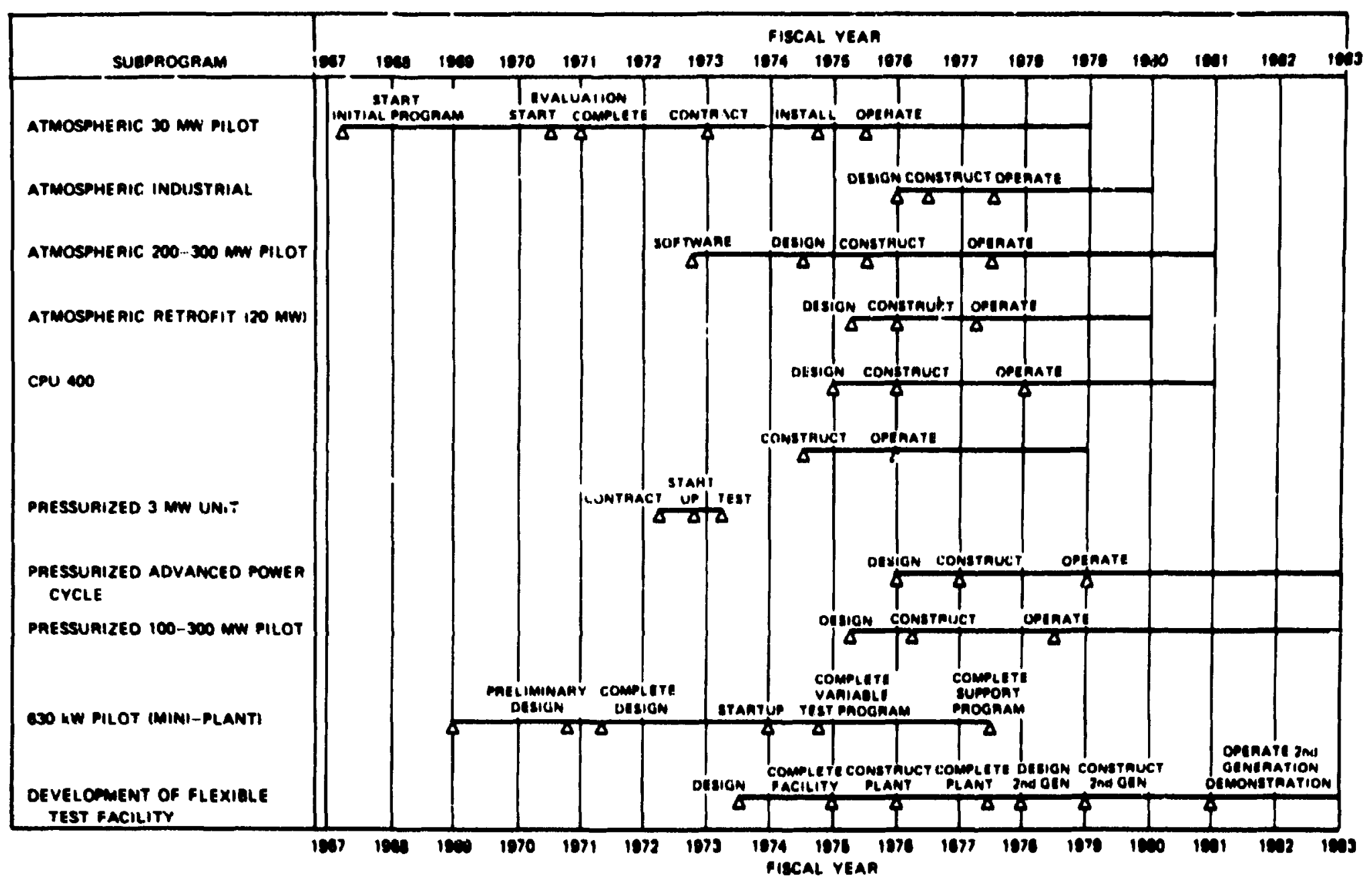

Fig. 6 12. Nallional Ruidized-bed combualion proseram. 
In a tetphone communication. Foster-Wheeler Company' stated that they felt that the nuidived bed would cost about the same as a conventixizal coat-fired boiler, however, the total phat cost would be less because no stact-gas clanup system is reyuired. The cost estimate of Table 6.I8 therefore is based on a "standard" coal-fired boiler cost of $\$ 25$ per pound of steam per hour.

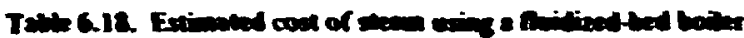

Hat apairy. $3 \times 10^{6} \mathrm{Brm}$ Uait boile apacies, $300000 \mathrm{blh}$ (10 vaits)

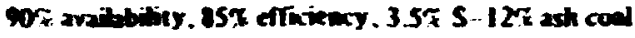

\begin{tabular}{|c|c|c|}
\hline Ifeen & $\begin{array}{c}\text { Anmed cost } \\
\left(10^{6} s\right)\end{array}$ & $\begin{array}{l}\text { Unis cost } \\
\left(\$ / 10^{6} \text { ia) }\right.\end{array}$ \\
\hline 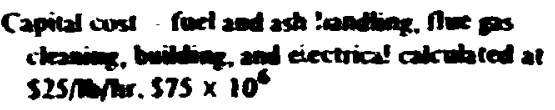 & $1 * 60$ & 60.7 \\
\hline Limescone ingetion (al sy(ton) & 1.82 & 6.0 \\
\hline Refoins and maintewance at st of chital & 3.75 & 13.7 \\
\hline Lotor, 17 men/shift at $57.70 \mathrm{hr}$ & 1.225 & 4.5 \\
\hline 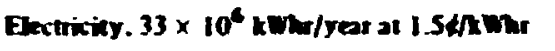 & 0.495 & 1.8 \\
\hline 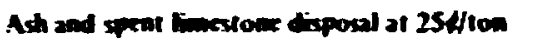 & $0.0 s$ & 0.4 \\
\hline 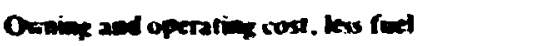 & 24.03 & $\overline{07.7}$ \\
\hline Fuel. cool at $74 / 10^{6}$ are & 23205 & e7.1 \\
\hline Total & $\overline{47.9}$ & 775 \\
\hline
\end{tabular}

\subsubsection{Dincetfined Proces lleaves}

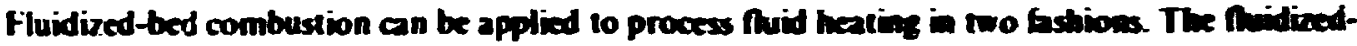
bed boikt an be used as a process fluid heater essentially by pumping the process noid throus the sab-

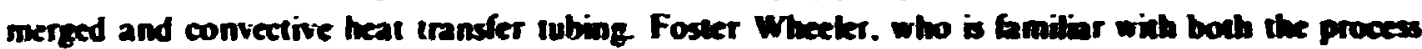
heaters and the fluidized bed boike. has done a preliminary stody and faels the nuidined-bed boilet is suitable as a process flud heater with the following reservations.

I. The heat hux in the submerged surface is about frve times that of convective or radiative surfe-s. so the film coefficient of the thid must be adequate to asante transier to the bult huid without overtheating at the wall.

2. The hea. capacity of the bed is high: 30 in the event of bas of now. even though the fuel is shut off. a significant heat addition to the thid will continue. The system must be designad to accommodate the results of overheating the process mid.

A Muidized bed bumer (no submerged heat transfet surfece) can be used as the heat source for conventional or existing process fuid heaters (or boilers) by ducting the clanned combustion gas to the heater. It may be desirable or necessary to install radiative surface above the bed for combuation

111. Private communication from Henn Phillips. Fosver whecker Corporation to E. C. Hise. OA.VI. 
temperature coatrol. The berners bave ben cemmercially avaibble for over 12 years, have bern buil in sizes up $10300 \times 10^{\circ} \mathrm{Bu}$; hr. and are conventionally equipped with heat recovery boilers ard emission coatrol equipment. They have been designed to bum liquid usses, studges, and wood wastes (inctuding bos) and can be designed to burn any conventional fucl. irphuting coal. Alhough there have been no retrofit instalbtions of bumers to existing heaters or boilers. one manufacture: stated a willingness to design and fabricate such units and is now preparing a conceptual design and cost estimate for a prospective chient. This applization represents a reasonable modification of existing technology. and ine design and delivery time are felt to be comparable to those of conventional industrial equipment.

\subsection{LOW-AND INTERMEDIATE-DW GAS}

\subsubsection{Gesernd Description}

One possible way to burn coal and meet emission standands is through a iwo-slage cumbustion process in which the cual is partially oxidired in a gasifier. the particubles and sulfur are scrubbed from the gas stream. and the gas is burned in a boikt or radiant furnace. The process may he retrofitted to existing equipment buming gas. oil. or coal or may be integrated winh new capacity construction. The gas produced has a heating value of 150 to $300 \mathrm{Bu}$ sel. dependiug on whether air or oxygen is used in the gasifier. Oxygen-blown gasifers produce a gas with a beatine valuc that is intermediate between low-Btu and pifaibe-quality gas (1000 BHu sen). Inermediate-buu gas has a heating value range of about 300 to 500 Bue sef. Because of the bow-tive content. the gas is not economical or suited for pipeline gas. but neithes of these constraints apply to ia-ptant or perhaps regional distribution. The advaneapes of gaifeation as epposed to direct coal combustion followed by stack-eas cleanup. in addition to the fact that the paifw may be retrofined to existing pas or oilfired eyuiponent. are that the sobume of ges to be claned is apprexiably las and that the sulluer is in the form of H:S as a resuh of the reducieg stmosphere in the gasiix:. Estimales of the fuel canerg! utitivation of the processes range from 75 to 99 ;. dependies on the specife process and the amoum

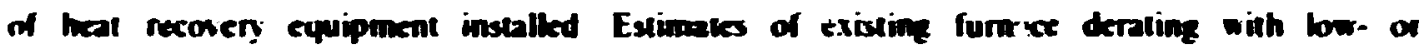
intermediake-Bhu gas range from 5 to 30 ;. depending on the fuel it was desizned for. the method of firing. and sive.:

There are at least four sompanics oflering gasifiers commercially in the United States and at keast ouc industry firing its furnace with exerated gas. However. that one installation is about 17 years old. and there have been no commercial gasifers built in the ti nited states in the interim.

Processes for the production of low-Phu gas generally contemptate the use of a gasitice in which hot coal or coke is contacted with air or oxyexn and steam at temperatures ranging from 927 to $1371^{-}\left(1700\right.$ to $\left.2500^{\circ}+\right)$ and pressures from atmospheric to about 450 paig. The oxygen in the air or from an oxygen generator reacts with carbon to form carbon monoxide. with the evolution of a

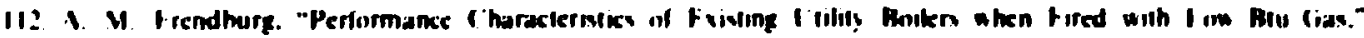

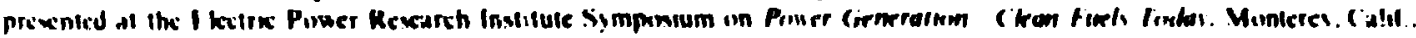
Inr $\times 111.1474$ 
considerabte ywamity of heat: $1:$

$$
C+120:-\operatorname{CO}(\Delta H=-26.416 \mathrm{Cal} z \text {-mok) } .
$$

This reaction supplies the heat needed for the endothermic water-ges reaction. in which carbon and steam react to produce ( 'rbon monoxide and hydrogen:

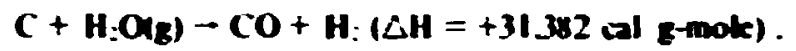

The $\mathrm{CO}$ shift or water-gas shift reaction abo occurs 10 a significant extent. In this reaction. carbon: monoxide reacts with steam to yield carbon clioxide and hydrugen:

$$
\mathrm{CO}+\mathrm{H}_{-} \mathrm{O}(\mathrm{g})-\mathrm{CO}:+\mathrm{H}_{:}(\Delta H=-\$ \mathrm{Hal} \mathrm{g} \text {-mole })
$$

Another important reaction is the formation of methane from carbon and hydrogen:

$$
\mathrm{C}+2 \mathrm{H}:-\mathrm{CH}_{3}(\Delta \mathrm{H}=17.859 \mathrm{cal} \mathrm{g} \text {-mok) } \text {. }
$$

However. this reaction lakes phece onby to a small exkent at the contixions used in the gas producers under consideration.

Under the high-temperature conditions and in the reducing atmosphere of the reactor. sulfur compounds in the coal are decumposed principally to H.S. winh small quantities of carbonyl sutfote (COS) and carbon disulfide (CS:) abo being produced. The decomposition or cracting of bre coal molecules abo yielts ars. oxyernaled compounds such as phenots, and lizht hydrocarbons such as methane and ethane. Some of the processes chim complete gasification of these compounds.

After panicuble matker. lars. phenots. and sulfur compounds have beent removed. the principal components of the low-Bhu ges are carton monoxide, hydrogen. nitrogen (if air is used). carbun dioxide. and methane.

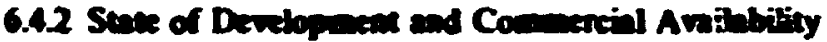

The priacipal processes for producing bow- and or intermediak-Beu gas are summarived in Tabte 6.19. The Lurgi processs is offered by the American Lurgi Company. New York. N.Y. 10017: the Koppers-Tourth process is offered by the Koppers Company. Pitusburgh. Pa. 15219: the Wellman-Galusha process is offered by the MeDowell Wellonan Company. Cleveland. Othio 4114: and the Winklet process is offered by Davy Powergas. Inc.. Lakeland. Fib. 33803.

\subsection{Symer Chancturition}

Coal pasification proceses may be categorized according to the type of equipment in which gasification vakes place. Firs. there are the so-called fixed-bed processes. of which the Lurgi and Wellman-faluch are typical. In thise gasifiers. a bed of coal moves slowly downward and is contacted by an uplowing stream of hot gases. A second type is the vortex-flow combustion chamber gasifer. typified by the Koppers-Totzek process. Puherized coal and oxyeen-enriched air are injected into a refractory-lined chamber in which rapid combustion and gasification take place. and molten ast (shg) is withdrawn from the bottom. A third type includes muidized- or entrained-bed pasifrers, typifined by the Winkler process. In these gasifiers. the coal partictes are

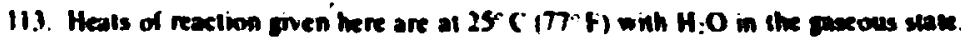




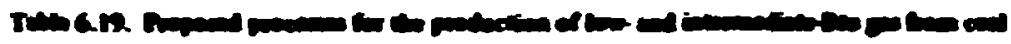

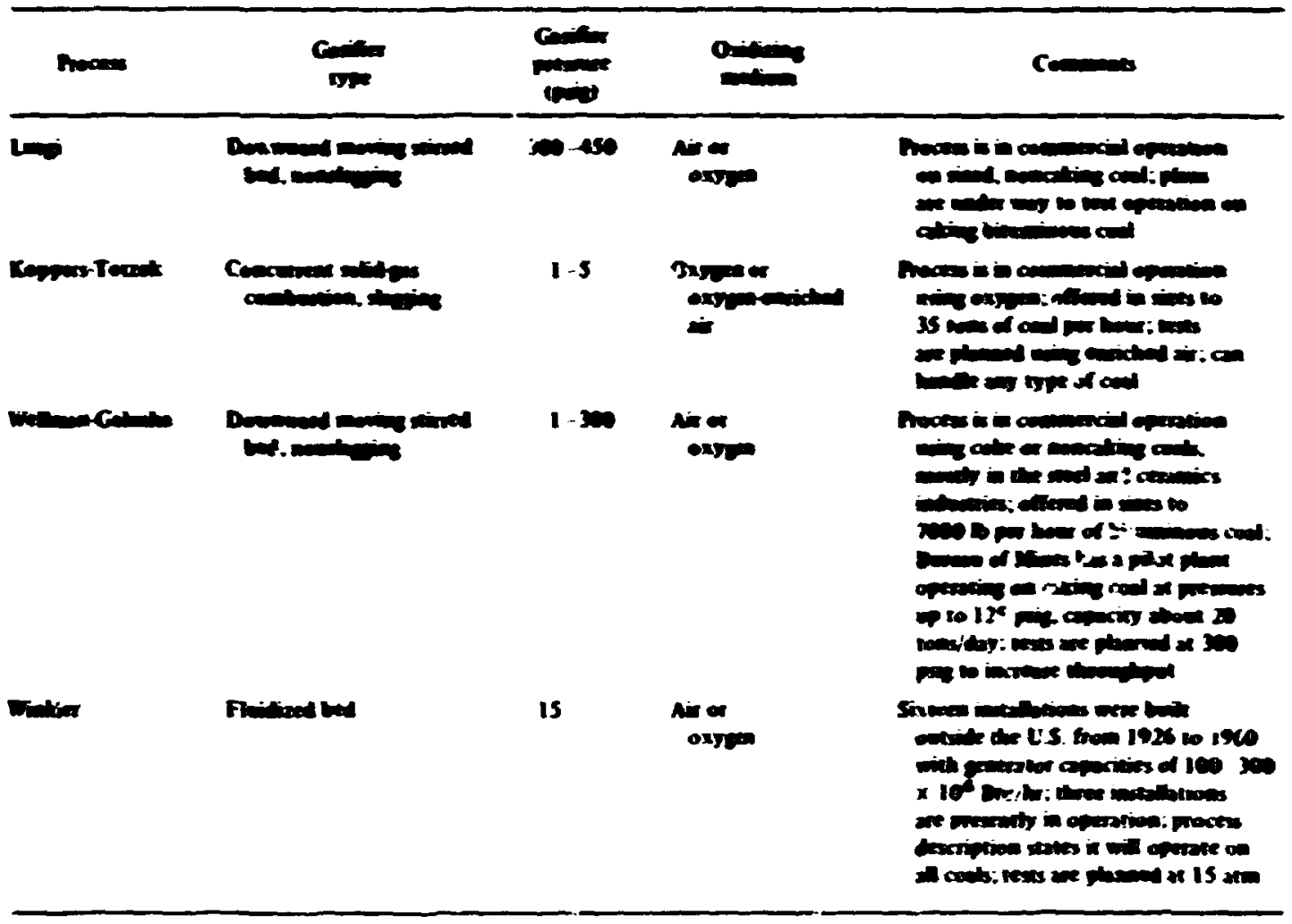

suspended in rapid molion in an upllowing stream of hot gases. Secteral gasifers. inctuding the Bigas. Hyges, Sỵnthane. CO: Acciptor. Bureau of Mines hydrogasification. and I niwn ("artiole ash-agelomerat ing t!pes. are under ckevelopment. The three categories mentioned comprixe most of the piocesses proposed thus far. Othrr types include the Kelkeze process and the Atgas process. in which the gasification reactions occur in molien salts and molten iron respectively.

The iutsections that follow conts: more detaikd information concerning the barisus gasification pincesses and processes for removing sulfur compounds from the ran gas.

\subsubsection{Commercial Symems Presendy Availubte}

\section{Lori proces}

The l.urgi " gasificr (fig. 6.13) operates at a pressure of about .00) so 450 psig. Sived cual enters the top of the gasifier through a lock hopper. and air and steam are blown in at the hotton. Ihe gasifier may also be oxygen blown. The coal travels downward and. after gasificatium is completed. is discharged as a dry ash through a rotating grate. Raw gas exits frum the top of the gasifker and is routed to a scrubbing system where solids. tars. H.S. and COS are removed. The finished gas has a higher heating value of 150 io 230) Btu sef and is at a pressure of aloout 290 in 450 paig.

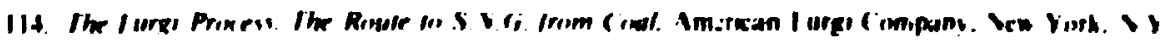




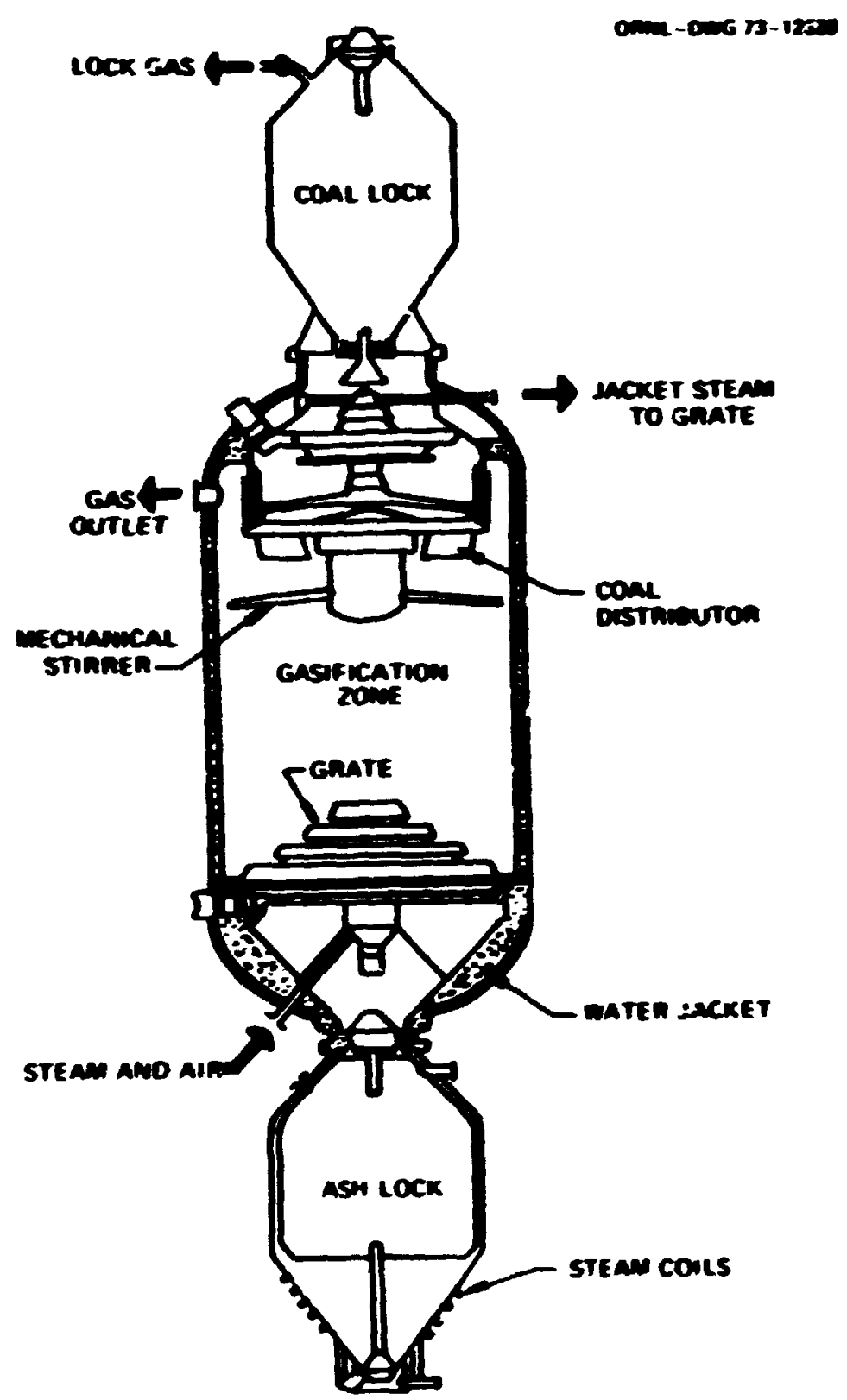

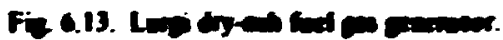

Many l. urgi gasifiers have heen operawed succesufully on noaswelling coats. More than 50 uniks have been buith. primarity in Europe. The capabiliny of the Lurgi paifer for operation on Iypical easkem U.S. bituminous coob. which tend to swell. become sticky. and cake. is now being demonstroted.

Commonwealth Edison Company" is proceeding with an instalbion of three Lurgi pasifers at their Powerton Station. The phnt capacity to be supplice by low-Beu gas is $120 \mathrm{MW}(\mathrm{e})$ : stanup is

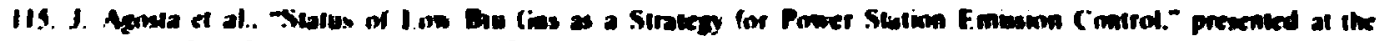

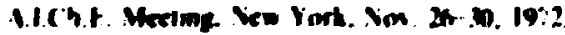




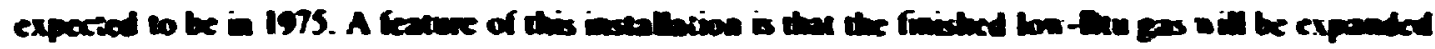

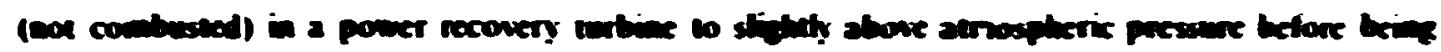

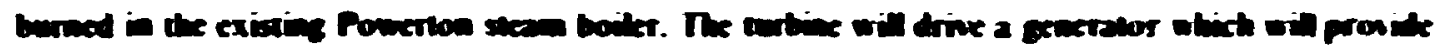

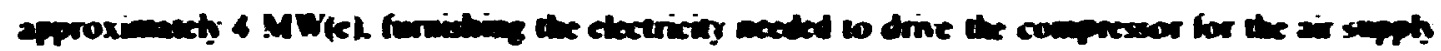

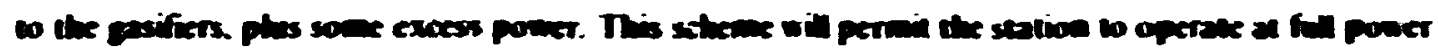

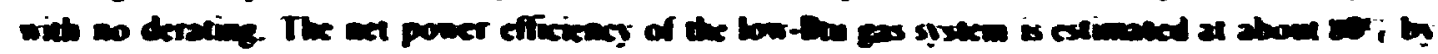

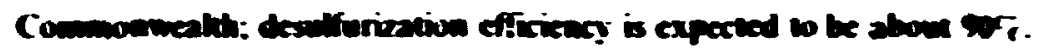

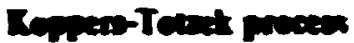

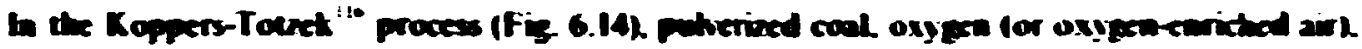

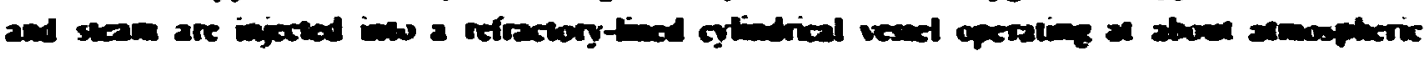

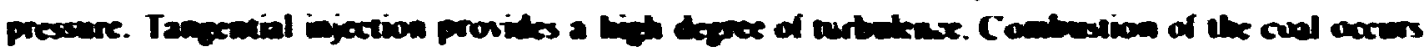

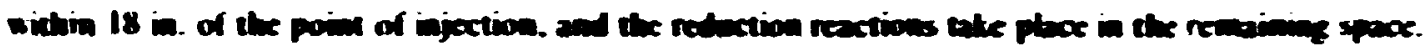

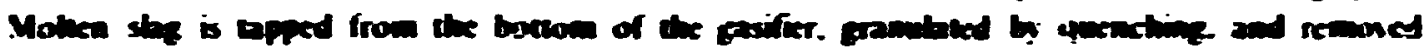

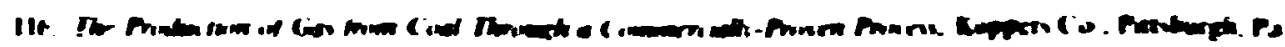

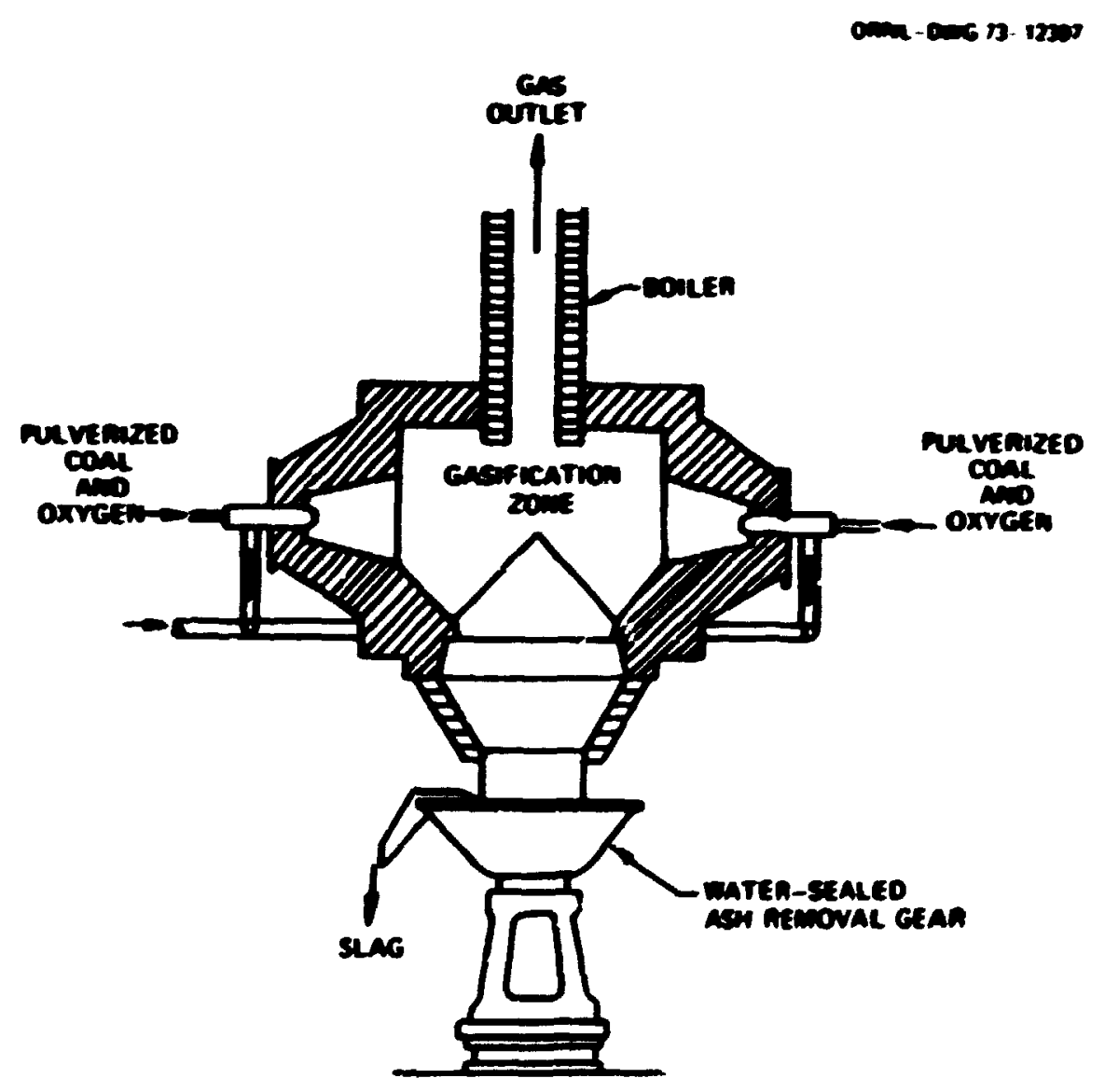

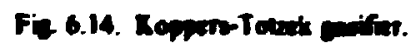




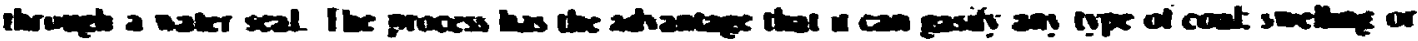

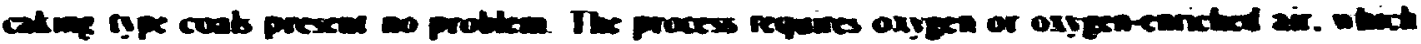

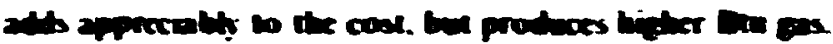

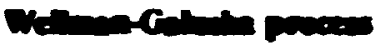

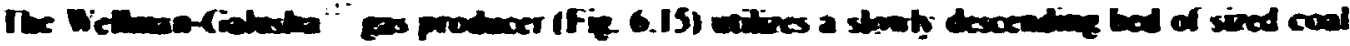

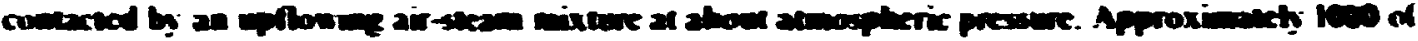

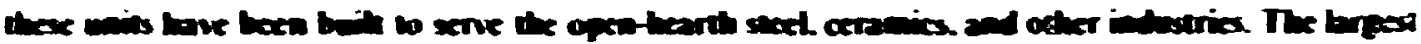

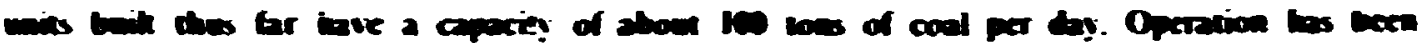

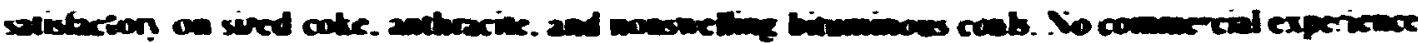

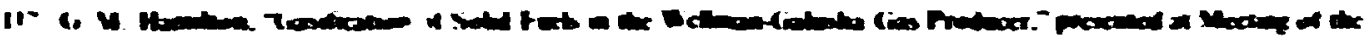

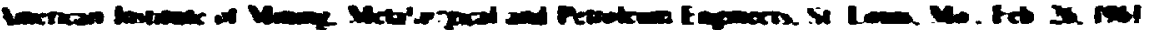

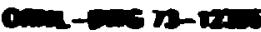

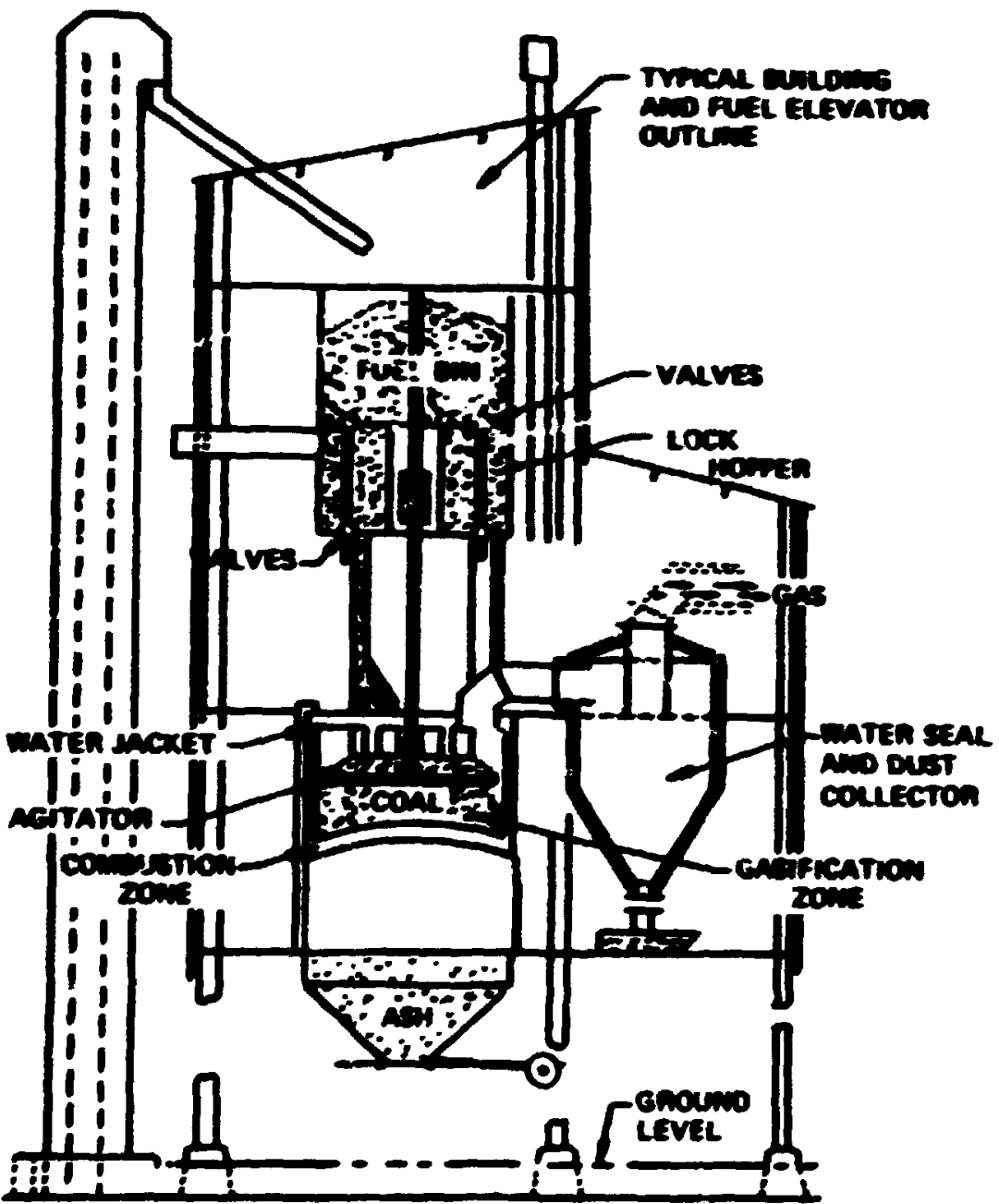

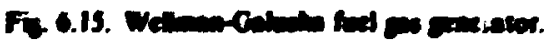




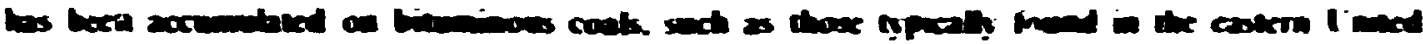

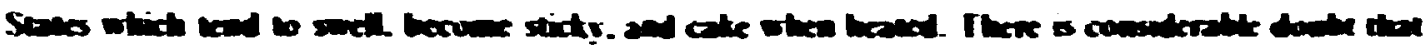

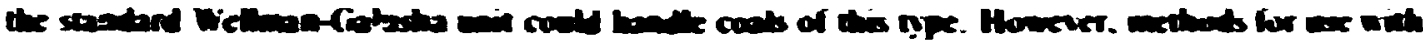

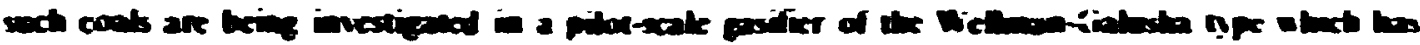

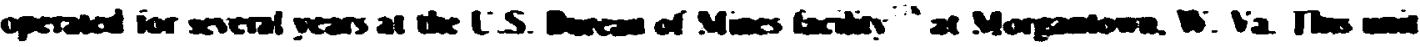

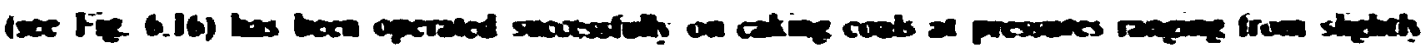

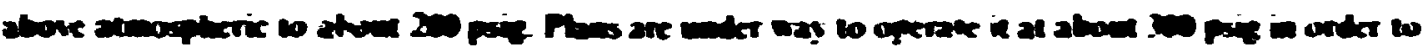

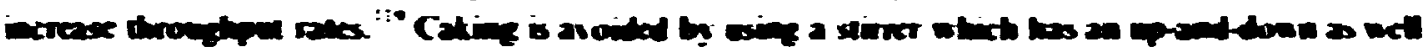

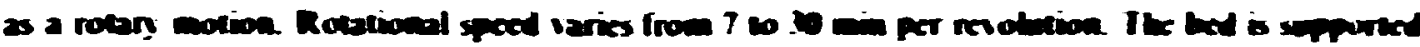

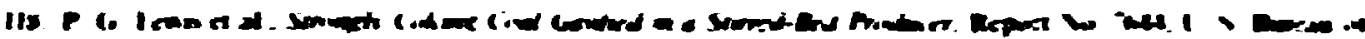

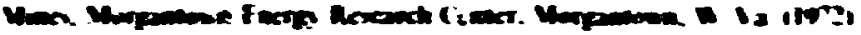
$19-3$

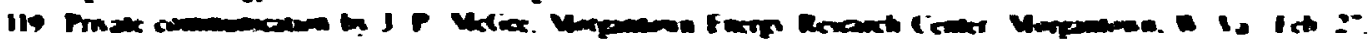

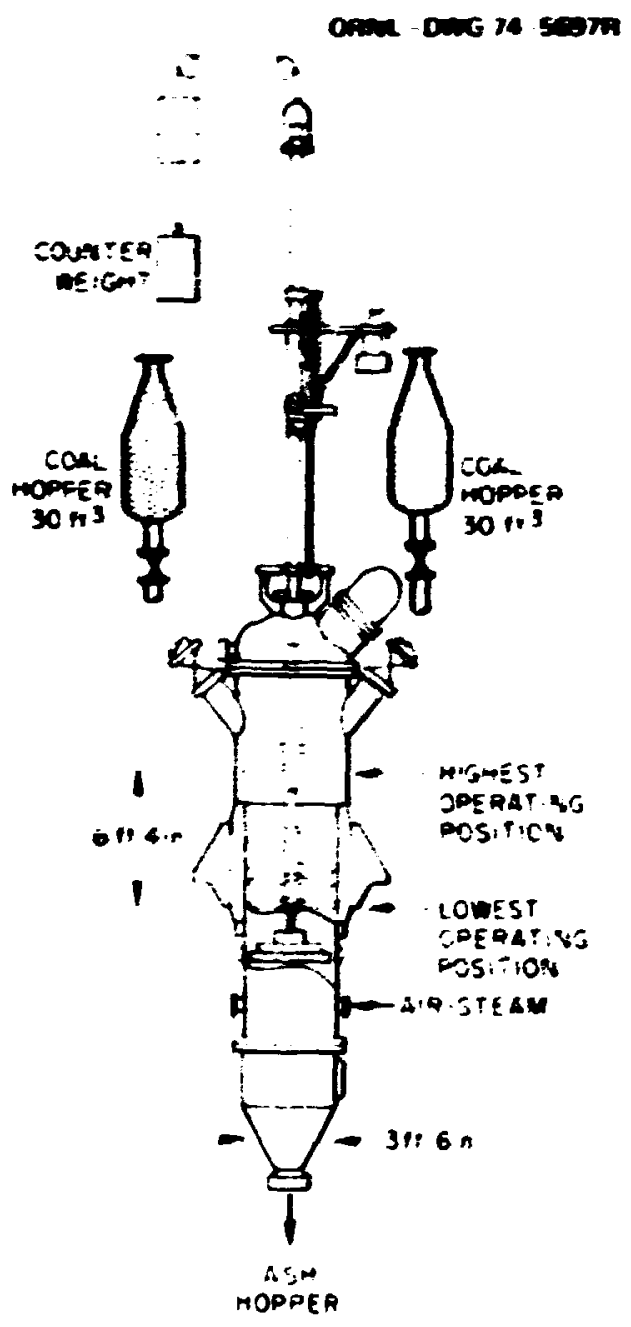

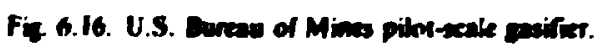




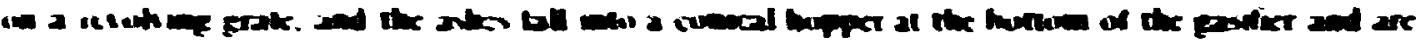

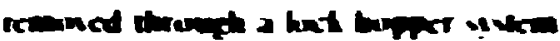

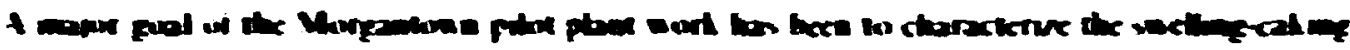

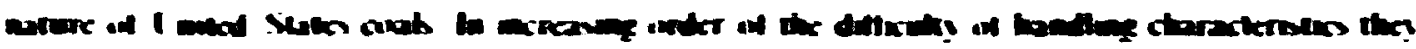

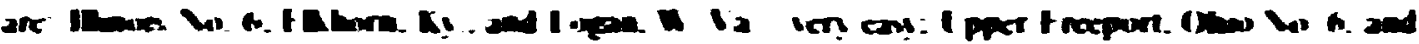

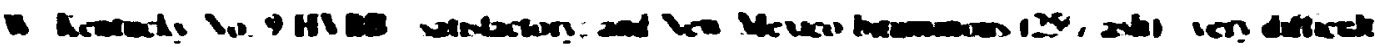

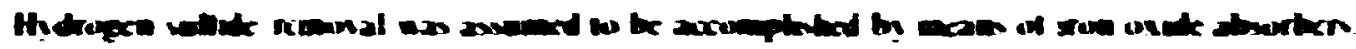

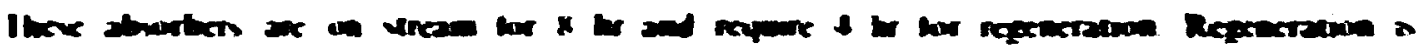

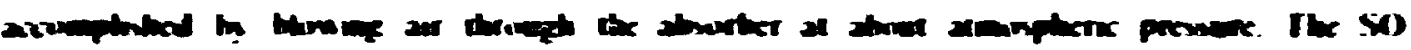

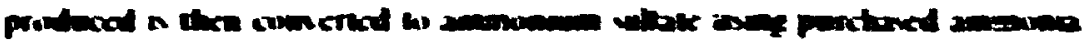

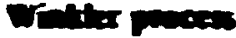

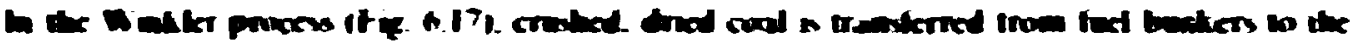

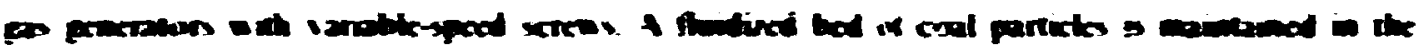

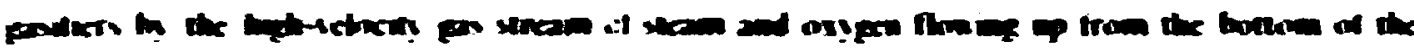

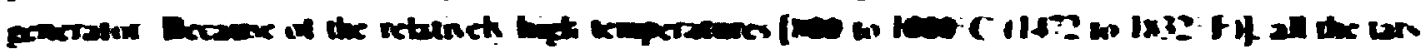

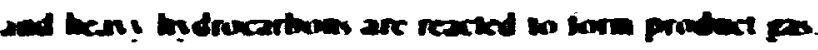

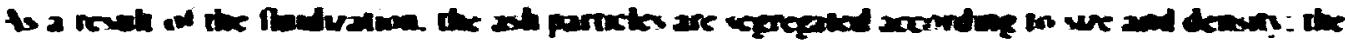

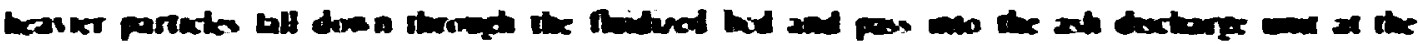

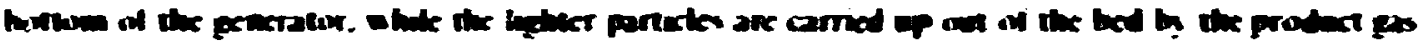

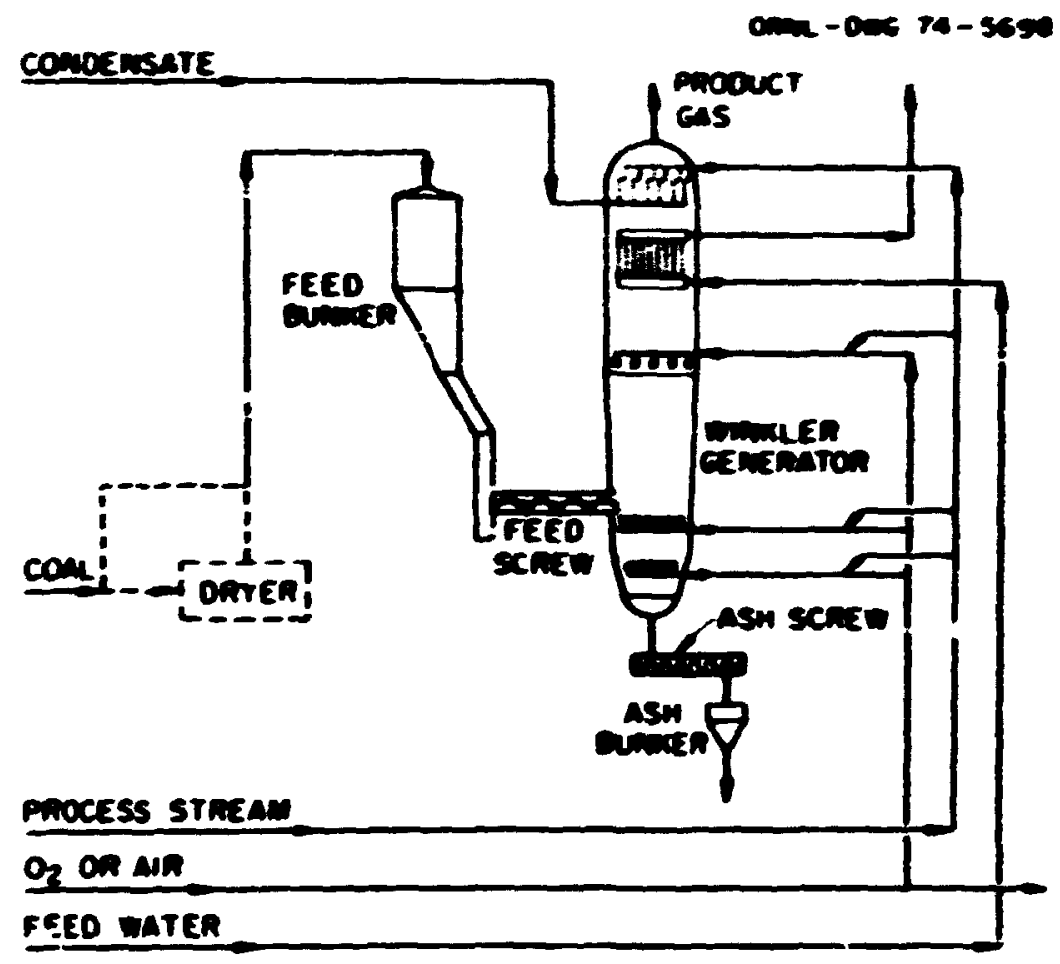

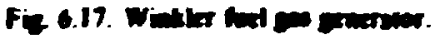


ts be further gasified in the spece above the bed. The manufacturer chims that great flexibility in copacity can be provided and that shutdown Lin be achicent in minutes; e.s.. a generator with a nominal apacity of $2 \times 10^{\circ}$ sef hr can be operated without apprecinble loss of effriency over the range of $0.5 \times 10^{\circ} 103 \times 10^{\circ} \mathrm{sel}$ hr.

\subsection{New Srivers Under Developanent}

Several additional coal gasifications schermes are uncer development but are not being offered commircinily at the present.

\section{Unwia Carbide ach-apdoweration fluid-bed process}

In this process.' "'" rushed coal is fed to the gasifier either as a water slurry or as a diy solid. It is subsequently contacted by steam and by the hot ash agglomerates produced by the combustion process. The hot ash agglomerates fumish the heat aceder by the endotherinic steam-carbon reaction. The gas probiust contains carton monoxide. hydrogen, and about $10 \%$ methane.

One of the advantages siaimed is that the gas from the reactor is essentin:liy duss free. A second advantage of this process is that the nitrogen in th= air used for regeneration does not appear in the product gas (since the combustion gas from the regenerator is not mixed with the product gas frem the gasifier). Another advantage is that the self-agelomerating characteristics of the gasifier help to colket the ash partickes in the coal, thus producing a product gas that contains vety inicic palticulate marter This simplifies the gas ckanup and facilitates uxe of the gas in an expander turbine for encrgy recovery.

The use of fluidized-bed gasification avoids the probicms of swelling. stickiness. and caking that may be encountered in íxed-bed procesces operating on easter., U.S. bituminous coaks. If the process proves successful. it should be insensitive to the type of roai used and shnuld be suitable for a wide variety of feedsicciss. including eastern and western coal. lignites. or char.

\section{Ateas Process}

The Applied Technology Corporation Atgas process ${ }^{1201}$ is ac continuous process in which ground coal ( 1 \& to I 4 in.) is dissolved by injection into a pool of molten iron. Simultaneously, the dissolved coal carbon is oxidized to $\mathrm{CO}$ by air injected below the surface of the iron. limestone is continuously added to react with sulfur present ir, the coal.

The Bigas and 10 . Azceptor processes, discussed in Sect. 6.5.3. can also produce low- or internediate-Biu gas.

\subsubsection{Gas Purification}

When coal is gasifiec, most of the 'ulfur is converted to H.S. which subsely'tently appears in the raw product gas. Small amounts of carbonyl sulfide (COS). phenol. etc.. are ilso formed. Gas treating processes are concerne ' principa!ly with the removal of these sulfur compoumis. The prectesses fall into

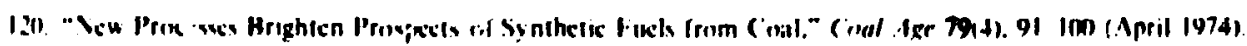


two general classes: those in which the H:S is absorbed by sen bbing with a solution of t regenerable absurbent and those in which the H:S is absorted by reaction with a solid material.

A sulid material absorption process that will operate at e!lun at gas semperature would improve the ecunomy and efrciency of gasifuation by eliminatine the gas cooling step.

tiquid scrubbing proce: $x^{\text {'"' }}$ for $\mathrm{H}: \mathrm{S}$ removal have been in commencial use for many yearsand are highly developed. These processes can be divided into rwo general catezories: those in which absorption is accompanied by chemical reaction and those in which absorption takes ptoce by physical solvent action alone. The btter ame into prominence in the 1960s, whereas the former bave been in use longer.

Currenty. the manufacturers of coll gasirication equipment ofler an altali scrubbing system (e-b., potassium carbonate solution followed by a Chus unit 10 produce elemeatal sulfur). A Stretford phat is also offered as an altemate to produce elementri sulfur as well as xisral proprietary setsemes. Additional processes are alto avaibble, as shown in: Table 6.20.

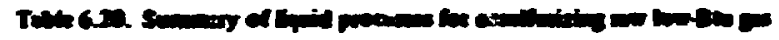

\begin{tabular}{|c|c|c|c|c|c|}
\hline Inecos: & 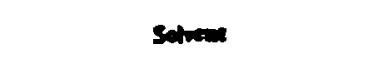 & $\begin{array}{l}\text { Trmasure } \\
\text { PC(P) }\end{array}$ & $\lim$ & Angeration & Pont \\
\hline 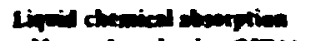 & & & & & \\
\hline 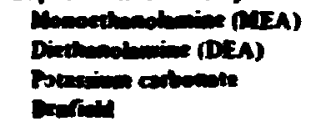 & 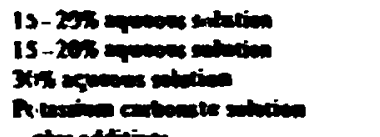 & $\begin{array}{l}322-54(30-130) \\
322-34(30-130) \\
110-127(230-25) \\
110-127(230-250)\end{array}$ & $\begin{array}{l}1-1000 \\
1-1000 \\
1-1000 \\
1-1000\end{array}$ & a & 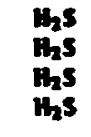 \\
\hline Allavid & 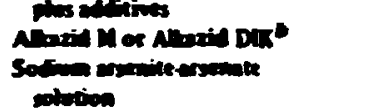 & $\begin{array}{l}322-54(20-130) \\
322-54(20-120)\end{array}$ & $\begin{array}{l}1-1000 \\
1-1000\end{array}$ & Air unowing & $\begin{array}{l}\text { ins } \\
5\end{array}$ \\
\hline 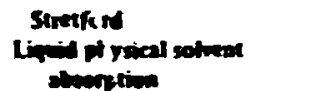 & $\boldsymbol{c}$ & $32.2-\operatorname{se}(30-130)$ & $1-1000$ & Air verien & $\mathbf{s}$ \\
\hline 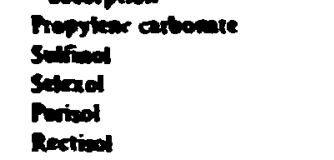 & 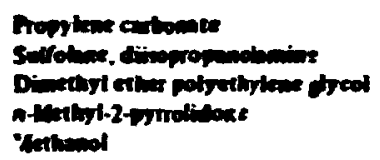 & $\begin{array}{r}32.2-5(30-130) \\
-17.0--16.7(0-2)\end{array}$ & $\begin{array}{l}-1-1000 \\
000-1000\end{array}$ & d & $\begin{array}{l}\mathrm{H}_{2} \mathrm{~s} \\
\mathrm{H}_{25} \mathrm{~s} \\
\mathrm{H}_{2} \mathrm{~s} \\
\mathrm{H}_{2} \mathrm{~s} \\
\mathrm{H}_{2} \mathrm{~s}\end{array}$ \\
\hline
\end{tabular}

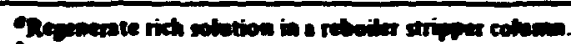

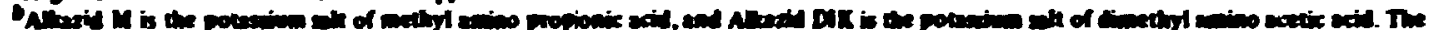

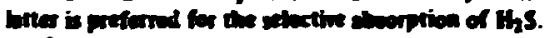

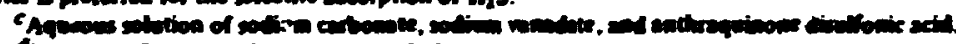

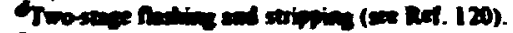

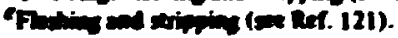

\subsubsection{Economic Analyses}

The major items in the cost of gas production are coal, capital, babor, electricity, water. and maintenance. In an oxygen-blown gasification plant. the capital and operating costs of the plant are also significant. As shown in Table 6.21. the oxygen required per pound of fuel differs considerably. depending on which of the commercially avaibble gasifiers is used. At oxygen-_oal cost ratios between 1.5 and 2 , the cost of oxygen repre sents about $50 \%$ of the raw material cost for the Lurgi process and about 60\% !ot the Koppers-Totrek suspension gasifier.

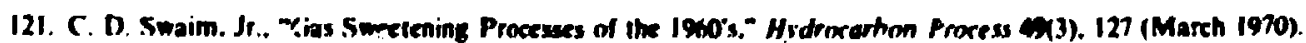


Four U.S. vendors of coal gasification equipment have supplied budgeting costs for turn-key phants with the two caveats that the amount of installed equipme $x$ is a function of the type of coal and that their unit cost estimates are being restudied and possib.y will be revised. Further, there is litte recent U.S. operating experience with coal gasification phnts.

Cost estimates ar: presented in Tables 6.22 through 5.25 for production of bow-Bath gas (air blown) and intermediate-Blu gas from oxygenblown plants using different gas producers and feed coals. Oxygen plant costs were supplied by the Lind Division of Union Carbide Corporation. and coal preparation and handline costs were based on unpublished Bureau of Mines data. In some cases. vendor estimates were stated to be \pm 50 fi of a firm bid cost. pending exact site becation. avaibability of water. sulfur recovery scheme used. and delivery schedules. Hecause of the uncertainties in cost data supplied by some vendors, we have presented two cost estimates each for low- and intermediate-Btu gas. We believe these estimates span the range of costs, and possibly the high estimate for kw-Btu gas may be the most realistic.

Estimated gas costs ranged from $\$ 1.86$ per 10" Btu for bow-Btu gas using eastern 3.5f; sulfur coal delivered via New Orkans to the Houston area 10 52.37 per $10^{\circ}$ Btu for intermediate-Btu

\begin{tabular}{|c|c|}
\hline Cosifies iype & $\begin{array}{l}\text { Oxymen required } \\
\text { (16 O/b fuel) }\end{array}$ \\
\hline Lurgi & 0.37 \\
\hline Wiaklet & 0.49 \\
\hline Koppets-Tottek & 0.80 \\
\hline
\end{tabular}

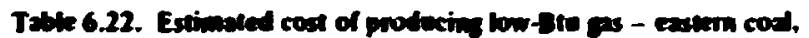

$$
\text { 357 salfer. } 11500 \text { Etwits }
$$

Annul production $=32.850 \times 10^{12}$ Bru/year of 120 Blu/sci gas: air-blown shaging gasifiers: $00 \%$ cool conversinn efficiency: ps producets. 62 units if are speres): $5100.24 \times 10^{6}$ installed capial cost, includise cost of caal handling and preparalion equipment (first quarter 1974 dollars)

\begin{tabular}{|c|c|c|}
\hline & $\underset{\text { Annual }\left(10^{6}\right.}{\text { ost }}$ & $\begin{array}{l}\text { linit cost } \\
\left(d / 10^{6} \mathrm{Btu}\right)\end{array}$ \\
\hline Capiral charges at 22.2\% fixed charge rate & 22.25 & 67.7 \\
\hline Repairs and maintenance matetials al 27 of capic if & 2.52 & 6.1 \\
\hline Labor (includes 40\%, CokA overhesd) & $n .85$ & 2.f. \\
\hline Waler. $3959 \times 10^{6}$ plat as $35 / 1 \mathrm{~mm}$ gal & 1.39 & 1.2 \\
\hline Flectricily, $18 \mathrm{kWhr} / \mathrm{Ion}$ coal at $30.01 \mathrm{~S} / \mathrm{k}$ Whr & 0.65 & 2.0 \\
\hline Coal handling and ash dispmal & 0.30 & 0.9 \\
\hline Sulfur removal and recovety & 3.14 & 9.6 \\
\hline $\begin{array}{l}\text { Anrual corl kss fuel } \\
\text { Conal at } 74 \$ 110^{n} \text { Biv }\end{array}$ & $\begin{array}{l}30.58 \\
30.39\end{array}$ & $\begin{array}{l}93.1 \\
9 !\end{array}$ \\
\hline Tntal & 6197 & $\overline{186}$ \\
\hline
\end{tabular}




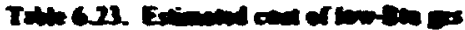

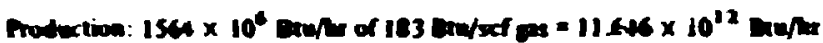
Comersion eficieary: $7 x$

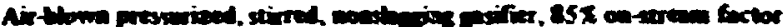

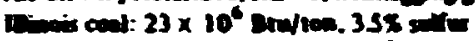

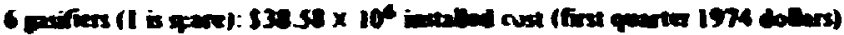

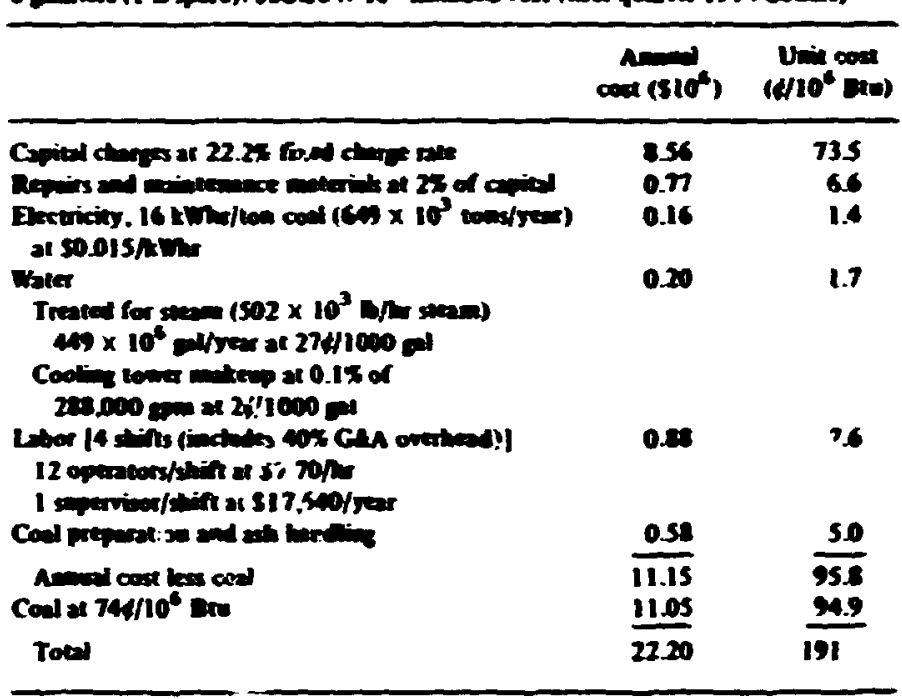

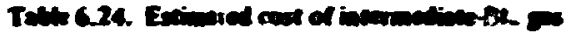

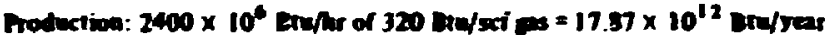

Conversion efriciency: $7 \mathrm{x}$.

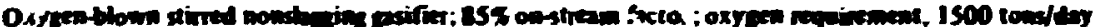

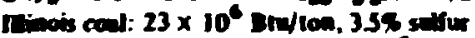

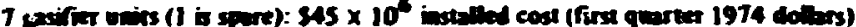

Oxyen phan: $512 \times 10^{\circ}$

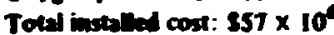

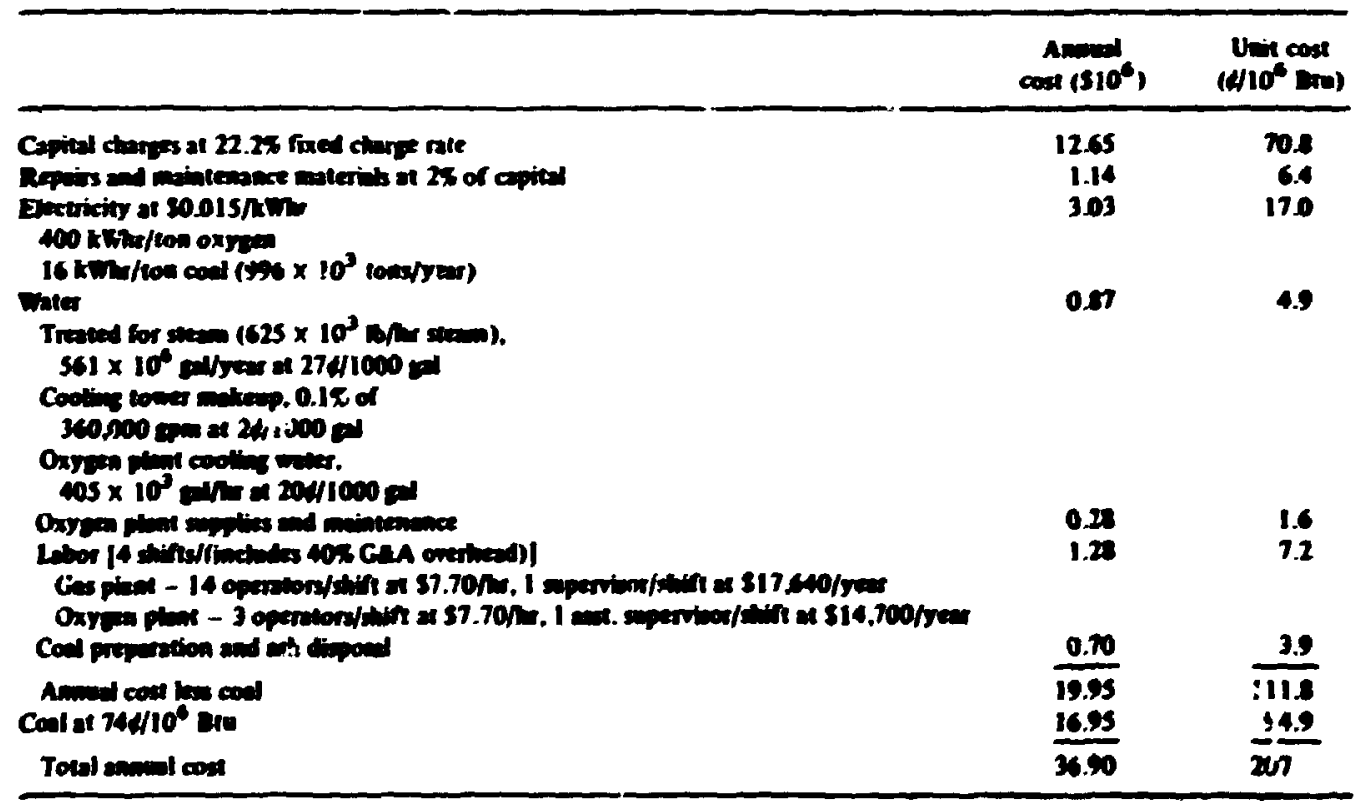




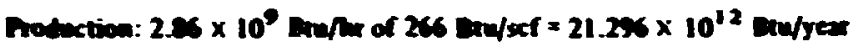

Conversion tificieacy: $69.7 \times$

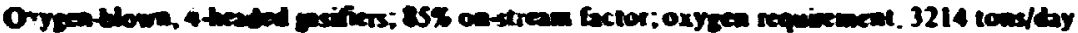

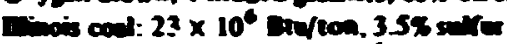

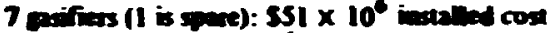

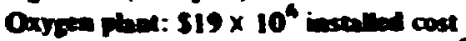

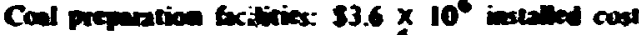

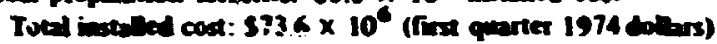

\begin{tabular}{|c|c|c|}
\hline & Aost (s) $10^{\circ}$ & $\begin{array}{l}\text { Unit cost } \\
\left(d 10^{\circ} \text { Dru }\right)\end{array}$ \\
\hline 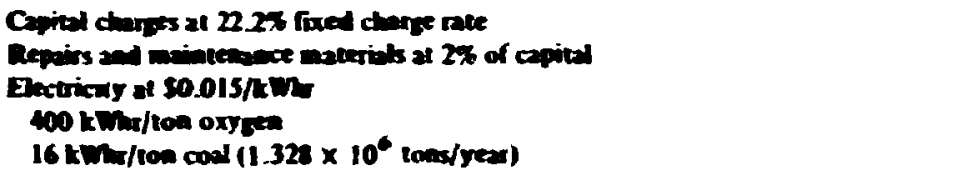 & $\begin{array}{r}16.33 \\
1.47 \\
6.30\end{array}$ & $\begin{array}{r}76.7 \\
6.9 \\
29.6\end{array}$ \\
\hline 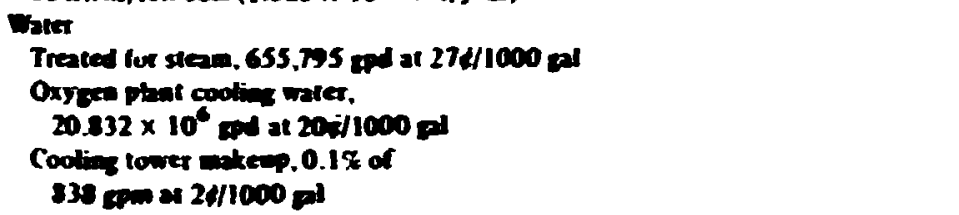 & 1.42 & 6.7 \\
\hline 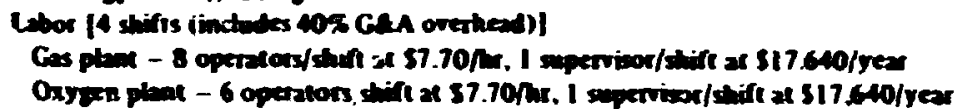 & 0.98 & 4.6 \\
\hline 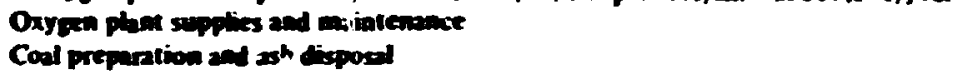 & $\begin{array}{l}0.45 \\
0.22 \\
\end{array}$ & $\begin{array}{r}2.1 \\
3.9 \\
\end{array}$ \\
\hline 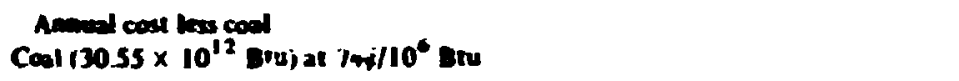 & $\begin{array}{l}27.77 \\
22.61\end{array}$ & $\begin{array}{l}131 \\
106\end{array}$ \\
\hline Total ansel cost & 50.38 & 237 \\
\hline
\end{tabular}

gas prepared from high-sulfur (lllinois) coal delivered via View Orkans. Abo costs of intermediate-Btu gas varied with the type of gasifer used and the oxygen reyuivements per ton of coal. All installed plant costs and coal costs are based on a Houston area facility.

Estimates of the cost of steam using low- and intermediate-fleu gas-fired boikers are presented in Tabte 6.26. Note that the installed cost of the plant using low-Bru gas was esimated to be about it ; higher than the plant using intermadiate-Btu gas due to the additional costs for brger ducts. fans. stack. etc., which would be required to accommodate the increased volume of gas resulting from the use of low-Btu gas. Resulting steam costs mange from $52.6410^{\circ}$ Butu using low-Btu gas to $53.1810^{\circ}$ Bu using intermediate-But gas.

Estimales of steam costs using low-Btu fuel assume new instalkions which have been designed specifically to handk low-Btu gis. There is scme uncertainty about the use of low-Btu gas in existing hoikrs. 


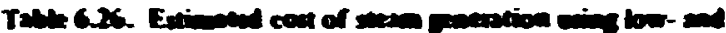

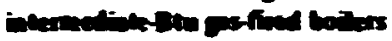

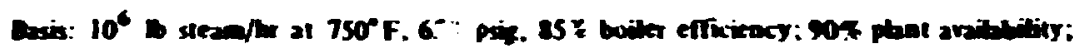

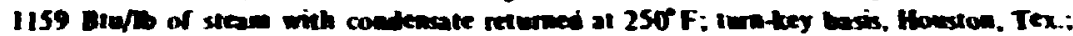

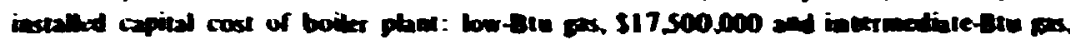
S1S.000000

\begin{tabular}{|c|c|c|c|c|}
\hline & \multicolumn{4}{|c|}{ Anmol cost : $510^{\circ}$ ) } \\
\hline & \multicolumn{2}{|c|}{ Lombru gas } & \multicolumn{2}{|c|}{ 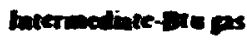 } \\
\hline 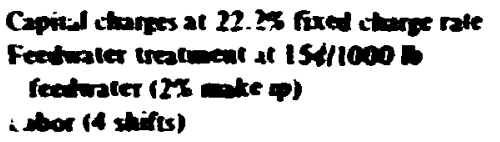 & $\begin{array}{l}3.205 \\
0.026 \\
0.118\end{array}$ & & $\begin{array}{l}3.330 \\
0.026 \\
0: 18\end{array}$ & \\
\hline 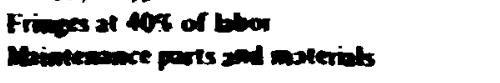 & $\begin{array}{l}0.047 \\
0.025\end{array}$ & & $\begin{array}{l}0.047 \\
0.025\end{array}$ & \\
\hline 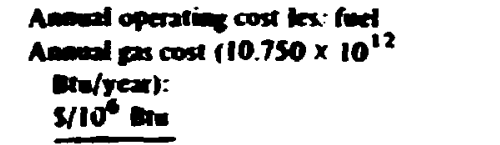 & 4.10 & & 355 & \\
\hline IEs & 20.00 & 20.53 & & \\
\hline $\begin{array}{l}2.07 \\
237\end{array}$ & & & 22.25 & 25.48 \\
\hline 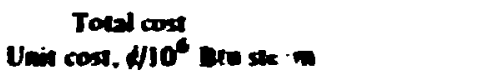 & $\begin{array}{l}24.10 \\
264\end{array}$ & $\begin{array}{l}24.27 \\
270\end{array}$ & $\begin{array}{l}253 \\
252\end{array}$ & $\begin{array}{l}2903 \\
318\end{array}$ \\
\hline
\end{tabular}

\section{HICHAD GAS}

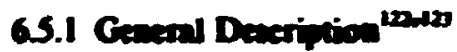

\section{Dacie chesivery}

The hydrogen content of coal. averagine abou sf, by weight. is very low compared to that of methane $(25 \mathrm{f})$. which must be the major componemt of pipeline ges. Therefore, a key problew in conversion of coal to pipeline gas is the generation of hroe quaminies of hydrocen which comes from waker decomposed by reaction with coal or ctar. The reaction of conl and secan is hinthy

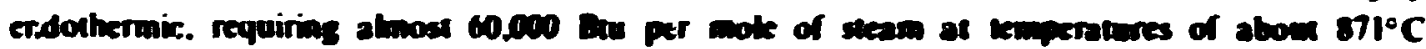

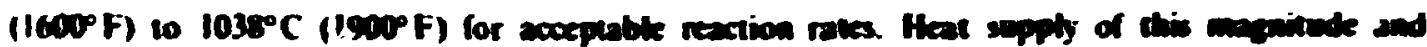

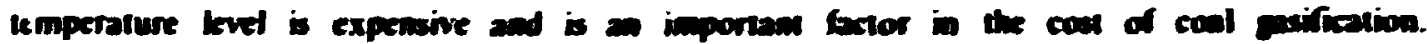

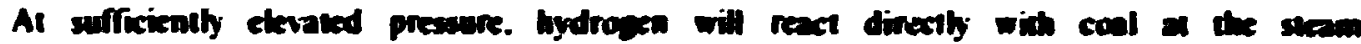

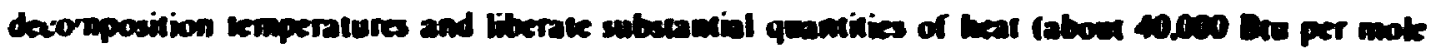

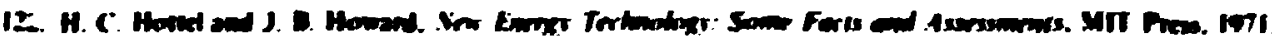

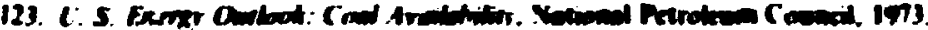


of methanel. Since I moke of methane is stoichiumetnesly equival:nt is a inok of stean. being decomposed. it is clear that the coal hydrogenaticn reacion can supph a mijor ponine of the heal needed for the steam decumposition reaction if both reactions occur in the same rone. This will result in reducing the endothermic. high-temperature heat supply to one-thind of the steam decumposition heat in the absence of hydroxenation. thus significanty reducing pipeline gas custs.

To the extent that hydrogenation (i.e.. hydrogen consumption) is incomplete. the reactur heat duty increases. and. in addition. synthesis gas generated at about $871^{\circ} \mathrm{C}\left(1600^{\circ}\right.$ ) fows from the high-temperature reactor and must be coaverted to methane in a methanation reactor The batter reaction. which occurs at about $310^{\circ} \mathrm{C}\left(600^{\circ} \mathrm{F}\right)$. releases almost 100.000 Btu per mok of methane formed from synahesis gas and reyuires a volumetrix pas llow through a number uf process sleps four times as great as the equinalent volumetrix Abw of methane. Consequenth. decreasing synthesis gas methanation is abo impurtant in reducing the cost of pipeline gas.

The various processes for pipelin: gas production avaibble or under development differ primarib with respect to the method of gas-solid contact. supph of heat to the steam decompoxition reaction. and the extent to whirh jirect hydrogenation of coal to methanc o sombined with steam decomposition in the high-temperature reaction system. Tabke 6.27 illustrates ?hese key reactions.

In adition to these two major process steps. the complete pipeline gas plant reyuires imper rant Gailities to prepare the cual for reaction, to purify and convert the high-icmperature gases for methanation. and to dry the pipeline gas.

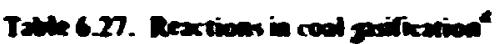

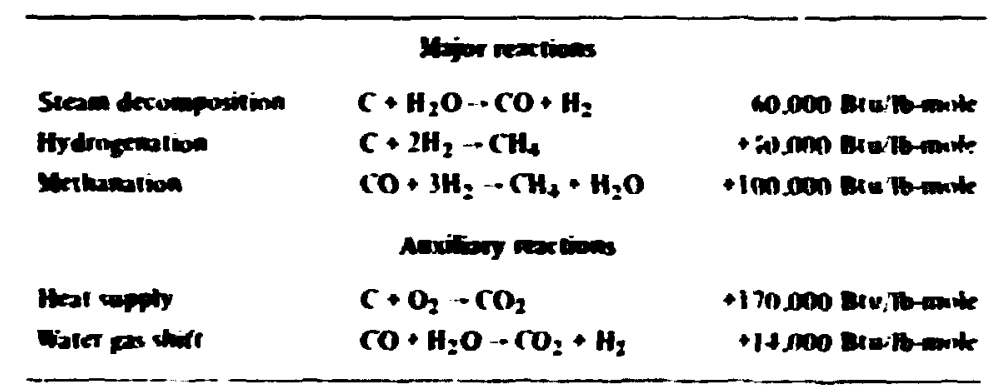

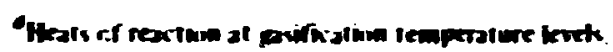

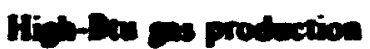

A bibct diagram of the individual operatioms that mush he cairied ont in veyuence to make

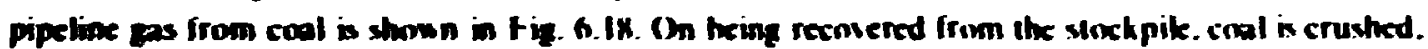
pround. and dried. The coal is then charged to a pretreatment and hydrngenation operation. where it is reacted with hydrogew-rich synthesis pas and steam under pressures ranging from 40 in 1200 psi

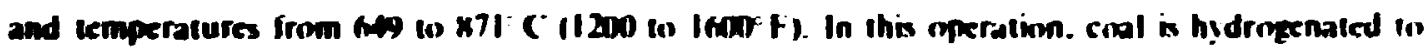
yich methane in amounts that depend on the pressure and coal activity. and the exinthermic heat is

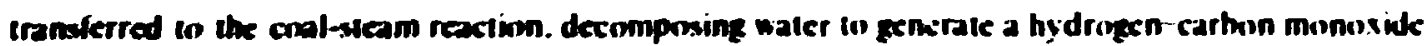
in xture (synthesis gas). The proxess can be carried out in a commerciulty proved mosing-hed system or under nuidived thed or entrained solids conditions in ceveral onher procenses ander active 
and - 20 3-1200

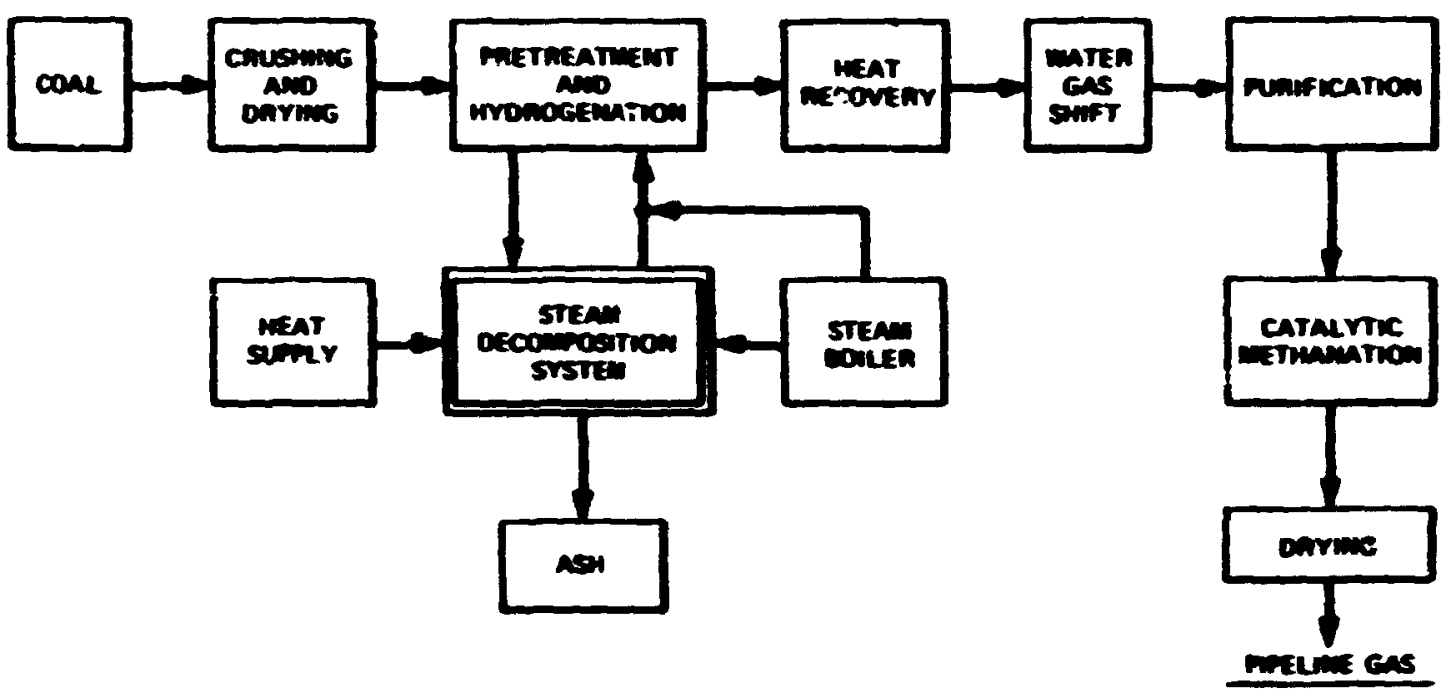

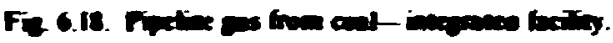

developinent. The prodects of the pretnestment-bydrogenotion sep are ran fas and hot char. In Eencral. the pretreatruest step is unnecessary for moncaking conts bed is necessary fur caking coab in some reaition systems such as moving or flundined beds.

The hot char is transferred to a final pasification sep. where in decowiposes stean to penerale

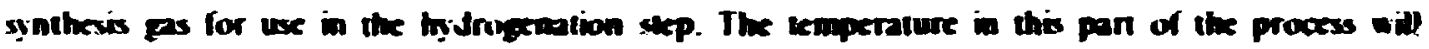
depend on the methoe of heat supply but coudd rive to above $1093^{\circ}$ ( (2000) F). Various processes avibble or undet developonemt combine the bydropenation and psification reactions in difierem ways.

The stream of gases lea. ing the hydrogumion section is paxed throds a vaske beat reconery section which coots the gases to the ceaperalune requined for forth. procesting. Dependine on the rank and anatysis of thr coal and on the balance between the bydropination and water

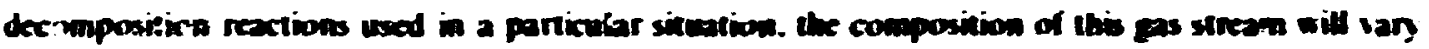

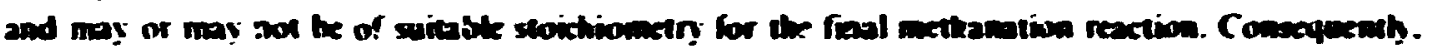

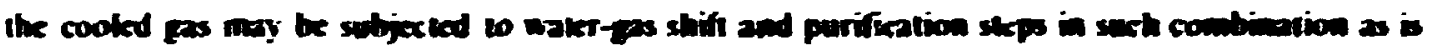

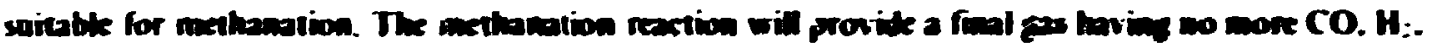

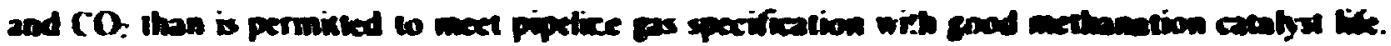

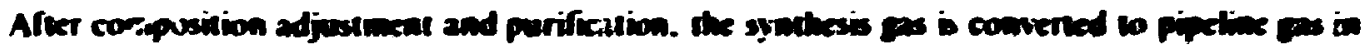

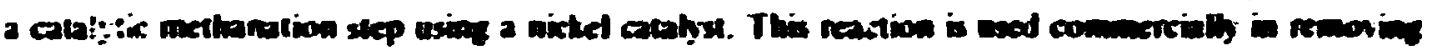

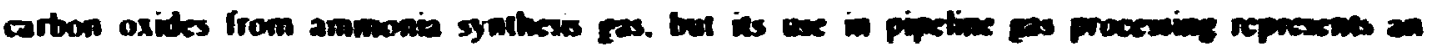

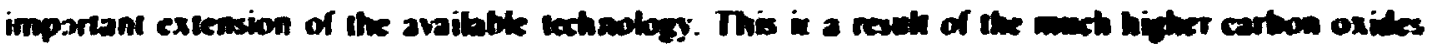

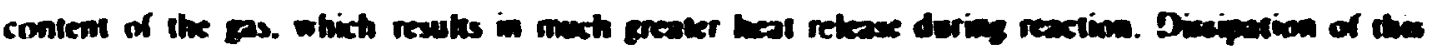

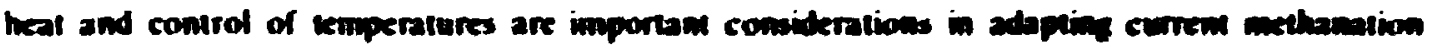

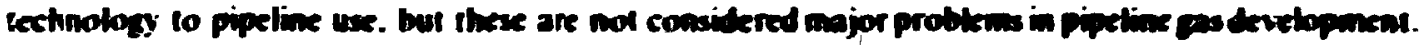


The exireme sensitining of aicket calahyses reuuires a very thorough removial of sll sulfur compounds in the purification step. Hence, syndhetix pipeline gas will stand cul is a gas that is unuswally sulfur frex.

Afier pipetion gas has been prodeced by methamation. the water produced by the reaction must te removed in orker to aneet drywess spexifications for pipeliene we. The major aress undergoing exkeasive developaneat at the presem time are the steam decomposition cool hydroganation steps. Throse are the processes tisat provide the best podeminal for cost reduction.

Figure 6.19 is a comparison of hidh-and bow-Bru gasification processes.

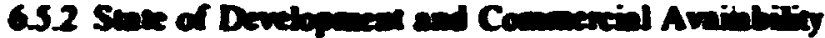

A commercially developed process, avaibute from the wellthown furm l.urgi G.m.b.H., is well suied to most western coals and can handle the caking coals of the eastern fretds after pretreatmeat.

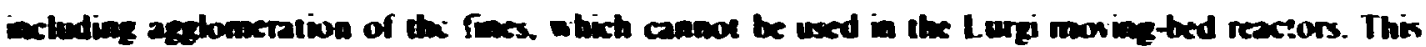
coel preparation would require some modest developonem wort.

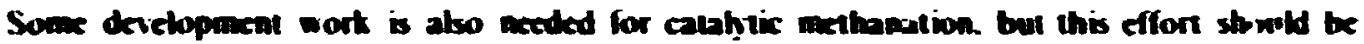
substantially swalke than that needed fer gasification.

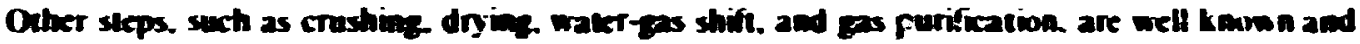

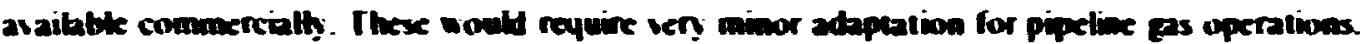

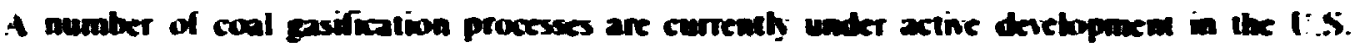
These are comacened bareth with the coal gasidication and coal hydrogenation reactions and with the

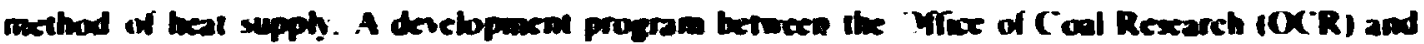
the American (jas Association IAGAR. mon onder way. is funded at the level of 530 miltivon per

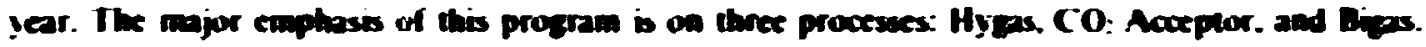
The Burean of Mines is independenth mohed in wort on two proceswes. The rased adhabeed of

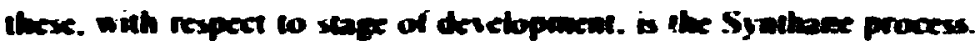

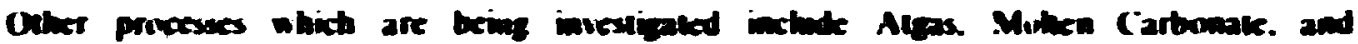
Hydrane.

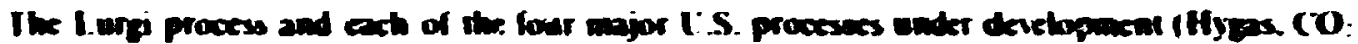

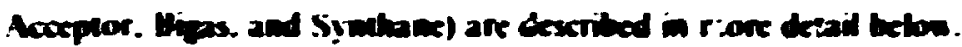

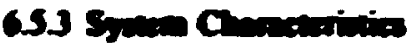

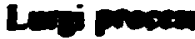

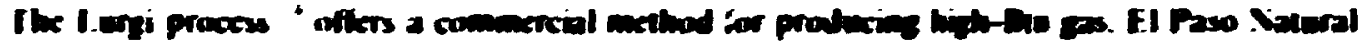

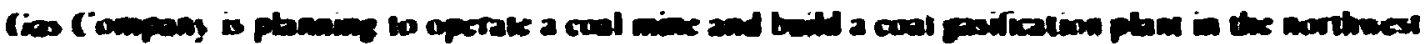

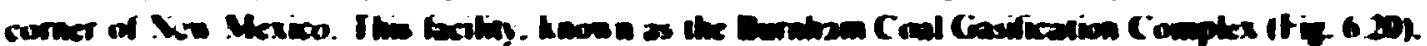

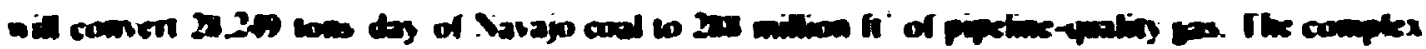

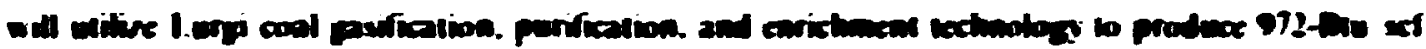

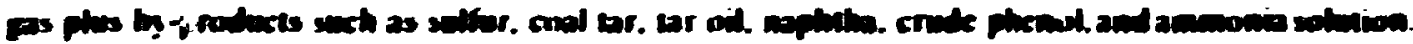

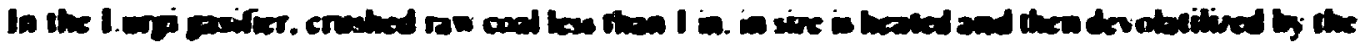

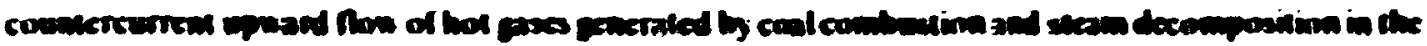

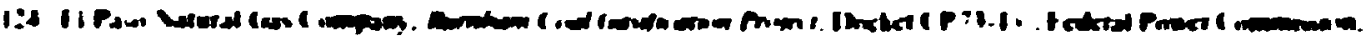
Intenter 10*1 


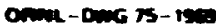

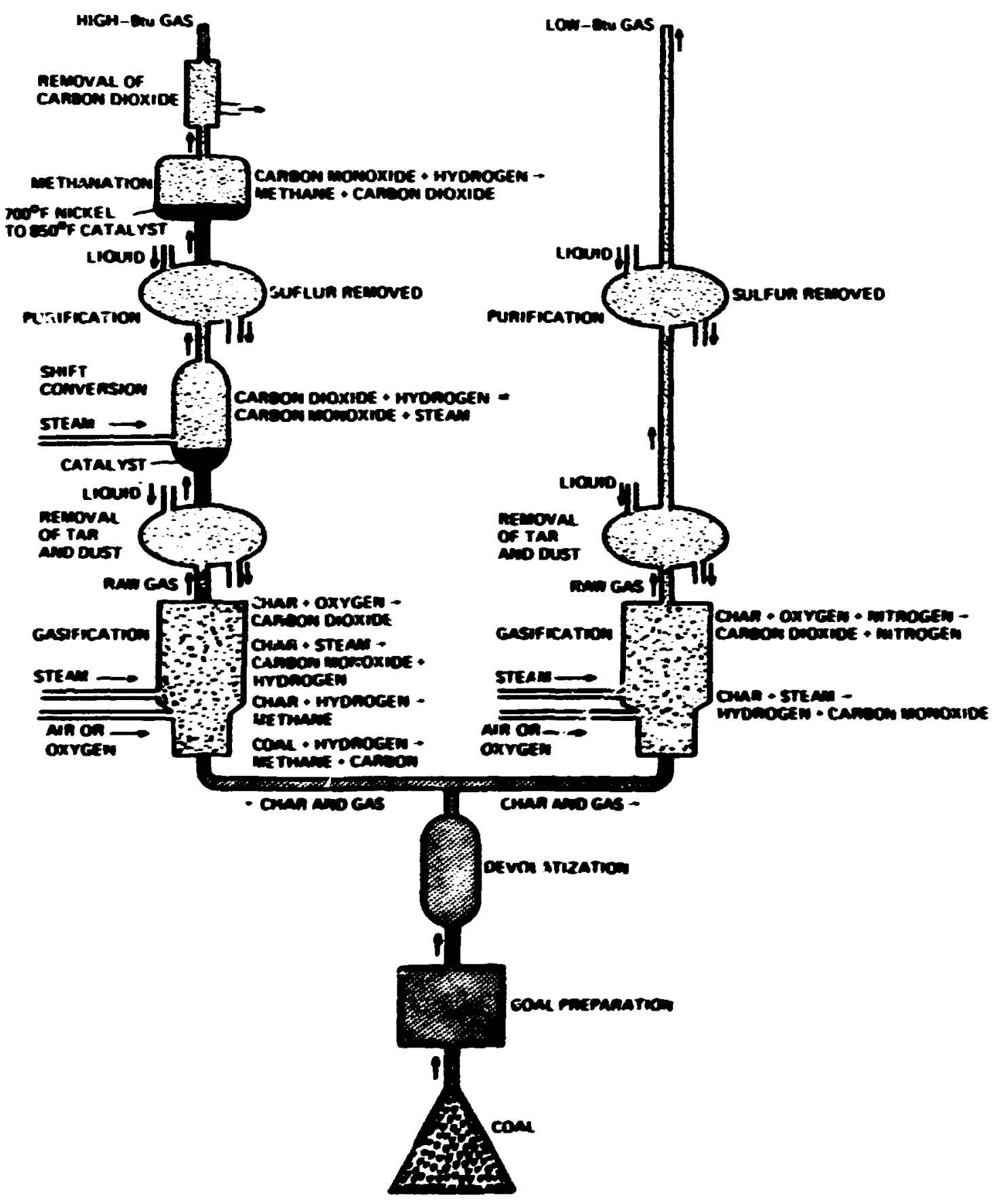

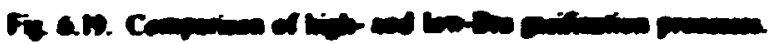


ORNL DWC IA ISEOA

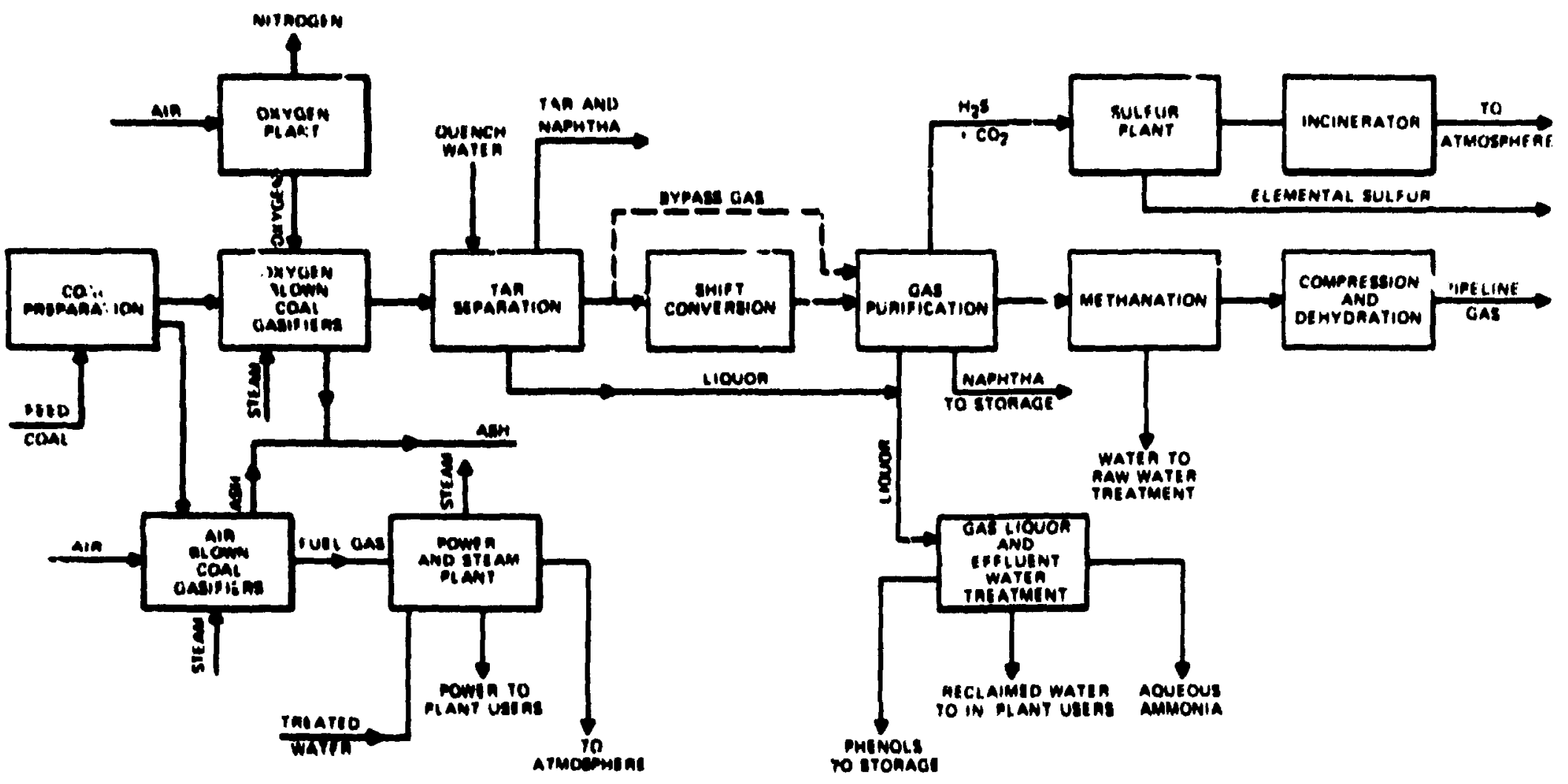

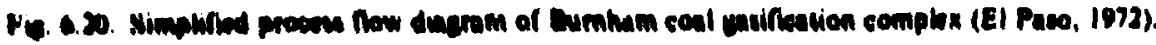


gasifier base. The gasifier is essentialty a refractony-lined. water-cooled cylindrical shell approximately IIf in diameter with dry ash removed in granubr fo:m via a bock hopper. Toprevent clinker formatior. the highest temperature in the gesifier is held below the coal ash fusion temperature 1093 to $1482^{\circ} \mathrm{C}$ (2000 to 2700' F). Beause the coal moves by graviny to a fixed grate at the base of the gasifier. it is sometimes called a gravitatina-bed gasifier. Low-Bu producer for s leaving the gasifier at approximately $510^{\circ} \mathrm{C}\left(950^{\circ} \mathrm{F}\right)$ and 300 psi is cooled to saturation uemperature $\left[160^{\circ} \mathrm{C}\left(320^{\circ} \mathrm{F}\right)\right]$ in a waste hat boike and creaned in a water scrubber to remove residual tar and dusa. Sulfur compounds (H:S and COS) may be remned by any of a number of wet or dry processes. Most desulfuriontion systems absorb the sulfur compourds with a material which is subsequently regenerated. The H.S-rich gas from the stripper regencrator nay then be seat to a Cbus comerket to produce elemental sulfur.

Final processione inctudes the shift convexion and methamation. which will increase the beating value of the eas to aboun 972 Bur sef.

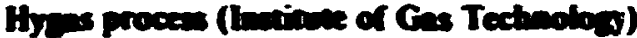

The main units in this process (fic 6.21) are a mo-scage Raidinadbed hydropasifier and a

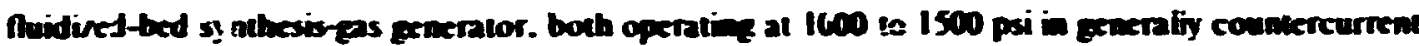

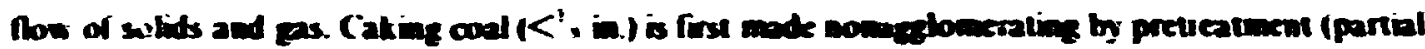
devobtilivation) with bot air in a Ridined bed at I atw and $3 \%$ C (750 F) (with offers not

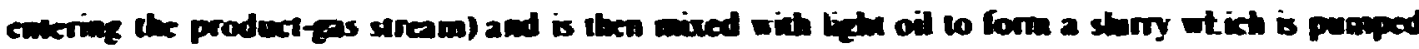

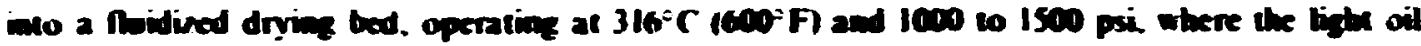
copporaves.

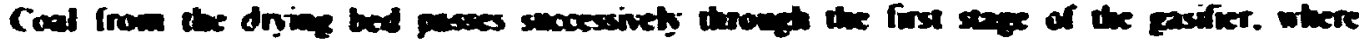

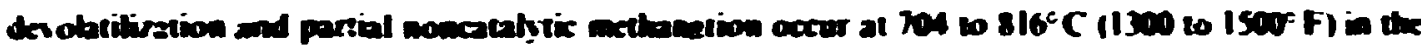
presence of bydrogen-rict gat then as chur weo the second seape. where partial gasification

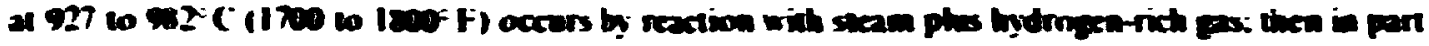

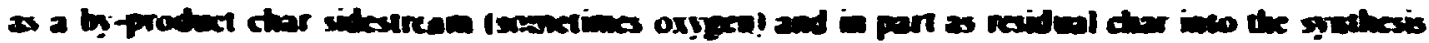

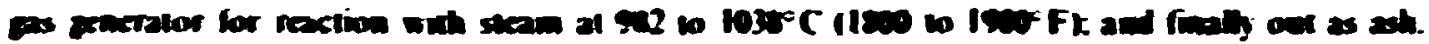

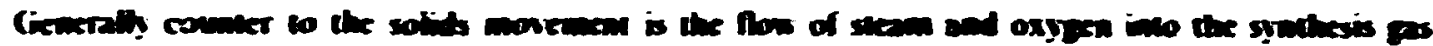

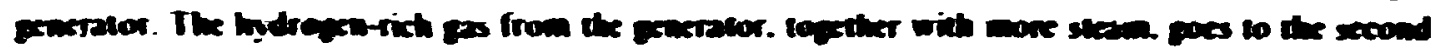

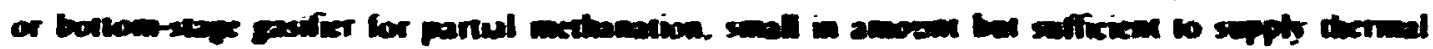

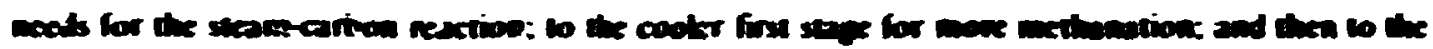

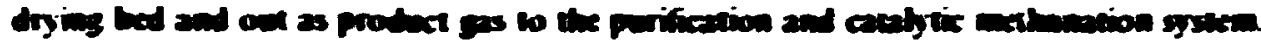

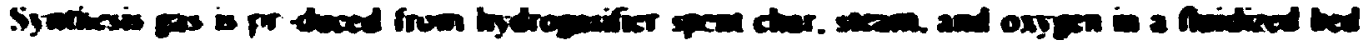

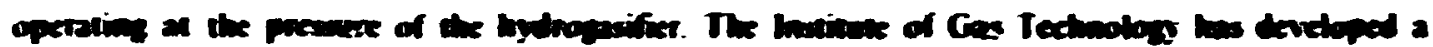

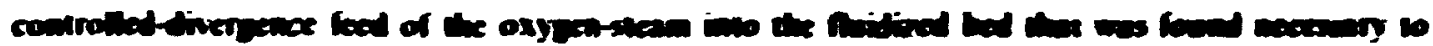

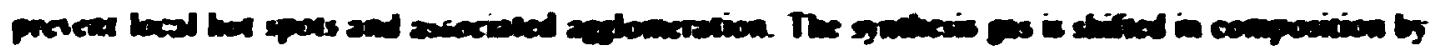

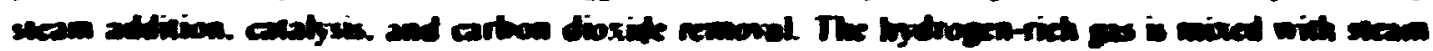

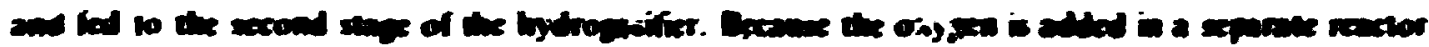

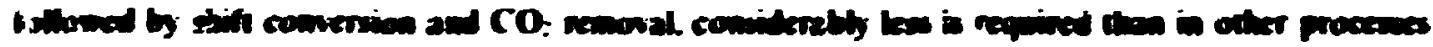

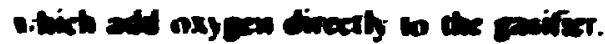

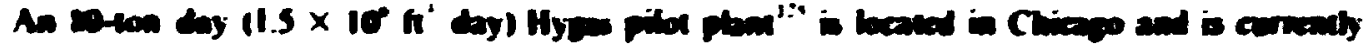

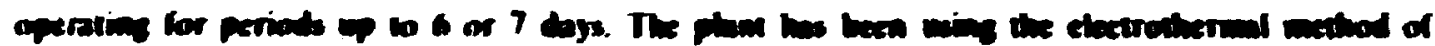

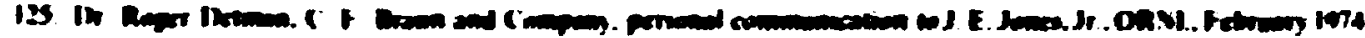


Oann-Ding 24-12015

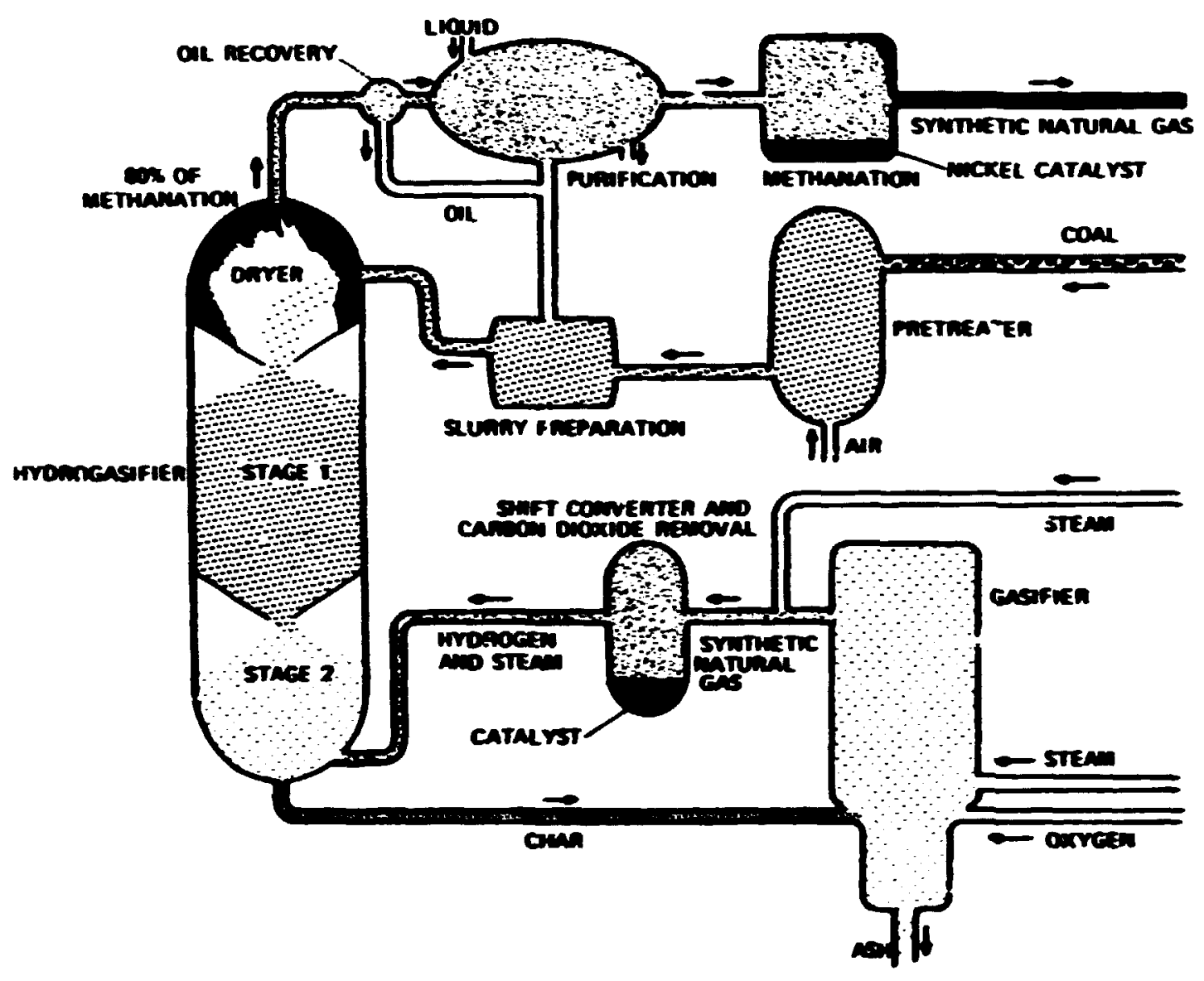

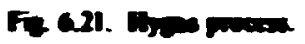

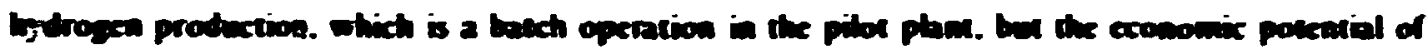

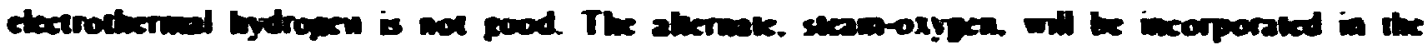

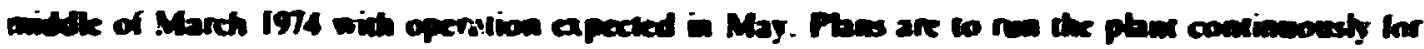

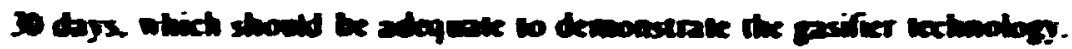

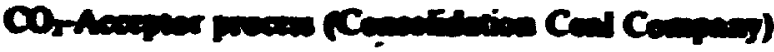

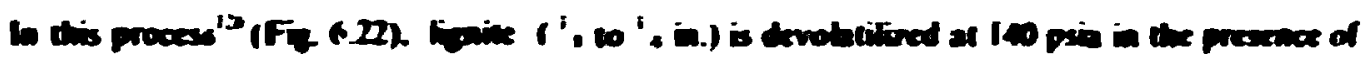

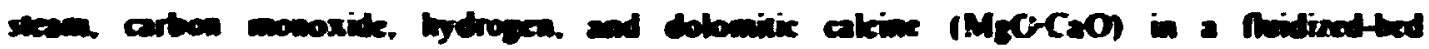

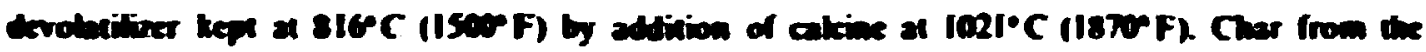

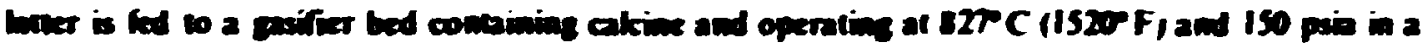

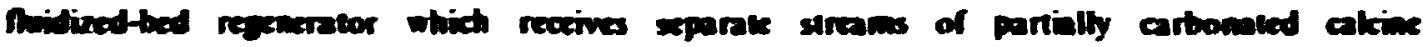

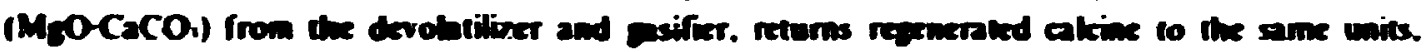

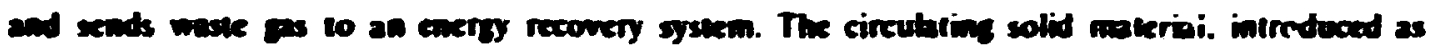

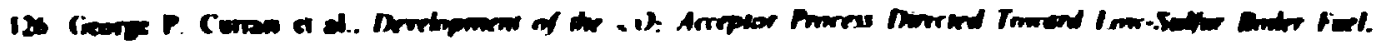

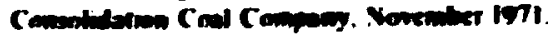


Oame-0ug 75 - 1971

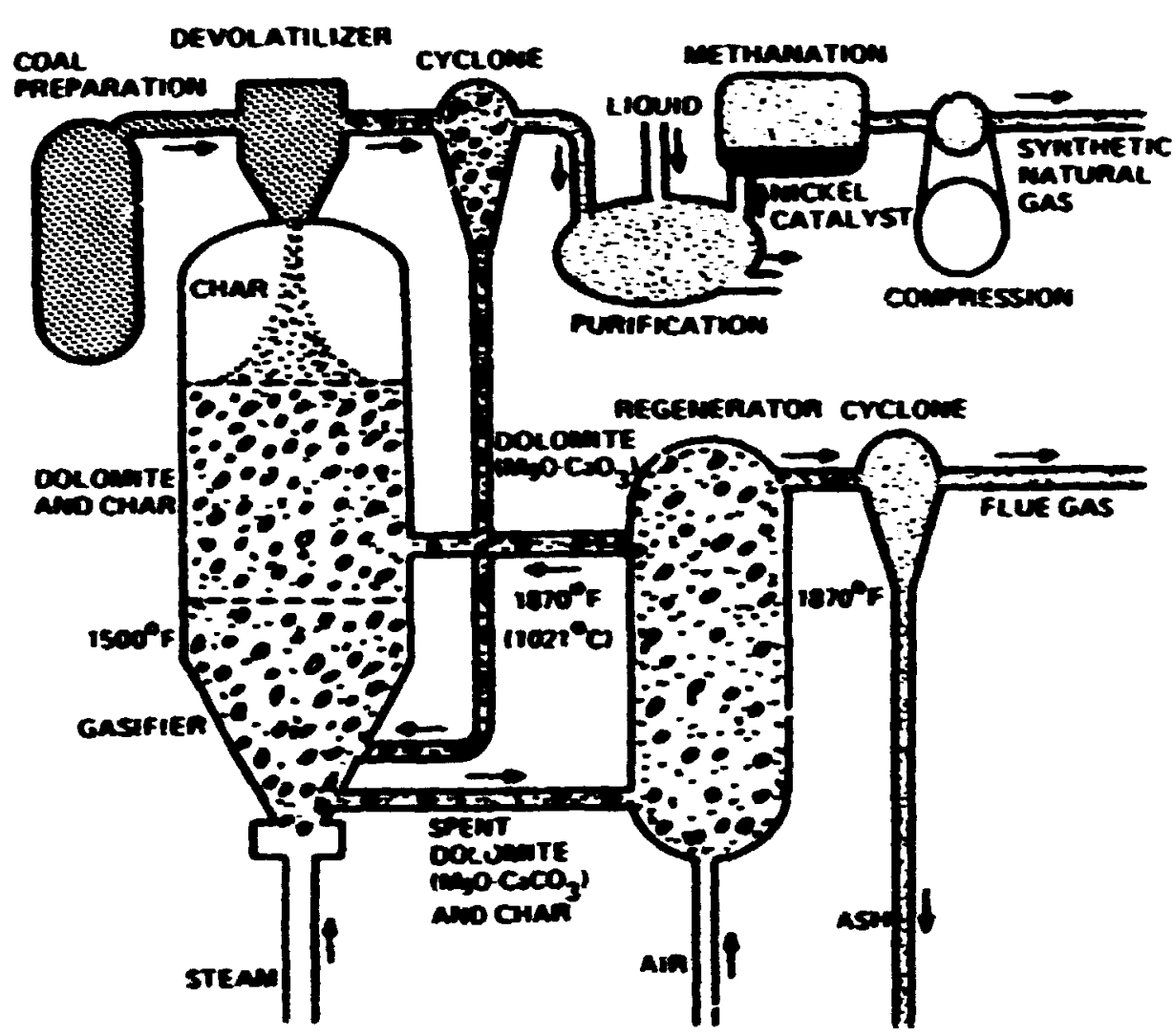

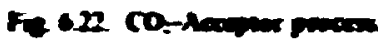

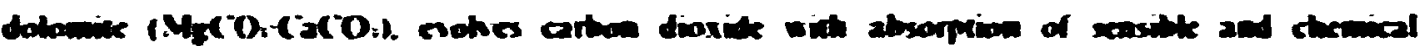

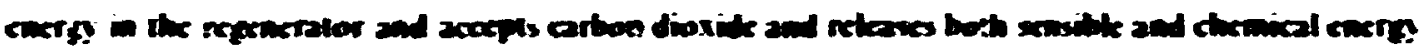

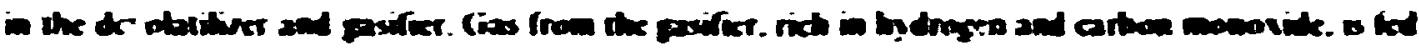

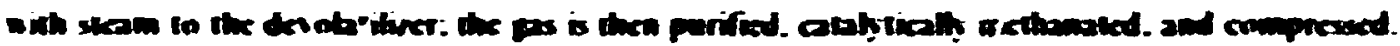

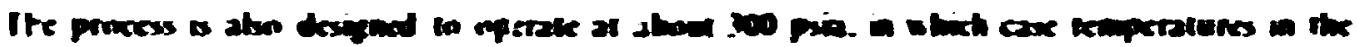

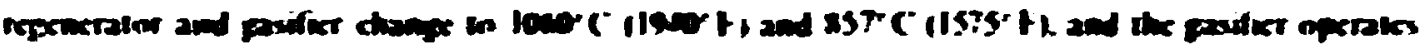
- inth a mocke sunam.

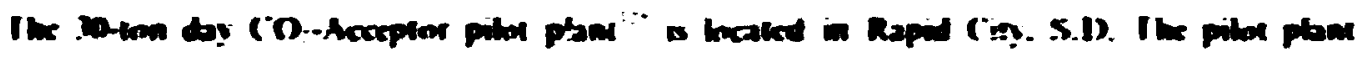

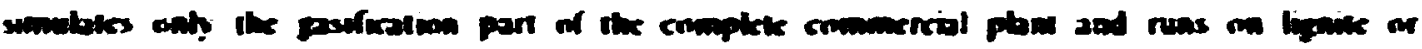

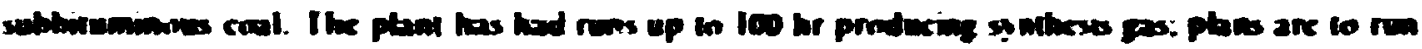

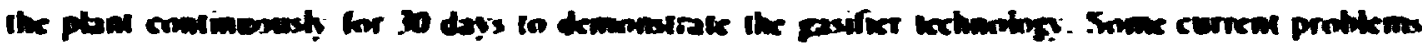

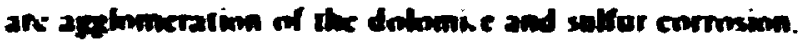

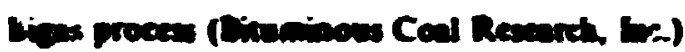

Ihis process" (fig. 6.23) uxes a vertical-a vis inn-slage pasifier which operales at iso in ison

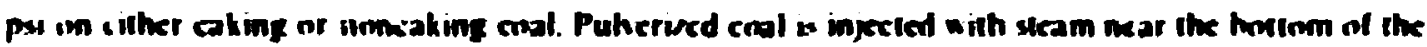

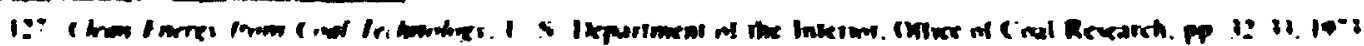




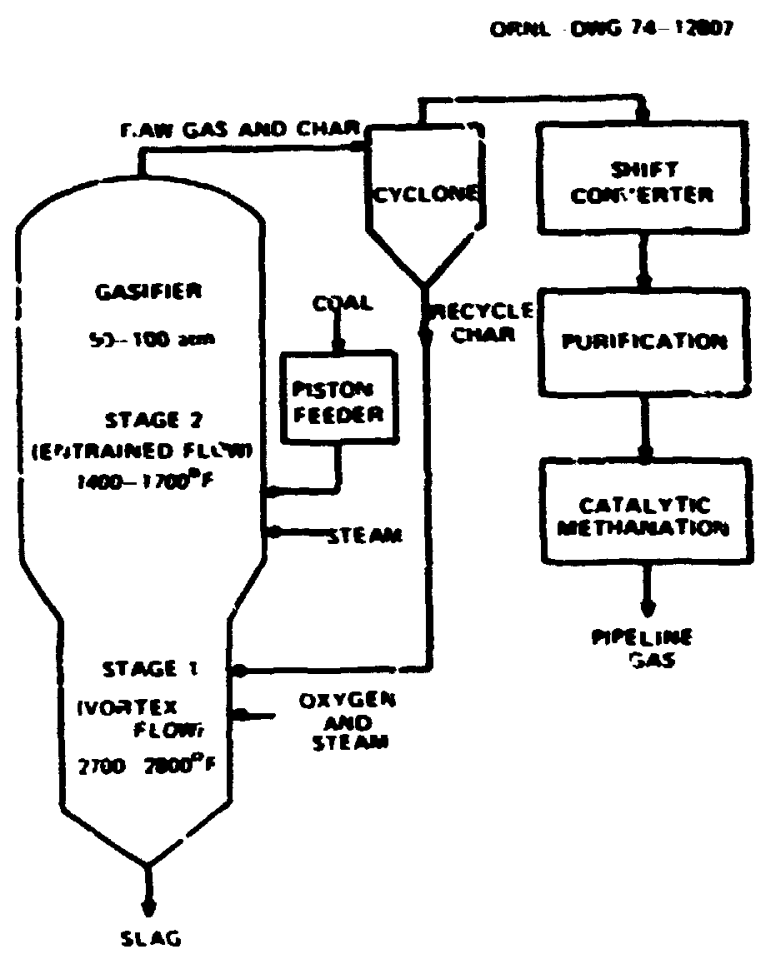

Fi. 6.23. Dips process.

top chamber [760-927 $\left.\mathrm{C}\left(1+00-1700^{\circ} \mathrm{F}\right)\right]$, where it mixes with synthesis gas rasing from the lower chamber and volatilizes and partially methanates. The product gas-unreacted char mixiure !aving tile top passes through a cyclone separator from which the unreacted chat stream (94; as large as the raw coal feed stream, whicl: indicutes only a litte more than Sor, reaction per pass, on the average) is then fed tangin:ially into the upper part of the lower cyclone gasilication cha rixer where it gasifies with oxygen and steam under slagging conditions [ $\left.14 \% 2-1536^{\circ} \mathrm{C}\left(2700-2800^{\circ} \mathrm{F}\right)\right]$ : the gas product is purificd and catalytically methanated. The slag is water quenched in granular form and dropped to almospheric pressure by neans not yet specilied.

A 120-10n day pilot plant: is under construstion near Homer (itv. Pa. The pilot plant is to be completed in carly 1975.

\section{Synthane process (.Sureau of Mines)}

This process'" (fig. 6.24). operating at 600) psi (with proposal to kr in IOMOO). gasifics pulseri/ed caking of noncaking coal by possage in succession through the three fones of a Easifier: (1) a nuidied coal-pretreating top section [399 ( 1750 ) F)] in which the coal. injected with hot steam and oxygen is partially devolatilied: (2) a dense nuidied hed in an expanded midsection that is neidiec by hol gases from below and provides the main residence time for cumpletion of

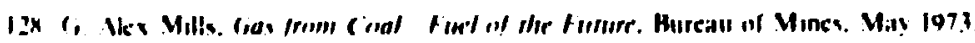


OANL cing 751972

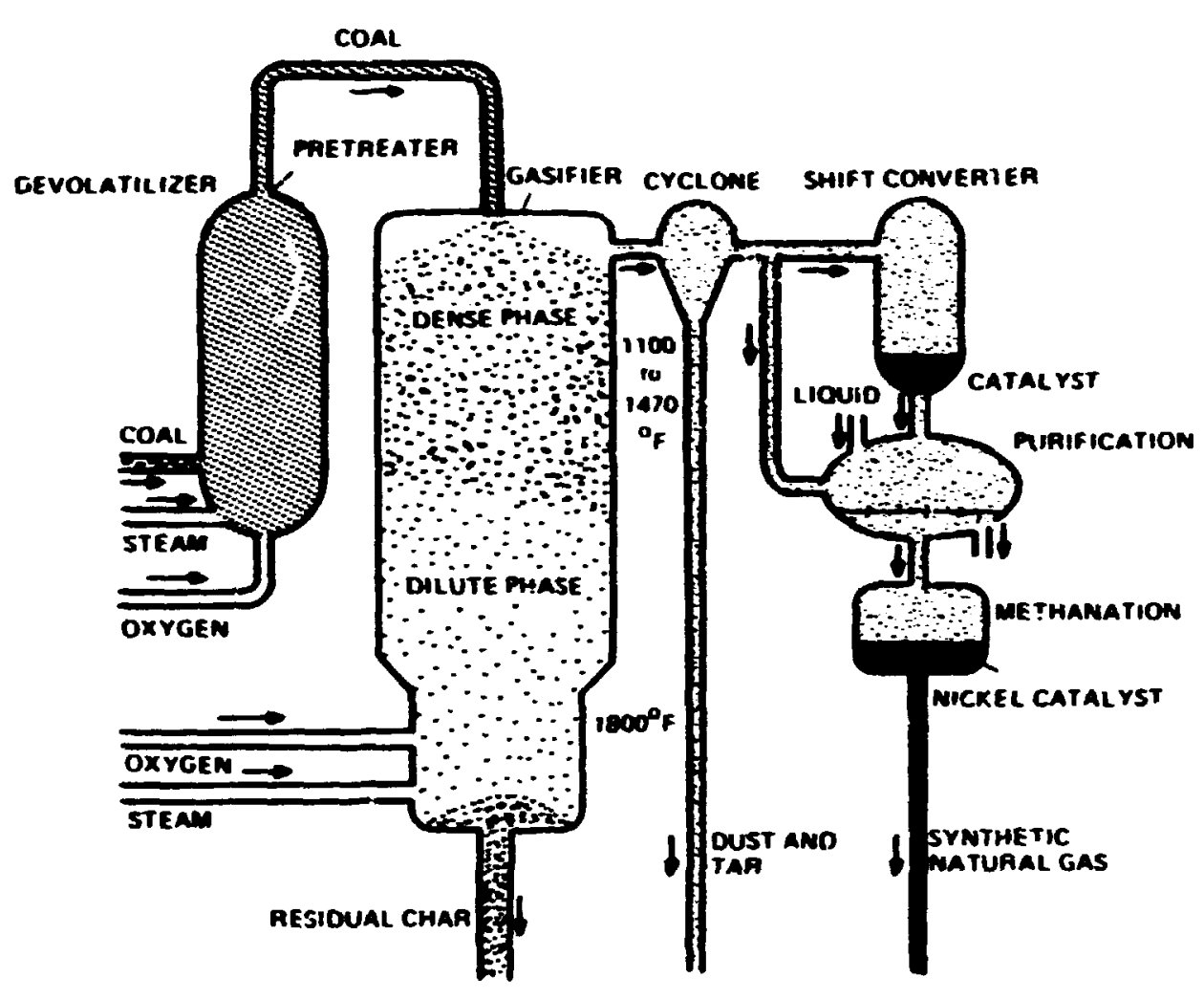

Fi. 6.24. Synthane process.

devolatilization and for uncalaly/ed methanation at 593 to $799^{\circ} \mathrm{C}$ ( 1100 to 1470 F): and (3) a hot. dilute nuidized bed in the contracted hottom section. where entering oxygen and steam furnish reaction heat and material for producing. at 954 to $1010^{\circ} \mathrm{C}\left(1750\right.$ to $1850^{\circ}+$ ). the synthesis(H:-CO) entering fone 2. (har residue is withdrawn at the bottom of the gasifier. and th: gas product leaves the system at a point between ynnes I and 2. The preúvel gas is ckaned. passed thlough a waterkas shift converter. crubbed almost f,ee of sulfur con;iwurds and carbon dioxide. and methanated catalytically.

A 72-ton day $\left(1.3 \times 10^{n} \mathrm{ft}^{\mathrm{i}}\right.$ day) pilnt plant ${ }^{1: 4}$ is under construction by the U.S. Bureau of Mines and is scheduled for completinin 'y the end of 1974 .

\subsubsection{Economic Analyris}

\section{Lungi process}

The I.urgi process':" is the only commercially available procr:ss for producing high-Btu g:.: from coal. An excellent source of economic data for this process is from E! Paso's Burnham Coal Gasification Project (Table 6.28). 


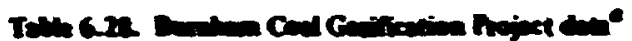

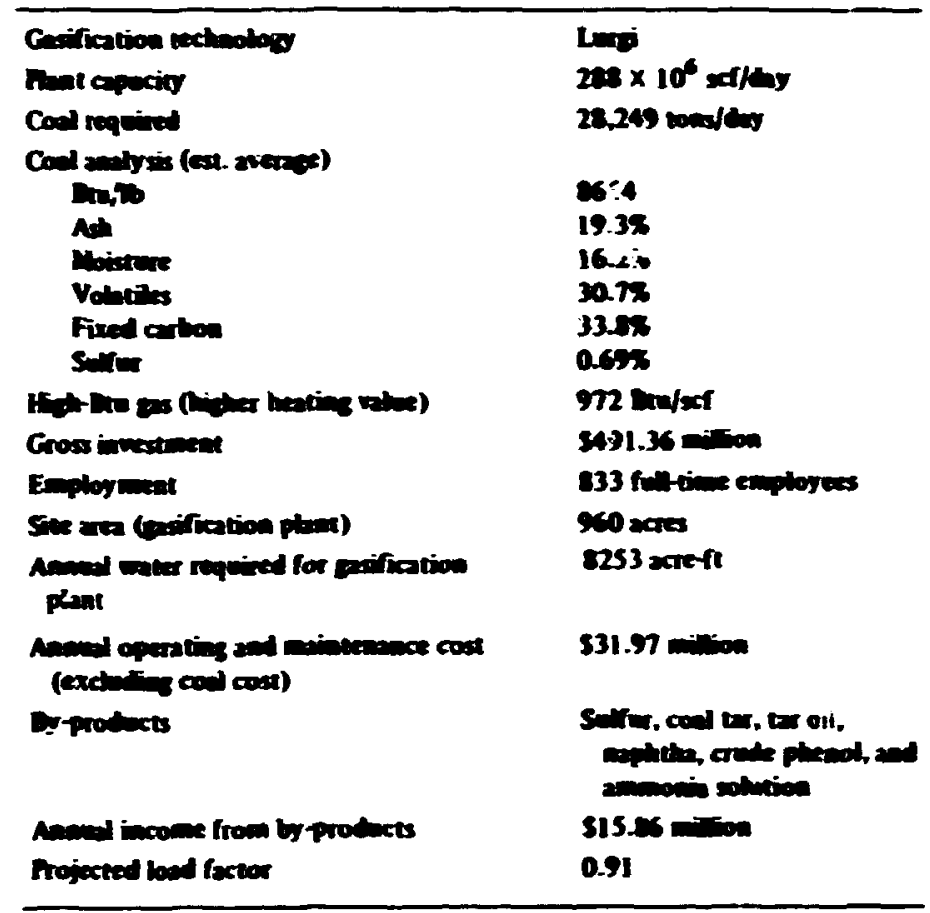

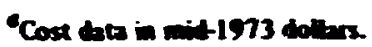

Using the example ground rules of 22.2\% fixed chare rate and 50e $10^{\circ}$ Bu for mine-mouth su', bituminous con:! the cust of high-Bru gas from the Lurgi technobogy can be determined as follows:

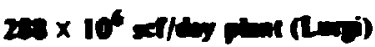

Annol cost opital $=9431.36 \times 10^{6}$

$=\operatorname{si39.08}: 10^{\circ}$

Annual cost OAM $=\$ 31.97 \times 10^{\circ}$

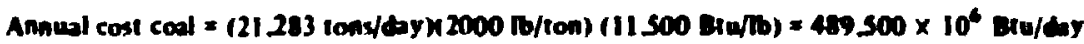

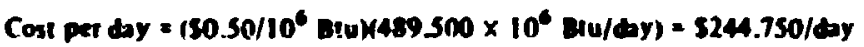

Anuual cost $=(\$ 244.750 /$ day $M 365$ dy/year $\times 0.91$ boud tactor $)=581.29 \times 10^{\circ}$

Tntal annual $\cos \mathrm{f}=5222.35 \times 10^{\circ}$

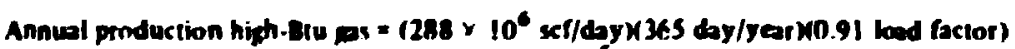

$=95.660 \times 10^{6}$ sef/yer

$=195,650 \times 10^{6}$ xef/yearW972 Btu/chn = $92.98 \times 10^{12}$ Bu/year

Hiah-Btu pos product cost $=\frac{\$ 222.35 \times 10^{6} / \text { year }}{92.98 \times 10^{12} \text { Btu/yer }}=\$ 2.39 / 1 \mathrm{C}^{6}$ But 


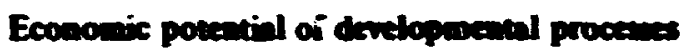

Est tes of the investment an peratiag costs of the gasification processes under developaneat have be . published.": These f gures are based on small-scale test data and are quite variable. Uatil pilot phat verification of the asumptions used in phat designs and sost estimates becones avaibble, it appears proper to use these estimates primarily to guide the researeh and developueat programs. Vevertheless, it is possible to derive an iden of the povential of the cost saviass these proceses any provide upon satisfectory completion of the wort rivw under way.

The avaibble estimates differ widely and are besed on a variety of coals and we a variety of ancass of caryine out the required reactions. The plant investuents for capecities of abon 250 willon sef day. includine utiling facilitio, ranye from about 55 to 955 of the Lugi estimates on an equivaleat besis.

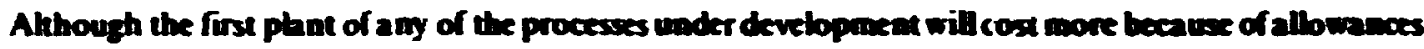

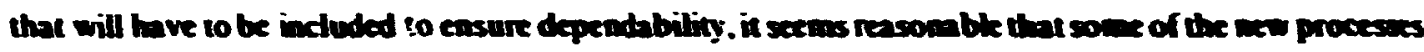
should provide savias over the enblished process. Real saving woold appear to be avathble as a

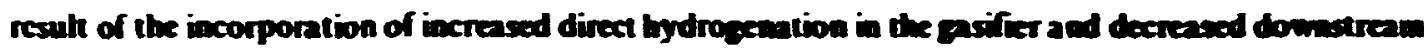

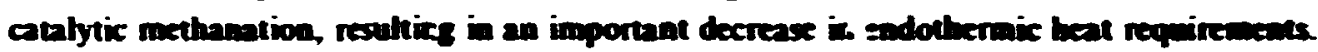

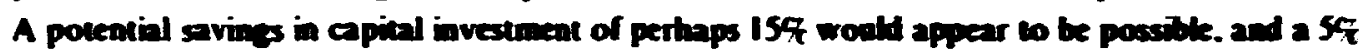
increase in fucl ecowowy may be achieved. Besed on these esiomes, one can project a reasonable anticipated cost for the developanental process of $5219.10^{\circ} \mathrm{gm}$. In terus of add-on costs over and above the coal cost, these my be interpreted as $51.8910^{\circ}$ Bu for the Lugi process and SI. 6910 fou for the developeneneal processes. as shown betow.

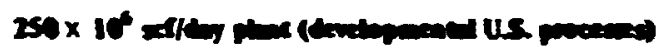

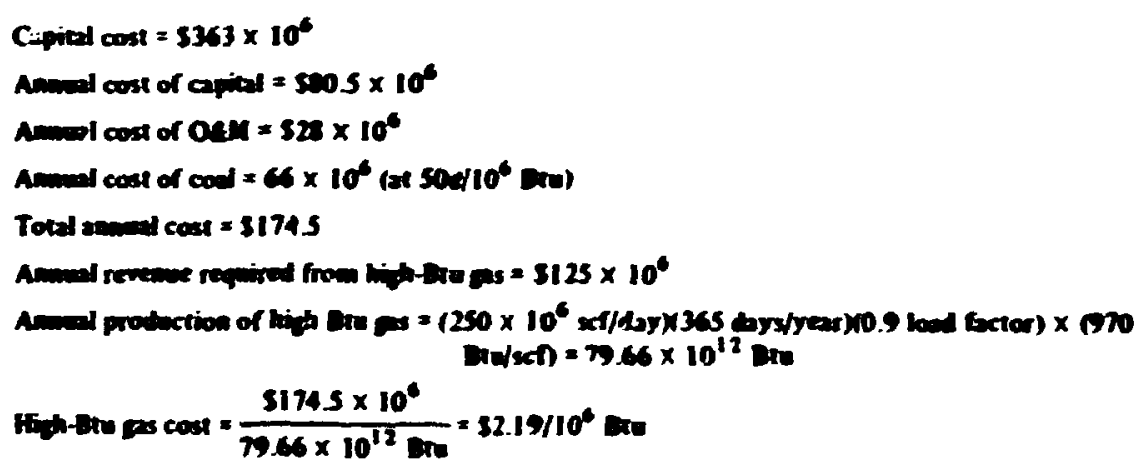

\subsection{Avnibutiog}

The Luri process is currently avilable. For a $250 \times 10$ sef i day phnt. the anticipated conaruction period (from start of consinution) is 3 years.

The developmental processes could be avaibble in about 5 years. This assumes a demonetration plant is started in about $1 \%$ ycars with 2 '; yars construction time and I year for operation. Allowingan additional 4 years for construction of a ptant, one can see that it will be at last 9 years before high-Btu ans could be avaibble from the developmental processes.

The cost of ream generation using high-Bru gas from coal is grven in Table 6.29. 


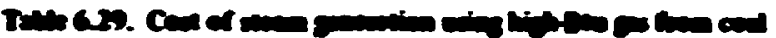

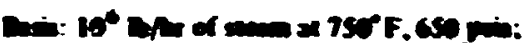

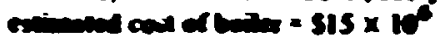

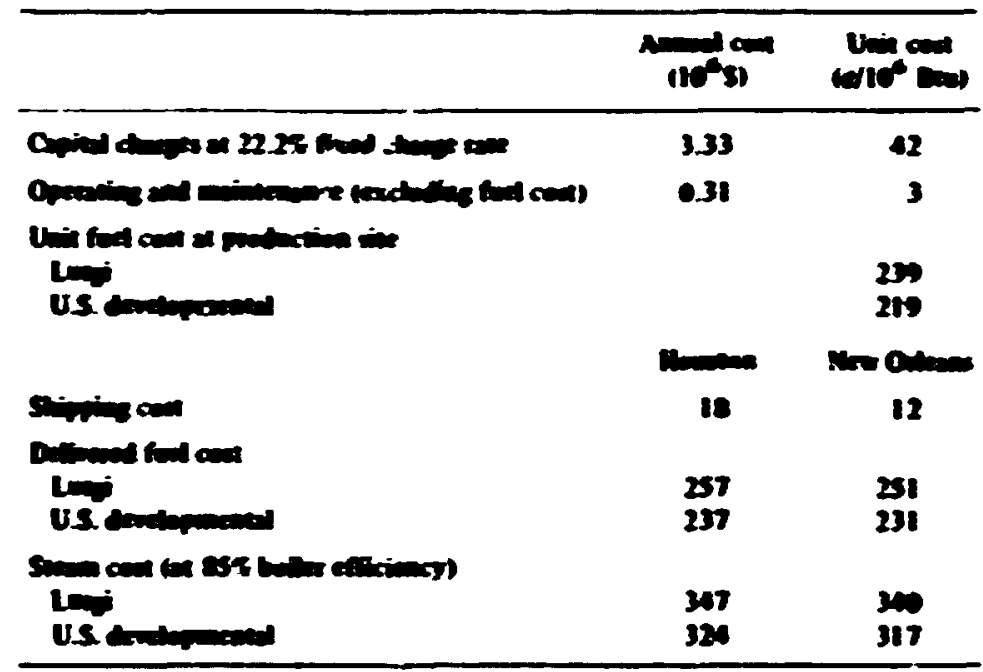

\subsection{LQPUEFACTION AND CLEAN DOULA FUELS FROA COAL}

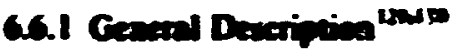

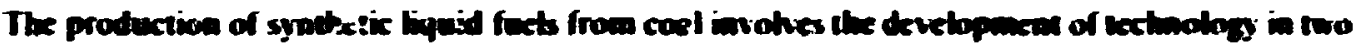

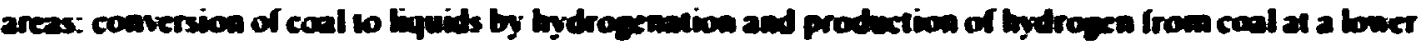

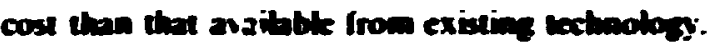

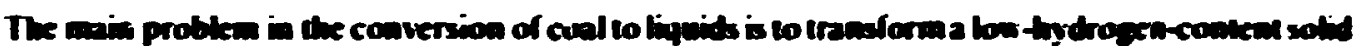

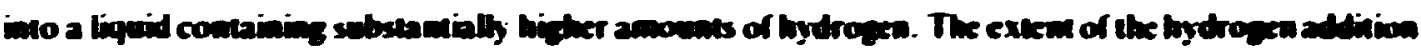

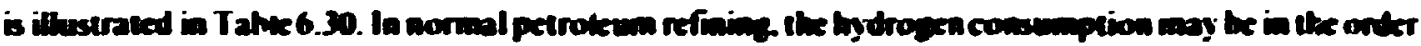

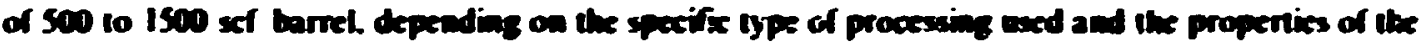

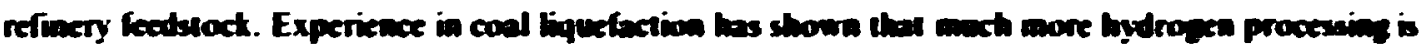
maded. requiring brex amponts of bydragen and severe procesaing conditions. To comert the organic

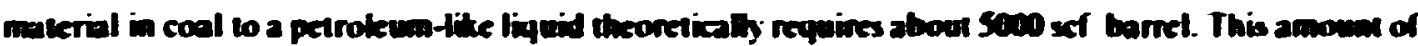

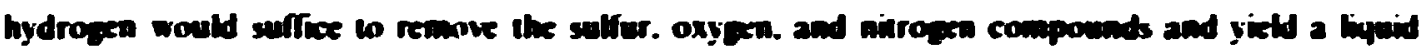

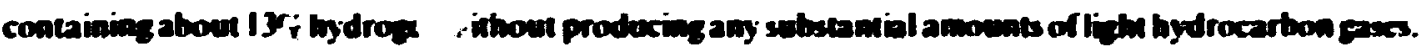

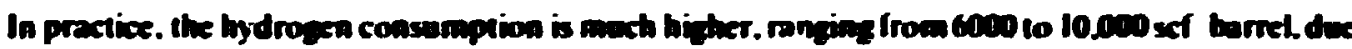
primarily to a sabstantial production of beje bydrocarbon gases and to lass oi hydrosen into the

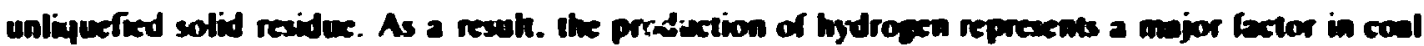
biquefaction and the processing of coal hiquids.

Orher problems arive from the nature of coul itsel. The presence of organic nitrogen componuds inhibits many of the reactions in convertine the coal liquids. Further. the presence of ach has several

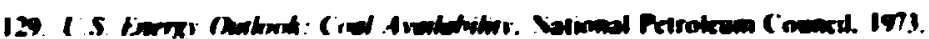

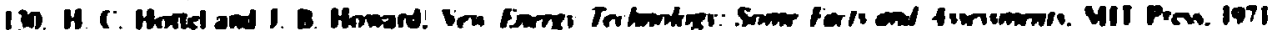




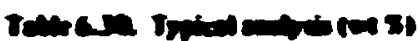

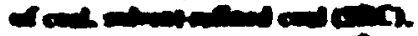

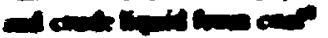

\begin{tabular}{|c|c|c|c|}
\hline Andro & 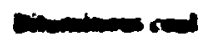 & $s x$ & 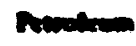 \\
\hline $\begin{array}{l}6 \\
10 \\
0 \\
5 \\
5 \\
50\end{array}$ & $\begin{array}{c}10 . \\
4.1 \\
4 \\
1.8 \\
2.8 \\
10 \\
10\end{array}$ & $\begin{array}{l}1.0 \\
5.2 \\
3.7 \\
1.0 \\
\text { a. }\end{array}$ & $\begin{array}{l}13 \\
01 \\
01\end{array}$ \\
\hline Intw & 10 & $\infty$ & 10 \\
\hline
\end{tabular}

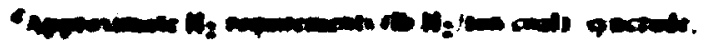
13. $\sin .3010$.

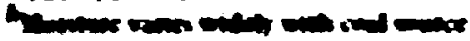

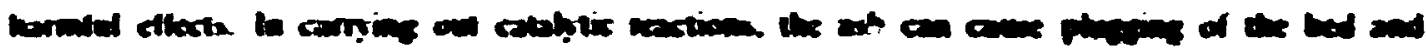

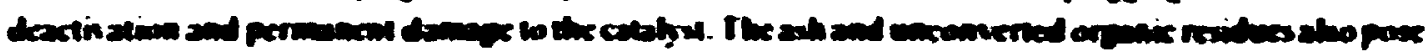

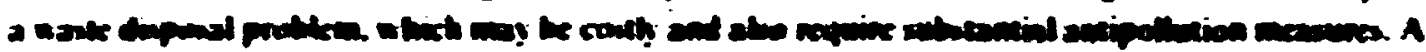

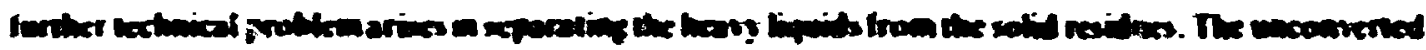

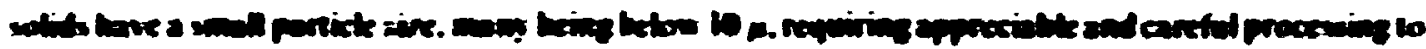

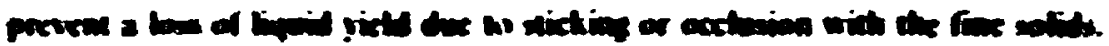

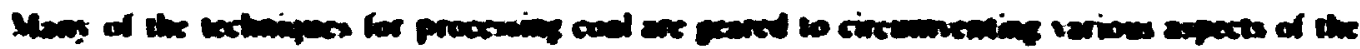

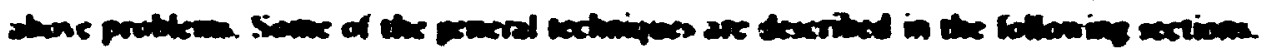

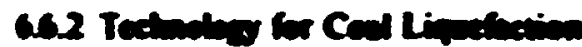

\section{Prongris}

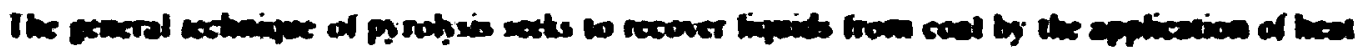

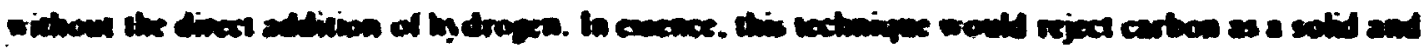

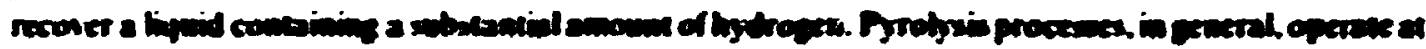

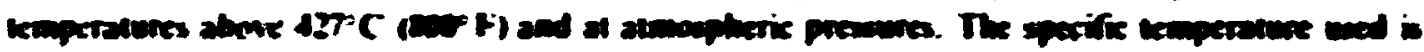

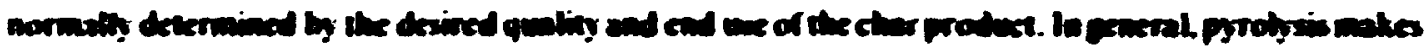

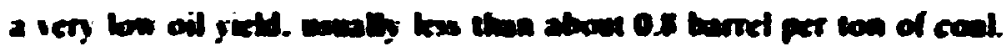

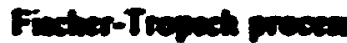

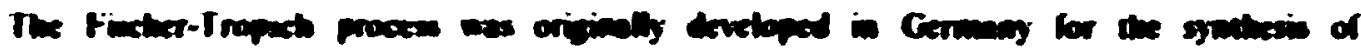

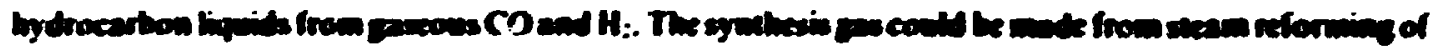

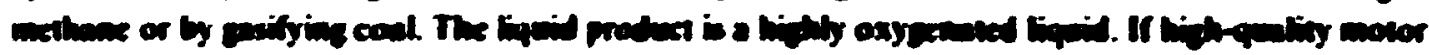

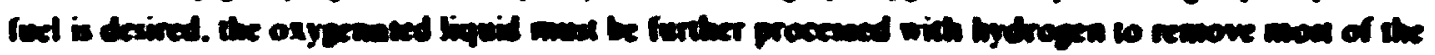
oxysin.

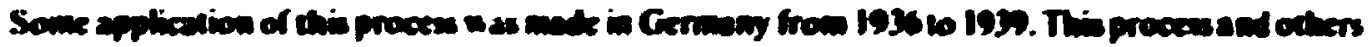

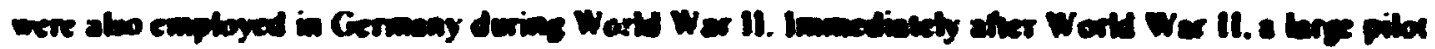

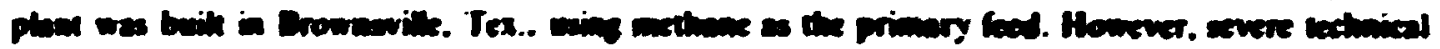

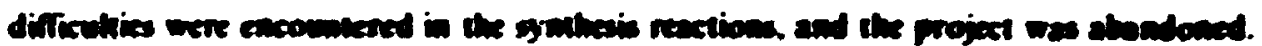




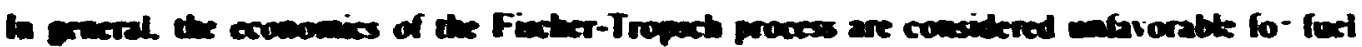
promese

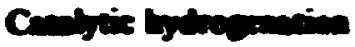

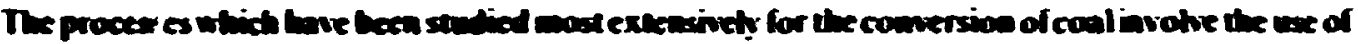

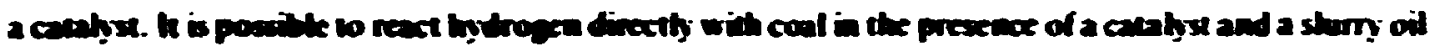

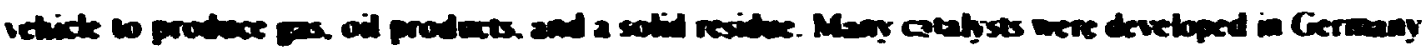

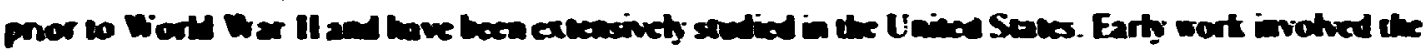

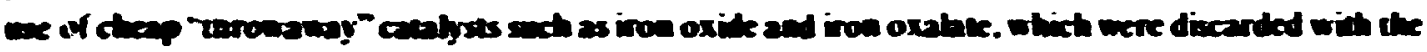

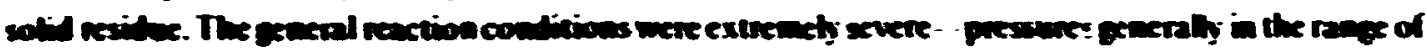

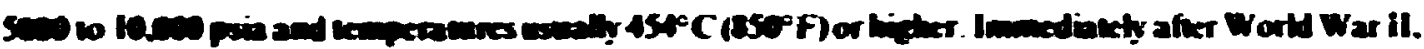

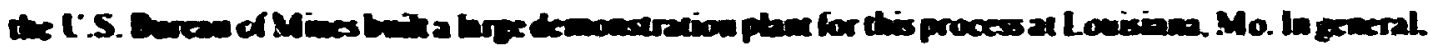

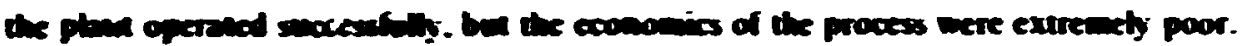

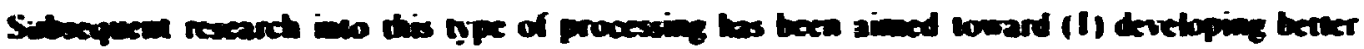

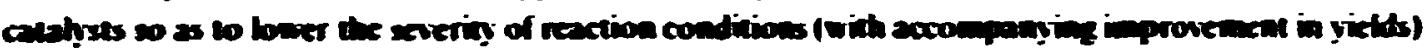

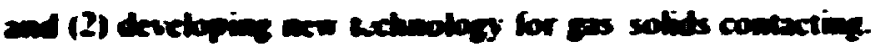

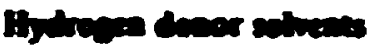

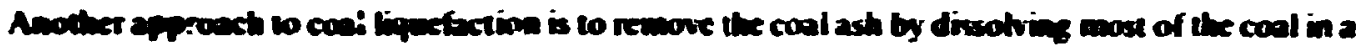

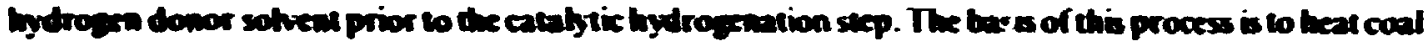

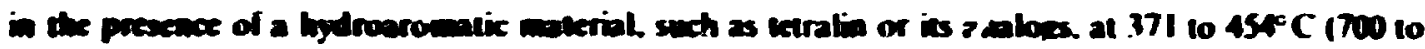

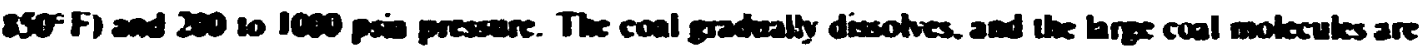

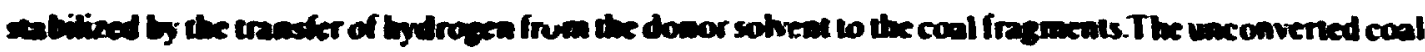
and ahe filmered from the sointion of sobent and extrect. The spent solvent is subsequenty recovered

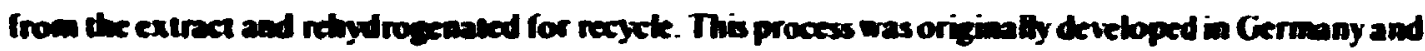

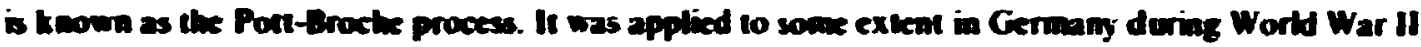

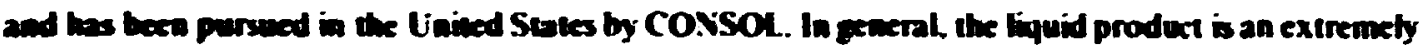
heory exiract its molecular weith is well above IODO. thes requiring that the extract be upgroded subsanting to male fad products. This upsoding an be accomplished by adding hydrogen

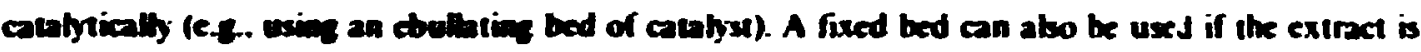
cocovially free of solid panictes.

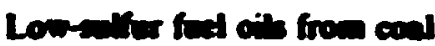

Heavy fucl oils can abo be prodexed from coal. Since a great deal of the sulfur in coal is tied up as inorganc constiveats of the ash. it is posible. by bufuefaction and removal of the ash, to produce a heary fuet oil (or de-ashad coal) from which a portion of the sulfur has been removed. This material has a high metring point [above $93^{\circ} \mathrm{C}\left(200^{\circ}+\right.$ )] The sulfur content of the de-ashed coal depends on the coal feod. The usual type of processing consists in contacting coal (in a sherry oil vehick) with hydrogen at 1000 to 5000 pie and 399 to $454^{\circ}$ C (750 to 850 F). Under these conditions. the coal depolymerives surficienthy. so that the toht mixture ean be fihered to recover the heavy oil product and a solid residue. 


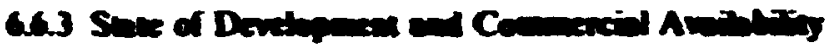

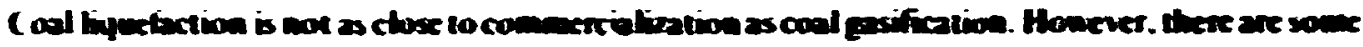

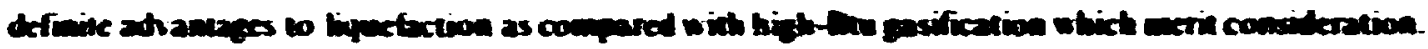

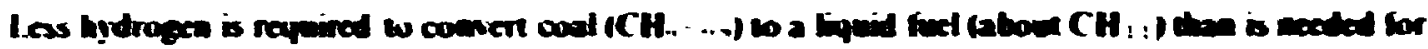

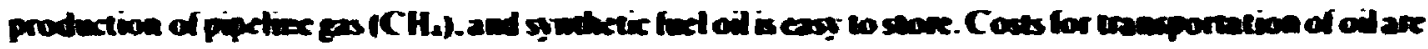

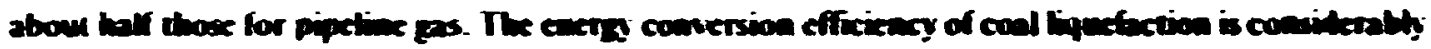

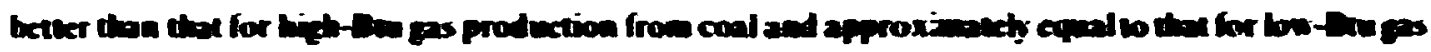

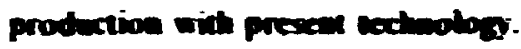

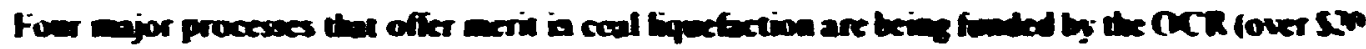

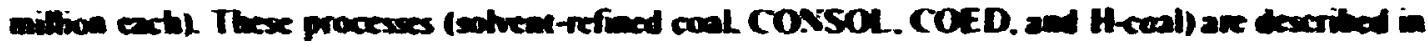
more detad in the following section.

\section{Q64 Symen Onderivios}

Solventrefined condistiss

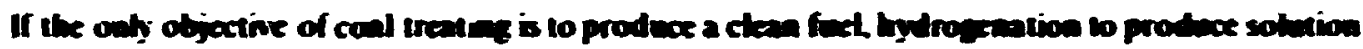
cas be mimimized and be followed by ash separation and conversion of selfor to removable form.

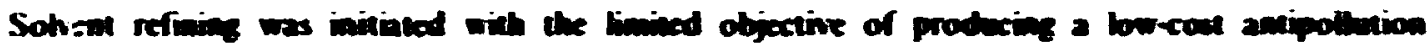
ahernative to residul oil and watural gess for we ender boilers.

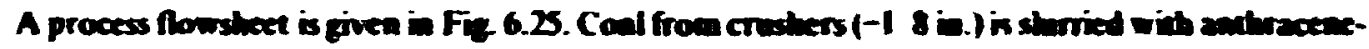

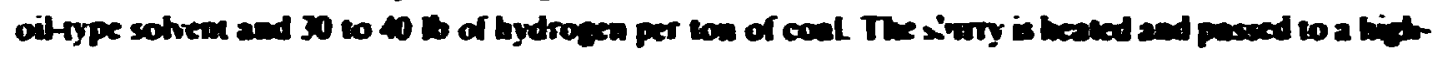

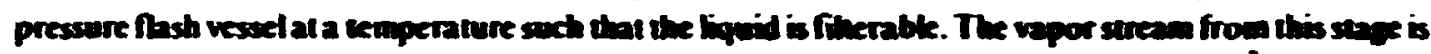

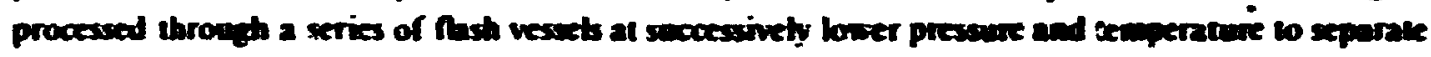
rarious tractions for hydrogen recycline phewol and creylic acid recovery. and acid gas removal.

The liquid portion of the dissolver efiluent is flashed to the finer preasere and passed to precoested

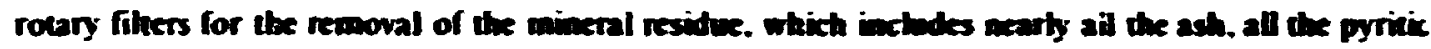

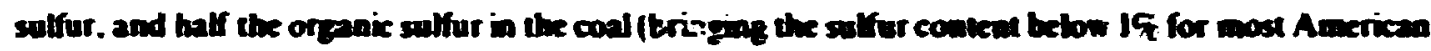
coals). The residve is solvent-washed and stored for noe as a fiect. Ges from the finer is removed and

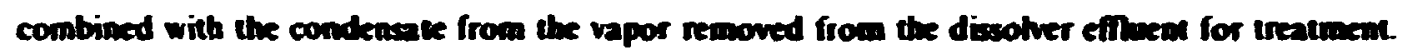

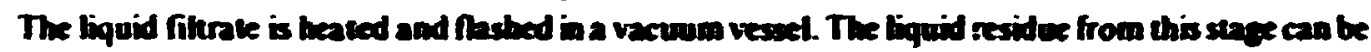
used either in liquid form as a fuel or solidified to form the fral fuel product. The solidification process at commercial seale is litely to require considerable development, but Stearns-Rover has indicaled the use of thaking drums and silos for product solidification and storage.

The condensale from the vapors removed by the vacuwm Mash stage pasees through two fractionators to recover various products. The firse separaces conl solvem from the wash solvent for the mincral residues and light oil products; and the second separates wash solvent from the light ends. Vapors from this process are recovered for processiag in the acid ans removal phem, while the fraal tiquid yields phenols. cresylic acid. and lighe oil. An additional planned by-product of the phat will be sulfur.

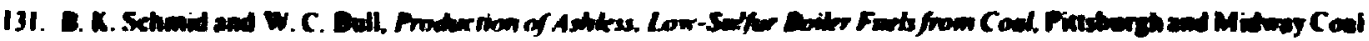
Minim Company. Seprember int.

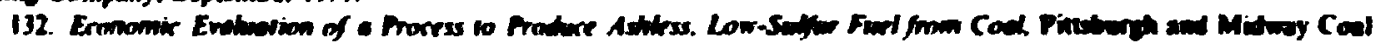

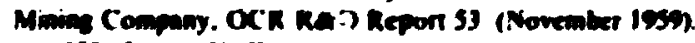
1974.

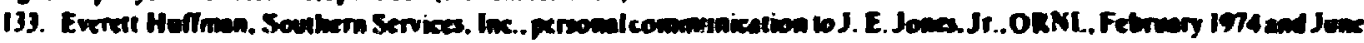




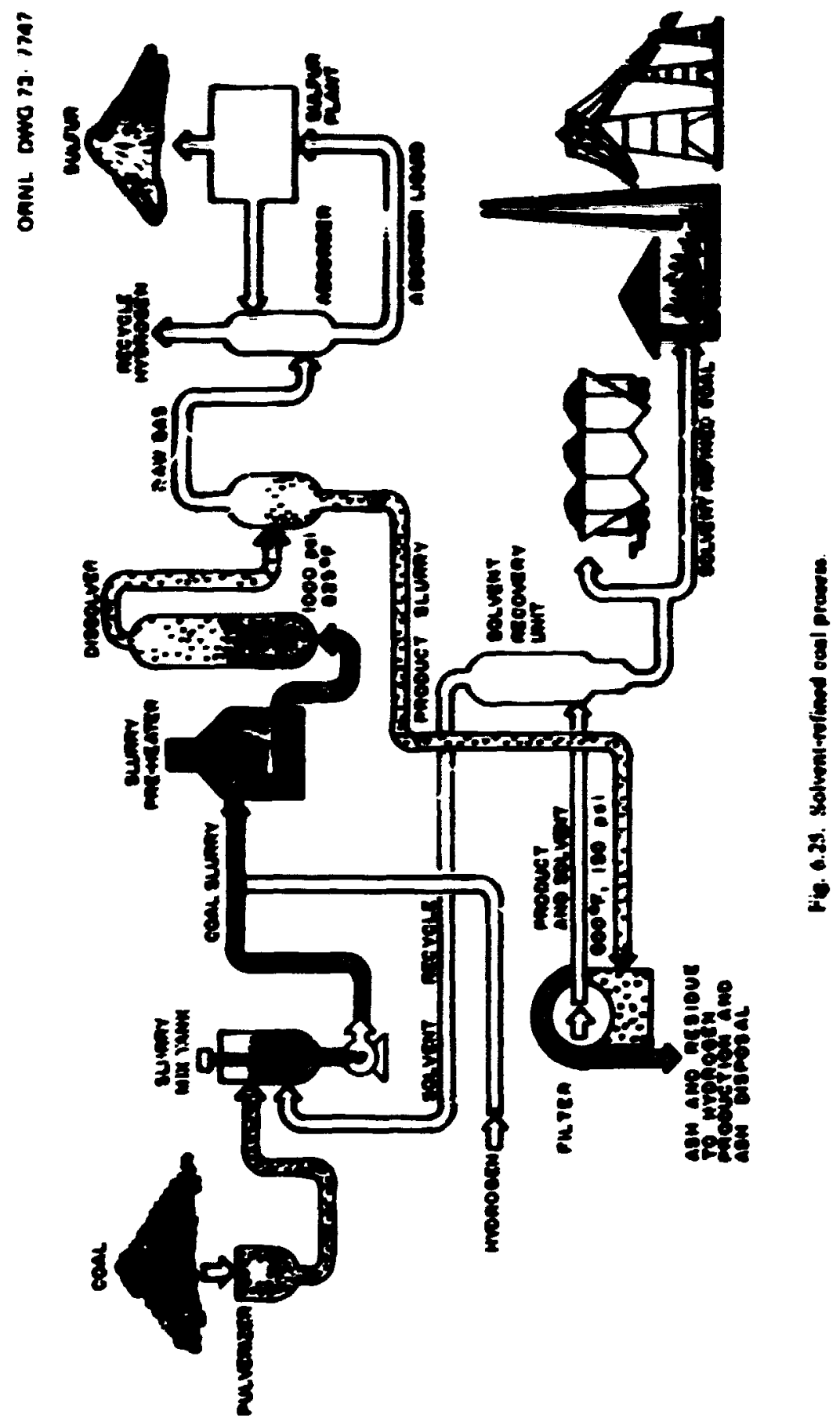




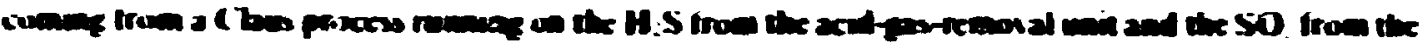

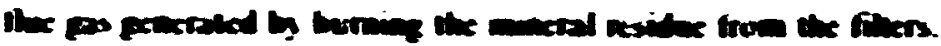

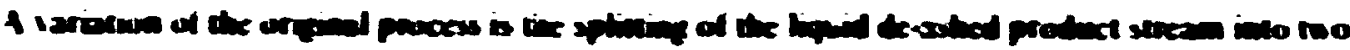

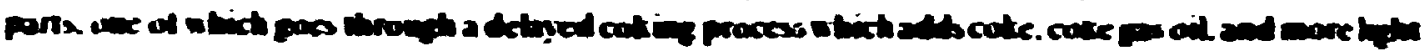

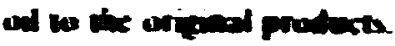

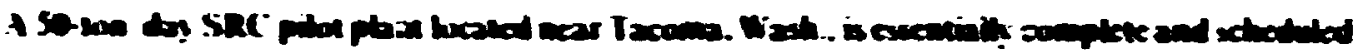

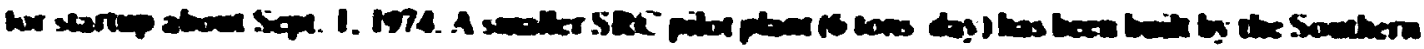

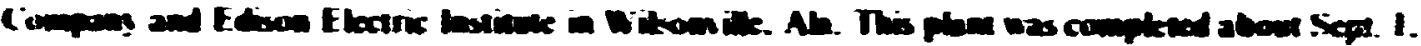

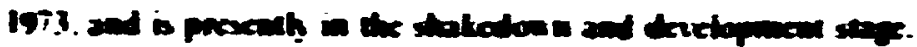

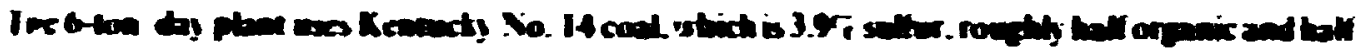

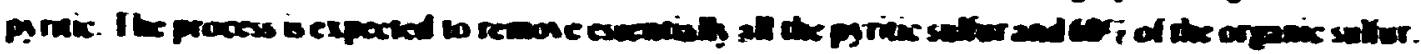

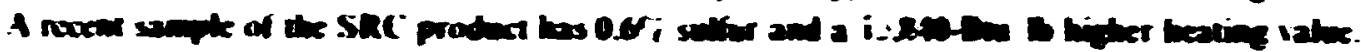

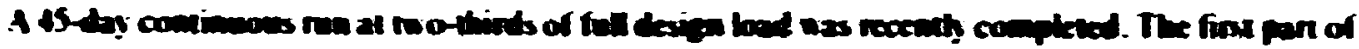

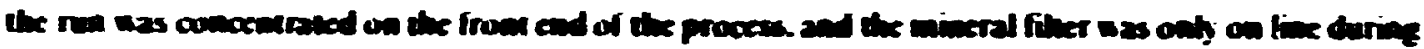
the las 20 hys.

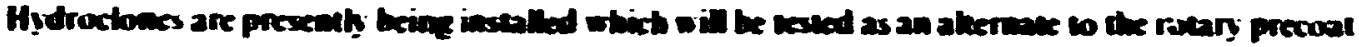
finct.

\section{COAsCL mais}

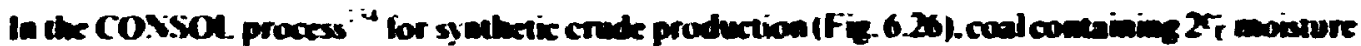

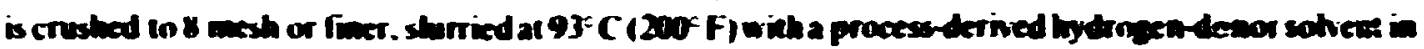

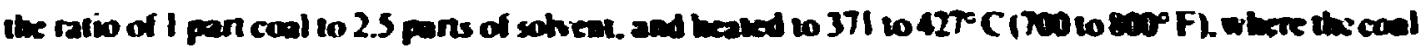
undergoes a complex disolution and crection process from which gases and watet are evolved. The

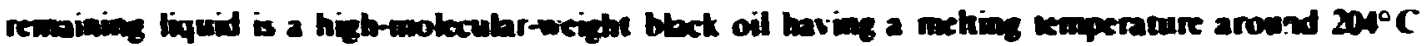

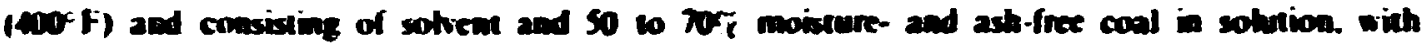
undissohed coal and ash in suspension. The bhet oil extract is cooled to 240 10 $371^{\circ} \mathrm{C}$ (500 to 700 F) and put through cyciox separntors to form a retaively solids-free streara and a solids concentrace. The

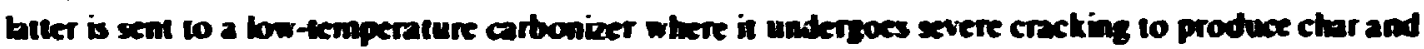
symatictic diailbtes.

The fihmate or cycione overfow strem is fashed. and the botloms are washed with waler at 1750

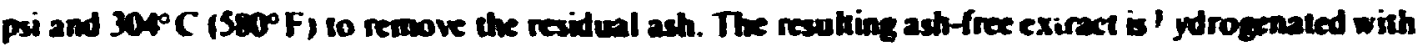
rinc chloride catalyst in an ebalbed bed operating at 4200 pai, and the hydropre Jue is dropped in pressure and separated by diatilbtion into heavy recycle solvent bottoms (conenang the hydrogin donor) and synthetic crude product. The solvent bottoms are returned to the coalshurrying point.

The Consolidation Coal Company has for many years been developing proceses for making synthetic liquid fuets from coal, leading in 1963 to a coatect with the Offec of Coal Research for design of a pilot phene." The ptant. dedicated in 1967, was inkended to make liquids in the peoline range and was christened Project Gasoliace (Consolidation Coal Co., (970). Later studies indicated the advisability of ctanging the objactive to the manufacture of bow-sulfur synthetic crude oil; the better process was described above.

This process has been subjected to detailed examination by a National Academy of Engineering Panel and the Foster Wheeler Corporation, resulting in a recommendation for extensive modifications

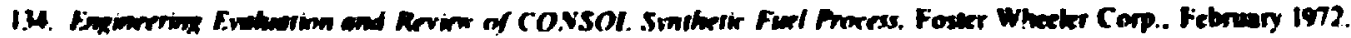

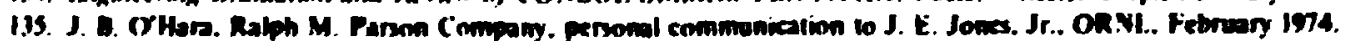




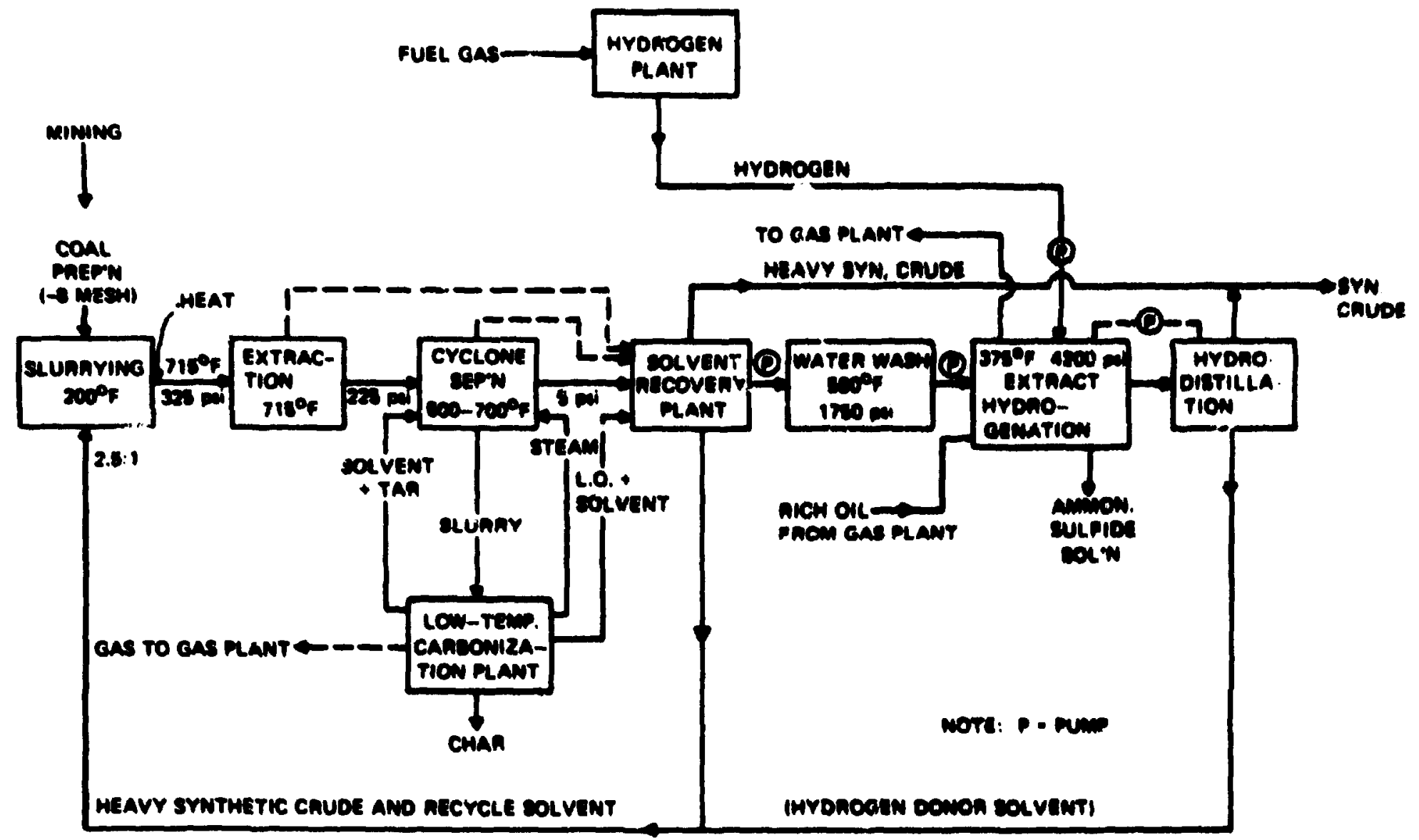

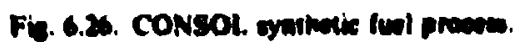




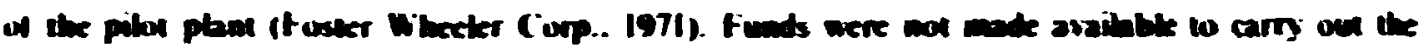

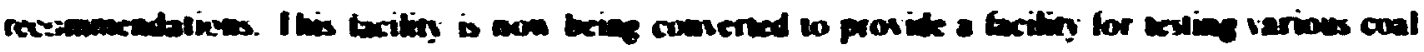
ingefaction processes.

COSD mases

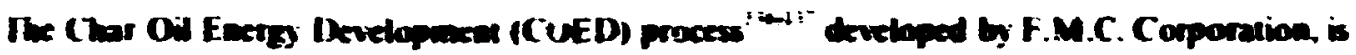

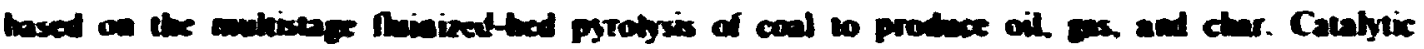

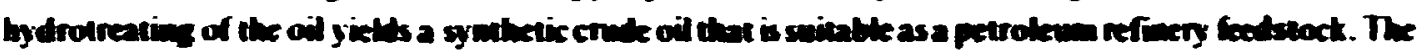

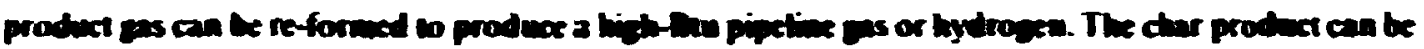

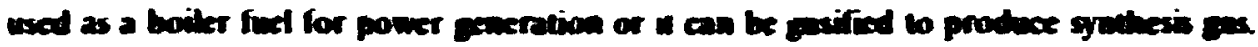

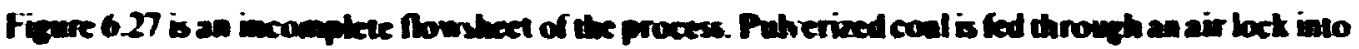

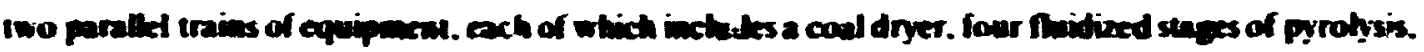

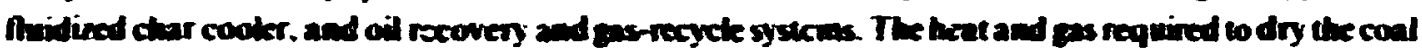

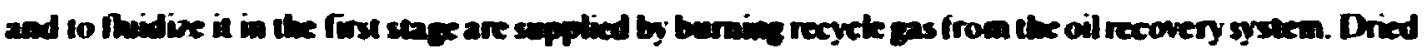

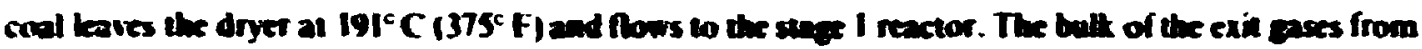

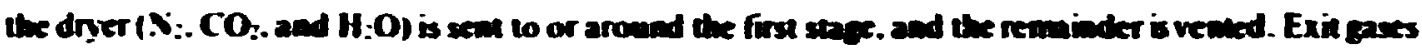

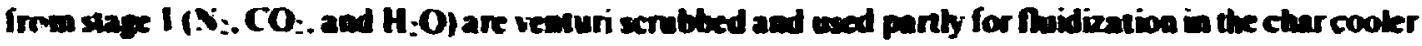
and parth for rexycte to the dryer; the oil and bquor from the scrubber go to a shimmer-decander system in the second-stape recovery system.

Stapes 2 and 3 are combined in one vesol. Product gas and resycle char at $871^{\circ} \mathrm{C}(1600 \%$ F) from staxe 4 supply the heat requined in the second-and thid-stage reactors. Product fases from stage 2 low to the oil necovery system. Product char from stape 3 at $530^{\circ} \mathrm{C}$ (1000 F) is haved $10871^{\circ} \mathrm{C}\left(1600^{\circ} \mathrm{F}\right)$ in sage 4 by combustion of a portion of the cher with oxygen. Product char from seage 4 is cooled in a Auidiaed thed char cooler. The product as from seage 2 at $454^{\circ} \mathrm{C}\left(850^{\circ} \mathrm{F}\right.$ ) passes through a venturi condenser. where it is cooled to $77^{\circ} \mathrm{C}\left(170^{\circ} \mathrm{F}\right)$. Escentilly all the oik are condensed and removed in the Farliyuid separator. The eflnem gas flows through an electrostatic precipitator for fog removal and then to a spray tower to remove the bat iraces of oil. The ges leaving the tower at $38^{\circ} \mathrm{C}\left(100^{\circ} \mathrm{F}\right)$ is sent to a pas purification unit (not shown). The decanted oil. including that from the stage I recovery system. nows to an oil dehydrator, a fiter for removal of char arried over from the second-stafs reactor, and an oil hydrotreating section. The.c the oil is rump.d 103100 psi. joined by recycle and makeup hydrogen. and hested $10343^{\circ} \mathrm{C}\left(650^{\circ} \mathrm{F}\right)$ by heat exctange on the product stream from the bottom of the hydrotreater. This stream is heated further $\left(0413^{\circ} \mathrm{C}\left(775^{\circ} \mathrm{F}\right)\right.$ in a gas-fired fumace prior to entering the top of the hydrotreater. Oil prodiet is separated from the lighter hydrocarbons in a series of coolers and nash orums, and the product oil is pumped to bulk storage.

The product gas from the oil-recovery section is compresed to 410 psia. The $H_{2}, \mathrm{~S}$ and $\mathrm{CO}_{2}$ are removed by a purification system. followed by a zinc oxide guard for removal of sulfur imces. The hydrocarbon pases ore then reformed and shifted with steam at approximately 300 psin, and the $C O$; is removed. A methanation step then fullows for the final removal of $C O$. A portion of the COED product pas is used as process heat for the reformer section and for the other areas where heat is required.

Instead of using the COED process to moke the three products listed above, the fuel gas (of about SOO Btu $\mathrm{ft}^{3}$ ) an be used to make hydroyn at a claimed pie of about $12,000 \mathrm{ft}^{3}$ per con of coal for use in

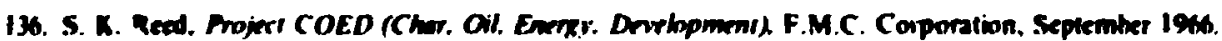
1972.

137. H. A. Sharer. Eromomir Evetwation of COED Proress phus Char Gesifrewion. Ameriean Oil Company. September 


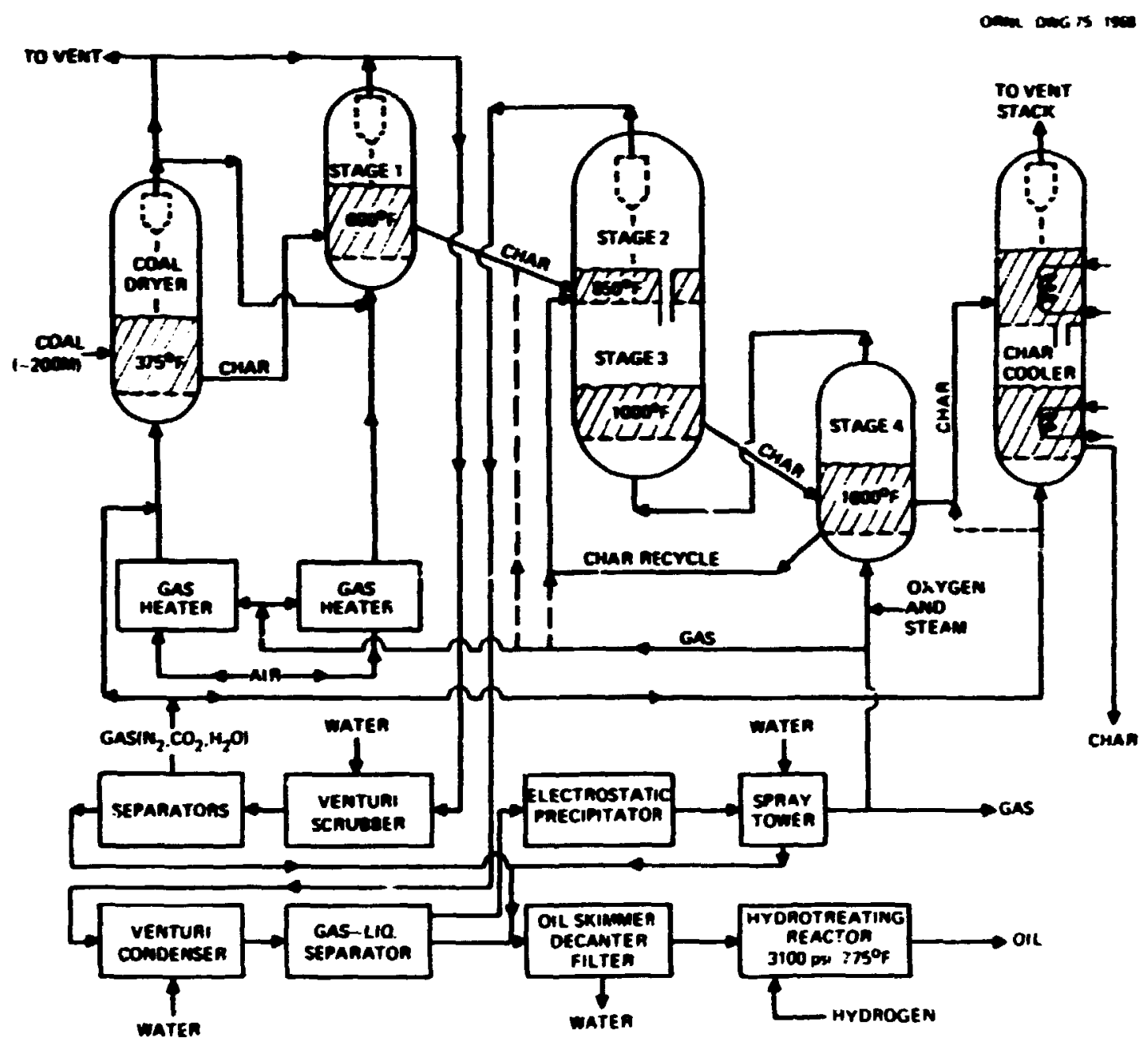

Fia. 6.2i. COE' process.

o.l hydrogenation. Similarly. the char can be used to make synthesis gus. With a scak of operation targe cnough to consider the gas streams from COED as raw material for pipeline-quality gas, this process might be considered for integration with the methanation operations of one of the gas-making processes.

A 36-ton day pilot plant ${ }^{1 \text { " }}$ is Incated at Princeton. N..1. The C OED process has operated well in pilot plants.

The COED process is intended to maximize the gas yield oblainable by coal pyrolysis alone. with temperature staging to avoid agglomeration and countercurrent gas-char now to minimize product decomposition. It produces about the same char yield as the standard ASTM proximatc analysis for fixed carbon plu's ash. The process is stated to have produced. on a 30-day run on Colorado hituminous 
cual. the fuibuine yields based un dny coul feed:

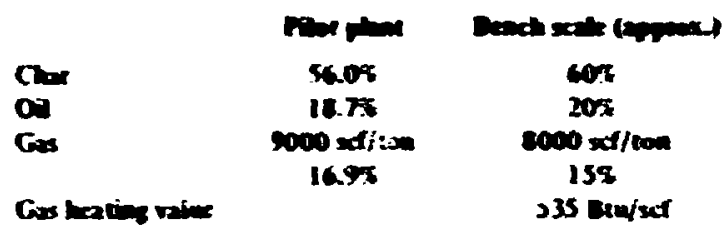

The second columen gives. For comparison, the results of earlier bench-seak experiments. These and other results. combined with product heating values. correspond to thermal effriencies in the vicinity of 100\%. Such a high value is not realistic. and "n is not clear whether there were other thermai inputs: howerer. the dat do support th: reasomabte conclusica tha: this process operales at high thermal efficienc: The oil yield of 18.7 e corresponds to about 1.2 barsels per ton of coal.

\section{H-coul process}

Hydrc stbon Research. Inc. (HRI). under spunsorstip of the OfTrce of Ceal Research. has developed a process for coal lipuefaction by calabtic nydrogenation. "int io Cushed coal (Fig- 6.23) is mixed with recyck oil to form a slurry which is pumped with hydrogen into a greheater operating at 2700 psi. The slurry and preheated recycle gas from the main reactor are pumped sto the $H$-coal reactor. an ebulbted-cata!yst column operating at 2700 psi and $454^{\circ} \mathrm{C}(850 \mathrm{~F})$. The catalyst, cobalt molybdate. settes below a point in the bed at which liquid product is drawn off to a hot atmospheric flash drum. There the produrt separates into an overtead stream that is split. part going to a varuum fash drum which separates it into vacuum overhead product and bottoms sturry product and part to a retum line to the slurning operation. At the reactor the oveshead vapors are partly condensed. and the urcondensed gas (containing most of the fuel sulfur as $H: S$ ) is sent to a maphtha recoveny operation. to acid pas removal. and finaly to the hydrogen plant with other fur! zas. The fnowsheet (Fic. 6.28) shows tizal products which must be subjected to further refinery operations. The char-oil product, containing unconverted solids. can be used as a fuel nr can be arbonized to rheain mone liquid product.

Tine process" " has had bench-scak developmeni in a 3-ton day process development unit. A proposal has recently been made that a variation of the pr.wess. knowin as the HRI fuel-oil process. be tested at pilot-plant scale at the Cresap pilot plant of Consolidativil Coal Companj. under contract of both companies to the Office of Coal Research. The fuel-oil process will differ somewhat from the one described above. A two-reactor. two-stage conversion system will be used. with the light and middke distillate materials rexycled with coal to yield the fucl-oil product stream. Residual materials remaining unconverted would require separation and arbonization.

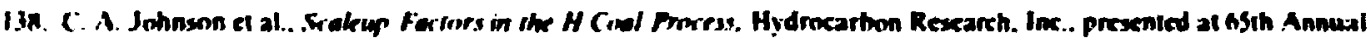
A. Ch.t. Mecting. November 1972. (1\%5).

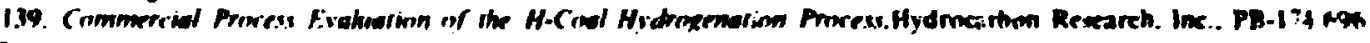


CAinl-Ding 73-4003

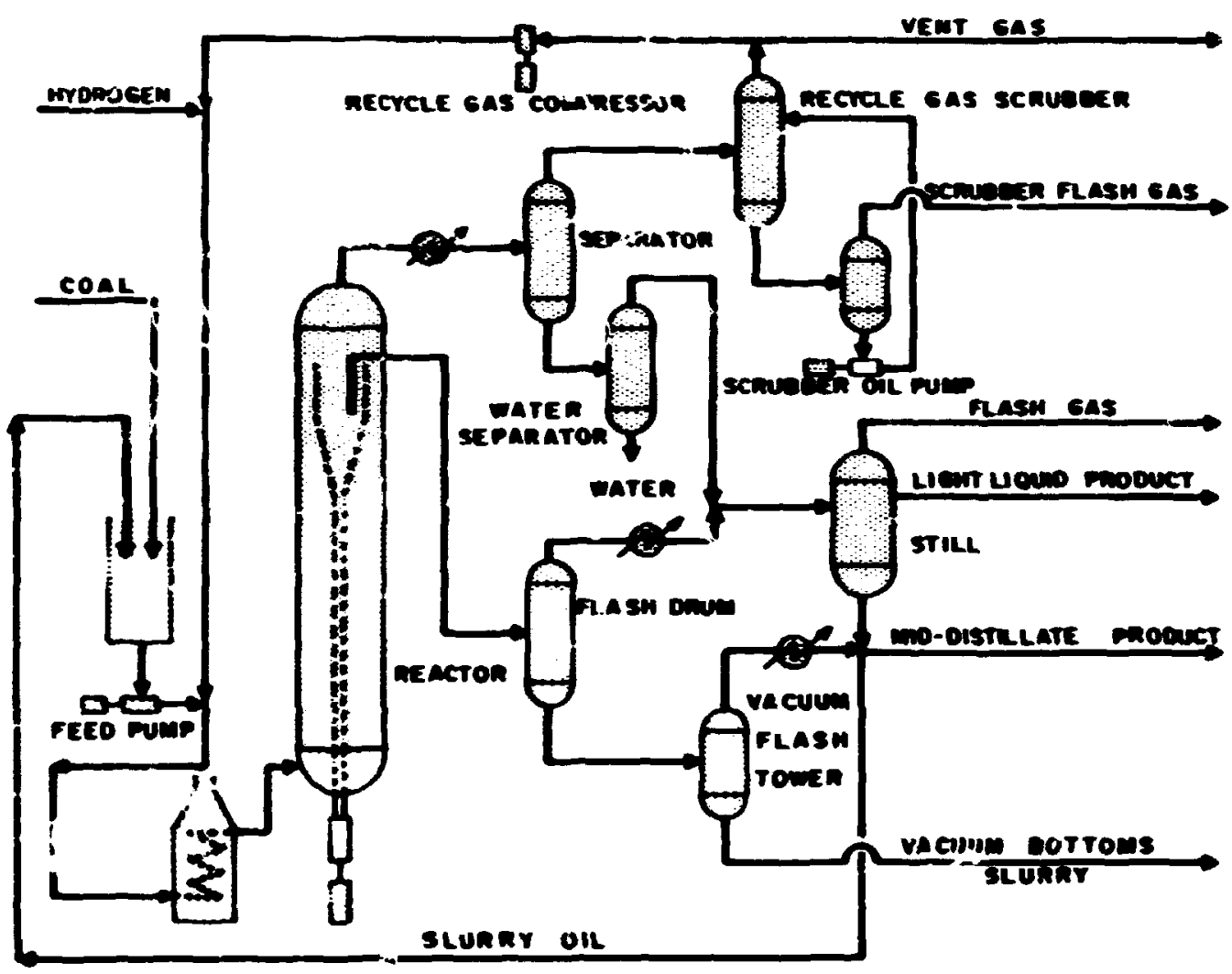

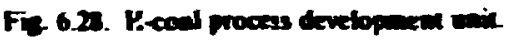

\subsubsection{Economic Analysis}

For buth solvent-refinea coal and cle an liuquia fuel. it is appreciably more economical to consider a large mine-mouth plans that distributes product to si:sal industries rather thas a smialt plant at the industrial sive. Botk products aice cheaper to ship than th: coal and ther: are economic advantages of scaling to a barge plant size.

Solvent-retined conl

A $34.100-10 n$ day tas received) SRC plant i; considered to be heated in the southern Illinois area. " The plant uies high-sulfur bituminous cosal at an estimateci coss of $50610^{n}$ Btu at the minemouth plant. The technical and economic data for this plarit are tabulated in Tabk 6.31. and the unit cost of steam generation using SRC is shown in Tank 6.32 .

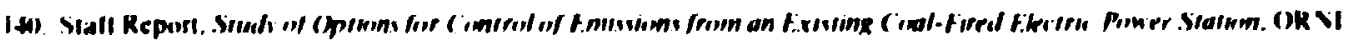

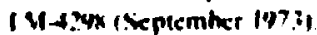




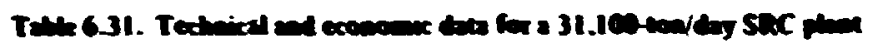

\begin{tabular}{|c|c|}
\hline $\begin{array}{l}\text { Cool required (as received) } \\
\text { Unit coul con }\end{array}$ & $\begin{array}{l}31.100 \text { tonditay } \\
50 \text { t } 10^{6} \text { ane }\end{array}$ \\
\hline Fant factor & 0.9 \\
\hline Ansul coul cost & $5117.5 \times 10^{6}$ \\
\hline Tocol copitall investanean & $5339 \times 10^{6}$ \\
\hline Anat copital cost fat 22.27 fired chare rate) & $575.2 \times 10^{6}$ \\
\hline 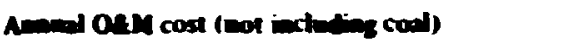 & $535 \times 10^{6}$ \\
\hline Total anom cos & $5227.7 \times 10^{6}$ \\
\hline \multicolumn{2}{|l|}{ Dyproducts } \\
\hline Lith oil & 16856 buliby $(2697$ toms/by) \\
\hline Fuened & 90 toas/day \\
\hline Cresylix acid & 300 roma/day \\
\hline Tot & 3032 lomedby \\
\hline SAC producticn & 14.650 tome/by at is $650 \mathrm{Dtw} / \mathrm{b}$ \\
\hline Total production & $\begin{array}{l}17.737 \text { towes/by }=5.83 \times 10^{6} \text { toma/yem }=182.5 \times 10^{12} \text { Erwiyear } \\
5227.7 \times 10^{6}\end{array}$ \\
\hline SxC uit cost & $\overline{1825 \times 10^{12} \mathrm{Bu}}=51.25 / 10^{6} \mathrm{du}$ \\
\hline \multicolumn{2}{|l|}{ Simpinges cos } \\
\hline To New Orleans & $\sec 13 / 10^{\circ} \mathrm{bru}$ \\
\hline To Howston & $50.18 / 10^{6}$ bes \\
\hline $\begin{array}{l}\text { Total delivered SAC cost } \\
\text { Howsion } \\
\text { New Orleans }\end{array}$ & $\begin{array}{l}51.43 / 10^{6} \mathrm{Cxe} \\
81.38110^{\circ} \mathrm{Dov}\end{array}$ \\
\hline
\end{tabular}

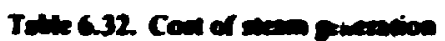
cins $\sin$

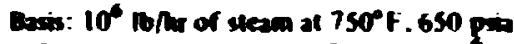
Estimated cuat of boiler. $\$ 18.75 \times 10^{8}$

\begin{tabular}{|c|c|c|}
\hline & $\begin{array}{l}\text { Anmat cose } \\
\text { (s10 }\end{array}$ & $\lim _{\left(1 / 10^{\circ} \cos (x)\right)}$ \\
\hline 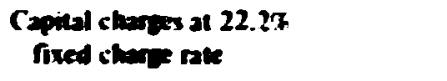 & 4.16 & 45.5 \\
\hline $\begin{array}{l}\text { Oparting aud moinirasence } \\
\text { (excloding foet cos: }\end{array}$ & 0.31 & 3.4 \\
\hline Uain fuet cost al production site & & 125 \\
\hline Shipping cost & 10 & $13^{6}$ \\
\hline Delivered fuet cost & 143 & $138^{6}$ \\
\hline Seean con (at $85 \%$ boiter efriciency) & 217 & 211 \\
\hline
\end{tabular}

Gouston.

BNew Orleans. 
Liquid boiker foed

Cost anabyses have beer. piepared for producing layuid boiker fuel or syncrude using the direct hydrogenation method (H-coal) or a two-step extraction-hydrogenation method (using the basic SRC process plus hydrugenation). ${ }^{\text {tiois- }}$. These processes appear to have about eyual economic potential at this tume.

Tabke 6. 33 presents a cost estimate for the extraction-hydrogenation process. Data are derived from an extrapolation of a Ralph M. Parsons Co. Repon. is: This estimate is considered to be more conservative than similar estimates for the H-coal process. ${ }^{\text {1: }}$ Two lipuid boike fuel products are produced plas by-product mphtha. The rwo productsise roughb equivakent to No. 6 and Nu. 4 fuel oil. The thoike fuel cost presented does not cistinguish between these wo products.

The unit cost of steam generation using the liyuid boike fuel from coal is shown in Tabke6.34.

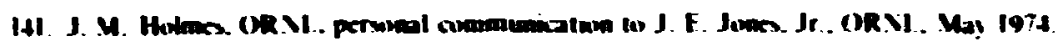

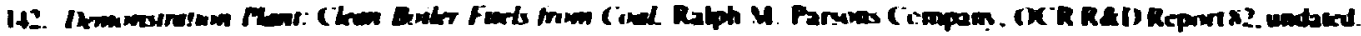

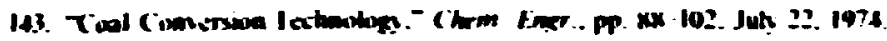

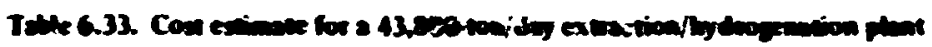

\begin{tabular}{|c|c|}
\hline 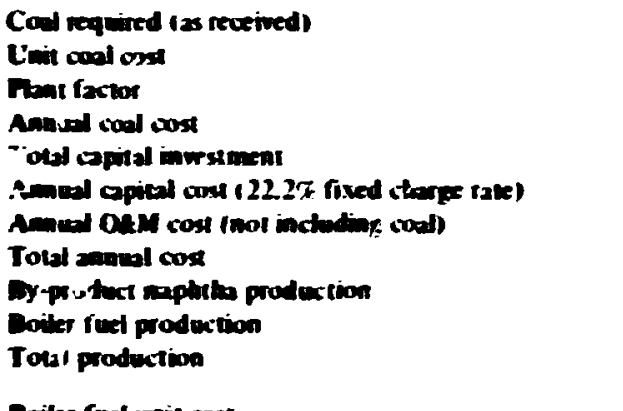 & 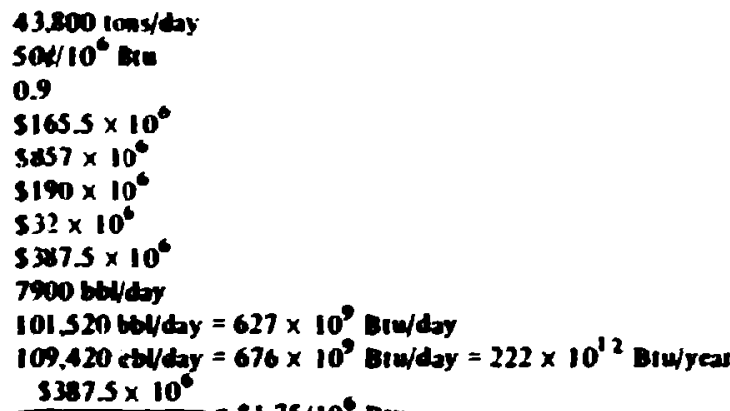 \\
\hline Doilet foet wait anst & $\overline{222 \times 10^{12} \mathrm{Btw}}=\$ 1.75 / 10^{\circ} \mathrm{Blu}$ \\
\hline 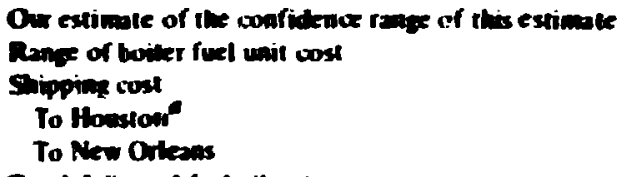 & 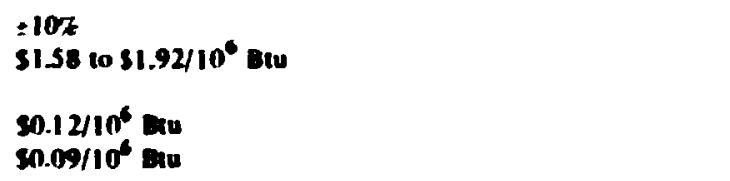 \\
\hline $\begin{array}{l}\text { Total detivered fuel oil unit cost } \\
\text { Howston } \\
\text { New Ontens }\end{array}$ & $\begin{array}{l}51.87 / 10^{\circ} \text { gie } \\
51.84 / 10^{\circ} \text { sin }\end{array}$ \\
\hline
\end{tabular}

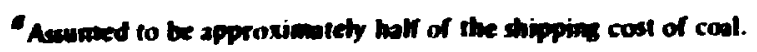




\begin{tabular}{|c|c|c|}
\hline & 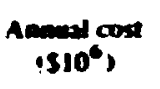 & $\lim _{1 / 10^{6}} \cos$ atel \\
\hline $\begin{array}{l}\text { Capical charges at } 22.2 \% \\
\text { fived cturege rate }\end{array}$ & 3.33 & 36.4 \\
\hline $\begin{array}{l}\text { Operating and maintenance } \\
\text { (excluding fuet cosel) }\end{array}$ & 0.31 & 3.4 \\
\hline Unie fuet cosa at prodection site & & I7s \\
\hline Shippies cost & 12 & s \\
\hline Detivered fuet cost & 187 & $184^{6}$ \\
\hline Stean cost (at 85\% boikt efficieacy) & 260 & 256 \\
\hline
\end{tabular}

\subsection{METHANOL FROM COAL.}

The technology for making methanol is avaitable. Several types of suitahk coal gasifers are avaibable. and at kast tho methanul synthesis processes are in commercial use. However. no intezration of this technology has ever been attempted on a currently commercial scak of production.

Methanol via coal gasification would undoubiedly be produced at or near the mine mouth to obviate the extra handling and transport of raw coal. Selection of a gasifier for a methanol-from-coal plant would be significantly influenced by the site chosen for the plant and the type of coal used for feed stock. For example. for an eastem site and caking bituminous coal. the Koppers-Totrek gasifier appears to be the optimum choice. On the dther hand. for a western site and noncaking stibbituminous coal. lurgi gasifiers would be the likely choice.

There are many options for combining the gasification and the methanol synthesis steps reyuired for the production of methanol from coal. Most economic evaluations which have been published have focused on the production of "methyl-fuels" for the automotive market. ${ }^{\text {istist }}$ Because of its high cost. methanol holds no promise as a base fuel for utility boikers. Howerer, since it can be readily transported and stored in conventional eyuipment. it might. under some circumstances. be of interest as a standby or peak-shaving fuel. A 2-week firing program carried out in 1973 by Vukan Cincinnati. Inc.. at the A. B. Patterson Steam Cenerating Station of New Orkans Public Service demonssated that "methyl-fucl" is suitable for firing utility boikers. ${ }^{\text {in }}$

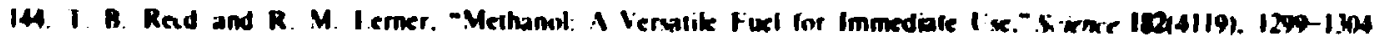
(IXecember (973).

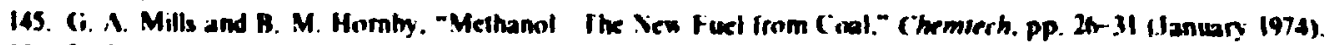

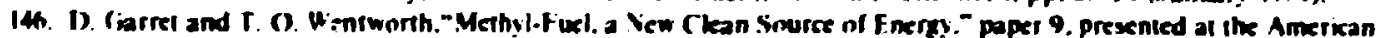
Chemical Sixiety 1971 Annual Meetmg. Iniskin of Fuel Chemising. Aug. 27. 1973. 


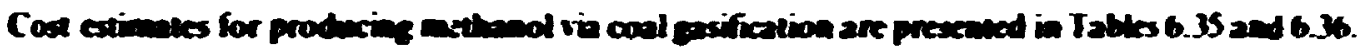

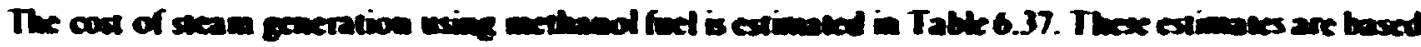

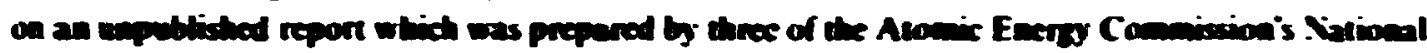

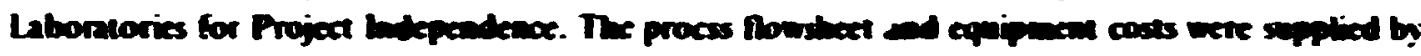

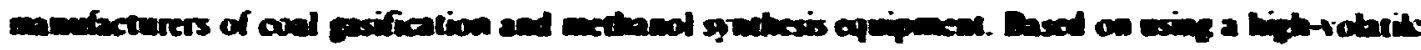

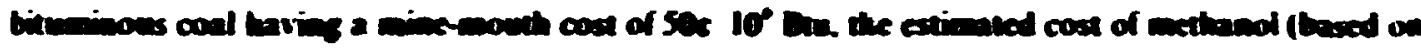

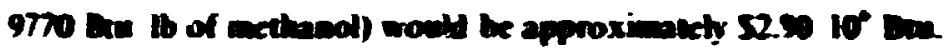

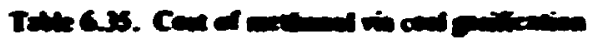

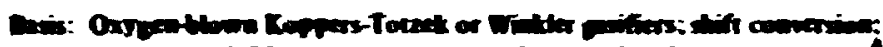

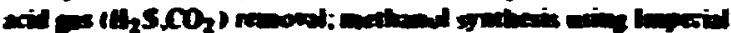

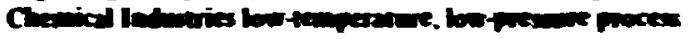

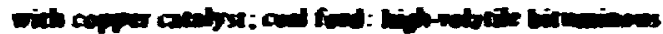

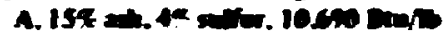

Den

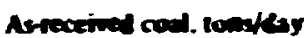

8260

Oxyou, tom

670

Drear. pis.

3320

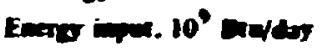

177

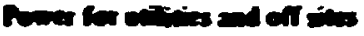

Asteceived coal. 10as/by

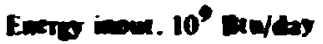

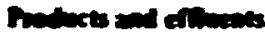

Nethonol (at 9770 are/b). coms/by

Total ewers onter. $10^{9} \mathrm{Bde} / \mathrm{by}$

Ads. romilay

Anoseselinimey

Total energo ontpet/total enerpy inpel. *

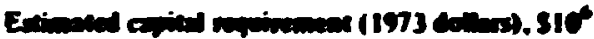

Onsite process unins"

Cosificalion

54.5

Oxyeren production

36.1

Cas thif conversion and purification

28.6

Methunool symbissis

38.1

Or-ire units and uditities"

Continjemey

$$
-18.6
$$

Total pbat investmeon

204.5

Imeres durting comaruction

34.5

Stariup costs

9.7

Working apiral

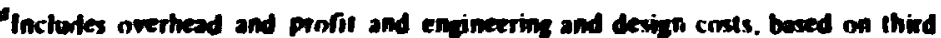
querter 1973 dollars. 


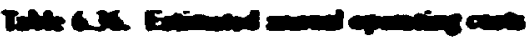

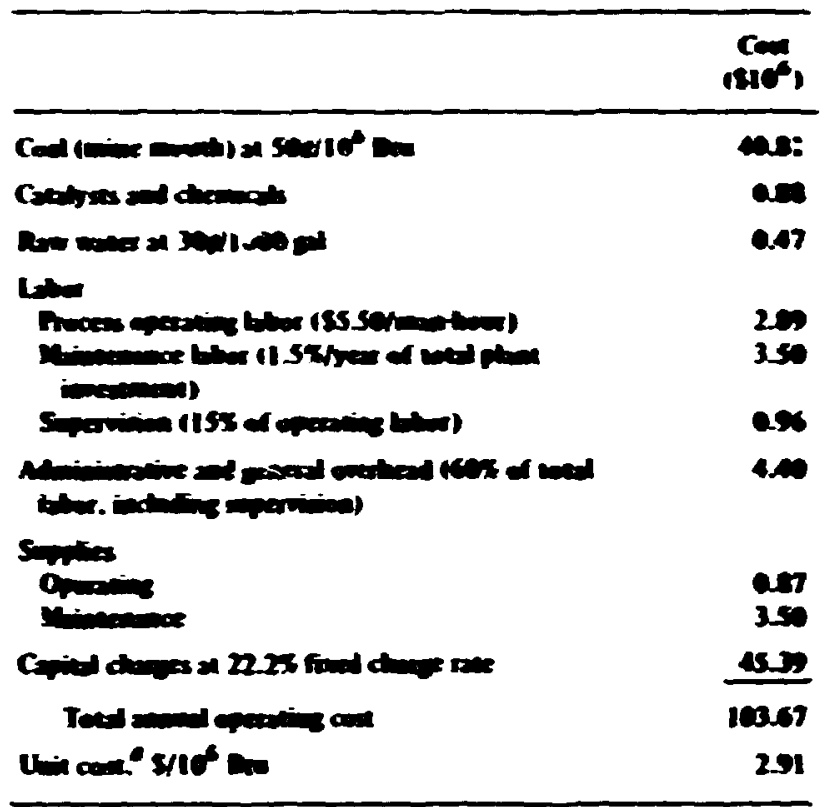

- $\quad 10367 \times 10^{6}=0$

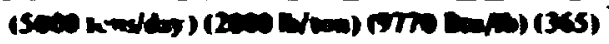

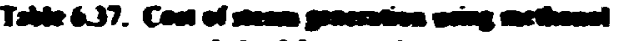

inind tom and

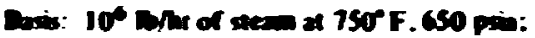

eximered cout of toiler. S15 $\times 10^{\circ}$

\begin{tabular}{|c|c|c|}
\hline & ${ }_{\left.\mid s 10^{\circ}\right)}^{A \infty}$ & (anis \\
\hline 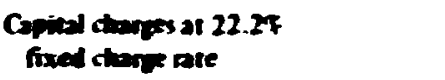 & 3.33 & 36.4 \\
\hline 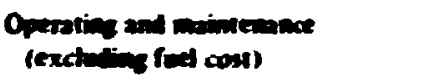 & 0.31 & 3.4 \\
\hline Unia fed con at prodection site & & 21 \\
\hline shinime cost & 12 & ڤ \\
\hline Detivered foet cost & $305^{*}$ & $300^{\circ}$ \\
\hline stem cost (at est boils efficiency) & 3 & 393 \\
\hline
\end{tabular}

Alowston.

Hew Oriens. 


\section{Part III. Assessment}

Pan III is an werall assessmem of the various options described in Pant II in the cratext of costs commercial avaibbiling. and posem.al for retrofinime systems that are presenth being fored

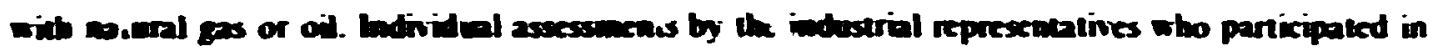
itc stidy ane included in this section.

\section{Assessment of Energy Alternatives}

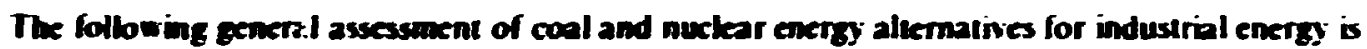
specifically directed lowand brge industrial energy applications in the Gulf Coast region of the U.S. . where industry has been ising bow cose. high-quality natural gas almost exclusively. Natural gas is now quite expensive and. more importanth. may soon be umavilable to industn for steam generation and process heating at any cost. Conversion to an alternate energy source involves an almost unmanagable number of options and decisions. many of which may be affected by national or intemational policies beyond the control of the industries concerned.

This assessment is intended to provide some useful guidelines for the industries involved and to contribute. abon with industrial input. to a better understan" is within the federal Government of enerey system development needs for industrial applications.

Each system is evaluated in term: of its application in or near Houston. Tex. Selection of this reference site has tended to make westen. coal more attractive as compared with some alternate site cast of the Mississippi River. The reader stould be cognivant of this factor in interpreling these results for altemate sites.

\section{I NUCLEAR ERERGY}

Three nuckear systems were evaluated in various sizes: commercial LWRs (PWRs and BWRs). HTGRs. and the consolidated nuclear steam geneiator (CNSG), a small I.WR development concept.

The cost of steam for a typical two-unit utility-financed reactor station is shown in Fig. 7.1. The 3750-MW(t) PWR and the 3000- and 2000-MW(1) HTGRs are standard commeicial sizes. The 


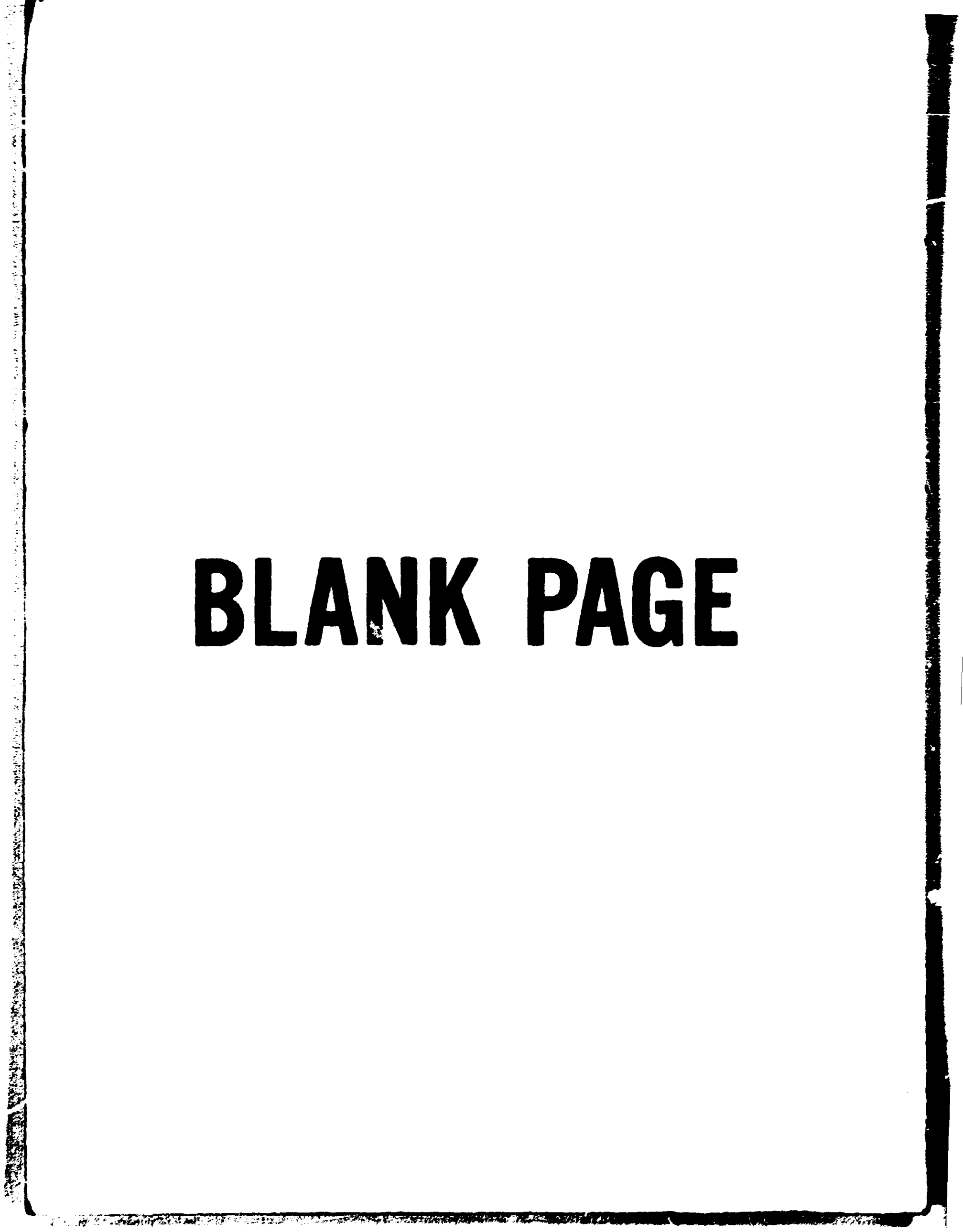




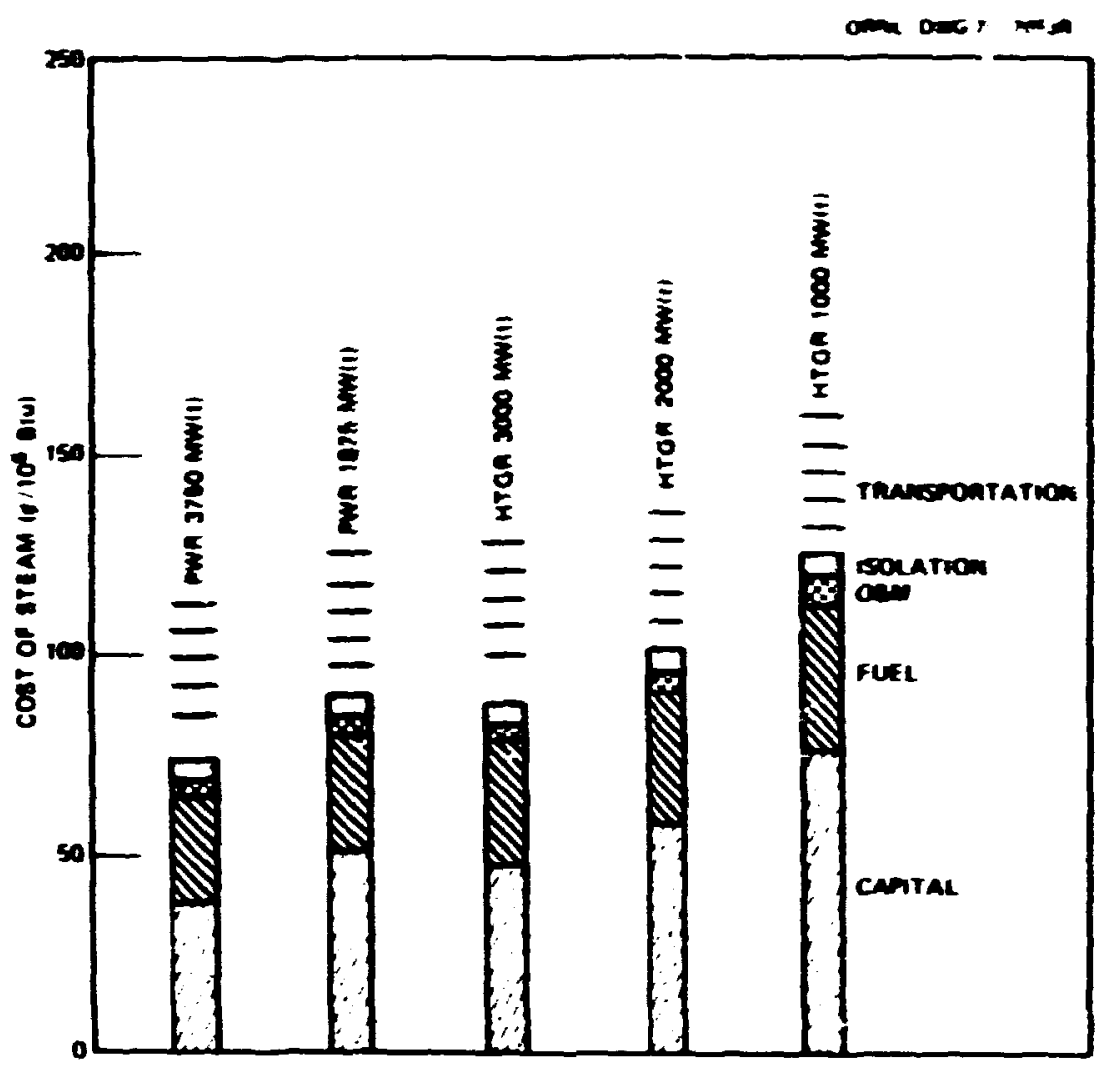

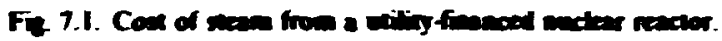

1875-MW(t) PWR is marketed in Europe but not in this country currenth. The 1000-MW(t) HTGR is an extrapotation of our cost information and is not presently being martetec. Steam costs. including an isolation loop. vary from $78 \mathrm{e} 10^{\circ}$ Bu for the targest I. WR $10 \mathrm{SI} .2510^{\circ}$ Btu for the IOOO-MW(t) HTGR. The CNSG is not illustrated with utiliny fonancing.

The cost of steam from a two-unit station with industrial financing is shown on Fig. 7.2. In this ase. costs. incluoing an isotation bop. vary from $51.0810^{\circ}$ Btu for the brges PWR to $52.4110^{\circ}$ Beu for the 314-MW(t) CNSG.

Several comments are needed to qualify and explain these resulss. First, the cost difference between the equivalent PWR and HTGR sizes is compensated for by the higher qriality of the steam generated in the HTGR. In terms of electricity production. these systems are equally competitive. However. the current HTGR design precludes the extraction of high-quality steam. Our estimate presumes a modification of the helium circula!ni ciesign so that prime steam is available.

Transpontation of the HTGR prime steam or very high-iemperature. high-pressure process steam which could be generated from an isolation loop is not economically attractive. We have assumed transportation of 650 psi. $750^{\circ} \mathrm{F}$ steam from the HTGR without any credit for b.-product power which could be produced. 


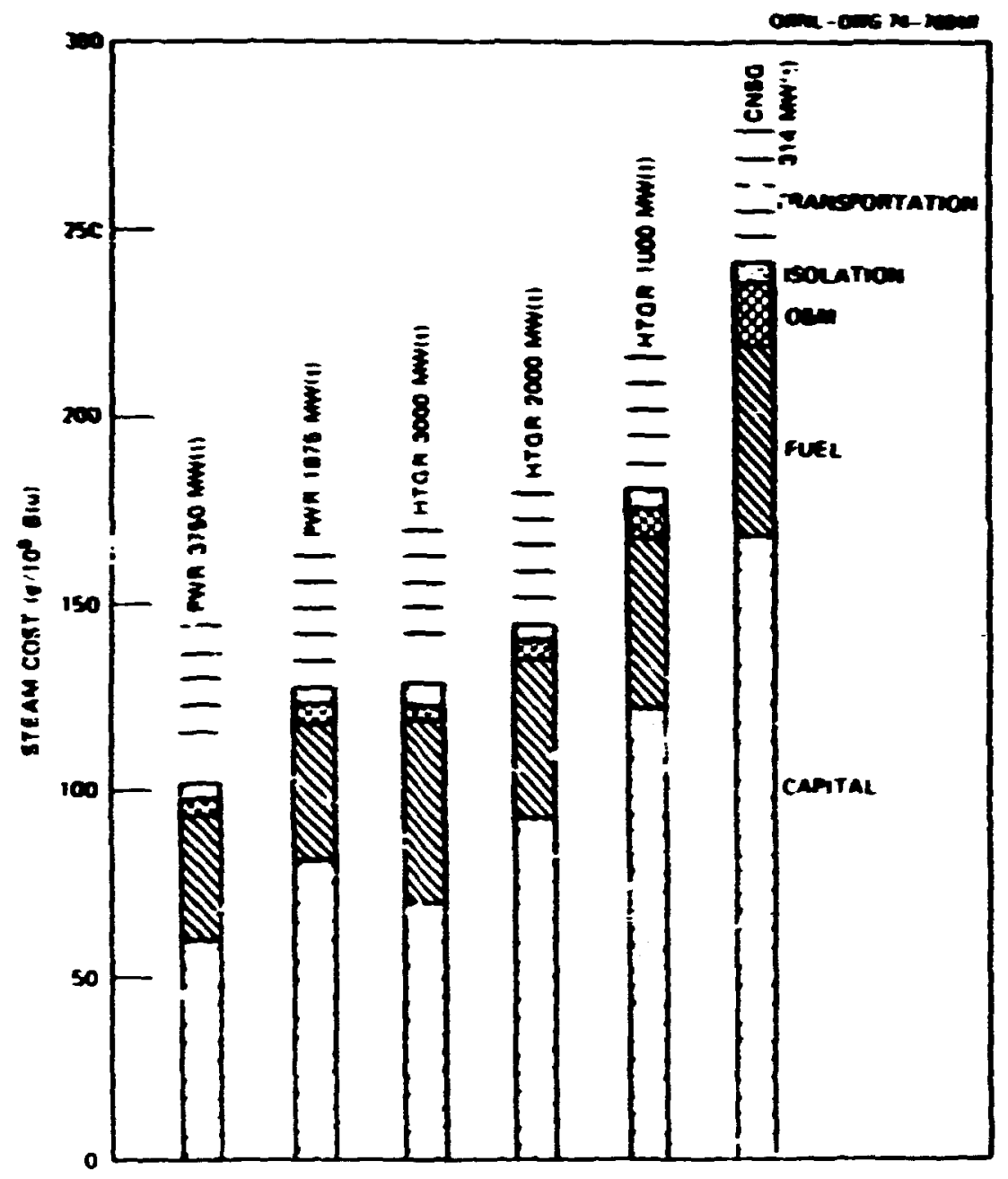

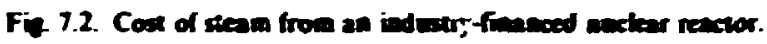

Recently the General Atomic Company has proposed a tboosted reheat" cycle for HTGR prucess steam application. This cyck provides a modest amount of power from the high-pressure turbing $[i$ i 0 $M W(e)$ for a 2000-MW(t) reactor] and still provides steam from the reheater at approximatety 726 psia and $913^{\circ} \mathrm{F}$. A major advantage of this cyck other than the improved steam conditions is that the steam pressure is greater than the reactor helium pressure throughout the steam-generator reheiter. Thus the potential for radioactive contamination within the steam is greatly reduced. The question of whether a reboiler is required in this case may be debatable. but even if it is required, ind ustrial steam conditions of 650 co 675 psia and $750^{\circ} \mathrm{f}$ should be available. The modified cycle is accomplished by adding a pressure control valve on the outlet line of the reheater. Other system components are identical to the conventional HTGR cycle equipment.

A quick evaluation of the effect of this improved cycle on the cost of steam from an HTGR reveals that by allowing credit of 12 mills $\mathrm{kWhr}$ for the power generated 117 mills $\mathrm{kWhr}$ for 


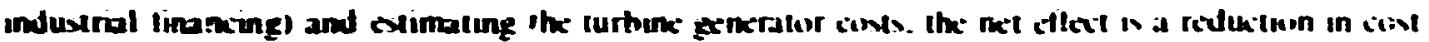

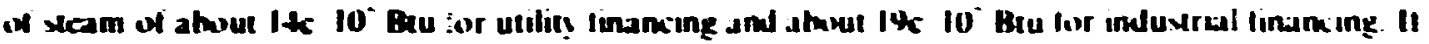
the rebuikt on be climinated. there would be edditumal cims sisings.

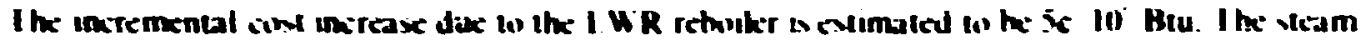

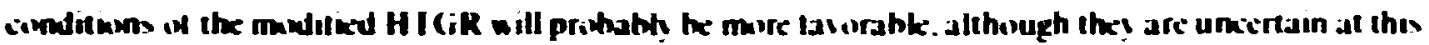

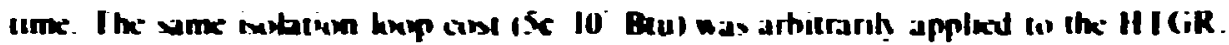

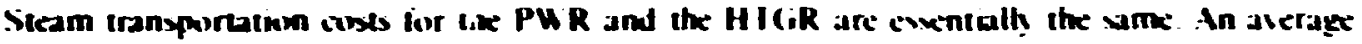

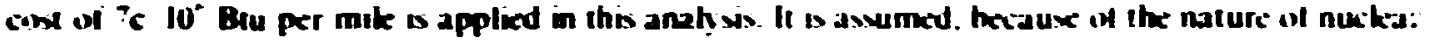
reatir sting that the nuilear steam jupph mal be lanter awas from the industrial applatation

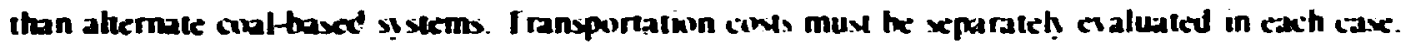

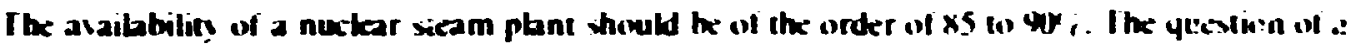

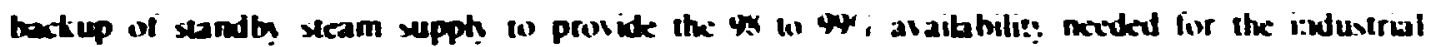
applications is a dificult one. This hactup is generalh achieved through a multiple sf srall units. The more cconomical nuctear units are ieng large. Ithe CXS6; is a much more attractic unil sive. but is small size results in a substantial eccmomic penalty.

If the industrial plant is. or can be. heated near a brge electric utility nuckear sation. there is no doube that nucteat energy is the hest hey.

It is also possible that a group of neqhboring industrial plants could jointly utilic a two- or three-unit industrially fuanced nucker station. Even wo. it nouid the more attractive to induce the beal utility to build and operate the facility either as an industral energy supply inly or as $a$ dualpu: pose industrial and electrical energy supp.

\subsection{DIRECT COAL-FIRED BOILER}

Three direct coa:-fired options have ber. evaluated: 11 ho-sulfur western coal in a conveni:onal d alkr. (2) histh-sulfur eastern coal in a conventional boike with stack-gas ckanup. and (3) high-sulfur eastern coal in a fluidived-hed boike. The cost of steam from these systems is shoun in Fig. 7.3. Tw.v costs are presented for hw-ulfur westem coal as a function of coal transportation costs. The siram costs are $51.5310^{\wedge}$ Btu for westem coal delivered $b$ : unit train to Houston and $51.7810^{\wedge}$ Beu for we:iem coal delivered by unit train to the S:. I.ouis area and hy harge to Houston. The mine-mouth coal c.ist is extimated at 30k $10^{\wedge}$ Btu. and the ;otal cost of coal delicered (1) Houston is 75e $10^{\wedge}$ Bu and $9610^{\wedge}$ Btu for the two rouies. Orce again we should point nut that the major effect of transportation cost on westem coal mist ine carefully considered for alternate sites.

High-sulfur eastern coal is stimated to cost SOC $10^{\wedge}$ Btu at the mine mouth and $74610^{\wedge}$ Btu in Houston. The cost of steam for a high-sulfur eastern-coal-fired boiker with stack-gas cleanup is estimated to be $51.8410^{\wedge}$ gij The s:acti-gas ckeanup system cost. illustrated separately, is estimated to contribute 37e $10^{\wedge}$ Btu to the total ste:m cost.

The nuidized-bed boikr is currently under tevelopment. The total steam cost from this boiker is estimated at $51.6510^{n}$ Btu. This estimate. which is admittedly a crude one, should be updated as the development and commercial design proguam progresses. However, it seems obvious at this time. harring some major setback in scaling up the concept, that the nuidized-bed boikr will be a most attractive approach for direct coal-fired boikers with high-sulfur coal. It may also be applicable for process heaters using coal. 


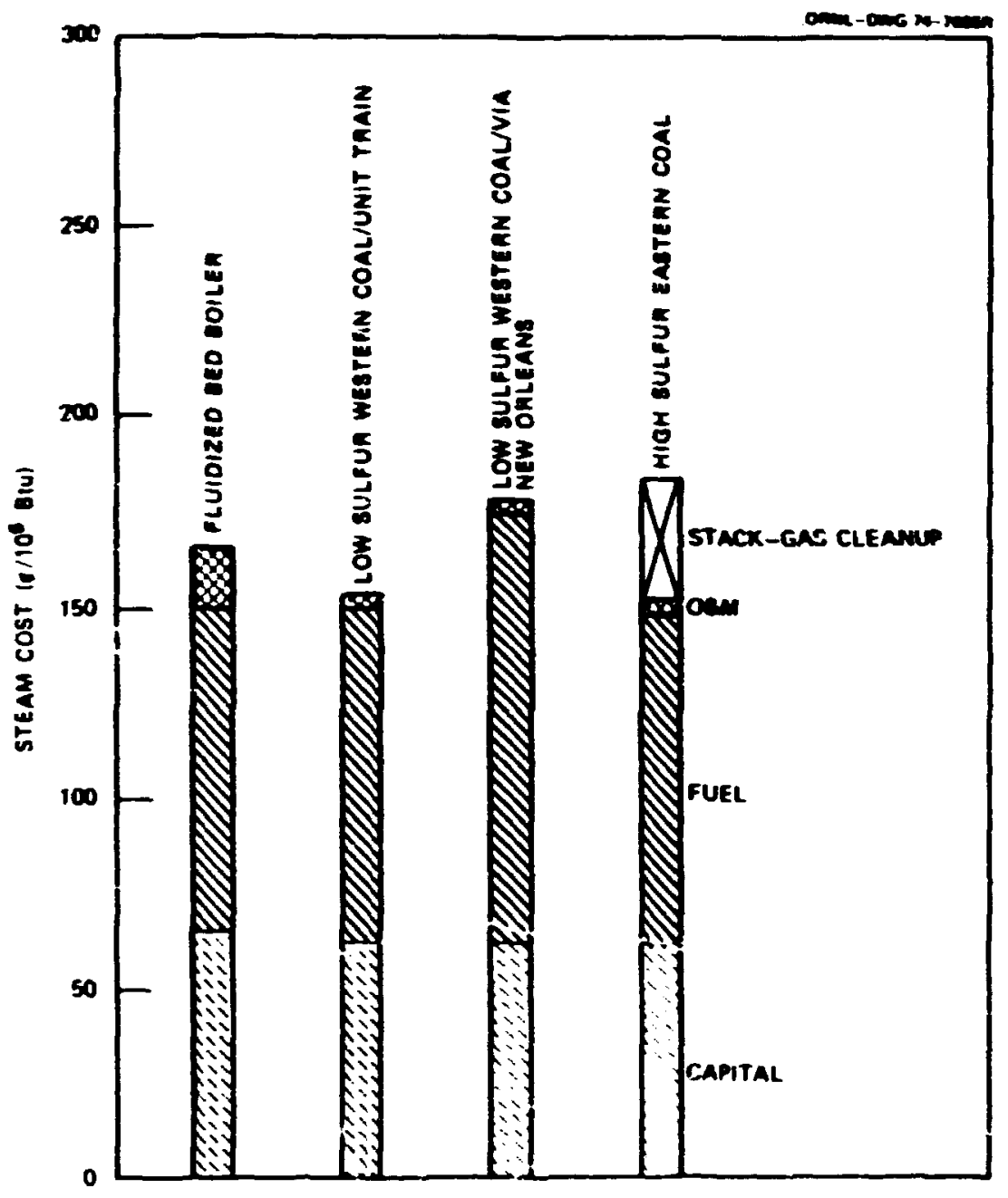

Fin. 7.3. Cost of stam from a cont-fired boikr.

\subsection{LOW-, INTERMEDIATE-, AND HIGH-BtU GAS FROM COAL}

The cost of stemu from a gas-firel boiler is :llustrated in Fig. 7.4. Tuo bars are illusiraled for each proces:: the first represents the cos' of producing the gas from coal, and the second represents the cost of steam from a gas-fired boiler utilizing the gas production cost (first har) (o) develop the fuel cosi for the hoiler.

The two processes illustrated for Inw-Btu gas. Wellman and I.urgi. show steam cr sts of \$2.38 and $\$ 2.7210^{\wedge}$ Btu respectively. The gas production costs are $\$ 1.5710^{\circ}$ Btu for $\mathrm{V}$ ellman and $\$ 1.8610^{\wedge}$ Btu for I.urgi. This coil difference is almost entirely in capital cost of the equipment.

Intermediatc-Btu gas costs for the I.urgi and Koppers oxyen-blown gasifiers are $\$ 2.01$ and \$2.38 $10^{\circ}$ Hiu respectively. In this case the processes are quite different. and the cost differince ciln he explained by the much higher oxygen and electricity requirements of Koppers process. The cost 


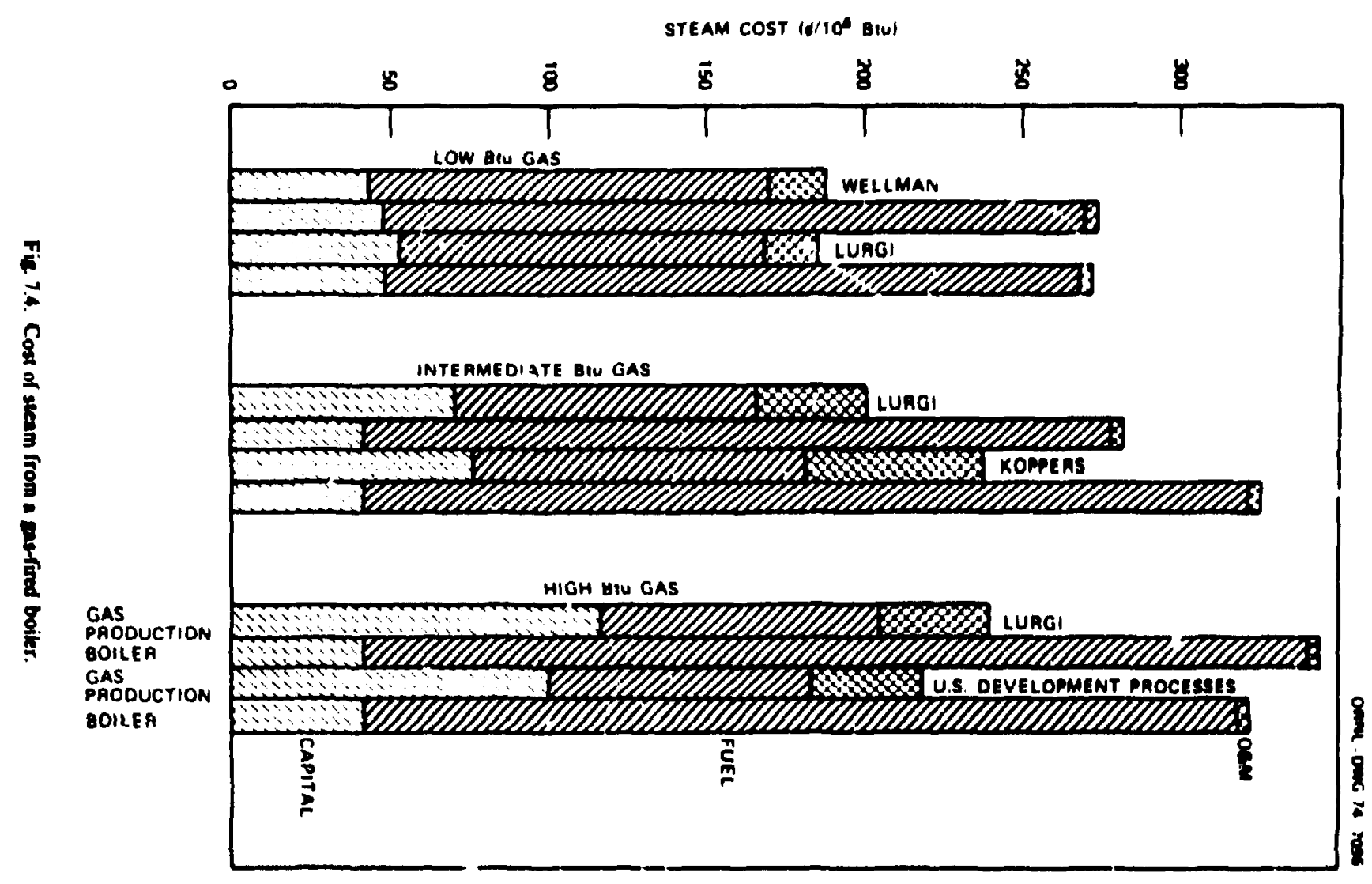


of steam from the gas-fired boikr for these processes is $\$ 2.8210^{\circ}$ Btu for Lurgi and $\$ 3.2610^{\circ}$ Buu for Koppers

High-Btu gas production by the Lurgi process is presented along with a projection of probable costs for the $\mathrm{L}$.S. develupment processes. Hrgh-Btu gas is assumed to be a mine-mouth process at soc $10^{\wedge}$ Bu coal cost. Four major processes are under development in the $\mathrm{C}$.S. and several ouhers are receiving isss emphasis. The composite projection assumes a 15\%; reduction in capital coss and a 5r; increase in conversion eftevency as compared with the Lurgi process. The costs for high-But gas delivered to Houston are 52.39 and $52.1910^{\circ}$ Btu for the I.urgi and $\mathcal{L}$.S. deveiopment processes respectively. Steam costs are $\$ 3.46$ and $\$ 3.2210^{\circ}$ Btu respectively.

Low-quality steam is produced as a by-product for all gasifwation processes. The Koppers access yields more steam than the others. In our analysix, no credit or value has been assumed for this steam. However. in a paper mill, where there is a targe demand for iow-quality stears for drying. this by-product steam could be of significant value.

Two advantages of gasification. especially intermediate or high Bu. are case of retrofitting and possible use as feedstock. The major disadvantage is obvioush higher cost than some altermate methods of cual utilimation.

\subsection{SOLVENT-REFINED COAL AND LYQUID BOILER FUEL FROM COAL}

The cost of steam fro.n an oil-fired boikt using solvent-refined coal (SRC) and linuid boiker fuel froun coal is shown in Fig. 7.5. For comparison. the cosis of steam from an oil-fired boiker using crude or residual oil at $\$ 1.50$. $\$ 2.00$. and $\$ 2.50$. $10^{\star}$ Btu are also presented. These are approximately equivalent to $\$ 9.512$. and $\$ 15$ per barxei respectively.

Solvent-refined coal is a devinupanental process in which the coal is dissolved in a coal-derived wolvent at about 700 to $800 \mathrm{~F}$ with a minimum of hydrogenation. Minerals are removed by filtration, and light oils and gas are removed by distilbion. Inorganic sulfur is removed in the minerals, and organic sulfur is removed as H:S from the vent gas. The process shows greal potential for producing a low-cost clean boiker fuel from coal. Solvent-refined cual solidifies at about 300 F :nd apparently can be remelted at abour $400 \% \mathrm{~F}$ and fed as a liquid boike fuel or pulverived and fed like coal. The product is about 0.6 to $0.7 r$; sulïur and 0 . I to $0.4 \%$; ash with a higher heating value of 15.6.50 Btu lb. It should be suilable for oil-fired boilers or gas-fired hoikers converted to (iif.

liquid hoiler fuet from coal is produced by exiraction-hydrngenation (the SRC process plus additional catalytic hydrogenation) or hy the H-coal process.

Both the SRC and liquid fuel processes provide 10 to $20 \mathrm{r}_{\mathrm{g}}$ of the product in the form of high-quality gas and light oils. Our analysis does nnt include any higher value credit: that is. thexe by-products are considered to have the same value as the SRC or :aquid boiler fuel

The cost of SRC is estimated to be $51.2510^{\wedge}$ Btu at the mine mouth. and the cost of steam generation in Housivn using SRC is $\$ 2.1510^{\wedge}$ Btu. I. iquid hoiker fuel costs $\$ 1.7510^{*}$ Btu at the mine mouth. and the cost of steam generation in Houston using the liquid hoiler fy:.: is S2.M6 I0 Btu.

The cost of producing methanol fuel from coal was also evaluated bu was not presented in fig. 7.5 because it far exceeds any of the altematives. Methanol fuel from coal costs $\$ 2.9110^{*}$ Btu at the mine mouth. and the cost of sicam generation in Houston using methanol fuel is $54.0110^{*}$ Btu. 


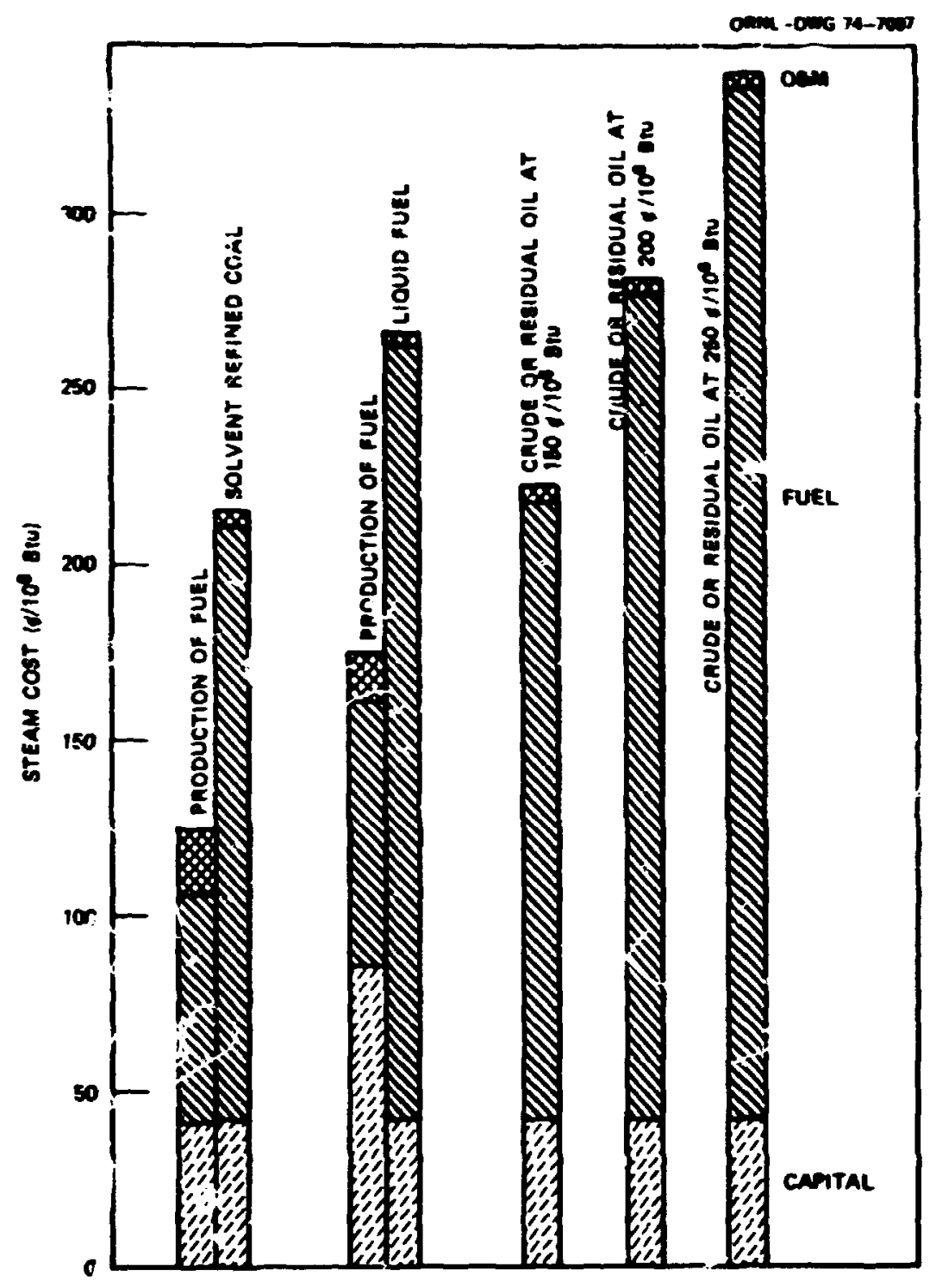

Fi3. 7.3. Cost of sceam from an oil-fired boiker.

\section{\%.5 SELECTED COMPARISON OF STEAM COSTS FROM ALTERNATIVE PROCESSES}

Figure 7.6 illustrates stean costs for many of the altematives previously discussed. This comparison and all analyses to this point have ässumed all new equipment (boilers, etc). One point which seems obvious is that any process which is not competitive with crude or residual oil is of little near-term ecunomic intcrest. Unfortunately, the loni-term co..t of ciude oil is very uncertain. 


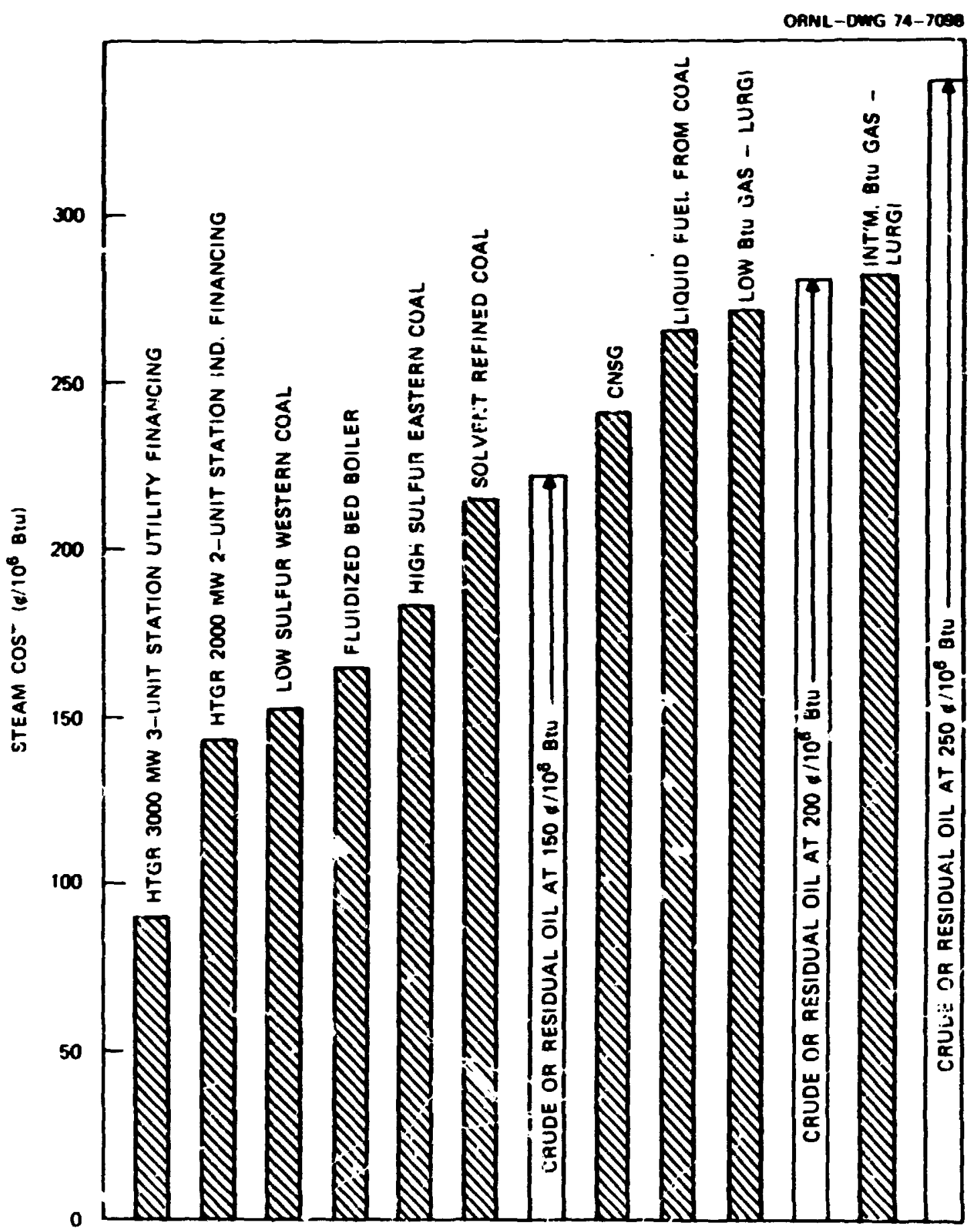

Fig 7.6. Selected comparison of steam cost from alternative procesus. 


\subsection{RETROFTTING AN EXISTING GAS-FIRED BOILER (OR PROCESS HEATER)}

All data to this point have been presented in terms of new capacity. The cost of steam from retrufitting an existing gas-fired boiker is presented in Fig. 7.7. High-Btu gas involves no capital expense: only fuel. operation. and maintenance costs are invohed. We have assumed that conversion to intermediate-Btu gas or to oil will require $10 \%$, of the capital cost of a new boikt. and conversion to low-Btu gas will require 259 , of the capital cost of a new boike. It is presumed that adequate modifications are made, so that no huss of efficiency or capacity is incurred.

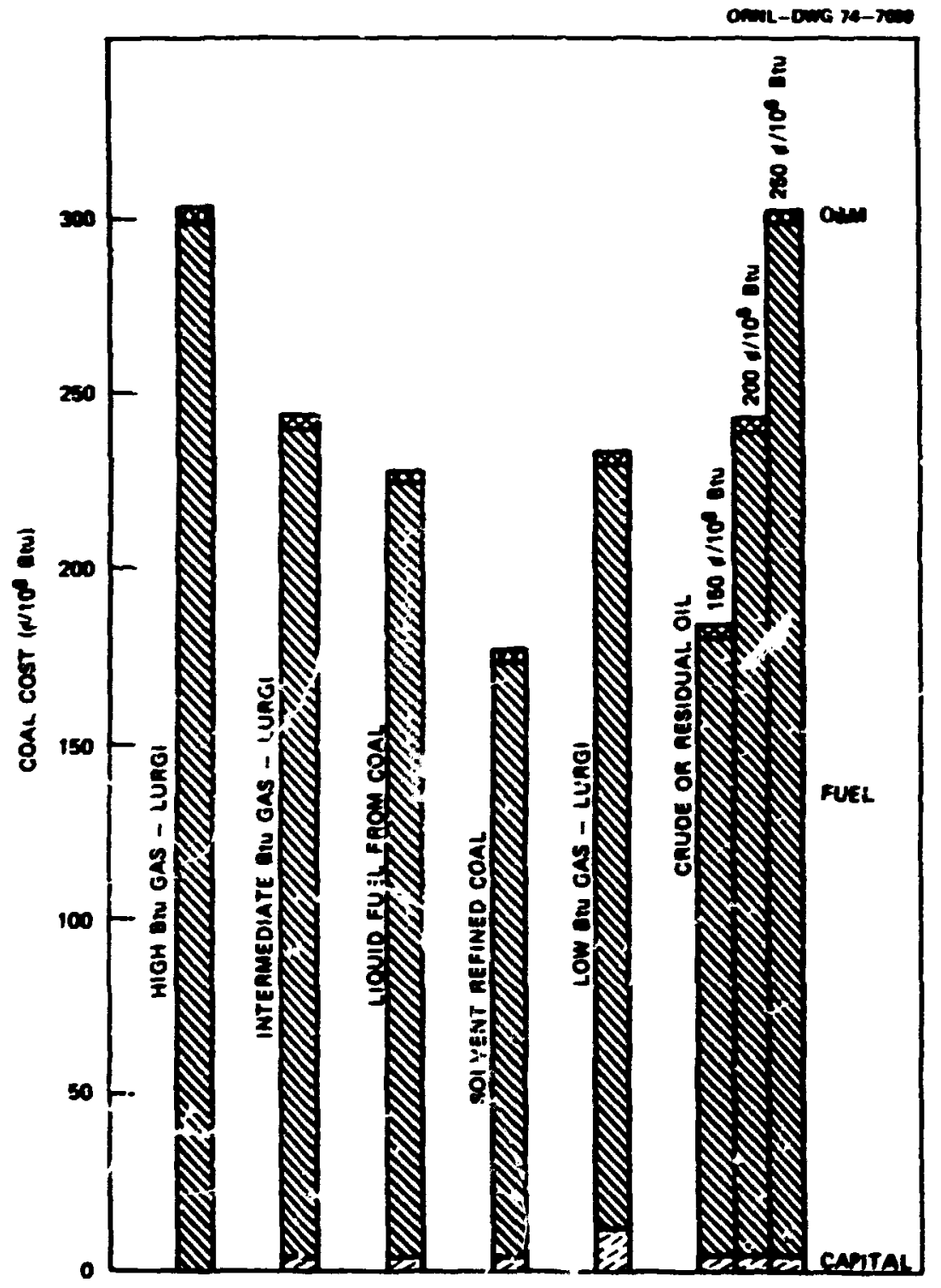

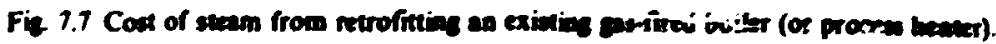


it seems bogical that gas-fired process heaters could also be converted to alternate fuels with sirilar capital expenditures.

Again. crude or residual oil is included for comparison. The cost of steam varies from $\$ 1.7710^{\circ}$ Reu for SRC to 53.03 10' Biu for high-But gas.

Figure 7.8 illustrates a selected comparison of stcam costs for retrofiting vs new coal-fired boikrs. The new coal-fired boiker for western low-sulfur coal at $\$ 1.53 \cdot 10^{\circ}$ Bu and the fluidized-bed boiker at $\$ 1.65,10^{\circ}$ Biu are more Guorable economically than any of the retrofit processes. Factors such as process heating or a limited plant life, which are not considered, would tend to favor the retrofit systems.

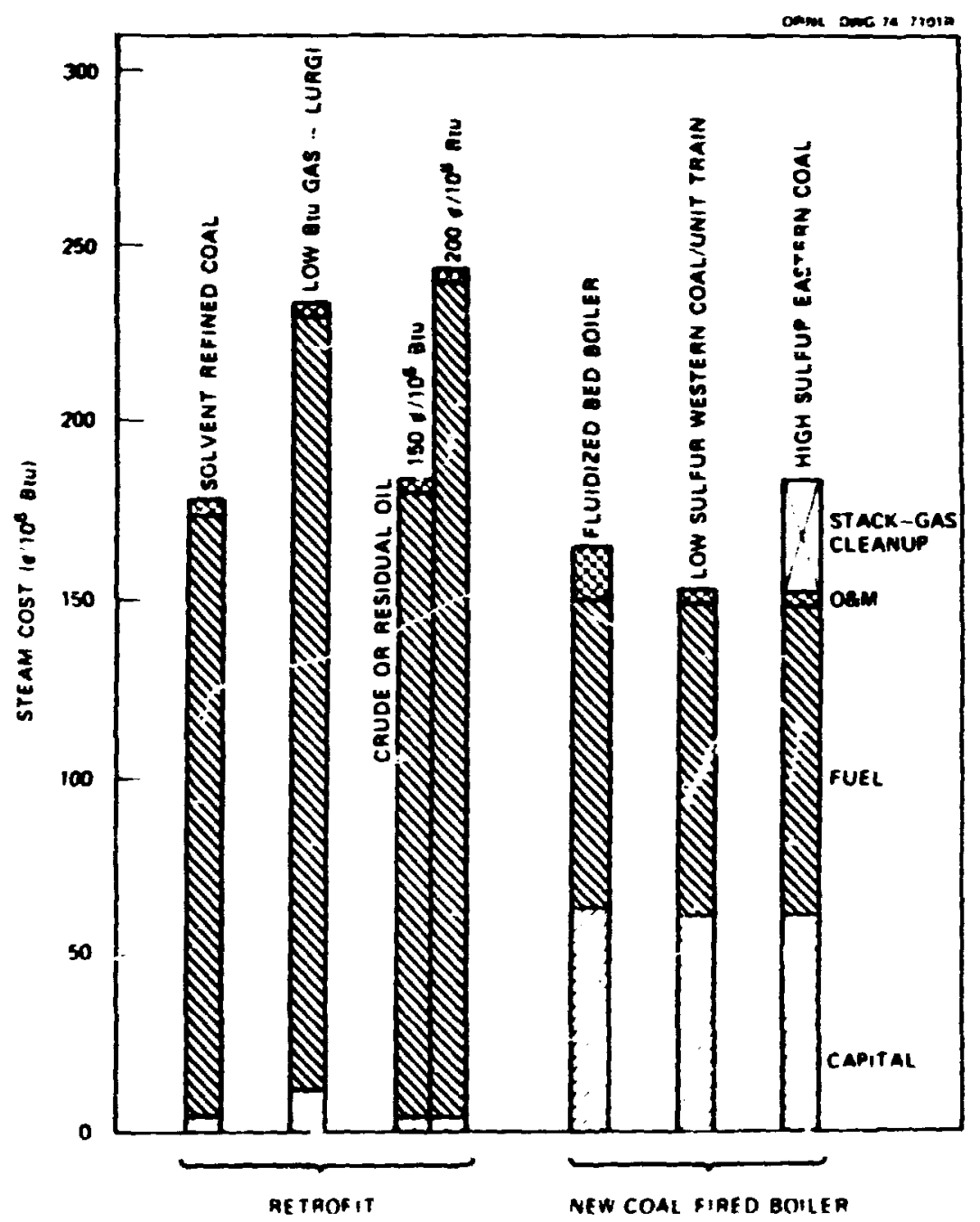

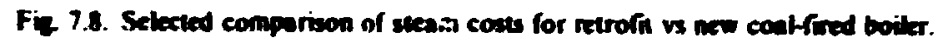




\section{7: SËNSTTIVITY ANALYSIS}

The sensitivity of the cost of the cual-based processes to changes in coal prices. capital investment. and cost of money was cvaluated. Occasionalh. an evaluation such as this reveals the fact that certain processes are very sensitive to the ground ruks assumed and perhaps muxh less (or more) attractive when assumptions a e varied. In this case. the results in general do not change the order of preference of the pr xeesses significantly.

Figure 7.9 illustrates the cost of steam tioin ccal processes is coal cost. The high-Btu gas. lixyuid fucl from coal. and SRC are n.ine-mou'h processes at a reference coal cost of $50 \mathrm{c} 10^{\circ}$ Btu. The low-sulfur westem cual reference ".ost is $75 \times 10^{\circ}$ Btu delivered to Houston by unit train: the other processes are based on eastern coal delivered to Houston at $74 \mathrm{c} 10^{\circ}$ Btu.

Figure 7.10 illustrates the cosi or steam from coal-based processes as a function of the percent of reference design capital cost. The canital cost of conventional boiiers was not saried: only the capital cost of the fuel process was varied. The high-Biu gas processes and fiquid fuel from coal are the most capital-intensive processes.

Figure 7.11 shows the effects of changes in the cost of money on the cost of producing steam for selected energy systems. As noted previously. the reference costs of money values useci in this study are interest rate on bonds. $8 \%_{\%}$ : retum cn equity for utility financing. $10 \%$ : and retum on equity for industrial financing. $15 \Gamma_{C}$.

Generally. the effect on the coal-based systems of increasing the cost of money is to widen the gap between the direct-fired systems based on processed coal (high capital investiment). Energy systems most sensitive to cost of money are the CVSG (small reactor) and high-Btu gas derived from coal.

\subsection{CONCLUSIONS}

A general ranking of the various processes in vther ways may provide additional insight. Table 7.1 presents a ranking by range of application. High-and intermediate-Btu gas processe. are the only ones considered suitable as feedstock. Liquid fuels. low-Btu gas. and SRC could be used in process heaters. All systeras are suitable for steam generation, and the HTGR and direct coal-fired systems may also be developed for process heat.

The processes. ranked according to ease of retrofit to existing gas-fired equipment. are as follows:

1. nigh-Btu gas.

2. intermediate-Btu gas.

3. Jiquid fuels.

4. soivent-refined coal.

5. low-Btu gas.

6. Nuidized bed boiker.

7. conventional boiler with hw-sulfur coal.

8. conventional boike with stack-gas rkanup.

9. HTGR. 


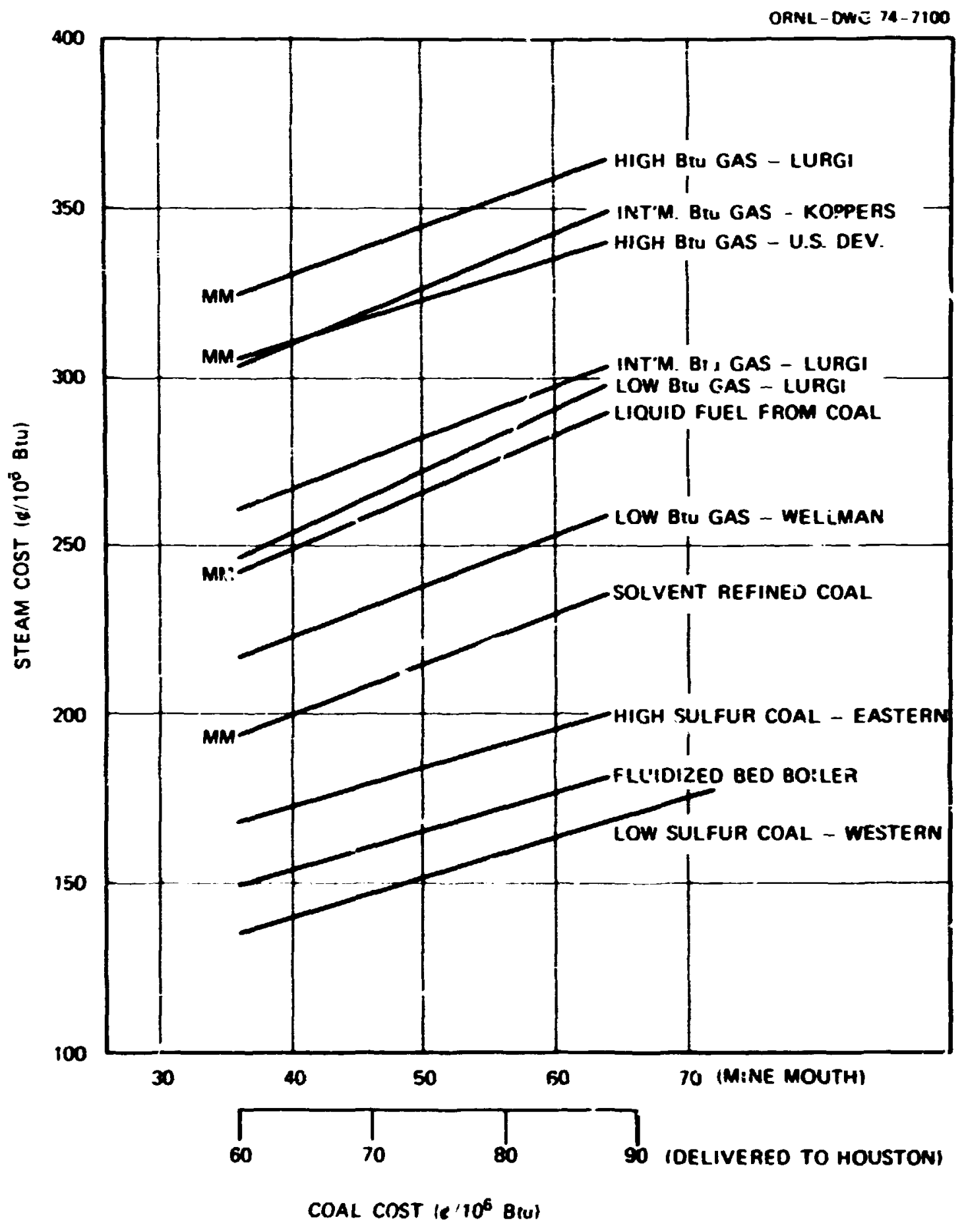

Five 7.9. Cost of stean from coal procesess vs coel cout. 


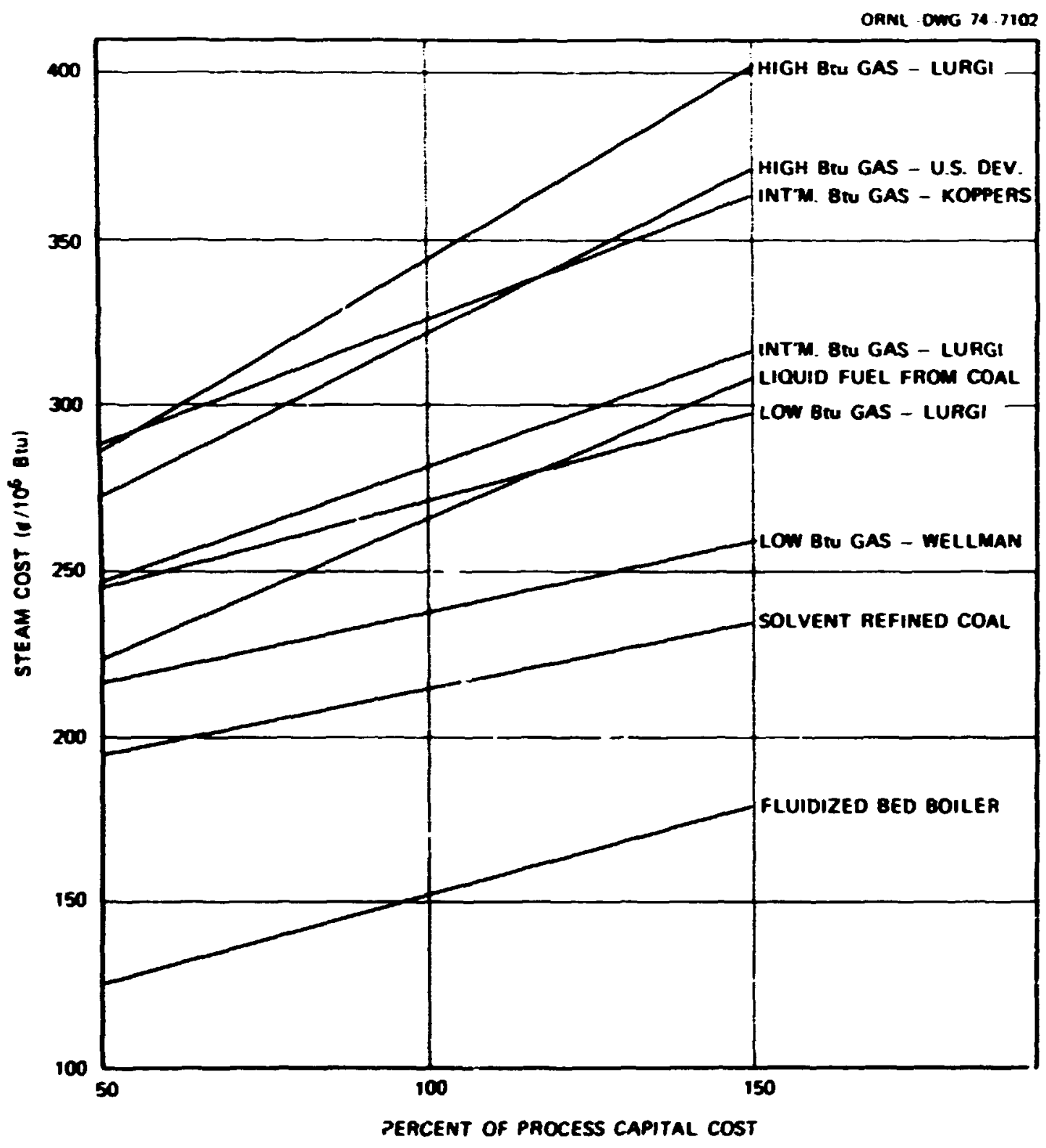

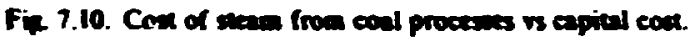




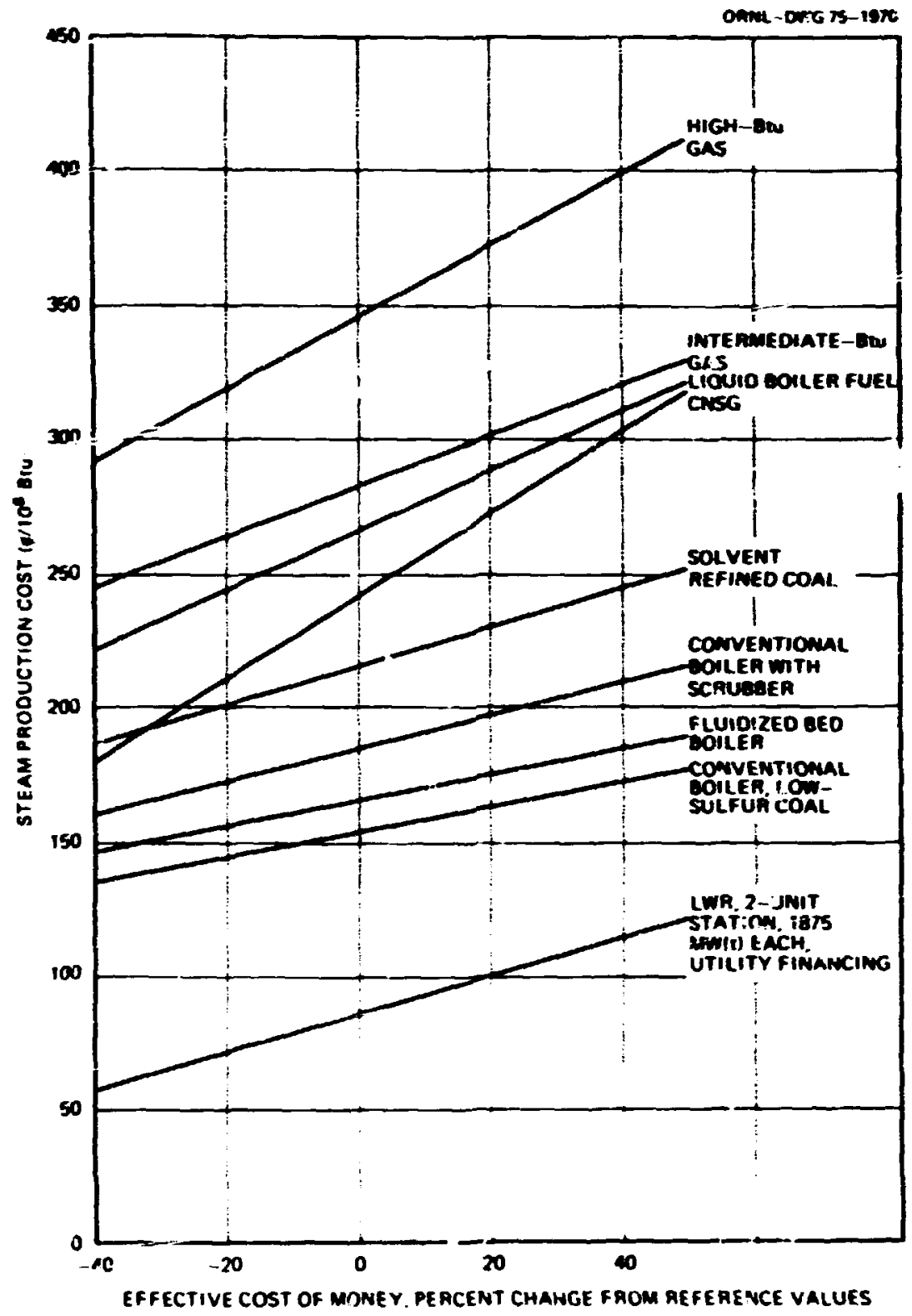

Fig. 7.11. Effects of changes in the cont of mony on the econowies of selected energy systerne. 
10. small LWR.

\section{Large LWR}

Table: 7.2 and 7.3 present date of rankings by the user's options for action and by date of earliest commercialization or application respectiveh. In a sense. these are interrelated in that some of the promising developmental processes are not likeh to reach commercialization on an! reasonable schedule without interest and cooperation from industry as well as industrial influence on the government's development programs.

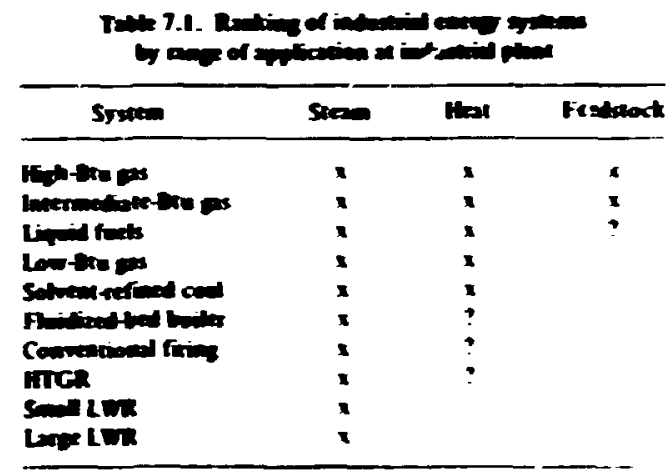

\begin{tabular}{l} 
Srate \\
\hline
\end{tabular}

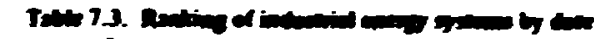

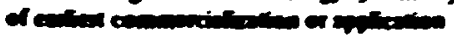

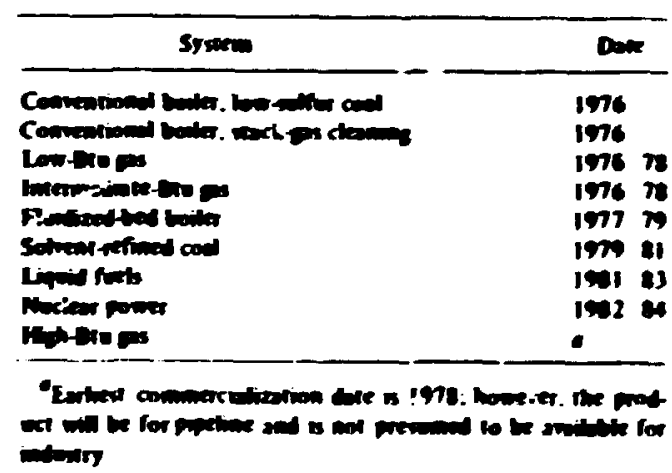




\section{Industrial View of Alternatives}

\section{I PULP AND PAPER MaNUfacturng}

\subsubsection{Crown Zellerbach}

Crown Zelkerbach Corporation, a major producer in th: wood industry, has sawmills and pulp and paper mills mainly located in the southem states and the west coast of America and Canada. The annual sawmill production is 589 millior. bd fi. and pulp and paper production is $\mathbf{2 . 6 3 6 . 0 0 0}$ tons.

There are two pulp and pape: operations bocaked at St. Francisville and Bogaluso. La. ithe major difference in the operation of these two milts is that St. Francisville pulps continuousty in a Ki:myr digester and Bogalusa uses batch oigesters. The energy requirements and probtems are besically the same. The energy requirements for the Bogalus operation, which are typical. al: described here.

The mill is docaled in the town of Bogakn. some 60 miles north of New Ortans. The popubtion of the toul complex is 2230.

The timber supply originales from local forests mameed by Crown Zelkerbach and others. The mill consumes about 600.000 cunits (झiw fit of solid wood) of southern pine and hardwood and produces 45.000 tons of paper annualty. Twenty percent of this production is converted on the mill site ar cuslomer requirements. and the babnce is comented at other Crown Zelkerbech phants.

\section{Enzog ropinemeat}

The overall process from wood room 'o frished product requires energy in the form of heat for promess stam and ekctricity. This energy is used as follows:

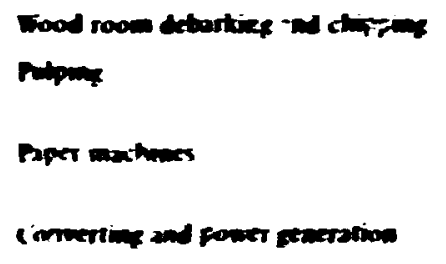
3 tretrition
173 knisition
10.72700 Exiton
4) kntiton
9.123000 betrow

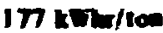
10355000 Eariton

This amounts to a lotal of $817 \mathrm{kWhr}$ ton and 30.210 .000 Bu con of paper produced.

Preseni fuels are natural gas. hark. and beck liyuor from the pulpine process. The amounts

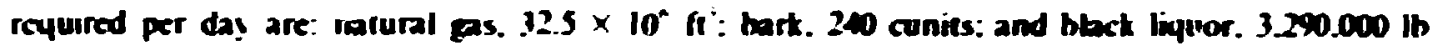
solids. Tiase fuels supply the reyuurements of 30.210 .000 But 10 .

Spacil problem

The major prohkem at the Bogalusa mill is the shortage of natural gas. The mill was desizned in

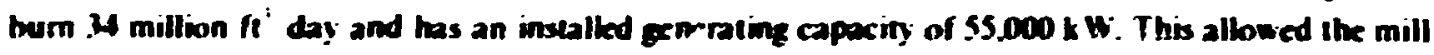
in the inviepe ndent of outside electrical supply e:cepn for emergencies.

With imlay"s gas shortage due to the depteion of ite company's rexerves. about $24 \times 10^{\circ} f^{\circ}$ day of gas is a taibaike. The plane dres not have the anility to increase bark huming: therefore. the net resull as that there is idle generaling capacily and $18,000 \mathrm{k}$ Whr must he purchased form the beal authority. 
Crown Zelkrbach cannot purctaxe further gas supplies. and present gas resen rs are depkting al a rate that they will be exhausted by December 1978 or carlier.

To continue producing. the plant is being centsred to use No. of fuel oil. A gas-lired beike will be shut down and replaced with a 125.000-1b hr package unit which will burn No. 6 oil: this unit is to be on line Jan. 15. 1974. The line kiln will be converted to No. 6 oil by Jan. 15. 1974. and the first c. isting boiker will be converted to No. 6 oil Mar. 1. 1974. These three units will rekcase 5 million if of gas per day. which will onk be banked to improve reserves.

Plans arr to convert an additional five boikers by the end of 1976. kavura two more to be conected in 1977 and 1978.

\section{Enery abernatives at Dopaluen}

1. Shortterm conditions are satisfed b: sonverting from natural gas to .io. 6 fucl oil.

2. Bhack liquor recoven boikers will continue utiling the heat value of spent cooking lipuos (6800 Bru lb).

3. The study is complete on conversion to coal as major fuel as follows: (a) install net. 800.000-1b hr putserized-coal-fired boike (8S) psiz) with presipitalor: (b) continue to operate 250.000-1b hr wood waste and oilfired boike at 850 psig: (c) continue to operate two recovery boikrs generatire $380.000 \mathrm{lb}$ hr at 850 psig; (d) install new $40.000-\mathrm{kW}$ do ble automatic extraction condensing curbogenerator: and (e) continue to operate exissing $15500 \mathrm{~kW}$ single automatic extraction condensing turbin.

4. Continue efforts to obtain a further gas supply. Increase of gas price to fuel oil zquivakent price is resulting in incieased activity in iurther explorations and to date indicates an upgrading of reserves which may take this segment of industry through the next fise years. This could change the near-term conversion plan to .io. 6 fuel oil on all existing units.

\section{Reconomention}

Bogalusa outlined the following six recommendations.

1. continue study on mass produced C.NSG:

2. iurther develop barge-mounted application of C.SSGs:

3. examire commercial reactors to use in industrial part development concept:

4. use fluidized-bed boikers as base foed units and incinerator capabilities:

5. continue development of SRC. aiming tomard end product as a liquid:

6. continue research and developenent on bow-Bug gas.

\section{Prioritives}

Priorities were established as follows:

I. conventional boikers with stack eas cleanine.

2. low Ba pas.

3. C.NSG. barge mounted. 
4. Aluidized bed.

S. SRC.

6. Large reactors applied to industrial park.

\subsubsection{Interaational Paper Company}

Most International Paper Company mills are located in areas which made natural gas the primary fuel for many years. and most of the equipment was purchased and instalked on this basis. Ihis eyuipment has since been converted to have ftel uil capabilities. Fuei oil is now the priman fuel.

Also keep in mind that in uur industry we self-generate (black liquor and bark) some 40;, of our fuel requirement. Also. we generate practically all of our electrical requirements thrcugh the use of extraction :urbines.

\section{Recommendations}

The application of nuckear systems for industriai energy is not feasible at present. and iuture opportunities would appear to be limited. One of the most significant limitations is the availability factor of a nuckear steam plant. Dual plants or a backup steam and power supply of some type nould be essential.

If the development of factory-assembled barge-mounted units should progress to the point that a multiple of such small uniis could be justified. nuckear energy could certainly become feasibte. However. under the present state of the art. this approach is not economically possible. Another possibility of future nuckar power for industrial application would be through establishment of an -encrgy cente:" that is. the location of a large nuclear station and industrial plants so that the utility could fumish steam and power to the industries. This appears to be a remote possibility but is worthy of possible future consideration. Here again. multiple units or backup of some type would have to be provided.

The preferred method of a coa-based system would be direct firing. both from an sconomical standpoint as well as riaximum utilization of existing equipmerit. Recognizing that there will not be sufficieri lon-sulfur coal economically asailable. the preference would be high-su!fur coal with stack-gas c!-anup. Present slack-gas scrubbing systems are not satisfactory, and more rescarch is needed in this area for ind:sirial boike application. The direct coat-fired boike $w$ ith high-sulfur coal and an improved stack-gas cleanup system is the most promising system. hxth for application to existing cquipment as uell as for acu installations. Hore si idy is needed to better define the harr.iful ekments of stack gas in relatiol, (o) real and more meaningful requirements, giving full cofisideration to feasibility and side effects or conseyuences. and the werall net effect obtained towar, achieving the desired results.

Fluidized-hed boilers could have application for new instellations. but they are handicapped for industrial application duc to pone load change characteristics. Onc i...se-loaded tluidived-bed unit in a plant with other houlers to carn the had changes could offer gond fuide possibilities.

(n-site zasification does not appar feasible for application at this time due to high cost of gasification equipment. as well as the probkms of coal. availability. trans wrtation. disposal, ctc.. ascriciated w ith direct firing. It sirrply docs not make sense to expend huge amo ints of capital. material. cquipment. and ma npouer to gasify coal at the plave site instead of firing the coal in a boiks designed for coal firing 


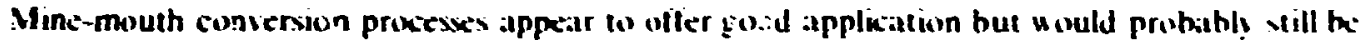

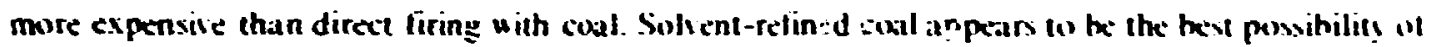
the mine-nouth processes.

Based on the above, w: cecommend study program pricicinces as foliows:

1. stach-zas ckeanup for direct firing with high-sulfur cosul ș sit:m:

2. solvent-refined cosal:

3. mine-mouth coal gasification iniermediate and high Btu:

4. Huidized-bed combustion:

5. encrgy center. process steam and (nower from multioke units. .. tility phant to industrial phint:

6. small shop-assembled industrial plant reactor.

\subsection{PETROCHEMICAL MANUfACTURING}

\subsubsection{Cebnese Chemical Company}

A hypothetical plant in the Houston. Tex.. area was assumed for this study. The plant produces oxyerated petrochemicals for the bulk market with an ant ual capacity in excess of $2 \times 10^{*}$ It. steam consumption is approximately $1.5 \times 10^{\circ} \mathrm{lo} \mathrm{hr}$ at 650 psig and $750^{\circ} \mathrm{F}$. and electrical consumption is in th: order of $25 \mathrm{MH}(\mathrm{e})$. Direct procesas ieat is reyuired in a single lurnace. designed exclusively for fuel gas. and is not considered part of tive problem. Oniy a small purtion of the $\mathbf{6 0 0}$-psig steam is utilized in process heaters. Most of the steam is broken down across turbines 10 150 and 50 psig steam and condensed at that pressure. All electricity is purchased. Because of the costs and hazards involved in shutdowns. the steam plant reliability must he essentially toor. with each individual boiker at 98.6\%. Sufficient capacity is inslalkd to allow the largest singk boiker to be down without a total shutdown of a unit.

Ahout the only near-term option availative tor this plant is iow-sulfur western coal. There is no way that nuckear reactors in this size range car be economically installed prior to the depletion of gas. $v^{\cdots}$ should be around 1980 . While this is actually a near-term option. once the money is committed for boiler replacements. it hecomes the primary kng-term option. There are some suboptions. such as direct firing of solient-refined coal or the char products from some of the liquefaction processe:. Since coal-fired twikers could probably be easily adapted to these fuels. they represent the only long-term option. Treir justification would probahly be hased on freight savings and by-product recovery. They must imagine full commercialization or: a significant scak prior to the time boikers would be ordered for 1980 operation. Also. it would probably be in the early 1980 s before freight is escalated suificiently to justify an approach if this sort. Another possible suboption is the use of fluidired-bed boikers. It appears that the cost $A$ ill be esentially the same as that of the conventional :.:ol-fired boilers: however. there is an advintage in the ability to run high-sulfur coals. This advantage would be more pronounced in areas where high-sulfur coal is localed.

Oil was considered as an option due 10 its lower capila' requirements and other intrinsic advantages. I.ow-sulfur No. o gil is probably the only oil which will be available. but this is only in limited supply. Whether oil is viable over the long term depends on the availability and cost relative to coal. This could vary among companies, depending upon whether they hold reserves and other 
lactors. In this particular case. mo reserves or refining capacity is available: therefore, whike judgmental, it appean that wil cannot compete with coai.

There are several major problem areas in implementing a conversion to coal. First is the capital reyuired in a relatively stort perind of time. Of almost eyual importance is the technical manpower required for the program. Eyuipment deliverg could also be a probkm. not only for the plant but for rolling stock as well. Railroad reliability could be questeoned as the existing lines become haoed.

In essence. the future of this particular plant is reasonably well established insofar as fuel supply. is concerned. Continued study is required. hower $-\mathrm{r}$. for the piants of the future. This could be accomplished by keeping the current program. but on a inuth wuer key le.g. an update of the presentation plus new developments every 6 months). Currently. participating companies would probably he willing to furnish represcrtatives for industral input. In addition. special studies mizht be reyuired from time to time. and provisions for these studies should be made in a request for appropriations. In connection with research and deveiopment rey:irements. it is felt that a new program should be initiated. perhaps with the same participants. to give direction to the research and develepment funds currently fumished by the Federal Government. It wovid scem today tha! the research and development effort is much too fragmented in be effective. and there seems to be appreciable misdirection. For example. most linuefaction processes seem to be directed toward heary oils for power plants winere coal could be used. It would seem more appropriate to direct this effort toward lighter fuels and petrochemical feedstocks. One of the bonger term goals of a natior:al progran should be the marriage of manufacturing and power plants for economy ard reduction of thermal pollution. How OR.V. could motivale power companies to enter into arrangemznts of this type is not known: howeter. this does require acceleration of the HJGR piogram. The one overall problem which will continue to be an impediment to the use of nuckar power in chemical plants and refineries is the lead times required. It is felt thai the AFC should take the initivive in reducing these lead times. Just how this could be done through GR.M. is not known, but it is a must if we are to avoid economic stagnation.

\subsubsection{Dow Chemical, USA}

The Dow Chemical plant complex in Freeport. Tex.. is a large integrated plant. The produc' mix includes chlorine. caustic. magnesium metal. and petrochemicals such as ethylene glycol. ethylene oxides. polyethylenes, and stỹene.

The basic energy requirements are supplied from fre power plants delivering approximately o million th hr of process steam and I million $k$ Whr of electricity. A block of power is also purchased from the local utility. These plants, which range in age from 30 years to 4 years. ars presenily fucked by nalural gas. The power plants have conventional-fired boikrs and also several advanced combined-cyck gas turbine-waste heat steam turbine systems. The power plants. to a degree. use the chemical plant heat sink to generate electric power.

The altematives in nigy use are being studied and are somewhat limited. Gas turbines ?nd waste heat boilers require piemium fuels such as natural gas and $\mathrm{No} .2$ diesel oil due to metallurgical restraints and heat-recovery surface conditions. These fuels tre becoming increasingly scarce and prrhibitively expensive. Our power plants will soon haie the capability of burning any oil from crude to Nio. 6. The petroleum fuels do not seem to be a firm altemative. 
Coai is an altemative, but it reyuires new facilition to supply. transixert, unload. burn. and grnerate sicam and power. Ash handling. stick-pas treatment, anc' other environmental considerations are stagernng in their capital and band use requirements.

Designing and building coalbuming equipment require a firm coal supply inat will bst for the life of the plant. Boikers must be desigred with the ash cunstituents known in order to have a highly reliabte. maintainable system. fistustrial power plants operate in a much more dcmanding environment the t the typical public utility.

The hst aivernative is nuclear power. The HTGR has a steam cycle that is: quite aitractive to a large base-loaded industrial plant, and its low fue! cjcle costs insist that it be cons dered. towever. the problems are large. varied, and comptex; ihe b. yest plant to date-the $100-1: 4 W(e)$ Fo.t St. Vrain Demonstration Plant-has taken much too long to get to full power. In. 10 - to 1 - year lead time and large capital cost are way out of the normp: industrial planning and decision-inaking envelope. It is difficult to commit to a specific technology anl nut be able to use it for 12 years into the future and also not be able to react to new technobay.

This study has done a tremendous job in bringing trether the present alserikiti es in cosl and nucleal. The: computer code ORCOST is a good ton: to evaluate costs for harge uti'ity plapts. It wo's be diffucult to expand she model to include sonalker units and industrial hackf ressure tuabine units. but this kind of tool is needed for our evaluations. We are waiting fot ise iesiit!s from the drmonstration of the fluidired-bed coal-burning boiker. This has the potential o: Ilowing industrial plants to use muct advanced steam cycles with an improved heat rate and still, se marginal coals ihat otherwise would be environmentally unacceptable.

The solvent-refined coal reseach is interesting and should contribute to futu:x energy systems.

Coal technology needs much continuing research and development.

Mare reserret and development are needed on unterground mining to develop new technology to remove more cosl from the seam. Coal preparation should be able to upgrade rau coal to remove more ash. in particular. sulfur compounds a: the mine site. This particular study has reviewed stack-gas cleaning and showed how difficult and expensive this tailend effort is. Much more work needs to be dene on tice front end before we contaminate the combustion air.

The fluidized-bed boikr is being demonstrated for small utility use $(300.000 \mathrm{lb}$ hi). There is a very gieat need for a smalker size to replace the numerous package boilers that are capable of burning gas or oil.

\subsubsection{Monenoto Compuny}

For piants such as our two at Texas City and Chocolate Bayou. Tex.. as well as our nylon plant at Pensacoia. Fla.. th: near-term energy options are probably (I) a transition from natural gas so residual fuel oil for boiler iux: and (2) the installation of new coal-fired boikrs. Fluidized-bed combustion appears to be :te choine for new coal-burning units. Ouring the near-term period, we would hope to be anle to continue the use of nati ral gas for direct-ífiet process treating.

Over the hnger ierm. we must seiiously consider nuclear .rergy. It:e small HT( $R$ seems best suited II) cur overall reyuirements. Siting limitations. whik p:rhapr less severe than originally anticipated. may still be cne of the major obstacles to overcome. I.my lead times. capital costs. ant, osational reliability are other critical factors.

In the area of future research and development priorities. fuidired-bed combustion should is: given added emphasis immediately. since it has the potential for solving the stack-gas problems 
associated with the use of coal as a basic energy source. Both industrial and central station utility energy problems should be lessened if nuidixed-bed combustion yields tre results it seems $t 0$ nffer.

For the petroleum and petrochemical industries, a high priority should be given to the small HTGR. One further area for research and development effort should be transport of high-temperature fluids. A central station energy source with the capabiity for producing and transporting high-temperature nuids for use by customers piesently being supplied with electric energy only could have a major impact on the industriai cirergy supply problem.

The approximate energy use for the Texas City and Atvin. Tex.. plants is as lijiows:

\begin{tabular}{|c|c|c|}
\hline & Texs City & Avim \\
\hline Prodect & Styno monomer & Cshyluze \\
\hline Fowds per yeax & $13 \times 10^{9}$ & $0.5 \times 10^{\circ}$ \\
\hline Enety ue & $1500 \times 10^{6}$ & $2100 \times 10^{6}$ \\
\hline $\begin{array}{l}\text { Stean, Biw/wa } \\
\text { Fud (mitural gos) for process } \\
\text { haters. Bru/hr }\end{array}$ & $\begin{array}{l}1500 \times 10^{\circ} \\
\left.350 \times 10^{6}, 1600^{\circ} \mathrm{F}\right)\end{array}$ & $\begin{array}{l}2100 \times 10^{\circ} \\
1400 \times 10^{6}\left(1400^{\circ} \mathrm{F}\right)\end{array}$ \\
\hline Electricity purctosed, twW & 36.000 & 60000 \\
\hline Anasod lood factor. $T$ & 90: & 96 \\
\hline
\end{tabular}

\subsubsection{Union Carbide Corpontion (UCC)}

A typical UCC Chemicals a.nd Plastics Division plant is bocated on the Gulf Coast. This location was dictated by the availabiliny of low-cost natural gas and of ethane and propane derivis from this gas and usable for chemical feedstock.

A Iypical plant contains one or two units for the production of ethylene and prepylene. First-line derivatives of ethylene ard propane are minufactured. including polyethylene. ethykne oxide. ethanol. butanol, isopropanol. etc. Second-line derivatives of some of the first-line derivatives are also produced. Shipment from these plants may range frnm 1.0 to $4.0 \times 10^{\circ}$ ib year.

Energy 1 quirements in these plants obvicusly wiis vary considerably. depending on the products made at the location. Energy requirements for one of the targer plants are outlined below.

\begin{tabular}{|c|c|}
\hline \multicolumn{2}{|c|}{ seem requirtencues" } \\
\hline Preasere level (poid) & $U \operatorname{seg}\left(10^{3} \mathrm{H} / \mathrm{hu}\right)$ \\
\hline 600 & 1500 \\
\hline$\angle 00$ & 650 \\
\hline $20 / 10$ & 350 \\
\hline Total & 2500 \\
\hline
\end{tabular}

CSee also Fig. 8.1.

Sonse of the steam requirements are maje avaihble by by-pinduct recoviny from the process units. 


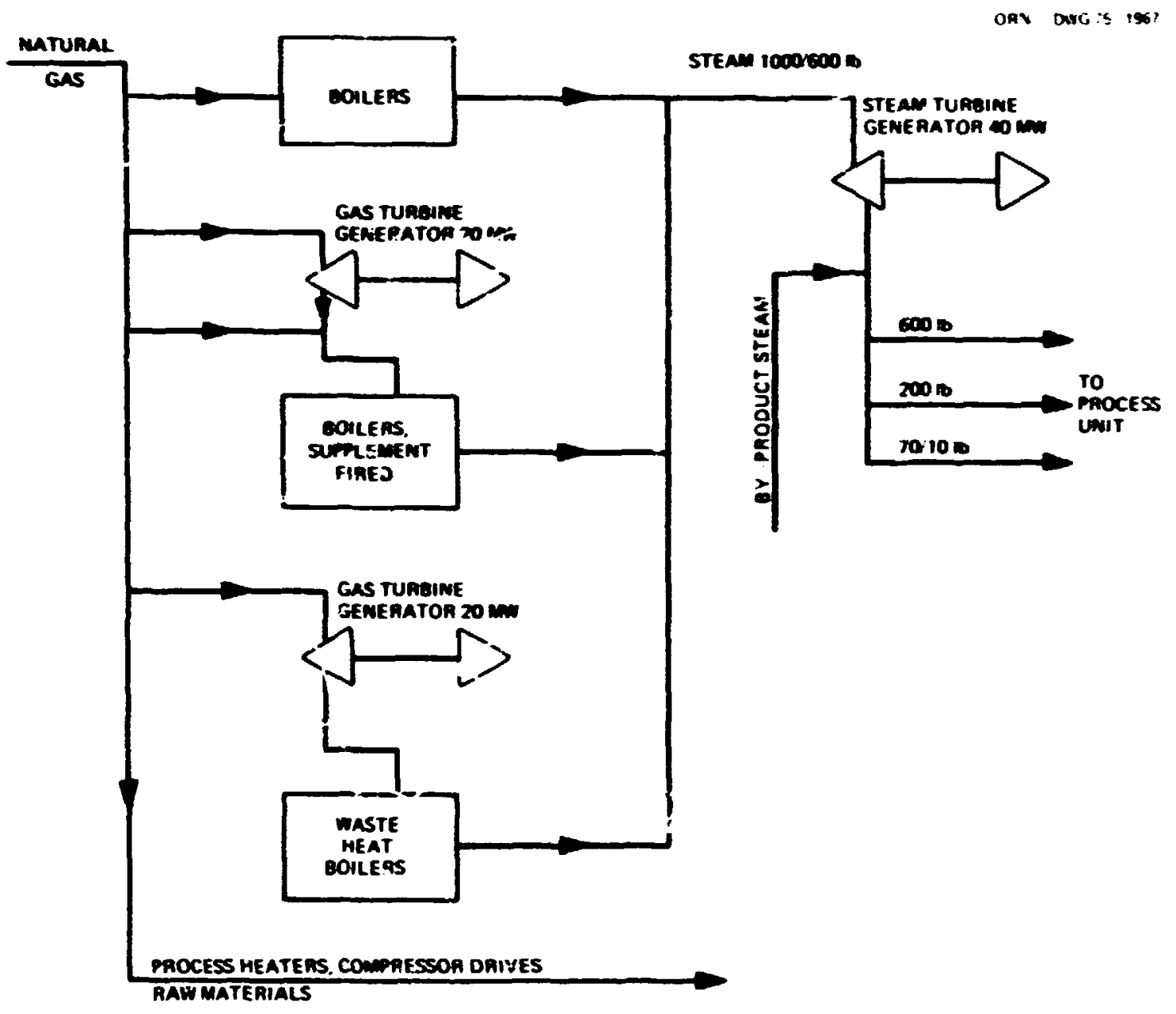

Fin 8.1. Trpial enery cycle of UCC EAP Diviaion.

Power requirements are about $80 \mathrm{MW}$. These requirements may be supplied by a combination of topping turbines, a minimum of condensing turbine';. gas turbire generators. and purchased power. Projections indicate a trend to higher power requirements in relation to the steam requirements.

In addition to the fuel required to generate steam and or power, the plant has a fuel usage of $75 \times 10^{\circ}$ Btu any: $50 \times 10^{\circ}$ Btu day is produced as by-products from processing units. particularly Okefin units. and the balance inust be purchased. This fuel is required for process heat. c'mpressor drives. and raw materials.

Economics have dictated that the energy sytems hivea $99+\%$ availability to the consuming units. 
UCC is currenty assessing altemate energy sources for the Guif Const phans. The possibulities isllow:

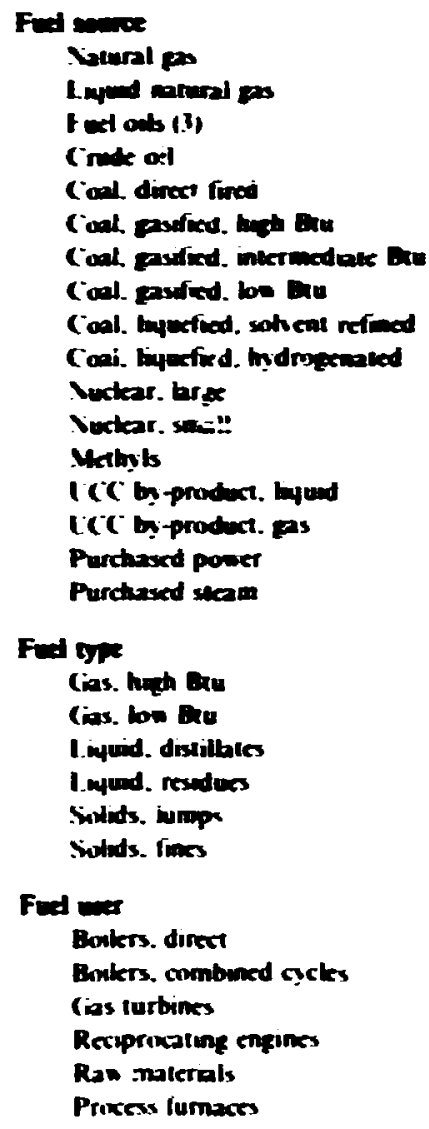

In general. UCC conclusions paralkel those of the OR.VI study: UCC does not expect that natural gas will be available for the intermediate term. Fuel oils are acceptable alternatives in many situations. tut pricing problems are apparent. Union Carbide agrees that the direct use of coal to generate steam is a likely prospect for the Gulf Coast piants. Problems in sizing. timing. and reliability will preclude the use of nuclear plants in the early 1980 s.

A particular problem to UCI: will i- to supply the process heat requirements that cannot be met with steam. Some of the requirements are not readily adaptable to fuel: oils. particularly the heavier residues. Second-generation coal gasifmation technology will not be available until the early I9t0s. Gasification is a logical choice for supplying those requirements.

The major problem areas in imolementing conversion of Gulf Coast plants to coal revolve around ervironmental considerations. Incertainties in governmental policies regarding leasing of federally ownerl coal deposits in the west :-nd in restricticns regarding restoring stripped areas make planning difficilt. Uncertainties regarding l,ture EPA requlations on sulfur dioxide removal also present a probleil. Othei problems include kngthening equipment delivery times. particularly for the mining equipment: financing for the considerable livestment required: and competition for engineering and construction labor. 
Reganding focure sudies. ORNI could serve a very useful purpose as a focal point for updating the curneat studies. As exthoology develops funther information will be forthcomine on cosl pasifation and lipuefaction. ORNL condd serve as a focal point for induseng assessument of these ahinater.

Pertaps ORNL could abo fill a sole in assessing the ccomomic impact of overty restuctive

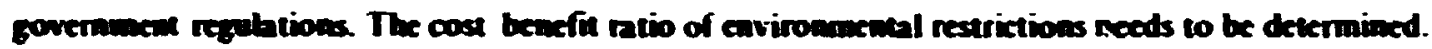
Opinions of an independeat ageacy such as DRNL mey carty more weight than a presamably biesed industrial opinion.

Possible ineus for indensifod resench and devetopment inctude:

1. devetspmem of a small metar reactor sized for indestrial phass and with an invesument per unit bow enough to make nockear energy avaibule at lower cost than coatbased energy.

2. devetoponen of coal biquefaction and grivice ion technolosy.

3. development of the flaidized bed burner iot stesm or process requirements.

4. He of etectrical eneray for process heat requirements above 1000 -bo steam temperatures.

\section{PETROUFCT REFDILG}

\subsubsection{Anow $0.1 \mathrm{Conamg}$}

A typical oil refinery proceses raw crode oil into a brge number of products, including gasoline, kerosene and jet fuels, heating and diesel oik, industrial fuxts, waxes. lubricating oik and

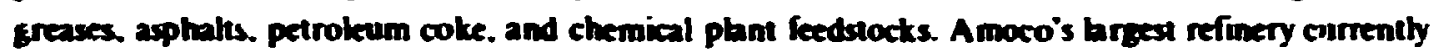
can process 330.000 bot of crude oil per day.

\section{Enedy repiremeats}

Fuet wage in most existing refineries averages about 8 to $10 \%$ of crude charged. This represents the en:ire hat requirement, including steam and elestric power yeneration and coke burned in the 1.zeneration of catalyse. A new modem refinery is estimated to require only about 7 to $9 \%$ of crude charged for its fuel requirements.

Energy consumed at our largest refinery, inchuding the needs of a styrene unit and two ammonia raits, is projected to be:

\begin{tabular}{|c|c|}
\hline Electricity, in & 105,0100 \\
\hline suan, D/ner & 5250,000 \\
\hline 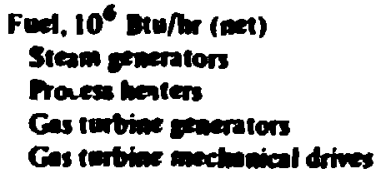 & $\begin{array}{r}3700 \\
6000 \\
370 \\
830\end{array}$ \\
\hline
\end{tabular}

Steam and gas turbine generators produce $68,000 \mathrm{~kW}$, and $38,000 \mathrm{~kW}$ will be purchased. Of the steam requirements, $2,600,000 \mathrm{lb} / \mathrm{hr}$ will be produced by recovery of process heat including $\mathrm{CO}$ boilers and heat-recovery units on process heaters. 


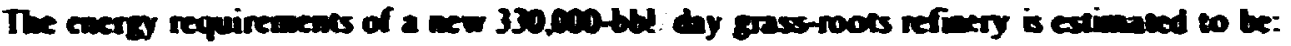

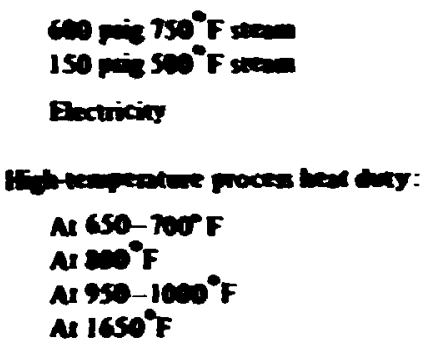

\author{
1200000 \\ 300000 intras \\ 2000
}

Energy supphy for refinery operations must be highly reibble. because disruptions can result in

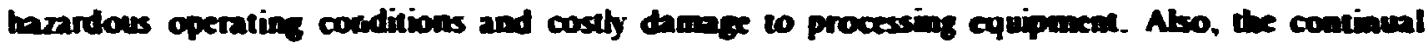
escabtion in cost of iscreasingly sophistionted refisery equipment makes operating fectors imperative to holl down capical changes apainse production costs. A vemporary enscheduled loss of

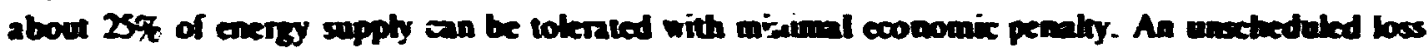
of more than 30 to 35\% of eserny supply can resulk in hazardous operating conditions and

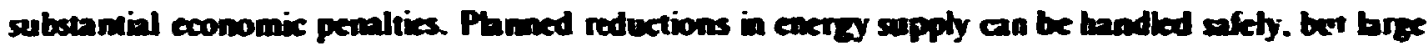
reductions for extended periods of time, as may be needed for refueling of nuciear reactors. are not acceptable from an economic point of view. A planmes maintenance shurduwn of an entive refinery or a targe part thereof 10 coincide with an outage of energy supply is inpractical. The brge amount of trained manpower and equipment required for such an operation just would not be avaibble.

\section{Enery sources}

Amoco's refineries currently use gas and oil supplemented by purchased ebectric power to supply all energy needs. In the nearterm future. we expect to increasingly use oil in place of gas as the sor ares of gas decrease. This will require retrofitting of fuet-firing equipment in areas where natural gas was previously low in cost and plentiful as in the southwest.

If the rost of liquid fueis con! inues to increase faster than the cost of coal, as current projections indicate. gasification of coal wili become an altractive source of fuel for existing refineries. It requires the kast amount of retrofitting of existing fuet-firing equipment.

Along with the advent of coal gasification. new steam-generating equipment in existing refineries probably will be coal fired using either low-sulfur coal in conventional boikers or high-sulfur coal in a fluidized-bed boiker. The choice will depend primarity on delivered cust of cosl and reliability of supply. The same coal (or petrokum coke) would be used for both gasification and steam generation. In cases where low-silfur coal is avaibhle, it will cost kess to replace existing gas-fired steam generatory with coal-fired units rather than go the coal gasification route. Electric power will be purchased from electric utilities wherever supply is reliable and its cost reasonably reflects the true cost of delivery. A nuckear-based electric utility showidi in able to deliver energy at a lower cost than industrial self-generation systems using fossil fusls. Economy of scak and the relatively stable cost of nuckear fuel should be unbealable. However. if industrial utility rates are keveled or made regressive in the erronesus belief that this will kad to the conservation of energy or to subsidizat.on of the cos: oi electricity in the consuming public. self-generation will quickly become attractive. Industrial energy plans must allow for such an eventuality. 
The energy sapply to a wer grass-roots sefiacty probably will be coal based. The purchax of boh stean and etectricity from a nearby thetric utiling would be an attractive alkermative. Steam

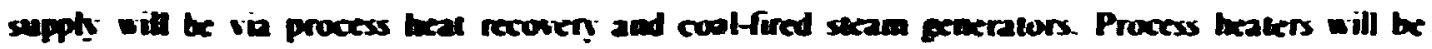
designed to use tusl oil and a mixture of refinery by-product gas and bow-bev cual ges. Low-sulfur

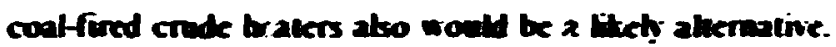

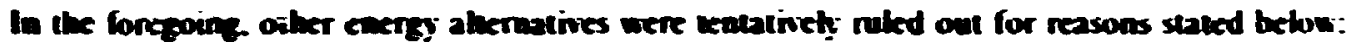

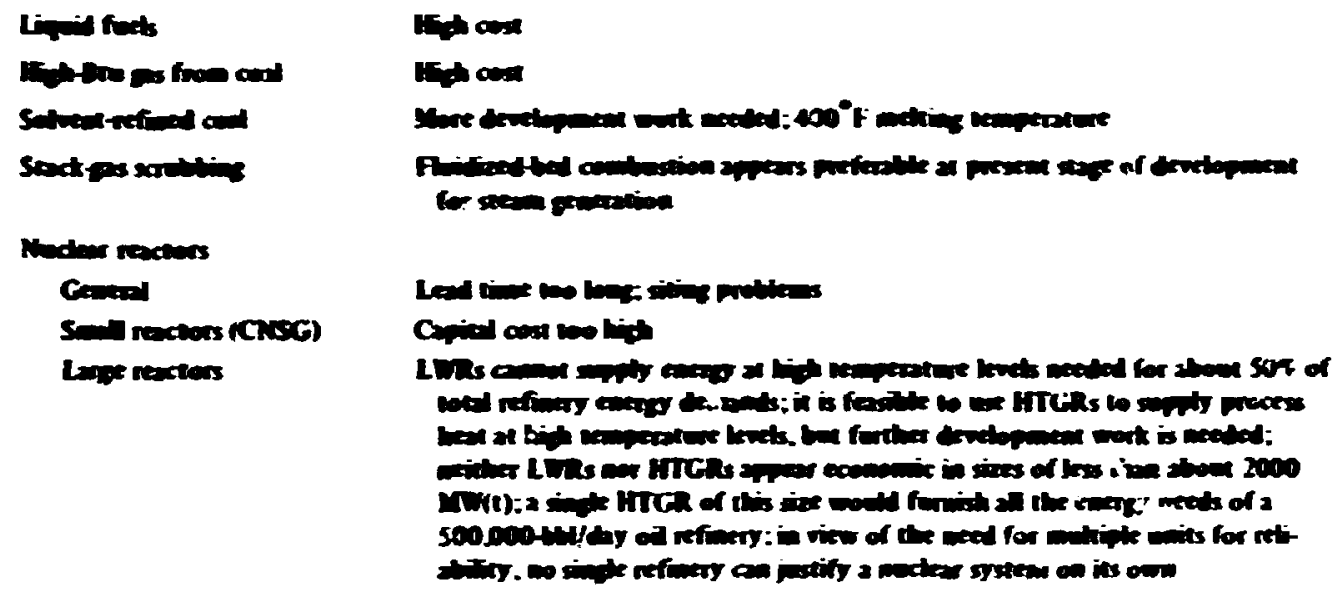

\section{Reconsondation}

Continue the cooperative sucty of industrial energy altematives to monitor developments in all forms of energy systems and to provide a forum for the exchange of information hetween governmen! and industry.

Promote the idea of brex-scale industrial parks with a centrally located electric utility fumishing all industrial energy needs. including steam. electricity. and possibly high-temperature process heat. State governments conceivably could sponsor such parks as means of attracting industry to their areas.

Develop a HTGR designed to furnish process heat at high temperature levels and study alternative methods for transmission of a high-temperature heating medium.

Continue development of the C.XSG or a simitar shop-assembled package type nuckear reactor with emphasis on reduction of cost and delivery time.

\subsubsection{Stall Oil Company}

\section{introduction}

The hypothetical complex conceived for this study would . :uire 500 acres of usable tand to accommodale the processing equipment, whart. and taik farm. Additional land requirements would include (1) exclusion zones for a nuclear complex; (2) coal handling. storage. gasification. etc.. if coal is used: and (3) some acreage for a surrounding green belt as required by appropriate st-te or local agencies to reduce the visual impact on the neighborhood. 
Since the future use of matural gas by industry could be severety cartaier and the supphy and demand batance for pertokum products will continue to be sritical aluermake energy soures or a cumbination of direct fired and gasifed coal into a grass-rooks complex will be required.

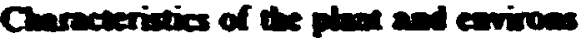

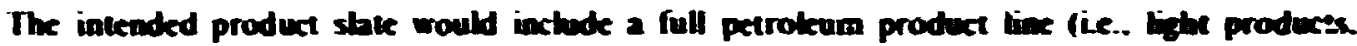
middk distilbles. heav oils, and chrmsials). Production rales of any giren product would vary

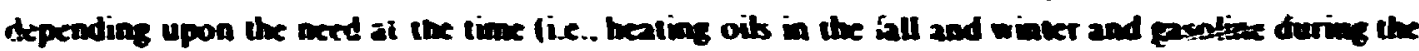
spring and summerl and the type of crude being processed. Ton production rates would be

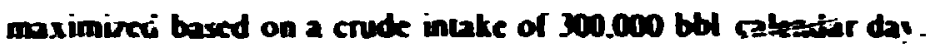

It is assumed that the necessary hill be avaibble te accommodate the needs of the project.

The site would a adjacent te a major waterway or coasuline on had roned for bavy industrial tuec. Easy access to water transportation is most desirable: bowerer, rail. inuct. and pipeline acoess will also be required.

Process requirements for cooling an be partinlly sisfied with air cookers: however. approximatety $8500 \mathrm{epm}$ of makeup cinling water would be required. An additional $3000 \mathrm{gpm}$ of makeup water is nectal for process stean requirements. Water required for reactor cooline steam for eketrial generation. stc.. is not meluded in this foure.

Dux to the sire and weight of normal processing equipment. Ind loading designs of tall columns. efc.. rebatively good soil conditions are reyuired. Inessual geological conditions such as faults are as undesirable for process eyuipment as they are inr reactors. Meteurobgical conditions will affect process design: however. pctrochemical complexes can and do operave in all ctimates and under almost any weather conditions.

Petrochemical complexes are designed for safe and ord:rhy shutdowns under all normal and abnormal conditions (abnormal conditiens include total power Gailures). This complex would be designed to solisty all known conditions rebtive to protecting the environment.

\section{Energy requirements}

Finergy reyuirements. classificd by temperature and pressure. are as follows:

\begin{tabular}{|c|c|c|}
\hline Drexoune (avis) & Texpreteum $\left({ }^{\circ} \mathrm{F}\right)$ & Quantity reysined ( $10^{3}$ mor) \\
\hline 1250 & $90 \mathrm{c}$ & 1500 \\
\hline 650 & 7SO & 2000 \\
\hline $2 m$ & 500 & $750^{\circ}$ \\
\hline 50 & 300 & $\sin \theta^{\circ}$ \\
\hline
\end{tabular}

"Depressured frum 1 250/650 presuire levels throuph toppirg "I "ines and nor iactuded in total steam renerated.

Vormal design cuntingencies will require enough cxcess capacity so that normal operations will no: he affected h! a shuldoun of the largest singk steam-generating unit.

The quantity of steam uxed is hased on a total of the normal demands for each of the refinery chmical processes. On the bisis of long operating intervals experienced hetween maintenance shutdowns by most uperating processes (freyuently up to 3 years). an annual utilization factor of 95"; has heen select:d. 
The dined handere heal reypined is given betow.

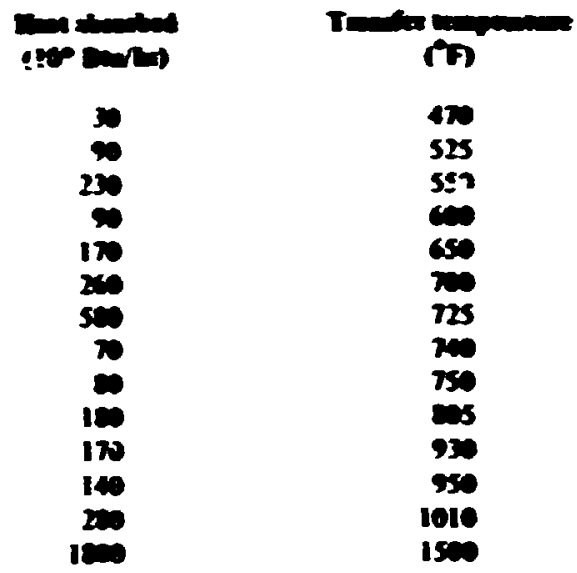

The bat absorpion ales show above are for individal blocks as listed for the particubr cemperature.

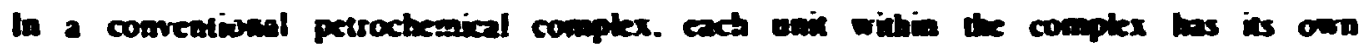

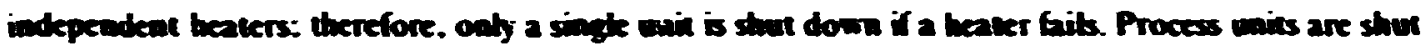

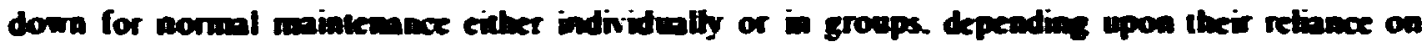

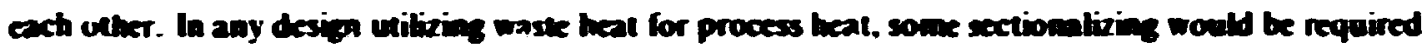
to minimize the need for bro blocts or evea lotal complex shuidowns.

Mos refinery chemical proorses (inchuding direct-fired heacers) have operation onstram factors of $95 \%$ or higher. Therefore. a direct furmace beat utilization factor of 95 f ins been selected.

This complex would require approximatety $200 \mathrm{MW}$ of power. assumedty all self-pencrated. The method of generation will depend on the kevets of steam avaibble vs the kevets required by the process. Sone turbines will prebably be extraction type to babace the steam needs and the remainder condensing units.

\section{Enery abterative}

The systems showing the greatest promise from tahnotogical and economial standpoints are as follows:

I. Coal-based systems

A. Direct firing: low-sulfu: coal: tigh-sulfur coal and stack-gas scrubbing: and nuidied-bed combution.

B. Coal conversiun: pyrolysis-char, eas, or liquid fuel; solvent-refined coal; and liquid fuets. including methanol.

C. Gasification: gasification coupled with a combined cycle for improved efficiency.

2. Nuclear systems (commercial ptants)

A. Utility or cooperntive ownership producing electricity and low-cost process steam; maximum steam transport distance is limited to about 10 miles.

B. Small PWRs for in jividual industrial electricity and steam needs.

C. Process heat reactors producing heat to 1200 to $14000 \mathrm{~F}$. 


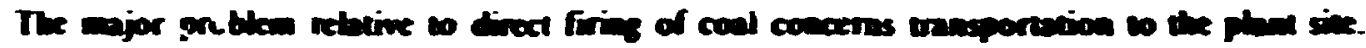

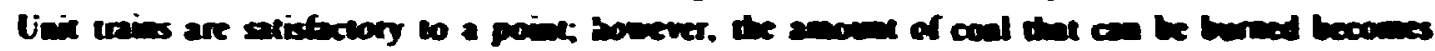

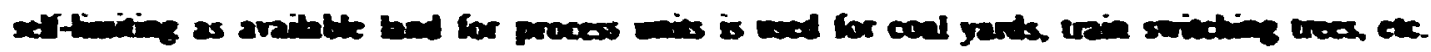

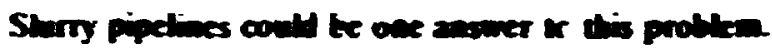

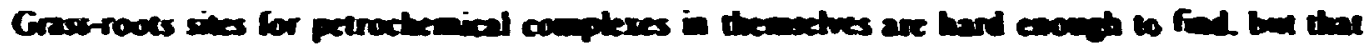

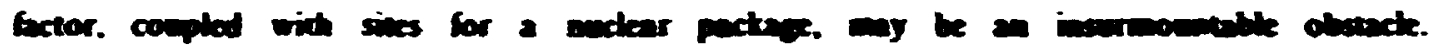
Stine EPA AEC resurictions nou be resolved before ang serions invexiontioss of the we of ancar energy are warrabed.

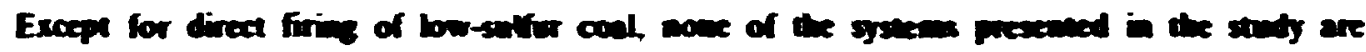

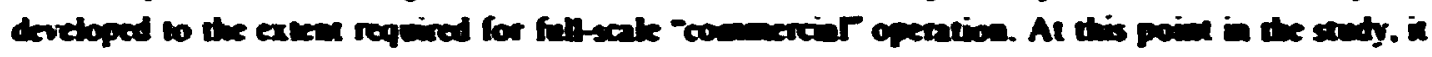

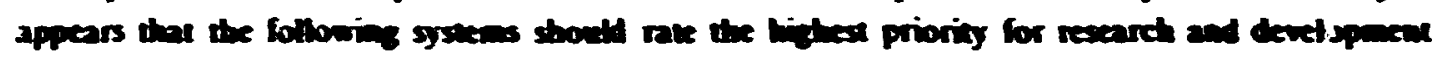
efforts:

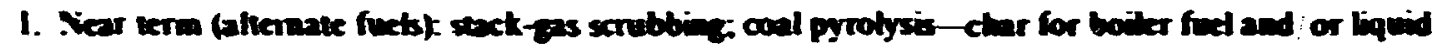
or gas for process leaters: and Ruidied bed combestion.

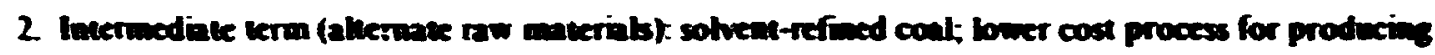
ons from coal couphed with a combined cycte for inproved efficiency; process beat reactors using HTGRs; and $\operatorname{sinall}$ PWRs. 
Appendices 


\section{Appendix A}

\section{Nuclear Fuel Cycle Analysis}

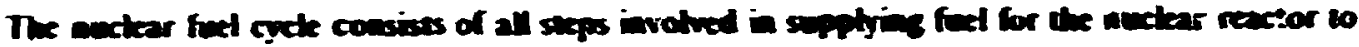

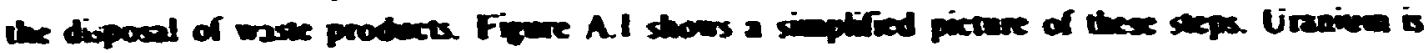

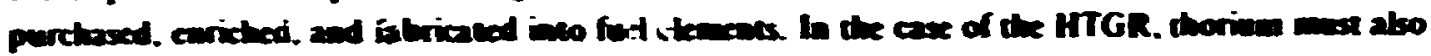

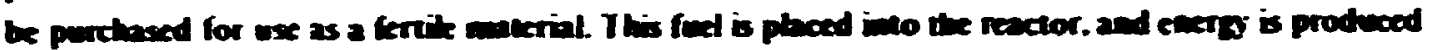

$0 \operatorname{con}-0 \sin x-\pi 0$

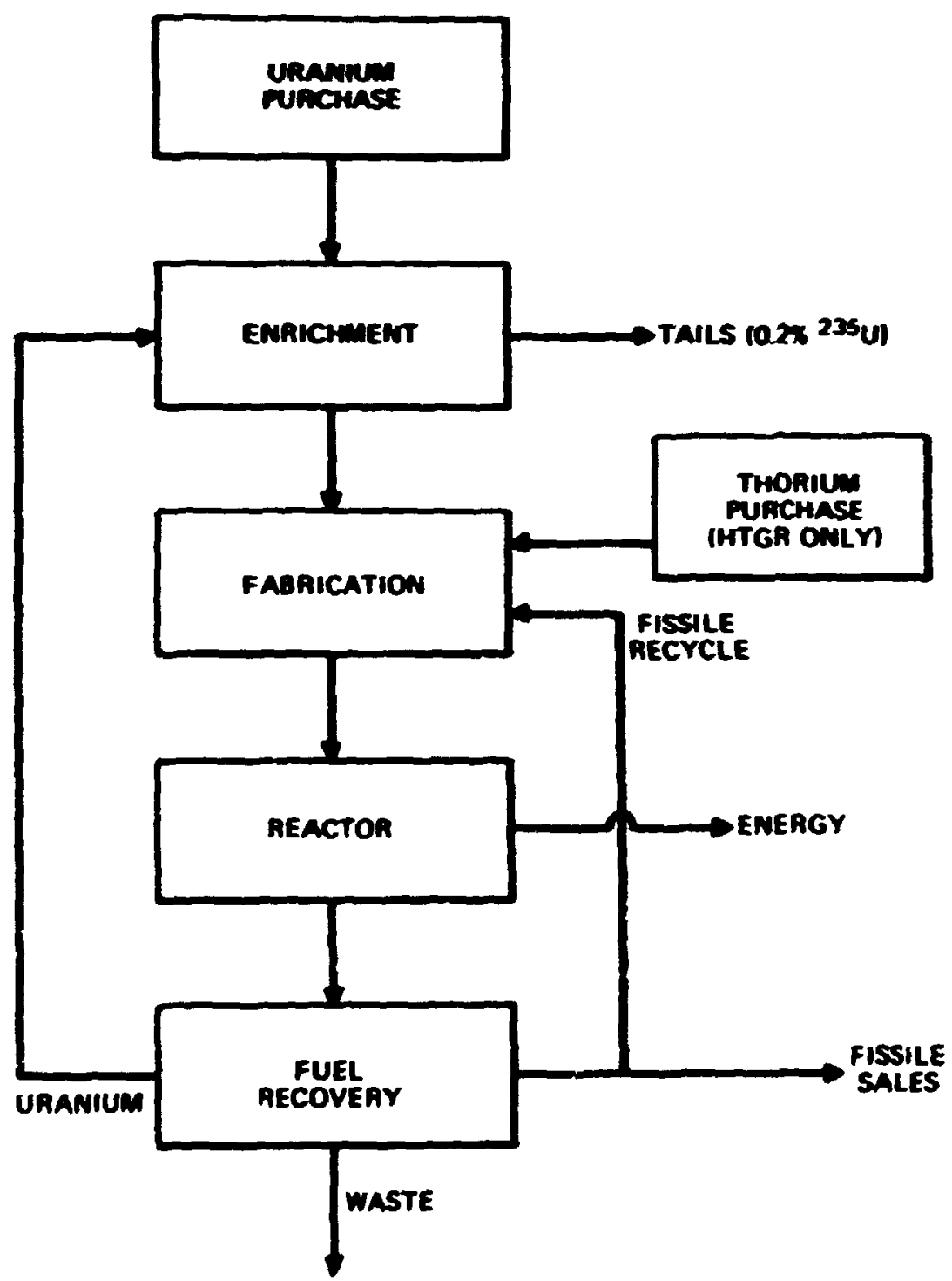

Fit A.I. Nuclear ful cyele. 


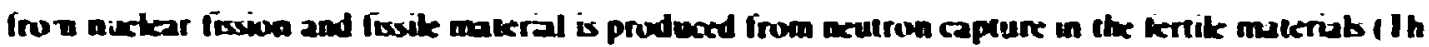
and :-(i).

When ihe fuet is remoned from she core, in is shipped (after a cuotiag period) to a reprocessing plane shere the fosiva products are separated from the uranium and phutonium. The uraaium os seme

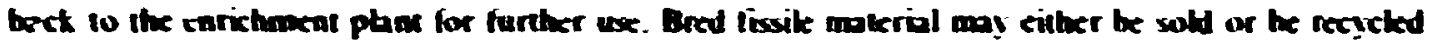
bact through the system.

\section{SYSTEM MASS RALANCES}

Thirty-year foci cacte mass balances were wed for an HTCR. a PWR. and a CNSG system.

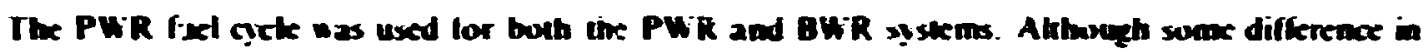
cost exists between the twu sistims this fifference is seall.

The PWR uses 22 ansul refueling setienc. A non-recycte mode is used where all plutonium produced is sold. Reprocessed uranions is neturned to the enrichunem plant for retase.

The CISG system uses a bianaual refucling. with the sak of ang bred plutonium. Reprocessed uranium is returned to the enrichment plant.

The HTrR system sonsidered uses highty enriched uranum as fuel and thoriuan as the kerike material. Bred " $\mathrm{C}$ " is recteled cuntinuoush throughout the reactor life. and the remaining inventory at the end of the reactor life is sold. The reprocessed uranium from the fuel etenents containing the highty enriched uranium has a bre proportion of 1 . Because of this. the credit received when tirs material is returned th the errichenent plant is reduced to 70 ; of what uranium of the returned enrichment would ordinarity be worth. The HIGR has an annual refueling sibeme.

A 0.5r; fabrication lass and a l.ori reprocessing loss are used for non-recycled fuel. For the recyeled:": $l$ and its products in the HTGR. a net loss of $1 r_{;} ;$is used.

\section{UNIT costs}

Estimations of the nuckar fuel cycke unit costs in 1974 dolbars were made for a period of frown present until the year 2022. As one might expect. there is considerable uncertainty in predicting prices 40 to 50 years in the future. cren on a constant dollar basis. These uncertaintics not only involve technology and the ability to find the necessary uranium. but atso uncertainties as to the degree of penetration of various nuckear systems. Increased penetration will kead to reduced unit costs due to the economics of scak in items such as fabrication and reprocessing piants. With these caveats in mind. we have put together our best estimates of unit prices. An altempt is also made to give the degrees of reasonable uncertainty.

\section{Raw Material Price}

The price of $U, O$, was discusced in Section S.I. The reference price scheduk used in the economics cakulations is that for the 20,i above the AEC "mose likely" deinand case by the year 2000. The price after 2000 is assumed to rise linearly 12546.80 / tb by 2022 . This price schedule is also considered to be the high price in the range of reasomable uncerainty.

The lower range of uncertainty was uken as the A.EC base ore use-price estimate, assumi ig an added 20 ; to nuclear capacily by the year 2000 . We further assurned for this price schedule that enough low-grade ore will be found 30 that the price never rises above 530 ib of $U, O$. Plots of uranium price us time are shown in Fig. A.2. 


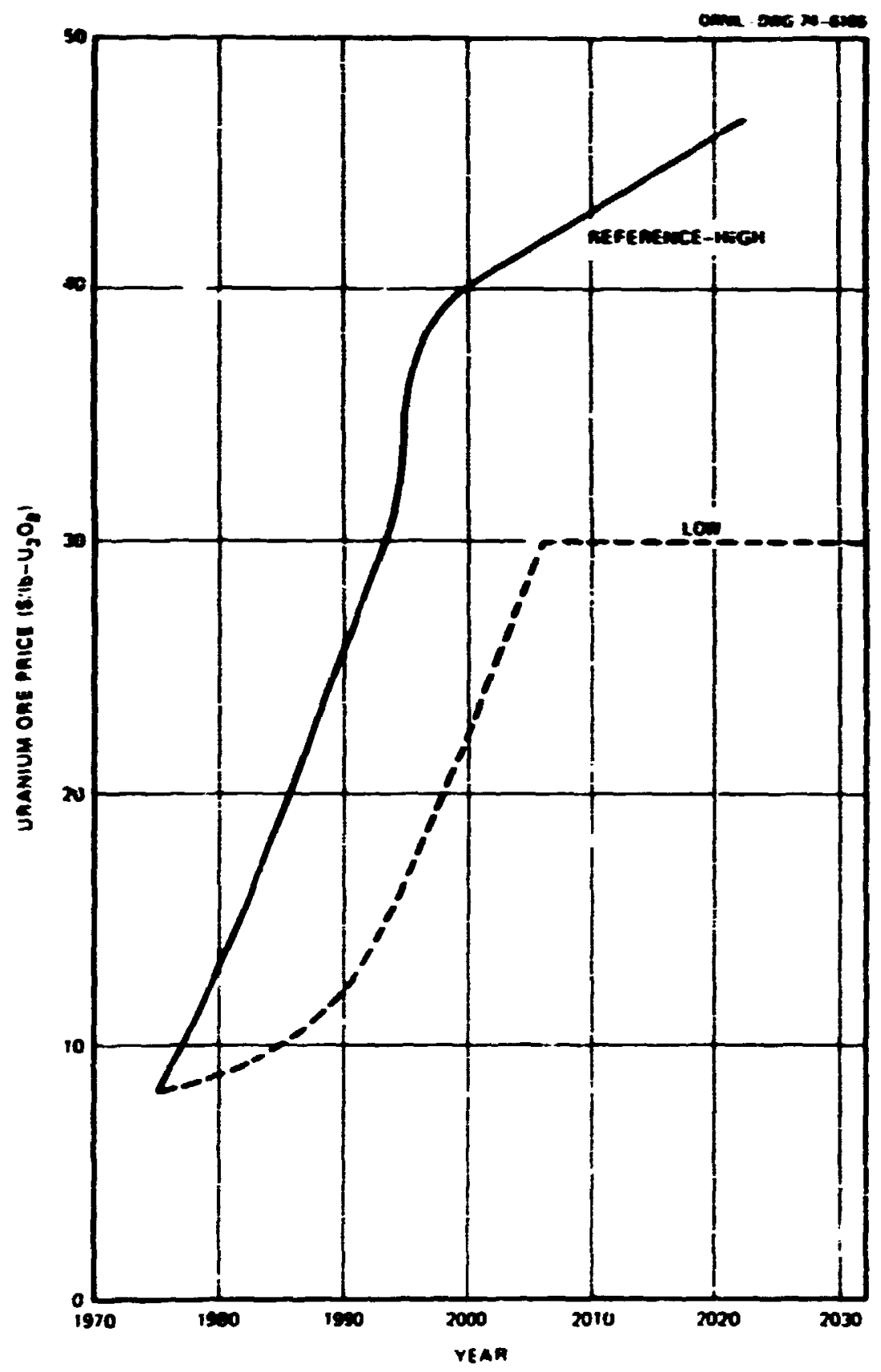

Fi. A.2. Unanien ore prize.

The effect of thorium price on system econnmics is small even if thorium is not recycked. In this study we use the current valic reeommended by General Atomic' of $\$ 9 \mathrm{~kg}$ of ThO.: This price is not varied with time.

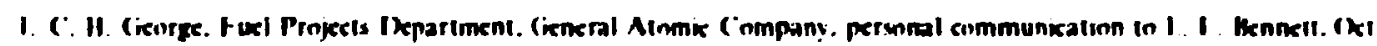
In. 1973. 
In our economics calcubtions, the cost of converting $\mathrm{Vi}_{3} \mathrm{O}_{\text {, }}$ io UF, as noeded in the enrichment plant is included with the uranium purchase price. This is not a major expense. Present prives are around $S I$ Ib of $\mathrm{U}, \mathrm{O}$. This price was assumed to be an invariam throvighour the study.

\section{Segandive Wouk}

Separative work was discussed un Section 5.1. The reference price :ctredule uned in this study starts a' SA? SWI: in 1975 and increases by SI : SWU each year intil if icactes SSO SWU: it remains corstant at S50. SWU therafict. The range of reasomable uncertairity is assumed to be the range of uncertainty in privately financed centrifue: enrichment plants. 0. 540 to 560 SWU. Th: high side price scheduk starts at S44 SWU in 1975 and increises 52 SWU per yar to 1983 and then remains constant at 560 SWU. The bow price schedule aseames a constans $\$ 10$ SWU throughout. Figure A.3 shows a plot of these prices.

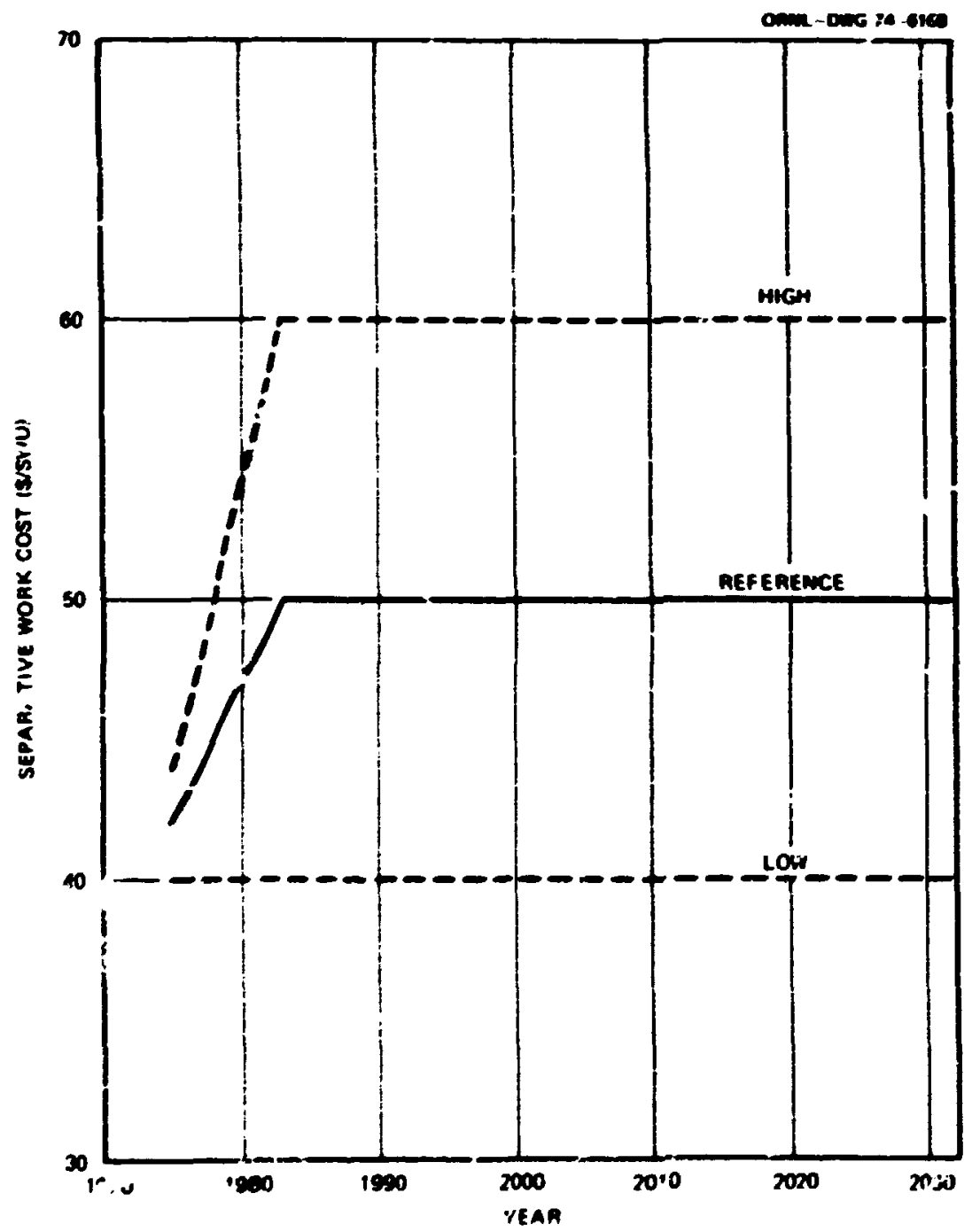

Fie A.3. Separtive wort or 


\section{Feluriontion}

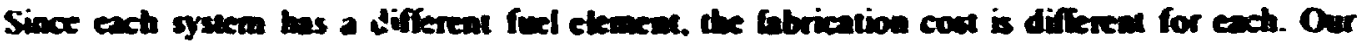
refereme unit Gbrication phes reconversicn coets for the PWR and HTGR systems are thoec weed in

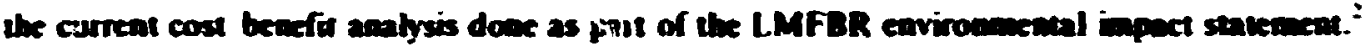

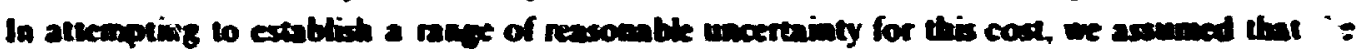

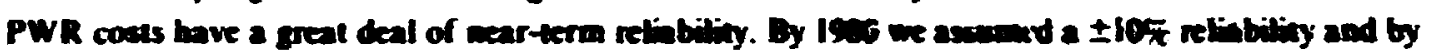

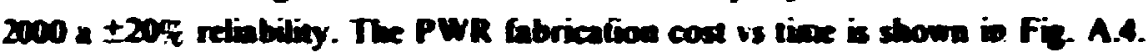

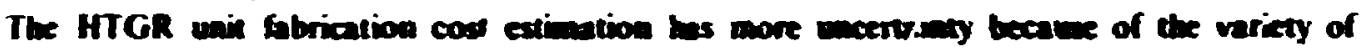

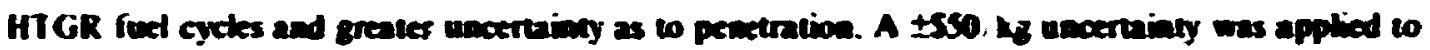
the referewar Gabrication con. These oness are aloo ploted in Fis. A.A.

The unit costs for the C.SSG inel element fabrigation were extivalud based un Gabrication in a

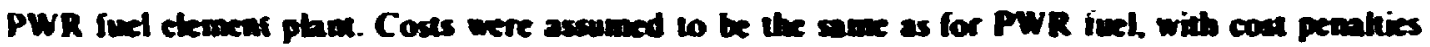
caused by chamep of the fabrication facility dec to chanpover to and from the CNSC element and additional moterial unin costs in Gbrionting the shorter C.VSG eiement.

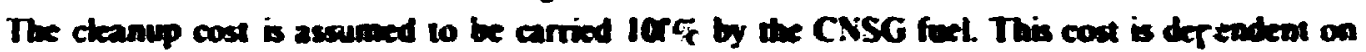

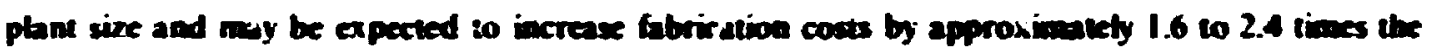
unit coses without ctamp.' We extimate ihat in increased hardware costs would increase unit fabrication costs by I.1: to 1.24 limes the price of a standand PWR foel element.

The iset effeet is that the C.SG fuel Gabreation will probably $\cos 1.8$ to 3 times the unit cost

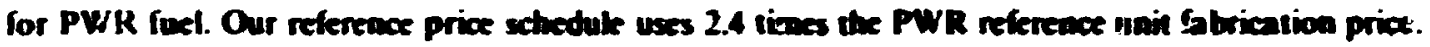

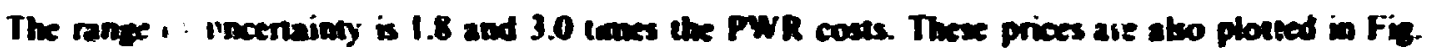
A.4.

When do se the economics caicubtions. shipping cums of ine inesh fuei were inchoded with the Gabrication coses. These costs are not varied in this study and are gives in Table A.I.

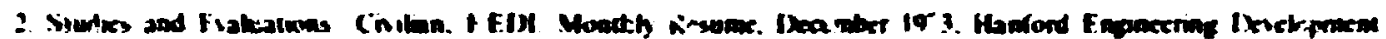
lathurationy. Jan. 9.1978.

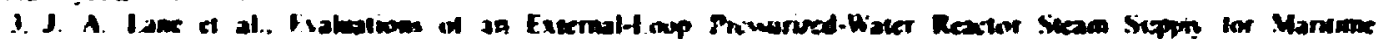

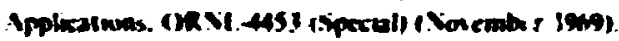

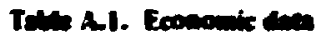

\begin{tabular}{|c|c|}
\hline 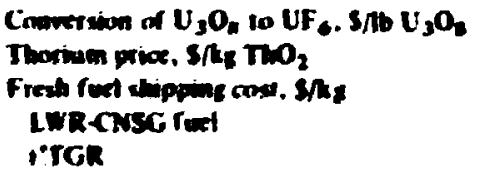 & $\begin{array}{r}1.00 \\
9.00 \\
3.50 \\
25.00\end{array}$ \\
\hline $\begin{array}{l}\text { Sprotfuel shoping cost. She } \\
\text { LWRensci fuet } \\
\text { HTCR }\end{array}$ & $\begin{array}{r}6.50 \\
50.00\end{array}$ \\
\hline
\end{tabular}




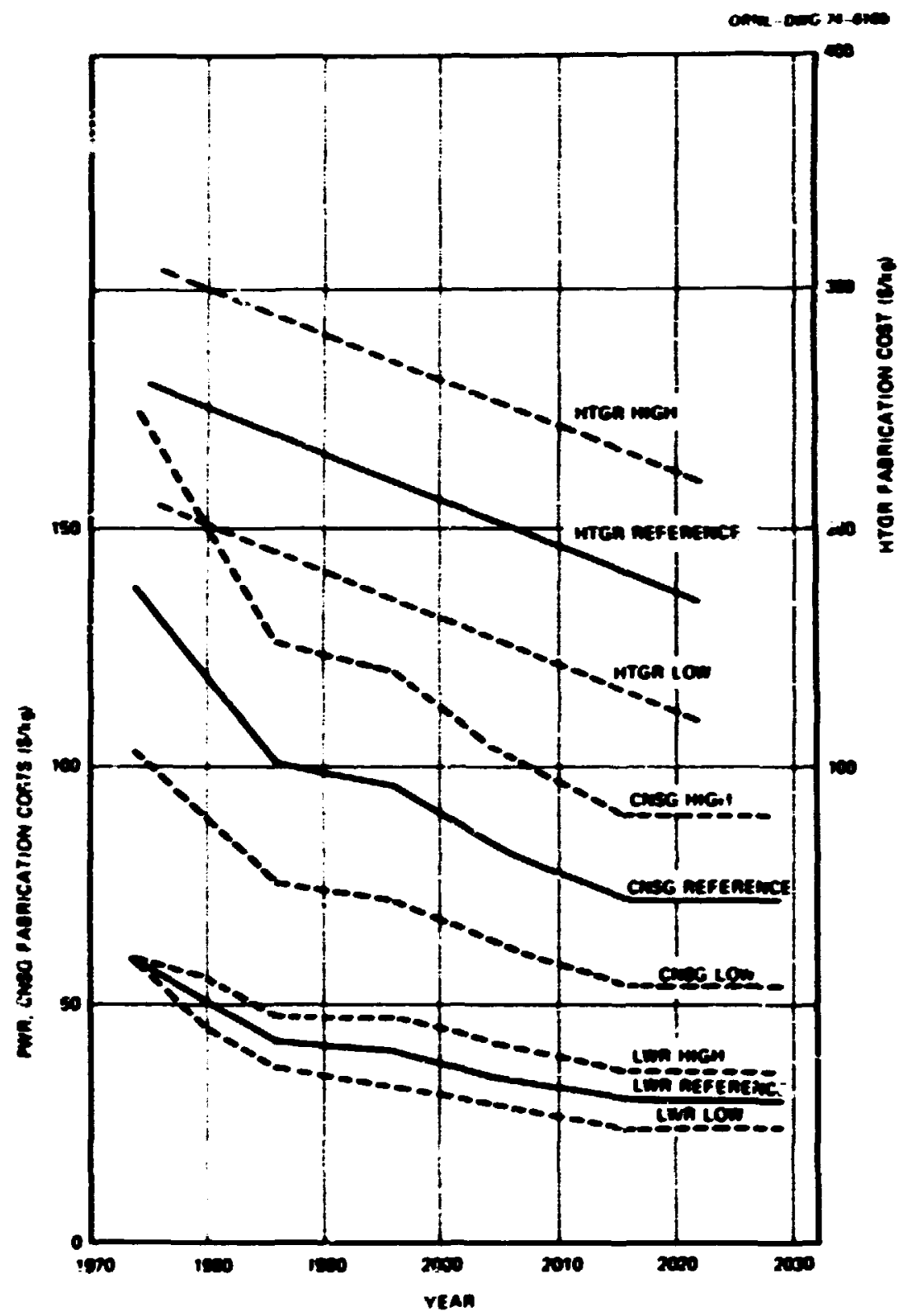

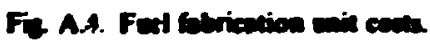

\section{Fed keovery}

In our econumic ealcubtions, the furi recovery cost include shipping of apem fuel. fuel reproceseing. waste disposal. and converion of unanissm to UF, for retum to the diffusion ptant. The unit shippine charges, asaumed to remain constant in time, are given in Table A.1.

For the fuel recovery cos, excluding the shipping charge, we was the cod serveture ascumed in the LMFBR con benefil analysis work. The valwes uned here for the PWR unit costs represent a 


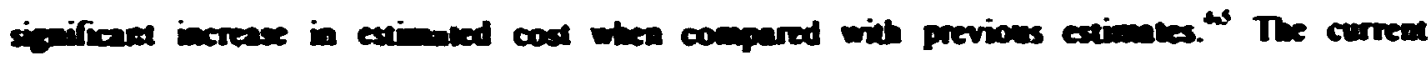

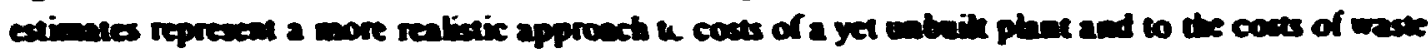

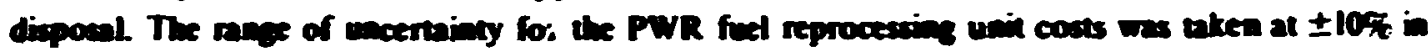

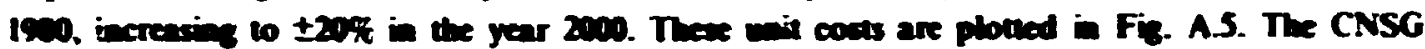

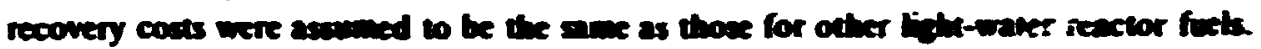

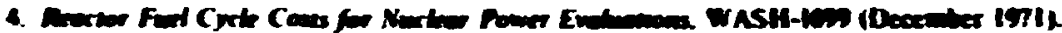

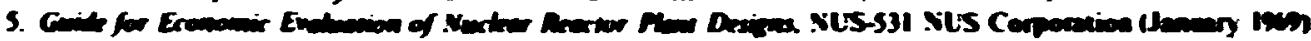

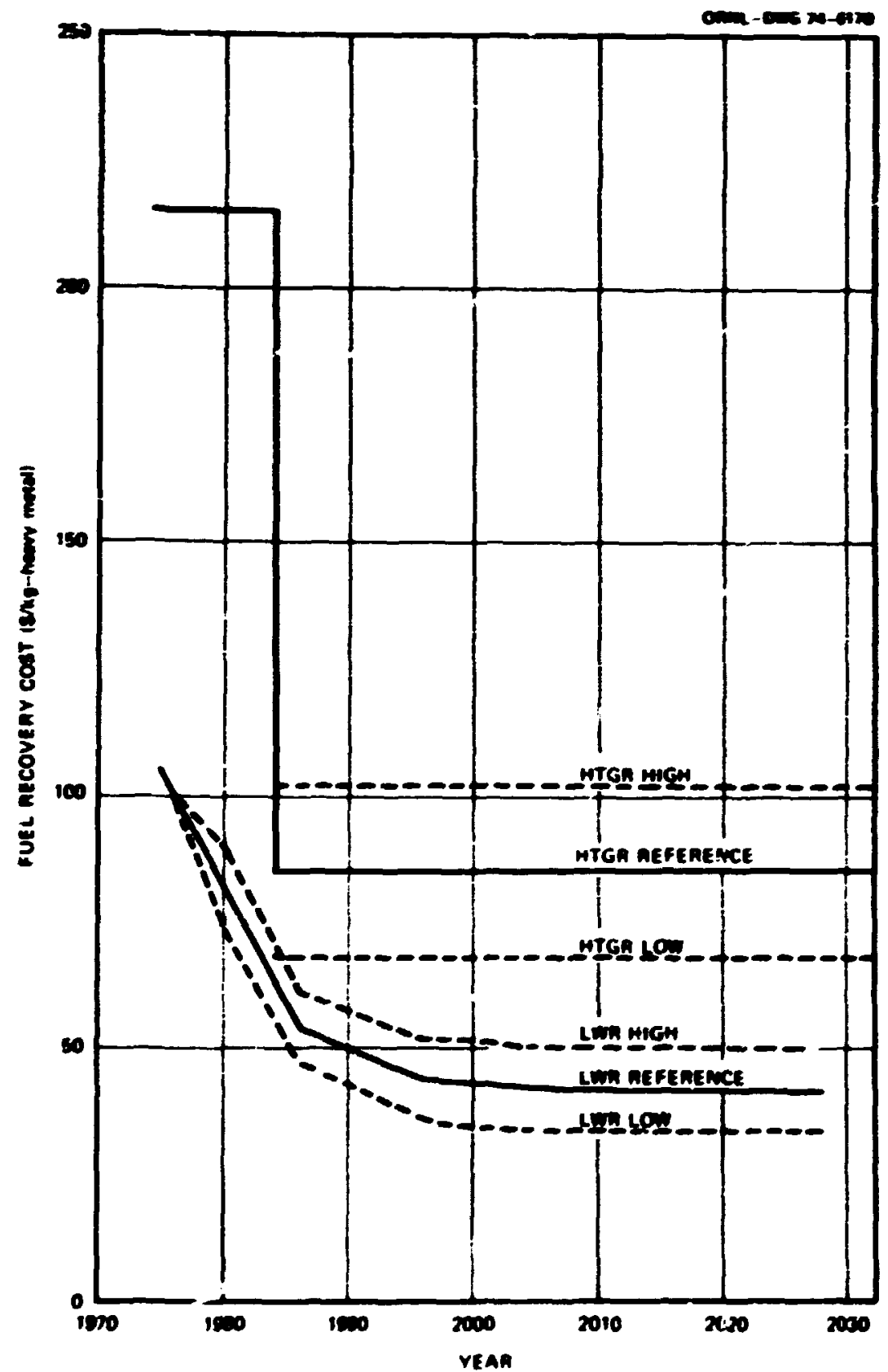

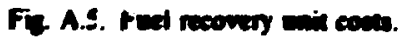


The HTGR recovery costs ased in the LMFBR cost benefit anslysis wort are besed on current

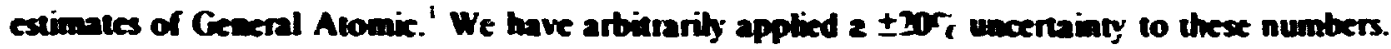

\section{Ded Mexil Wort}

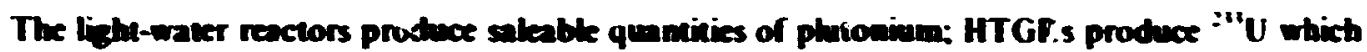

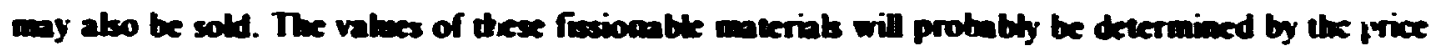
of enriched uravium, since they are a competinive fel with " $U$ in some types of fuel cycles. ize

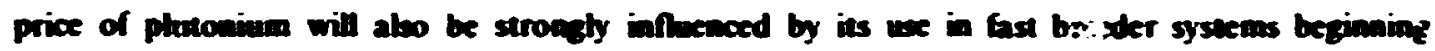
wourd the end of the cemary.

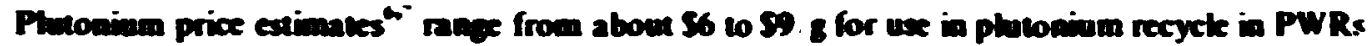

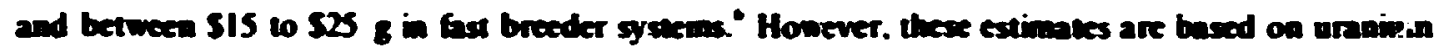
cre price projections bower than those used in this study. Provions studies' at ORNL have used a

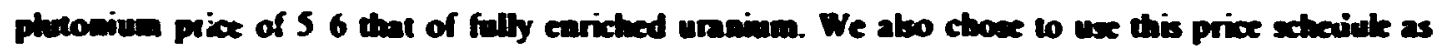

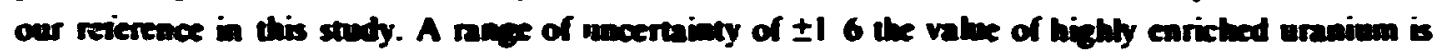
alo comidered.

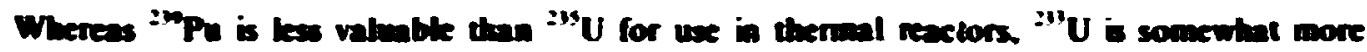

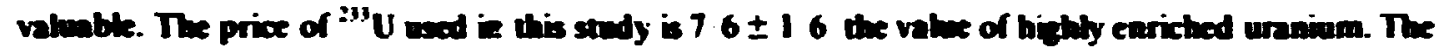
price projections for facile pleconium and " $U$ used in this stody are pioted in Fis. A.6.

\section{COST EVALUATION METHODS}

Average frefycte cocts calculated in this sudy for a 30-year reactor lifetime were based on present value discouming lechniques. The averagf, or leveliaed. fuel cost was determined by compution the present value (value discouned to reactor siartup) of all fuel costs and credis and dividing this by the discomated amoun of eneng sold burine the life of the plan.

In the discounted ach flow procedure used here, the and of the present-worthed ash incomes und equal the sum of the present-worthed cash expenditures. These expenditures inchude divect costs anch as ore punchase and fuet fobricition as well as mxes. For income wx purposes. the direct costs are acenoned to be deductible on a prumta basis with power production.

The fuel cycle coat is made up of two components, the direct coed and the indirect chanes aseociated with an item of cost. The direct cos contribution is obvined by summing up all couts and credits durias the reactor hisusy and dividion this bo the total enery sold with no divcounting or

$$
c=\frac{\sum z_{n}}{2 E_{n}}
$$

where $D$ is cotal direet cose, $Z_{n}$ is lotal fuel cons and credits durias period $n$. and $E_{n}$ is energy produced durine period $n$.

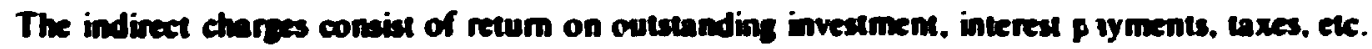
To calculate the indirect chares. we firs determine the total diecounted present value of all direct

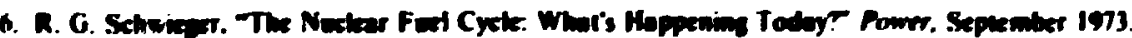

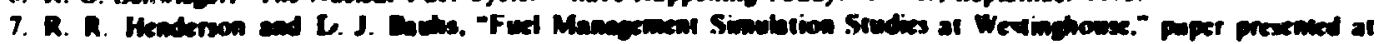

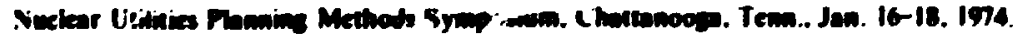




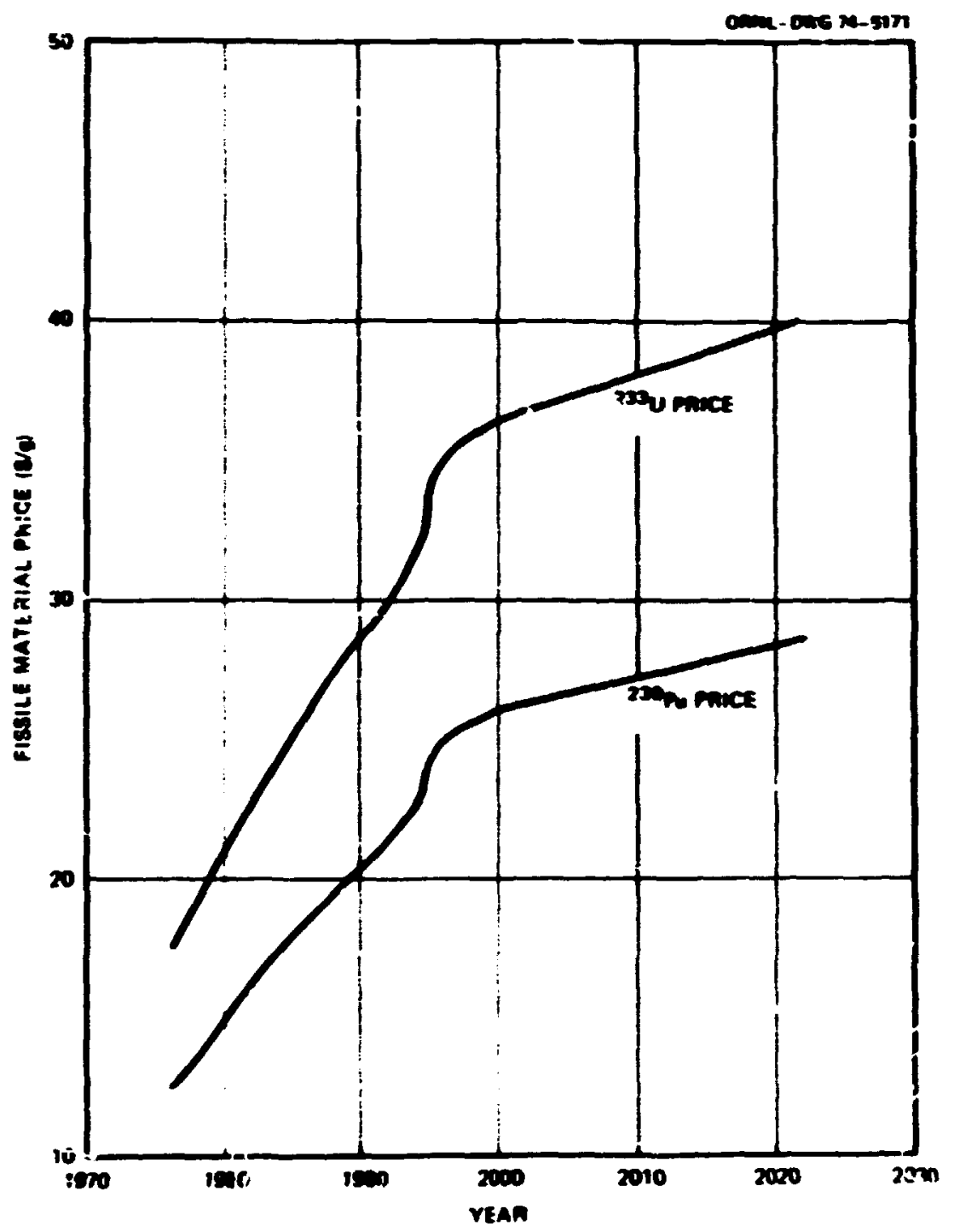

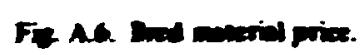

fuet cosus over the seactor lifetime and dinide this by she divcounted amount of energy delivered. or

$$
r=\frac{\sum(1+x)^{-n} Z_{n}}{\sum(1+x)^{-n} E_{n}} .
$$

where $x$ is disenome factor and $r$ is lotal cost before pro-rate eflect. The result is the toul cost. if all expenacs can be deducted lor tax purposes as they occur. The lotal indirect charge. including the pro-rata iffect. is the difkerence between tijs total cost and the direct cosi multiplied by

$$
\frac{1.0}{(1-n)(1-5)}
$$


or

$$
l=(r-D) \frac{! S}{(1-.)(1-5)}
$$

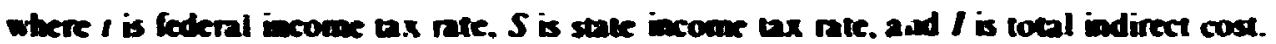

The discoon fector to be osed with this procedare is given by

$$
x=(1-b) i_{e}+(1-t)(1-5) b i_{b}
$$

where $b$ is frention of investment from debt; is is eamings rate on equity after enxes: and is is interest

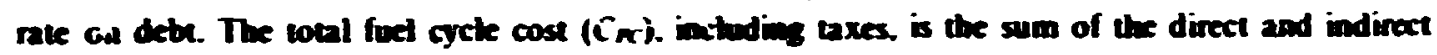
ctarges

$$
C_{\mathrm{FC}}=\mathrm{D}+\boldsymbol{I}
$$

It is asemmed in doing these calculations that debt and equity remain in constant proportion chronfbout the tife of the project. For calculational puposes. we aswuned that incone from energy

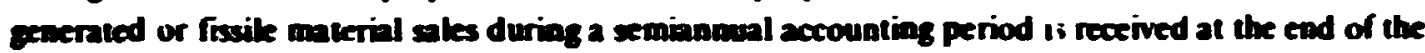
period. Costs such as fuel purchase. fabrication, and reprocessing were charger. at the beginning of the period in which shey occurred. The accountiog lead and be times used in the fuel cycle are

\begin{tabular}{|c|c|}
\hline & Nomber of 6 \\
\hline 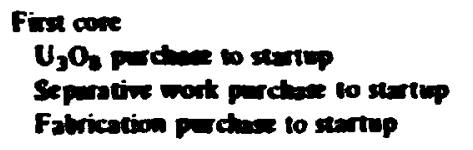 & $\begin{array}{l}3 \\
3 \\
2\end{array}$ \\
\hline 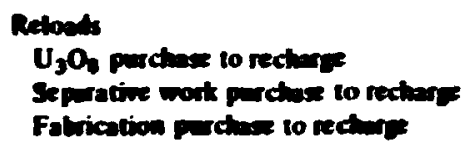 & $\begin{array}{l}2 \\
2 \\
1\end{array}$ \\
\hline Dinchare to reproces ins pry ment & 1 \\
\hline Diachere to forite gale & 2 \\
\hline
\end{tabular}
shown in Table A.2.

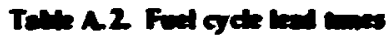

\section{FUEL CYCLE COSTS}

Fual cycle costs as a function of discount factor before income tax are shown in Figs. A.7 te. A.9. Thase coats were calculated using Eq. (A.2) and are based on our reference unit cost aructure and mass balances for the PWR, CNSG, and HTGR reactor systems. Ato tabulated on these 


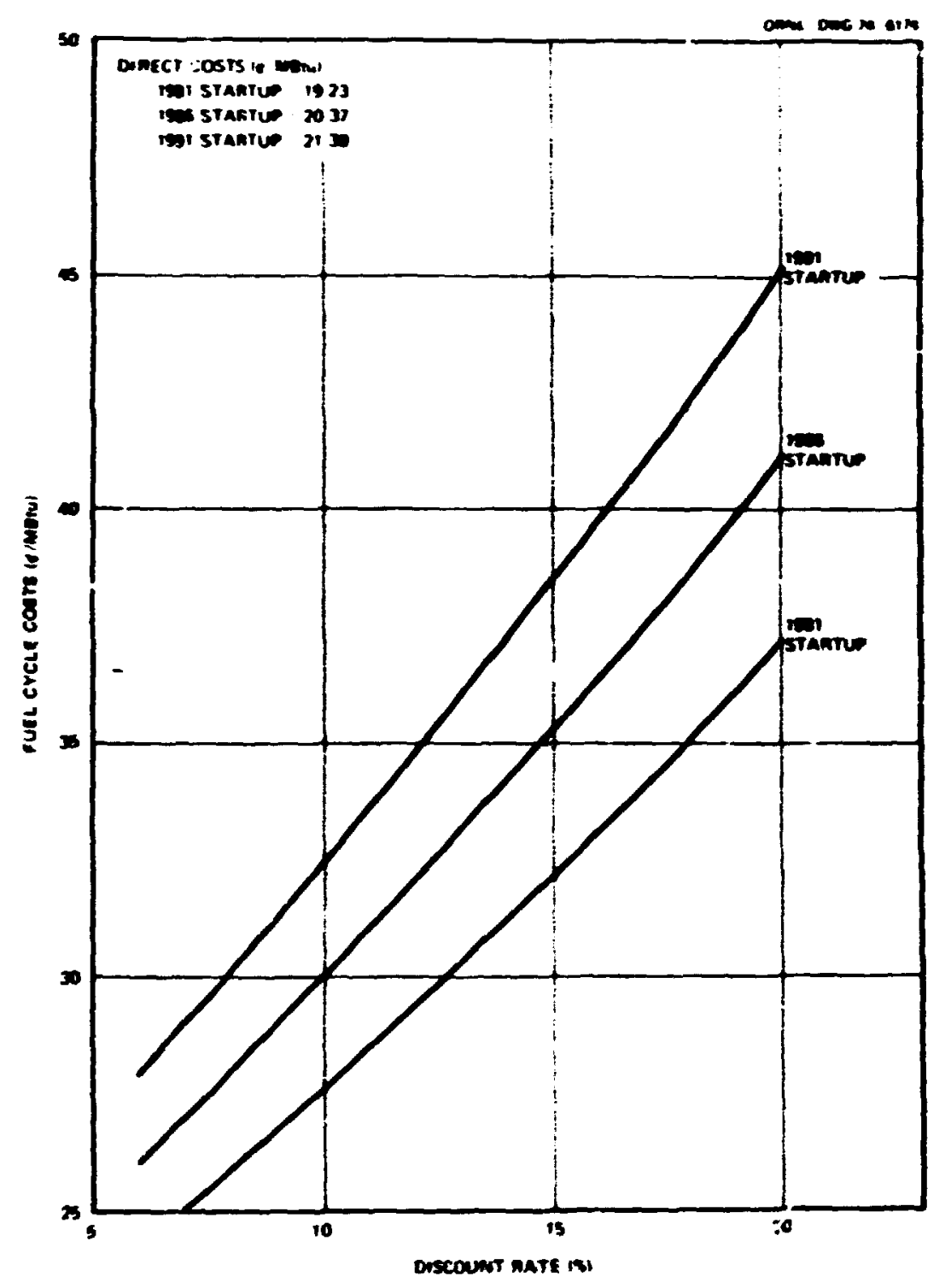

Fis A.7. LWR fuet cyele consts.

figures are the direct costs calculated using E4. (A.1). Thres startup dates. Jan. I. 1981, 1986. and 1991. are considered. I sing these curres and E4s. (A.4) to (A.6), the total fuel cyck cost may be cakulated for a wide variely of tax and financial assumptions.

Fur example. using f.y. (A.S) and the utility reference casc assumptions. we have lor; after tax

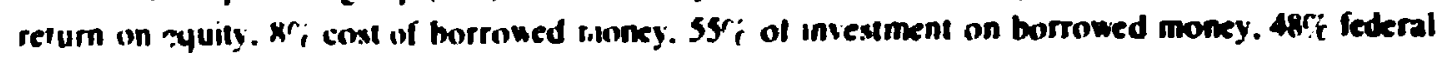
income tax ratc. and $y^{\prime}$, state and local income tax rate. The discount factor from Eq. (A.5) is 6.72\%, For a 19\%t startup of an I. WR (PWR or BW R). the fuel cyck cost hefore income taxes from Fig. A.7 for this discount rale is 2 he per $10^{\wedge}$ Btu. The direct cost is $22 \mathrm{e} 10^{\circ} \mathrm{Bru}$. The indirect 


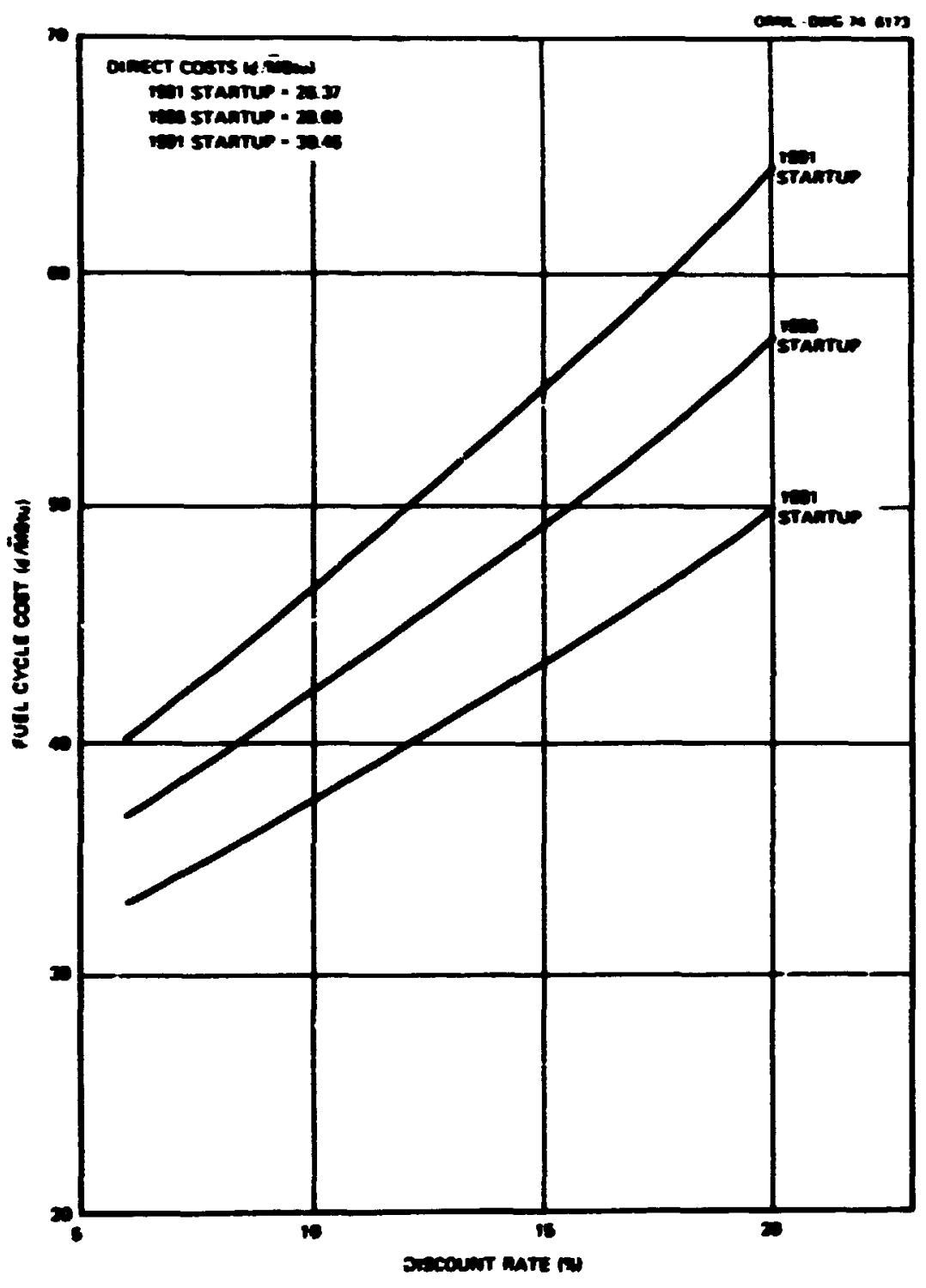

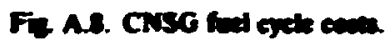

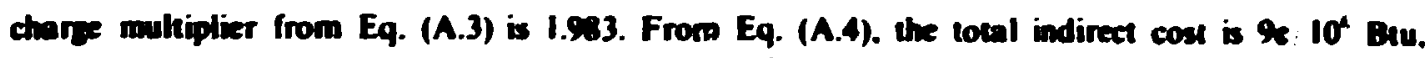
and the toul fuel cycle cout from Eq. (A.6) is 31s; $10^{\circ}$ But.

All the fuet cycle coats given here are based on 2i? 80\% plant fector. For other phant factors. the indirect costs will be inversely proportional to the plant factor, whik the direct coats will be unchanged.

A summary of the fuel cycle costs calcuinted for the utility and industrial reference cases is given in Tabte A.3. Tables A.4 and A.S give the vohue of the initiol core and the average vearly direct fuel cycle expenses respectively.

The fuel cycle costs calcuhted for the PWR and HTGR reactor systems are fairly close for the same startup dates and economic eroundrules. The calculated heat cos for the HTGR is slightly 


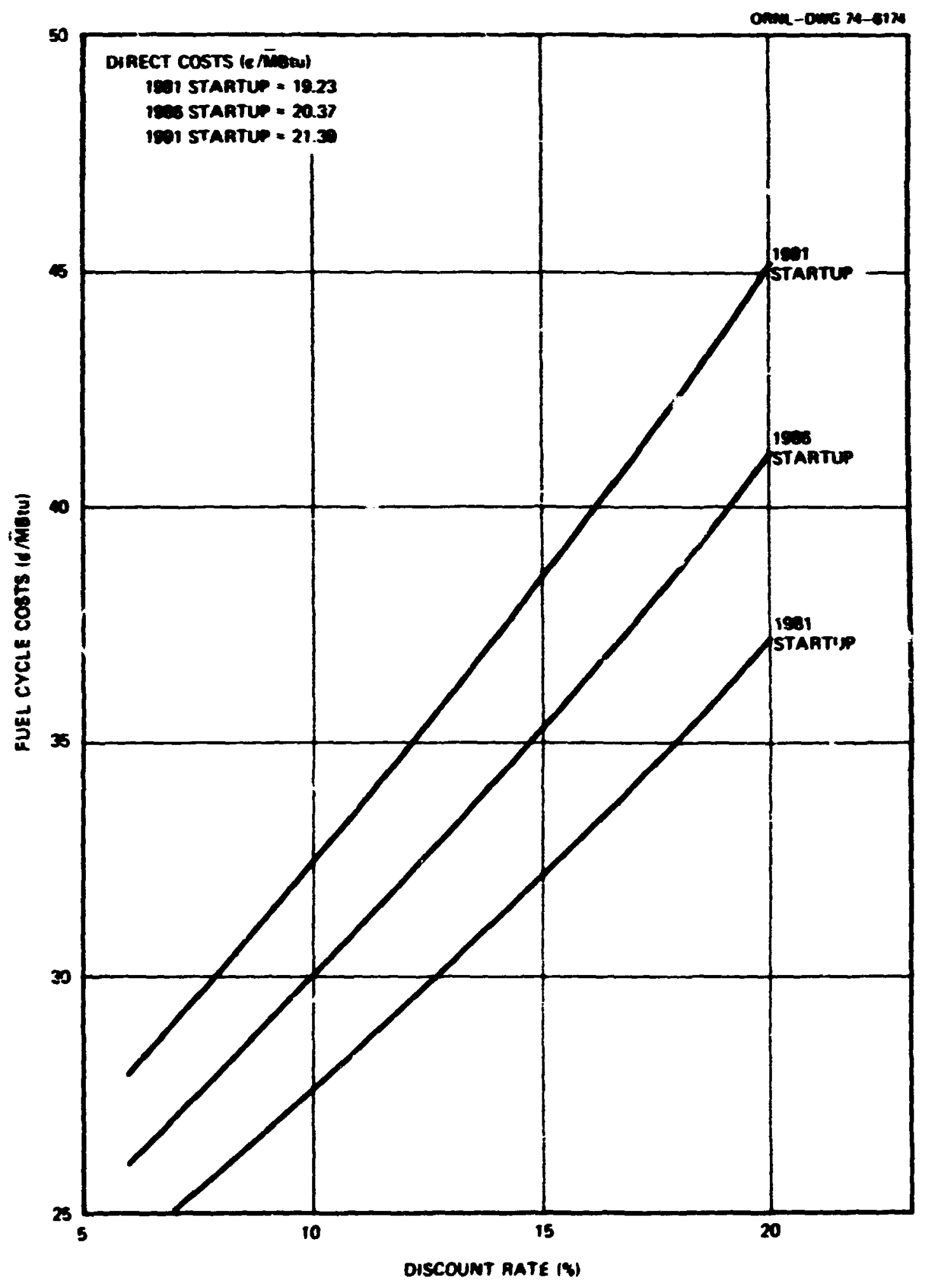

Fit A.2. ITGR fart grele conts 


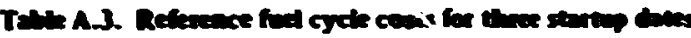

\begin{tabular}{|c|c|c|c|c|c|c|}
\hline \multirow{2}{*}{ System } & \multicolumn{2}{|c|}{19.31} & \multicolumn{2}{|c|}{1986} & \multicolumn{2}{|c|}{1991} \\
\hline & Utïsy & Industrial & Unitity & 1:usturial & Etility & Indestrin! \\
\hline $\operatorname{lwm}_{t / 10^{\circ} \mathrm{De}}$ & $\begin{array}{c}27.3 \\
2.91\end{array}$ & $\begin{array}{c}32.7 \\
3.49\end{array}$ & $\begin{array}{c}31.0 \\
3.31\end{array}$ & $\begin{array}{l}380 \\
4.05\end{array}$ & $\begin{array}{c}34.6 \\
3.69\end{array}$ & $\begin{array}{r}43.4 \\
4.63\end{array}$ \\
\hline 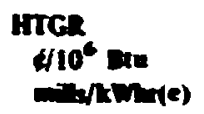 & $\begin{array}{c}30.2 \\
2.67\end{array}$ & $\begin{array}{c}38.7 \\
3.42\end{array}$ & $\begin{array}{c}33.0 \\
2.91\end{array}$ & $\begin{array}{c}43.0 \\
3.00\end{array}$ & $\begin{array}{c}35.9 \\
3.17\end{array}$ & $\begin{array}{c}4.3 \\
4.17\end{array}$ \\
\hline $\begin{array}{l}\text { CNSG } \\
410^{\circ} \text { bee } \\
\end{array}$ & $\begin{array}{r}41.4 \\
4.86\end{array}$ & $\begin{array}{r}52.4 \\
6.15\end{array}$ & $\begin{array}{c}46.7 \\
5.48\end{array}$ & $\begin{array}{c}60.3 \\
7.07\end{array}$ & $\begin{array}{r}51.8 \\
6.03\end{array}$ & $\begin{array}{c}6.1 \\
7.99\end{array}$ \\
\hline
\end{tabular}

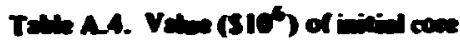

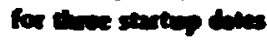

\begin{tabular}{lccc}
\hline Srate & 1981 & 194 & 1991 \\
\hline LWR & 29.2 & 35.2 & 110 \\
HTGR & 40.7 & 46.5 & 51.0 \\
CRSC & 6.2 & 7.3 & 8.3 \\
\hline
\end{tabular}

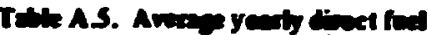
cyche expenan (S10)

\begin{tabular}{lrrr}
\hline System & 1981 & 1926 & 1991 \\
\hline Lim & 16.20 & 17.57 & 18.75 \\
ITCR & 13.80 & 14.63 & 15.36 \\
Crisc & 1.97 & 2.14 & 2.28 \\
\hline
\end{tabular}

Ieches ininial core.

higher than that for the PWR. However, since the HTGR sysem has a higher thermal efficiency, its electrical energy cost is slightly lews than that for the PWR. The fuel cyck coul for the CNSG is significantly higher than that for the reference HTGR or the PWR. This is mainly due to the higher fuel enrichment in the CNSG when compared to brger LWRs. This higher fuel er.richment is secessitated because of the higher relative neutron leakage from the small CNSG core. A CNSG reactor of the same size as a PWR system should have the same fuel cycke costs if operoted in a like manne:- including simibr fueling scinedules. 


\section{FUEL CYCLE COST Sanstrivmixs}

The effect on the ivel cycke costs of variatives in the unit costs iven calculated for the utility reference econssicie coaditions. The high and low unit cost price scheduiss mentioned previoushy were used. The resulss are given in Table A.6.

It can be seen from this cost breakdown that the brest direct cost component is the uranium cost, followed by sepantive wort cost. There is a brge fasile ales (Pu) credit for the PWR and CNSG systems. The hTGR, which recycles the bred ${ }^{23} \mathrm{U}$, has a bower fissile credit which arives from the sale of the core at live end of life. The inbrication and reprocessing costs, althoush sizairicant. are smallet than the enriched uranium cost (uranium punthase plus separative work). For 1981 startup, the fabrication and reprocessing together account for about 20\% of the PWR and CNSG direct costs and about $32 \%$ of the HTGR direct cost for the reference (base) unit price conditions. These percentages become smaller for hler startups due to the decrease in these unit costs with time compared to the rise in ore cost with time.

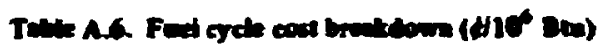

\begin{tabular}{|c|c|c|c|c|c|c|c|c|c|}
\hline & \multicolumn{3}{|c|}{1981 sartep } & \multicolumn{3}{|c|}{ ISte startip } & \multicolumn{3}{|c|}{1991 startup } \\
\hline & Dare & hish & Low & Dase & Fin & Low & Dose & Hin & Low \\
\hline \multicolumn{10}{|l|}{ rwh } \\
\hline Uravien parchose & 13.53 & 1353 & 7.83 & 15.79 & 15.79 & 9.42 & 17.69 & 17.69 & 10.93 \\
\hline Separative wut & 8.48 & 10.13 & 683 & 853 & 10.24 & 6.83 & 8.53 & 10.24 & 6.83 \\
\hline Fabriation & 1.74 & 1.99 & 150 & 1.53 & 1.8 & 1.38 & 155 & 1.81 & 1.28 \\
\hline Fued recovery & 2.13 & 2.45 & 1.20 & 2.01 & 2.33 & 1.68 & 1.95 & 2.29 & 1.62 \\
\hline Fosite soles & & & & & & & & & \\
\hline Total direct cost ${ }^{\circ}$ & $\overline{19.85}$ & $\overline{22.88}$ & $\overline{1302}$ & $\overline{2154}$ & $\overline{24.70}$ & $\overline{13.98}$ & $\overline{22.97}$ & $\overline{26.24}$ & $\overline{15.00}$ \\
\hline Indirect charger & 7.45 & 755 & 5.94 & 9.44 & 9.76 & 5.96 & 11.63 & 12.00 & 7.05 \\
\hline Total fuet crcke cost & 27.30 & 30.43 & 18.96 & 30.98 & 34.46 & 19.94 & 34.60 & 38.24 & 22.05 \\
\hline \multicolumn{10}{|l|}{ HTGR } \\
\hline $\begin{array}{l}\text { Uraniven parctase } \\
\text { Sepperative wost } \\
\text { Fabriation }\end{array}$ & $\begin{array}{l}8.10 \\
686 \\
3.84\end{array}$ & $\begin{array}{l}8.10 \\
8.17 \\
4.64\end{array}$ & $\begin{array}{l}4.80 \\
5.56 \\
3.04\end{array}$ & $\begin{array}{l}9.51 \\
6.95 \\
3.64\end{array}$ & $\begin{array}{l}9.51 \\
8.34 \\
4.44\end{array}$ & $\begin{array}{l}5.69 \\
5.56 \\
2.84\end{array}$ & $\begin{array}{r}10.77 \\
6.95 \\
3.44\end{array}$ & $\begin{array}{r}10.77 \\
8.34 \\
4.24\end{array}$ & $\begin{array}{l}6.59 \\
5.56 \\
2.64\end{array}$ \\
\hline Fued recovery & 2.28 & 254 & 2.02 & 2.16 & 2.43 & 1.89 & 2.16 & 2.43 & $1 . \infty$ \\
\hline Fivile rales & (1.85) & $(2.26)$ & $(1.16)$ & (i.89) & (2.31) & $(1.16)$ & $(1.93)$ & (2.35) & (1.16) \\
\hline Total direct const" & $\overline{19.23}$ & $\overline{21.19}$ & $\overline{14.26}$ & $\overline{20.37}$ & $\overline{22.4 i}$ & $\overline{14.82}$ & $\overline{21.39}$ & $\overline{23.43}$ & $\overline{1552}$ \\
\hline Indirezt charger & 10.94 & 12.49 & 8.16 & 12.65 & 14.49 & 8.10 & $1 / .50$ & 16.36 & 8.85 \\
\hline Tobal foet cycke cost & $\overline{30.17}$ & $\overline{33.68}$ & $\overline{22.42}$ & $\overline{33 n 2}$ & $\overline{36.90}$ & $\overline{22.92}$ & 35.89 & 39.79 & 24.37 \\
\hline \multicolumn{10}{|l|}{ CNSG } \\
\hline $\begin{array}{l}\text { Uranivum purchase } \\
\text { Separative work }\end{array}$ & 15.33 & 15.33 & 8.75 & 18.17 & $\begin{array}{l}18.17 \\
13.4\end{array}$ & $\begin{array}{r}10.72 \\
8.96\end{array}$ & $\begin{array}{l}20.54 \\
11.20\end{array}$ & 20.54 & $\begin{array}{r}12.36 \\
8.36\end{array}$ \\
\hline Fabrication & $\begin{array}{r}11.10 \\
3.64\end{array}$ & $\begin{array}{r}13.23 \\
4.52\end{array}$ & 2.76 & 3.38 & 4.20 & 2.57 & 3.21 & 3.98 & 2.44 \\
\hline Fued recovery & 1.91 & 2.20 & 1.62 & 1.82 & 2.11 & 1.51 & 1.7 & 2.07 & 1.47 \\
\hline Fisuile soles & $(5.61)$ & (48) & $(461)$ & $(5.97)$ & (5.14) & (4.96) & (6.26) & (5.38) & $(5.26)$ \\
\hline Total divect cost & $\overline{26.37}$ & $\overline{30.43}$ & $\overline{17.48}$ & $\overline{28.60}$ & $\overline{32.78}$ & $\overline{18.80}$ & $\overline{30.46}$ & $\overline{34.65}$ & $\overline{20.17}$ \\
\hline Indirect cost & 15.01 & 16.08 & 11.49 & 18.14 & 19.45 & 11.62 & 21.38 & 22.72 & 12.96 \\
\hline Total fuet cycke cost & 41.38 & $\overline{46.51}$ & 28.97 & $\overline{46.74}$ & 52.23 & $\overline{30.42}$ & 51.84 & 57.37 & 33.12 \\
\hline
\end{tabular}

Aumbers in parentheses indicate feel cycle credif.

Dinete costs are independent of finoncine assumptions.

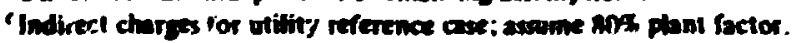


The fosile credit shown for the high and bow cost cases is not the absolute highest (more positive) or bowest (more negative) cost. This cost is consistent with the uranium and separative work costs and a price range of $5.6 \pm 1.6$ times the value of highty enriched uranium for plutonium sales and $7.6 \pm 1.6$ the value of highty enriched uranium for : $U$ sales.

The total cost shown for the high and bow conditions are simply the totals of the individual high and bow cost components. It is not expected that all costs will be high or low in andem. Fxcept for the fact that Pu and "U prices are based on the highly enriched uranium price, interactive effects were not considerad. Such interactions could be cased by the availability of more low-cost uranium. leading to the bo uranium purchase cost estimate. If this were to occir, the enrichment plant ails would probably be higher than the $0.2 \%$ used here. This would increase the ore usage and decrease the separative wort required. Abo, if more uranium is avaibble. the plutonium recycle option in LWRs will be less attactive, and the incentive for fast breeder reactors will abo be reduced. This could lead to a decrease in plutonium demand. which would be reflected in a reduced price.

\section{ALTERNATE SIZE REACTORS}

Fuel rycle costs wete also estimated for a 1900-MW(t) PWR, a 1235-MW(t) CNSG system, and for both a 2000-MW(t) and a 1000-MW(t) HTGR. Lifetime fuel cycle cakulations werc not made for these aliemate systens. The fuel cycle costs shown in Table A.7 are based on extrapolations from the ref-ence size PWR [3420 MW(t)] and HTGR [3000 MW(t)].

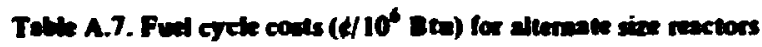

\begin{tabular}{|c|c|c|c|c|c|c|c|}
\hline \multirow{2}{*}{ System } & \multirow{2}{*}{$\begin{array}{c}\text { Siz= } \\
\text { [MIV(t)] }\end{array}$} & \multicolumn{2}{|c|}{1981} & \multicolumn{2}{|c|}{1986} & \multicolumn{2}{|c|}{1991} \\
\hline & & Utility & Indentrial & Utinity & Indon:m:a: & Utility & Inductrial \\
\hline rwh & 1900 & 28.2 & 33.8 & 32.1 & 39.3 & 35.9 & 44.9 \\
\hline CAsc & 1235 & 29.4 & 36.1 & 33.5 & 42.0 & 37.5 & 48.2 \\
\hline \multirow[t]{2}{*}{ HTCR } & 2000 & 31.8 & 40.7 & 34.9 & 45.4 & 38.0 & so.1 \\
\hline & 1000 & 34.8 & 44.6 & 38.3 & son & 41.9 & 55.3 \\
\hline
\end{tabular}

If the size of a reactor system is decreased, there will be a greter aeutron leakage from the amaller core. A larger fissile material loading is then needed to compensate for this increased leakage. This causes an increase in the fuel cycle costs. The fucl cycle cost for the 1900-MW(i) PWR was estimated by computing the change in fiscile looding required to compensate for the increased fractional neutron lakage from the sma!ker core. The results are consistent with a comparison of a GOD-MW(e) and a $1000-M W(e)$ PWR ractor as given in WASH-1082."

The fuel cycle costs for the 1235-MW(t) CNSG were extimated based on information fumished by Babcock and Wikox with adjustments for economic assumptions and fuel element size.

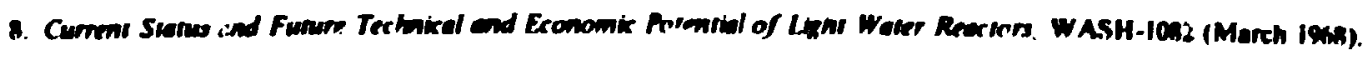


Information on the fasile material bading for a w00-and a 2000-AWW(t) HTGR was obcained

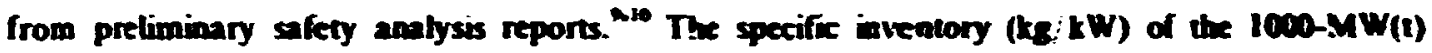
:-TGR was esizated by extmpoktias from the respective 3000 and $2000-M W(t)$ values. The fuel cycle costs for the 2000- and I000-MW(t) HTGR reflect the coes penalty of the bigher specific inventories of thex two systems when compared to the 3000-MW(t) reference design.

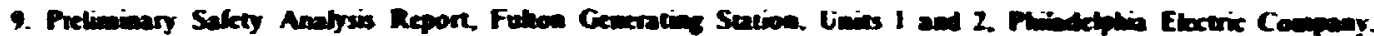
Jamary 1974.

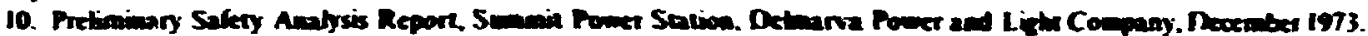




\section{Appendix B}

\section{Steam Line Cost Study-Basis of Cost Estimate}

This estimate is based on conceptual assumptions fumished by John Yarbrough of the Engineering Mechani.s Department. UCC Nuckar Division. The material listed covers the reyvirements for I mile of line. The pipe is assumed to be in 20 -fi lengths with ends beveled for welding. The calcium silicate insulation will be instalked in 2-in. byers of material premolded in segments conforming to the diameter of the pipe. Three hyers will be applied. and the insulation will be covered with aluminum jacketing. Supports will consist of concrete footings with soncrete piers extending above the grouni and sadules of metal plate. Rolkrs will be used to allow for expansion and contraction.

It is assumed that road and small stream crossings an be accommodated by the arrangement of expansion loups which are included. No provisions are made for wide seream crossings or rugged terrain. Aver ige accessibility and terrain conditions are assumed.

Escalation must also be applied after July 1974. Labor prices are those which are current in the Oak Ridge. Tenn.. area and will need adjusting to the area in which the work is ptenned. The costs as shown indicate construction funding per mile of proposed line. No provisions for costs of band. land rights. easements. or engineering are made in this estimate.

The calculations in Tabies B.I and B.2 were made in order to estimate the cost of a steam pipeline, either 24 or 36 in. diameter. to deliver stearn from a generating facility to distribution points. The pipeline is 5 to 10 miles long.

No actual geography was considered, and it was assumed that all obstacks, such as roads, could be cleared by the expansion bons (10 loops mile) (Fig. B.I). Any larger obstacles. such is wide rivers, would require special sonsideration and would result in considerable cost increas:.

The design parameters obtained were irot optimized or refined but are repres:ntative for purposes of estimating cost. The steam operating condition considered was 850 psig. $525^{\circ} \mathrm{F}$. An additional condition of $2400 \mathrm{psig}, 950^{\circ} \mathrm{F}$ steam was included initially but was dropped due to excessiv: wall thickness requirements.

The design was based on seamless pipe: A-106 grade B for the 850 psig. $5250 F$ condition; and SA-199 grade 3 t, for the 2400 psig. $950^{\circ} \mathrm{F}$ condition. From availability considerations, welded pipe may have to be substituted. This may afiect the cost.

St:am traps were not ancluded in the design but should be covered (costwise) within the $5 \%$ contingency.

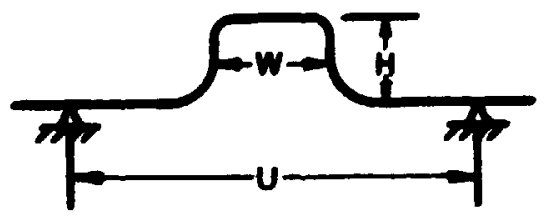

Fiy B.1. Expasion loop detids. 
Tam B. B.

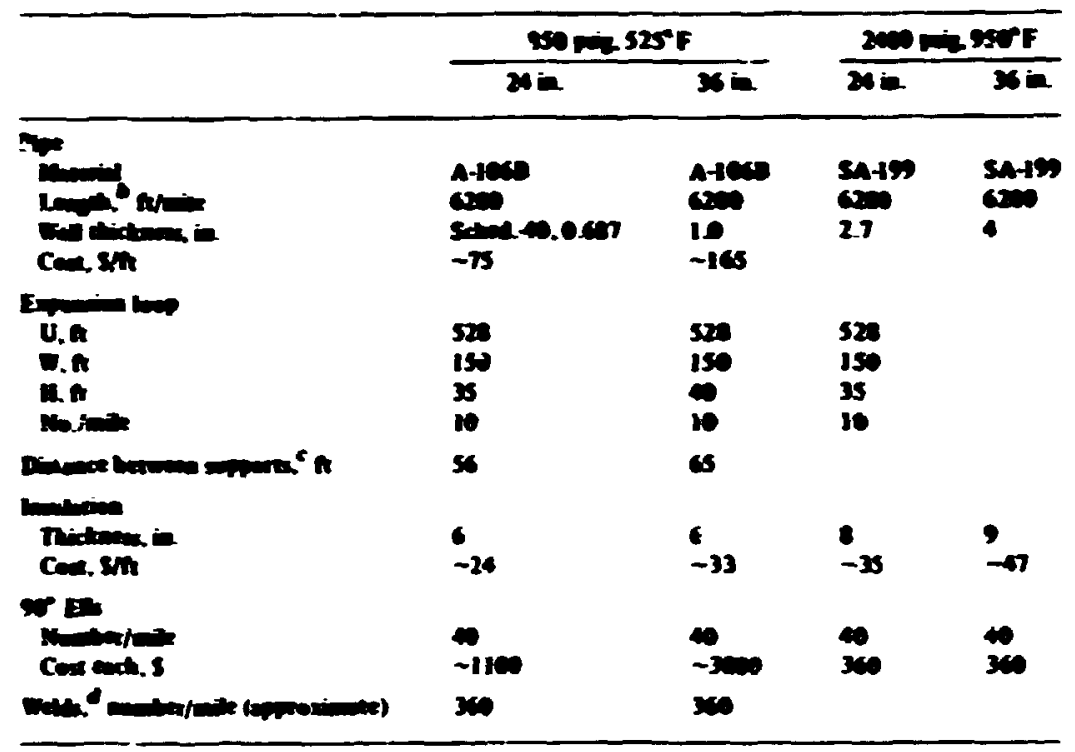

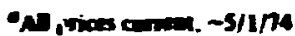

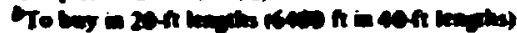

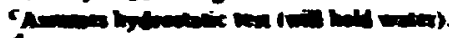

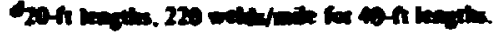

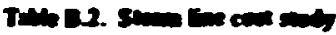

\begin{tabular}{|c|c|c|c|c|c|c|c|}
\hline \multirow{2}{*}{ } & \multirow{2}{*}{$Q_{\text {mans }}$} & \multirow{2}{*}{$\operatorname{lin} \theta$} & \multicolumn{2}{|c|}{ Imanil } & \multicolumn{3}{|c|}{ Enes } \\
\hline & & & thil cod ist & Iocal (S) & iness & $\operatorname{sen}(8 / n)$ & $T(a) \mid(S)$ \\
\hline 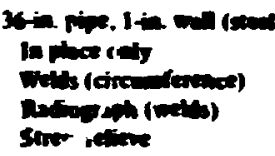 & $\begin{array}{l}6200 \\
300 \\
300 \\
300\end{array}$ & $\begin{array}{l}\text { Ef } \\
\text { End } \\
\text { Eadh } \\
\text { Eand }\end{array}$ & $\begin{array}{l}175 \\
100 \\
100 \\
100\end{array}$ & $\begin{array}{l}1005000 \\
36000 \\
30000 \\
35000\end{array}$ & $\begin{array}{r}2 \\
0\end{array}$ & $\begin{array}{l}9.25 \\
9.25 \\
4.00 \\
4.00\end{array}$ & 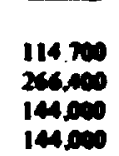 \\
\hline 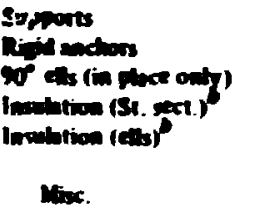 & $\begin{array}{r}120 \\
10 \\
40 \\
6200 \\
40\end{array}$ & $\begin{array}{l}\text { End } \\
\text { Endh } \\
\text { Eads } \\
\text { Ex } \\
\text { Eath }\end{array}$ & $\begin{array}{r}\operatorname{sen} \\
\sin 0 \\
4000 \\
35 \\
630\end{array}$ & $\begin{array}{r}60000 \\
5,000 \\
100000 \\
217000 \\
25200 \\
1,00200 \\
59200\end{array}$ & $\begin{array}{r}12 \\
4 \\
4\end{array}$ & $\begin{array}{r}10.00 \\
20.00 \\
9.25 \\
9.75 \\
9.75\end{array}$ & $\begin{array}{r}1200100 \\
20000 \\
4,400 \\
241.00 \\
24.500 \\
1000.300 \\
103.700\end{array}$ \\
\hline & & & & 1,700000 & & & 1.140000 \\
\hline 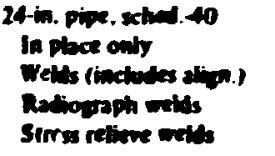 & $\begin{array}{r}6200 \\
360 \\
360 \\
300\end{array}$ & $\begin{array}{l}\text { LF } \\
\text { Each } \\
\text { Exch } \\
\text { Each }\end{array}$ & $\begin{array}{l}75 \\
50 \\
50 \\
50\end{array}$ & $\begin{array}{r}455000 \\
18,000 \\
18000 \\
18000\end{array}$ & $\begin{array}{r}1 \\
40\end{array}$ & $\begin{array}{l}9.25 \\
9.25 \\
2.00 \\
2.00\end{array}$ & $\begin{array}{r}57.350 \\
133.200 \\
72.000 \\
72.000\end{array}$ \\
\hline 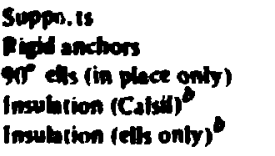 & $\begin{array}{r}120 \\
10 \\
40 \\
6200 \\
40\end{array}$ & $\begin{array}{l}\text { Euch } \\
\text { Euch } \\
\text { Euch } \\
\text { LF } \\
\text { Each }\end{array}$ & $\begin{array}{r}400 \\
400 \\
1200 \\
25 \\
300\end{array}$ & $\begin{array}{r}48,000 \\
4000 \\
48.000 \\
155000 \\
12.000\end{array}$ & $\begin{array}{r}4 \\
24\end{array}$ & $\begin{array}{r}6.00 \\
10.00 \\
9.25 \\
9.25 \\
9.25\end{array}$ & $\begin{array}{r}72.000 \\
10.000 \\
1.400 \\
114.700 \\
0.100\end{array}$ \\
\hline Misc. & & & & $\begin{array}{r}786,000 \\
47.000\end{array}$ & & & $\begin{array}{r}541,610 \\
54,390\end{array}$ \\
\hline & & & & 833,000 & & & 596000 \\
\hline
\end{tabular}

thF a linear feet.

ofncheses abminem peket. 


\section{Appendix C}

\section{Step-by-Step Procedure in AEC Licensing of Nuclear Power Reactors*}

\section{RADIOLOCICAL SAFETY AND ENVIRONMENTAL MMPACT REVIEW}

I. An electric utility phanaine to berild and operate a nuclear power phant for the purpose of generating etectricity for distribution to its service aren must sect approval from the Atomic Energy Commission.

2. The AEC licensing process for a auclear power phat invohes a twostage procedure. The initial stage consists of the filing and processing of an application for a construction permit. The second seage consists of the filine and processine of an application for an operating license. Construction of a nuctar power plant may not begin until a construction permit has been issued by the AEC. Simibrty. a muckear power ptant may not be baded with fuel or operated until an operatine license has been issued by the AEC.

3. A construction permit application is propared with the assistance of the utility's contractors including the contractor ist the auckear steam supply system. The appliation contains a detailed description of the profosed sive and proposed desien of the phant. an accounting of the fianncial yualifications of the etility as mell as other information which is encrally provided for in the Commission's Regubtions on -ticensing of Prestuction and Utilization Facilities." At the time the application is submitted the applicam must abo submit to the AEC an environmental impact report retatine to the proposed ptant. Guides to the preparation of the reports. detailing the kind of information required to be incloded. tave been developed by the AEC Regublory Suff!

4. The AEC arranges for documents and correspondence rehtian to the case to be avaitable for public inspecion at a beal public document room (usually in a public library) established in the vicinity of the proposed focility as well as in the AEC Pubtic Document Room in Washington. D.C.

5. Fach applization is initially reviewed oy the AEC Regublory Soff to devermine whether the application. including the preliminary safety amalysis repon and the environmental repon. contains sufficient information to antisfy the AEC requirements for a complete application. In addition, a substantive review and inspection of the applicant's quality assurance program covering desizn and procurement is conducted If the application is not sufficiently complete and/or the quality aseurance prozsam is not acceptable, the application is rejected. If the application satisfies the AEC. requirements it is formelly accepted for detailed review. The initial acceptance review takes about 30 days.

6. AEC is required under the Atomic Energy Act to hold a public hearing before issuance of a construction permit. The hearing is conducted by a three-man Atomic Safety and Licensing Board. the Chairman of which is a bwyer qualified in the conduct of administretive proceedings and two

\footnotetext{
- Reproduced from a booklet: U.S. Alomic Energy Commission. Ofrice of Informption Senvices. "Nowa Word about Stepby-Step Procedure in AEC Licensing of Nucker Power Reactors Radinhegical Sal :ty and Environmental Impact Review," Wanhington. D.C.. Jily 1973.
} 
other members who have appropriele qualifications. Within a few weets of accepance of an application, the Commission iswes a sotice of the public bearing which will be beld after the safety and environmental reviews have been completed. The notice of hearing includes the basic issues which must be considered at the hearing. Opportunity is afforded to interested members of the public to intervene as a party to the proceeding or to participace in the form of a "limited appearance" simply to express their views. An intervenor in the proceeding may ate a position either in suppon of or against the proposed construction permit. The notice of hearing is issued at this earty stage of the licensing process, even though the actual hearing will not be held for several months, in order to provide for full public participation in the decision makine process.

Because of the quasi-judicial mature of the hearing, there are specific requirements for becoming - full party to the proceedings by intervention. A petition to intervene, accompanied by a supporting affdavit. must state in reasonably specific detail. the petitioner's interest. how that interest may be affected by the proceeding. the specific aspects of the case on which he wishes to intervene and the basis for his contentions. In addition. the petition must be filed within the time specified in the notice of hearing. Paricipation by limited appearance is kess formal and the only requirement is that a request be made to the Commission or the Licensing Board. The Regubtory Staff may hold meetings with potential intervenors to discuss their concems.

Within 60 days of publication of the notice of hearing in the Fedend Ryiver, a special prehearing conference is convened to consider the petitions to intervene: to permit identification of the issues in controversy. if any; to determine the need for discovery by the parties (obaining further information and documents): and to discuss a funther sctieduk of actions.

7. In the meantime. the AEC Regubtory Staff has begun its comprehensive study of the application for the purpose of defermining whether there is reasomable assurance that the ptant as proposed can be built to operale safely with minimum environmental impact. This study which takes several months involves a review of the technical reports subminted by the applicant. meetings with the utility and nuctear supply system manufacturer and others as neceseany to discuss the design of the plant and details of the proposed site from the radiological safety standpoint.

After the Staff formulates its final position with nespect to radiohgical safety. it isues a Safesy Evaluation which also is made availabte in the public. The safery aspects of the application then are reviewed by the independent staturony Advisony Commitice on Reactor Safeguards. The ACRS furnishes its advice on the safety of the reactor in writing to the Atomic Energy Commission. This ketier becomes a part of the public recond.

The Regubtory Stafl abo prepares and cincubles a draft emiroamental stakemem on the impect of the proposed plam for concurnent study by odher Federal and State agencies as required Inder the provisions of the National Emvironmental Policy Act. and the regubtions of the Council on Emirononental Qualiny and the AEC inplementing that Act. After evaluation of comments received on the draft. the Regulatory Staff prepares a Final Emironmental Statement which is made available to the poblic.

The Final Environmental Statement and Safety Evahuation. inchuding changes in design or other aspects of the application. will be offered as evidence by the Regubtony Staff at the public hearing.

8. The public hearing begins normally at the nearest suitable place in the vicinity of the proposed plant site. If the hearing is uncontested. it may require as little as one day. In an uncontested case, the presiding Atomic Safety and Licensing Board's function is to consider, withoui duplicating the review already performed by the Regubtory Staff and the ACRS. whether the 
appication and the recond contain adeyuate information to support the issuance of the construction permit. However, if the hearing is cuntested. it may reyuire many weeks of testimony by expert winesses. The rime will depend on the nature of the matte: in dispute and the vigor with which opposing internenors present their case. In a contested case. the licensing Buard must decide the issues in controversy.

9. After the public hearing is completed. the Atomic Stfety and licensing Board issues an initial decision. Inder the Commission Regubtions. if the initial decision authorires the issuance of a construction permit. the AEC may issue the constuction permit prompth on the basis of the initial decisiun. Any party to the proceeding may fik exceptions to the mitial decisiun. but such exceptions in not interfere with any auhorization to issec a construction permit or reyuire that censeruction be stupped if the permit has been issued pending any action by the Appeal Boand.

10. The initial decision and any exceptions are reviewed by an Atomic Safety and Licensing Appeal Board. Normally. the administrative review process will end with the Atomic Safety and Licensing Appeal Board: however. the Commissioners can. sn their own initiative. rev ien particular issues.

11. AEC Regulations prohibit the beginning of construction of nuckar power plants and other licensed facilities tentil a construction permit has been issued. This inchudes activities such ds clearine of band. exovation. construction of nen-nuclear facilitics (such as turbo-gxnerators and turbine buibings). or other substantial action that would averseh affect the natural environment of a site.

However. certain activities such as preconstruction monitoring to establish background information rebted to the suitability of the site or to the protecicion of environmental values are permitted. This includes geologic. seismix. hydrologic. and meteorologic investigations and such ckaring and building of roads and physical structures as are reasonably necessary for the pupose of determining site suitability. These activities must be couducted in a mamer that woub keep their environmental impact to a minimum.

In some cases. the AEC can issue specific exemptions which authorixe certin orher oreconstruction permit activities where good ause exists. However, these exemptions are made cl: a case-by-case basis.

12. After about two years of consinuction work. the utility files with the AEC a inal technical safety analysis and another environmental report in support of its application for an operating license. These are subjected to the same kind of thorough safety review by the Regutatory Staff as was the case at the construction permit stage. The ACRS a ain reviews the project and fumishes its advice to the Commission. The environmental review at this licensing stage takes into account any environmental impact matters which are significantly different from those considered earlier.

13. Soon after acceptance of the operating license appliatiun. the Commission publishes notice that it is considering issuance of the license. The notice provides that any person whose interest may be affected by the proreeding may petition the AL = to hold a hearing and specifes the period of lime within which such petitions must be filed. The requirements for a valid petition are the same as those described earlier at the construction permit stage.

If no hearing is requested. the AEC iscues an operating license after the safety and environmental reviews are completed and the facility is inspected to be wre it has been satisfactoriby completed and ready for fuel loading.

If a request for a hearing is received and granced. the hearing process proceeds in much the same fashion as for the construction permit stage. Obviously, if a hearing is held at the operating 


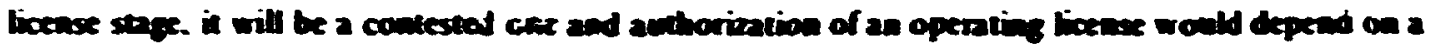
Grorable decision of the Alomic Safety and Licensing Doad.

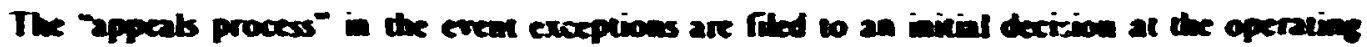

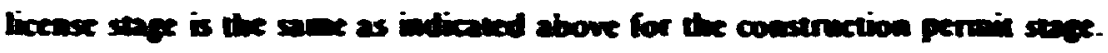

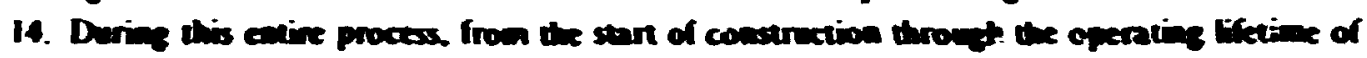

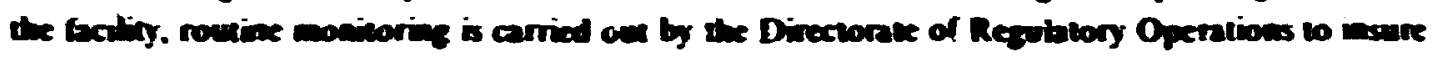

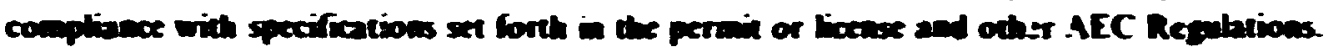




\title{
Appendix D
}

\section{Standard Fermat and Content of Safety Analysis Reports for Nuclear Power Plants}

\author{
CHATER 1.0 - INTIOSUCTON AND GENERAL DESCRITION OF FLAT
}

1.1 Introbetion

1.2 Ceneral itran Decription

1.3 Comperivan Tralos

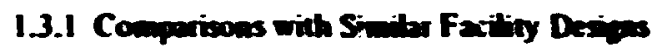

1.3.2 Comporicon of Fial and fretimiany information

1.4 Idemcification of Arents and Coatractors

is Reque racents for Furter Teciancal boformotion

1.6 Material liscoporated ty Refereme

\section{CHATIER 2.0 - STE CHARACTERISTKS}

2.1 - coppaphy and Democaphy

2.1.1 Site Location

2.1.2 Sice Description

2.1.3 Population and Population Distribution

2.1.4 Uses of Adjaceat Lads and Waters

2.2 Nearby Industrial. Transportation and Military Facilities

2.2.1 Localions and Routes

2.2.2 Descriptions

2.2.3 Evaluations

23 Mrteordogy

2.3.1 Regional Climatology

2.3.2 Local Meteoroloy

23.3 Onsite Meteorolojical Mexaurements Frograms

2.3.4 Short Tem (Accident) Diffusion Euimeles

23.5 Long Term (Routine) Diffusion Estimates

24 Hydologi Enginering

2.4.1 Hydrologic Description

2.4 .2 Floods

2.4.3 Probable Maximum Flood (TMF) on Sireans and Rivers

2.4.4 Potentiad Dem Faiteres (Seisanicelly Induced)

2.4.5 Probable Maximuna Sure and Seiche Floodiay

2.4.6 Probeble Maxinum Trunomi Floodiag

2.4.7 la Froding

2.48 Cooline Waver Canch and Rearvoins 


\section{4: Cranod Dinersions}

24.10 Pownes Prowection Requivenoms

24.11 Lon Eaver Coningations

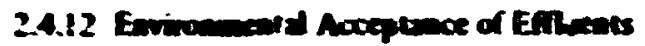

24.13 conomons

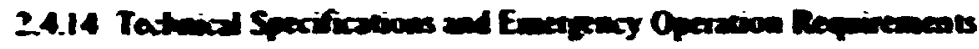

25 Coolus and Stinding

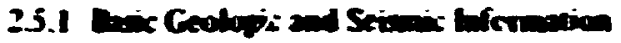

25.2 Vincang Grom Mosion

253 Surface Fandine

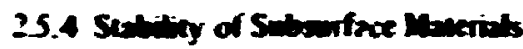

255 Sope seming

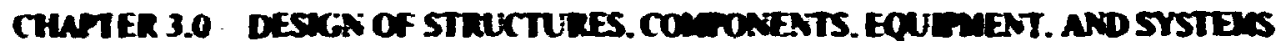

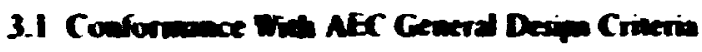

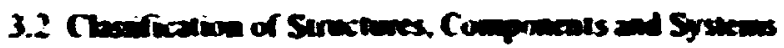

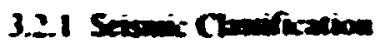

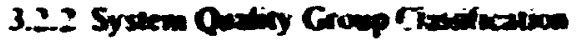

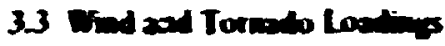

3.3.1 Wind Loumings

3.3.2 Turma Lontios

3.4 Wake Lend (Food) Desiep

3.4.1 Flood Elevativas

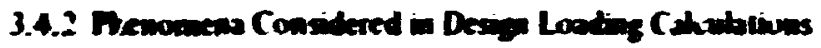

3.43 Floud force Apriciation

3.4.4 Food nowerion

3.5 miste Protextion

3.5.1 misile Eurriers and Lantings

3.5.2 Mine Setertion

3.5.3 Selected Misiles

3.5.4 Derriet Dexipe Anowleres

3.5.5 Mivile Drrict Fealures

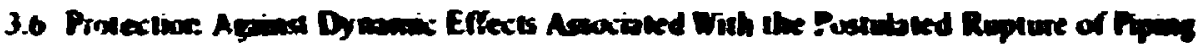

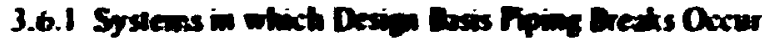

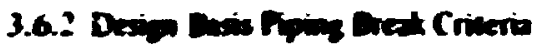

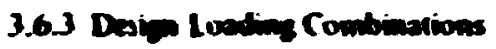

3.6 .4 Dymanc Antyres

3.6 .5 Protective Mlaneses

3.7 Stranc Desing

3.7.1 Srimic lapel

3.7.2 Sexinc Sysiem Aadys

3.7.3 Scinin Sobeystem Adys

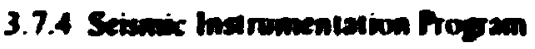

3.7.5 Setivenc Detivg Control 
3.8 Desion vil Campony i Sencetumes

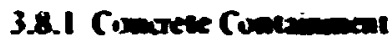

38.2 Suet Contrinem Syster

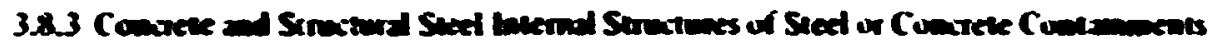

38.4 Odwa Cancony 1 Strutumes

38.5 Fonditions ad Concrete Sisports

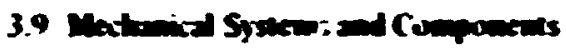

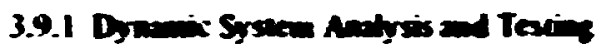

3.9.2 Aste Code Clan 2 and 3 Componens

3.9.3 Componenes Non Conened by Ascie Cole

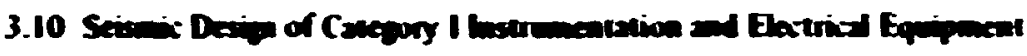

3.10.1 Setwic Desige Criveria

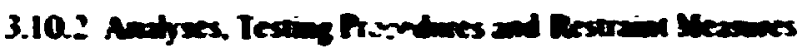

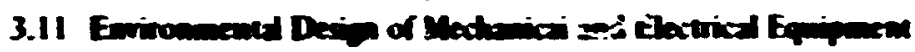

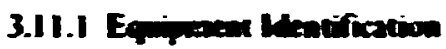

3.11.2 Quaficotion Texes and Amatyses

3.113 Qentifation Tex Resdes

3.11.4 Low of Ventibaion

\section{CHANTER 4.0 - REACTOR}

4.1 Smang Dexcripion

4.2 Mathanal Deine

421 Fed

\$2 Rexior Vand laverents

\$.2.3 Deactivity Control Syseres

4.3 Nuctera Decis

4.3.1 Desin Des

4.3.2 Dacripition

4.3 .3 Andytical Methods

4.3.4 Changs

4.4 Therinal and flychadic Desiph

4.4.1 Daiph Dis

4.4.2 Dractipion

4.4.5 Enduation

4.4.4 Teating and Verification

4.4.5 Inarmomencation Requirements

CHAPTER 5.0 - REACTOR COOLANT SYSTEM AND CONNECTED SYSTEAS

S.1 Sumomary Descriplion

5.1.1 Scthematic Flow Dieprem

S.1.2 Mipies and Instrumentation Dipram

S.1.3 Elevation Drawios 


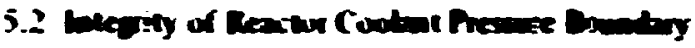

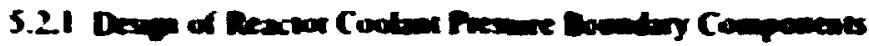

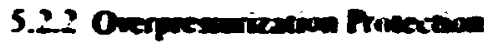

5.3 Conar Mand Condarions

5.24 Frecture Toundor

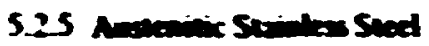

526 Rmp Fyomeds

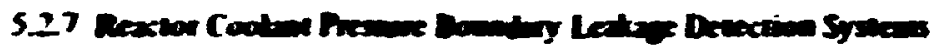

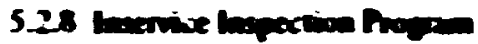

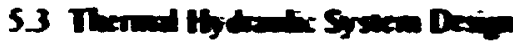

5.3 .1 Andyical welowis and Dox

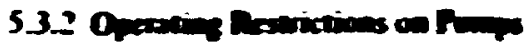

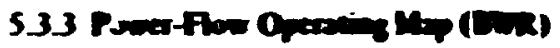

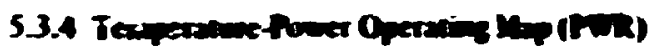

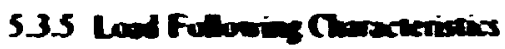

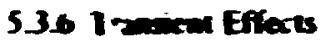

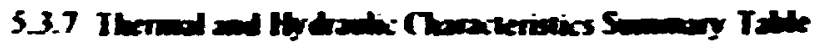

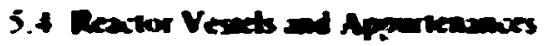

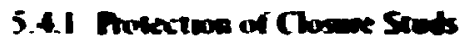

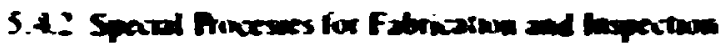

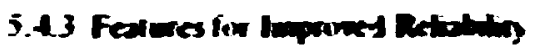

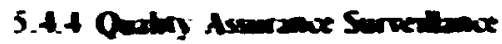

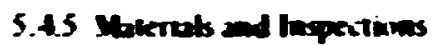

5.46 Deron Vexaet Despe Data

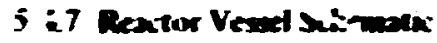

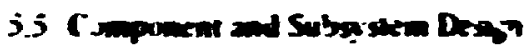

5.5.1 Reatux Cindat Rumps

5.5.2 Stean Cencraturs

5.5 .3 Deacter Cinteat hing

5.5.t 3y- Stean Lue Fhr Resirntions

$5.5 .5 \mathrm{Mb}$ Stean Len lsubion System

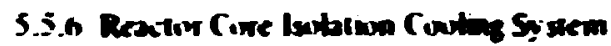

5.5.7 Residual Heal Rewnowal Sy slem

5.5.8 Reatur Conbat Cleasup Sy suen

5.5.4 Mbin Stean Lme and feed Water hping

5.5 .10 Mresourinet

5.5.11 Mesouriar Retief Tank

5.5.12 Vatres

5.5.13 Safery and Retief Vatwes

5.5.14 Component Supporis

5.6 Instrumentalimm Requirements 


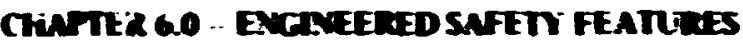

a) Const

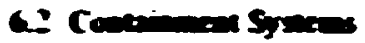

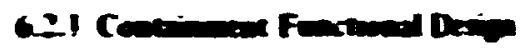

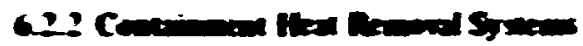

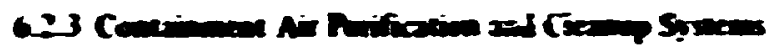

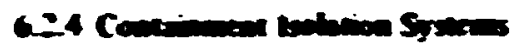

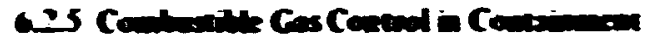

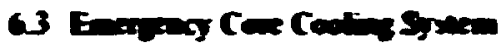

63.1 Das as

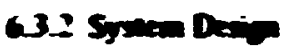

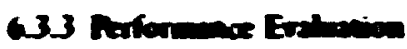

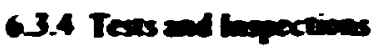

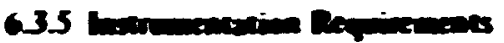

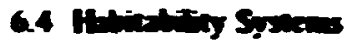

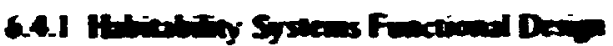

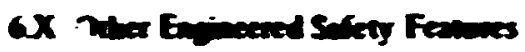

6x) Dain Dos

$6 \times 2$ Stsian Dain

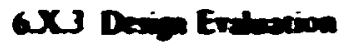

$6 x 4$ Tots and bections

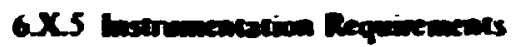

CHATER 70 - INSTREYENTATON ANDCONTHOLS

7.J Introthetion

7.1.I Lavification of Sefety Relaned Systems

7.1.2 Ilendifention of Sefery Criveria

1.2 Rector Fip Syacm

1.21 Descripuion

7.22 Antysis

73 Enjected Sofety Featwe Sydems

7.3.1 Description

1.3.2 Ambis

7.4 Syseems Requiced for Safe Suntdown

7.4.1 Descripation

1.4.2 Analysis

7.5 Sefety Related Daplay Instrumentation

7.5.1 Dacription

1.5.2 Andysis

7.6 Al Oher Systems Recuired for Safety

7.6.1 Decription

7.6.2 Analysis 


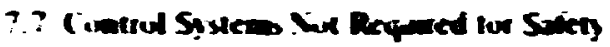

$? .1$ Oxnptum

7.8. Ashos

\section{CHATTE X.0 ELCTRK NOWER}

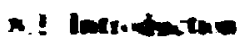

a.: Orifule Anoer Systes.

n. I Dexipara

$x=1$ indes

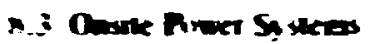

x.j.I He numet Snstems

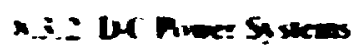

\section{chater 90 Al xulariststes}

4.1 Fucisionge ad thboring

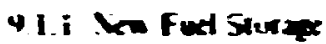

4.1 I Spent Fad Sirmex

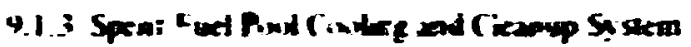

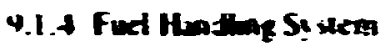

4 : viter Sustems

4.:! Suatmm Service Diler St seem

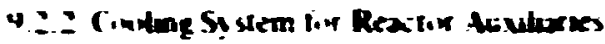

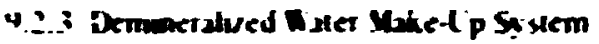

4.: I Rowable and Sonitar Mater jyskems

4 . 5 Chromic Heal Sonh

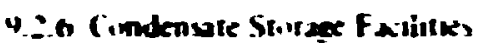

4.3 Privess turvalures

4.3.1 Cimprexud Air St Hems

4.3.2 Pr.iess Simpling Sy stem

4.3.; Fyupmeni and Fhr x Dranaze System

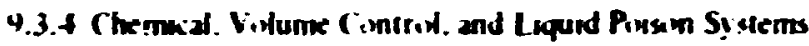

4.3.5 Faukd Fued Detecin'? System

9.4 Findinming. Hearmg Fondeng. and Ventulaikn Systems

4.4.I Controd Rimm

4.4.2 Auxiliary Budding

9.4.3 Radwaste Area

0.4.t Turbine Budding

9.5 Other Auxilary Systems

9.5.1 Fire Prutection 5ystem

9.5.2 Communicatikm Systems

4.5.3 Lighting Systems

9.5.4 Diesel Ceneralor Fuel Oil Siorage and Transfer Sysiem

9.5.5 Diesel Generator Coxiling Woler Sysiem

9.5.6 Dicsel Generalur Siarling Sysiem

9.5.7 Dissel Cenerdior Luhrication System 


\section{CHAPTER IN.0 - STEAM AND POWER CONVERSION SYSTEM}

10.1 Summary Description

1).2 Turbine-Generalor

10.2.1 Design Bases

10.2.- Desiription

10.2.3 Turbine Missiies

10.2.4 Eviluation

10.3 Main Stearn Supply System

10.3.1 Design Bases

10.3.2 Description

10.3.3 Evaluation

10.3.4 Inspection and Testing Requirements

10.3.5 Winter Chemistry

10.4 Other Fealures of Steam and Power Conversion System

10.4.1 Main Condensers

10.4.2 Main Condensers Evacuation System

10.4.3 Turbine Gland Sealing System

10.4.4 Turbine Bypazs System

10.4.5 Circulating Water System

10.4.6 Condensate Ckan-Up System

10.4.7 Condensate and Feedwater Systims

10.4.8 Steam Generator Blowdown Systems

\section{CHAPTER II.0 - RADIOACTIVE WASTE MANAGEMENT}

II.I Source Terms

II.2 Liquid Waste Systems

11.2.1 Design Objectives

11.2.2 Systems Descriptions

11.2.3 System Design

11.2.4 Operalıng Procedures

11.2.5 Performance Tests

1:.2.6 Estimuted Releases

11.2.7 Release Points

11.2.8 Dilution Factors

11.2.7 Estumated Doses

11.3 Gaseou= Wrefr Syer pms

:1.3.1 Drsig: Objectives

II.3.2 Sy stems Descriptions

11.3.3 System Design

1.3.4 Operatir.g Procedures

i 1.3.5 Performance Tests

11.3.6 Estimated h.eleases

II.3.7 Release Points 
11.3.8 Ditution Faxtors

1!3.9 Estimated Doses

11.4 Hovess and Efluent Radiological Monitoring Systems

11.4.I Design Objectives

11.4.2 Continuour Lonitorias

11.4 Samplas

11.4.4 Inservive Inepections, Calibration, ad Mainenance

11.5 Soldd Waste System

11.5.1 Desion Objectives

11.5.2 System inputs

11.5.3 Equipment Descriptiun

I!.j.4 Expecteu Votumes

11.5.5 Packzing

11.5.6 Storeq Facilities

11.5.7 Shipment

11.6 Orfsite Radiological Monitoring Program

11.6.1 Expected Background

11.6.2 Critical Pathways

il 1.3 Sampling Mediz, Locations and Frequensy

11.5.4 Analytical Sensitivity

11.6.5 Data Analyss and Presentation

11.6.6 Program Statisixal Sensitivity

CHAPTER 12.0 - RADHATION PROTECTION

12.1 Shiclding

12.1.1 Design Objectives

12.1.2 Design Description

12.1.3 Source Terms

12.1.4 Area Monitoring

12.1.5 Operating Procedures

12.1.6 Estimaies of Exposure

12.2 rentilation

12.2.1 Design Objectives

12.2.2 Design Desription

i 2.2.3 Source Terms

12.2.4 Airborne Radioactivity Monitoring

12.2.5 Operating Procedures

12.2.6 Estimates of Inhalation Doses

12.3 Health Physics Progam

12.3.1 Progiam Objec'ives

12.3.2 Faxilities and Equipment

12.3.3 Personnel Dosimetry 
CHATTER 13.0 - CONDUCT OF OEERATIONS

13.1 Orpanimational Structure of Applioan

13.1.1 Corporate Orgaization

13.1.2 Operation Orgaization

13.1.3 Qualification Requirenaents for Nuctear Mant Personael

13.2 Training Program

13.2.1 Program Description

13.22 Retrining Rogran

13.2.3 Replecewant Truining

13.24 Records

13.3 Eunerpency Fianing

13.4 Review and Audit

13.4.1 Review and Audit - Construction

13.4.2 Review and Audit - Test and Operation

13.5 That Rrocedures

13.6 Fant Records

1 3.6.1 Plant History

13.6.2 Operation Records

13.6.3 Event Records

13.7 Industriol Security

13.7.1 Personnel and Plant Design

13.7.2 Security Plan

CHAPTER 14.0 - INITI.HL TESTS AND OPERATION

14.1 Test Progam

14.1.1 Admiristrative Procedures (To ding)

14.1.2 Administrative Procedures (Modifications)

14.1.3 Test Objectives and Procedures

14.1.4 Fuel Looding and Initial Operation

14.1.5 Administrative Procedures (System Operzion)

14.2 Augmentation of Applicant's Staff for Initial Tests and Operation

14.2.1 Organizational Functions, Responsibilities and' Authorities

14.2.2 Intcrelationships and Interfaces

14.2.3 Personnel Funtions, Responsibilities and Authorities

14.2.4 Personnei Qualitications

CHAPTER 15.0 - ACCIDENT ANALYSES

15.1 Ceneral

15.1.X Event Evaluation

CHAPTER 16.0 - TECHNICAL SPECIFICATIONS 


\section{CHAPTER [1..) - WUALTY ASSURANCE}

17.1 Quality Assurance During Deciog and Construction

17.1 i Cremization

17.1.2 Qu-lity Asourzace Rrogrin

17.1.3 Desion Control

17.1.4 Procurement Document Control

17.1.5 Instructions, Trocedures, and Drawings

17.1.6 Document Control

17.1.7 Control of Purchosed Material, Equipment, and Services

17.1.8 Identification aed Control of Malerials, Parts and Components

17.1.9 Control of Speciel Processes

17.1.10 Imspection

D.1.11 Tesi rontrol

17.1.12 Crnircl of Mesouring and Tes Equipment

17.1.13 Handives, Slorave, and Shippine

17.1.14 Inspection Test and Operatine Status

17.1.15 Nonconforming Materials, Perts or Componxnts

17.1.16 Conrective Action

17.1.17 Quaity Asourance Records

17.1.18 Audits

17.2 fuality iverance Proge an for Seation Operztion 


\section{Appendix E}

\section{Standard Format and Content of Environmental Reports for Nuclear Power Plants}

1. FURROSE OF THE RRONOSED FACTLTY

1.I Need for powet

1.I.I Lod ctaraiteristics

I.I.2 Fower supply

1.1.3 Capocity requirement

I.t.4 Sencement on area need

1.2 Ober objectives

I. Consequesaces of detay

2 THE SITE

2.1 Sile barivon and byoul

2.2 Regonal demugraphy . bad and waler use

2.3 Regional histuric, senic. cultural and natural bondmarks

2.4 Geology

2.5 Ibydrology

2.6 Meseurulugy

2.7 Eavlogy

2.8 Backpound radiohyikal tharaiteristics

2.9 Oher envirommental features

3. THE PLANT
3.1 External appearance
3.2 Reactor and steam-etectric system
3.3 Pant water use
3.4 Heat dissipation sy stem
3.5 Radwaste systems
3.6 Chemical and biocide wastes
3.7 Sanitary and other waste gystems
3.8 Radioactive materials inventory
3.9 Transmission faxilıties

4. ENVIRONMENTAL EFFECTS OF SITE PREPARATION. PLANT AND TRANSMISSION FACILITIES CONSTRUCTION
4.1 Site preparation and plant consiruction
4.2 Transmiscion facilities construction
4.3 Resources committed 
S. ENIIRONMENTAL EFFECTS OF PLANT ORERATION

S.1 Effects of operation of heat discipation system

5.2 Rudio poal inpact on biote other the inan

5.2.1 Exposenre pethways

5.2.2 Redioactivily in enviroament

5.2.3 Dose rate estimples

5.3 Radulagical inapent on man

S.3.1 Exposare pathways

5.3 .2 Liquid efficents

5.3.3 raseous eflowents

5.3.4 Direct radintion

5.3.4.1 Radiation from facility

53.4.2 Traspontation of radiosctive materiats

5.3 .5 Sumanary of annul radiation doses

5.4 Effects of chemical and biocide diechares

5.5 Effects of maicary and odher waste diach res

5.6 Effects of operation and mainteasace of the trandinision system

5.7 Ohat effects

5.8 Rexources committed

5.9 Recomaniovionis and dimation

6. EFFLUENT AND ENVIRONMENTAL MEASURGMENTS AND MONITORING RROCRAMS

6.1 Applicant's pre-pperational eaviomanental prograns

6.I.I Surface waters

6.1.2 Ground water

$0.13 \mathrm{Air}$

6.1.4 Lind

6.1.5 Ractologion surneys

6.2 Applicant's proposed operational monitories proporas

6.2.1 Radiologial movitorias

6.2.2 Chemical efllwent monitorion

6.2.3 Thermal efll went wowitorias

6.2.4 Meteorolojot momitoring

6.2.5 Eeologid momitoring

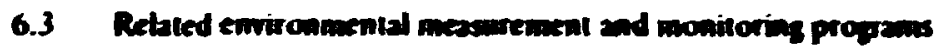

7. ENVIRONUENTAL EFFECTS OF ACCIDENTS

7.I That accidents burling redionctivity

7.2 Ohber accidents

8. ECONONK AND SOCIAL EFFECTS OF MLAT CONSTRUCTION AND ONERATION

8.1 Bomefins

8.2 Coss 


\section{ALTERNATIVE ENERGY SOURCES AND STTES}

9.1 Alteratives not requiries the creation of new fanctative capocity

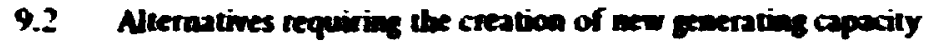

9.2.1 Selection of candidate areas

9.2.2 Selectiva of and inte siz-phat alterwatives

9.3 Costeffectiveness cumperison of candith sieptat alkermatives

10. RANT DESGN ALTERNATTVES

10.1 Coolias system (exchsive of iatche and diatange)

102 latice system

103 Dixchere ysuem

104 Chemical wrete treatheat

10.5 Diocide ineatmeat

10.6 Sziton wase gystem

107 ingid radwate sysicus

108 Guncous radwaste gystems

10.9 Transaivion facitives

10.10 Oriner systems

I. SUMMARY DENEFT COST ANALYSIS

12 ENYIRONENTAL AMOV ALS AND CONSULTATIONS

13. REFERENCES

Tares

Table I bevefus from dhe Hoposed Facility

Trbie 2 mometiad bens for Ceneratiog Costs

Tale 3 Environenatal Factors to be Used in Comparing Altemative Frant Systems

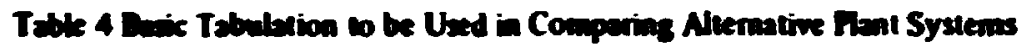
Table 5 Dusc Tabulation to be Used i Companing Ncermative Transuision Routes Table 6 Cost Description of Proposed Factity and Transmiation Hookup

\section{Ansumess}

1. Quedionative for Eliciting Data for Rodionctive Source-Term Calculations

2. Example of Charts Strowiag Radiation Expowire Pathorys 
Appendix F

Population Risk Profiles for Texas and Louisiana Industrialized Areas 
20
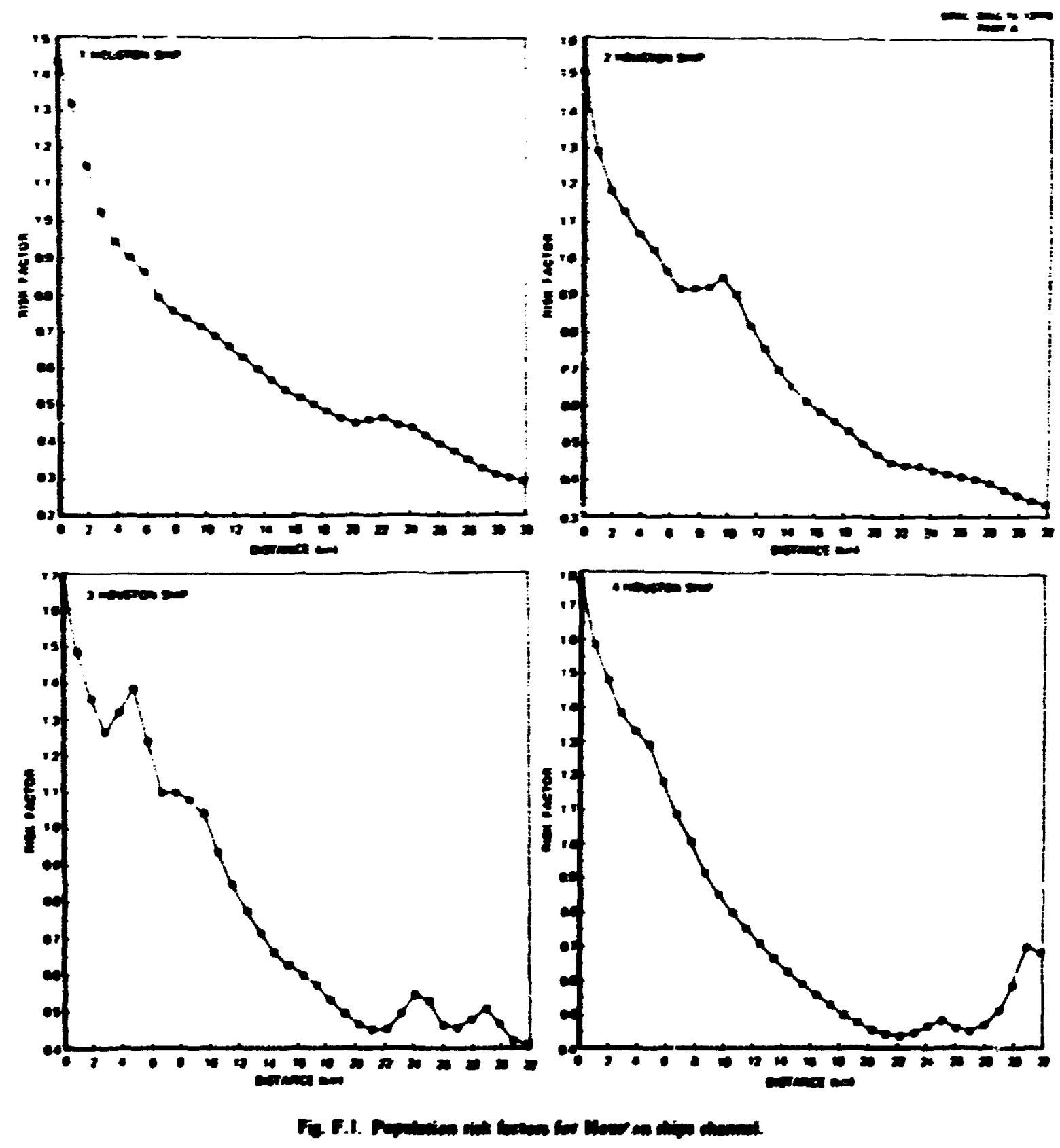

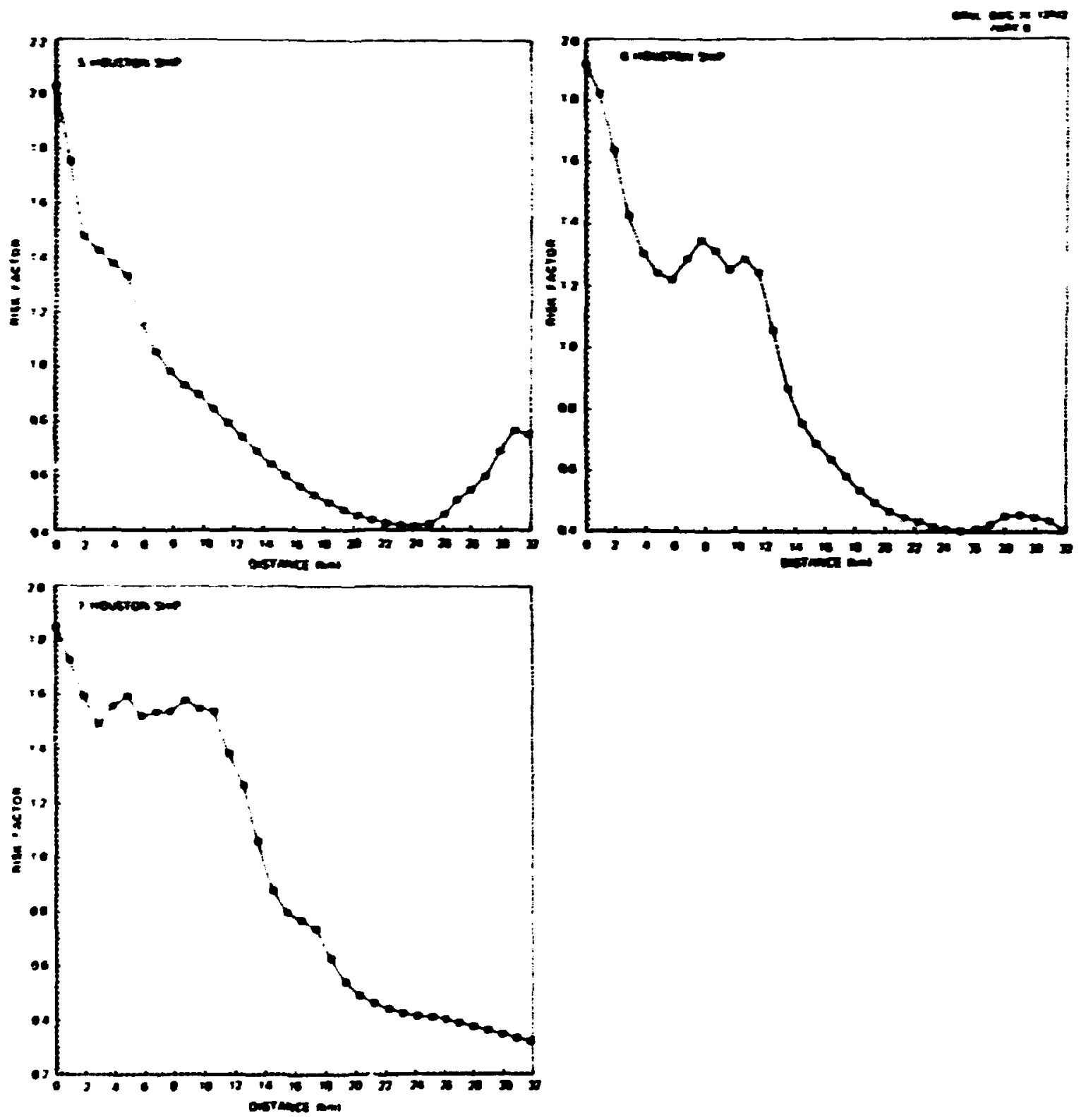

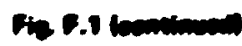



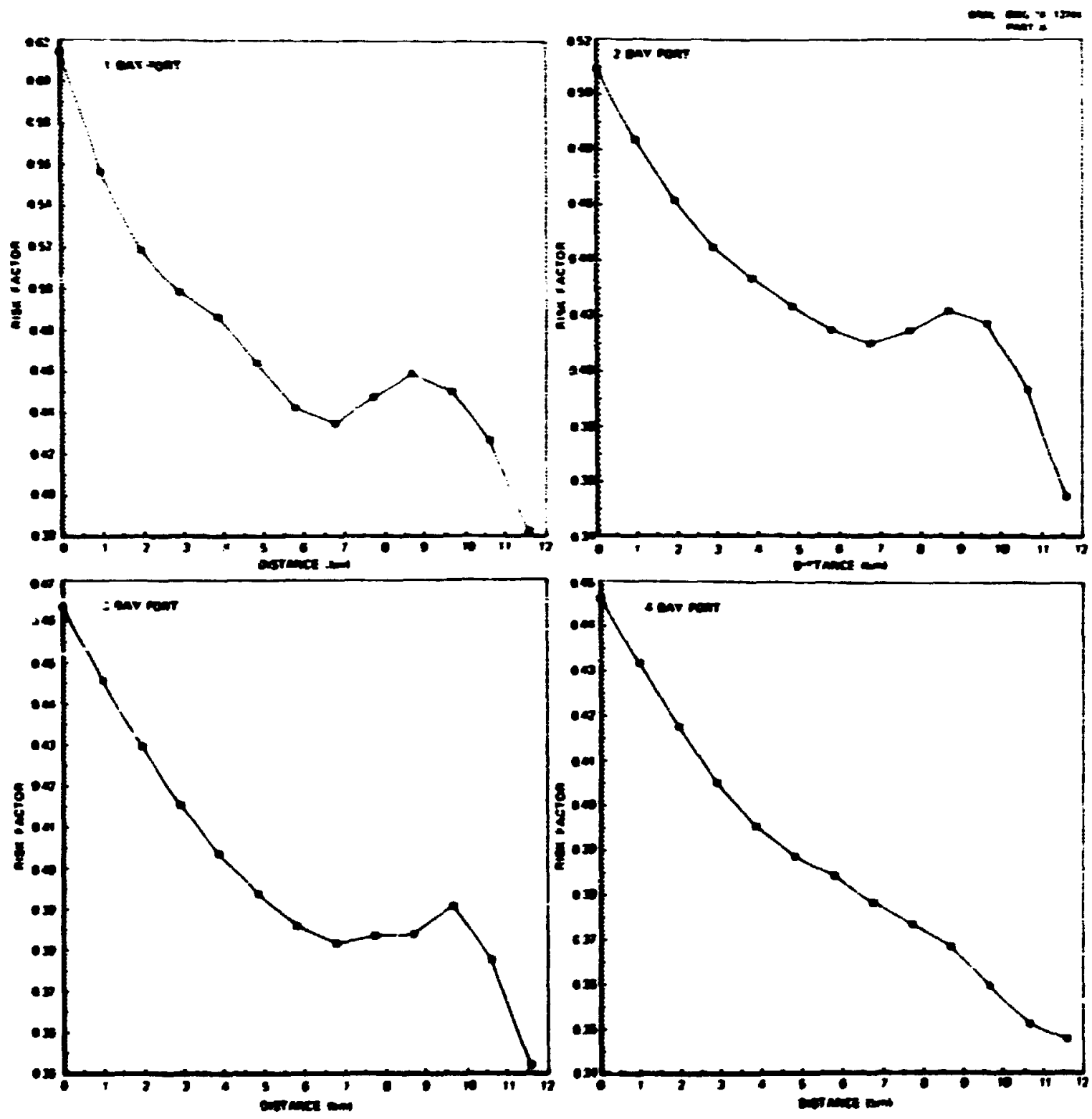

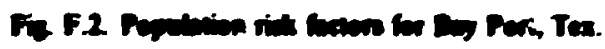



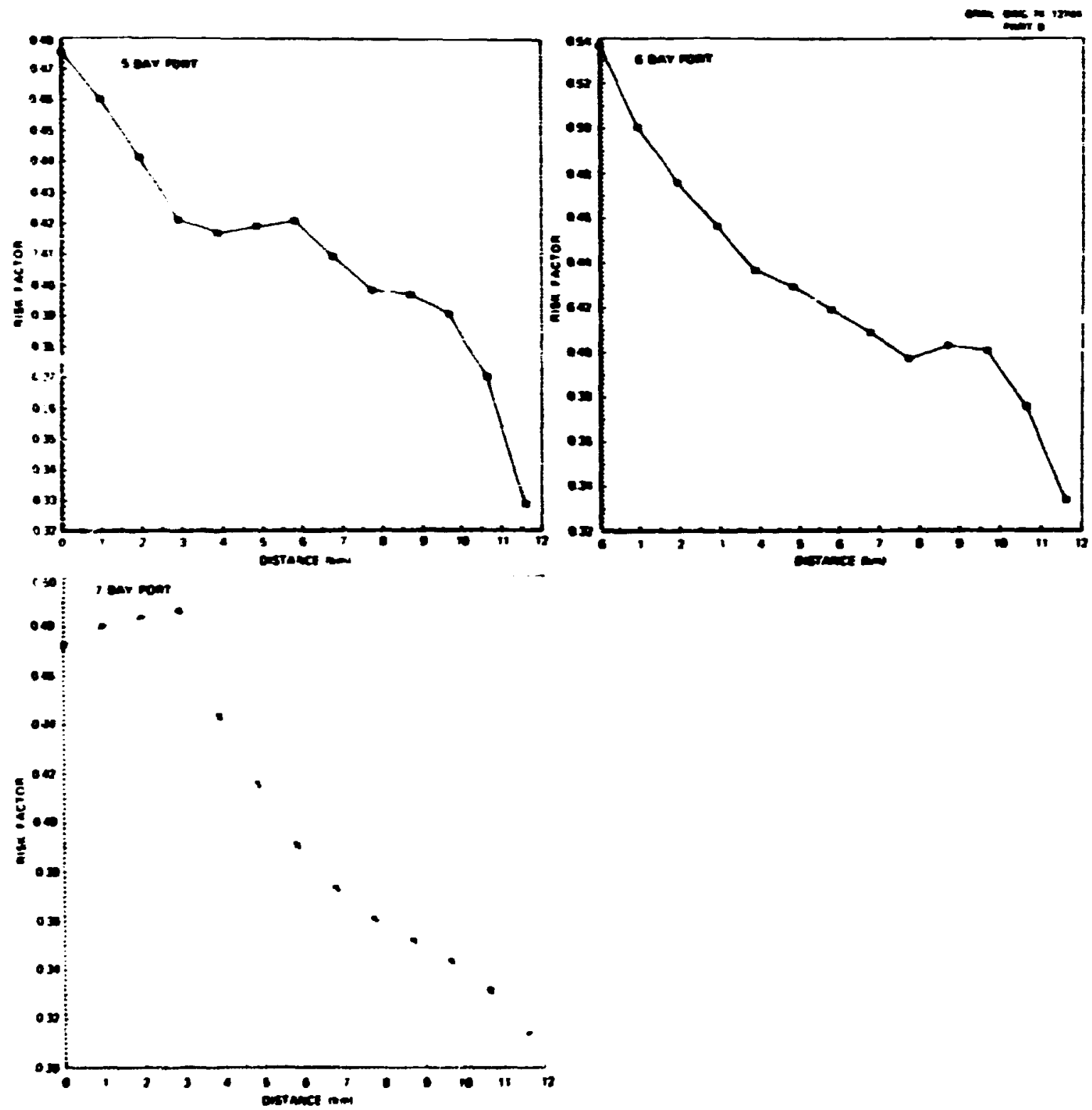

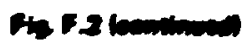


233
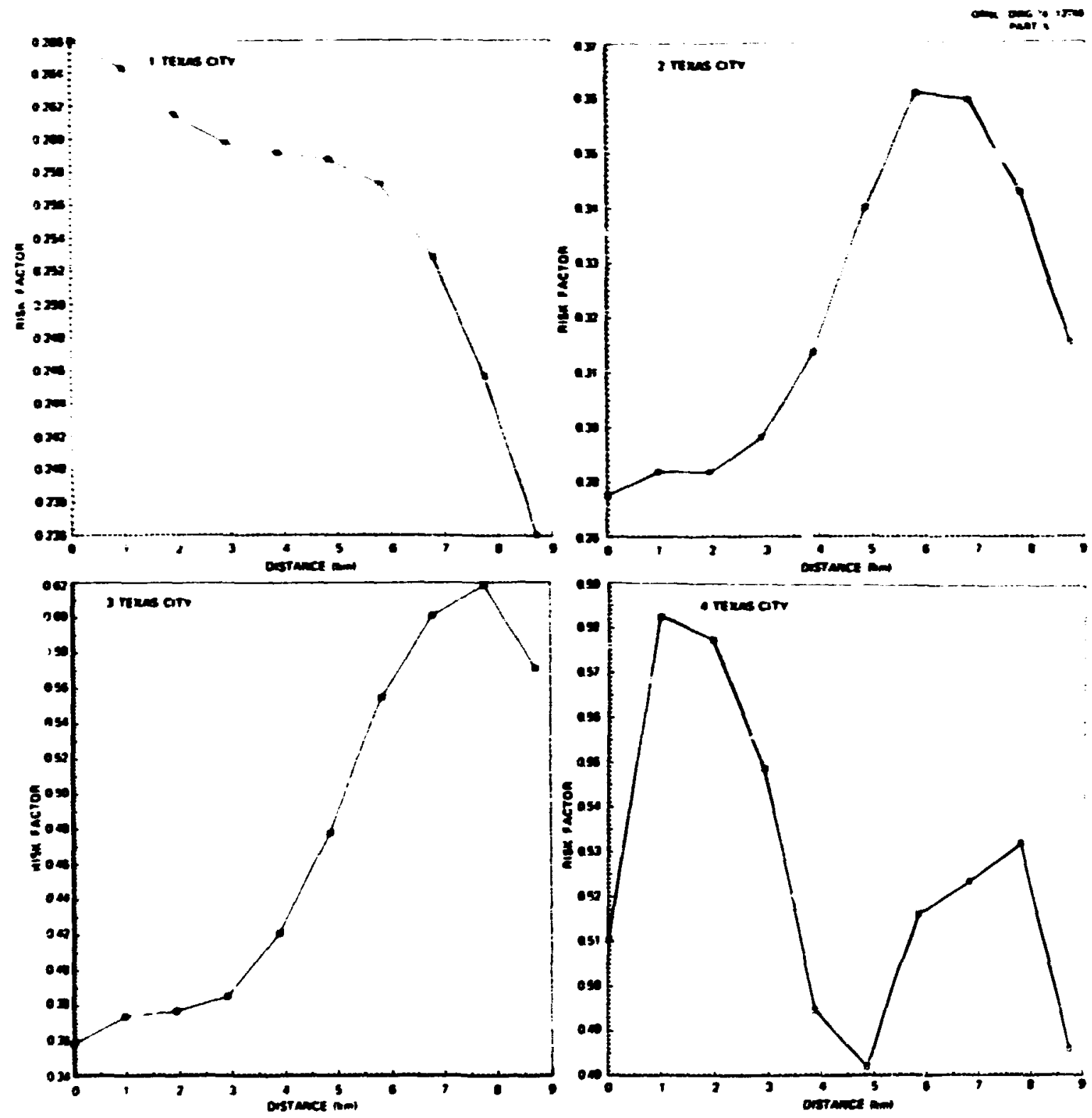

Fe F.3. Population rist fecton for Texas Cing. Tex. 

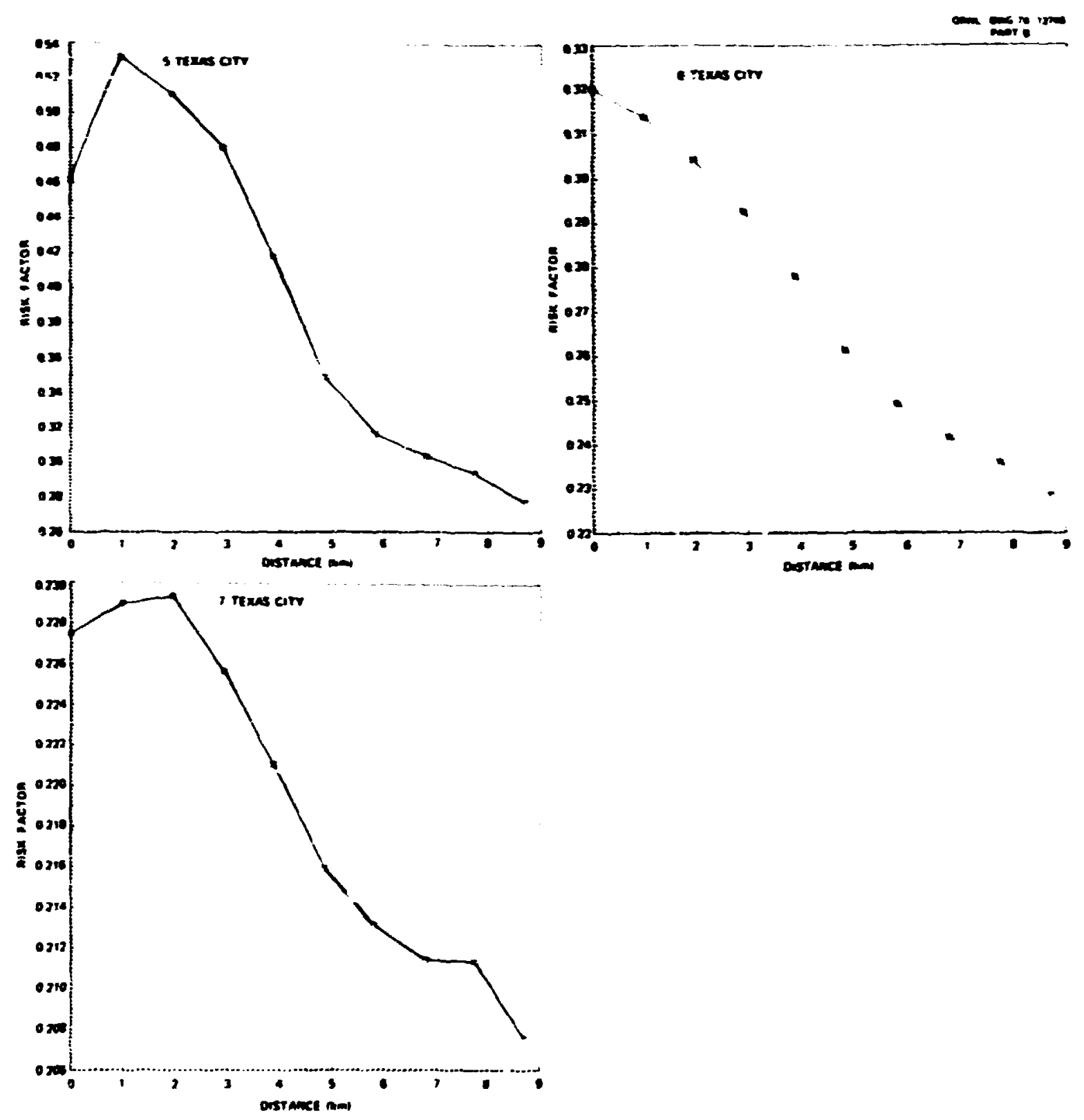

Fis F. 3 leontionens 


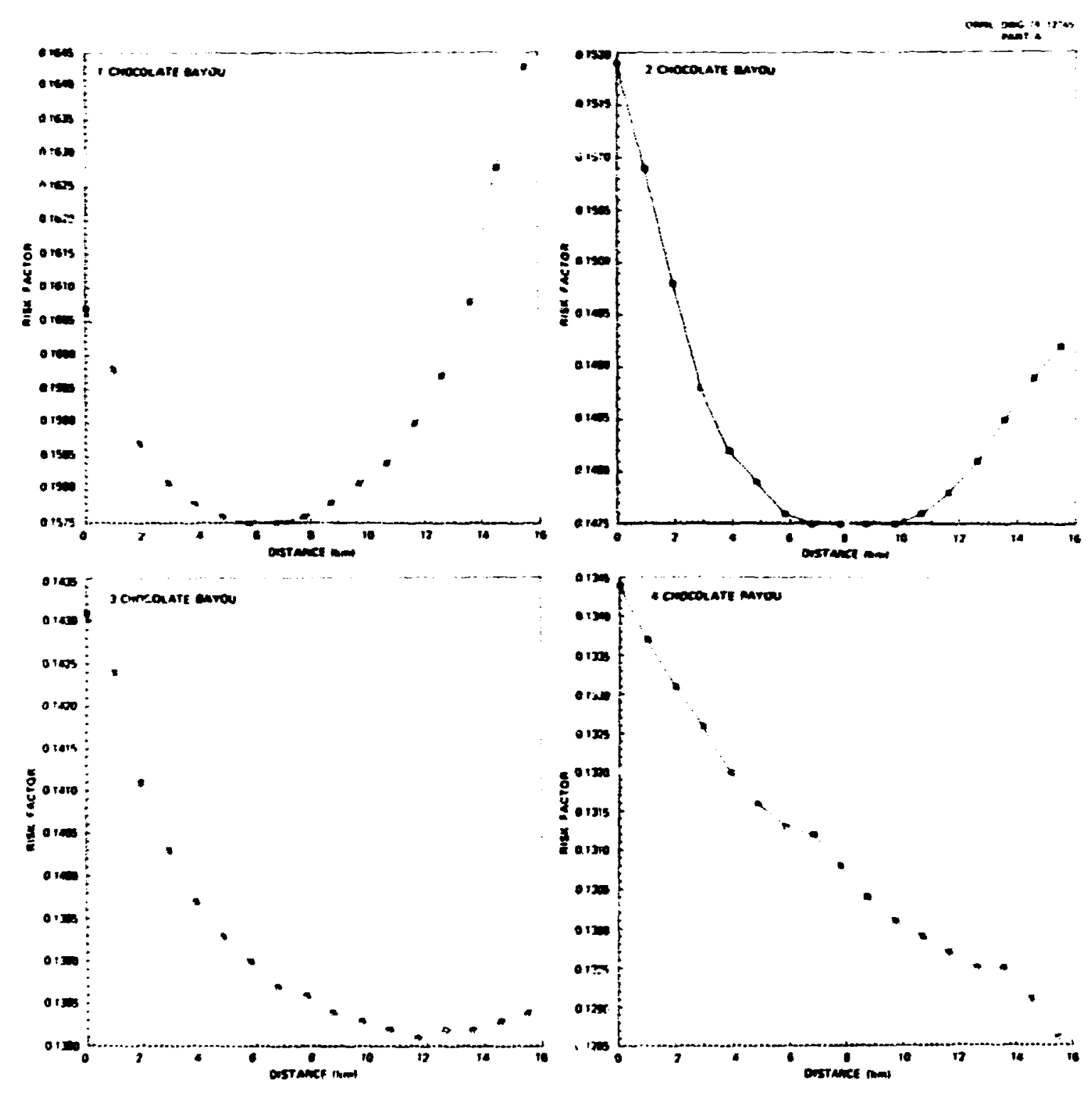

Fie F.4. Popolution riak fectors for Chocolute Beyou, Tex. 
30:
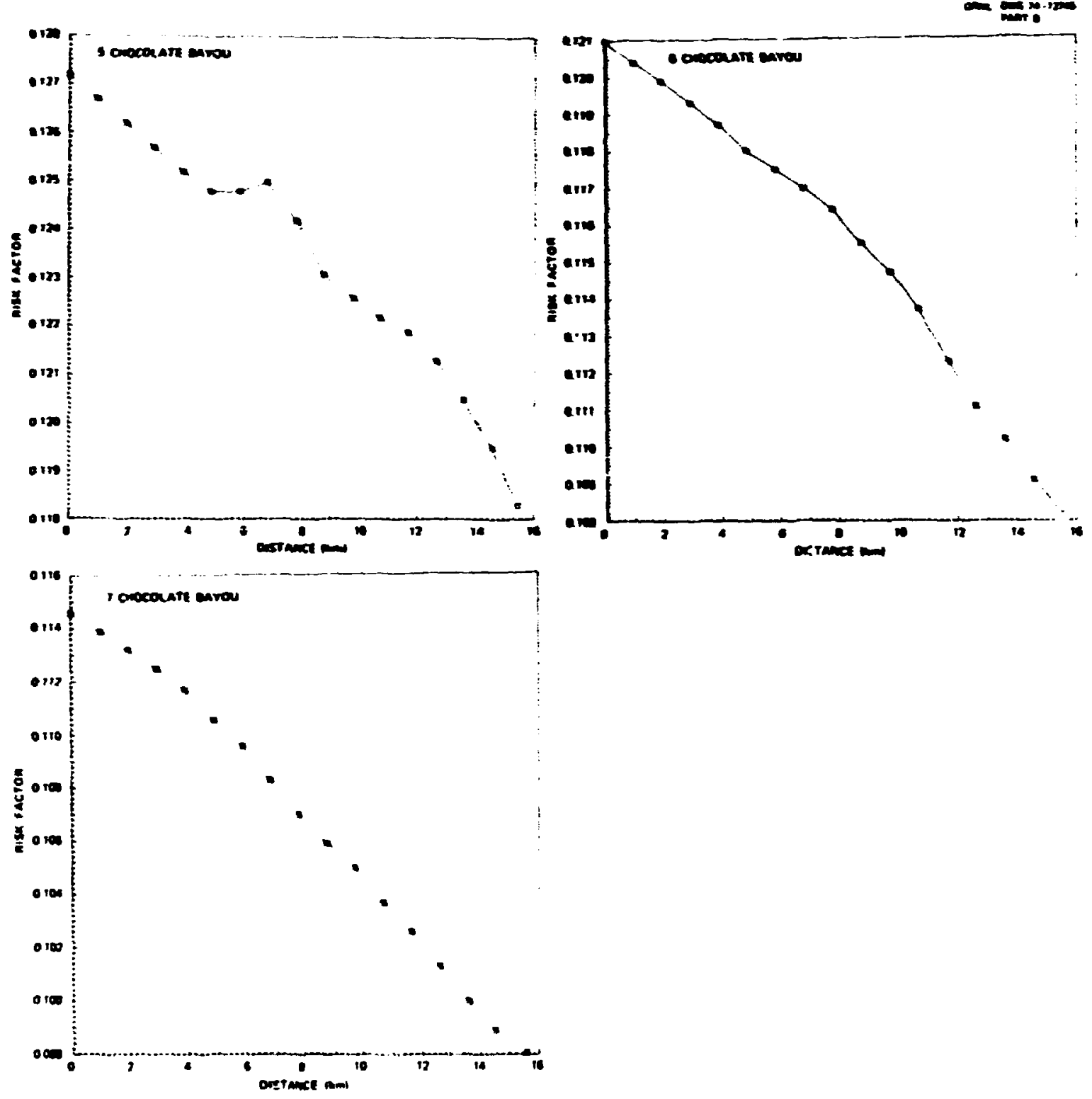

Fin F.A leordinged 

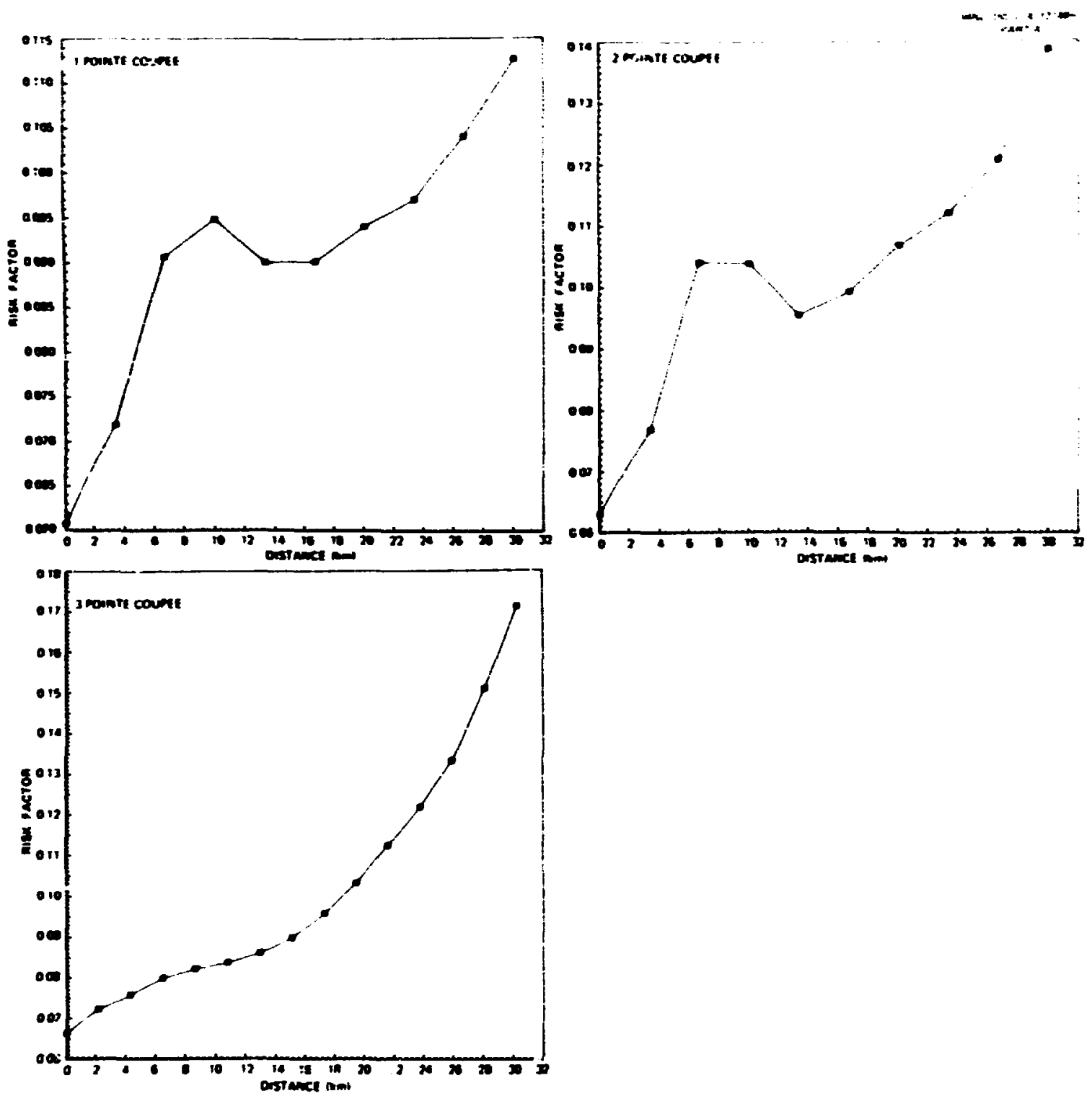

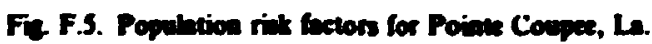



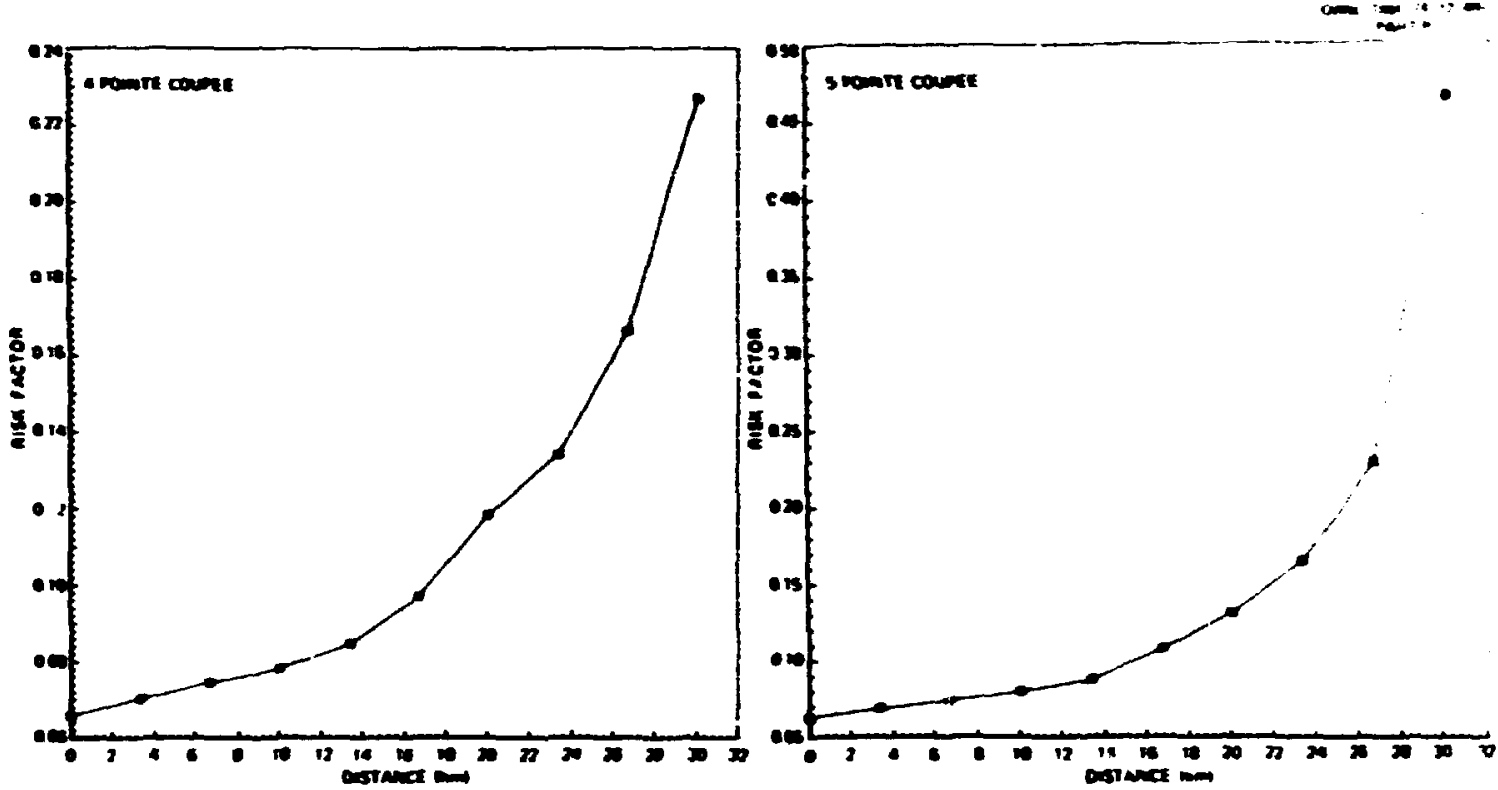

Fis FS Genominan 

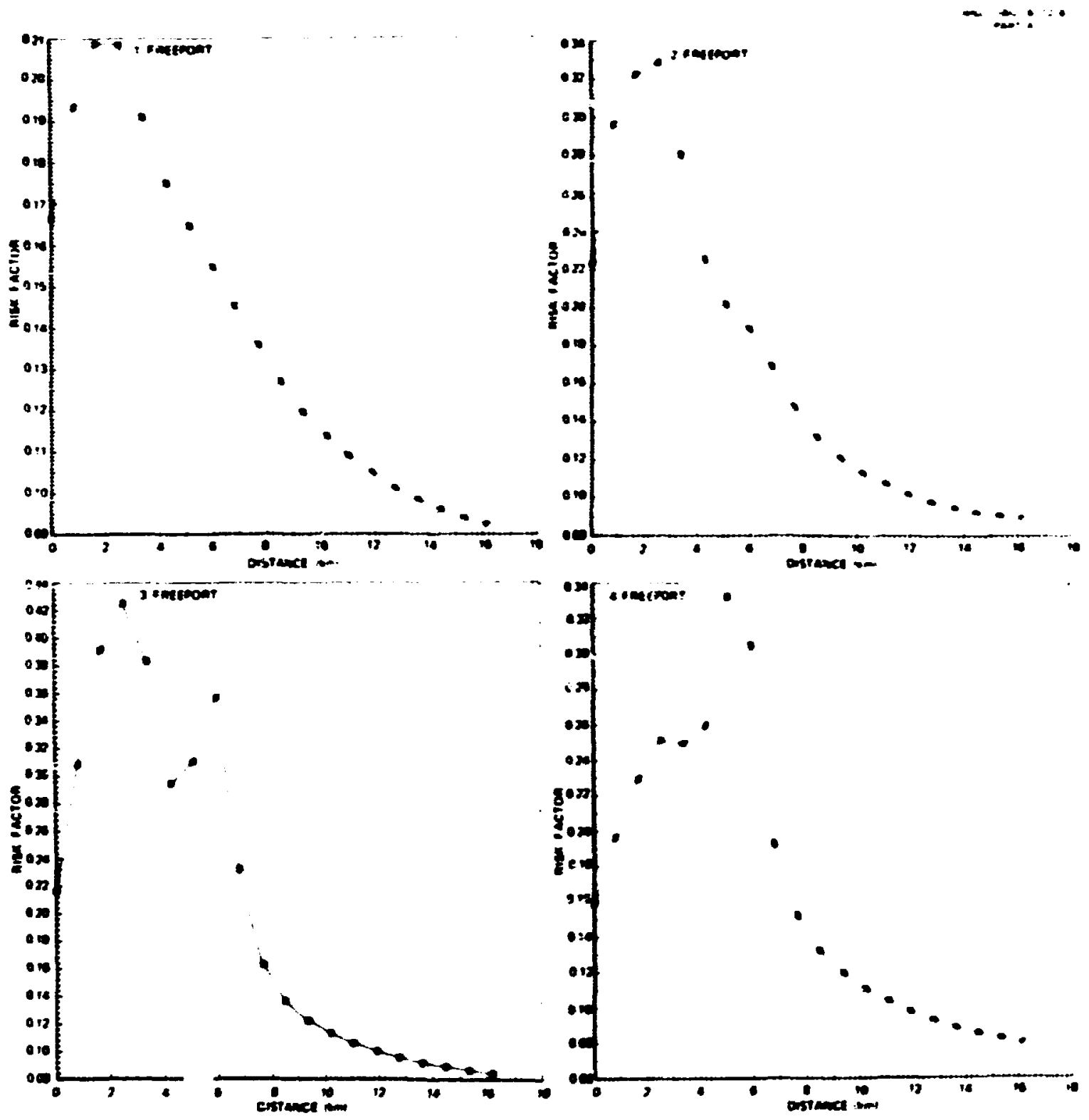

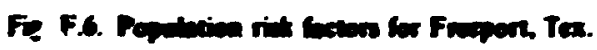




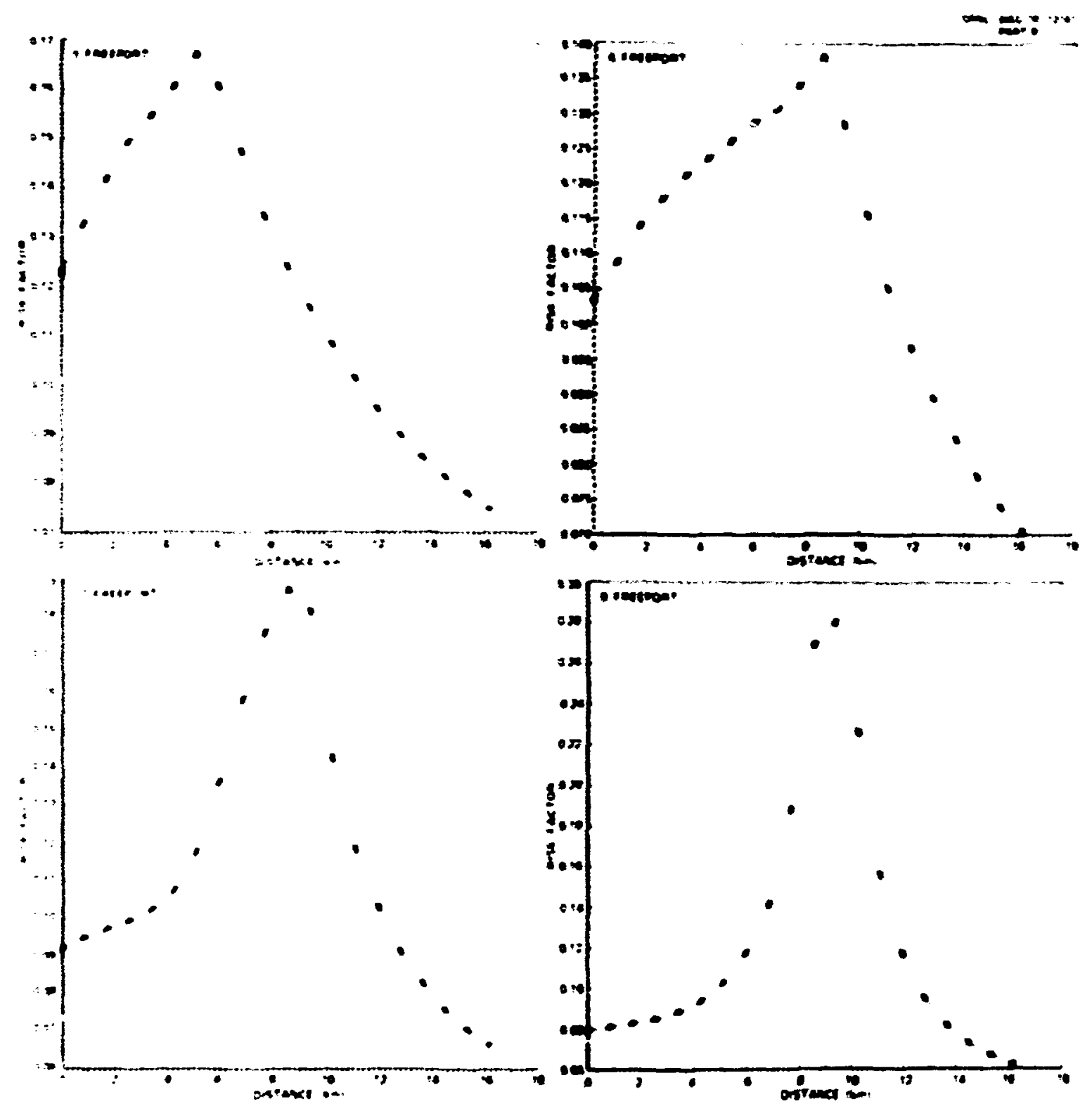

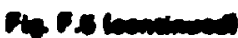


306
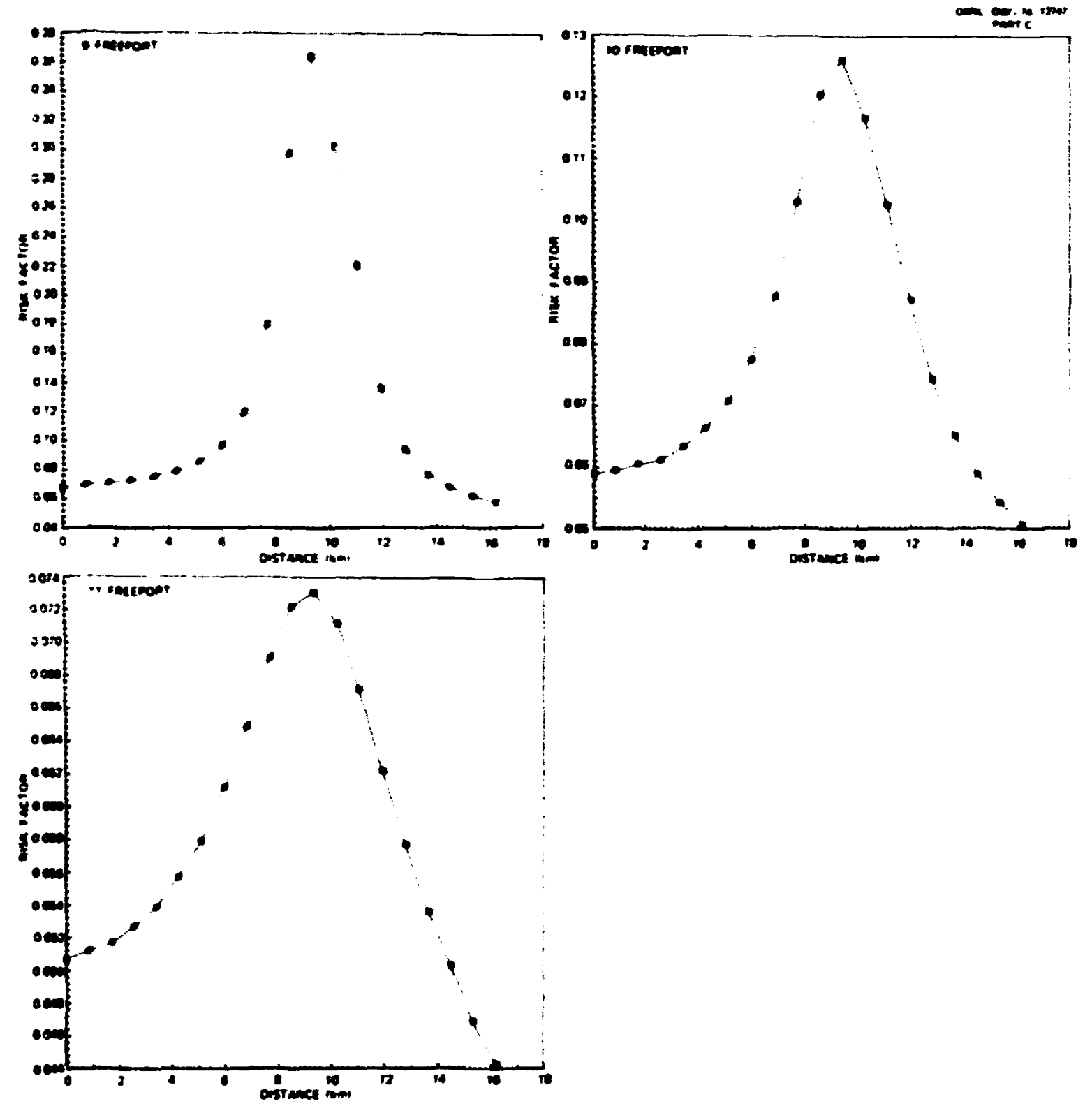

Pe Fo leantimans 

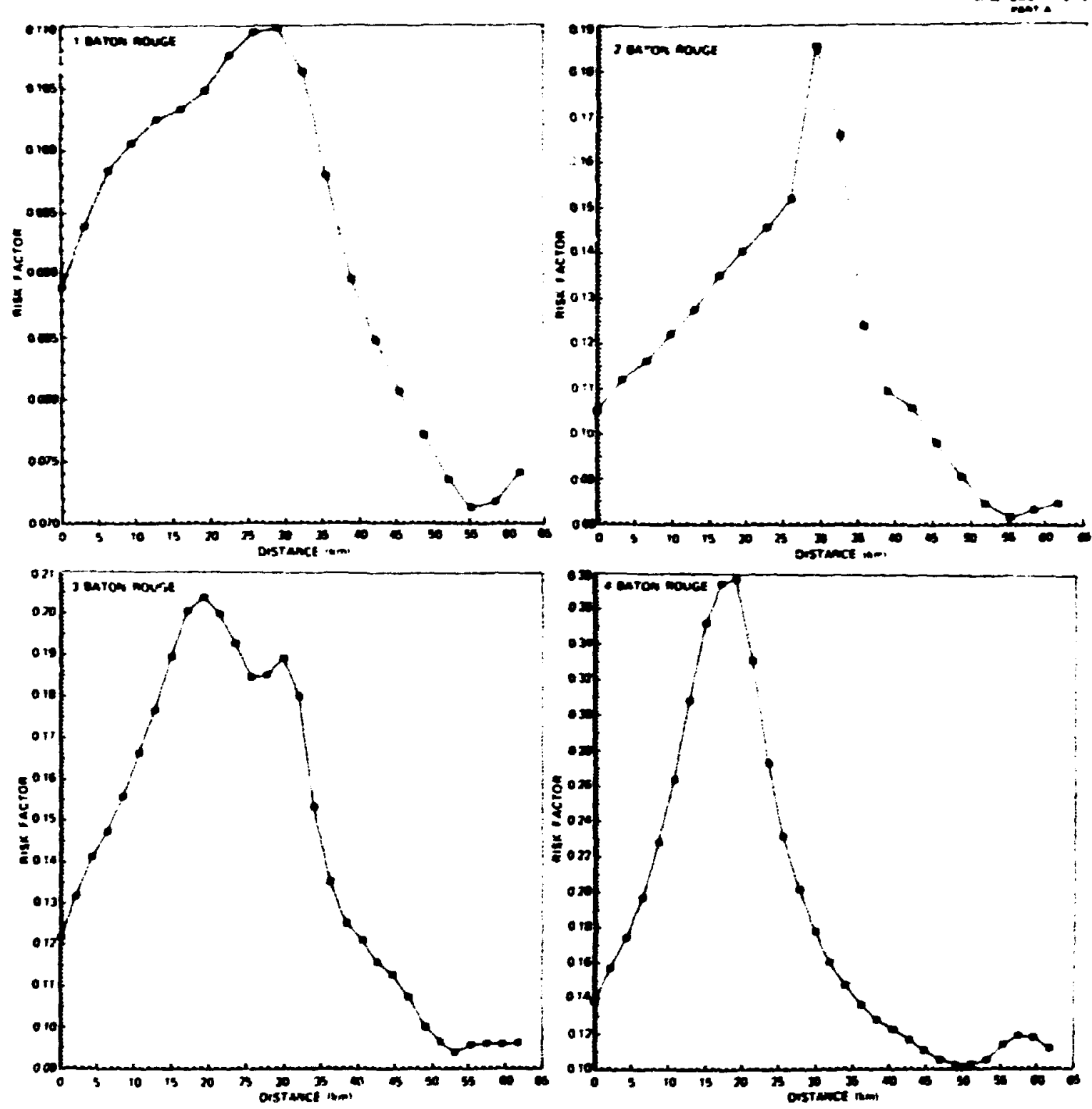

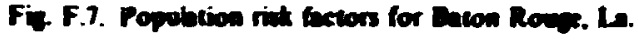



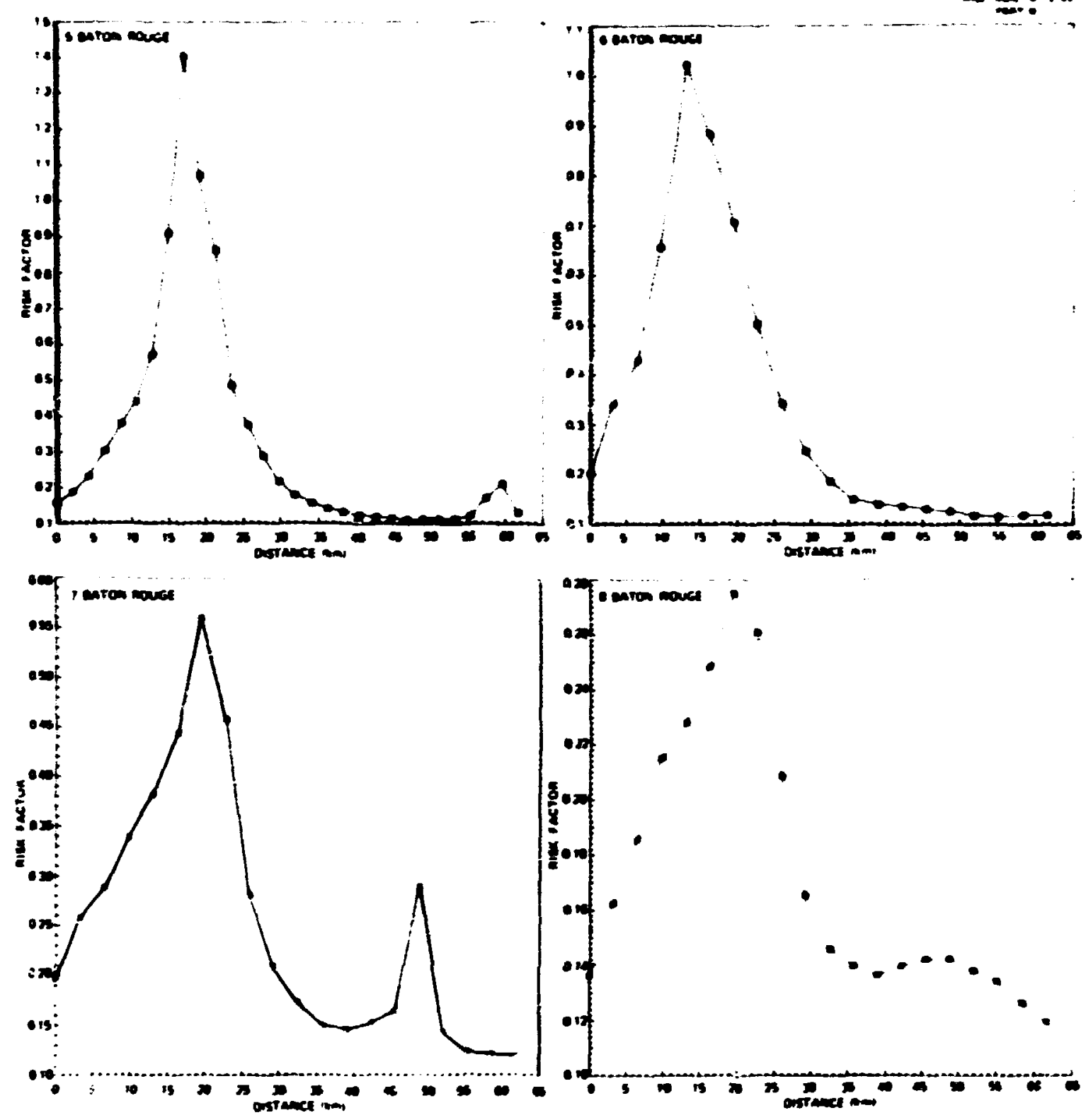

Fis 5.7 imationas 

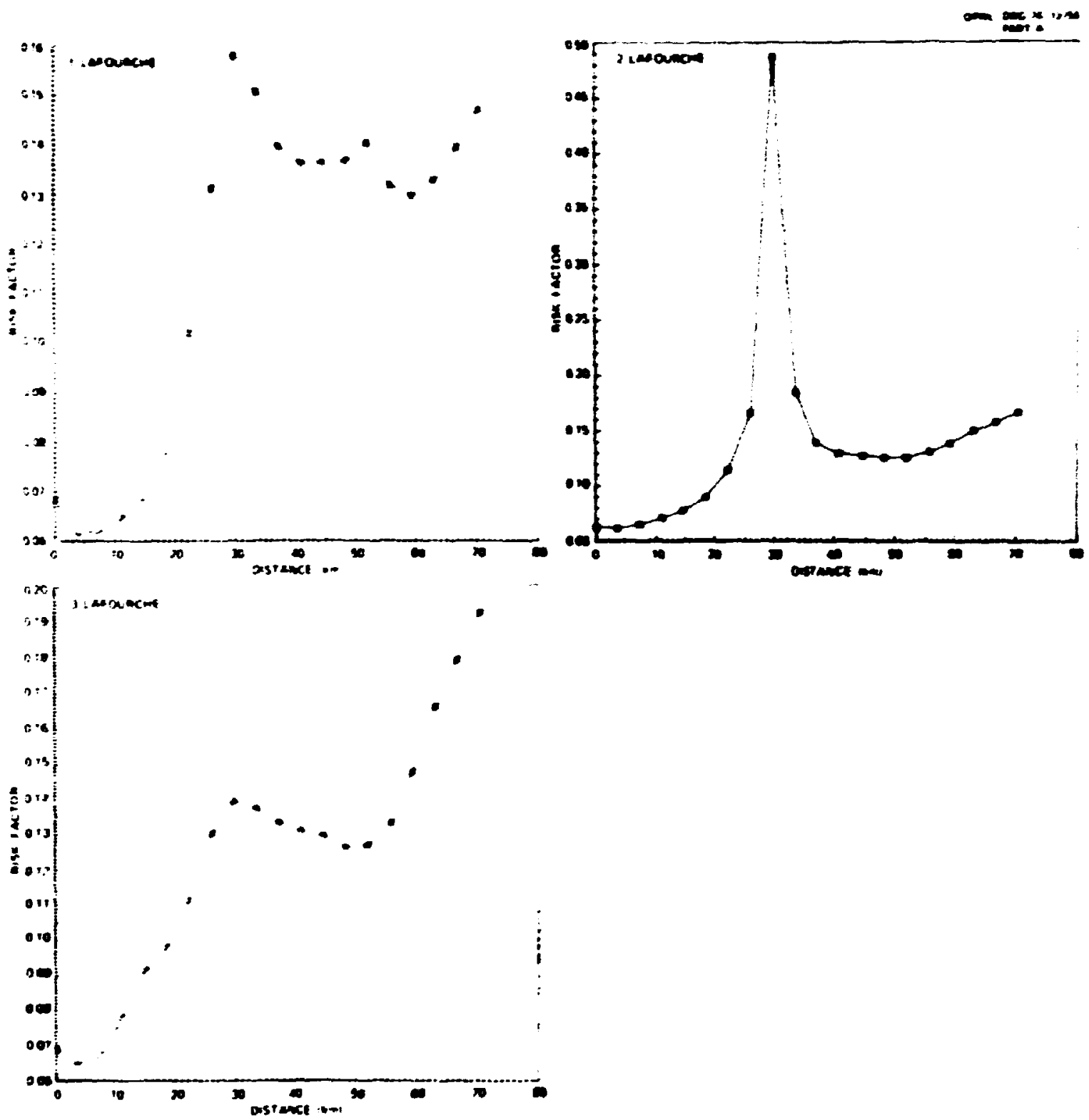

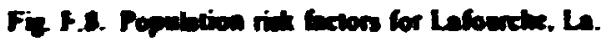


310
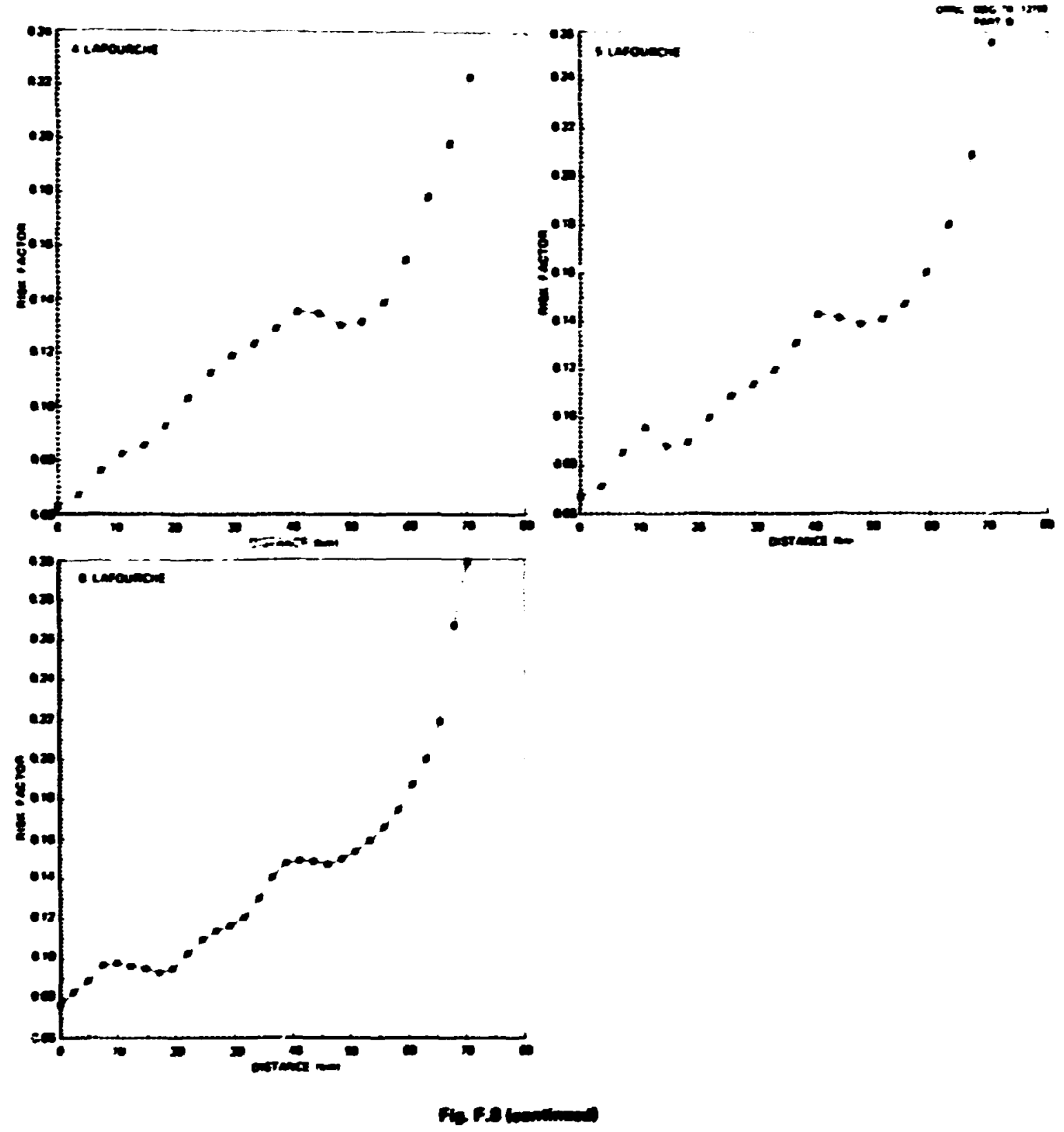

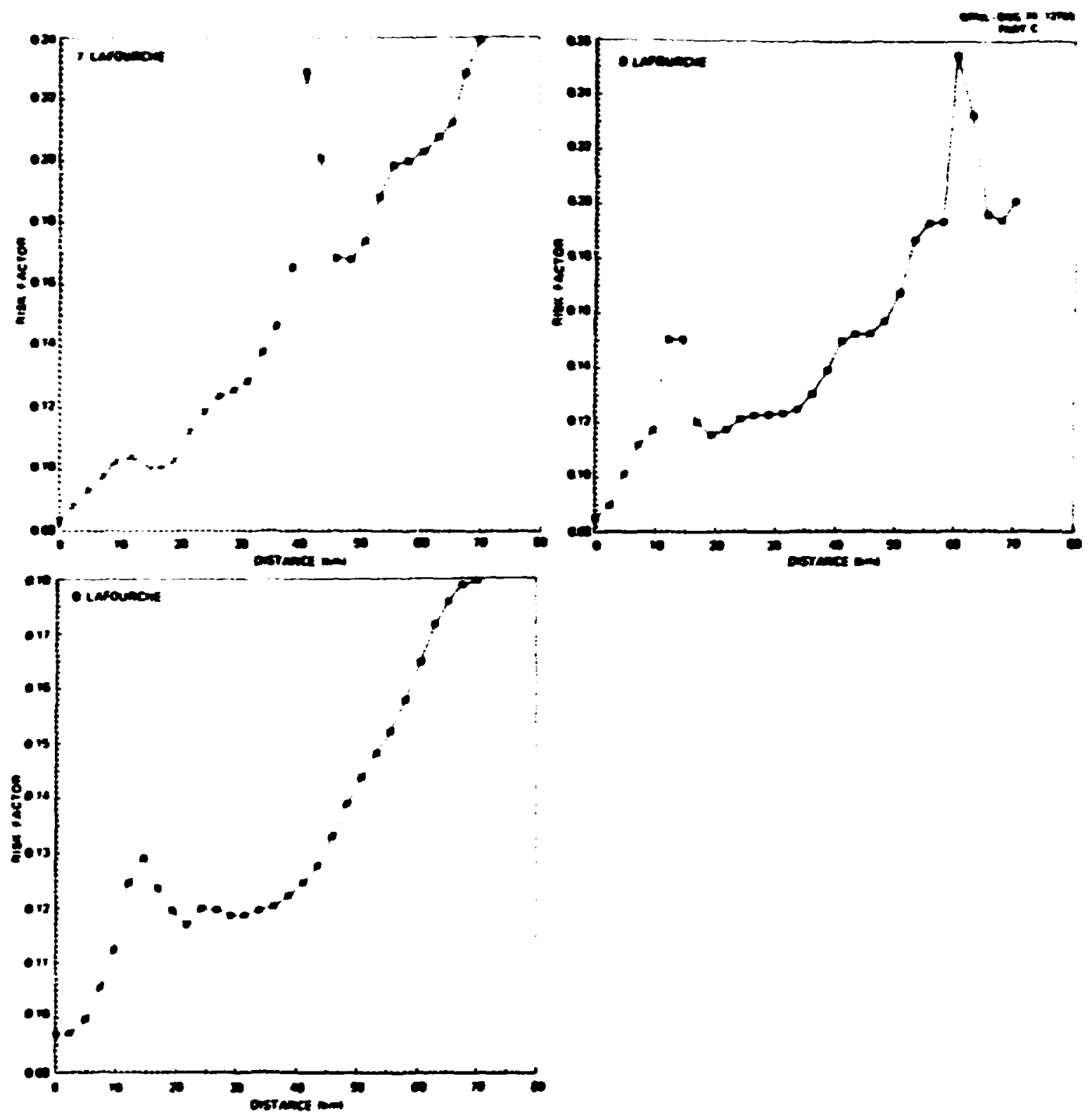

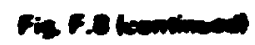



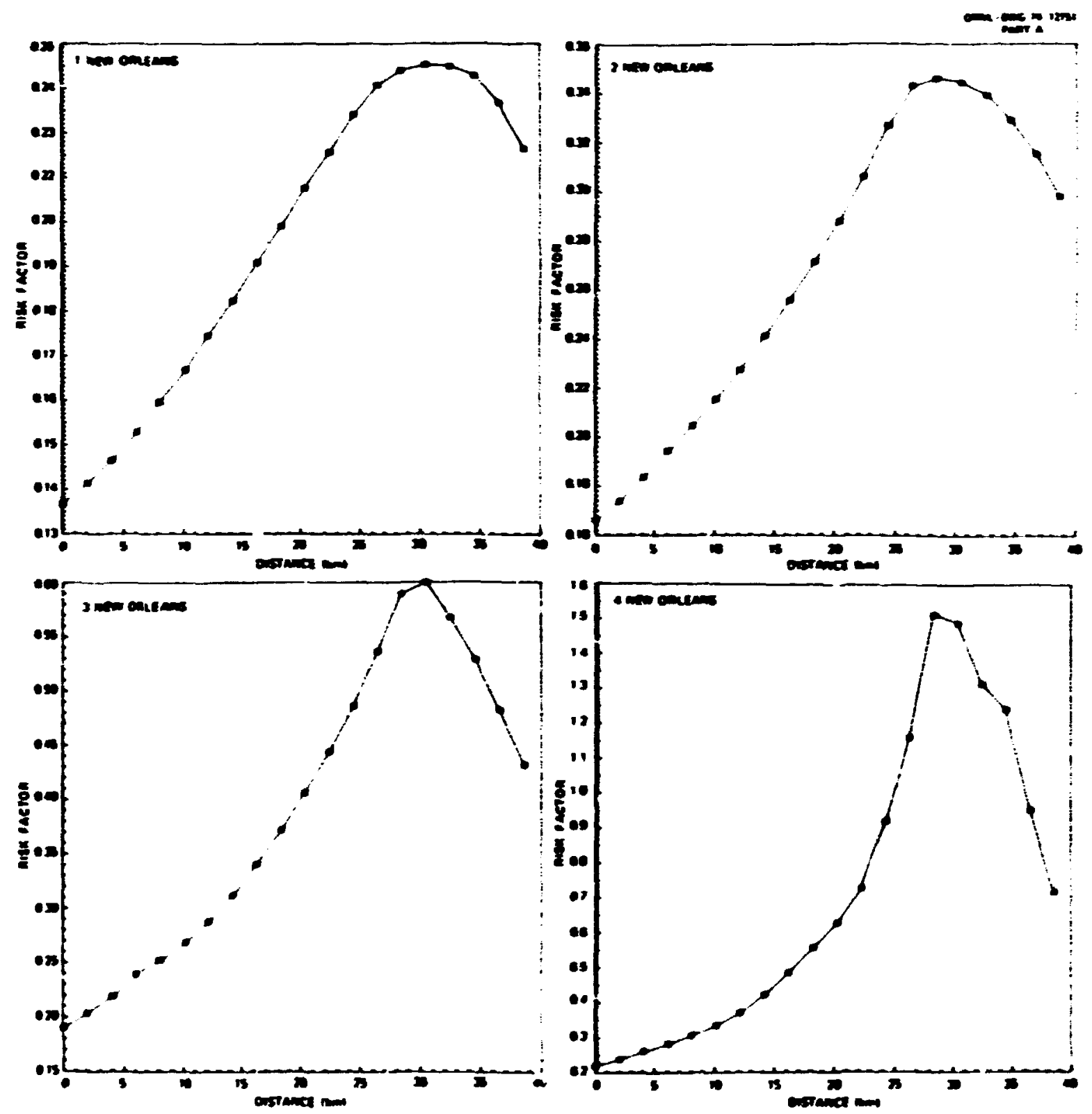

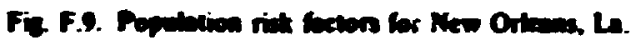




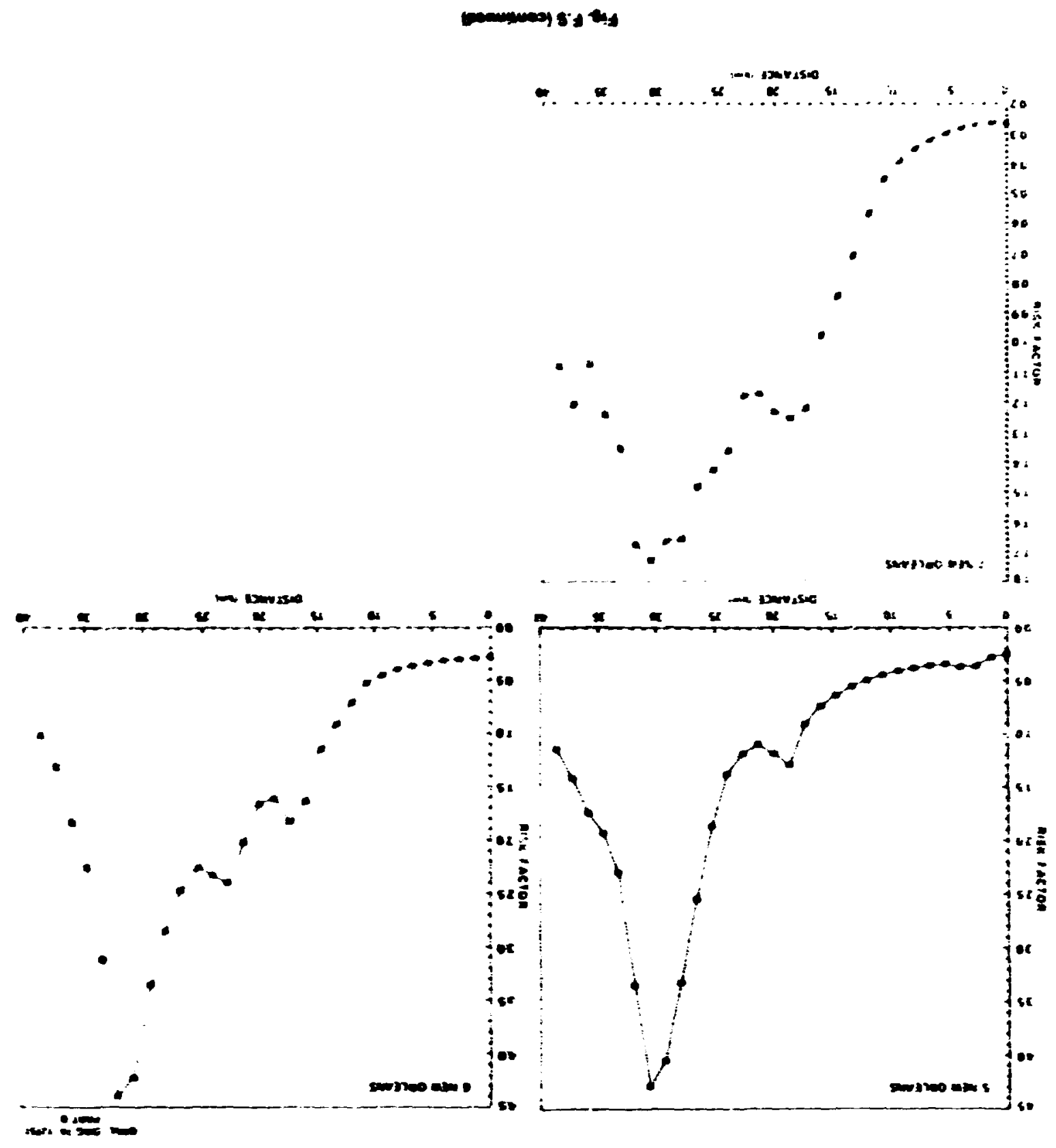



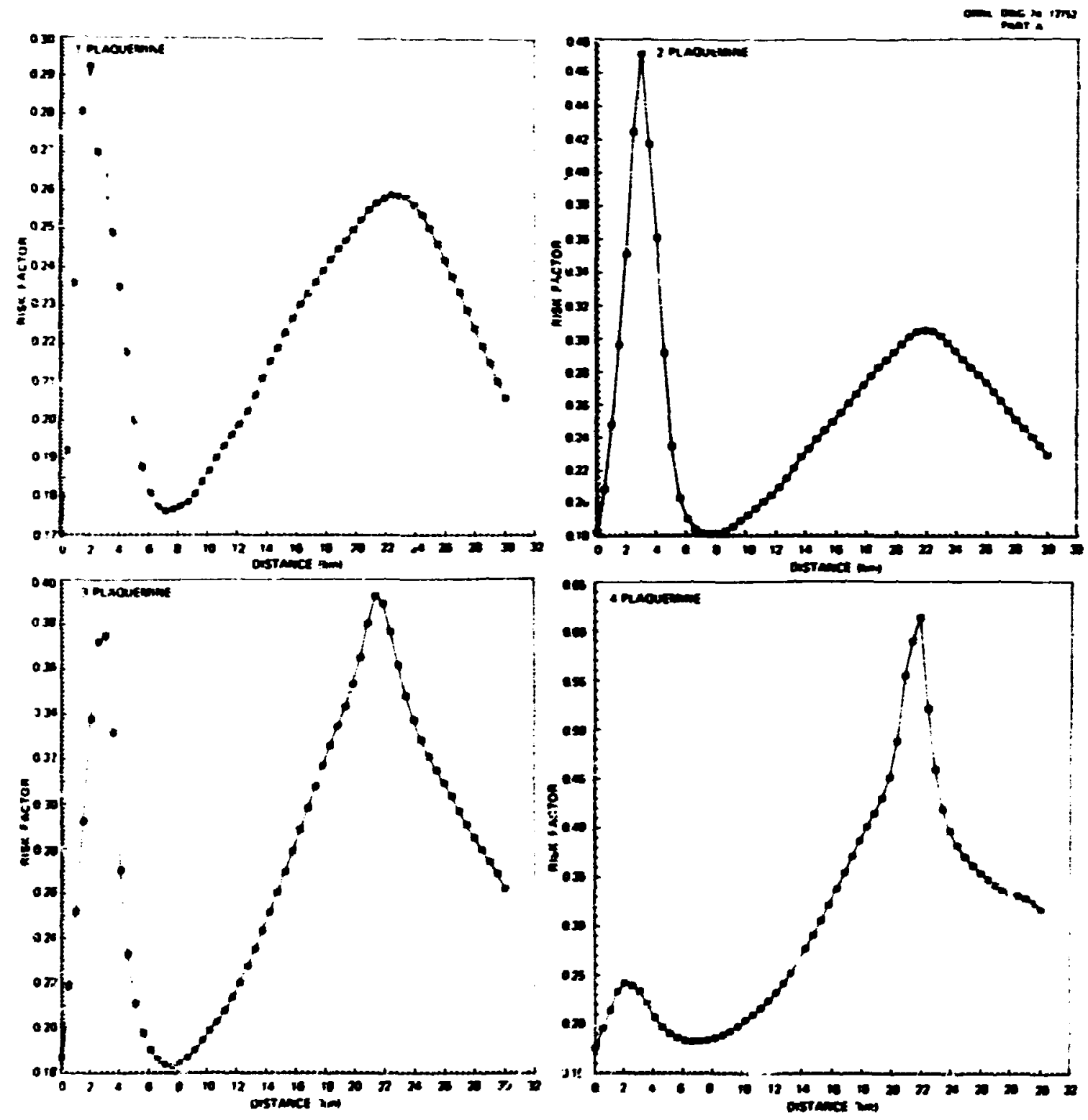

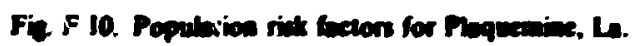



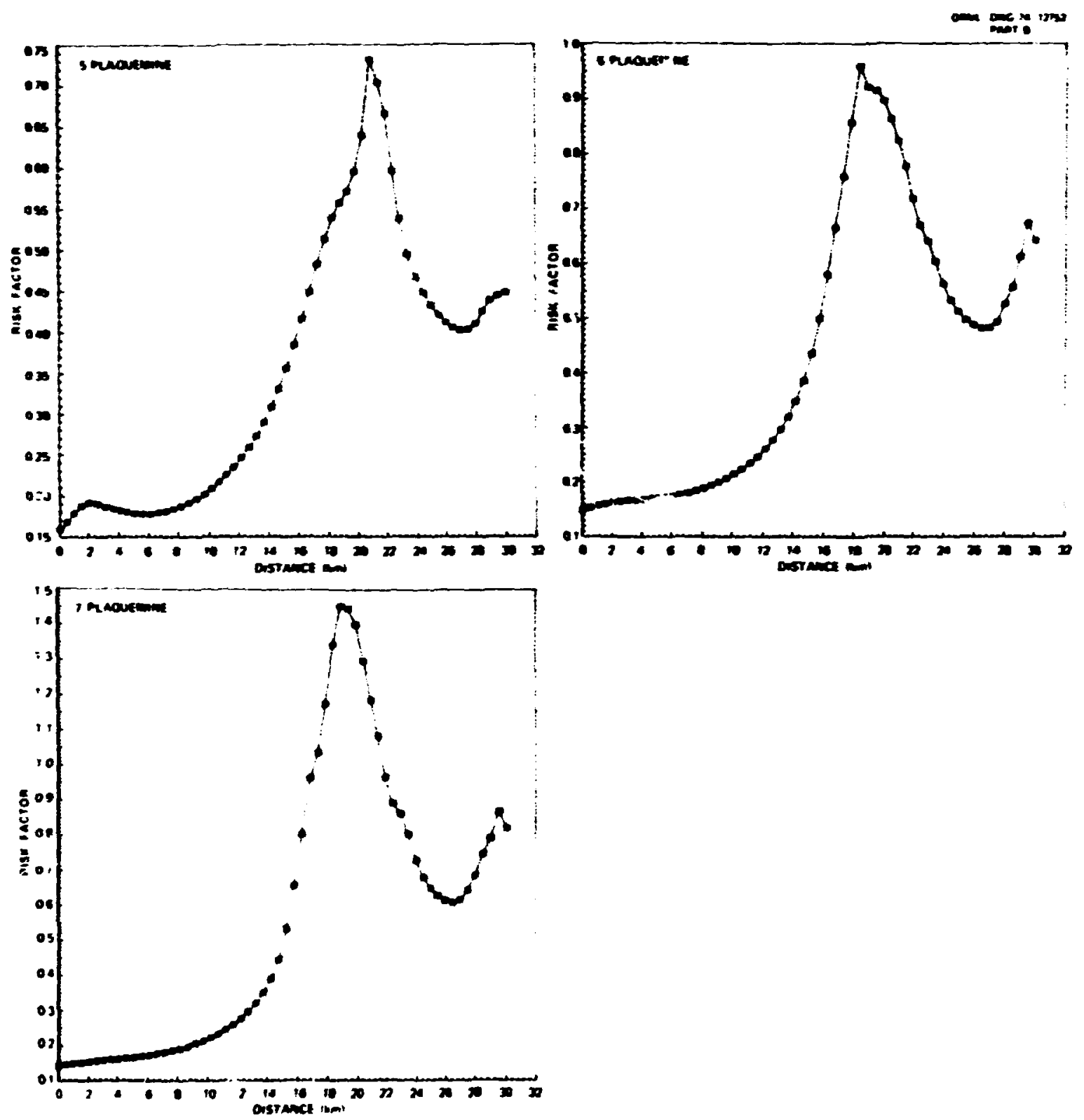

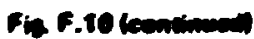



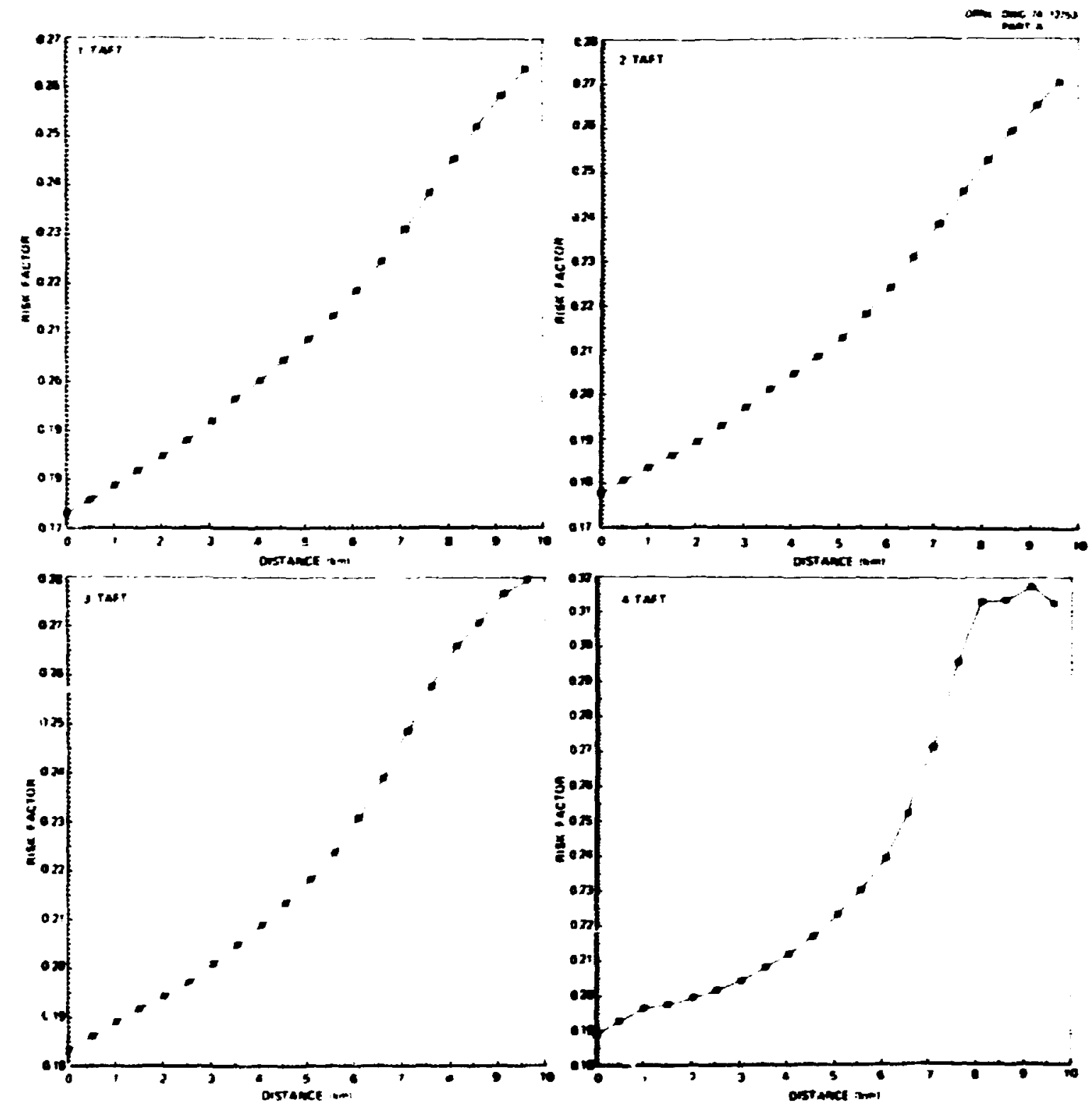

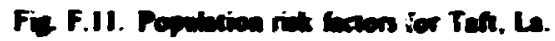




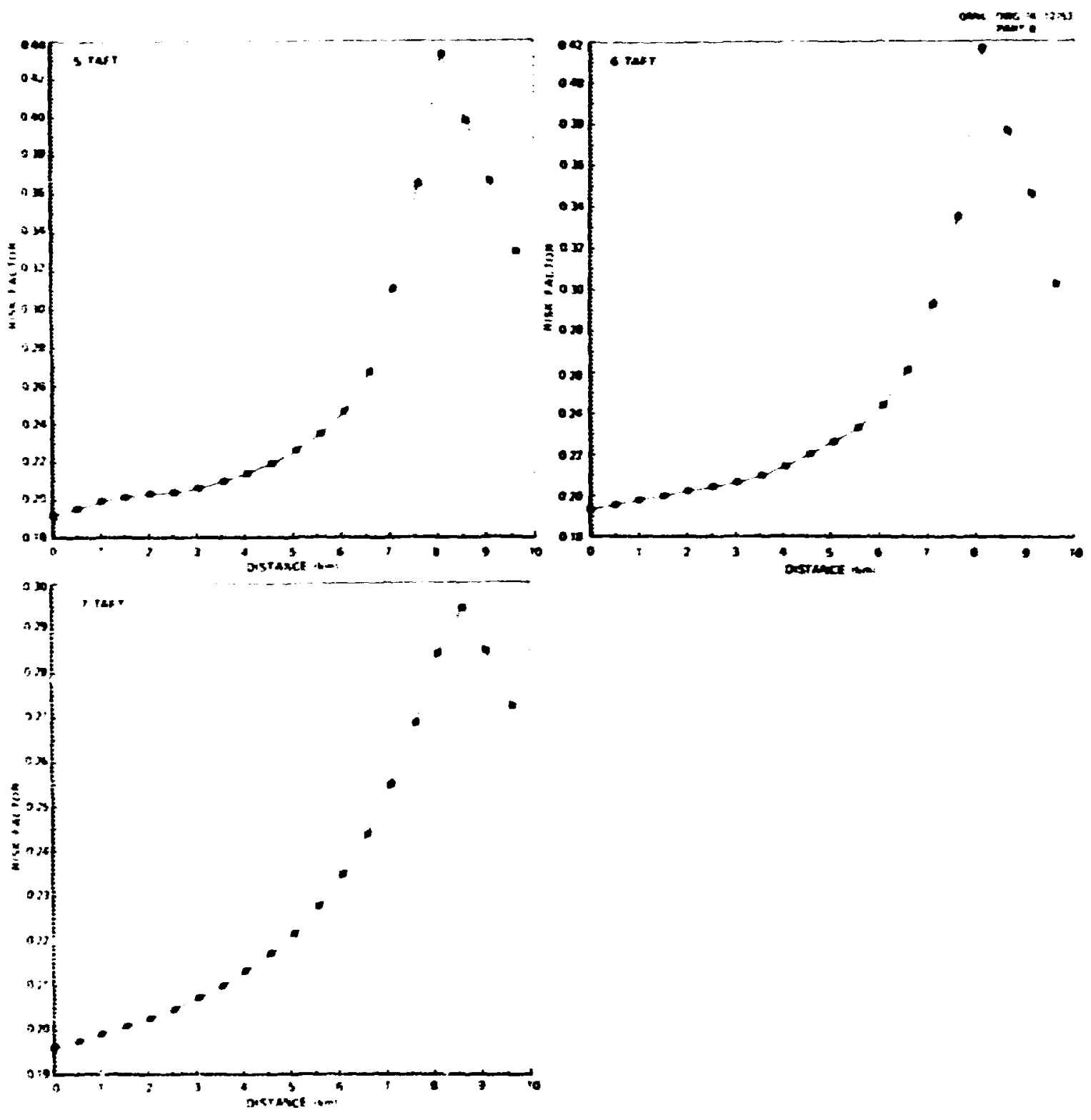

Fis F.11 kentiman 
318
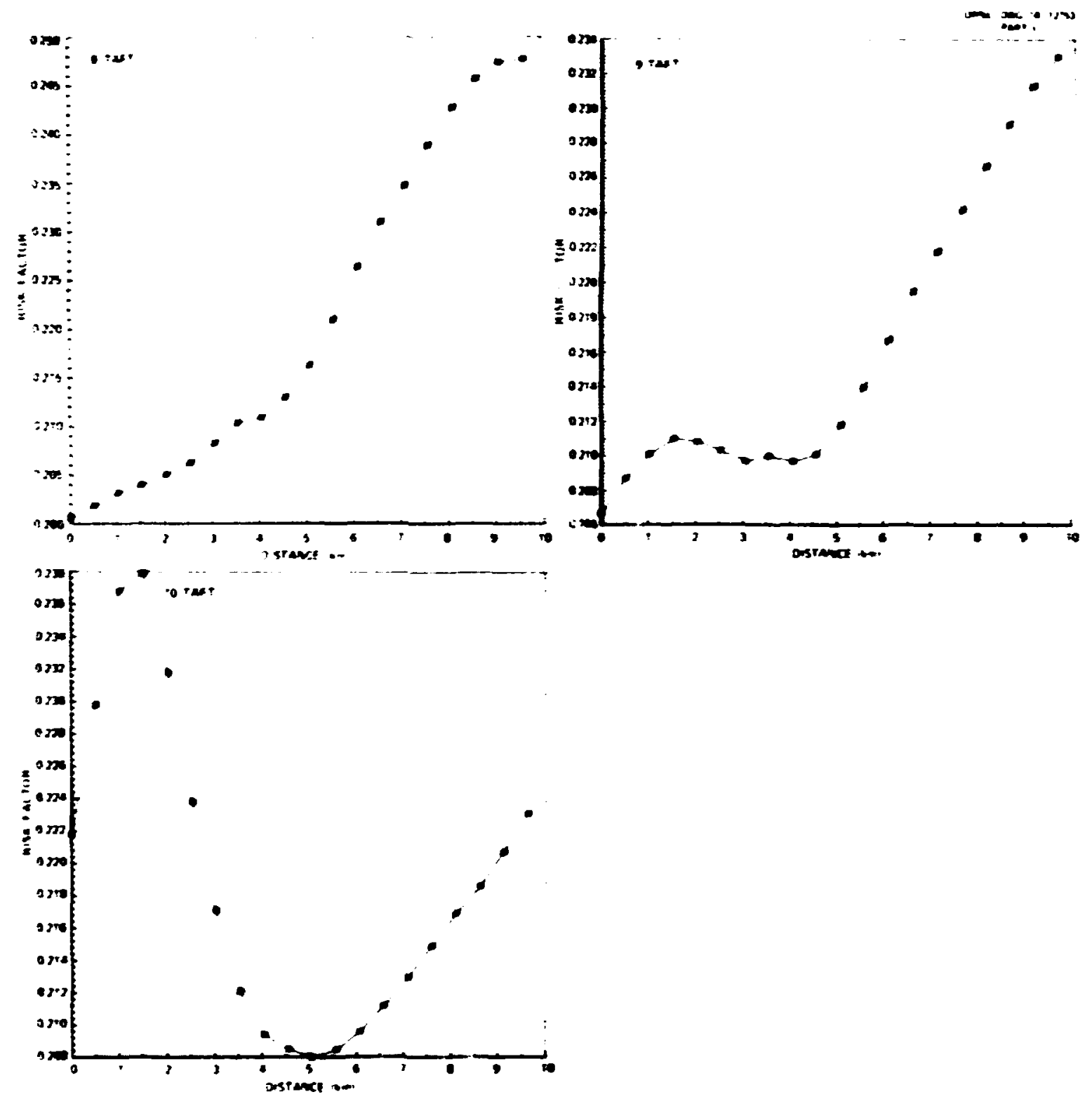

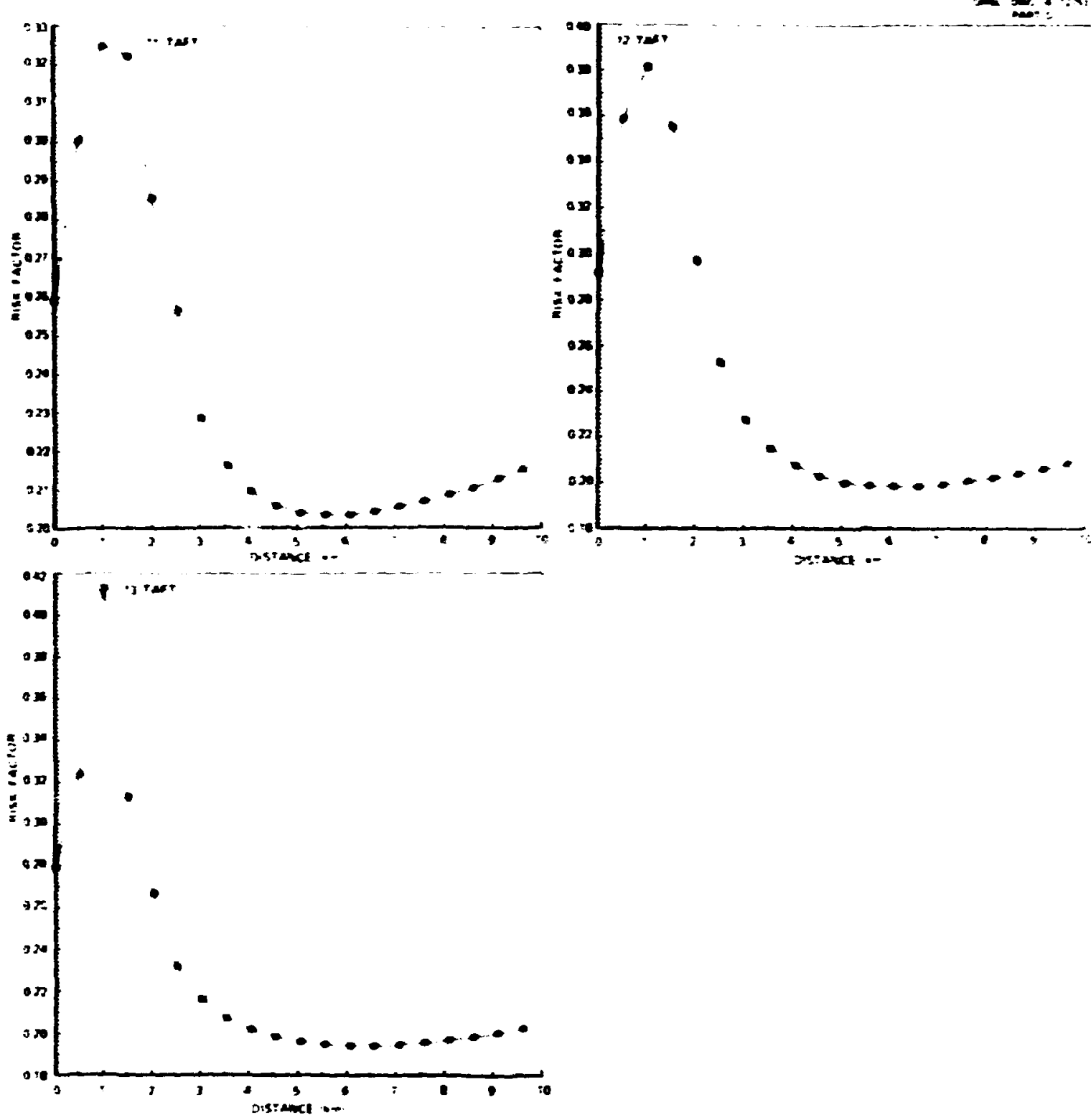

Fie F.11 leantionsen 